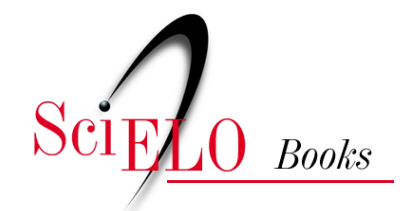

EDUFU

\title{
Peregrinação de Egéria uma narrativa de viagem aos Lugares Santos
}

\author{
Maria Cristina Martins
}

MARTINS, M.C. Peregrinação de Egéria: uma narrativa de viagem aos Lugares Santos [online]. Uberlândia: EDUFU, 2017, 324 p. ISBN 978-85-7078-519-0.

https://doi.org/10.7476/9788570785190.

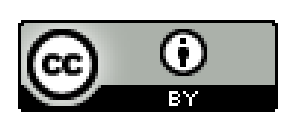

All the contents of this work, except where otherwise noted, is licensed under a Creative Commons Attribution 4.0 International license.

Todo o conteúdo deste trabalho, exceto quando houver ressalva, é publicado sob a licença Creative Commons Atribição $\underline{4.0}$.

Todo el contenido de esta obra, excepto donde se indique lo contrario, está bajo licencia de la licencia $\underline{\text { Creative Commons }}$ Reconocimento 4.0. 
Peregrinação de Egéria:

uma narrativa de viagem aos Lugares Santos 


\section{GUFU Editora da Universidade Federal de Uberlandia www.edufu.ufu.br}

Av. João Naves de Ávila, 2121

Campus Santa Mônica - Bloco 1S Cep 38408-100 | Uberlândia - MG Tel: (34) 3239-4293

$\begin{aligned} \text { REITOR } & \text { CONSELHO EDITORIAL } \\ \text { Valder Steffen Jr. } & \text { Carlos Eugênio Pereira } \\ & \text { Décio Gatti Júnior } \\ \text { VICE-REITOR } & \text { Emerson Luiz Gelamo } \\ \text { Orlando César Mantese } & \text { Fábio Figueiredo Camargo } \\ & \text { Hamilton Kikuti } \\ \text { DiRETOR DA EDUFU } & \text { Marcos Seizo Kishi } \\ \text { Guilherme Fromm } & \text { Narciso Laranjeira Telles da Silva } \\ & \text { Reginaldo dos Santos Pedroso } \\ & \text { Sônia Maria dos Santos }\end{aligned}$

\section{Equipe de Realização}

Editora de publicações

Assistente editorial Revisão

Projeto gráfico e editoração Produção gráfica do Manuscrito
Maria Amália Rocha

Leonardo Marcondes Alves

Luciana Malacarne

Ivan da Silva Lima

Leonardo Richesky de Ávila 


\section{Peregrinação de Egéria: \\ uma narrativa de viagem aos Lugares Santos}

Introdução, texto crítico, tradução e notas

Maria Cristina Martins

Prefácio

Bruno Fregni Bassetto

$E D \cup F U$ 


\section{Copyright 2017 (C) Edufu}

Editora da Universidade Federal de Uberlândia/MG

Todos os direitos reservados. É proibida a reprodução parcial ou total por qualquer meio sem permissão da editora.

\section{Dados Internacionais de Catalogação na Publicação (CIP)} Sistema de Bibliotecas da UFU - MG, Brasil

M386p Martins, Maria Cristina.

Peregrinação de Egéria : uma narrativa de viagem aos Lugares Santos. / introdução, texto crítico, tradução e notas, Maria Cristina Martins ; prefácio, Bruno Fregni Bassetto. - Uberlândia : EDUFU, 2017. 324 p. : il.

Inclui bibliografia.

ISBN: 978-85-7078-427-8

1. Língua latina. 2. Língua latina - Latim vulgar. 3. Filologia românica. 4. Línguas românicas. I. Título. 
Dedico esta obra ao meu filho Daniel. 


\section{Agradecimentos}

Agradecemos a todos que nos ajudaram a realizar este trabalho, não só por meio de palavras de incentivo, mas também pela participação intelectual e material. Agradecemos à Capes pela bolsa de pós-doutoramento na Universidade de Paris IV, que nos possibilitou reunir o material necessário à realização desta edição crítica, e à professora Michèle Fruyt, que nos recebeu; ao professor Pierre Maraval, pelo auxílio com a bibliografia; à Véronique Thomson-Ballif, pela amizade e acolhimento em Paris; às bolsistas de Iniciação Científica pela participação - Elisa Vigna, Pietra Acunha, Mauni Oliveira e, em particular, Luciana Malacarne, a quem devemos um agradecimento especial pela perfeita simbiose de trabalho -; ao monitor de latim Pedro Jung Thomé, que nos auxiliou na formatação e diagramação do livro; à família, pelo apoio e ajuda no quotidiano; ao professor e amigo Bruno Fregni Bassetto, que nos encorajou a realizar esta edição crítica e nos ajudou a solucionar muitas questões sobre ela. 


\section{Sumário}

11 Prefácio

15 Introdução

15 Esta edição crítica

15 As peregrinações do século IV

23 Nome da autora e título da obra

25 Identidade da autora

25 Origem da peregrina

26 Condição social da autora

27 Data da viagem

29 Língua, estilo e fontes da obra

30 Transmissão do texto

33 Legado da obra do ponto de vista filológico e cultural

34 A liturgia em Jerusalém

43 Principais edições da obra

44 Edição crítica

45 Critérios de tradução e de transcrição do manuscrito

49 Bibliografia

54 Abreviaturas e símbolos do aparato de crítica textual

57 Texto e tradução

59 Primeira Parte

149 Segunda Parte

235 Glossário

267 Índices

267 Índice de palavras que compõem o Glossário

272 Índice de palavras referidas nas notas filológicas

279 Manuscrito do séc. XI - Codex Aretinus (405) 


\section{Prefácio}

Para os estudiosos da Filologia Românica, uma tradução para o português, em edição crítica e bilíngue, da narrativa de peregrinação de Egéria - a Peregrinatio Egeriae -, com elaborado glossário e anotações filológicas, é motivo de comemoração. Não se trata apenas de mais uma edição do conhecido documento latino, mas o resultado de um paciente trabalho de anos. Em busca das indispensáveis fontes bibliográficas, a autora permaneceu um ano em Paris, junto à Sorbonne, num curso de pósdoutoramento, seguindo um bem elaborado planejamento que lhe mereceu a aprovação de sua Universidade (UFRGS) e uma bolsa da Capes, sem dúvida imprescindível para a execução do pretendido. Os anos seguintes foram consumidos por trabalho metódico e minucioso, cujo resultado final é agora apresentado aos interessados.

Algumas considerações, sem dúvida, ajudarão a compreender melhor a importância deste documento sob os vários aspectos analisados pela autora. Assim, a avaliação final, o último aspecto da crítica histórico-literária, revela que esta certamente não é uma obra de arte literária; a peregrina não pretendeu escrever com arte; não seguiu as regras complexas da composição clássica, embora assomem, por vezes, distantes alusões a influências de leituras de autores famosos, sobretudo de Virgílio e de César, através dos quais, como se sabe, a língua latina era ensinada nas escolas. De fato, trata-se de uma narrativa singela de uma peregrinação aos lugares santos, num estilo enxuto e sem floreios. Seu valor, portanto, não está nesse aspecto, mas é múltiplo seu valor documental, conforme se verifica na presente obra.

Inicialmente, verifica-se a profundidade da penetração do cristianismo, até então, praticamente em todo o Império Romano; não há referências a cismas, fazendo supor uma unidade perfeita. Os liturgistas encontram neste documento farto material para a história dos ritos, das celebrações, do calendário litúrgico, dos mosteiros e das igrejas, erguidas por toda parte. A hierarquia eclesiástica se apresenta já constituída, adequada às necessidades da época, qual eco ao que se lê no Novo Testamento, sobretudo nos Atos de Lucas. Como ainda hoje, a celebração da missa perfaz a parte central do culto. Um aspecto importante, 
sob o ponto de vista histórico, é o processo do catecumenato, levado muito a sério, uma vez que muitos eram batizados já adultos. Por outro lado, fica evidente que, naquela época, os principais ritos, os sacramentos e a organização da Igreja são essencialmente os mesmos dos de hoje, mutatis mutandis, e ainda com o dado adicional de sua universalidade.

Ressaltem-se também as informações geográficas e históricas, nas quais se nota a preocupação de ligar os lugares aos fatos correspondentes, mesmo os apontados no Antigo Testamento. Outros aspectos serão facilmente verificados com a leitura desta obra, realmente rica em tais informações.

Tem sido muito discutido o latim usado pela peregrina. Inicialmente, urge não esquecer que, à época do documento, o Império Romano, ainda que cristianizado, sobretudo depois de o imperador Constantino Magno decretar a liberdade religiosa através do Édito de Milão (313), se mantinha firme e sua língua geralmente falada era o latim. No período áureo da literatura latina (séc. I a.C. - I d.C.), havia três variedades do latim: o sermo litterarius, só escrito, instrumento de arte e, como tal, estilizado, correto e regrado; o sermo urbanus, falado pelas classes cultas, razoavelmente correto e gramatical, norma que desapareceu com o fim do Império; e o sermo plebeius, hoje dito "latim vulgar" e falado pela grande massa popular inculta em todas as províncias do Império, embora em concorrência com a koiné grega nas províncias do Oriente.

Talvez não seja possível determinar quando o latim deixou de ser falado ou de ser entendido. Sua própria evolução, extremamente lenta, até se transformar nas diversas línguas românicas, quando o povo não mais entendia o que era dito em latim, só foi detectada pelo Concílio de Tours, em 813, que, em seu cânon 17, determinou ao clero que pregasse não mais em latim, mas na romana lingua, na variedade local: o próprio nome, romana lingua, a qualifica como derivada do latim, certamente pela semelhança de ambas, mas suficientemente diferenciadas para impedir a compreensão mútua. Portanto, essa atestação de que o latim não era mais falado e compreendido pela população data de aproximadamente cinco séculos após a época da Peregrinatio. Logo, a língua falada por sua autora era o latim, que ela usa com tanta liberdade e desembaraço.

Deduz-se que, também na Península Ibérica, a língua falada era o latim, ainda que em sua norma "vulgar" e talvez na do sermo urbanus pelas classes cultas, que realmente não seria o mesmo do séc. I. Portanto, a autora da Peregrinatio devia falar comumente o latim e conhecê-lo bem. Além disso, há fortes indícios de que ela pertencia à classe alta, cujos membros frequentavam 
escolas; nelas se estudava, entre outras disciplinas, a língua, como afirma Quintiliano (aliás, nascido na Hispania Citerior) várias vezes em sua Institutio Oratoria. É óbvio que as escolas ensinavam o sermo litterarius, e nesse contexto nossa autora hauriu conhecimentos dessa variedade, posteriormente empregados na redação de seu relato, entremeados com muitos elementos da língua que ela falava. Assim, afigura-se uma mescla de duas normas de um mesmo idioma, sem que houvesse preocupação em distingui-las. É bem possível que a leitura assídua do Novo Testamento, na versão da Vetus Latina, tenha tido influência.

Há muitos elementos da norma culta, como o emprego da passiva dita sintética e de verbos depoentes, as formas sintéticas do comparativo dos adjetivos e advérbios, construções do acusativo com infinitivo, o ablativo absoluto e o particípio conjunto, entre outros. É notável que esses torneios, próprios do latim literário, se caracterizam pelo sintetismo e não passaram para as línguas românicas, preponderantemente analíticas, pois não tiveram a influência da norma culta, como a teve nossa autora.

Por outro lado, o latim do texto apresenta muitos pontos conflitantes com os correspondentes clássicos: os demonstrativos ille e ipse assumem a função do artigo definido românico e unus a do indefinido; há emprego generalizado das preposições, inclusive como substitutas de flexões casuais, como se observa nas línguas românicas, além de muitos elementos que o leitor encontrará no presente trabalho.

Afinal, estamos diante de um documento desafiador, na medida em que levanta muitas questões filológicas, históricas e factuais, que especialistas tentaram e ainda tentam responder. O leitor verificará que a presente obra traz algumas contribuições importantes para uma melhor compreensão desse documento.

Bruno Fregni Bassetto 


\section{Introdução}

\section{Esta edição crítica}

A obra, que, pela segunda vez, é apresentada ao público brasileiro, ${ }^{1}$ mas agora em edição crítica, comentada e bilíngue, insere-se no contexto das viagens de peregrinação aos Lugares Santos do cristianismo, iniciadas no século IV.

A ideia de realizar esta edição crítica em português, à qual damos o nome de Peregrinação de Egéria: uma narrativa de viagem aos Lugares Santos, surgiu à medida que traduzíamos e analisávamos a obra, com o objetivo de publicar uma tradução comentada. Ou seja, nossa meta inicial, além da tradução em edição bilíngue, era a elaboração de comentários filológicos abrangendo não só as características particulares da variedade de latim apresentada no texto, mas também notas histórico-geográficas e culturais que mostrassem a riqueza cultural da obra. Porém, devido à variação de certas palavras do texto latino, encontradas entre os mais renomados editores, percebemos a necessidade do estabelecimento de nosso próprio texto latino, com base no manuscrito, para que realizássemos uma edição fidedigna e a mais próxima possível do original. Nasceu, assim, esta edição crítica.

Ao longo dos anos de trabalho com o texto da peregrinação de Egéria, apresentamos palestras e publicamos artigos sobre o tema, que incluem partes desta Introdução.

\section{As peregrinações do século IV}

Por ordem cronológica, estes são os textos que tematizam peregrinações no séc. IV: 1) o Itinerarium Burdigalense, de autor anônimo, conhecido como

\footnotetext{
${ }^{1}$ A primeira edição apresenta o texto apenas em língua portuguesa, tendo sido realizada por Maria da Glória Novak, da Universidade de São Paulo, e publicada em 1971, pela Editora Vozes, com o título Peregrinação de Etéria: liturgia e catequese em Jerusalém no século IV. A segunda edição em língua portuguesa é bilíngue, realizada em Portugal, em 1998, por Alexandra Mariano e Aires Nascimento: Egéria. Viagem do Ocidente à Terra Santa no séc. IV (Itinerarium ad loca sancta), Coleção Obras Clássicas da Literatura Portuguesa, Edições Colibri, Lisboa.
} 
“o peregrino de Bordéus" (333); 2) um texto de Gregório de Nissa (381); 3) a Peregrinatio Egeriae, objeto desta edição crítica (381-384); 4) uma carta de São Jerônimo (Epistula 108), na qual ele relata a peregrinação de Paula, acompanhada de sua filha Eustóquia e dele mesmo (385-386).

O Itinerarium Burdigalense $e^{2}$ é de especial importância, não apenas por ser o mais antigo relato de peregrinação do séc. $\mathrm{IV}^{3}$ mas também porque foi considerado um guia de viagem para os peregrinos que partiam de Bordéus (a cidade francesa de Bordeaux). $\mathrm{O}$ autor menciona que partiu para Jerusalém em 30 de maio de 333, sob o consulado de Dalmácio e Zenófilo, e retornou em 25 ou 26 de outubro do mesmo ano. O texto nos chegou anonimamente e, também, nada sabemos sobre a condição social do autor. Devido às informações históricas e arqueológicas que são dadas no texto, além do cuidado com que o autor menciona os lugares de parada (mansiones) e de troca de cavalos (mutationes), podemos supor que ele tenha sido um funcionário imperial a serviço do correio da época, o cursus publicus: essa função permitia, desde o tempo do imperador Augusto, que os funcionários civis e militares circulassem em melhores condições ao longo da rede viária. Parece bastante provável a hipótese de que o autor tenha sido um funcionário público dessa natureza, pois terminou sua viagem em Milão, cidade que, a partir do séc. III, tornou-se sede da residência imperial. Supôs-se, ainda, que o texto teria sido uma ficção literária, a partir da compilação de três fontes: 1) um itinerário civil, o Itinerário de Antonino (ca. 280-290), famoso texto sobre as estradas do Império Romano; 2) um texto reagrupando algumas tradições judaicas; 3 ) um texto breve de origem cristã. De qualquer forma, mesmo se fosse comprovada a veracidade dessa compilação, nada impediria que o texto fosse de um autêntico viajante, de um verdadeiro peregrino que se desloca para ver e venerar os lugares que considera como santos. Segundo os estudiosos, os peregrinos cristãos se orientavam pelo Itinerarium Burdigalense, e a própria autora da Peregrinatio Egeriae ter-se-ia guiado pelo itinerário do peregrino de Bordéus,

${ }^{2}$ GEYER, P; CUNTZ, O. Itinerarium Burdigalense. In: ITINERARIA ET ALIA GEOGRAPHICA. Turnhout, v.175, 1965. (Corpus Christianorum, Series Latina). In: MARAVAL, 2002b, p.11-41.

${ }^{3}$ A obra Onomastikon de Eusébio de Cesareia, escrita em 295, é considerada a primeira a tratar dos Lugares Santos, embora não seja propriamente um itinerarium, mas uma compilação de nomes de sítios venerados na Palestina, relativos ao Antigo Testamento. Em 390, São Jerônimo traduziu-a para o latim sob o título De situ et nominibus locorum Hebraicorum. 
pois a indicação de uma parada em Mansocrenas (cap. 23,6) só é encontrada na Peregrinatio e no Itinerarium.

O segundo texto de peregrinação do séc. IV é uma carta escrita no idioma siríaco por Atanásio, ${ }^{4}$ bispo de Alexandria (328-373), datada de cerca de 350. Uma grande parte da carta é dedicada a dar conselhos a virgens, tema muito frequente nos escritos desse bispo, e outra parte cita os mais importantes Lugares Santos de Jerusalém (Anástase, Gólgota, Martyrium, Monte das Oliveiras) e de Belém. Além disso, o texto atesta que virgens realizavam a peregrinação a Jerusalém, umas vivendo isoladamente, outras em comunidade, inclusive dividindo a habitação com homens, e que estes também deviam fazer a profissão de virgindade. Em outra parte do texto, elogiando aqueles que faziam a peregrinação a Jerusalém, o autor aproveita para mostrar as lições espirituais advindas da peregrinação e destaca que o mais importante é que os fiéis retenham os ensinamentos da romaria. Deve-se enfatizar a riqueza do texto em citações e alusões à Bíblia.

Gregório de Nissa (330-395) foi um Padre da Igreja que, em 381, foi enviado à província da Arábia, a leste do Jordão, para tentar resolver problemas que dividiam uma Igreja local. Na volta, aproveitou para visitar Jerusalém e aí escreveu uma carta, na qual revelou que sua estadia na Cidade Santa não fora pacífica. Um tempo mais tarde, quando alguns monges e monjas lhe perguntaram como seria fazer uma peregrinação a Jerusalém, Gregório não lhes poupou algumas críticas a tal empreitada. Gregório expõe sua concepção sobre as peregrinações em várias cartas; de um modo geral, sua percepção sobre as peregrinações é espiritualizada e um pouco semelhante àquela de Atanásio. A título de exemplo, com base na "Carta sobre aqueles que vão a Jerusalém" (apud Maraval, 1990b, p.106-123), ele afirma que uma mudança de lugar, no caso das peregrinações a Jerusalém, não garante nenhuma aproximação com Deus, pois, onde quer que a pessoa esteja, Deus virá até ela, se o domicílio de sua alma permitir que Deus nela habite e ali circule. Ao contrário, se a pessoa tiver um interior cheio de maus pensamentos, mesmo se ela estiver no Gólgota, no Monte das Oliveiras ou na Anástase, estará longe de receber Cristo.

São Jerônimo (ca. 345/347 - ca. 419/420) era o diretor espiritual de damas da aristocracia romana, entre elas Paula e sua filha Eustóquia, descendentes dos Cipiões e dos Gracos. Com a morte do Papa Dâmaso, amigo de Jerônimo e de Paula, um grande número de clérigos romanos criou

\footnotetext{
${ }^{4}$ LEBON, J. Athanasiana Syriaca. II. Une lettre attribuée à saint Athanase d'Alexandrie, Le Muséon, 41, 1928, p.170-188. In: MARAVAL, 2002b, p.43-47.
} 


\section{Maria Cristina Martins}

dificuldades para Jerônimo, inclusive invejando e suspeitando da amizade que ele mantinha com a dama. Jerônimo é forçado, em agosto de 385, a deixar a cidade de Roma, quando então volta a Antioquia, onde estava vinculado ao bispo Paulino. Paula vai ao seu encontro alguns dias mais tarde e, no final do mesmo ano, de lá partem a Jerusalém e empreendem uma visita a todos os Lugares Santos da Palestina e do Egito. Na volta, se estabelecem em Belém, onde passariam o resto de suas vidas, no comando de mosteiros que tinham fundado com o dinheiro de Paula. As personagens da peregrinação são Paula, Eustóquia, uma dama de companhia das duas mulheres e Jerônimo, que as acompanha como diretor espiritual. São Jerônimo havia se tornado, pouco a pouco, um erudito e perito em assuntos bíblicos e, nesse particular, influenciou Paula e suas companheiras: a narrativa da peregrinação tem um lado um tanto erudito, com a menção de lugares pouco conhecidos ou com a evocação de uma exegese erudita, inspirada em Orígenes. A carta (Ep. 108, 6-14) apresenta aspectos concretos, pelos quais podemos retraçar o itinerário que eles percorreram: desceram de Antioquia a Jerusalém, passando por Cesareia, Lida e Emaús; visitaram Jerusalém, depois Belém e os lugares ao sul desta cidade, chegando até Hebron; daí voltaram a Jerusalém, de onde partiram em direção a Jericó e lugares próximos do rio Jordão, subindo novamente à Samaria e à Galileia; por fim, foram ao Egito e voltaram a Belém. Tudo aconteceu em poucos meses, e o retorno à Palestina foi apressado por causa do grande calor do verão de 386 . O texto mostra a pressa do peregrino, que é um traço característico do "tempo do peregrino" (Maraval, 1984, p.480-482).

A expressão "Lugares Santos" foi usada pela primeira vez por Eusébio (Vida de Constantino, 3, 52, apud Maraval, 2002b, p.28), bispo de Cesareia da Palestina, no início do séc. IV, e aparece correntemente desde o fim desse mesmo século, sendo empregada inclusive por São Jerônimo, para designar os lugares em que se relatam os acontecimentos do Novo e do Antigo Testamento, e ainda os lugares nos quais se conservam os restos mortais de mártires cristãos. Em escritos que datam de 314 a 320, Eusébio faz referência a fiéis que, vindo de todas as partes, se reúnem no Monte das Oliveiras ou no jardim de Getsêmani para orar. Diz ainda que os cristãos costumam visitar a gruta da Natividade em Belém e se fazem batizar no rio Jordão, no local onde se supõe que Cristo tenha sido batizado. Pouco a pouco, os cristãos começaram a fazer um inventário dos Lugares Santos e construíram igrejas e oratórios para que pudessem venerar assiduamente os mártires. Esses santuários, que inicialmente foram construídos 
para receber relíquias de mártires, passaram a servir de habitação para monges e, posteriormente, também abrigaram seus túmulos.

O inventário dos Lugares Santos se tornou mais produtivo e de reconhecimento mais rápido na parte oriental do Império Romano, mais exatamente na região que hoje se chama Oriente Médio. A Palestina, especialmente, contava com muitos sítios bíblicos que a fizeram ser o maior centro de atração de peregrinações; no entanto, todas as regiões do Oriente - Egito, Síria, Palestina, Ásia Menor -, onde a perseguição de Diocleciano (imperador entre 284 e 305) se deu de maneira bastante violenta, apresentavam numerosos túmulos de mártires.

Uma das razões que explicam o surgimento e o desenvolvimento das peregrinações aos Lugares Santos é a liberdade de culto para o cristianismo, advinda do Édito de Galério, no ano 311, e confirmada em Milão, em 313, por Constantino e Licínio. O Édito de Tolerância de Galério, também conhecido como Édito de Tolerância de Nicomédia, foi um decreto de indulgência pelo qual as perseguições aos cristãos deveriam ser cessadas: ele oficialmente pôs termo à perseguição do imperador Diocleciano aos cristãos, concedendo-lhes legalidade a seu culto e liberdade para se reunirem e construírem templos. Assim, a prática das peregrinações surgiu no século IV e conseguiu se estender de maneira homogênea até antes da conquista árabe, no século VII.

O estudo das peregrinações durante os primeiros séculos do cristianismo carrega consigo um problema de terminologia: a palavra "peregrino", derivada, por via fonética, da palavra latina peregrinus, não possui o significado clássico, que está ligado à área jurídica. Peregrinus era o estrangeiro, aquele que vinha de fora, em oposição ao cidadão, o ciuis, aquele que tinha direitos civis. Esse sentido de peregrinus é exatamente o mesmo do grego ł́cvoc. Na Bíblia, por exemplo, temos: "Escuta, Senhor, minha oração e presta ouvido ao meu clamor! Não fiques insensível ao meu pranto! Porque diante de ti sou apenas um forasteiro, um peregrino 5 como todos os meus pais" (Exaudi orationem meam, Domine, et clamorem meum auribus percipe. Ad lacrimas meas ne obsurdescas, quoniam aduena ego sum apud te, peregrinus sicut omnes patres mei) (Sl 39,13); "Caríssimos, peço-vos que, como forasteiros e peregrinos, vos abstenhais dos desejos da carne que combatem contra a alma" (Carissimi obsecro tamquam aduenas et peregrinos abstinere uos a carnalibus desideriis quae militant aduersus animam) (1Pd 2,11). Invoca-se também a semelhança com o Cristo, que não

\footnotetext{
${ }^{5}$ Em algumas traduções da Bíblia para o português, como a da Editora Vozes, nesta passagem, peregrinus foi traduzido como "hóspede".
} 


\section{Maria Cristina Martins}

tem uma pedra onde repousar sua cabeça (Mt 8,20). Em um sentido derivado e mais amplo, o termo "peregrino" se aplica ao viajante, sem que seja dada à sua viagem - a peregrinatio - uma conotação particular. Foi numa época bem tardia que "peregrino" apareceu com motivação religiosa.

A motivação de um peregrino para empreender uma viagem de peregrinação é ver e venerar uma relíquia num dado local, uma vez que não há lugar de peregrinação onde não haja um elemento concreto ou abstrato que possa ser objeto de veneração, de culto e de vislumbre. O termo "relíquia", que está relacionado ao verbo latino relinquĕre e pode ser traduzido pelo grego $\lambda \varepsilon i$ íava, significa “o que foi deixado para trás". De fato, as relíquias representam os restos do passado, de um acontecimento ou personagem que carregam em si um testemunho e permitem evocar sua lembrança. Isso é válido para todos os sítios bíblicos, sendo a Palestina como um todo considerada um lugar santo, pois foi lá que viveu Cristo. Efetivamente, é em torno das relíquias que estão os lugares de peregrinação, e os elementos materiais que constituem uma relíquia são os ossos de um mártir ou qualquer outro objeto relacionado a ele. Quando não há uma prova material que constitua uma relíquia, há sempre um lugar relacionado a um fato importante que atrai peregrinos e que acaba por ser considerado um lugar santo. É importante destacar que, através de investigações históricas, paleológicas e arqueológicas, torna-se possível a descoberta de uma relíquia ou a constatação da autenticidade de um lugar outrora considerado santo apenas pelo testemunho cultural. Em suma, alguns lugares são considerados santos porque contêm traços reais ou supostos dos personagens que fazem a história do Antigo e do Novo Testamento ou porque são sítios onde viveram mártires cristãos e, em seguida, os monges mais ilustres.

A peregrinação, tendo por base uma razão religiosa, pode orientarse em duas direções: uma que mantém algo do sentido primitivo, em que se destaca a viagem por si só, e outra em que o destino final ou objetivo da viagem é o mais importante para o peregrino. No primeiro caso, o peregrino se coloca como um ser errante que busca a espiritualidade através de um deslocamento perpétuo, defendendo, dessa forma, um modo de vida ascético, ainda que muitos tomem um lugar santo como destino; no segundo caso, o peregrino tem como objetivo venerar um lugar ou alguns lugares específicos de peregrinação, ou seja, os "Lugares Santos".

Convém ressaltar que podemos fazer distinção entre os locais que 
são objeto de peregrinação e os lugares de culto habituais das comunidades cristãs, em particular os lugares de culto eucarístico. No primeiro caso, o lugar atrai peregrinos pelo seu valor próprio e particular, que faz dele um lugar santo, independentemente do culto que aí se celebra. Isso se manifesta em particular pelo fato de que as peregrinações se situam fora do contexto habitual e costumeiro da prática religiosa. Esse caráter excepcional, extraordinário, evidencia-se no caso dos peregrinos que empreendem longas viagens, que partem de longe à procura dos Lugares Santos, cuja fama chegou até eles, embora também existam aqueles fiéis que partem a um lugar de peregrinação bem próximo de si. O segundo caso é o dos vários Lugares Santos de Jerusalém em que também se desenvolve a liturgia da comunidade, que, de certa forma, também "peregrina” de um local a outro conforme o que está sendo celebrado. Além disso, desenvolver-se-á o costume de se introduzirem relíquias nas igrejas destinadas ao culto ordinário, o que as levará, muitas vezes, a se tornarem autênticos lugares de peregrinação.

Seja qual for a natureza da peregrinação ou do peregrino, isto é, se ele partiu de longe ou de perto, se viaja só ou em grupo, se busca atingir um lugar em particular ou se o que importa é a viagem como um todo, a viagem é um acontecimento especial e possui traços que são comuns a qualquer peregrinação: 1) o caráter sagrado do sítio aonde se vai especialmente; 2) a importância do deslocamento - individual ou coletivo - a um dado lugar; 3 ) a obtenção de um determinado bem material ou espiritual.

Pierre Maraval, em seu livro Lieux saints et pèlerinages d'Orient, trata de modo minucioso a constituição do que se pode denominar "geografia sagrada". Obviamente, havia uma política da Igreja de se aproximar dos fiéis e, ao mesmo tempo, de lutar contra o paganismo. O que queremos dizer é que, no âmbito deste trabalho, não será possível tratar do assunto das peregrinações aos Lugares Santos de modo amplo e com a profundidade que ele merece.

\section{A peregrinação de Egéria}

Cronologicamente, a presente obra ficou conhecida pelos seguintes nomes: Sanctae Siluiae Aquitanae peregrinatio ad loca sancta, Peregrinatio Aetheriae e Itinerarium Egeriae. As variações a respeito do título da obra ocorrem por ela ter chegado até nós incompleta: faltam-lhe o começo, o fim e ainda duas folhas internas. O texto, além de não apresentar um título, é 
também anônimo e não indica o local de origem do autor. Por último, não há um consenso entre os estudiosos sobre qual seria a condição social da pessoa que realizou tal viagem. Não há dúvidas, no entanto, de que se trata de uma mulher, pois essa informação é revelada no texto: Tunc ego, ut sum satis curiosa, $[\ldots]$ "Então eu, que sou bastante curiosa, $[\ldots]$ " $(16,3)$.

$\mathrm{O}$ nome Itinerarium deve-se ao fato de terem sido escritos vários Itineraria aos Lugares Santos entre os séculos IV e VII, quase como roteiros ou guias de viagem, tais como o Itinerarium Burdigalense, o primeiro do gênero, ao qual já nos referimos. Nós, porém, preferimos usar o termo Peregrinatio, uma vez que a obra é mais que um catálogo de lugares visitados ou um guia de lugares e pousadas, característicos de um Itinerarium. Trata-se efetivamente de uma peregrinação, narrada quase como um diário de viagem, cuja motivação religiosa é bastante clara. Assim, assumindo o texto como um diário de peregrinação, optamos por denominar a obra como "Peregrinação de Egéria: uma narrativa de viagem aos Lugares Santos".

O texto divide-se em duas partes. A primeira parte (cap. 1-23) é um diário de viagem aos Lugares Santos da História Sagrada, onde são descritas quatro viagens de Egéria: 1) a peregrinação ao monte Sinai e o retorno a Jerusalém pela terra de Gessen (1-9) - como o texto se apresenta fragmentado, não sabemos qual foi o ponto de partida, mas ela parece ter iniciado a viagem no Egito e daí ter se dirigido ao Sinai (cf. cap. 9); 2) a peregrinação ao monte Nebo (10-12), onde Egéria quer contemplar, tal como Moisés, o panorama da Terra Prometida; 3) a peregrinação à Idumeia, país de Jó (13-16) - essa viagem permitiu que os peregrinos visitassem lugares onde se conservam lembranças de outros personagens bíblicos, como Melquisedec, João Batista, Elias e Jefté, como atesta o culto que lhes ofereceram nesses lugares; 4) a peregrinação à Mesopotâmia e a volta a Constantinopla, passando por Tarso, Selêucia e Calcedônia (17-23). Na segunda parte (24-49), é feita uma descrição da liturgia de Jerusalém: os ofícios feriais da semana e o ofício dominical (24-25); as festas litúrgicas da Epifania (Natal) e da apresentação de Jesus no Templo (25-26); a Quaresma, a Semana Santa, a Vigília Pascal, a Semana da Páscoa, o Tempo Pascal (chamado Quinquagésimas), a Ascensão e o Pentecostes (27-44). Ela também descreve os principais ritos da iniciação cristã, dando ênfase especial à catequese (45-47). A obra termina de modo incompleto, com a narração da festa da consagração das igrejas de Jerusalém, até o início da descrição do quarto dia de festa (48-49). 
A julgar pela interlocução estabelecida com suas amigas ou companheiras de religião, mulheres para as quais Egéria descreve enfaticamente sua alegria de vivenciar certas situações nos Lugares Santos, supõe-se que a autora sabia que seu texto chegaria às mãos dessas mulheres. O que nos leva a essa suposição é a presença de expressões como dominae uenerabiles sorores $(3,8 ; 20,5)$, affectio uestra $(5,8 ; 7,3 ; 17,2 ; 20,13 ; 24,1)$, domine uenerabiles $(12,7)$, dominae animae meae $(19,19)$, dom(i)nae lumen meum $(23,10)$ e dominae sorores $(46,1 ; 46,4)$. Isso nos remete à prática, comum entre os escritores das Antiguidades Clássica e Tardia, de enviar livros e escritos a amigos ou pessoas importantes a fim de divulgá-los, ou para pedir conselhos e correções. Era natural que os autores não assinassem suas obras, pois, na época, não se preocupavam com os direitos autorais. Isso acontecia também porque não era comum que os escritores pusessem seus livros à venda, já que a obra literária era considerada um dom gratuito. Em todo caso, no que se refere à obra de Egéria, acreditamos que o fato de ela dialogar, em certas passagens, com suas dominae ou sorores, tendo uma aparente certeza de que seu texto chegaria a elas, nos dá o testemunho da eficácia da circulação dos manuscritos no mundo romano.

A Peregrinatio Egeriae é um importante documento para a arqueologia e a história da Igreja, além de fundamental para a filologia e a liturgia comparativa. O valor da obra é inquestionável, embora ainda hoje muitas questões permaneçam em aberto, como o nome exato da autora e sua procedência ou país natal.

\section{Nome da autora e título da obra}

Como dissemos acima, o texto que possuímos, endereçado de Constantinopla às correspondentes ocidentais da autora, é anônimo. Tomou-se conhecimento do nome da autora através da carta do abade Valério de Bierzo, que viveu na Cantábria, no século VII. Na sua Epistola de laude Egeriae Virginis, Valério (apud Maraval, 2002a, p.336) menciona uma beatissima sanctimonialis Egeria, que, "apesar de sua fragilidade de mulher, partiu do extremo litoral do oceano ocidental e se fez conhecida no Oriente". Foi Férotin (apud Gingras, 1970, p.3) quem descobriu a ligação entre a carta de Valério e Egéria, pois na carta de Valério, escrita por volta de 650, há a menção de uma corajosa mulher que havia feito uma peregrinação aos Lugares Santos, muitos anos antes de sua 
época. Tem-se, em sua carta, a mesma sequência de apresentação dos Lugares Santos que se encontra na Peregrinatio, na descrição dos sítios visitados. Na verdade, há seis manuscritos dessa carta (o original, de Toledo, se perdeu: restou apenas uma cópia, que se encontra em Madri), que se repartem em duas famílias, e neles apresentam-se três formas diferentes para o nome da autora: Egeria, Eiheria e Echeria. Atualmente, os estudiosos preferem Egeria, argumentando que esse é o único nome que aparece nas duas famílias de manuscritos e que, além disso, aparece duas vezes no Codex Toletanus Egeria - códice tido como o melhor testemunho da primeira família. Eiheria é a lição mais frequente nos manuscritos da segunda família, mas, segundo estudiosos, esse nome poderia ser uma transcrição fonética do nome Egeria, da mesma forma que a transcrição fonética Echeria: tanto em Eiheria quanto em Echeria, tem-se uma aspiração no meio da palavra. Quanto à grafia Echeria, esta é uma lição duvidosa, pois o manuscrito que a continha perdeu-se. Acreditouse, até bem pouco tempo, que Aetheria ou Etheria seria o nome da peregrina, pois essas duas formas aparecem no manuscrito de Carracedo. Férotin, em um artigo intitulado "Le véritable auteur de la Peregrinatio Siluiae: la vierge espagnole Ethérie" primeiramente rejeitou o nome Egeria, porque, para ele, esse nome existia apenas como nome de uma ninfa da Antiguidade Clássica, sendo difícil que uma cristã se chamasse assim. Por fim, conjecturando que o primeiro $i$ na forma Eiheria deveria ter sido um $t$, e observando que na Espanha e na Gália havia pessoas chamadas Aetherius e Aetheria, adotou a última forma. Uma geração inteira de estudiosos, como Löfstedt, Cabrol, Heraeus, GarcíaVillada, Meister e Bludau, entre outros, aceitou a denominação de Férotin. Isso explica porque temos várias obras cujo nome para a autora é Etéria, incluindo a primeira edição brasileira.

Das variantes do nome presentes nas cópias da carta de Valério, apenas Egeria aparece em documentação independente. Uma dessas fontes independentes são catálogos do século XIII pertencentes à biblioteca de SaintMartial, em Limoges, na França, em que há a menção do título Itinerarium Egeriae (Maraval, 2002a, p.18). Outro testemunho é a citação no Liber glossarum de Ansileubus, um espanhol que escreveu, por volta de 750, um glossário onde se lê Egeriae. Por fim, o título Ingerarium Geriae aparece numa carta de Santo Rosendo, bispo de Mondoñedo. Datada de 935, essa é a carta de fundação

${ }^{6}$ Revue des questions historiques 74 (1903) 367-397, apud GINGRAS, 1970, p.4. 
da abadia de San Salvador de Celanova: a "Peregrinação de Egéria" é um dos manuscritos destinados a constituir a biblioteca de base da abadia.

\section{Identidade da autora}

Ainda hoje permanece em aberto qual seria exatamente a identidade da autora. Conforme nos explicita Maraval (2002a, p.21-23), houve várias tentativas de desvendar esse mistério. A primeira hipótese, aventada por Kohler (1884), foi a de que a autora seria filha de Teodósio, o Grande, e que seu nome seria Galla Placídia. Essa hipótese não obteve credibilidade, e em seguida Gamurrini (1885) a identificou como Sílvia, irmã de Flávio Rufino, prefeito de Constantinopla entre 393 e 395. Dessa identificação, restam os primeiros títulos atribuídos à obra, em particular o da edição de P. Geyer, de 1898. Férotin (1903) supôs igualmente ter sido a autora parente de Teodósio, por ser esse imperador originário da Galícia e ter levado sua família a Constantinopla; de fato, tendo-se em vista as datas de nascimento e morte de Teodósio (347-395) e as datas da viagem de Egéria, a hipótese é plausível. Bouvy (1903) propôs Eucheria como nome da autora e a fez parente de Eucherius, tio materno de Teodósio. Lambert (1950) aventou a hipótese de se tratar da irmã de Galla, parente de Flacilla e, além disso, priscilianista, sustentando essa afirmação em fórmulas fixas usadas por Egéria, tais como iubente Deo nostro. Nenhuma dessas identificações da autora se revelou sólida; apenas se pode dizer que ela fazia parte de uma classe social elevada, pelas condições materiais em que viajava e pelo tratamento que recebia, não só dos membros da Igreja, mas também dos funcionários imperiais que encontrava.

\section{Origem da peregrina}

Para alguns, a peregrina vem do sul da Gália (Aquitânia ou Gália Narbonense); para outros, da Galícia. Maraval (ibid., p.19) afirma que o texto não apresenta elementos suficientes para que se possa adotar uma ou outra opção. Ainda segundo o estudioso, o elogio do bispo de Edessa, que diz ter ela vindo do fim do mundo - de extremis terris $(19,5)$-, pode servir tanto para a Gália quanto para a Galícia. A observação sobre a impetuosidade do Eufrates, que a peregrina compara à do Ródano $(18,2)$, pode fazer supor que as destinatárias da sua narrativa de viagem conhecessem o rio da Gália e que, portanto, habitavam nos seus arredores, ou que ela mesma já teria passado pelo local, tendo se referido a esse rio numa carta 


\section{Maria Cristina Martins}

anterior ou na parte perdida da obra. Podemos questionar por que Egéria faria tal comparação entre os rios - talvez porque suas correspondentes fossem cultas e conhecessem o Ródano através da obra de César. Porém, mesmo que ela tenha escrito para correspondentes que habitavam próximo ao Ródano, isso não implica, necessariamente, que ela própria fosse originária desse local.

\section{Condição social da autora}

As opiniões divergem entre considerar a peregrina uma freira - já que em algumas passagens ela se dirige às suas sorores -, ou uma dama da alta sociedade, a exemplo de Paula e Marcela, pertencentes ao círculo religioso e cultural conduzido por São Jerônimo. O que nos resta do texto não nos permite afirmar com certeza que a autora era uma religiosa.

Porém, uma evidência de que ela pode ter sido uma freira é a carta de Valério, em que ele se refere à autora da viagem como uma beatissima sanctimonialis "religiosa bem-aventurada". Poderíamos imaginar que essa informação estivesse contida no manuscrito que Valério tinha em mãos, que era mais completo do que aquele que chegou até nós. Há ainda outros indícios de que Egéria pode ter sido uma religiosa, seja pelo seu interesse pela vida dos monges e as frequentes visitas a mosteiros, seja pelo encontro com a diaconisa Martana (23,3), dirigente de um convento de freiras em Selêucia, além do fato de ser acolhida pelos monges em seus mosteiros e lá pernoitar (cf. 3,1$)$ e de descrever em detalhes a liturgia de Jerusalém.

Um argumento extra em favor da identidade religiosa de Egéria é sustentado por Bastiaensen (1962, p.23-24). Segundo ele, o próprio vocabulário empregado pela autora sugere que ela é uma freira: ela utiliza a palavra laicus em oposição a monachus, o que não é usual no latim cristão, uma vez que neste a oposição de laicus se faz em relação a clericus. Baseando-se nessa particularidade lexical e na carta de Valério, Bastiaensen afirma que ela teria sido uma uirgo sacra e que, com certeza, escrevia para outras religiosas. Arce (1980, p.67-69), baseando-se na carta de Valério, afirma que Egéria foi, sem dúvida, uma freira, pois o abade não se referiria arbitrariamente a ela através do termo sanctimonialis.

Mohrmann (apud Maraval, 2002a, p.26), por sua vez, afirma que Egéria não mostra um comportamento de alguém que leve uma vida ascética e que, lendo a obra, percebe-se que a autora é alegre e otimista, sem disposição à 
penitência. Essas características levam Mohrmann a pensar que Egéria não era uma freira. Além de usar os mesmos argumentos de Mohrmann, Maraval afirma que a liberdade que Egéria tinha para viajar e fazer suas escolhas tende à suposição de que ela não fosse uma freira, embora Arce (ibid.) afirme que as freiras daquela época não estavam sujeitas à clausura, mas tinham liberdade para sair de sua casa ou mosteiro e comunicar-se com o mundo, como faziam em Alexandria, no tempo do bispo Atanásio (328-373), conforme esse mesmo bispo informa.

Para sustentar a hipótese de que Egéria não era uma freira, Maraval apresenta outros dois argumentos. O fato de que ela usa o termo sorores (“irmãs”, "irmãs na fé") para se dirigir às suas correspondentes não assegura que ela seja uma freira: em primeiro lugar, o sentido monástico desse termo não é atestado em nenhum outro texto do século IV e, em segundo lugar, mesmo que suas correspondentes fossem religiosas, não quer dizer que Egéria também o fosse. Além disso, a forma como Egéria era recebida por bispos, monges e funcionários imperiais, além das condições materiais da viagem, com escolta e animais de carga, nos leva a pensar que ela pertencia à alta sociedade, porém com características espirituais de uma pessoa religiosa.

Por fim, o fato de Egéria jamais fazer alusão a uma condição de vida semelhante à dos monges com os quais se encontrava durante a viagem nos permite duvidar que ela fosse uma monja. Uma hipótese bastante plausível é a de que ela pertencesse a um círculo cultural e religioso, tal como o que São Jerônimo presidia, mais ou menos na sua época, e do qual faziam parte damas da alta sociedade, que muitas vezes se tornavam religiosas mais tarde, a exemplo de Paula (Santa Paula), sua filha Eustóquia e Marcela. De fato, nessa época havia um grande número de leigos entre os peregrinos que visitavam os Lugares Santos - inclusive São Jerônimo escreveu algumas cartas, como a 47, em que incentiva os cristãos ocidentais a irem em peregrinação a Jerusalém.

\section{Data da viagem}

A partir das pesquisas realizadas até hoje, foram propostas as seguintes datas para a viagem de Egéria: 1) a década de 380; 2) o fim do séc. IV (mais precisamente, após 394) ou os primeiros anos do séc. V; 3) a metade do séc. VI. Como nos explica Maraval (2002a, p.27ss), atualmente devemos a Paul Devos, a partir de uma série de artigos bem fundamentados, o estabelecimento do período da viagem, a qual teria se realizado entre 381 e 384 .

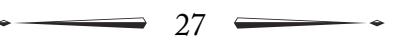


O próprio texto de Egéria nos fornece o terminus post quem, ou seja, a observação de que ela não pôde visitar Nísibis porque essa cidade estava em poder dos persas (cf. 20,12): de fato, foi em 363 que os persas se apoderaram de Nísibis. O terminus ante quem da viagem seria o meio do século VI, pois a situação encontrada no Sinai é anterior a 557, data na qual o mosteiro-fortaleza de Santa Catarina foi erguido por ordem de Justiniano. ${ }^{7}$ Além disso, a estadia de uma semana em Antioquia, no caminho de volta, indica que ainda não haviam ocorrido as destruições causadas pelo rei persa Cosroes I, em 540, senão Egéria as teria relatado.

O elemento decisivo para a datação da viagem nos é fornecido pelo relato do encontro de Egéria com os bispos de Batânis $(19,1)$, Edessa $(19,5)$ e Carra (20,2). Ela não nomeia os bispos, mas os qualifica como "confessores", título que naquela época possuía um sentido muito específico: era concedido aos bispos por sua firmeza durante as perseguições ou na luta pela ortodoxia católica. Ou seja, os bispos confessores são os que sofreram pela fé, sem morrer nos tormentos (ao contrário dos mártires). O termo latino confessor, assim

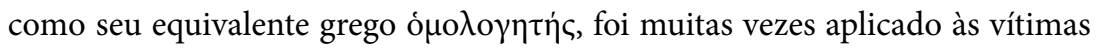
da perseguição ariana de Valente. Os três bispos referidos pela autora, que sabemos serem Eulógio de Edessa, Protógenes de Carra e Abraão de Batânis, possuíam o título de confessores no período entre 381 e 387, portanto a viagem de Egéria não pode ter ocorrido antes de 381 ou depois de 387. Assim, podemos datar a viagem à Mesopotâmia entre a instalação de Protógenes em Carra, ocorrida em meados de 381, e a data da morte de Eulógio, em 387.

Por fim, há ainda uma forte evidência em favor de a viagem ter ocorrido entre 381 e 384: Egéria não se refere à tradicional festa da Ascensão do Senhor, que ocorre no $40^{\circ}$ dia após a Páscoa. No capítulo 42, Egéria descreve a celebração do $40^{\circ}$ dia após a Páscoa, em Belém, precisando que lá se orava de maneira apropriada ao dia e local. Essa celebração, dentro do período correspondente a 381-384, houve apenas em 383, ano em que caiu em 18 de maio. O Leccionário Armênio (apud Maraval, 2002a, p.35), que é datado por volta de 439 e tido como a segunda fonte que descreve a liturgia de Jerusalém a primeira é Egéria -, assinala nessa data uma celebração litúrgica em honra aos Santos Inocentes, em Belém. H. Leclercq (apud Mariano e Nascimento, 1998, p.233) destaca que Egéria não se refere à festa da Ascensão, que ocorre no $40^{\circ}$

\footnotetext{
${ }^{7}$ BENEŠEVIČ, V. Sur la datation de la mosaïque de la Transfiguration au Mont Sinaï. In: Byzantion 1, 1924, p.146-153. Apud MARAVAL, 2002a, p.29.
} 
dia depois da Páscoa, e que esse fato não foi suficientemente bem explicado até hoje. No entanto, admitindo-se a realização da festa dos Santos Inocentes nessa data, justifica-se que não tenha sido mencionada a festa da Ascensão, uma vez que esta teria sido substituída pela festa dos Santos Inocentes.

Em resumo, a datação proposta por Devos (1967) somada a essas explicações derruba as outras datações propostas antes dele.

\section{Língua, estilo e fontes da obra}

A língua latina de que Egéria faz uso foi e ainda é objeto de numerosos estudos, inclusive o que apresentamos nesta edição crítica, tendo sido esse uso da língua o impulso inicial para a realização da nossa pesquisa. Para os filólogos, a obra é considerada uma das principais fontes para a reconstituição e o estudo do latim vulgar e dos romances primitivos, isto é, das fases iniciais das futuras línguas românicas. Segundo Prinz (apud Maraval, 2002a, p.51), a língua de Egéria é um latim de coloração vulgar e, sem dúvida, esse é o aspecto mais estudado da obra, sendo que, no nosso entender, a contribuição de Väänänen (1987) é a mais importante. Não podemos deixar de mencionar, entretanto, a notável obra de Löfstedt, escrita em alemão (edições de 1911 e 1936, com tradução italiana em 2007), sobre os aspectos filológicos da obra.

Embora possamos dizer que o latim de Egéria espelha muito do que se convencionou chamar "latim vulgar", sobretudo com relação à sintaxe e à tendência analítica desse latim em comparação à tendência sintética do latim clássico, vemos a convivência de duas variantes da língua latina: a popular ou "vulgar" e a literária ou "clássica". Muitas dessas características vulgares são apresentadas nas notas filológicas que fazem parte da nossa edição crítica. Apenas para citar como exemplo, observa-se, do ponto de vista clássico, um abundante emprego de verbos depoentes, que nunca fizeram parte da língua falada, sem contar a sintaxe dos casos e a morfologia dos nomes, que, com exceção de alguns deslizes da autora, é essencialmente clássica.

Um importante estudo sobre o estilo da obra é o de Leo Spitzer. No artigo intitulado "The epic style of the pilgrim Aetheria” (apud Gingras, 1970, p.45; Maraval, 2002a, p.52), a Peregrinatio é tratada do ponto de vista de seu gênero literário, que, segundo o autor, é o gênero da peregrinação, que possui um estilo próprio. Assim, Spitzer não considera certas características do texto como sendo de um latim mal escrito, como, por exemplo, o uso excessivo de 


\section{Maria Cristina Martins}

demonstrativos, as numerosas repetições, além da falta de uma única citação de autores clássicos. Para ele, o único propósito da autora foi enfatizar a realidade concreta de tudo o que tinha sido mostrado pelos guias e tudo o que ela tinha testemunhado em sua viagem. De fato, qualquer leitor atento percebe que a repetição de palavras tem como objetivo fazer com que o leitor se coloque no mesmo lugar onde ela estava e sinta as emoções que ela sentia.

Spitzer destaca algumas caraterísticas presentes na narrativa que, segundo ele, fazem uma tentativa de idealização, em que o individual está subordinado à verdade que esse individual representa. Por exemplo, durante todo o texto, a autora não cita nenhum nome próprio de seus contemporâneos, a não ser o da diaconisa Martana - nome citado posteriormente em "Os milagres de Santa Tecla", obra datada do século V -, mantendo anônimas todas as pessoas que encontra: guias, monges, bispos e demais informantes. Ademais, quase todas as ações da narrativa são descritas com a voz passiva impessoal, que põe foco nas ações e não nos agentes. Ou seja, as coisas não são descritas individualmente, mas em termos de seu valor atemporal. Conforme Spitzer, a obra apresenta um estilo particular e não clássico, perfeitamente representativo do seu gênero, antecipando o estilo de certas formas literárias medievais.

Estamos de acordo com a análise apresentada por Leo Spitzer e acrescentamos que essa tentativa de idealização está presente no objetivo do próprio peregrino, que busca atingir uma condição mais elevada, uma graça, uma ascensão espiritual através de sua jornada. Isso se coloca em um nível místico superior, em que os agentes materiais ou concretos não tomam parte, pois a experiência mística é pessoal.

Quanto à fonte das citações bíblicas que constam no texto de Egéria, podemos dizer com certeza que a Bíblia da qual ela se serviu foi a versão préVulgata, ou seja, a Vetus Latina, pois a tradução realizada por São Jerônimo é um pouco posterior, do início do século $\mathrm{V}$.

\section{Transmissão do texto}

Encontrado na biblioteca da Fraternità dei Laici, importante instituição da cidade italiana de Arezzo, em 1884, por Gian Francesco Gamurrini, seu primeiro editor e comentador, o texto faz parte de um códice do século XI, hoje chamado Codex Aretinus (405), copiado no mosteiro de Monte Cassino, 
também na Itália. Todas suas edições provêm desse único códice manuscrito, que é apógrafo - copiado por um copista -, e não autógrafo - escrito pelo próprio autor. O códice, em escritura beneventana, é composto de 37 folhas de pergaminho e contém três textos: nas folhas 1 a 13, o Tractatus de Mysteriis de Santo Hilário de Poitiers, nas folhas 14 e 15, os Hymni, do mesmo autor, e, nas folhas 16 a 37, o texto da peregrinação de Egéria.

Gamurrini não teve dificuldades para identificar a data aproximada em que foi copiado o manuscrito, assim como sua origem. A escritura beneventana é originária de um lugar específico - a região de Benevento, da qual o mosteiro de Monte Cassino é o principal expoente, tendo sido nesse local que São Bento de Núrsia criou a Ordem dos Beneditinos (ca. 529) - e de um período específico - entre os séculos IX e XII. No entanto, pelas particularidades de escrita que existem nos dois textos, vê-se que foram copiados por amanuenses diferentes. Assim como a narrativa de Egéria, a obra de Santo Hilário também está incompleta.

Outro elemento que ajudou a identificar a origem do manuscrito foi o fato de Pedro Diácono, bibliotecário de Monte Cassino no início do século XII, ter-se servido nitidamente do texto de Egéria como um roteiro para escrever seu livro sobre os Lugares Santos, o De Locis Sanctis, sem nunca ter viajado a esses lugares. Gamurrini percebeu que as páginas finais do livro de Pedro Diácono eram compostas de excertos dos primeiros sete capítulos da parte que nos restou do relato de Egéria. Uma vez que na obra de Pedro Diácono não apenas há muitas paráfrases da Peregrinatio na descrição dos Lugares Santos, mas também a descrição de lugares que estão ausentes do texto da peregrina, temos motivos para pensar que ele possuía um exemplar da obra mais completo que o nosso. No entanto, além de Egéria, Pedro Diácono serviu-se ainda de outras fontes, dentre elas o tratado de São Beda, o Venerável, sobre os Lugares Santos, datado do século VIII, que facilmente pode ser identificado em alguns trechos do De Locis Sanctis. Por último, também alguns escritos anônimos serviram de guia para Pedro Diácono poder escrever sua obra sem nunca ter ido à Palestina.

No início do século XVII, o manuscrito foi levado à abadia das santas Flora e Lucila de Arezzo, por meio do abade Ambrogio Rastrellini, que assumiu a direção dessa abadia em 1610, após ter dirigido o mosteiro de Monte Cassino, entre 1599 e 1602. Em 1810, o governo francês fechou as portas da abadia, o que provocou a dispersão da biblioteca e, desse modo, o manuscrito chegou ao local onde Gamurrini o encontrou. 
Em 1909, De Bruyne, no artigo "Nouveaux fragments de l'Itinerarium Eucheriae" (apud Maraval, 2002a, p.41), publicou alguns fragmentos descobertos em um manuscrito de Madri do século IX (Bibl. Nat. Toletanus 14,24). Esses fragmentos são apresentados como uma série de breves instruções topográficas retiradas do relato de Egéria, as quais seguem a ordem do texto conhecido, e duas dentre essas instruções supostamente correspondem a partes perdidas do manuscrito. Uma delas provavelmente foi retirada da descrição de Faran, local próximo ao monte Sinai. Com efeito, a parte do texto que nos restou começa com a visita de Egéria ao monte Sinai, e ela própria dá a entender que havia passado por Faran para chegar ao Sinai: "para nós, portanto, que íamos daquele ponto onde fizéramos a oração ao chegar de Faran, assim foi o caminho: que atravessássemos pelo meio a entrada do vale e assim chegássemos à montanha de Deus" $(2,4)$. A segunda instrução do fragmento de Madri fornece uma informação sobre o túmulo de Jó, que podemos encaixar na lacuna que há no meio do capítulo 16, provocada pela ausência de um fólio. As passagens do fragmento de Madri que podemos comparar ao texto de Egéria mostram que as citações do autor do fragmento não são literais.

O trecho do fragmento de Madri que pode ser encaixado no capítulo 16 é o seguinte:

In loco illo ubi Iob sedebat in stirquilinio, modo locus mundus est, per girum cancellis ferreis clusum, et candela uitrea magna ibi lucet de sero ad serum. Fontem uero ubi testa saniam radebat quater in anno colorem mutat, primum ut purulentum habeat colorem, semel sanguineum, semel ut fellitum et semel ut limpida sit (apud Maraval, 2002a, p.194).

"Naquele lugar onde Jó sentava no estrume, agora é um lugar limpo, fechado em volta por grades de ferro e uma grande candeia de vidro aí brilha de entardecer a entardecer. Na verdade, a fonte, onde ele raspava o pus com um caco, muda de cor quatro vezes ao ano, primeiro para uma cor purulenta, depois para sanguínea, depois para a cor do fel e depois se torna límpida” (tradução nossa).

Como dissemos acima, no item em que tratamos do nome da autora, outra breve menção de Egéria é fornecida pelo Liber glossarum, escrito por um espanhol chamado Ansileubus, datado aproximadamente de 750, onde podemos ver registrado, numa das margens, o nome Egeriae como sendo uma 
de suas fontes. Nesse item, também nos referimos à carta do monge Valério (séc. VII) e ao tratado sobre os Lugares Santos, de Pedro Diácono (séc. XII), que são as principais obras que constituem a tradição indireta do relato da peregrinação de Egéria. A carta de Valério permitiu preencher certas lacunas a respeito da obra - é a ele que devemos a identificação da peregrina da obra descoberta por Gamurrini -, pois Valério possuía um texto mais completo que o nosso. Sua contribuição, no entanto, é limitada: basicamente nos deu a conhecer o possível nome da peregrina - "Egéria", que aparece no título da carta e duas vezes no texto - e mencionou que a mesma saiu dos confins do Ocidente para ir à Terra Santa. Na carta, de um estilo que se conhece como um "elogio retórico", evocam-se as viagens de uma peregrina, bastante elogiada por sua fé e coragem.

\section{Legado da obra do ponto de vista filológico e cultural}

O texto de Egéria é um documento primordial para o estudo das transformações do latim, seja no contexto da filologia clássica ou da filologia românica. Também é uma importante fonte para a arqueologia, geografia, história da Igreja e liturgia. Porém, a riqueza de informação que a obra contém será melhor apreciada se a entendermos dentro do objetivo religioso e específico que motivou a viagem da peregrina.

Conforme comentamos mais acima, no item "As peregrinações do século IV", o peregrino é movido por um desejo de reviver os acontecimentos da Bíblia, narrados em locais determinados e que são suas verdades de fé. Além de buscar a revitalização de sua fé, o peregrino busca uma recompensa material ou espiritual através do contato com as relíquias existentes nos Lugares Santos. No século IV, eram constantes as viagens de habitantes do mundo grecoromano para visitar os locais do nascimento, da morte e da ressurreição de Cristo, além das numerosas igrejas e santuários existentes desde a época de Constantino. Assim, Egéria se comporta como um verdadeiro peregrino, mas sua narrativa acrescenta muito mais informações do que as dos peregrinos de seu século, como o peregrino de Bordéus, que praticamente apenas indica uma lista de pontos de parada e distâncias entre esses pontos, enquanto que Egéria, quando se refere à distância, limita-se a dizer o número de dias necessários para alcançar determinado destino, optando por dar mais ênfase à descrição dos lugares que visita. 
Há certos relatos da viagem de Egéria que se constituem como os primeiros testemunhos de alguns fatos bíblicos. Por exemplo, sua descrição do monte Sinai faz com que o mesmo seja identificado com o monte que atualmente se chama Djebel Musa. Egéria também é uma das fontes que confirma a antiga tradição de se situar a travessia do Mar Vermelho por Moisés perto da atual cidade de Suez (embora atualmente se considere que a travessia teria se realizado nos Lagos Amargos, que ficam mais ao norte no Egito). Além disso, segundo pesquisadores da Bíblia, o texto fornece dados sobre quais foram as etapas de parada (mansiones) realizadas pelos filhos de Israel em sua fuga do Egito, ajudando a precisar a localização de algumas cidades, tais como Pitom, a greco-romana Herópolis e a cidade de Arábia, um centro administrativo e episcopal egípcio durante a Antiguidade Tardia.

Ademais, nenhuma outra fonte se refere ao culto de um certo Santo Helpídio, em Carres. A obra também mostra o interesse dos peregrinos na veneração das santas Tecla e Eufêmia e é testemunha da importância de evangelhos apócrifos (Atos de São Tomé e Atos de São Paulo e Santa Tecla), além da lenda da correspondência entre Abgar e Cristo, na cultura religiosa daquele tempo e lugar.

\section{A liturgia em Jerusalém}

A segunda parte do relato de Egéria, dos capítulos 24 a 49, trata da liturgia diária e do ciclo do ano litúrgico em Jerusalém. Embora a ênfase religiosa não seja o propósito de nossa edição crítica, não podemos negar que foi essa segunda parte da obra que recebeu maior atenção nos últimos anos, sobretudo pelas informações topográficas das primeiras igrejas cristãs de Jerusalém e arredores. Não foram poucos os estudiosos que se dedicaram ao estudo da liturgia e das igrejas citadas por Egéria. Cabrol (apud Gingras, 1970, p.23), por exemplo, enfatiza que cada um dos ofícios do dia ou cada uma das festas do ano eram celebrados em uma igreja ou local particular.

Destacamos anteriormente que a liturgia em Jerusalém assemelhavase a uma peregrinação local (em Jerusalém e arredores), já que os ofícios eram realizados de igreja em igreja. A segunda parte da narrativa de Egéria é justamente um testemunho nesse sentido. Seis igrejas desempenhavam o papel mais importante na liturgia: a Basílica do Santo Sepulcro e a Igreja de Sião, ambas dentro dos muros de Jerusalém; Imbomon e Eleona, duas igrejas 
situadas no Monte das Oliveiras; a Basílica da Natividade, em Belém; a Igreja de Lázaro, ou Lazário, em Betânia. Egéria nunca se refere pelo nome à Basílica da Natividade, mas menciona ofícios realizados na igreja de Belém, "igreja na qual está a gruta onde nasceu o Senhor” (cap. 42). O Lazário servia como sede para o ofício solene do sábado anterior ao Domingo de Ramos, o Sábado de Lázaro.

Um leitor atento poderia praticamente reconstruir o plano da Basílica do Santo Sepulcro a partir das referências da autora aos vários ofícios realizados em cada espaço que faz parte desse complexo estrutural: a Anástase, o Martyrium e a Cruz. Do oeste para o leste, encontramos, primeiro, a Anástase ou Igreja da Ressurreição, em cujo centro se encontra a gruta do Santo Sepulcro e onde uma missa diária era celebrada. Em seguida, se encontra o átrio da Cruz, um pátio interno circundado por pórticos em três lados, com o lado leste ligado ao coro da igreja do Martyrium, a igreja principal do complexo. Esse amplo pátio ao ar livre, chamado Ante Crucem, caracterizava-se pela presença de uma cruz, no suposto local da crucificação de Jesus, e servia de sede para certos rituais sazonais e para os elaborados ritos de despedida das vésperas diárias. Atrás da cruz havia uma capela chamada Post Crucem, onde era realizada a missa da Quinta-feira Santa e era venerado o santo lenho da cruz na Sexta-feira Santa. O Martyrium, uma igreja com cinco naves e uma abside no extremo oeste, era a igreja principal ou "igreja maior" (ecclesia maior) de Jerusalém, onde a missa de domingo era celebrada. Frequentemente chamada no texto de "a igreja no Gólgota", o Martyrium situavase sobre a gruta onde foi encontrada a Verdadeira Cruz de Cristo. Egéria não menciona o pátio a leste do Martyrium e apenas uma vez refere-se às portas principais que constituem parte do propileu, ou seja, a entrada ornamentada com colunas, situada no extremo leste da basílica, que se abria para o meio da rua do mercado, o qual era chamado de quintana $(43,7)$.

A igreja de Sião era a sede da liturgia da quarta e da sexta-feira durante todo o ano. Uma pequena capela havia sido construída no monte Sião, situado a sudoeste de Jerusalém. Por volta do ano 130 e entre 335 e 347, essa estrutura original havia sido ampliada pelo acréscimo de uma basílica. São Cirilo de Jerusalém (313-386) refere-se à igreja de Sião como o local tradicional do Cenáculo, onde a Eucaristia foi instituída e os apóstolos receberam o Espírito Santo. Essa era a igreja reservada à liturgia principal de Pentecostes.

No cume do Monte das Oliveiras, ficava a igreja chamada Imbomon, marcando o lugar da ascensão de Cristo. Descendo a encosta a partir desse lugar, encontrava-se a igreja do Eleona, construída sobre a gruta onde o Senhor 


\section{Maria Cristina Martins}

ensinou os apóstolos durante a primeira Semana Santa. Nessas duas igrejas, iniciava-se a procissão do Domingo de Ramos, eram comemorados os eventos da Quinta-feira Santa, e realizados importantes ofícios litúrgicos durante o período de Páscoa e na tarde do Domingo de Pentecostes.

Através do relato fornecido por Egéria, temos um panorama geral da liturgia em Jerusalém, bem como dos locais em que ela acontecia, e sabemos que havia orações, hinos e salmos específicos para cada lugar visitado e, ainda, que eram apropriados para cada ocasião, embora não tenhamos a indicação precisa a respeito de quais fossem tais orações, salmos e hinos praticados. Tal como nos referimos na seção em que falamos sobre as peregrinações, verificamos que a liturgia em Jerusalém era uma espécie de peregrinação local, já que o ofício não era celebrado em um único lugar, mas em várias igrejas, grutas e lugares ao ar livre, desde que tivessem ligação com os acontecimentos sobre Jesus narrados na Bíblia. Além disso, podemos ter uma ideia da quantidade de pessoas que participavam dos rituais. De um modo geral, os ofícios matutinos e noturnos eram monásticos, mas os vespertinos tinham a participação de todo o povo, incluindo uma grande quantidade de crianças. Aos domingos, a multidão era tão grande quanto no dia de Páscoa. No Domingo de Ramos, Pentecostes e na noite de Quinta-feira Santa, uma multidão se deslocava do Monte das Oliveiras a Jerusalém: Egéria afirma que, no dia de Pentecostes, nenhum cristão permanecia em casa $(43,4)$.

Em toda a segunda parte da obra, há oito tópicos principais relacionados à liturgia em Jerusalém. São eles: 1) a liturgia diária, ou seja, vigília, ofício da manhã, sexta hora, nona hora e lucernário $(24,1-7) ; 2)$ a liturgia de domingo, composta por três ofícios: o primeiro é realizado antes do cantar do galo, na frente da Anástase, no qual os fiéis, entoando hinos e rezando, esperam a chegada do bispo; o segundo é a vigília, realizada dentro da Anástase, a partir do primeiro cantar do galo; e o ofício da manhã, na aurora, realizado no Martyrium $(24,8-25,6) ; 3)$ a Epifania, composta pela vigília, ofícios do dia, a oitava e a festa da Apresentação $(25,6-26)$; 4) as festas pascais: Quaresma, ofícios da liturgia diária quaresmal (os de domingo e de todos os dias da semana), regras dos jejuns, particularmente os rigorosos jejuns praticados pelos ascetas (27-28), o Sábado de Lázaro, o Domingo de Ramos, a liturgia da Semana Santa (da segunda-feira ao sábado) (29-38), a liturgia de Páscoa e o período de Páscoa (39-41); 5) a festa da Quadragésima, correspondente ao $40^{\circ}$ dia após a Páscoa (42); 6) Pentecostes e a liturgia do tempo após Pentecostes 
(43-44); 7) a instrução dos catecúmenos para o batismo (45-47); 8) a festa da Consagração da Basílica do Santo Sepulcro (48-49).

Egéria segue uma ordem na apresentação dos rituais litúrgicos em Jerusalém. Inicia expondo as cerimônias que eram realizadas diariamente e, em seguida, volta-se às que eram celebradas todos os domingos. Há uma lacuna no texto, na metade do capítulo 25,6, mas mesmo assim é relatado o que acontecia semanalmente às quartas e sextas-feiras. Finalmente, Egéria cita as grandes festas e o ciclo sazonal da liturgia que acontecia anualmente. Além disso, ela nos dá uma noção da estrutura do culto na Igreja de Jerusalém daquela época - que se distinguia da que existe hoje - e do estágio de desenvolvimento da liturgia, tanto para a época quanto para o local específico.

Aparentemente, cinco ofícios distintos aconteciam em Jerusalém na liturgia dos dias de semana: ofícios noturnos e matutinos, ofícios da sexta e da nona hora, e as vésperas. Egéria não chega a se referir ao ofício diário da terceira hora, ainda que se refira a um ofício na terceira hora durante a Quaresma. Porém, há testemunhos de que esses ofícios eram realizados diariamente e durante todo o ano, desde o século II (cf. Tertuliano, De Oratione, 25; Jerônimo, Epistula 108, 20, apud Gingras, 1970, p.28).

Quanto aos termos empregados para o ofício, a terminologia é semitécnica, pois o vocabulário empregado na liturgia não estava fixado nessa época. Não se sabe com clareza em que sentido o próprio termo missa estava sendo empregado. Para a maioria dos tradutores, trata-se da "despedida" da missa e não da "cerimônia" chamada missa. Dentre as lacunas do vocabulário litúrgico está o nome do ofício da noite. Ele é referido de várias formas, como ocorrendo na vigília ao cantar do galo (de pullo primo vigiletur), ou como o ofício realizado ao cantar do galo (ad pullorum cantum), ou simplesmente na vigília (ad uigilias). O ofício da manhã recebe um nome indiretamente, pois Egéria classifica seus hinos como matutinos hymnos, e a despedida desse ofício é referida como missa matutina. Os ofícios da manhã são ocasionalmente referidos como ofícios ad lucem "na aurora", ad mane "de manhã" ou ad lucescere “ao amanhecer”. As vésperas são o "lucernário" (lucernarium ou lucernare), e os ofícios das nonas e sextas são referidos por expressões variadas, sugerindo que não havia termos próprios para designá-los.

Através do relato da peregrina, sabemos que o serviço da vigília e o ofício da manhã eram justapostos um ao outro $(24,1)$. O primeiro era realizado por religiosos - as partenas e os monazontes - e assistido por uns poucos leigos, dois 
ou três padres e um mesmo número de diáconos, os quais recitavam orações após cada hino ou salmo. O ofício da manhã, que era completamente público, seguia-se logo após o serviço da vigília e era presidido pelo bispo e assistido pelo clero, pelos fiéis e pelos catecúmenos. Os serviços da sexta e da nona hora eram presididos pelo bispo, que fazia uma oração e benzia os fiéis $(24,3)$.

O ritual diário de oração coletiva em Jerusalém era mais completo no lucernário ou vésperas - serviço realizado aproximadamente duas horas antes de anoitecer, momento em que se acendem as luzes -, quando uma grande multidão, incluindo muitas crianças, reunia-se na Anástase para um serviço com estrutura similar ao ofício da manhã, mas apresentado por Egéria com mais detalhes, parecendo mais importante. O bispo se sentava para participar do canto com os clérigos, ao passo que, no ofício da manhã, ele permanecia na gruta do Santo Sepulcro, de pé, atrás da balaustrada. Além disso, no lucernário a prece comemorativa parecia ter uma forma mais solene. $\mathrm{O}$ canto de hinos, salmos e antífonas e uma série de comemorações e ritos prolongados de bênçãos e despedidas caracterizavam ambos os serviços. A estrutura das comemorações do ofício das vésperas se desenvolveu em uma litania recitada pelo diácono (à qual respondiam as crianças), seguida de uma prece feita pelo bispo (à qual respondiam todos os fiéis), de duas bênçãos (dos catecúmenos e dos fiéis) intercaladas por uma prece, e da despedida.

A estrutura da vigília de domingo intrigou e dividiu os liturgistas (Gingras, 1970, p.30), pois, antes da vigília propriamente dita, uma multidão esperava pela abertura das portas da igreja, bem cedo, muito antes do cantar do galo, horário em que se abriam as portas. O povo cantava hinos e salmos, e a oração era conduzida por presbíteros e diáconos, que já estavam preparados para a vigília. Tudo isso, então, assumia as proporções de um ofício litúrgico. Ao cantar do galo, quando o bispo chegava, as portas da Anástase eram abertas e acontecia, então, o ofício aberto a toda a comunidade. Eram cantados três hinos, cada um deles seguido por uma oração, era lida a passagem da Bíblia referente à ressurreição do Senhor e, logo após, havia uma procissão até a Cruz, onde, então, eram realizados os ritos de despedida $(24,10)$.

Aparentemente, pelo que se depreende através do texto, um ofício era celebrado duas vezes aos domingos na Basílica do Santo Sepulcro, primeiramente no Martyrium e depois na Anástase. Muitos estudiosos de liturgia divergem quanto à natureza dessa cerimônia. Leclercq (apud Gingras, 1970, p.31), por exemplo, pensa que havia apenas uma missa de catecúmenos, ou seja, para os 
ainda não batizados, no Martyrium, enquanto Bludau (ibid.) interpreta que o serviço da Anástase era simplesmente uma ação de graças. Seja como for, não temos condições de saber exatamente o que era a missa naquele tempo. Certamente a missa, ou cerimônia religiosa, era diferente da atual, pois não só era itinerante, tal como uma pequena peregrinação de local em local, como também havia restrições para a participação ou não dos fiéis e catecúmenos. Vale dizer que Egéria relata que existiam ofícios reservados apenas aos clérigos. Nos capítulos 27, 41 e 44, podemos reconstruir uma característica adicional da liturgia de Jerusalém, que é a celebração em todas as quartas e sextas-feiras de uma cerimônia na igreja de Sião, exceto durante a Quaresma. O horário dessa cerimônia variava: nos dias comuns, a cerimônia religiosa ocorria à nona hora, isto, é no meio da tarde, enquanto que, durante o período da Páscoa e nos dias da festa de um mártir, ocorria de manhã.

A descrição do ano litúrgico começa com a Epifania, celebrada no Oriente como a festa da Natividade. A falta de um fólio do manuscrito, que deveria estar interpolado no meio do capítulo 25,6, nos impossibilita de saber o que a autora poderia ter relatado sobre o ano litúrgico. Todavia, podemos conhecer os locais que sediavam as etapas das cerimônias e saber que essa celebração durava a noite inteira, como uma vigília. Além disso, sabe-se através de Egéria que a decoração das igrejas de Belém e Jerusalém era bastante rica, repleta de ouro, mosaico e mármore $(25,9)$ - tal decoração acentuava a pompa da festa.

Uma das contribuições inéditas da obra de Egéria é sua referência à festa da Apresentação de Jesus no Templo, que ocorria 40 dias após a Epifania. Igualmente, ela é a única testemunha de que, no século IV, a Quaresma era celebrada durante oito semanas em Jerusalém (27,1). Segundo Maraval (2002a, p.257), não há nenhum outro documento que contradiga ou que confirme esse testemunho.

A ordem e o tipo de ofícios realizados nas primeiras sete semanas da Quaresma diferiam do ritual semanal normal em três pontos: havia um ofício na terceira hora em todos os dias de semana; a habitual missa da tarde era substituída pela liturgia da palavra (sermões, orações e salmodia); havia uma vigília que durava toda a noite às sextas-feiras, culminando numa celebração eucarística pouco antes do amanhecer. A oitava semana, ou seja, a Semana Santa, era marcada por numerosas cerimônias de representação, que começavam no sábado anterior ao Domingo de Ramos, o Sábado de Lázaro. Na sétima semana da Quaresma, o local da vigília da noite de sextafeira era transferido da Anástase, onde havia sido realizada durante as seis 
semanas anteriores, para a igreja de Sião. Na manhã de sábado, após a missa, era anunciada a procissão a Betânia para comemorar o Sábado de Lázaro. Nesse rito rememorativo, dois diferentes acontecimentos do ministério de Cristo eram revividos: a invocação de Cristo para a ressurreição de Lázaro e a ida de Cristo a Betânia na véspera de sua entrada triunfal em Jerusalém. A procissão observava uma parada numa pequena igreja, onde as irmãs de Lázaro se encontraram com Cristo, e então dirigia-se a Betânia, onde uma grande multidão se juntava a ela $(29,4-5)$.

Egéria é quem primeiro descreve a imitação dramática da entrada de Jesus em Jerusalém, rito que veio a se tornar uma das principais contribuições da Igreja de Jerusalém à liturgia (cap. 31). A ênfase estava claramente na imitatio, pois o bispo fazia o papel de Jesus, sendo levado da mesma maneira como Jesus havia sido conduzido (cf. Mt 21,8): et sic deducetur episcopus in eo typo, quo tunc Dominus deductus est, "e assim o bispo é conduzido do mesmo modo pelo qual então o Senhor foi conduzido". O ritual começava na sétima hora (por volta da $1 \mathrm{~h}$ da tarde), quando todo o povo se reunia em Eleona, no Monte das Oliveiras. À nona hora (por volta das $3 \mathrm{~h}$ da tarde), todos iam a Imbomon, local da Ascensão, onde na décima primeira hora (por volta das $5 \mathrm{~h}$ da tarde) era feita a leitura correspondente ao Domingo de Ramos, conforme São Mateus. Uma procissão descia lentamente o Monte das Oliveiras, com o povo cantando o refrão "Bendito o que vem em nome do Senhor" $(31,2)$ e crianças carregando galhos de oliveira e ramos de palmeiras. A procissão marchava por toda a cidade e terminava o trajeto na Anástase, onde era celebrado o ofício de vésperas. Não há relatos sobre a bênção dos ramos, e a procissão se apresenta como um rito independente da missa do Domingo de Ramos, à qual ele foi posteriormente vinculado. Egéria fornece detalhes sobre as mudanças no ritual habitual da Quaresma durante a Semana Santa, tanto em relação aos ofícios quanto aos locais em que eram realizados.

A autora enfatiza duas características da Quinta-feira Santa: a celebração da missa no Martyrium e depois na Cruz, e a vigília durante toda a noite em várias estações no Monte das Oliveiras. O mais notável dessa liturgia é a ausência de uma estação de parada em Sião, local tradicionalmente ligado à Santa Ceia - o Leccionário Armênio (apud Gingras, 1970, p.37), do século V, menciona uma parada em Sião, em que a principal leitura bíblica era a narração da instituição da Eucaristia segundo São Paulo. Podemos pensar que a ausência de um relato sobre essa estação em Egéria indicaria a falta de uma tradição em 
sua época vinculando a instituição da Eucaristia a Sião. Todavia, Thibaut (ibid.) sugere que a celebração na Cruz foi motivada por um desejo de acentuar a união do sacrifício do altar com o sacrifício da cruz.

Durante a vigília da noite de Quinta-feira Santa, rememorava-se a fala de Cristo aos apóstolos na gruta que se encontra na igreja de Eleona e, à meia-noite, uma procissão ia a Imbomon para um ofício de orações, salmos e leituras (35,34); ao cantar do galo, a vigília culminava com uma procissão para o local onde o Senhor orou, onde ocorria um ofício e, daí dirigia-se a Getsêmani, local onde era lida a passagem do Evangelho em que o Senhor foi preso - Egéria descreve a emoção do povo, que gemia, gritava e chorava com a leitura desse passo $(36,3)$. A procissão então voltava a Jerusalém e atravessava a cidade, indo até a Cruz (Post Crucem), onde era lida a passagem do Evangelho em que Cristo é apresentado a Pilatos e se narra tudo aquilo que este disse ao Senhor e aos judeus $(36,4)$.

A liturgia da Sexta-feira Santa era caracterizada por uma cerimônia solene e por um extenso ofício da palavra. Por volta das 8 horas da manhã até o meio-dia, os fiéis veneravam o santo lenho da cruz $(36,5)$. O relato de Egéria da adoração da Verdadeira Cruz é o primeiro testemunho que temos desse rito. Ao meio-dia, começava um ofício de três horas diante da Cruz, que consistia em leituras do Antigo e do Novo Testamento que tratam da Paixão do Senhor. Esse ofício terminava com a leitura do passo de São João em que é narrado que o Senhor entregou o Seu espírito (37,7). Depois, havia o ofício de vésperas no Martyrium, seguido de uma procissão à Anástase, onde se lia o passo do Evangelho em que José de Arimateia pede a Pilatos o corpo do Senhor para sepultá-lo. Seguia-se uma vigília durante toda a noite.

A preparação de candidatos adultos para o batismo era um aspecto importante do período da Quaresma. Nos capítulos 45 e 46, Egéria narra os ritos que acompanhavam a instrução dos candidatos antes do batismo formal na vigília da Páscoa. O costume de batizar apenas pessoas adultas, e não crianças, é um dos aspectos que se diferenciam dos ritos da Igreja Católica atual. Temos esse testemunho também em São Jerônimo, igualmente do século IV. Segundo Egéria, no primeiro dia da Quaresma, o catecúmeno que tivesse dado seu nome era formalmente aceito como um competens "competente", isto é, como um candidato ao batismo. O candidato inscrito recebia a catequese, durante três horas por dia, de segunda a sexta-feira. Depois de cinco semanas do início da instrução catequética, os candidatos recebiam, da mesma pessoa por quem tinham sido ensinados (46,3), o Symbolum - o Símbolo ou Credo, 
a afirmação dos dogmas da Igreja -, e após duas semanas de seu recebimento recitavam-no ao bispo $(46,5)$.

Outra particularidade relatada por Egéria é o fato de os candidatos entrarem acompanhados pelo padrinho, no caso do homem, e pela madrinha, no caso da mulher $(45,2)$, e de as testemunhas serem interrogadas pelo bispo a respeito da conduta moral dos que se apresentavam ao batismo. Caso o bispo ouvisse alguma falha de conduta do candidato, mandava-o sair dizendo: "Que se corrija e, quando tiver se corrigido, que se dirija ao banho <batismal>" $(45,4)$. Durante os oito dias que se seguiam da Páscoa até sua oitava, ou seja, o domingo seguinte, os recém-batizados iam em procissão à Anástase para receber instrução naqueles mistérios da fé que não tinham sido revelados aos catecúmenos $(47,1)$.

A liturgia da semana de Páscoa, ou dos oito dias pascais, tinha um caráter estacional. No domingo, na segunda e na terça-feira, a missa era celebrada pela manhã no Martyrium, na quarta-feira, no Eleona, na quinta-feira, na Anástase, na sexta-feira, em Sião, no sábado, na Cruz e, no domingo, no Martyrium. Nessa semana de Páscoa, em todas as tardes havia uma procissão ao Monte das Oliveiras $(39,3)$, onde era realizado um ofício de orações e hinos, tanto em Eleona quanto em Imbomon, após o qual seguia-se o lucernário na Anástase. Finalmente, duas cerimônias lembravam acontecimentos do Evangelho que aconteceram no dia de Páscoa e na sua oitava: no domingo de Páscoa, depois do lucernário, ia-se à igreja de Sião, onde era lido o passo do Evangelho de São João que narra a primeira aparição de Cristo aos discípulos após a Ressurreição e a incredulidade de São Tomé (39,5); na oitava de Páscoa, havia uma cerimônia similar em Sião, lembrando a segunda aparição de Cristo e sua repreensão ao discípulo incrédulo $(40,2)$.

Como já explicamos anteriormente, no item "Data da viagem", Egéria não menciona a ocorrência da tradicional festa da Ascensão do Senhor, observada no $40^{\circ}$ dia após a Páscoa, mas narra apenas uma celebração litúrgica em Belém, o que poderia indicar que a festa da Ascensão fora substituída por essa celebração (que, segundo o Leccionário Armênio, teria sido em honra aos Santos Inocentes). Em todo caso, muitos estudiosos da liturgia buscaram desvendar esse assunto, mas as tentativas de explicação não são conclusivas (Gingras, 1970, p.41).

No dia de Pentecostes, a duração da liturgia excedia à de qualquer outro dia de festa descrito por Egéria: o ritual da manhã de domingo era realizado 
na Anástase e no Martyrium, a despedida era feita cedo o suficiente para que a congregação se reunisse à terceira hora ( 9 h da manhã) em Sião, e aí, na hora e local tradicionalmente associados à descida do Espírito Santo, havia leituras apropriadas ao dia e ao lugar e era celebrada a missa.

A última festa do ano litúrgico da Igreja descrita por Egéria é a dupla comemoração das Encênias ou Consagração da Basílica do Santo Sepulcro (englobando o Martyrium, a Anástase e a Cruz), e a descoberta da Verdadeira Cruz. Essa festa era celebrada em oito dias, de domingo a domingo, começando em 13 ou 15 de setembro, a partir do ano de 335. Infelizmente, o manuscrito termina de modo incompleto, no momento em que Egéria começava a descrever o quarto dia de festa. Certamente Egéria deve ter descrito todos os dias da festa.

\section{Principais edições da obra}

As duas primeiras edições da Peregrinatio devem-se a Gamurrini. A editio princeps é de 1887, realizada três anos após a descoberta do manuscrito, na qual Gamurrini transcreveu todas as obras que fazem parte do Codex Aretinus (405). Assim, seguindo a ordem apresentada no manuscrito, a primeira edição de Gamurrini contém o "Tratado dos Mistérios e Hinos” (Tractatus de Mysteriis et Hymni) de Santo Hilário, seguido da "Peregrinação aos Lugares Santos de Santa Sílvia da Aquitânia" (Sanctae Siluiae Aquitanae: Peregrinatio ad Loca Sancta), e como apêndice segue-se ainda o livro "Dos Lugares Santos" (De Locis Sanctis), de Pedro Diácono. Em 1888, Gamurrini publicou uma segunda edição do relato de Egéria no periódico Studii e documenti di storia e diritto 9, p.97-174 e, no mesmo ano, publicou-o isoladamente, pela editora do Vaticano. Na primeira edição, Gamurrini propôs algumas correções ao texto e, na segunda, acrescentou mais correções, provavelmente por influência de outros filólogos. Alguns problemas de transcrição persistem nas duas edições, tal como a transcrição do ditongo $a e$, escrito de forma abreviada, o que nem sempre foi percebido por Gamurrini. Justamente, há divergências até hoje nos editores modernos quanto à transcrição do pronome relativo quae, que em algumas edições está grafado que e, em outras, quae.

Depois da segunda edição de Gamurrini, Pomialovsky publicou uma nova edição (1889), com tradução para o russo, seguindo o texto latino estabelecido na segunda edição de Gamurrini, mas incorporando muitas correções de Cholodniak, que estudara o manuscrito original. Em 1898, surgiu

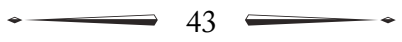


a apurada edição de Geyer, que transcreveu novamente o manuscrito, fazendo muitas correções para torná-lo mais inteligível e mais adequado às normas do latim clássico. Durante muito tempo, a edição de Geyer foi adotada por outros editores e tradutores, devido justamente à correção que ele realizou no estabelecimento do texto latino, embora atualmente as edições bilíngues procurem manter o texto latino, tanto quanto possível, fiel ao manuscrito, não incorporando correções. Após ter examinado o manuscrito, Heraeus, em suas quatro primeiras publicações $(1908,1921,1929,1939)$ e na quinta $(1960)$, editada por Prinz, também anotou muitas variantes e correções. Em 1949, surgiu a renomada edição crítica de Hélène Pétré, em texto bilíngue latimfrancês, tendo por base o estabelecimento do texto latino de Geyer. Em 1958, a editora Brepols, que editou o Corpus Christianorum, publicou no tomo 175 da Series Latina a edição crítica de Franceschini-Weber. Após essas, seguem-se por ordem cronológica as seguintes edições críticas europeias, todas bilíngues e abundantes em notas histórico-religiosas: a edição espanhola de Agustin Arce (1980), a francesa de Pierre Maraval (1982 e 2002), a catalã de Janeras (1986), a italiana de Natalucci (1991) e a portuguesa de Mariano e Nascimento (1998).

A edição crítica que apresentamos é a primeira que incorpora uma análise filológica do texto latino. Além disso, apresenta em anexos um glossário de termos históricos, geográficos e culturais e uma cópia do manuscrito, apócrifo e único, redigido na escritura beneventana.

\section{Edição crítica}

O trabalho de reconstrução total ou parcial de um texto, assim como a determinação e o esclarecimento dos aspectos relevantes do mesmo, é a meta de uma edição crítica. Essa meta se estende da crítica textual, cujo objeto é o próprio texto, até as questões históricas e literárias. De acordo com Lachmann (1793-1851), a quem devemos a ciência da crítica textual, esse método envolve os seguintes passos: recensio (recensão), collatio codicum (comparação dos códices), originem detegere (estemática ou genealogia dos manuscritos) e emendatio (correção). Na crítica histórico-literária, ele reconhece os seguintes passos: autenticidade ou autoria, datação, fontes, circunstâncias, sorte, unidade e integridade, linguagem do texto, avaliação crítica e exegese.

Tendo-se em mãos uma cópia do manuscrito, datado do século XI, e um total de doze importantes edições críticas europeias modernas, iniciamos

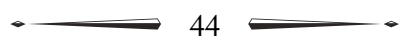


a comparação dos diversos códices ou edições já existentes, ou seja, a collatio codicum. Esse trabalho de comparação das diversas edições críticas entre si e delas em relação ao manuscrito único teve por objetivo o estabelecimento ou fixação do nosso próprio texto latino, fundamental para a edição crítica. A fim de podermos realizar a leitura direta do manuscrito, ademais, foi necessário fazer o estudo da escritura beneventana, o tipo de escrita medieval em que o manuscrito foi redigido. É importante ressaltar que a leitura cuidadosa do manuscrito possibilitou descobrir que, em relação a três palavras do manuscrito, todas as edições críticas analisadas transcreveram-nas erroneamente. As notas de edição crítica, na forma de notas de rodapé, abaixo do texto latino estabelecido, apontam as divergências encontradas entre as diversas edições críticas e o manuscrito.

Além dessas notas de edição crítica, nosso trabalho é enriquecido por notas de caráter filológico, gramatical e linguístico que pontuam determinados itens lexicais, mostrando sua diferença em relação ao latim clássico e explicitando o que já se apresenta como germe formador das línguas românicas. Também consta da nossa edição crítica um glossário, constituído de palavras em que há uma especialização de sentido, originando assim um termo, e de certas palavras que necessitam de uma melhor contextualização histórica, filosófica, religiosa, geográfica etc. Tanto as notas histórico-literárias, apresentadas como notas de rodapé, como as palavras do glossário são parte da exegese do pormenor, a última etapa do trabalho filológico de uma edição crítica.

\section{Critérios de tradução e de transcrição do manuscrito}

Comentamos, brevemente, que muitos críticos já se preocuparam em descrever o estilo de Egéria, bem como a variedade de latim em que ela escreveu. Nós mesmos tentamos enumerar os vários aspectos linguísticos presentes na obra. Em função das experiências que a autora pretende transmitir enquanto peregrina, percebe-se que o texto produzido reflete sua intenção de mostrar, com clareza e simplicidade, o que está sendo vivenciado. Por isso, a autora usa em abundância algumas expressões que servem para despertar a atenção do leitor para os fatos e emoções vividos, que ela tenta manifestar através de palavras. A excessiva repetição de termos e de partículas enfáticas torna o texto latino menos cuidado do ponto de vista literário.

Em termos gerais, distinguem-se dois tipos de tradução: uma que se prende mais fielmente ao significado e ao estilo do texto de partida, e outra que 
se apresenta mais interpretativa e menos preocupada com a fidelidade rigorosa ao texto original. Chamamos a primeira de tradução literal e a segunda, de tradução livre. Na tradução que realizamos, preferimos manter tudo o que se encontrava no original, mesmo que isso tenha acarretado um texto em português aparentemente truncado, ou seja, mal escrito ou não harmonioso. Tivemos como objetivo, justamente, manter o estilo do texto latino, com suas imperfeições e características gerais, sobretudo porque nos propusemos a realizar um estudo linguístico e filológico do latim em que foi escrita a obra. Nesse sentido, a nossa tradução foi a mais literal possível e não a que produzisse um texto mais apurado em português, porém distante do original. Para ilustrar o critério de tradução literal aqui seguido, vejam-se os sintagmas in eo ergo loco (cf. 1,2; 4,4;4,8; 6,3;10,9), itaque ergo (cf. 2,$3 ; 5,1 ; 10,2$ ), ac sic ergo (o mais abundante, usado 31 vezes; cf. 3,$2 ; 3,7 ; 4,7 ; 4,8 ; 5,3 ; 5,8$ ) e at ubi autem (cf. 25,8 ; 29,$3 ; 33,2$ ), que são usados repetidamente e cuja tradução nem sempre seria necessária. Além dessas expressões, que são empregadas em abundância, como se fossem fórmulas fixas, há muitas outras construções sintáticas prolixas que fazem parte do próprio estilo da autora.

Entretanto, há casos de justaposição de partículas sinônimas impossíveis de serem traduzidas todas ao mesmo tempo. Nec non etiam et, por exemplo, foi traduzido como "e nem", “como também", "não só, mas também”. Outro aspecto que nos obrigou a fugir de uma tradução literal diz respeito ao uso do subjuntivo em latim, que nem sempre pudemos conservar em português. $\mathrm{Na}$ maior parte das vezes, precisamos traduzir as orações temporais pelo modo indicativo, como neste exemplo: Cum ergo descendissemus, ait nobis ille sanctus presbyter "Quando, pois, descêramos, nos falou esse santo presbítero" $(14,2)$. Ainda a respeito de tempos e modos verbais, convém dizer que nem sempre nos pareceu ser a melhor escolha manter no português a tradução do infinitivo empregado nas orações subordinadas substantivas de acusativo com infinitivo. Em 2,7 Illud sane satis admirabile est et sine Dei gratia puto illud non esse "É realmente admirável, e eu creio que não acontece sem a graça de Deus", por exemplo, não o mantivemos na tradução, ao passo que em passagens como a seguinte, conseguimos manter a tradução do infinitivo perfeito: 12,7 columna autem ipsa dicitur mari Mortuo fuisse quooperta "a própria coluna dizem ter sido coberta pelo Mar Morto".

No que diz respeito aos critérios de transcrição do manuscrito, servimonos do livro The beneventan script, de E.A. Loew, no qual é apresentada a

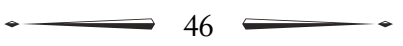


história da escritura beneventana dos séculos VIII a XIII e descrito o aspecto morfológico não só das letras, mas também dos números, das ligaduras, das abreviaturas e dos sinais de pontuação específicos de cada século da escritura beneventana, exemplificados com base nos principais manuscritos. Para desdobrar as abreviaturas utilizadas no texto de Egéria, seguimos as indicações de Loew, mas nem sempre a nossa interpretação segue as dos outros editores, 0 que pode ser verificado nas notas de edição crítica.

Uma das grandes variações entre os editores é a transcrição do ditongo $a e$, escrito de forma abreviada, em que o $a$ é representado como uma cedilha ligada à curva inferior do $e$, tal como o que se vê neste que: presente em 27,4. Na nota de edição crítica $n^{\circ} 391$, por exemplo, temos a seguinte distribuição de transcrições: Gamurrini, Geyer, Heraeus, Pétré e Prinz - quae, conforme o manuscrito; Franceschini-Weber, Arce, Maraval, Janeras, Natalucci e Mariano - que, em desconsideração ao sinal de abreviatura. Outro exemplo de oscilação entre $e$ ou $a e$ ocorre na transcrição da abreviatura do prefixo prae - $\bar{F}$-, tal como em 13,2, em que o prae de praestare está escrito nessa forma abreviada. Os diversos editores dividem-se entre a transcrição de Gamurrini (1887), que interpreta prestare - Franceschini-Weber, Arce, Maraval, Janeras, Natalucci -, e a transcrição de Gamurrini (1888), que é praestare - Geyer, Heraeus, Pétré, Prinz, Mariano. De fato, essa abreviatura é usada tanto para abreviar um prae quanto um pre, pois também aparece na abreviação da forma verbal prendet, em 24,10. Em todos os casos em que houve uma variação entre os editores na interpretação de uma abreviatura do manuscrito, em que uns optaram pela transcrição vulgar e outros pela clássica, optamos sempre pela transcrição da forma clássica.

Paralelamente ao que ocorre nas variações quae/que e prae/pre para um mesmo elemento gráfico da escritura beneventana, verificam-se variações também do pronome mihi, que no manuscrito aparece onze vezes escrito em sua forma abreviada: th้s. Essa é a forma consagrada na escritura beneventana para representar o pronome pessoal mihi do latim clássico. No entanto, porque no texto encontramos 16 ocorrências da forma michi, escrita por extenso, podemos conjecturar que a forma abreviada represente, na verdade, michi; de fato, não encontramos nenhuma ocorrência de mihi por extenso. Sabemos que por volta do século XI, época em que foi copiado o manuscrito, já havia alguns textos das diversas línguas românicas. Porém, uma pessoa letrada, como era o copista, deveria saber latim e conhecer as duas variantes da língua, a popular e a 
clássica. Talvez michi fosse a forma falada pelo copista, o que o levou a registrála por extenso. Assumimos que a abreviatura mostrada acima é a transcrição da forma clássica do dativo de ego - mihi - e mantivemos essa coerência ao longo da transcrição, ao contrário da maioria dos editores, que a transcrevem ora como mihi ora como michi, com exceção de Natalucci, que acredita que a abreviatura representa michi. 


\section{Bibliografia}

\section{Manuscrito}

Codex Aretinus (405) (anteriormente Codex Aretinus VI,3), século XI. Arezzo: Biblioteca da Sociedade Fraternità dei Laici.

\section{Edições críticas}

ARCE, A. Itinerario de la virgen Egeria (381-384). Madrid: La Editorial Católica, 1980. (Biblioteca de Autores Cristianos, 416).

FRANCESCHINI, E.; WEBER, R. Itinerarium Egeriae. In: ITINERARIA ET ALIA GEOGRAPHICA. Turnhout, v.175, p.27-90, 1965. (Corpus Christianorum, Series Latina).

GAMURRINI, G.F. Sancti Hilarii, tractatus de mysteriis et hymni, et Sanctae Siluiae Aquitanae, peregrinatio ad loca sancta quae inedita ex codice arretino deprompsit. Romae: P. Puggiani, 1887.

. Sanctae Siluiae aquitanae peregrinatio ad loca sancta. Editio altera, nouis curis emendata. Romae: T. Vaticanis, 1888.

GEYER, P. Sanctae Siluiae quae fertur peregrinatio ad loca sancta. In: ITINERA HIEROSOLYMITANA SAECULI IIII-VIII. Vindobonae: Academia Litterarum Caesarea, 1898. (Corpus Scriptorum Ecclesiasticorum Latinorum, 39).

HERAEUS, W. Siluiae uel potius Aetheriae peregrinatio ad loca sancta. Heidelberg: Carl Winter, 1921. (Sammlung Vulgärlateinischer Texte, 1).

JANERAS, S. Egèria: Peregrinatge. Barcelona: Fundació Bernat Metge, 1986.

MARAVAL, P. Égérie: journal de voyage. Paris: Les Éditions du Cerf, 2002a. (Sources Chrétiennes, 296).

MARIANO, A.; NASCIMENTO, A. Egéria: viagem do Ocidente à Terra Santa no séc. IV. Lisboa: Colibri, 1998.

NATALUCCI, N. Egeria: pellegrinaggio in Terra Santa. Firenze: Nardini, 1991.

PÉTRÉ, H. Éthérie: journal de voyage. Paris: Les Éditions du Cerf, 1948. (Sources Chrétiennes, 21).

POMIALOVSKY, J. Peregrinatio ad loca sancta saeculi IV. São Petersburgo: Scripta Societatis Rossicae Palaestinensis, 1889.

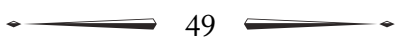


PRINZ, O. Itinerarium Egeriae (Peregrinatio Aetheriae). Heidelberg: Carl Winter, 1960. (Sammlung Vulgärlateinischer Texte, 5).

\section{Obras de apoio}

ALMENDRA, A.M.; FIGUEIREDO, J.N. Compêndio de gramática latina. Porto: Porto Editora, 2003.

BASSETTO, B.F. Elementos de filologia românica. São Paulo: Edusp, 2001.

. Elementos de filologia românica: história interna das línguas românicas. São Paulo: Edusp, 2010.

BASTIAENSEN, A.A.R. Observations sur le vocabulaire liturgique dans l'Itinéraire d'Égérie. Utrecht: Dekker et Van de Vegt, 1962.

BERNARD, J.-H. The pilgrimage of S. Silvia of Aquitania to the Holy Places circa 385 A.D. Tradução, introdução e notas, com um apêndice de Sir C.W. Wilson. Londres, 1891. (Palestine Pilgrim’s Text Society, 16).

BÍBLIA. Latim. Biblia Sacra iuxta uulgatam uersionem. Editio quinta. Stuttgart: Deutsche Bibelgesellschaft, 2007.

BÍBLIA. Português. Bíblia de Jerusalém. São Paulo: Paulus, 2002.

BÍBLIA. Português. Bíblia sagrada. Petrópolis: Vozes, 1985.

BOURCIEZ, E. Éléments de linguistique romane. Paris: Klincksieck, 1967.

BROOKE, A.E.; MCLEAN, N. (Ed.). The Old Testament in Greek. 4 v. According to the text of Codex Vaticanus, supplemented from other uncial manuscripts, with a critical apparatus containing the variants of the chief ancient authorities for the text of the Septuagint. New York: Cambridge University Press, 2009.

COMPÊNDIO DO CATECISMO DA IGREJA CATÓLICA (CCIC). Tradução de Orlando Moreira e Marcelo Perine. São Paulo: Loyola, 2005.

COUTINHO, I.L. Gramática histórica. Rio de Janeiro: Livraria Acadêmica, 1973.

DEVOS, P. La date du voyage d'Égérie. In: Analecta Bollandiana, Bruxelles, v.85, p.165194, 1967.

Une nouvelle Égérie. In: Analecta Bollandiana, Bruxelles, v.101, p.43-66, 1983.

DÍAZ Y DÍAZ, M.C. Antología del latin vulgar. Madrid: Gredos, 1962.

DUCHESNE, L. Origines du culte chrétien: étude sur la liturgie latine avant Charlemagne. Paris: Thorin, 1889.

ELIA, S. Preparação à linguística românica. Rio de Janeiro: Ao Livro Técnico, 1979.

ERKELL, H. Zur sogenannten 'Peregrinatio Aetheriae'. In: Eranos, v.56, p.41-58, 1958. Recensão da edição de O. Prinz. In: Gnomon, v.33, p.805-807, 1961.

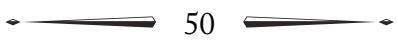


ERNOUT, A. Morphologie historique du latin. Paris: Klincksieck, 1989.

ERNOUT, A.; THOMAS, F. Syntaxe latine. Paris: Klincksieck, 1993.

FONDA, E. A síntese orgânica do 'Itinerarium Aetheriae'. Faculdade de Filosofia, Ciências e Letras, Universidade do Estado de São Paulo (UNESP), Assis, 1966.

GINGRAS, G.E. Egeria: diary of a pilgrimage. Mahwah, New Jersey: The Newman Press, 1970. (Ancient Christian Writers, 38)

HAVET, L. Règles pour éditions critiques. Paris: s.n., 1911.

HERRERO, V.J. Introducción al estudio de la filología latina. Madrid: Gredos, 1965.

LAUSBERG, H. Linguística românica. Tradução de Marion Ehrhardt e Maria Luísa Schemann. Lisboa: Fundação Calouste Gulbenkian, 1981. Título original: Romanische Sprachwissenschaft.

LOEW, E.A. The beneventan script: a history of the south Italian minuscule. Oxford: OUP, 1914.

LÖFSTEDT, E. Commento filologico alla "Peregrinatio Aetheriae": ricerche sulla storia della lingua latina. Tradução, notas e apêndice de Paolo Pieroni. Bologne: Pàtron, 2007. Título original: Philologischer Kommentar zur "Peregrinatio Aetheriae".

LYONS, J. Introdução à linguística teórica. São Paulo: Companhia Editora Nacional, 1979.

MARAVAL, P. Le temps du pèlerin. Le temps chrétien de la fin de l'Antiquité au Moyen Âge. Paris, C.N.R.S., 1984.

. Égérie et Grégoire de Nisse, pèlerins aux lieux saints de Palestine. In: Atti del Convegno Internazionale Sulla 'Peregrinatio Egeriae': nel centenario della publicatione del Codex Aretinus (405) (già Aretinus VI,3), Arezzo, 23-25 ottobre, 1987. Arezzo: Accademia Petrarca di Lettere, Arti e Scienze, 1990a, p.243-304.

. Grégoire de Nysse, Lettres. Introduction, texte critique, traduction, notes et index. Paris: Les Éditions du Cerf, 1990b. (Sources Chrétiennes, 363).

. Jerônimo: tradutor da Bíblia. Tradução de Mariana N. R. Echalar. São Paulo: Paulinas, 1998. Título original: Petite vie de Saint Jérôme.

. Récits des premiers pèlerins chrétiens au Proche-Orient ( $\mathrm{IV}^{\mathrm{e}}-\mathrm{VII}{ }^{\mathrm{e}}$ siècle). Paris: Les Éditions du Cerf, 2002b. (Sagesses Chrétiennes)

. Lieux saints et pèlerinages d'Orient: histoire et géographie des origines à la conquête arabe. Paris: Les Éditions du Cerf, 2004.

MAURER JR., T.H. A unidade da România ocidental. São Paulo: Universidade de São Paulo (USP) - Faculdade de Filosofia, Ciências e Letras, 1951. (Boletim 126, Filologia Românica $n^{\circ} 2$ ).

. Gramática do latim vulgar. Rio de Janeiro: Acadêmica, 1959. (Biblioteca Brasileira de Filologia, 16). 
MAURER JR., T. H. O problema do latim vulgar. Rio de Janeiro: Acadêmica, 1962. (Biblioteca Brasileira de Filologia).

MEILLET, A.; VENDRYES, J. Traité de grammaire comparée des langues classiques. Paris: Ancienne Edouard Champion, 1928.

MEILLET, A. Esquisse d'une histoire de la langue latine. Paris: Klincksieck, 1933.

MENÉNDEZ PIDAL, R. Orígenes del español: estado lingüístico de la península Ibérica hasta el siglo XI. Madrid: Espasa Calpe, 1950.

MEYER-LÜBKE, W. Introducción a la lingüistica románica. Madrid: Publicaciones de la RFE, 1926.

\section{0.}

Romanisches Etymologisches Wörterbuch (REW). Heidelberg: Carl Winters,

MILLER, S.M.; HUBER, R.V. A Bíblia e sua história: o surgimento e o impacto da Bíblia. Barueri: Sociedade Bíblica do Brasil, 2006.

NEIDERMANN, M. Précis de phonétique historique du latin. Paris: Klincksieck, 1959.

NOVAK, M. Peregrinação de Etéria: liturgia e catequese em Jerusalém no século IV. Petrópolis: Vozes, 1971.

NUNES, J.J. Compêndio de gramática histórica portuguesa. Lisboa: Livraria Clássica Editora, 1969.

OUSTINOFF, M. Tradução: história, teoria e métodos. São Paulo: Parábola Editoral, 2011.

RIEMANN, O. Syntaxe latine. Paris: Klincksieck, 1927.

SALUM, I. A problemática da nomenclatura semanal românica. Tese (Concurso) - Faculdade de Filosofia, Letras e Ciências Humanas, Universidade de São Paulo (USP), São Paulo, 1968.

SCHILTE, R.; BIGUENET, J. Theories of translation: an anthology of essays from Dryden to Derrida. Chicago: The University of Chicago Press, 1992.

SILVA NETO, S. História do latim vulgar. Rio de Janeiro: Ao Livro Técnico, 1977.

SPINA, S. Introdução à edótica: crítica textual. São Paulo: Cultrix, 1994.

TAGLIAVINI, C. Le origini delle lingue neolatine: introduzione alla filologia romanza. Bologna: Pàtron, 1962.

TOVAR, A. Gramática histórica latina: sintaxis. Madrid: Aguirre, 1946.

VÄÄNÄNEN, V. Le latin vulgaire des inscriptions pompéiennes. Helsinki: Annales Academiae Scientiarum Fennicae, 1937.

Latin, langue parlée et langue écrite: réactions et régressions. In: Linguistique et Philologie Romanes: Actes du $\mathrm{X}^{\mathrm{e}}$ Congrès International de Linguistique et Philologie Romanes, Strasbourg, 23-28 avril 1962. Paris: Klincksieck, 1965.

. Introduction au latin vulgaire. Paris: Klincksieck, 1981. 
VÄÄNÄNEN, V. Le journal-épittre d'Égérie (Itinerarium Egeriae): étude linguistique. Helsinki: Suomalainen Tiedeakatemia, 1987.

VALERIUS DU BIERZO. Lettre sur la Bienheureuse Égérie. Introduction, texte et traduction par M.C. Díaz y Díaz. In: MARAVAL, P. Égérie: journal de voyage. Paris: Les Éditions du Cerf, 2002. (Sources Chrétiennes, 296).

WEBER, R. Note sur le texte de la 'Peregrinatio Aetheriae'. In: Vigiliae Christianae, Amsterdam, v.6, p.178-82, 1952.

WISTRAND, E. Textkritisches sur 'Peregrinatio Aetheriae'. Göteborg: Wettergren och Kerber, 1955.

WÖLFFLIN, E. Über die Latinität der 'Peregrinatio ad loca sancta'. In: Archiv für lateinische Lexikographie und Grammatik, Leipzig, v.4, p.260, 1887.

\section{Dicionários e enciclopédias}

BAILLY, A. Dictionnaire grec-français. Paris: Hachette, 1963.

BLAISE, A. Dictionnaire latin-français des auteurs chrétiens. Turnhout: Brepols, 1954. . Le vocabulaire latin des principaux thémes liturgiques. Turnhout: Brepols, 1966.

CHANTRAINE, P. Dictionnaire étymologique de la langue grecque: histoire des mots. Paris: Klincksieck, 1999.

DU CANGE, C.D. Glossarium mediae et infimae latinitatis. 7 v. Parisiis: Instituti Regii Franciae Typographi, 1840. Disponível em: <http://gallica.bnf.fr $>$. Acessado em 02 de fevereiro de 2015.

ERNOUT, A.; MEILLET, A. Dictionnaire étymologique de la langue latine: histoire des mots. Paris: Klincksieck, 2001.

FARIA, E. Dicionário latino-português. Belo Horizonte, Rio de Janeiro: Garnier, 2003.

FOUILLOUX, D. et al. Dictionnaire culturel de la Bible. Paris: Perrin, 2010.

GAFFIOT, F. Dictionnaire illustré latin-français. Paris: Hachette, 1934.

HAMMOND, N.G.L.; SCULLARD H.H. The Oxford classical dictionary. Oxford: Clarendon Press, 1970.

MALHADAS, D.; DEZOTTI, M.C.C.; NEVES, M.H.M. Dicionário grego-português. Cotia: Ateliê Editorial, 2006.

MARTIGNY, J.-A. Dictionnaire des antiquités chrétiennes: contenant le résumé de tout ce qu'il est essentiel de connaître sur les origines chrétiennes jusqu'au moyen-âge. Paris: Hachette, 1877. Disponível em: <http://catalogue.bnf.fr>. Acessado em 02 de fevereiro de 2015.

SARAIVA, F. Novíssimo dicionário latino-português. Belo Horizonte: Livraria Garnier, 1993.

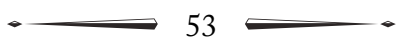




\section{Maria Cristina Martins}

SMITH, W., LLD. Dictionary of Greek and Roman Geography. Illustrated by numerous engravings on wood. London. Walton and Maberly, Upper Gower Street and Ivy Lane, Paternoster Row; John Murray, Albemarle Street. 1854. Disponível em: <http://www. perseus.tufts.edu/>. Acessado em 16 de dezembro de 2014.

THE CATHOLIC ENCYCLOPEDIA. Desenvolvido por: Kevin Knight, 2012. Disponível em: <http://www.newadvent.org/cathen/>. Acessado em 16 de dezembro de 2014.

TORRINHA, F. Dicionário latino-português. Porto: Gráficos Reunidos, 2003.

\section{Abreviaturas e símbolos do aparato de crítica textual}

A Codex Aretinus (405), saeculum XI.

Arce A. Arce ed., 1980.

Bast A.A.R. Bastiaensen, Observations sur le vocabulaire liturgique dans l'Itinéraire d'Égérie, 1962.

Bern J.-H. Bernard ed., 1891.

Chol M. Cholodniak (in editione Pomialovsky), 1899.

Devos P. Devos, Une nouvelle Égérie, 1983.

Duch L. Duchesne, Origines du culte chrétien, 1889.

Erk1 H. Erkell, Zur sogenannten 'Peregrinatio Aetheriae', 1958.

Erk2 H. Erkell, recensio editionis O. Prinz, 1961.

FrW E. Franceschini et R. Weber ed., 1965.

Gam1 G. F. Gamurrini, editio princeps, 1887.

Gam2 G. F. Gamurrini, editio altera, 1888.

Geyer P. Geyer ed., 1898.

Her W. Heraeus ed., 1908.

Jan S. Janeras ed., 1986.

Löfst E. Löfstedt, Commento filologico alla 'Peregrinatio Aetheriae', 2007.

MaN A. Mariano et A. Nascimento ed., 1998.

Mar P. Maraval ed., 2002. 
Nat N. Natalucci ed., 1992.

Pétré H. Pétré ed., 1948.

Pom J. Pomialovsky ed., 1889.

Prinz O. Prinz ed., 1960.

Vään V. Väänänen, Le Journal-Épître d'Égérie, 1987.

Weber R. Weber, Note sur le texte de la 'Peregrinatio Aetheriae', 1952.

Wistr E. Wistrand, Textkritisches sur 'Peregrinatio Aetheriae', 1955.

Wöl E. Wölfflin, Über die Latinität der 'Peregrinatio ad loca sancta', 1887.

add. addidit

coni. coniecit

corr. correxit, correctio

del. deleuit

edd. editiones (maior pars)

om. uerbum omissum

*** indicação do número aproximado de caracteres ausentes no texto latino

$<>\quad$ palavra(s) acrescentada(s)

[ ] palavras(s) suprimida(s)

$\dagger \quad$ A cruz indica que o editor interpreta que há omissão de uma ou mais palavras no texto latino.

[31] a [74] Os números entre colchetes presentes no corpo do texto latino indicam a paginação do manuscrito, no exato local onde ocorre a troca de fólio. 
Texto e tradução

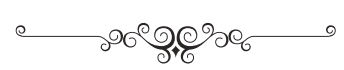




\section{Prima Pars}

\section{Textus ad fidem codicis Aretini 405}

\section{[Multa desunt]}

1.1. (...) [31] ostendebantur iuxta Scripturas. Interea ambulantes peruenimus ad quendam locum, ubi $\operatorname{sex}^{1}$ tamen montes illi, inter quos ibamus, aperiebant et faciebant uallem infinitam, ingens, planissima ${ }^{2}$ et ualde pulchram, et trans uallem apparebat mons sanctus Dei Syna. Hic autem locus, ubi se montes aperiebant, iunctus est cum eo loco, qui ${ }^{3}$ sunt Memoriae Concupiscentiae.

${ }^{1}$ sex $A$ se $\mathrm{Gam}^{2}$ edd.

${ }^{2}$ infinitam ingens planissima A Gam infinitam, ingens, planissima FrW Prinz Arce Mar Nat Jan MaN infinitam ingens, planissima Her infinitam ingens, planissimam Geyer Pétré.

${ }^{3}$ qui $A$ MaN quo Gam edd. 


\section{Primeira Parte}

\section{[Faltam muitas coisas]}

1.1. (...) mostravam-se conforme as Escrituras. Neste momento, chegamos andando a um certo lugar, onde enfim os montes por entre os quais caminhávamos abriam-se e formavam um vale infinito, enorme, ${ }^{1}$ planíssimo e muito belo, e para além do vale aparecia o Sinai* ${ }^{\star}$ monte santo* de Deus. Este lugar onde se abriam os montes está ligado àquele lugar no qual ${ }^{2}$ estão as Memórias* da Concupiscência (Nm 11,34).

\footnotetext{
${ }^{1}$ Enorme (ingens): nesta frase, ingens refere-se ao vale, e isso fica claro pelo próprio testemunho da autora, logo em seguida, em 1,2 per ualle illa, quam dixi ingens, e também em 2,1 uallis autem ipsa ingens est ualde. De acordo com o latim clássico, ter-se-ia (sc. montes) aperiebant et faciebant uallem infinitam, ingentem, planissimam et ualde pulchram. Geyer e Pétré corrigem planissima para planissimam, mas não corrigem ingens para ingentem. Löfstedt (2007, p.32-34) destaca que ingens pode estar sendo usado como advérbio, sendo esse uso atestado em Plauto, porém com outros adjetivos, declinados no acusativo, mas com o valor de advérbio - insanum e bonam. Väänänen (1987, p.93-94), por sua vez, diz que ingens é um adjetivo indeclinado. Mais adiante $(16,4)$, temos um problema semelhante, em que infinitum é empregado para se referir ao monte: mons ingens et altus infinitum. Löfstedt interpreta infinitum como advérbio, se bem que também é possível interpretá-lo como um recurso para a formação do superlativo do adjetivo altus. Conforme a interpretação assumida, caberiam as traduções "infinitamente alto" ou "altíssimo". Optamos por considerar infinitum como um advérbio, modificando altus.

${ }^{2}$ No qual (qui): essa tradução parte da interpretação de Gamurrini (a quem todos os outros editores seguiram) - quo -, porque, evidentemente, esse é o caso do pronome relativo que faz sentido na frase, e não o qui presente no manuscrito. Porém, na sintaxe clássica, a preposição in viria precedendo esse quo ("no qual"). Assim, mantemos o que se encontra no manuscrito, mas interpretamos in quo.
} 
1.2. In eo ergo loco cum uenitur, ut tamen commonuerunt deductores sancti illi, qui nobiscum erant, dicentes: "Consuetudo est, ut fiat hic oratio ab his, qui ueniunt, quando de eo loco primitus uidetur mons Dei": sicut et nos fecimus. Habebat autem de eo loco ad montem Dei forsitan quattuor milia totum per ualle illa, quam dixi ingens. 
1.2. Quando se chega a esse lugar, como, entretanto, aqueles santos guias que estavam conosco avisaram-nos dizendo: “" seja feita por aqueles que chegam, quando deste lugar tão logo se avista o monte de Deus", assim como também nós fizemos. Havia ${ }^{4}$, desse lugar até o monte de Deus, talvez quatro milhas ${ }^{\star}$ ao todo ${ }^{6}$, através $\mathrm{do}^{7}$ vale que chamei de enorme.

\footnotetext{
${ }^{3}$ Dizendo (dicentes): o particípio presente dicentes retoma uma ideia que está implícita no verbo que vem antes (commonuerunt), mas sua presença não é sintaticamente necessária na oração.

${ }^{4}$ Havia (habebat): este é um uso do verbo habere com o valor impessoal de "existir". Além dessa, no texto há outras ocorrências de habere impessoal, como em 23,2: habebat de ciuitate forsitan mille quingentus passus.

${ }^{5}$ Autem não foi traduzido. Muitas vezes, essa conjunção ou partícula é usada como elemento de transição, para renovar ou introduzir um novo assunto, sendo de difícil tradução, porque de fato pode funcionar como uma partícula expletiva. Quando essa conjunção é utilizada em seu sentido pleno, tem valor adversativo: "porém", "entretanto" etc.

${ }^{6}$ Ao todo (totum): Väänänen (1987, p.101) propõe a análise desse termo como sendo parte de uma "fórmula fixa", empregada no caso acusativo, com valor adverbial. Segundo ele, essa mesma interpretação pode ser aceita em 3,1 totum ad directum subis (equivalente à expressão tout droit do francês), em 20,8 penitus nullum Christianum inueni sed totum gentes sunt, e em 31,4 per totam ciuitatem totum pedibus omnes. Parece-nos bastante plausível a análise de Väänänen, por isso traduzimos, nessa ocorrência, totum como "ao todo". Em outras ocorrências, totum poderia ser traduzido como "totalmente".

${ }^{7}$ Através do vale (per ualle illa): a tradução do artigo definido na composição de $+o$ provém da interpretação de ille, illa, illud como algo próximo do artigo definido das línguas românicas que, na maioria delas, teve aí sua origem (v. nota abaixo). De fato, esse demonstrativo é empregado por Egéria com muita frequência, com um emprego que muitas vezes não pode ser interpretado como o clássico aquele, aquela, aquilo.
} 
2.1. Vallis autem ipsa ingens est ualde, iacens subter latus montis Dei, quae habet forsitan, quantum potuimus uidentes estimare ${ }^{4}$ aut ipsi dicebant, in longo milia passos forsitan sedecim, in lato autem quattuor milia esse appellabant. Ipsam ergo uallem nos trauersare habebamus, ut possimus montem ingredi.

2.2. Haec est autem uallis ingens et planissima, in qua filii Israhel commorati sunt his diebus, quod sanctus Moyses ascendit in montem Domini ${ }^{5}$ et fuit ibi quadraginta diebus et quadraginta noctibus. Haec est autem uallis, in qua factus est uitulus, qui locus usque in hodie ostenditur; nam lapis grandis ibi fixus stat in ipso loco. Haec ergo uallis ipsa est, in cuius capite ille locus est, ubi sanctus Moyses, cum pasceret pecora soceri sui, iterum locutus est ei Deus de rubo in igne.

${ }^{4}$ estimare $A$ edd. aestimare Geyer Pétré

${ }^{5}$ domini A edd. Dei coni.Geyer (in nota) 
2.1. É, além disso, muito imenso esse ${ }^{8}$ vale, estendendo-se sob o lado da montanha de Deus, que talvez tenha, pelo que pudemos avaliar vendo ou pelo que eles diziam, dezesseis mil passos ${ }^{\star}$ de comprimento e, de largura, quatro mil. ${ }^{9}$ E nós tínhamos que atravessar ${ }^{10}$ esse mesmo vale para que pudéssemos entrar na montanha.

2.2. Este é o vale imenso e planíssimo onde os filhos de Israel $^{*}$ se detiveram naqueles dias (Ex 19,2) quando ${ }^{11}$ o santo Moisés ${ }^{\star}$ subiu ao monte do Senhor e lá permaneceu durante quarenta dias e quarenta noites (Ex 24,18). Este é, por outro lado, o vale em que foi feito o bezerro (Ex 32,4), lugar que ainda se mostra até hoje; de fato, no próprio lugar uma grande pedra aí está fixada. Este é, pois, o mesmo vale em cuja extremidade é o lugar onde, quando o santo Moisés apascentava os rebanhos de seu sogro (Ex 3,1), Deus falou pela segunda vez $(\operatorname{Ex} 3,15 ; 4,6)$ a ele, de uma sarça em chamas (Ex 3,4).

\footnotetext{
${ }^{8}$ Esse (ipse): o sentido deste ipse não é o do latim clássico "ele mesmo", "ela mesma”, mas do nosso "esse" (tal como em muitas outras ocorrências no texto), um equivalente de iste e de hic e, às vezes, de um artigo. Ipse torna-se um demonstrativo de sentido menos enfático do que na língua clássica, tendendo a substituir o antigo iste. Em latim clássico, ipse é um dos seis pronomes demonstrativos, enquanto que hic, iste, ille, is e idem são os outros. A língua vulgar só conservou três desses seis demonstrativos: iste, ipse e ille. Esse sistema substitui o clássico hic, iste e ille com as funções de $1^{\text {a }}$ pessoa (pessoa que fala), $2^{\text {a }}$ pessoa (pessoa a quem se fala) e $3^{\text {a }}$ pessoa (posição remota). No latim vulgar, o demonstrativo ipse, ipsa, ipsum passou a ser usado como artigo definido em algumas poucas línguas (numa região da Sardenha, em alguns pontos da Catalunha, da Gasconha e Ilhas Baleares), sendo ille, illa, illud a forma geral adotada como pronome pessoal de $3^{\text {a }}$ pessoa e também como artigo definido.

${ }^{9}$ Appellabant não foi traduzido, pois parece uma repetição do que já havia sido dito com a forma verbal dicebant "diziam", empregada mais acima.

${ }^{10}$ Tínhamos que atravessar (trauersare habebamus): perífrase formada com o infinitivo de um verbo e o indicativo de habere em substituição à forma perifrástica ativa com o verbo auxiliar no imperfeito do indicativo (trauersaturi eramus). O futuro, tal como era empregado no latim clássico, não passou para as línguas românicas, sendo essa perífrase uma das formas que o latim vulgar transmitiu ao romance e que originou, posteriormente, a criação propriamente dita do futuro românico. Note-se que essa inovação românica respeita a regra clássica na ordem das palavras: laudare hayo originou em português louvar-hei, em espanhol loar-é, em francês je louer-ai, em provençal lauzar-ai, em italiano lauder-ò. Com base na ordem vulgar, esperar-se-ia hayo laudare. Além do auxiliar habere, utilizado na maior parte da România Ocidental na formação dessa perífrase de futuro, temos uolo no romeno (uoi lauda) e debeo no logudorês (depo kantare). O futuro na língua vulgar, além de ser expresso por essa(s) perífrase(s), confundia-se frequentemente com o presente, como se pode ver nas notas $51,113$.

${ }^{11}$ Quando (quod): no latim clássico, empregar-se-ia cum, ubi ou ut para introduzir uma oração subordinada temporal no modo indicativo, com sentido de "quando".
} 


\section{Maria Cristina Martins}

2.3. Et quoniam nobis ita erat iter, ut prius montem Dei ascenderemus, qui hinc paret, ${ }^{6}$ unde ueniebamus, melior ascensus erat, et illuc ${ }^{7}$ denuo ad illud caput uallis descenderemus, id est ubi rubus erat, quia melior descensus montis Dei erat inde: itaque ergo hoc placuit, ut uisis omnibus quae desiderabamus, descendentes a monte Dei, ubi est rubus, ueniremus, et inde totum per mediam uallem ipsam, qua iacet in longo, rediremus ad iter cum hominibus Dei, qui nobis singula loca, quae scripta sunt, per ipsam uallem ostendebant, sicut et factum est.

2.4. Nobis ergo euntibus ab eo loco, ubi uenientes a Faran feceramus orationem, iter sic fuit, ut per medium transuersaremus caput ipsius uallis et sic plecaremus nos ad montem Dei.

2.5. Mons autem ipse per giro quidem unus esse uidetur; intus autem quod ingrederis, plures sunt, sed totum mons Dei appellatur, specialis autem ille, in cuius summitate est hic locus, ubi descendit maiestas Dei, sicut scriptum est, in medio illorum [32] omnium est.

2.6. Et cum hi omnes, qui per girum sunt, tam excelsi sunt ${ }^{8}$ quam nunquam me puto uidisse, tamen ipse ille medianus, in quo descendit maiestas Dei, tanto altior est omnibus illis, ut cum subissemus in illo, prorsus toti illi montes, quos excelsos uideramus, ita infra nos essent, ac si colliculi permodici essent.

\footnotetext{
${ }^{6}$ qui hinc paret A Gam qui hinc paret, quia Geyer Her Pétré FrW Arce MaN quia hac parte Erk Prinz Jan Mar quia hinc, parte Chol Nat

${ }^{7}$ illuc A Gam Nat MaN illinc Geyer edd.

${ }^{8}$ sunt A Gam MaN sint Geyer edd.
} 
2.3. E, visto que nosso caminho* era tal que primeiro subiríamos ao monte de Deus, que daqui aparece, porque, de onde vínhamos, era melhor a subida, e dali novamente desceríamos até a extremidade do vale, isto é, onde estava a sarça, porque a descida do monte de Deus era melhor de lá, então ${ }^{12}$ nos aprouve que, tendo visto tudo o que desejávamos, descendo do monte de Deus, chegássemos onde está a sarça e, de lá, pelo meio de todo aquele vale, que ${ }^{13}$ se estende em comprimento, voltássemos ao caminho com os homens de Deus, que mostravam ${ }^{14}$ a nós, através desse vale, cada um dos lugares que estão escritos, e assim foi feito.

2.4. Para nós, portanto, que íamos daquele ponto onde fizéramos a oração ao chegar de Faran*, assim foi o caminho: que atravessássemos pelo meio a entrada do vale e assim chegássemos à montanha de Deus.

2.5. Esse mesmo monte parece ser único <quando se está> ao seu redor, porém, depois de entrares nele, são vários, mas o todo é chamado "montanha de Deus"; no meio de todos eles está aquele específico em cujo cimo fica o lugar onde desceu a majestade ${ }^{\star}$ de Deus (Ex 24,16), como está escrito.

2.6. E ainda que todos estes, ao redor, sejam tão altos como eu penso jamais ter visto, ainda assim, o do meio, no qual desceu a majestade de Deus (Ex 19,18), é tão mais alto que todos os outros que, quando subimos nele, bem à nossa frente todos os montes que havíamos achado elevados ficavam tão abaixo de nós como se fossem morrinhos muito pequenos.

\footnotetext{
${ }^{12}$ Então (itaque ergo): itaque ergo, usado 12 vezes no manuscrito, é uma justaposição de partículas quase sinônimas, muitas vezes de difícil tradução literal. Ac sic ergo, etiam et, nec non etiam et são outras construções prolixas do mesmo tipo, de sentido vago (VÄÄNÄNEN, 1987, p.129). V. notas 20, 121.

${ }^{13}$ Que (qua): acreditamos que o qua do manuscrito é o nominativo feminino singular do pronome relativo qui, que em latim clássico seria quae (forma que é igual à do plural) e que, portanto, foi escrito sem o $e$ final. O qua também poderia ser um advérbio de lugar ("lugar por onde"), mas aqui faz mais sentido a primeira interpretação.

${ }^{14}$ Mostravam (ostendebant): no texto, o verbo ostendere aparece, às vezes, construído com dois complementos, acusativo e dativo, e outras vezes só com o acusativo, exatamente como acontece em português. Além dessa ocorrência, há muitas outras, como em 5,7: Ostenderunt etiam nobis locum (...) "Mostraram também a nós o lugar (...)"; Item ostenderunt locum ubi (...) "Igualmente mostraram o lugar onde (...)". Em latim clássico, ostendere é um verbo transitivo, ou seja, se completa com o acusativo, mas também pode ser usado absolutamente. Por outro lado, monstrare aparece apenas com o complemento em acusativo - 5,3 Nam et monstrauerunt locum, ubi fuerunt castra -, e demonstrare, com os dois complementos, em acusativo e dativo - 5,1 semper nobis sancti illi loca demonstrabant. Do ponto de vista discursivo, Egéria usa repetidamente o verbo ostendere para enfatizar a ação de ver e vivenciar os Lugares Santos, sobretudo porque há um leitor (no caso, as suas sorores) a quem está sendo endereçada a narrativa de viagem.
} 


\section{Maria Cristina Martins}

2.7. Illud sane satis admirabile est et sine Dei gratia puto illud non esse, ut cum omnibus altior sit ille medianus, qui specialis Syna dicitur, id est in quo descendit maiestas Domini, tamen uideri non possit, nisi ad propriam radicem illius ueneris, ante tamen quam eum subeas; nam posteaquam completo desiderio descenderis inde, et de contra illum uides, quod, antequam subeas, facere non potest ${ }^{9}$. Hoc autem, antequam perueniremus ad montem Dei, iam referentibus fratribus cognoueram, et postquam ibi perueni, ita esse manifeste cognoui.

3.1. Nos ergo sabbato sera ingressi sumus montem, et peruenientes ad monasteria quedam ${ }^{10}$ susceperunt nos ibi satis humane monachi, qui ibi commorabantur, praebentes ${ }^{11}$ nobis omnem humanitatem; nam et aecclesia ${ }^{12}$ ibi est cum presbytero. Ibi ergo mansimus in ea nocte, et inde maturius die dominica cum ipso presbytero et monachis, qui ibi commorabantur, cepimus ${ }^{13}$ ascendere montes singulos. Qui montes cum infinito labore ascenduntur, quoniam non eos subis lente et lente per girum, ut dicimus in cocleas, ${ }^{14}$ sed totum ad directum subis ac si per parietem et ad directum descendi necesse est singulos ipsos montes, donec peruenias ad radicem propriam illius mediani, que $^{15}$ est specialis Syna.

\footnotetext{
${ }^{9}$ potest $A$ edd. potes Gam ${ }^{1}$ Geyer Pétré

${ }^{10}$ quedam $A$ edd. quaedam Gam Geyer Pétré

${ }^{11}$ praebentes A Gam Geyer Her Pétré Prinz prebentes FrW Arce Mar Jan Nat MaN

${ }^{12}$ aecclesia $A$ edd. ecclesia Gam ${ }^{1}$ Geyer Her Pétré

${ }^{13}$ cepimus $A$ edd. coepimus Geyer Pétré

${ }^{14}$ cocleas A Gam Geyer Her Pétré MaN coclea Löfst FrW Arce Mar Prinz Jan Nat

${ }^{15}$ que (fortasse corr. in qui) $A$ qui $\mathrm{Gam}^{2}$ edd.
} 
2.7. É realmente admirável, e eu creio que não acontece sem a graça de Deus, que aquele que fica no meio, que é chamado propriamente Sinai, isto é, aquele em que desceu a majestade do Senhor, embora seja mais alto que todos, ainda assim não possa ser visto, a menos que chegues até a sua própria base, antes, contudo, que o escales; de fato, depois que desces dali, tendo realizado esse desejo, ele se torna visível também de frente, ${ }^{15}$ coisa que antes que subas não é possível fazer. Isso eu já sabia antes de chegarmos à montanha de Deus, pelos relatos dos nossos irmãos ${ }^{\star}$, e, depois que lá cheguei, vi claramente assim ser.

3.1. Portanto, no sábado à tarde, nós caminhamos para o monte e, chegando a um certo mosteiro ${ }^{*}$, acolheram-nos ali, com bastante bondade, ${ }^{16}$ os monges ${ }^{\star}$ que habitavam ali, oferecendo-nos toda a hospitalidade; pois existe nesse lugar também uma igreja ${ }^{\star}$ com um presbítero*. Permanecemos, pois, ali naquela noite e, desse lugar, ao amanhecer do dia de domingo, com o mesmo presbítero e os monges que ali moravam, começamos a subir cada um dos montes. Estes montes são escalados com infinita dificuldade, pois não podes subi-los muito lentamente em círculo ou, como dizemos, em caracol, mas sobes em linha reta e como por uma parede, e é necessário descer os mesmos montes um a um, em linha reta, até que enfim se chega à raiz daquele que está no meio, que é o Sinai propriamente dito.

${ }^{15}$ De frente (de contra): de contra é uma inovação do latim vulgar, pois contra é um advérbio que por si só significa "em frente", "defronte". Aqui há o reforço da preposição de. V. nota 41.

${ }^{16}$ Com bondade (humane): humane é um advérbio derivado do adjetivo humanus, $-a$, -um e em sentido literal significa "humanamente", mas, por extensão, refere-se a virtudes próprias do homem a que o cristianismo dá ênfase - clemência, benevolência, bondade -, daí a tradução "com bondade". O significado de humane para os escritores cristãos não é o mesmo usado nos autores clássicos, pois, para os primeiros, o termo incorpora os valores do cristianismo. Entre os cristianismos semânticos podemos ainda citar: salus, lat. clássico "saúde", "bem-estar", mas lat. cristão "salvação da alma" (daí saluator "salvador", correspondente ao grego $\sigma \omega \tau \eta \dot{\eta} \rho$ ); spiritus, que no lat. clássico corresponde ao grego $\pi v \varepsilon \tilde{v} \mu \alpha$, "sopro", mas no lat. cristão significa "espírito", com sentido imaterial; peccare, não com o sentido clássico e profano de "cometer erro", mas sim no religioso de "ofender a Deus". Sanctus, uirtus e dominus são também reinterpretados no contexto dos valores cristãos, e não correspondem em sentido ao latim clássico. Em Egéria, humane e humanitas dão também a noção específica de hospitalidade, isto é, a prática da caridade relacionada ao acolhimento dos peregrinos. 
3.2. Hac sic ergo iubente Christo Deo nostro, adiuta orationibus sanctorum, qui comitabantur, et sic cum grandi labore, quia pedibus $\mathrm{me}^{16}$ ascendere necesse erat, quia prorsus nec in sella ascendi poterat, tamen ipse labor non sentiebatur, ex ea parte autem non sentiebatur labor, quia desiderium, quod habebam, iubente Deo uidebam compleri: hora ergo quarta peruenimus in summitatem illam montis Dei sancti Syna, ubi data est lex, in eo id est locum, ${ }^{17}$ ubi descendit maiestas Domini in ea die, qua mons fumigabat.

3.3. In eo ergo loco est nunc ecclesia, non grandis, quoniam et ipse locus, id est summitas montis, non satis grandis est, quae tamen aecclesia ${ }^{18}$ habet de se gratiam grandem.

3.4. Cum ergo iubente Deo persubissemus in ipsa summitate et peruenissemus ad hostium ipsius ecclesiae, ecce et occurrit presbyter ueniens [33] de monasterio suo, qui ipsi ecclesie ${ }^{19}$ deputabatur, senex integer et monachus a prima uita et, ut hic dicunt, ascitis, et quid plura? Qualis dignus est esse in eo loco. Occurrerunt etiam et alii presbyteri, nec non etiam et omnes monachi, qui ibi commorabantur iuxta montem illum, id est qui tamen aut ${ }^{20}$ etate $^{21}$ aut inbeccillitate ${ }^{22}$ non fuerunt impediti.

3.5. Verum autem in ipsa summitate montis illius mediani nullus commanet; nichil enim est ibi aliud nisi sola ecclesia ${ }^{23}$ et spelunca, ubi fuit sanctus Moyses.

\footnotetext{
${ }^{16}$ Há uma rasura de algo que foi apagado no manuscrito, antes de me, correspondente ao tamanho de uma letra. Somente FrW se refere a essa rasura, interpretando-a como um a, com o que não concordamos. Para nós, vê-se claramente que é um e.

${ }^{17}$ locum corr. ex loco A loco Gam Geyer Her Pétré Nat MaN locum FrW Prinz Arce Mar Jan

${ }^{18}$ aecclesia $A$ Gam $^{2}$ edd. ecclesia Gam ${ }^{1}$ Geyer Pétré

${ }^{19}$ ecclesie A edd. ecclesiae Gam Geyer Pétré

${ }^{20}$ aut imbecillitate aut aetate transpos. $\mathrm{Gam}^{2}$ aut inbecillitate aut aetate transpos. Geyer Pétré

${ }^{21}$ etate $A$ edd. aetate Gam Geyer Pétré

${ }^{22}$ inbeccillitate $A$ edd. inbecillitate Geyer Pétré imbecillitate Gam

${ }^{23}$ ecclesia corr. ex ecclesie $A$
} 
3.2. $\mathrm{E}^{17}$ assim, pois, por ordem de Cristo nosso Deus, ajudada pelas orações dos monges que nos acompanhavam, e assim com grande sacrifício, porque era necessário que eu subisse a pé, porque em linha reta não era possível subir na sela - todavia sob esse aspecto o esforço não era sentido; o esforço não era sentido porque o desejo que eu tinha, via ser satisfeito por ordem de Deus -: na quarta hora* chegamos, pois, ao cume do monte santo de Deus, o Sinai, onde foi dada a Lei, isto é, naquele lugar onde desceu a majestade do Senhor (Ex 24,16), naquele dia em que ${ }^{18}$ o monte fumegava (Ex 19,18).

3.3. Pois bem, naquele lugar há agora uma igreja que não é grande, porque também o próprio lugar, isto é, o topo do monte, não é grande o suficiente; entretanto essa igreja tem uma grande graça por si só.

3.4. Tendo atingido, então, pela vontade de Deus, esse cume, ${ }^{19} \mathrm{e}$ chegando até a entrada da igreja, eis que correu a nosso encontro, vindo de seu mosteiro, o presbítero que era atribuído a essa igreja, velho íntegro, monge desde a juventude e, como aqui dizem, asceta ${ }^{\star}$, e o que mais? Tal que é digno de estar neste lugar. Também acorreram outros presbíteros e nem ${ }^{20}$ deixaram de vir também todos os monges que ali moravam, perto daquela montanha, isto é, pelo menos os que não foram impedidos pela fraqueza ou pela idade.

3.5. Na verdade, porém, na própria crista do monte do meio, ninguém mora, pois nada há ali senão a igreja, isolada, e a gruta onde esteve o santo Moisés (Ex 33,22).

\footnotetext{
${ }^{17} \mathrm{E}$ ( $\left.h a c\right)$ : no manuscrito está escrito hac em vez de $a c$. Pelo fato de não mais existir a aspiração do $h$ nessa época, o texto apresenta muitas incoerências na escrita de palavras sem $h$, quando deveriam apresentá-lo, e com $h$, quando não deveriam apresentá-lo. Em 3,6 (hac sic communicantibus nobis) e 3,7 (hac sic ergo posteaquam communicaueramus), ac aparece novamente escrito com $h$. V. notas 33, 41, 64 .

${ }^{18} \mathrm{Em}$ que (qua): no latim clássico, qua é o advérbio de lugar "por onde", que no latim vulgar parece ter adquirido um valor temporal. De fato, segundo Väänänen (1987, p.80), qua concorre com quando e cum. Esse emprego ocorre muitas outras vezes no texto, $\mathrm{p}$. ex., em 5,4 e 19,12. De acordo com Löfstedt (2007, p.140), a origem desse uso não é de todo conhecida, mas ocorre em Tertuliano (início do séc. III). V. nota 161.

${ }^{19}$ Cume (summitate): summitate é um dentre os inúmeros exemplos da falta do - $m$ final do acusativo: in ipsa summitate em vez de in ipsam summitatem (in + acusativo como complemento do verbo de movimento persubire).

${ }^{20}$ E nem (nec non etiam et): nec non etiam et é uma justaposição de partículas sinônimas ou quase sinônimas. V. notas 12, 121 .
} 
3.6. Lecto ergo ipso loco omnia ${ }^{24}$ de libro Moysi et facta oblatione ordine suo, hac sic communicantibus nobis, iam ut exiremus de aecclesia, ${ }^{25}$ dederunt nobis presbyteri loci ipsius eulogias, id est de pomis, quae in ipso monte nascuntur. Nam cum ipse mons sanctus Syna totus petrinus sit, ita ut nec fruticem habeat, tamen deorsum prope radicem montium ${ }^{26}$ ipsorum, id est seu circa illius, qui medianus est, seu circa illorum, qui per giro sunt, modica nerrola ${ }^{27}$ est; statim sancti monachi pro diligentia sua arbusculas ponunt et pomariola instituunt uel orationes $^{28}$ et iuxta sibi monasteria, quasi ${ }^{29}$ ex ipsius montis terra aliquos fructus capiant, quos tamen manibus suis elaborasse uideantur.

3.7. Hac sic ergo posteaquam communicaueramus et dederant nobis eulogias sancti illi et egressi sumus foras hostium ecclesiae, tunc cepi ${ }^{30}$ eos rogare, ut ostenderent nobis singula loca. Tunc statim illi sancti dignati sunt singula ostendere. Nam ostenderunt nobis speluncam illam, ubi fuit sanctus Moyses, cum iterato ascendisset in montem Dei, ut acciperet denuo tabulas, posteaquam priores illas fregerat peccante populo, et cetera loca, quaecumque desiderabamus uel quae ipsi melius nouerant, dignati sunt ostendere nobis.

\footnotetext{
${ }^{24}$ lecto ergo ipso loco omnia A Gam Prinz lecto ergo ipso loco omni Chol Geyer Her Pétré Mar Jan Nat MaN FrW lecto ergo, ipso loco, omnia FrW Arce lecta fortasse corrigend. (in nota)

${ }^{25}$ aecclesia $A$ edd. ecclesia Gam Geyer Pétré

${ }^{26}$ Em nota, FrW, Arce, Mar, Jan e MaN afirmam que, no manuscrito, montium foi corrigido a partir de montis. Para nós, isso não é evidente.

${ }^{27}$ nerrola A Gam terrola Chol edd.

${ }^{28}$ orationes A Gam Geyer arationes Wöl Her

${ }^{29}$ quasi $A$ edd. qua sibi Geyer (in nota)

${ }^{30}$ cepi $A$ edd. coepi Geyer Pétré
} 
3.6. Lido, pois, todo o passo correspondente ${ }^{21}$ do livro de Moisés e feita a oblação ${ }^{*}$ conforme o costume, ${ }^{22}$ e assim, comungando nós, como saíamos da igreja, os presbíteros do lugar nos deram eulogias*, isto é, frutas que nascem nesse monte. Porque embora a montanha santa do Sinai seja toda de pedra, a tal ponto que nem tenha um arbusto, ainda assim, embaixo, junto ao sopé desses montes, isto é, em volta do que está no meio ou em volta dos que o rodeiam, há um pouquinho de terra; constantemente os santos monges, por zelo, plantam arvorezinhas e estabelecem pomarezinhos e lavouras, ${ }^{23} \mathrm{e}$ junto dos seus mosteiros, para que colham alguns frutos da terra desse monte, que, contudo, parecem ser obtidos com o trabalho de suas mãos.

3.7. E assim, pois, depois que comungamos e que aqueles monges nos deram eulogias e saímos para fora da porta da igreja, daí comecei a pedir-lhes que nos mostrassem cada um dos lugares. Então aqueles santos dignaram-se a mostrar cada um dos lugares. Com efeito, nos mostraram aquela gruta onde estivera o santo Moisés quando pela segunda vez subira à montanha de Deus $($ Ex 34,1$)$ para receber novamente as tábuas, depois que quebrara as primeiras por causa do povo $^{\star}$ pecador (Ex 32,19); e também se dignaram a nos mostrar todos aqueles outros lugares que desejávamos e os outros que eles mesmos melhor conheciam.

\footnotetext{
${ }^{21}$ Lido, pois, todo o passo correspondente (lecto ergo ipso loco omnia): para uma correta concordância, deveríamos ter lecta omnia "lidas todas as coisas" (ablativo absoluto) e não lecto omnia. Outra solução - que incorporamos à nossa tradução -, seria corrigir omnia para omni, tal como foi proposto por Cholodniak (1899).

${ }^{22}$ Conforme o costume (ordine suo): ordine suo aparece seis vezes no texto. Em cada ocorrência, a expressão está associada a um ofício (cinco vezes ligada à palavra missa e uma vez à palavra oblatio), e há a sugestão ou indicação de que a missa foi celebrada (BASTIAENSEN, 1962, p.161ss). Contamos seis ocorrências de ordine suo em nossa edição, porque não adotamos, no texto latino estabelecido por nós, a conjectura de Geyer que substitui ordines por ordine suo em 26,1 , mas mantemos o que está no manuscrito. Iuxta consuetudinem, que aparece 29 vezes no texto, é uma expressão equivalente no sentido, mas empregada em contextos bem mais amplos, indicando qualquer ação que se faz "conforme o costume", não se limitando à cerimônia da missa (há uma só ocorrência com "missa") ou outros ofícios religiosos.

${ }^{23}$ Lavouras (orationes): os latinistas Löfstedt e Heraeus seguem a conjectura sugerida por Wölfflin (1887), que propôs aí aratio, -onis "ação de lavrar", "campo lavrado”, "lavoura”, acreditando num erro do copista. Certamente o vocábulo que faz sentido no contexto é esse, e não oratio, -onis, por isso nós também seguimos Wölfflin.
} 
3.8. Illud autem uos uolo scire, dominae uenerabiles sorores, qui ${ }^{31}$ de eo loco, ubi stabamus, id est in giro parietes ecclesiae, id est de summitate montis ipsius mediani, ita infra nos uidebantur esse illi montes, quos primitus uix ascenderamus, iuxta istum medianum, in quo stabamus, ac si essent illi colliculi, cum tamen ${ }^{32}$ ita infiniti essent, ut non me putarem aliquando altiores uidisse, nisi quod hic medianus eos nimium praecedebat. ${ }^{33}$ Egyptum autem et Palestinam et mare Rubrum et mare illut ${ }^{34}$ Parthenicum, quod mittit Alexandriam, nec non et fines Saracenorum infinitos ita subter nos inde uidebamus, ut credi uix possit; quae tamen singula nobis illi sancti demonstrabant.

4.1. Completo ergo omni desiderio, quo festinaueramus [34] ascendere, cepimus $^{35}$ iam et descendere ab ipsa summitate montis Dei, in qua ascenderamus, in alio monte, qui e ${ }^{36}$ periunctus est, qui locus appellatur in Choreb; ibi enim est ecclesia.

4.2. Nam hic est locus Choreb, ubi fuit sanctus Helias propheta, qua fugit a facie Achab regis, ubi ei locutus est Deus dicens: "Quid tu hic, Helias?", sicut scriptum est in libris regnorum. Nam et spelunca, ubi latuit sanctus Helias, in hodie ibi ostenditur ante hostium ecclesiae, que ${ }^{37}$ ibi est; ostenditur etiam ibi altarium lapideum, quem posuit ipse sanctus Helias ad offerendum Deo, sicut et illi sancti singula nobis ostendere dignabantur.

4.3. Fecimus ergo et ibi oblationem et orationem impensissimam, et lectus est ipse locus de libro regnorum: id enim nobis uel maxime $\mathrm{ea}^{38}$ desideraueram semper, ut ubicumque uenissemus, semper ipse locus de libro legeretur.

\footnotetext{
${ }^{31}$ qui $A$ quod $\mathrm{Gam}^{2}$ quia Chol edd.

${ }^{32}$ tamen $A$ edd. tam Gam

${ }^{33}$ praecedebat A Gam Geyer Her Pétré Prinz precedebat FrW Arce Mar Jan Nat MaN

${ }^{34}$ illut $A$ edd. illud Geyer Pétré

${ }^{35}$ cepimus A edd. coepimus Geyer Pétré

${ }^{36}$ ei om. Gam

${ }^{37}$ que $A$ edd. quae Gam Geyer Pétré Arce

${ }^{38}$ maxime ea $A \mathrm{Gam}^{2}$ maxime ego Prinz Mar Jan Nat MaN maxime FrW Arce maxime $\dagger$ ea Geyer Her Pétré (Geyer (in nota): cf. 10,7 uel maxime consuetudinis erat semper, ubicumque ad ea loca, quae desideraueram, uenissemus semper)
} 
3.8. Quero também que vós saibais, senhoras, minhas veneráveis irmãs, ${ }^{*}$ que do lugar onde estávamos - rodeando as paredes da igreja, do alto desse monte do centro -, tão abaixo de nós pareciam estar aqueles montes que com dificuldade escaláramos antes, como se fossem pequenas colinas, e eram, contudo, tão grandes que eu não pensaria ter visto maiores, não fosse o fato de que esse do meio os excedia em sobra. O Egito* e a Palestina ${ }^{\star}$, o Mar Vermelho* e o mar Partênico, ${ }^{\star}$ que leva a Alexandria, ${ }^{*}$ e mais ainda o território dos sarracenos ${ }^{\star}$ - imenso -, víamos dali tão abaixo de nós que é difícil crer; no entanto, aqueles santos nos mostravam <esses lugares> um após o outro.

4.1. Satisfeito, pois, cada desejo pelo qual nos apressáramos em subir, começamos a descer do cimo da montanha de Deus, na qual subíramos, em outro monte que está junto dele, lugar que se chama $\operatorname{Horeb}^{\star}$ (Ex 17,6); pois aí há uma igreja.

4.2. Este é o lugar chamado Horeb, onde esteve o santo profeta Elias* quando ${ }^{24}$ fugiu da presença do rei Acab e onde Deus lhe falou, dizendo: "Que fazes tu aqui, Elias?’”5 (1Rs 19,9) - como está escrito nos livros dos Reinos*. Com efeito, a gruta onde se escondeu o santo Elias até hoje se vê diante da porta da igreja que existe neste lugar; também se vê aí o altar de pedra que construiu o próprio santo Elias para fazer oferendas a Deus, como se dignavam os monges a nos mostrarem cada coisa.

4.3. Aí, pois, fizemos a oblação ${ }^{26}$ e uma oração ardentíssima, e foi lida a passagem apropriada do livro dos Reinos: isto, com efeito, havia desejado para nós com o maior empenho, que, aonde quer que chegássemos, sempre fosse lido um trecho do Livro.

\footnotetext{
${ }^{24}$ Quando (qua): v. nota 18.

${ }^{25}$ Que fazes tu aqui, Elias? (Quid tu hic Helias?): a partir dessa citação, comprova-se que a Bíblia utilizada por Egéria era a Septuaginta, ou uma versão latina anterior a São Jerônimo, já que na Vulgata se lê Quid hic agis, Elia? (3Rs 19,9). Nesse mesmo parágrafo, Egéria se refere aos livros dos Reinos, igualmente uma denominação da Septuaginta, enquanto que São Jerônimo denomina os livros dos Reinos como livros dos Reis.

${ }^{26}$ Oblação (oblationem): oblatio é derivado de offero, "ação de oferecer, de dar voluntariamente", "oferenda (de pão e vinho, elementos do santo sacrifício oferecidos pelos fiéis)”. Ver, no Glossário, oblação.
} 
4.4. Facta ergo et ibi oblatione, accessimus denuo ad alium locum non longe inde, ostendentibus presbyteris uel monachis, id est ad eum locum, ubi steterat sanctus Aaron cum septuaginta senioribus cum sanctus Moyses acciperet a Domino legem ad filios Israhel. In eo ergo loco, licet et tectum ${ }^{39}$ non sit, tamen petra ingens est per girum habens planitiem supra se, in qua stetisse dicuntur ipsi sancti; nam et in medio ibi quasi altarium de lapidibus factum habet. Lectus est ergo et ibi ipse locus de libro Moysi et dictus unus psalmus aptus loco: hac ${ }^{40}$ sic facta oratione descendimus inde.

4.5. Ecce et coepit iam esse hora forsitan octaua, et adhuc nobis superabant milia tria, ut perexiremus montes ipsos, quos ingressi fueramus pridie sera; sed non ipsa parte exire habebamus, quia ${ }^{41}$ intraueramus, sicut superius dixi, quia necesse nos erat et loca omnia sancta ambulare et monasteria, quecumque ${ }^{42}$ erant ibi, uidere et sic aut ${ }^{43}$ uallis illius, quam superius dixi, caput exire, id est huius uallis, quae subiacet montis ${ }^{44}$ Dei.

4.6. Propterea autem ad caput ipsius uallis exire nos necesse erat, quoniam ibi erant monasteria plurima sanctorum hominum et ecclesia in eo loco, ubi est rubus; qui rubus usque in hodie uiuet ${ }^{45}$ et mittet uirgultas.

4.7. Ac sic ergo perdescenso monte Dei peruenimus ad rubum hora forsitan decima. Hic autem ${ }^{46}$ rubus, quem superius dixi, de quo locutus est Dominus Moysi in igne, qui est in eo loco, ubi monasteria sunt plurima et ecclesia in capite uallis ipsius. Ante ipsam autem ecclesiam hortus est gratissimus ha[35] bens aquam optimam abundantem, in quo horto ipse rubus est.

\footnotetext{
${ }^{39}$ tectum $A$ edd. lectum Her (in nota) Prinz

${ }^{40}$ hac A Gam Her ac Geyer edd.

${ }^{41}$ quia $A$ qua Gam edd.

${ }^{42}$ quecumque $A \mathrm{Gam}^{2}$ quaecumque $\mathrm{Gam}^{1}$ Geyer Pétré

${ }^{43}$ aut $A$ ad $\mathrm{Gam}^{2}$ edd.

${ }^{44}$ montis $A$ monti Gam edd.

${ }^{45}$ uiuet $A$ edd. uiret Gam.

${ }^{46}$ est post autem add. Gam ${ }^{2}$ est ante autem add. Bern edd.
} 
4.4. Feita, pois, também aí a oblação, marchamos de novo a um outro lugar, não longe daí, que nos mostravam os presbíteros e monges, isto é, até aquele lugar onde estivera o santo Aarão* ${ }^{*}$ om os setenta ${ }^{\star}$ anciãos ${ }^{\star}$, enquanto o santo Moisés recebia de Deus a Lei destinada aos filhos de Israel (Ex 24,9-14). Nesse lugar, ainda que não tenha cobertura, há, contudo, uma pedra enorme, encerrando sobre si uma planície ao redor, na qual se diz terem estado esses santos e, efetivamente, quase lá no meio tem um altar feito de pedras. Foi lido nesse lugar o passo do livro de Moisés e dito um salmo apropriado ao lugar; e feita assim essa oração, descemos desse lugar.

4.5. Eis que começou já a ser a hora oitava e ainda nos restavam três milhas para que saíssemos daqueles montes nos quais havíamos entrado na tarde anterior; mas não devíamos sair pela mesma parte na qual entráramos, como disse, porque nos era necessário andar por todos os lugares santos e mosteiros que havia lá e vê-los, e, portanto, sair perto da extremidade do vale que acima descrevi, isto é, o vale que fica no sopé da montanha de Deus.

4.6. Por isso, era-nos necessário sair pela extremidade do vale, porque ali havia numerosos mosteiros de homens santos e uma igreja no lugar onde está a sarça; essa sarça até hoje vive e produz vergônteas. ${ }^{27}$

4.7. E assim, ao descer do monte de Deus, chegamos à sarça mais ou menos na décima hora. Esta é a sarça que mencionei acima, da qual, estando ela em fogo, Deus falou a Moisés, e que está nesse local onde há mosteiros numerosos e uma igreja na extremidade do vale. Há, diante dessa igreja, um jardim graciosíssimo, com água ótima e abundante, e é nesse jardim que se encontra a sarça.

${ }^{27}$ Vergônteas (uirgultas): a palavra uirgulta (um neutro plural, em latim) originou no português "vergôntea", que é sinônimo de "broto" e "rebento". 
4.8. Locus etiam ostenditur ibi iuxta, ubi stetit sanctus Moyses, quando ei dixit Deus: "Solue corrigiam calciamenti tui" et cetera. Et in eo ergo loco cum peruenissemus, hora decima erat iam, et ideo, quia iam sera erat, oblationem facere non potuimus. Sed facta est oratio in ecclesia nec non etiam et in horto ad rubum; lectus est etiam locus ipse de libro Moysi iuxta consuetudinem: et sic, quia sera erat, gustauimus nobis $\operatorname{locum}^{47}$ in horto ante rubum cum sanctis ipsis: ac sic ergo fecimus ibi mansionem. Et alia die maturius uigilantes rogauimus presbyteros ut et ibi fieret oblatio, sicut et facta est.

5.1. Et quoniam nobis iter sic erat, ut per ualle illa media, qua tenditur per longum, iremus, id est illa ualle, quam superius dixi, ubi sederant filii Israhel, dum Moyses ascenderet in montem Dei et descenderet: itaque ergo ${ }^{48}$ singula, que ad modum $^{49}$ uenimus per ipsam totam uallem, semper nobis sancti illi loca demonstrabant.

5.2. Nam in primo capite ipsius uallis, ubi manseramus et uideramus rubum illum, de quo locutus est Deus sancto Moysi in igne, uideramus etiam et illum locum, in quo steterat ante rubum sanctus Moyses, quando ei dixit Deus: "Solue corrigiam calciamenti tui; locus enim, in quo stas, terra sancta est".

${ }^{47}$ nobis locum $A$ Gam $^{1}$ Prinz Mar Jan Nat MaN nobis loco Bern Geyer Her Pétré FrW Arce aliquantulum $\mathrm{Gam}^{2}$ (in nota)

${ }^{48}$ ergo corr. ex ego $A$

${ }^{49}$ que ad modum $A$ quemadmodum $\mathrm{Gam}^{2}$ edd. 
4.8. Mostra-se também aí muito perto o lugar onde esteve o santo Moisés quando lhe disse Deus: "Desata a correia do teu calçado" (Ex 3,5) et cetera. E quando chegamos nesse local já era a hora décima e, porque já era tarde, não pudemos fazer a oblação. Porém, foi feita uma oração na igreja, como também no jardim perto da sarça; foi também lido um passo relevante do livro de Moisés, conforme o costume, e assim, porque era tarde, estando nós no lugar, ${ }^{28}$ no jardim diante da sarça, merendamos ali com os monges, e assim, pois, acampamos ${ }^{29}$ nesse lugar. No dia seguinte, ${ }^{30}$ acordando mais cedo, pedimos aos presbíteros para que aí também se fizesse a oblação, e assim foi feita.

5.1. E como o nosso itinerário era tal que fôssemos <cortando> pelo meio daquele vale que se estende em comprimento, isto é, o vale a que acima me referi, onde haviam permanecido os filhos de Israel enquanto Moisés subia ao monte de Deus e descia, assim, à medida que voltamos pelo vale todo, sempre aqueles santos nos mostravam os lugares um a um.

5.2. Efetivamente, na extremidade à frente do mesmo vale onde acampáramos e víramos a sarça da qual falou Deus ao santo Moisés no meio do fogo, víramos também o lugar no qual o santo Moisés estivera de pé, diante da sarça, quando Deus disse a ele: "Desata a correia do teu calçado, pois o lugar onde estás é terra santa" (Ex 3,5).

\footnotetext{
${ }^{28}$ Lugar (locum): para fazer sentido, foi proposta a correção de locum para loco. Mesmo assim, a presença desse ablativo de lugar não acrescenta nada, pois bastava a autora ter dito gustauimus in horto ante rubum, "merendamos no jardim diante da sarça", e não gustauimus nobis loco in horto ante rubum, "merendamos estando nós no lugar, no jardim diante da sarça", a menos que loco já tenha aqui o sentido temporal do português logo e do espanhol luego.

${ }^{29}$ Acampamos (fecimus mansionem): mansio relaciona-se com o verbo maneo, mansi, mansum, manere, "ação de permanecer, de se demorar, de morar" (derivam-se daí maison e ménage em francês). Esse verbo é sempre usado por Egéria no sentido de "passar uma noite", "fazer pousada", "acampar". Mansio, mansionis é o próprio local, a "pousada”. Esse vocábulo ocorre 23 vezes no texto e é empregado exclusivamente na primeira parte da obra. Ao ser usado com o sentido de "passar uma noite", mansio também marca o percurso de viagem, ou seja, suas várias etapas, que são contadas a partir das paradas para repousar (cf. 13,2; 20,12).

${ }^{30}$ No dia seguinte (alia die): alius dies com esse sentido se encontra desde Plauto e é frequente em Gregório de Tours, alternando com alter dies. Väänänen (1987, p.54-55) considera que o uso predominante de alius dies sobre alter dies é uma hipercorreção de Egéria, pois se sabe que alter é o indefinido que sobreviveu nas línguas românicas, tendo absorvido alius.
} 
5.3. Ac sic ergo cetera loca, quemadmodum profecti sumus de rubo, semper nobis ceperunt ${ }^{50}$ ostendere. Nam et monstrauerunt locum ubi fuerunt castra filiorum Israhel his diebus, quibus Moyses fuit in montem. Monstrauerunt etiam locum, ubi factus est uitulus ille, nam in eo loco fixus est usque in hodie lapis grandis.

5.4. Nos etiam, quemadmodum ibamus, de contra uidebamus summitatem montis, que ${ }^{51}$ inspiciebat super ipsa ualle tota, de quo loco sanctus Moyses uidit filios Israhel habentes choros his diebus, qua fecerant uitulum. Ostenderunt etiam petram ingentem in ipso loco, ubi descendebat sanctus Moyses cum Iesu filio Naue, ad quem ${ }^{52}$ petram iratus fregit tabulas, quas afferebat.

5.5. Ostenderunt etiam quemadmodum per ipsam uallem unusquisque eorum abitationes ${ }^{53}$ habuerant, de quibus abitationibus usque in hodie adhuc fundamenta parent, quemadmodum fuerunt lapide girata. Ostenderunt etiam locum, ubi filios ${ }^{54}$ Israhel iussit currere sanctus Moyses de porta in porta, regressus ad montem..$^{55}$

5. 6. Item ostenderunt torrentem ${ }^{56}$ nobis locum ubi incensus est uitulus ipse iubente sancto Moyse, quem [36] fecerat eis Aaron. Item ostenderunt torrentem illum, ${ }^{57}$ de quo portauit ${ }^{58}$ sanctus Moyses filios Israhel, sicut scriptum est in Exodo.

\footnotetext{
${ }^{50}$ ceperunt $A$ edd. coeperunt Geyer Pétré

${ }^{51}$ que $A$ edd. quae $\mathrm{Gam}^{2}$ Geyer Pétré

${ }^{52}$ quem $A$ edd. quam Gam Geyer Pétré

${ }^{53}$ ante abitationes littera $\mathrm{h}$ erasa $A$

${ }^{54}$ filios corr. ex filii $A$

${ }^{55}$ ad montem A Gam Prinz Mar Nat MaN a monte Geyer Her Pétré FrW Arce Jan

${ }^{56}$ torrentem om. Gam edd.

${ }^{57}$ Item ostenderunt $e$ illum estão apagados no manuscrito. Baseamo-nos na conjectura

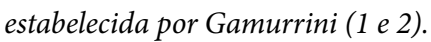

${ }^{58}$ portauit $A$ potauit Gam edd.
} 
5.3. E assim, pois, à medida que nos afastamos da sarça, começaram a mostrar-nos os outros lugares. Na verdade, mostraram-nos o lugar onde esteve o acampamento ${ }^{31}$ dos filhos de Israel naqueles dias em que Moisés esteve no monte (Ex 19,2). Mostraram também o lugar onde foi feito o famoso bezerro, ${ }^{32}$ porque nesse lugar está fixada até hoje uma grande pedra.

5.4. Nós ainda, à medida que caminhávamos, víamos defronte o cume do monte que contemplava o vale todo, lugar do qual o santo Moisés viu os filhos de Israel dançando naqueles dias em que fizeram o bezerro. Também mostraram a pedra imensa naquele lugar onde descia o santo Moisés com Josué*, filho de Nave, contra a qual, irado, quebrou as tábuas que trazia (Ex 32,19).

5.5. Mostraram também de que modo tiveram cada um deles habitações ${ }^{33}$ por esse vale, das quais até hoje aparecem os alicerces, de que modo foram cercados por pedra; mostraram ainda o lugar onde o santo Moisés, retornando do monte, ordenou aos filhos de Israel que corressem de porta em porta (Ex 32,27).

5.6. Igualmente nos mostraram o lugar onde foi queimado, por ordem do santo Moisés (Ex 32,20), o bezerro que para eles fizera Aarão (Ex 32,4). Além disso, mostraram a torrente da qual o santo Moisés fez beber os filhos de Israel (Ex 32,20), tal como está escrito no Êxodo (Ex 17,5-6).

${ }^{31}$ Acampamento (castra): pode significar também um campo ou aldeia fortificados. Em sentido figurado, é a Igreja militante a serviço de Deus, conforme expressões encontradas em Tertuliano - castra ecclesiae - e Cipriano - Dei castra. Devido à ocupação militar romana da Britânia, castra foi incorporado ao vocabulário da região, evoluindo no inglês para chester e entrando na composição de vários topônimos, como Manchester e Portchester, além da própria cidade de Chester. Em português, alguns termos da linguagem militar, como "castro", "castrense" e "castrício", estão ligados etimologicamente a castra, plural de castrum (no singular, a palavra fazia parte de nomes de lugares, como Castrum Nouum e Laurens Castrum; na linguagem militar, porém, era usado sempre no plural: castra 'acampamentos'). O sentido primitivo de castrum, segundo Ernout et Meillet (2001, p.104), é de 'separação, aquilo que serve para separar' e se relaciona ao verbo castrare 'castrar'.

${ }^{32} \mathrm{O}$ famoso bezerro (uitulus ille): essa é uma das poucas ocorrências em que ille é interpretado à maneira do latim clássico, como pronome enfático - "o famoso bezerro", "o célebre bezerro" -, tal como em Cícero: Medea illa "a célebre Medeia" (De Imperio Gnaei Pompei, 22).

${ }^{33}$ Habitações (abitationes): habitatio significa "ação de habitar", "lugar onde se habita", "habitação". A grafia abitationes parece atestar a perda da aspiração do $h$, fenômeno que afetou toda a România. Há outros exemplos desse tipo no texto e também do inverso, isto é, da introdução de um $h$ onde não deveria haver: hostia por ostia, hitur por itur, heremus por eremus. V. notas 17, 42, 64 . 
5. 7. Ostenderunt etiam nobis locum, ubi de spiritu Moysi acceperunt septuaginta uiri. Item ostenderunt locum, ubi filii Israhel habuerunt concupiscentiam escarum. Nam ostenderunt nobis etiam et illum locum, qui appellatus est Incendium, quia incensa est quedam ${ }^{59}$ pars castrorum, tunc qua orante sancto Moyse cessauit ignis.

5. 8. Ostenderunt etiam et illum locum ubi eis pluit manna et coturnices. Ac sic ergo singula, quecumque ${ }^{60}$ scripta sunt in libris sanctis ${ }^{61}$ Moysi facta fuisse in eo loco, id est in ea ualle, quam dixi subiacere monti Dei, id est sancto Syna, ostensa sunt nobis. Quae quidem omnia singulatim scribere satis fuit, quia nec retinere ${ }^{62}$ poterant tanta; sed cum leget affectio uestra libros sanctus ${ }^{63}$ Moysi, omnia diligentius peruidet, quae ibi facta sunt.

5.9. Haec est ergo uallis, ubi celebrata est Pascha completo anno profectionis filiorum Israhel de terra Egypti, quoniam in ipsa ualle Israhel ${ }^{64}$ commorati sunt aliquandiu, id est donec sanctus Moyses ascenderet in montem Dei et descenderet primum et iterato; et denuo tandiu ibi inmorati ${ }^{65}$ sunt, donec fieret tabernaculum et singula, quae ostensa sunt in montem Dei. Nam ostensus

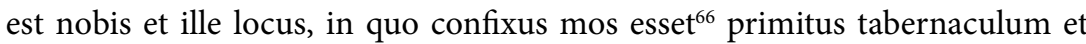
perfecta sunt singula, quae iusserat Deus in montem Moysi, ut fierent.

5.10. Vidimus etiam in extrema iam ualle ipsa Memorias Concupiscentiae, in eo tamen ${ }^{67}$ loco, in quo denuo reuersi sumus ad iter nostrum, hoc est ubi exeuntes de ualle illa grande reingressi sumus uia, qua ueneramus, inter montes illos, quos superius dixeram. Nam etiam ipsa die accessimus et ad ceteros monachos ualde sanctos, qui tamen pro etate ${ }^{68}$ aut inbecillitate occurrere in monte Dei ad oblationem faciendam non poterant; qui tamen nos dignati sunt in monasteriis suis aduenientes ualde humane suscipere.

\footnotetext{
${ }^{59}$ quedam $A$ edd. quaedam Gam $^{1}$ Geyer Pétré

${ }^{60}$ quecumque $A$ edd. quaecumque $\mathrm{Gam}^{2}$ Geyer Pétré

${ }^{61}$ sanctis $A$ edd. sancti Devos Jan

${ }^{62}$ retinere $A$ edd. retineri Geyer Her Pétré

${ }^{63}$ sanctus $A$ sanctos Gam edd. sancti Devos Jan

${ }^{64}$ filii ante Israhel add. Geyer edd. praeter Gam

${ }^{65}$ inmorati $A$ edd. immorati Gam Arce

${ }^{66}$ confixus mos esset $A$ confixit Moyses Gam $^{2}$ confixum a Moyse est Geyer edd.

${ }^{67}$ tamen $A$ edd. autem Gam

${ }^{68}$ etate $A$ edd. aetate Geyer Pétré
} 
5.7. Mostraram-nos também o lugar onde os setenta homens receberam de Moisés o seu espírito. Igualmente mostraram o lugar onde os filhos de Israel tiveram a cobiça de alimentos $(\mathrm{Nm} \mathrm{11,4).} \mathrm{Ainda} \mathrm{nos} \mathrm{mostraram} \mathrm{o} \mathrm{lugar}$ que é chamado Incêndio (Nm 11,1-3), porque foi incendiada certa parte dos acampamentos, quando então, ${ }^{34}$ rezando o santo Moisés, o fogo cessou.

5.8. Mostraram também olugar onde choveu para eles maná e codornizes (Ex 16,13-14; Nm 11,7-9; 31,33). E assim, portanto, uma a uma, quaisquer coisas que estão escritas nos livros santos de Moisés terem acontecido naquele lugar, isto é, no vale o qual disse que está situado abaixo do monte de Deus, isto é, o santo Sinai, foi mostrado a nós. Na verdade, escrever todas essas coisas uma por uma seria demais, porque nem sequer podiam ser lembradas, de tão numerosas, mas, quando Vossa Afeição ${ }^{35}$ ler os santos livros de Moisés, verá mais atentamente os fatos que aconteceram nesse lugar.

5.9. Este é, pois, o vale onde foi celebrada a Páscoa*, completado um ano da partida dos filhos de Israel da terra do Egito ( $\mathrm{Nm} \mathrm{9,1-5),} \mathrm{pois} \mathrm{nesse}$ mesmo vale os filhos de Israel se demoraram por algum tempo, isto é, enquanto o santo Moisés subiu ao monte de Deus e desceu pela primeira e segunda vez; e novamente algum tempo ficaram aí até que fosse feito o tabernáculo* e todas as coisas que nos foram mostradas no monte de Deus. Com efeito, nos foi mostrado o lugar em que foi fixado, primeiramente, por Moisés, o tabernáculo, e foi executada cada uma das coisas que ordenara Deus a Moisés, no monte, ${ }^{36}$ que se fizesse (Ex 40).

5.10. Vimos também, já no extremo do vale, as Memórias da Concupiscência (Nm 11,34) e, enfim, naquele lugar no qual novamente voltamos ao nosso caminho, isto é, onde, saindo do grande vale, reingressamos na estrada pela qual viéramos, entre os montes que acima descrevi. Efetivamente, ainda no mesmo dia nos encontramos com outros monges muito santos, que, porém, pela idade ou fraqueza, não podiam ir à montanha de Deus para fazer a oblação; entretanto, eles dignaram-se a acolher-nos em nossa chegada, com muita bondade, nos seus mosteiros.

\footnotetext{
${ }^{34}$ Quando então (tunc qua): no latim clássico apareceria tunc cum.

${ }^{35}$ Vossa Afeição (affectio uestra): forma de tratamento usada no texto. Outras formas de tratamento aplicadas a uma autoridade eclesiástica são Caritas Vestra e Dilectio Vestra, conforme C. Mohrmann, em Die altchristliche Sondersprache in den Sermones des hl. Augustin (apud PÉTRÉ, 1948, p.116).

${ }^{36}$ No monte (in montem): note-se o acusativo indicando um locus ubi ("lugar onde").
} 
5.11. Ac sic ergo uisa loca sancta omnia, quae desiderauimus, nec non etiam et omnia loca, quae filii Israhel tetigerant eundo uel redeundo ad montem Dei, uisis etiam et sanctis uiris, qui ibi commorabantur, in nomine Dei regressi sumus in Faran.

5.12. Et licet semper Deo in omnibus gratias agere debeam, non dicam in his tantis et talibus, quae circa me conferre dignatus est indignam et non merentem, ut perambularem omnia loca, quae mei meriti non erant: ${ }^{69}$ tamen etiam et illis omnibus sanctis nec sufficio gratias agere, qui meam paruitatem dignabantur in suis monasteriis libenti animo suscipere uel certe per omnia loca [37] deducere, quae ego semper iuxta Scripturas sanctas requirebam. Plurimi autem ex ipsis ${ }^{70}$ sanctis, qui in montem Dei uel circa ipsum montem commorabantur, dignati sunt nos usque in Faran deducere, qui tamen fortiori corpore erant.

${ }^{69}$ erant $A$ edd. erat Geyer (in nota)

${ }^{70}$ ipsis corr. ex ipsius $A$ 
5.11. E assim, pois, vistos todos os lugares santos ${ }^{37}$ que desejávamos e não só eles, mas ainda todos os lugares que os filhos de Israel alcançaram indo para a montanha de Deus ou vindo, e visitados todos os santos homens que aí habitavam, em nome de Deus, voltamos a Faran.

5.12. E ainda que eu sempre deva dar graças a Deus em tudo, não direi sobre as tão grandes e importantes < graças $>$ que se dignou a me destinar, indigna e não merecedora, que percorresse todos os lugares que não eram do meu merecimento, e também a todos aqueles santos nem posso agradecer, que se dignaram a receber minha insignificância, com prazer, em seus mosteiros, ou me levar incontestavelmente por todos os lugares que eu sempre, conforme as Santas Escrituras, requeria. Além disso, grande parte desses santos, pelo menos $^{38}$ os que eram mais fortes de corpo, que moravam na montanha de Deus ou nas imediações da montanha, dignaram-se a nos acompanhar até Faran.

\footnotetext{
${ }^{37}$ Vistos todos os lugares santos (uisa loca sancta omnia): conforme Herrero (1965), trata-se de um "nominativo absoluto", um arcaísmo empregado tal como o ablativo de mesmo nome, com o valor de uma proposição autônoma. Mas, levando-se em consideração o ablativo absoluto uisis etiam et sanctis uiris que vem coordenado, podemos pensar que não se trata de um arcaísmo, mas de uma confusão no emprego dos casos. V. notas 73, 84 .

${ }^{38}$ Pelo menos (tamen): conforme Väänänen (1987, p.117), nesta ocorrência, tamen apresenta um sentido restritivo: 'mais exatamente', 'todavia, 'pelo menos'. Parece-nos ser essa a interpretação adequada à frase. Com esse mesmo sentido, temos ainda as ocorrências de tamen em 25,2 e 45,3.
} 
6.1. Ac sic ergo cum peruenissemus Faram, ${ }^{71}$ quod sunt a monte Dei milia triginta et quinque, necesse nos fuit ibi ad resumendum biduo immorari. Ac tertia die inde maturantes uenimus denuo ad mansionem, id est in desertum Faran, ubi et euntes manseramus, sicut et superius dixi. Inde denuo alia die facientes aquam et euntes adhuc aliquantulum inter montes peruenimus ad mansionem, quae erat iam super mare, id est in eo loco, ubi iam de inter montes exitur et incipitur denuo totum iam iuxta mare ambulari, sic tamen iuxta mare, ut subito fluctus animalibus pedes cedat, ${ }^{72}$ subito etiam et in centum et in ducentis passus ${ }^{73}$ aliquotiens etiam et plus quam quingentos passus de mari per heremum ambuletur; uia enim illic penitus non est, sed totum heremi sunt arenosae.

6.2. Faranite $^{74}$ autem, qui ibi consueuerunt ambulare cum camelis suis, signa sibi locis et locis ponent, ad quae signa se tendent et sic ambulant per diem. Nocte autem signa cameli attendunt. Et quid plura? Diligentius et securius iam in eo loco ex consuetudine Faranitae ambulant nocte quam aliqui hominum ambulare potest in his locis, ubi uia aperta est.

\footnotetext{
${ }^{71}$ Faram A edd. Faran Gam Geyer Pétré Arce

${ }^{72}$ cedat $A$ edd. caedat Geyer Her Pétré

${ }^{73}$ ducentis passus $A$ ducentis passibus Her edd. ducentos passus Gam Geyer Pétré

${ }^{74}$ faranite $A$ edd. faranitae Gam ${ }^{2}$ Geyer Pétré
} 
6.1. E assim, logo que chegamos a Faran, ${ }^{39}$ que fica a trinta e cinco milhas do monte de Deus, foi-nos necessário ficar aí por dois dias para nos recuperarmos. E no terceiro dia, apressados, dali voltamos de novo para a pousada no deserto de Faran onde pousáramos na ida, conforme contei acima. Novamente, no outro dia, buscando a água e indo dali quase nada entre os montes, chegamos a um albergue que já era sobre o mar, isto é, naquele lugar onde já se sai de entre os montes e se começa novamente a andar muito perto do mar, mas tão próximo do mar, que de repente a onda toca nos pés dos animais, e também inesperadamente se anda por cem ou duzentos passos, e também, algumas vezes, se anda mais do que quinhentos passos do mar, pelo deserto; na verdade, lá não há absolutamente uma estrada, mas a totalidade do deserto é um areal. ${ }^{40}$

6.2. Os faranitas que costumavam andar aí com seus camelos colocam sinais para si, de lugar em lugar aos quais se dirigem, e assim andam durante o dia. Depois, de noite, os camelos prestam atenção aos sinais. E o que mais? Nesse lugar, os faranitas andam, por estarem acostumados, com mais exatidão e mais segurança, de noite, do que qualquer homem pode andar nos lugares onde há uma estrada aberta.

\footnotetext{
${ }^{39}$ Faran (Faram): nesta ocorrência, Faram tem a função de complemento de lugar "para onde". No texto, há uma oscilação na estrutura dos complementos de lugar que envolvem palavras de origem semita, como essa. Note-se que em 5,11 e em 5,12 encontra-se in Faran como complemento de verbos de movimento, obedecendo à regência do latim clássico. Repare-se, nessa palavra, também na alternância entre $n$ e $m$ finais.

${ }^{40}$ Areal (arenosae): para concordar com totum, deveria ser arenosum. Uma outra interpretação é pensar que há a elipse de terrae. De qualquer modo, fica inexplicado o plural do verbo.
} 
6.3. In eo ergo loco de inter montes exiuimus redeuntes, in quo loco et euntes inter montes intraueramus, ac sic ergo denuo plicauimus nos ad mare. Filii etiam Israhel reuertentes ad montem ${ }^{75}$ Dei Syna usque ad eum locum reuersi sunt per iter quod ierant, id est usque ad eum locum ${ }^{76}$ ubi de inter montes exiuimus et iunximus nos denuo ad mare Rubrum et inde nos iam iter nostrum, quo ueneramus, reuersi sumus. Filii autem Israhel de eodem loco, sicut scriptum est in libris sancti Moysi, ambulauerunt iter suum.

6.4. Nos autem eodem itinere et eisdem mansionibus, quibus ieramus, reuersi sumus in Clesma. In Clesma autem cum uenissemus, necesse nos fuit denuo et ibi denuo resumere, ${ }^{77}$ quoniam iter heremi arenosum ualde feceramus.

7.1. Sane licet terra Gesse iam nosse, ${ }^{78}$ id est qua primitus ad Egyptum fueram, tamen ut peruiderem omnia loca, quae filii Israhel exeuntes de Ramesse tetigerant euntes, donec peruenirent usque ad mare Rubrum, qui locus nunc de castro, qui ${ }^{79}$ ibi est, appellatur Clesma; desideriii ${ }^{80}$ ergo fuit, ut [38] de Clesma ad terram Gesse exiremus, id est ad ciuitatem quae appellatur Arabia, quae ciuitas in terra Gesse est; nam inde ipsum territorium sic appellatur, id est terra Arabiae, terra Iesse, quae tamen terra Egypti pars est, sed melior satis quam omnis Egyptus est.

\footnotetext{
${ }^{75}$ ad montem A Gam Prinz Mar Nat MaN a monte Geyer Her Pétré FrW Arce Jan

${ }^{76}$ reuersi sunt per iter quod ierant, id est usque ad eum locum librarius omiserat, eaque postea in fine paginae minutis litteris transcripsit.

${ }^{77}$ necesse nos fuit denuo et ibi denuo resumere $A$ edd. denuo, necesse nos fuit et ibi denuo resumere transp. Geyer Pétré necesse nos fuit denuo et ibi biduo resumere Her (in nota)

${ }^{78}$ terra Gesse iam nosse A edd. terram ... nossem Gam Geyer Pétré

${ }^{79}$ qui $A$ edd. quod Gam Geyer Pétré

${ }^{80}$ desiderii $A$ edd. desideri Gam
} 
6.3. Voltando, pois, saímos de entre ${ }^{41}$ os montes no mesmo lugar no qual, indo entre os montes, entráramos, e assim, pois, chegamos de novo até o mar. Também os filhos de Israel, voltando do monte de Deus, o Sinai, voltaram até aquele lugar pelo caminho que foram, isto é, até aquele lugar onde saímos de entre os montes e nos unimos novamente ao Mar Vermelho, e daí nós já retornamos ao nosso trajeto pelo qual viéramos; entretanto, os filhos de Israel, desse mesmo lugar, assim como está escrito nos livros do santo Moisés, seguiram seu caminho (Nm 10,12; 33,16-49).

6.4. Nós, porém, pelo mesmo itinerário e pelas mesmas pousadas que fôramos, voltamos a Clisma*. Depois, quando chegamos a Clisma novamente, foi-nos necessário nos recuperar, pois fizéramos muito o caminho arenoso do deserto. ${ }^{42}$

7.1. Muito embora já conhecesse a terra de Gessen, ${ }^{*} 43$ isto é, por onde fora pela primeira vez ao Egito, entretanto, para ver todos os lugares que os filhos de Israel, saindo de Ramsés* (Ex 12,37ss), indo atingiram em seu caminho até o momento em que chegaram ao Mar Vermelho, lugar que agora se chama Clisma, por causa da fortaleza que ali está, logo, foi desejo que saíssemos de Clisma à terra de Gessen, isto é, até a cidade* que se chama Arábia*, cidade que está na terra de Gessen $(\mathrm{Gn} 45,10 ; 46,34)$ e, na verdade, o próprio território a partir desse lugar é assim chamado, isto é, terra da Arábia, terra de Gessen; essa terra, todavia, é parte do Egito, mas é muito melhor do que todo o Egito.

${ }^{41}$ De entre (de inter): note-se a preposição de reforçando o advérbio de lugar ou preposição inter (cf. port. dentre). O reforço de um grande número de advérbios de tempo e de lugar e de certas preposições pela anteposição de uma preposição é um fenômeno comum do latim vulgar. Além de de, partícula de reforço por excelência destas duas categorias gramaticais, ocorrem ainda nesta função $a b$, ad e per. Ab aparece em abante (romeno antigo a-inte, italiano avanti, francês avant, provençal avan, etc.). Ad encontra-se em ad satis, ad trans, ad post (rom. apoi, it. ant. appo, logudorês ant. appus, port. após), afforas (rom. afara, it. ant. affuori, francês ant. afors, espanhol afuera, port. afora). Per encontramos em perante e per ad (port. e esp. para, catalão e port. arcaico pera, etc.). V. nota 15.

${ }^{42}$ Do deserto (heremi): heremus por eremus, “deserto". Egéria confunde o uso ou não uso do $h$, o que mostra que este não era mais aspirado na sua época. V. notas 17, 33, 64. ${ }^{43}$ Gessen (Gesse): este é um topônimo de origem semita que os dicionários apontam como indeclinável e terminado em $n$. Aqui, usado como aposto a um acusativo, o nome foi declinado como se estivesse no ablativo latino. Ocorrências desse tipo, bastante comuns em Egéria, mostram que a autora faz uma verdadeira miscelânea no uso das terminações casuais. 
7.2. Sunt ergo a Clesma, id est a mare Rubro, usque ad Arabiam ciuitatem mansiones quattuor per heremo, sic tamen per heremum, ut cata mansiones monasteria ${ }^{81}$ sint cum militibus et praepositis, ${ }^{82}$ qui nos deducebant semper de castro ad castrum. In eo ergo itinere sancti, qui nobiscum erant, hoc est clerici uel monachi, ostendebant nobis singula loca, quae semper ego iuxta Scripturas requirebam; nam alia in sinistro, alia in dextro de itinere nobis erant, alia etiam longius de uia, alia in proximo.

7.3. Nam michi credat uolo affectio uestra, quantum tamen peruidere potui, filios Israhel sic ambulasse, ut quantum irent dextra, tantum reuerterentur sinistra, quantum denuo in ante ${ }^{83} \mathrm{ibant}$, tantum denuo retro reuertebantur: et sic fecerunt ipsum iter, donec peruenirent ad mare Rubrum.

7.4. Nam et Epauleum ostensus ${ }^{84}$ est nobis, de contra tamen, et Magdalum fuimus. Nam castrum est ibi nunc habens praepositum ${ }^{85}$ cum milite, qui ibi nunc praesidet ${ }^{86}$ pro disciplina Romana.$^{87}$ Nam et nos iuxta consuetudinem deduxerunt inde usque ad aliud castrum, et ioe Belsefon ${ }^{88}$ ostensum $^{89}$ est nobis, immo in eo loco fuimus. Nam ipse est campus supra mare Rubrum iuxta latus montis, quem superius dixi, ubi filii Israhel, cum uidissent Egyptios post se uenientes, exclamauerunt.

\footnotetext{
${ }^{81}$ monasteria corr. ex manasteria $A$

${ }^{82}$ praepositis A Gam Geyer Her Pétré Prinz prepositis FrW Arce Mar Jan Nat MaN

${ }^{83}$ in ante $A$ edd. inante Geyer Pétré

${ }^{84}$ ostensus $A$ ostensum Gam edd.

${ }^{85}$ praepositum A Gam Geyer Her Pétré Prinz prepositum FrW Arce Mar Jan Nat MaN

${ }^{86}$ praesidet A Gam Geyer Her Pétré Prinz presidet FrW Arce Mar Jan Nat MaN

${ }^{87}$ Romana corr. ex Romanarum $A$

${ }^{88}$ et ioe Belsefon $A$ et Ioebelsephon $\mathrm{Gam}^{2}$ ((in nota) fortasse inde Belsephon) et locus Belsefon Geyer Pétré etiam Beelsefon Her et loco Belsefon FrW Arce Mar Jan Nat MaN ${ }^{89}$ ostensum A edd. ostensus Geyer Pétré
} 
7.2. Existem, pois, de Clisma, isto é, do Mar Vermelho, até a cidade de Arábia, quatro pousadas pelo deserto, assim $<$ dispostas $>$ pelo deserto, que cada ${ }^{44}$ uma das pousadas tenha um posto militar ${ }^{45}$ com soldados e comandantes, ${ }^{46}$ que sempre nos acompanhavam de acampamento a acampamento. Nesse percurso, pois, os santos que estavam conosco, isto é, clérigos ${ }^{\star}$ ou monges, mostravam a nós cada um dos lugares que eu sempre requeria, conforme as Escrituras; de fato, uns ficavam à esquerda, outros à direita em relação ao nosso caminho, uns muito perto, e outros ainda bem longe da estrada.

7.3. Efetivamente, quero que Vossa Afeição me creia, tanto quanto pude ver, que os filhos de Israel andaram assim, de modo que o quanto foram para a direita, tanto voltaram para a esquerda, novamente o quanto iam em frente, tanto outra vez voltavam para trás, e assim fizeram o mesmo caminho até que chegaram ao Mar Vermelho.

7.4. Com efeito, não só nos foi mostrado Epáulis ${ }^{\star}$ defronte, como também estivemos em $\mathrm{Magdol}^{\star}$ (Ex 14,2). De fato, agora existe um forte nesse lugar, contendo um oficial com soldado, que aí agora responde ${ }^{47}$ pela disciplina romana. Também, efetivamente, segundo o costume, nos conduziram daí até outro forte, e nos foi mostrado o lugar Baal-Sefon* (Ex 14,2), aliás, estivemos nele. Na verdade, é uma planície acima do Mar Vermelho, junto ao flanco da montanha, que acima disse, onde os filhos de Israel, como tivessem avistado os egípcios vindo atrás deles, gritaram (Ex 14,10).

\footnotetext{
${ }^{44}$ Cada (cata): cata é um novo indefinido distributivo que aparece, como neste exemplo, no lugar dos indefinidos latinos singuli, -ae, -a ou quisque (cf. cata mane na Vulgata, em Ez 46,14). Segundo Maurer Jr. (1959, p.118), “origina-se da preposição grega katá e devia pertencer já ao latim vulgar do Império, disseminando-se, porém, sobretudo no Ocidente, conforme o português, o espanhol e o catalão cada, e o francês meridional cade. Não existe no romeno". Esse indefinido mostra ainda uma das influências do grego no vocabulário do latim vulgar.

${ }^{45}$ Posto militar (monasteria): nesta passagem, a palavra monasteria não parece ter $\mathrm{o}$ sentido mais comum de "mosteiros", mas sim de "postos militares", devido à presença de soldados e comandantes. Ver, no Glossário, mosteiro.

${ }^{46}$ Comandantes (praepositis): praepositus é "comandante", “oficial", mas pode ser também o governador do lugar. Relaciona-se com o verbo praeponere "pôr à frente de", "colocar adiante" ou "colocar antecipadamente".

${ }^{47}$ Responde (praesidet): $3^{\text {a }}$ pessoa do singular do verbo praesideo, es, sedi, sessum, sidere (de prae + sedeo) 'estar sentado diante, adiante', 'ter o primeiro lugar', 'ter a presidência', 'presidir'. Aqui significa 'governa', 'preside', 'comanda', 'guarda'. A esse verbo relacionase praesidium 'presídio', 'força incumbida de guardar ou defender', 'guarnição, 'local de segurança, e também "presidiário" e "presidente", no português.
} 
7.5. Oton etiam ostensum est nobis, quod est iuxta deserta loca, sicut scriptum est, nec non etiam et Socchoth. Socchoth autem est cliuus modicus in media ualle, iuxta quem colliculum fixerunt castra filii Israhel; nam hic est locus, ubi accepta est lex Paschae.

7.6. Pithona etiam ciuitas, quam edificauerunt ${ }^{90}$ filii Israhel, ostensa est nobis in ipso itinere, in eo tamen loco, ubi iam fines Egypti intrauimus, relinquentes iam terras Saracenorum: nam et ipsud nunc Phitona castrum est.

7.7. Herorum ${ }^{91}$ autem ciuitas, quae fuit illo tempore, id est ubi occurrit Ioseph patri suo Iacob uenienti, sicut scriptum est in libro Genesis, nunc est comes, ${ }^{92}$ sed grandis, quod nos dicimus uicus. Nam ipse uicus ecclesiam habet et martyria et monasteria plurima sanctorum monachorum; ad quae singula uidenda necesse nos fuit ibi descendere iuxta consuetudinem, quam tenebamus.

7.8. Nam ipse uicus nunc appellatur Hero, quae tamen Hero [39] a terra Iesse miliario iam sexto decimo est, nam in finibus Egypti est. Locus autem ipse satis gratus est, nam et pars quedam ${ }^{93}$ fluminis Nili ibi currit.

7.9. Ac sic ergo exeuntes de Hero peruenimus ad ciuitatem, que ${ }^{94}$ appellatur Arabia, quae est ciuitas in terra Iesse, unde scriptum est dixisse Pharaonem ad Ioseph: "In meliori terra Egypti colloca patrem tuum et fratres, in terra Iessen, in terra Arabiae".

8.1. De Arabia autem ciuitate quattuor milia passus sunt Ramessen. Nos autem, ut ueniremus ad mansionem Arabiae, per media Ramesse transiuimus: quae Ramessen ciuitas nunc campus est, ita ut nec unam habitationem habeat. Paret sane, quoniam et ingens fuit per girum et multas fabricas habuit; ruinae enim ipsius, quemadmodum collapsae sunt, in hodie infinitae parent.

\footnotetext{
${ }^{90}$ edificauerunt $A$ edd. aedificauerunt Gam Geyer Pétré

${ }^{91}$ Herorum $A$ Heroum Gam edd.

${ }_{92}$ comes A Her come Gam edd.

${ }^{93}$ quedam $A$ edd. quaedam Gam Geyer Pétré

${ }^{94}$ que $A$ edd. quae Gam ${ }^{2}$ Geyer Pétré Arce
} 
7.5. Também nos foi mostrado Etam* (Ex 13,20), que fica junto aos lugares desertos, assim como está escrito, e ainda também Sucot* ${ }^{*}$ Ex 12,37). Entretanto, Sucot é uma ladeira moderada no meio do vale e, junto a esse outeirinho, plantaram acampamentos os filhos de Israel; na verdade, aqui é o lugar onde foi recebida a Lei da Páscoa (Ex 12,43).

7.6. Ainda a cidade de Pitom* (Ex 1,11), que os filhos de Israel construíram, nos foi mostrada no mesmo trajeto, porém naquele lugar onde já entramos no território do Egito, deixando já a terra dos sarracenos; com efeito, agora também Pitom é um forte.

7.7. Também a cidade de Herópolis*, que existiu naquele tempo, isto é, onde José correu ao encontro de Jacó ${ }^{\star}$, seu pai, que se aproximava, assim como está escrito no livro do Gênesis, agora é um povoado, ${ }^{48}$ porém grande, que nós dizemos aldeia. De fato, essa aldeia tem uma igreja, bem como martyria ${ }^{*} \mathrm{e}$ também numerosos mosteiros de monges santos; para ver cada um deles nos foi necessário ali descer, conforme o costume que mantínhamos.

7.8. Na verdade, essa aldeia agora se chama Hero*, Hero que, contudo, está precisamente a dezesseis milhas da terra de Gessen, pois está no território do Egito; esse lugar é, aliás, muito agradável, pois certa parte do rio Nilo* corre ali.

7.9. E assim, portanto, saindo de Hero, chegamos à cidade que se chama Arábia, cidade que está na terra de Gessen, <acerca $>$ da qual ${ }^{49}$ está escrito ter dito o Faraó a José: "Na melhor terra do Egito estabelece o teu pai e irmãos: na terra de Gessen, na terra da Arábia” (Gn 47,6).

8.1. Da cidade de Arábia há quatro mil passos a Ramsés. Nós, porém, para voltar à pousada de Arábia, atravessamos pelo meio de Ramsés, cidade a qual agora é uma planície, a tal ponto que não tem nem sequer uma habitação. Sem dúvida, está claro que também foi imensa em circunferência e teve muitas construções; ${ }^{50}$ na verdade, as ruínas dela, tais como estão caídas, hoje parecem imensas.

\footnotetext{
${ }^{48}$ Povoado (come): come macra em grego significa 'vila grande' e, segundo alguns, "comarca" em português tem aí sua origem. Egéria traduz nesta passagem a palavra come pelo termo latino uicus (Heroum ciuitas... nunca est come... quod nos dicimus uicus), o que mostra, mais uma vez, a difusão do grego no Mediterrâneo oriental.

${ }^{49}$ Acerca da qual (unde): aqui o sentido locativo de origem está sendo empregado de modo figurado. Daí a tradução "<acerca> da qual", pois a terra de Gessen seria a "origem" do que está narrado na Bíblia, ou seja, as palavras do Faraó a José (VÄ̈̈NÄNEN, 1987, p.99). ${ }^{50}$ Construções (fabricas): fabrica significa 'estrutura', 'composição', 'construção'. Fabrica ecclesiae designa às vezes o conselho ou diretoria de uma igreja (BLAISE, 1954, p.341).
} 
8.2. Nunc autem ibi nichil aliud est nisi tantum unus lapis ingens Thebeus, in quo sunt duae statuae exclusae ${ }^{95}$ ingentes, quas dicunt esse sanctorum hominum, id est Moysi et Aaron; nam dicent eo quod filii Israhel in honore ipsorum eas posuerint.

8.3. Et est ibi praeterea ${ }^{96}$ arbor sicomori, quae dicitur a patriarchis posita esse; nam iam uetustissima est et ideo permodica est, licet tamen adhuc fructus afferat. Nam cuicumque inquo moditas ${ }^{97}$ fuerit, uadent ibi et tollent surculos, et prode illis est.

8.4. Hoc autem referente sancto episcopo de Arabia cognouimus; nam ipse nobis dixit nomen ipsius arboris, quemadmodum appellant eam grece, ${ }^{98}$ id est dendros alethiae, ${ }^{99}$ quod nos dicimus arbor ueritatis. Qui tamen sanctus episcopus nobis Ramessen ${ }^{100}$ occurrere dignatus est; nam est iam senior uir, uere satis religiosus ex monacho et affabilis, suscipiens peregrinos ualde bene; nam et in Scripturis Dei ualde eruditus est.

8. 5. Ipse ergo cum se dignatus fuisset uexare et ibi nobis occurrere, singula ibi ostendit seu retulit de illa statua, ${ }^{101}$ quas dixi, ut etiam et de illa arbore sicomori. Nam et hoc nobis ipse sanctus episcopus retulit, eo quod Farao, quando uidit quod filii Israhel dimiserant eum, tunc ille, priusquam post illos occuparet, isset cum omni exercitu suo intra Ramesse et incendisset eam omnem, quia ${ }^{102}$ infinita erat ualde, et inde post filios Israhel fuisset profectus.

\footnotetext{
${ }_{95}$ exclusae $A$ edd. excisae Geyer Pétré

${ }^{96}$ praeterea A Gam Geyer Pétré Her Prinz preterea Arce Mar Jan Nat MaN

${ }^{97}$ inquo moditas $A$ commoditas Gam incommoditas Geyer Pétré inquomoditas Her edd.

${ }^{98}$ grece $A$ edd. graece $\mathrm{Gam}^{2}$ Geyer Pétré

${ }^{99} \mathrm{Na}$ margem do manuscrito, está anotado " $\delta \varepsilon ́ v \delta \rho o \varsigma \alpha ̉ \lambda \eta \theta i ́ \alpha \varsigma$ ". Prinz (p.11) interpreta que essa citação foi acrescentada recentemente ao manuscrito e que, portanto, não pode ser atribuída ao copista.

${ }^{100}$ Ramessen corr. ex tamessen uel qamessen $A$

${ }^{101}$ illa statua A Gam Nat MaN illas statuas Geyer edd.

${ }^{102}$ quia $A$ edd. quae $E_{k}{ }^{2}$ Mar Nat MaN
} 
8.2. Agora, contudo, lá não há outra coisa a não ser tão somente uma imensa pedra de Tebas*, na qual estão duas estátuas talhadas, enormes, que dizem ser dos santos homens, isto é, Moisés e Aarão; também dizem ${ }^{51}$ que os filhos de Israel as puseram em honra dos mesmos.

8.3. E lá, além disso, há uma árvore de sicômoro*, que se diz ter sido colocada pelos patriarcas; ${ }^{*}$ na verdade, já é velhíssima e por isso é muito pequena, embora ainda até agora dê frutos. De fato, todos aqueles que tenham tido um incômodo vão lá e arrancam uns galhos, e é útil a eles. ${ }^{52}$

8.4. Soubemos disso pelo relato do santo bispo* de Arábia; efetivamente, ele disse a nós o nome da própria árvore, como a chamam em grego, isto é, dendros alethiae, que nós dizemos "árvore da verdade". Esse santo bispo, por outro lado, dignou-se de correr ao nosso encontro em Ramsés; de fato, já é um homem velho, verdadeiramente muito piedoso e afável desde <o tempo em que foi $>$ monge, que recebe os peregrinos muito bem; na verdade também é grandemente erudito nas Escrituras de Deus.

8.5. Ele, pois, como tivesse se dignado a se abalar e lá correr a nosso encontro, lá mostrou ou contou sobre cada uma daquelas estátuas, as quais já mencionei, e também sobre aquela árvore de sicômoro. Ainda também o santo bispo nos contou que ${ }^{53}$, quando ${ }^{54}$ o Faraó viu que os filhos de Israel o tinham deixado para trás, antes de atacá-los, foi com todo seu exército para dentro de Ramsés e a incendiou inteira, que era bastante grande, e só então seguiu no encalço dos filhos de Israel.

\footnotetext{
${ }^{51}$ Dizem (dicent): futuro imperfeito que se confunde com o presente dicunt. V. notas $10,113$.

${ }^{52}$ É útil a eles (prode illis est): na construção prode illis est, há uma tmese, que significa uma disjunção de elementos que normalmente formam uma unidade lexical. $\mathrm{Na}$ verdade, o verbo do latim clássico é prodesse 'ser útil a', que foi desmembrado em duas partes, tendo sido interpolado o seu complemento em dativo: illis. Essa figura de construção ou figura de sintaxe tem origem no grego $\tau \mu \tilde{\eta} \sigma ı c_{\text {' }}$ corte', que passou ao latim como tmesis, sinônimo de dissectio. Alguns autores dão-lhe o nome de "mesóclise". Em 49,2, encontra-se o verbo interesse desmembrado e interpolado com o advérbio de negação non: inter non fuerit.

${ }^{53}$ Que (eo quod): eo quod forma uma única expressão, substituindo, ao lado de quod, quia, quoniam, a oração infinitiva usada no latim clássico após verbos declarativos.

${ }^{54}$ Quando (quando): neste caso, quando, um advérbio interrogativo em latim clássico, está sendo usado como conjunção temporal, concorrendo com ubi, ut e cum.
} 
9.1. Nobis autem fortuitu hoc gratissimum euenit, ut ea die, qua uenimus ad mansionem Arabia, pridie in ${ }^{103}$ beatissimo die Epiphania esset; nam eadem die uigiliae agende ${ }^{104}$ erant in ecclesia. Ac sic ergo aliquo biduo ibi tenuit nos sanctus episcopus, sanctus et uere homo Dei, notus mihi ${ }^{105}$ iam satis [40] de eo tempore, a quo ad Thebaidam fueram.

9.2. Ipse autem sanctus episcopus ex monacho est; nam a pisinno in monasterio nutritus est, et ideo aut tam eruditus in Scripturis est aut tam emendatus in omni uita sua, ut et superius dixi.

9.3. Nos autem inde iam remisimus milites, qui nobis pro disciplina Romana auxilia praebuerant ${ }^{106}$, quandiu ${ }^{107}$ per loca suspecta ambulaueramus; iam $^{108}$ autem quo ei iam, ${ }^{109}$ ager $^{110}$ publicum $^{111}$ erat per Egyptum, quod transiebatur ${ }^{112}$ per Arabiam ciuitatem, id est quod mittit de Thebaida in Pelusio: et ideo iam non fuit necesse uexare milites.

9.4. Proficiscentes ergo inde totum per terram Gessen iter fecimus semper inter uineas, quae dant uinum, et uineas, quae dant balsamum, et inter pomaria et agros cultissimos et hortos primos. ${ }^{113}$ Iter habuimus totum super ripam fluminis Nili inter fundos frequentissimos, quae fuerant quondam uillae filiorum Israhel. Et quid plura? Pulchriorem territorium puto me nusquam ${ }^{114}$ uidisse quam est terra Iessen.

9.5. Ac sic ergo ab Arabia ciuitate iter facientes per biduo totum per terram Gessen peruenimus Tatnis, in ea ciuitate, ubi natus est sanctus Moyses. Haec est autem ciuitas Tathnis, quae fuit quondam metropolis Pharaonis.

\footnotetext{
${ }^{103}$ in A Prinz Mar Jan Nat a Gam edd.

104 agende $A$ edd. agendae Gam² Geyer Pétré

${ }^{105}$ mihi $A$ edd. michi Nat

${ }^{106}$ praebuerant A Gam ${ }^{2}$ Geyer Her Pétré Prinz prebuerant Gam ${ }^{1}$ FrW Mar Nat Arce Jan $M a N$

${ }^{107}$ quandiu A edd. quamdiu Gam Geyer Pétré Arce

${ }^{108}$ iam $A$ edd. iter Gam $^{2}$

${ }^{109}$ quo ei iam $A \mathrm{Gam}^{2}$ quoniam $\mathrm{Gam}^{1}$ edd.

${ }^{110}$ ager $A$ edd. agger Gam $^{1}$ FrW Arce

${ }^{111}$ publicum A edd. publicus Gam Geyer Her Pétré Arce

112 transiebatur A Gam MaN transiebat Geyer edd.

${ }^{113}$ primos $A$ Gam $^{1}$ Prinz Mar Jan Nat MaN primo Gam ${ }^{2}$ plurimos Chol Her FrW Arce pulcherrimos Geyer Pétré

${ }^{114}$ nusquam $A$ edd. nunquam Gam $^{2}$
} 
9.1. Todavia, por acaso aconteceu-nos isto de extremamente agradável, que naquele dia em que chegamos à pousada de Arábia era véspera do felicíssimo dia da Epifania; ${ }^{*}$ de fato, naquele mesmo dia, deviam realizar-se vigílias na igreja. $\mathrm{E}$ assim, pois, nos reteve por dois dias nesse lugar o santo bispo, santo e verdadeiramente homem de Deus, já bastante conhecido por mim desde o tempo em que eu fora a Tebaida*.

9.2. Esse santo bispo é um antigo monge, pois foi, desde pequeno, criado no mosteiro e, por isso, é tão erudito nas Escrituras, como $^{55}$ é correto em toda a sua vida, como já disse acima.

9.3. Mas, a partir dali, nós já dispensamos os soldados que nos ofereceram auxílio por conta da disciplina romana durante todo o tempo em que andamos por lugares perigosos; porque agora já havia uma estrada ${ }^{56}$ pública através do Egito que passava pela cidade de Arábia, isto é, que conduz de Tebaida a Pelúsio*, e por isso já não foi necessário incomodar os soldados.

9.4. Partindo, pois, de lá, percorremos o caminho todo pela terra de Gessen, sempre entre videiras que dão vinho e videiras que dão bálsamo, e entre pomares e campos cultivadíssimos e jardins de primeira <qualidade>. Fizemos o caminho todo sobre a ribanceira do rio Nilo, entre quintas bastante numerosas que foram antigamente casas de campo dos filhos de Israel. E o que mais? Penso não ter visto território mais bonito, em nenhuma parte, do que é a terra de Gessen.

9.5. E assim, portanto, da cidade de Arábia, andando por dois dias inteiros pela terra de Gessen, chegamos naquela cidade de Táfnis*, onde nasceu o santo Moisés. Esta cidade de Táfnis é, de fato, a que foi antigamente a capital ${ }^{\star}$ do Faraó.

\footnotetext{
${ }^{55}$ Tão (...) como (...): na coordenação aut tam (...) aut tam (...) presente no texto latino, o aut não funciona como uma conjunção disjuntiva, por isso não foi traduzido. Aut isoladamente tem uma flutuação de emprego, assim como uel, entre conjunções aditivas e disjuntivas, como, por exemplo, em 39,1: Tam in ecclesia maiore quam ad Anastase aut ad Crucem uel in Eleona, sed et in Bethleem nec non etiam in Lazariu uel ubique, quia dies paschales sunt (sc. omnia ornata sunt). V. notas 67, 102, 144, 186.

${ }^{56}$ Estrada (ager): trata-se aqui não da palavra ager que significa 'campo,' 'território', mas da palavra agger, simplificada na grafia, que tem, entre outros sentidos, o de 'estrada', tal como nesta ocorrência.
} 
9.6. Et licet ea loca, ut superius dixi, iam nosse ${ }^{115}$, id est quando Alexandriam uel ad Thebaidem fueram, tamen quia ad plenum discere uolebam loca, quae ambulauerunt filii Israhel proficiscentes ex Ramesse usque ad montem Dei sanctum Syna: ac sic necesse fuit etiam denuo ad terram Gessen reuerti et inde Tathnis. Proficiscentes ergo de Tathnis, ambulans per iter iam notum perueni Pelusio.

9.7. Et inde proficiscens denuo faciens iter per singulas mansiones Egypti, per quas iter habueramus, perueni ad fines Palestinae. Et inde in nomine Christi Dei nostri faciens denuo mansiones aliquod ${ }^{116}$ per Palestina regressa sum in Helia, id est in Ierusolimam.

10.1. Item transacto aliquanto tempore et iubente Deo fuit denuo uoluntas accedendi usque ad Arabiam, id est ad montem Nabau, in eo loco, in quo iussit Deus ascendere Moysen dicens ad eum: "Ascende in montem Arabot, montem Nabau, qui est in terra Moab contra faciem Iericho, et uide terram Chanaan, quam ego do filiis Israhel in possessionem, et morere in monte ipso, in quem ascenderis".

10.2. Itaque ergo Deus noster Iesus, qui sperantes in se non deseret, etiam et in hoc uoluntati meae effectum praestare ${ }^{117}$ dignatus est.

10.3. Proficiscens ergo Ieruso[41]lima faciens iter cum sanctis, id est presbytero et diaconibus de Ierusolima et fratribus aliquantis, id est monachis, peruenimus ergo usque ad eum locum Iordanis, ubi filii Israhel transierant, quando eos sanctus Iesus filius Naue Iordanem traiecerat, sicut scriptum est in libro Iesu Naue. Nam et locus ille ostensus est nobis quasi modice altior, ubi filii Ruben et Gad et dimidia tribus Manasse fecerant aram, in ea parte ripae, qua est Iericho.

\footnotetext{
$\overline{115}$ nosse $A$ edd. nossem Gam Geyer Pétré

${ }^{116}$ aliquod $A$ edd. aliquot Geyer Pétré

${ }^{117}$ praestare A Gam Geyer Her Pétré Prinz prestare FrW Arce Mar Jan Nat MaN
} 
9.6. E ainda que, como falei acima, já tivesse conhecido aqueles lugares, isto é, quando fora a Alexandria e a Tebaida, contudo, porque queria estudar a fundo os lugares em que os filhos de Israel andaram, partindo de Ramsés (Ex 12,37ss) até o monte santo de Deus, o Sinai, assim também foi necessário novamente voltar à terra de Gessen e daí a Táfnis; pois bem, partindo nós de Táfnis, caminhando pelo caminho já conhecido, cheguei a Pelúsio.

9.7. E desse lugar partindo de novo, fazendo o caminho por cada uma das pousadas do Egito pelas quais tínhamos feito viagem, cheguei às terras da Palestina. E daí, em nome de Cristo nosso Deus, fazendo novamente algumas pousadas pela Palestina, voltei a Élia*, isto é, a Jerusalém*.

10.1. Assim, passado bastante tempo e por ordem de Deus, tive de novo vontade de subir até a Arábia, isto é, até o monte Nebo*, naquele lugar em que Deus ordenou Moisés que subisse, dizendo a ele: "Sobe no monte Arabot*, monte Nebo, que fica na terra de Moab*, em frente a Jericó ${ }^{*}$, e vê a terra de Canaã ${ }^{*}$ que eu dou aos filhos de Israel como colônia, ${ }^{57}$ e morre no mesmo monte em que subires" (Dt 32,49-50).

10.2. Assim, pois, Jesus nosso Deus, que não abandona os que esperam nele ${ }^{58}$ nisso também se dignou acrescentar realização à minha vontade.

10.3. Partindo, portanto, de Jerusalém, fazendo o caminho com os santos, isto é, com um presbítero e diáconos ${ }^{\star 59}$ de Jerusalém e muitos irmãos, isto é, monges, chegamos, pois, até aquele lugar do Jordão* onde os filhos de Israel atravessaram, quando o santo Josué, filho de Nave, os fez passar o Jordão, assim como está escrito no livro de Josué de Nave (Js 3-4). De fato, também nos foi mostrado aquele lugar, como que discretamente mais alto, onde os filhos de Ruben e de Gad e a metade da tribo de Manassés fizeram um altar, naquela parte da margem em que está Jericó (Js 22,9-10).

${ }^{57}$ Colônia (possessionem): possessio é 'possessão', 'o ato de possuir,' 'domínio', 'posse', 'propriedade'. Aqui possessionem significa 'colônia' (lugar onde um grupo de migrantes se estabelece em terra estranha).

${ }^{58}$ Nele (in se): se é o pronome reflexivo de $3^{\text {a }}$ pessoa no ablativo. O reflexivo sui, sibi, se é usado para se referir ao sujeito da própria oração em que se encontrar, ou, se estiver numa oração subordinada, para se referir a uma palavra (que designe uma pessoa) da oração principal e cujo pensamento seja representado pela oração subordinada.

${ }^{59}$ Diáconos (diaconibus): do ponto de vista morfológico, Egéria alterna a declinação de diaconus entre a segunda e a terceira declinação. Em 24,1 e 10,3, a palavra segue a flexão da terceira declinação (diacones e diaconibus, respectivamente). Ao contrário, em 24,6 Et at ubi diaconus perdixerit omnia quae dicere habeat, e em 24,5 Et diacono dicente (...), a flexão da palavra diaconus pertence à segunda declinação. Esperar-se-ia a forma diaconis em vez de diaconibus. 
10.4. Transeuntes ergo fluuium peruenimus ad ciuitatem, qui ${ }^{118}$ appellatur Libiada, quae est in eo campo, in quo tunc filii Israhel castra fixerant. Nam et fundamenta de castris filiorum Israhel et habitationibus ipsorum, ubi commorati sunt, in eo loco in hodie parent. Campus enim ipse est infinitus subter montes Arabiae super Iordanem. Nam hic est locus, de quo scriptum est: "Et plorauerunt filii Israhel Moysen in Arabot Moab et Iordane contra Iericho quadraginta diebus".

10.5. Hic etiam locus est ubi post recessum Moysi statim Iesus filius Naue repletus est spiritu scientiae: imposuerat enim Moyses manus suas super eum, sicut scriptum est.

10.6. Nam ipse est locus ubi scripsit Moyses librum Deuteronomii. Hic etiam est locus, ubi locutus est Moyses in aures totius ecclesiae Israhel uerba cantici usque in finem huius, qui scriptus est in libro Deuteronomii. Hic est ipse locus, ubi benedixit sanctus Moyses, homo de filio ${ }^{119}$ Israhel singulatim per ordinem ante obitum suum.

10.7. Nos ergo cum uenissemus in eodem campo, peraccessimus ad locum ipsum, et facta est ibi oratio, lecta etiam pars quedam ${ }^{120}$ Deuteronomii in eo loco nec non etiam et canticus ipsius, sed et benedictiones, quas dixerat super filios Israhel. Et iterato post lectione facta est oratio, et gratias Deo agentes mouimus inde. Id enim nobis semper consuetudinis erat, ut ubicumque ad loca desiderata accedere uolebamus ${ }^{121}$ primum ibi fieret oratio, deinde legeretur lectio ipsa de codice, diceretur etiam psalmus unus pertinens ad rem et iterato fieret oratio ibi ${ }^{122}$. Hanc ergo consuetudinem iubente Deo semper tenuimus, ubicumque ad loca desiderata potuimus peruenire.

\footnotetext{
${ }^{118}$ qui A Prinz Mar Jan Nat MaN quae Gam² Geyer Pétré que Her FrW Arce

119 de filio $A \mathrm{Gam}^{1}$ dei filios $\mathrm{Gam}^{2}$ edd.

${ }^{120}$ quedam $A$ edd. quaedam Gam² Geyer Pétré

${ }^{121}$ uolebamus A edd. ualebamus Bern Geyer FrW Pétré Mar Nat

${ }^{122}$ oratio ibi A Arce ibi oratio Gam edd.
} 
10.4. Atravessando, pois, o rio, chegamos à cidade que se chama Lívias, ${ }^{\star}$ que fica naquela planície em que naquela ocasião os filhos de Israel tinham armado acampamento. De fato, ainda os alicerces dos acampamentos dos filhos de Israel e das habitações dos próprios, onde ficaram, até hoje aparecem naquele lugar. $\mathrm{Na}$ verdade, essa planície é infinita sob os montes de Arábia, sobre o Jordão. De fato aqui é o lugar do qual está escrito: "E os filhos de Israel choraram Moisés em Arabot, em Moab e no Jordão, em frente a Jericó, por quarenta dias" (Dt 34,8).

10.5. Este também é o lugar onde, imediatamente após o afastamento de Moisés, Josué, filho de Nave, ficou repleto do espírito de conhecimento: de fato, Moisés impusera suas mãos sobre ele, assim como está escrito (Dt 34-9).

10.6. Efetivamente, esse é o lugar onde Moisés escreveu o livro do Deuteronômio (Dt 31,24); este também é o lugar onde Moisés falou aos ouvidos de toda a assembleia de Israel até o fim as palavras do cântico, o qual está escrito no livro do Deuteronômio (Dt 31,30; 32,1-43). Este é o mesmo lugar onde o santo Moisés, homem de Deus, abençoou os filhos de Israel um a um, por ordem, antes de sua morte (Dt 33,1).

10.7. Nós, portanto, quando chegamos àquela planície, nos aproximamos até o próprio lugar e ali foi feita uma oração, lida também uma certa parte do Deuteronômio naquele lugar, não apenas o cântico do mesmo (Dt 32,1-43), mas também as bênçãos que pronunciou sobre os filhos de Israel (Dt 33). E outra vez, após a leitura, foi feita uma oração e, dando graças a Deus, partimos dali. De fato, isto era sempre costume, que onde quer que quiséssemos chegar aos lugares desejados, primeiro uma oração se fazia ali, em seguida se lia um texto do Livro, se dizia também um ${ }^{60}$ salmo pertinente à ocasião e novamente pela segunda vez uma oração era feita ali. Mantivemos, pois, sempre esse costume, com a ajuda de Deus, toda vez que pudemos chegar aos lugares desejados.

\footnotetext{
${ }^{60} \mathrm{Um}$ (unus): psalmus unus não parece significar 'um único salmo', como no latim literário, mas 'um salmo', indicando que unus está sendo usado como o artigo indefinido das línguas românicas, que teve aí a sua origem. V. nota 91.
} 
10.8. Ac sic ergo, ut ceptum ${ }^{123}$ opus perficeretur, cepimus ${ }^{124}$ festinare, ut perueniremus ad montem Nabau. Euntibus nobis commonuit presbyter loci ipsius, id est de Libiadae ${ }^{125}$, quae ${ }^{126}$ ipsum nobiscum rogantes moueramus de mansione, quia melius ipsa loca nouerat; dicit ergo nobis ipse presbyter: "Si uultis uidere aquam, quae fluit de petra, id est quam dedit Moyses filiis Israhel sitientibus, potestis uidere, si tamen uolueritis laborem uobis imponere, ut de uia camsemus [42] forsitan miliario sexto".

10.9. Quod cum dixisset, nos satis auidi optati ${ }^{127}$ sumus ire, et statim diuertentes a uia secuti sumus presbyterum, qui nos ducebat. In eo ergo loco ecclesia est pisinna subter montem, non Nabau, sed alterum interiorem: sed nec ipse longe est de Nabau. Monachi autem plurimi commanent ibi uere sancti et quos hic ascites uocant.

11.1. Hi ergo sancti monachi dignati sunt nos suscipere ualde humane, nam et ad salutationem suam permiserunt nos ingredi. Cum autem ingressi fuissemus ad eos, facta oratione cum ipsis, eulogias nobis dare dignati sunt, sicut habent consuetudinem dandi his, quos humane suscipiunt.

11.2. Ibi ergo inter ecclesiam et monasteria in medio fluit de petra aqua ingens, pulchra ualde et limpida, soporis ${ }^{128}$ optimi. Tunc interrogauimus nos etiam et illos sanctos monachos, qui ibi manebant, quae esset haec aqua talis et tanti saporis. Tunc illi dixerunt: "Haec est aqua, quam dedit sanctus Moyses filiis Israhel in hac heremo".

11.3. Facta est ergo iuxta consuetudinem ibi oratio et lectio ipsa de libris Moysi lecta, dictus etiam psalmus unus; et sic simul cum illis sanctis clericis et monachis, qui nobiscum uenerant, perexiuimus ad montem. Multi autem et ex ipsis monachis sanctis, qui ibi commanebant iuxta aqua ipsa, qui tamen potuerunt imponere sibi laborem, dignati sunt nobiscum ascendere montem Nabau.

11.4. Itaque ergo proficiscentes de eodem loco peruenimus ad radicem montis Nabau, qui erat ualde excelsus, ita tamen ut pars eius maxima sedendo in asellis possit subiri; modice ${ }^{129}$ autem erat acrius, quod pedibus necesse erat subiri cum labore, sicut et factum est.

\footnotetext{
${ }^{123}$ ceptum $A$ edd. coeptum Geyer Pétré

${ }^{124}$ cepimus $A$ edd. coepimus Geyer Pétré

${ }^{125}$ Libiadae A edd. Libiade Gam Geyer Her Pétré

${ }^{126}$ quae $A$ quem $\mathrm{Gam}^{2}$ edd.

${ }_{127}$ optati A edd. ortati coni. Geyer (in nota)

${ }^{128}$ soporis $A$ saporis Gam edd.

${ }^{129}$ modice $A$ edd. modicum Geyer Pétré
} 
10.8. E assim, portanto, a fim de que fosse acabada a obra iniciada, começamos a nos apressar rumo ao monte Nebo. Ao irmos, nos advertiu um presbítero do próprio lugar, isto é, de Lívias, esse mesmo que, conosco mediante pedido, movêramos do acampamento, porque melhor conhecia esses lugares; disse-nos, pois, esse presbítero: "Se quiserdes ver a água que flui da pedra, isto é, a que deu Moisés aos filhos de Israel sedentos (Ex 17,6; Nm 20,8; 21-1618 ), podeis ver; mas se quiserdes impor a vós o trabalho, que nos afastemos ${ }^{61}$ [lacuna] talvez seis milhas da estrada".

10.9. Depois que ele assim falou, bastante desejosos, decidimos ${ }^{62}$ ir e, afastando-nos imediatamente da estrada, seguimos o presbítero que nos conduzia. Nesse lugar a igreja é pequena, abaixo do monte, não o Nebo, mas um outro mais escondido, porém este não está longe do Nebo e, aliás, moram aí muitos monges verdadeiramente santos que aqui chamam ascetas.

11.1. Estes santos monges dignaram-se a nos acolher com muita bondade, pois inclusive nos permitiram entrar para saudá-los. Depois que entramos até eles, feita a oração com eles, dignaram-se a nos dar eulogias, como têm o costume de dá-las aos que recebem com bondade.

11.2. Ali, pois, entre a igreja e os mosteiros, uma água abundante flui do meio da pedra, muito bonita e límpida, de ótimo sabor. Então nós perguntamos também ainda àqueles santos monges que moravam ali que água seria essa de tal e tão grande sabor. Então eles disseram: "Esta é a água que o santo Moisés deu aos filhos de Israel neste deserto" (Ex 17,6; Nm 20,8).

11.3. Foi feita ali, pois, conforme o costume, uma oração e lida a passagem dos livros de Moisés, dito ainda um salmo, e assim, juntamente com aqueles santos clérigos e monges que tinham vindo conosco, saímos em direção ao monte. Além disso, também muitos desses santos monges que aí viviam perto dessa água, que, entretanto, puderam impor-se o esforço, dignaram-se a subir conosco o monte Nebo.

11.4. E, portanto, partindo desse lugar, chegamos ao sopé do monte Nebo, que era muito alto, embora tal que a maior parte dele se possa subir sentado em burrinhos; porém, era pouca coisa mais íngreme, e isso era necessário subir a pé, com esforço, e assim foi feito.

\footnotetext{
${ }^{61}$ Afastemos (camsemus): camsemus por campsemus, do verbo campsare, oriundo do grego $\kappa \dot{\mu} \mu \pi \tau \omega$.

${ }^{62}$ Decidimos (optati sumus): optare 'desejar', 'escolher', 'apetecer', 'pedir' é um verbo regular, assim, esperar-se-ia o pretérito perfeito optauimus. Optati sumus, que se lê nesta frase, é formado segundo o modelo dos verbos depoentes, talvez por influência do pretérito perfeito que aparece em seguida, no mesmo período: secuti sumus.
} 
12.1. Peruenimus ergo ad summitatem montis illius, ubi est nunc ecclesia non grandis, in ipsa summitate montis Nabau. Intra quam ecclesiam, in eo loco, ubi pulpitus est, uidi locum modice quasi altiorem, tantum hispatu ${ }^{130}$ habentem, quantum memoriae solent habere.

12.2. Tunc ergo interrogaui illos sanctos, quidnam esset hoc; qui responderunt: "Hic positus est sanctus Moyses ab angelis, quoniam, sicut scriptum est, sepulturam illius nullus hominum scit, quoniam certum est eum $\mathrm{ab}$ angelis fuisse sepultum. Nam memoria illius, ubi positus sit, in hodie non ostenditur $^{131}$; sicut enim nobis a maioribus, qui hic manserunt, ubi ostensum est, ita et nos uobis monstramus: qui et ipsi tamen maiores ita sibi traditum a maioribus suis [43] esse dicebant".

12.3. Itaque ergo mox facta est oratio, et omnia, quae in singulis locis sanctis per ordinem consueueramus facere, etiam et hic facta sunt: et sic cepimus ${ }^{132}$ egredere de ecclesia. Tunc autem qui erant loci notores, id est presbyteri uel monachi sancti, dixerunt nobis: "Si uultis uidere loca, quae scripta sunt in libris Moysi, accedite foras hostium ecclesiae et de summitate ipsa, ex ${ }^{133}$ parte tamen ut possunt ${ }^{134}$ hinc parere, attendite et uidete, et dicimus uobis singula, quae sunt loca haec, quae parent".

12.4. Tunc nos gauisi satis statim egressi sumus foras. Nam de hostio ipsius ecclesiae uidimus locum ubi intrat Iordanis in mare Mortuum, qui locus subter nos, quemadmodum stabamus, parebat. Vidimus etiam de contra non solum Libiadam, quae circa ${ }^{135}$ Iordanem erat, sed et Iericho, que ${ }^{136}$ trans Iordanem; tantum eminerat ${ }^{137}$ excelsus locus ubi stabamus, id est ante hostium ecclesiae.

12.5. Maxima etiam pars Palestinae, quae est terra repromissionis, inde uidebatur, nec non et omnis terra Iordanis, in quantum tamen poterat oculis conspici. In sinistra autem parte uidimus terras Sodomitum omnes nec non et Segor, quae tamen Segor sola de illis quinque in hodie constat.

\footnotetext{
${ }^{130}$ hispatu $A$ hispatii Gam edd.

${ }^{131}$ in hodie non ostenditur $A$ edd. in hodiernum ostenditur FrW in hodie ostenditur (...) ubi positus sit ostensum est Geyer Her Pétré

${ }^{132}$ cepimus A edd. coepimus Geyer Pétré

${ }^{133}$ ex $A$ edd. ea Erk ${ }^{2}$ Mar Jan

${ }^{134}$ possunt $A$ edd. possitis Gam

${ }^{135}$ circa A Gam citra Pom edd.

${ }^{136}$ que $A$ edd. quae Geyer Pétré

137 eminerat $A$ Gam $^{2}$ eminebat Gam $^{1}$ edd.
} 
12.1. Chegamos, portanto, até o cume daquele monte, onde há agora uma igreja não grande no próprio ${ }^{63}$ cume do monte Nebo. Dentro da igreja, naquele lugar onde está o púlpito, vi um lugar um pouco mais alto, com tanto espaço quanto costumam ter a sepulturas.

12.2. Então logo interroguei àqueles cristãos $^{\star}$ o que seria aquilo; estes responderam: "Aqui foi sepultado o santo Moisés pelos anjos, pois que, como está escrito, nenhum homem conhece a sepultura dele (Dt 34,6), porque é certo ter sido ele sepultado pelos anjos. Na verdade, mostra-se até hoje onde foi colocada a sepultura dele, tal como a nós onde foi mostrada pelos mais velhos que aqui estiveram, e assim nós vos mostramos, como também os mais velhos diziam ter sido contado por seus antepassados".

12.3. Foi feita, portanto, sem demora, uma oração, e tudo quanto costumávamos fazer, sucessivamente, em cada um dos lugares santos, ainda aí o fizemos, e começamos a sair da igreja. Disseram-nos, então, os que eram conhecedores do lugar, os sacerdotes e os santos monges: "Se quiserdes ver os lugares que estão escritos nos livros de Moisés, dirigi-vos para fora da porta ${ }^{64}$ da igreja e, desse cume, reparai bem no que se pode ver daqui; nós vos diremos - um a um - que lugares são todos esses que aparecem".

12.4. Nós, então, muito contentes, imediatamente saímos para fora. ${ }^{65} \mathrm{De}$ fato, da porta da igreja vimos o local onde o Jordão entra no Mar Morto*; esse lugar aparecia abaixo de nós, do modo que estávamos de pé. Vimos também, defronte, não somente Lívias, que estava aquém do Jordão, mas também Jericó, além do Jordão, a tal ponto sobressaía o lugar elevado onde estávamos, isto é, em frente à entrada da igreja.

12.5. Via-se também, de lá, a maior parte da Palestina, que é a terra da promissão, e também toda a terra do Jordão, o tanto que podia ser visto pelos olhos. Do lado esquerdo, vimos todas as terras dos sodomitas e também Segor - das cinco, a única que ainda hoje subsiste (Gn 19,22).

\footnotetext{
${ }^{63}$ Próprio (ipsa): nesta ocorrência, o demonstrativo ipse, ipsa, ipsum está sendo empregado no sentido clássico de 'o próprio'. Para um confronto com outros empregos, ver a nota 8 .

${ }^{64}$ Porta (hostium): pode-se dizer que aqui temos um fenômeno de hipercorreção da autora, que escreve ostium 'porta' com $h$. Isto mostra que o $h$ não era mais aspirado no latim vulgar. Em 13,2 temos hiens e habundantem. V. notas 17, 33, 42.

${ }^{65}$ Saímos para fora (egressi sumus foras): trata-se de um pleonasmo vicioso, tal como ocorre em português.
} 
12.6. Nam et memoriale ibi est; de ceteris autem illis ciuitatibus nichil aliud apparet nisi subuersio ruinarum, quemadmodum in cinerem conuerse ${ }^{138}$ sunt. Locus etiam ubi fuit titulus uxoris Loth ostensus est nobis, qui locus etiam in Scripturis legitur.

12.7. Sed mihi ${ }^{139}$ credite, domine ${ }^{140}$ uenerabiles, quia columna ipsa iam non paret, locus autem ipse tantum ostenditur: columna autem ipsa dicitur mari Mortuo fuisse quooperta ${ }^{141}$. Certe locum uideremus, ${ }^{142}$ columnam nullam uidimus, et ideo fallere uos super hanc rem non possum. Nam episcopus loci ipsius, id est de Segor, dixit nobis quoniam iam aliquot ${ }^{143}$ anni essent, a quo non pareret columna illa. Nam de Segor forsitan sexto miliario ipse locus, ${ }^{144} \mathrm{ubi}$ stetit columna illa, quod nunc totum cooperit aqua.

12.8. Item de dextra parte ecclesiae, a foras tamen, accessimus et ostense $^{145}$ sunt nobis inde a contra duae ciuitates, id est Esebon, quae fuit regis Seon, regis Amorreorum, quae nunc appellatur Exebon, et alia Og regis Basan, quae nunc dicitur Safdra. ${ }^{146}$ Item de eodem loco ostensa est nobis a contra Fogor, quae fuit [44] ciuitas regni Edom.

12.9. Hae autem ciuitates omnes, quas uidebamus, in montibus erant positae, infra autem modice deorsum, planior locus nobis uidebatur. Tunc dictum est nobis, quia in isdem diebus, qua sanctus Moyses uel filii Israhel contra illas ciuitates pugnauerant, castra ibi fixa habuissent: nam et signa ibi parebant castrorum.

12.10. Sane illa parte ${ }^{147}$ montis, quam dixi sinistra, quae erat super mare Mortuum, ostensus est nobis mons praecisus ${ }^{148}$ ualde, qui dictus est ante Agrisecula. ${ }^{149}$ Hic est mons, in quo posuit Balac filius Beor Balaam diuinum ad maledicendos filios Israhel et noluit Deus ita permittere, sicut scriptum est.

\footnotetext{
${ }^{138}$ conuerse $A$ edd. conuersae Gam² Geyer Pétré

${ }^{139}$ mihi $A$ edd. michi Nat

${ }^{140}$ domine A edd. dominae Gam² Geyer Pétré

${ }^{141}$ quooperta $A$ edd. cooperta Gam ${ }^{1}$ Geyer Pétré

${ }_{142}$ uideremus $A$ cum uideremus $\mathrm{Gam}^{2}$ edd.

${ }^{143}$ aliquot corr. ex aliquod $A$

${ }^{144}$ ipse locus $A$ est add. Gam ${ }^{1}$ edd.

${ }^{145}$ ostense $A$ edd. ostensae Gam ${ }^{2}$ Geyer Pétré

${ }^{146}$ Safdra A edd. Sasdra Gam Geyer Her Pétré

${ }^{147}$ illa parte $A$ de illa parte Geyer edd. in illa parte Arce

${ }^{148}$ praecisus $A$ Gam $^{2}$ Geyer Her Pétré Prinz precisus Gam ${ }^{1}$ FrW Arce Mar Jan Nat MaN

${ }^{149}$ agrisecula $A$ agrispecula Gam edd.
} 
12.6. Há, realmente, aí um monumento, enquanto que nada mais aparece das outras cidades a não ser ruínas, como foram reduzidas a cinzas. Mostraram-nos, ainda, o lugar onde esteve a estela ${ }^{66}$ da mulher de Ló ${ }^{*}$ (Gn 19,26), passagem que também se lê nas Escrituras.

12.7. Mas crede-me, veneráveis senhoras, não mais se vê essa coluna e só se mostra o seu lugar; a própria coluna dizem ter sido coberta pelo Mar Morto. Embora incontestavelmente víssemos o lugar, não vimos nenhuma coluna e, por essa razão, não posso enganar-vos a esse respeito. Pois nos disse o bispo desse lugar, isto é, de Segor, haver já alguns anos que a tal coluna não aparecia. $\mathrm{Na}$ verdade, o lugar onde se ergueu a coluna e que agora a água encobre inteiramente fica, talvez, a seis milhas de Segor.

12.8. Igualmente aproximamo-nos do lado direito da igreja - porém pelo lado de fora - e daí nos foram mostradas, defronte, duas cidades, isto é, Hesebon $^{*}$, que pertenceu a Seon, rei dos amorreus ${ }^{\star}(\mathrm{Nm} 21,26)$, e que agora se chama Exebon, e outra, de Og, rei de $\operatorname{Basan}^{\star}(\mathrm{Nm} 21,33)$, que agora se chama Safdra $^{*}$. Desse mesmo lugar também nos foi mostrado, de frente, Fogor ${ }^{*}$ que foi cidade do reino de Edom* ${ }^{\star} \mathrm{Nm} \mathrm{23,28)}$.

12.9. Todas essas cidades que víamos estavam situadas sobre montanhas; abaixo, porém, um pouco abaixo, percebia-se um lugar mais plano. Então nos foi dito que, naqueles dias em que o santo Moisés $e^{67}$ os filhos de Israel lutaram contra essas cidades, aí tinham tido acampamentos fixos; e, com efeito, viam-se aí sinais de acampamentos.

12.10. Sem dúvida, daquela parte da montanha que eu disse <estar > à esquerda e que ficava acima do Mar Morto, foi mostrado a nós um monte muito escarpado, que foi chamado anteriormente Agrispecula. ${ }^{68}$ Este é o monte no qual Balac, filho de Beor (Nm 23,14), colocou o adivinho Balaão para amaldiçoar os filhos de Israel, e não quis assim permitir Deus, como está escrito (Nm 22,6).

\footnotetext{
${ }^{66}$ Estela (titulus): além de 'título' (de um livro, por exemplo), significa 'epitáfio, 'pedra monumental', 'obelisco', 'monumento'. Mas Egéria usa titulus nesta ocorrência como se fosse columna, a partir do que se lê na sequência, referindo-se à "estela de sal” ( $\sigma \tau \eta \dot{\eta} \lambda \eta$ á̀ós) da Septuaginta (Gn 19,26).

${ }^{67} \mathrm{E}$ (uel): este $u e l$ não pode ser considerado uma conjunção disjuntiva, pois difere de um emprego disjuntivo, tal como em 5,12: Qui (sc. ipsi sancti) in montem Dei uel circa ipsum montem commorabantur "esses cristãos moravam ou no monte de Deus ou em volta do próprio monte". V. notas 55, 144, 186.

${ }^{68}$ Agrispecula (agrisecula): em vez de agrisecula, seguimos a conjectura de Gamurrini,

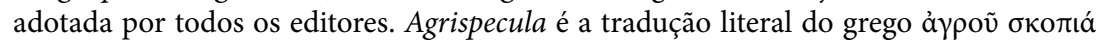
$(\mathrm{Nm} 23,14)$ e significa 'posto ou lugar de vigia do campo'.
} 
12.11. Ac sic ergo uisis omnibus, quae desiderabamus, in nomine Dei reuertentes per Iericho et iter omne, quod iueramus, regressi sumus in Ierusolimam.

13.1. Item post aliquantum tempus uolui ${ }^{150}$ ad regionem Ausitidem accedere propter uisendam memoriam sancti Iob gratia orationis. Multos enim sanctos monachos uidebam inde uenientes in Ierusolimam ad uisenda loca sancta gratia orationis, qui singula referentes de eisdem locis fecerunt magis desiderium imponendi michi laboris, ut etiam usque ad illa loca accederem, si tamen labor dici potest, ubi homo desiderium suum compleri uidet.

13.2. Itaque ergo profecta sum de Ierusolima cum sanctis, qui tamen dignati sunt itineri meo comitatum praestare, ${ }^{151}$ et ipsi tamen gratia orationis. Habens ergo iter ab Ierusolima usque ad Carneas eundo per mansiones octo Carneas autem dicitur nunc ciuitas Iob, quae ante dicta est Dennaba, in terra Ausitidi, ${ }^{152}$ in finibus Idumeae et Arabiae -: in quo itinere hiens uidi super ripam fluminis Iordanis ${ }^{153}$ uallem pulchram satis et amenam, ${ }^{154}$ habundantem uineis et arboribus, quoniam aquae multe ${ }^{155}$ ibi erant et optimae satis.

13.3. Nam in ea ualle uicus erat grandis, qui appellatur nunc Sedima. In eo ergo uico, qui est in media planitie positus, in medio loco est monticulus non satis grandis, sed factus sicut solent esse tumbae, sed grandis: ${ }^{156}$ ibi ergo in summo ecclesia est et deorsum per girum ipsius colliculi parent fundamenta grandia antiqua; nunc autem in ipso uico turbae aliquantae commanent.

\footnotetext{
${ }^{150}$ Inter lineas et supra uocabula uolui ad add. eqe uel ecie uel ecje $A$ uolui etiam ad Gam ${ }^{1}$ edd. uolui ad $\mathrm{Gam}^{2}$

${ }^{151}$ praestare A Gam ${ }^{2}$ Geyer Her Pétré Prinz MaN prestare Gam ${ }^{1}$ FrW Arce Mar Jan Nat

${ }^{152}$ au $^{\star * * * *}$ sitidi $A$

${ }^{153}$ iordanis fluminis A Geyer Her Pétré Arce fluminis iordanis Gam FrW Prinz Mar Jan MaN Nat

${ }^{154}$ amenam $A$ edd. amoenam Geyer Pétré

${ }^{155}$ multe $A$ edd. multae Gam ${ }^{2}$ Geyer Pétré

${ }^{156}$ grandis $A$ grandes $\mathrm{Gam}^{2}$ edd.
} 
12.11. Assim, pois, tendo visto o que desejávamos e voltando, em nome de Deus, por Jericó e por todo o caminho por onde viéramos, regressamos a Jerusalém.

13.1. Novamente, depois de um bom tempo, quis também chegar à região de Ausítis* (Jó 1,1) para visitar o túmulo do santo Jó* por motivo de oração. De fato, via muitos santos monges vindos de lá a Jerusalém para ver os lugares santos em razão de oração, que, contando coisas uma a uma daqueles mesmos lugares, provocaram mais o desejo de me impor o trabalho de ir também àqueles lugares, se, contudo, se pode chamar de trabalho quando o homem $^{69}$ vê o seu desejo ser satisfeito.

13.2. Assim, pois, parti de Jerusalém com os santos que se dignaram a oferecer acompanhamento à minha viagem, e estes, contudo, por causa da oração. Tomando, pois, o caminho desde Jerusalém até Cárneas, ${ }^{\star}$ passando por oito pousadas - aliás, agora a cidade de Jó se chama Cárneas, que antes foi chamada Denaba* (Gn 36,32), na terra de Ausítis, nas fronteiras da Idumeia* e da Arábia -, indo neste caminho, vi sobre a margem do rio Jordão um vale bastante bonito e ameno, abundante em vinhas e árvores, pois os cursos d'água eram ali numerosos e excelentes. ${ }^{70}$

13.3. Pois bem, naquele vale havia um povoado grande, que agora se chama Sedima*. Nesse povoado, pois, que está situado num lugar central da campina, bem no meio há um montículo não muito grande, mas da medida que costumam ter as tumbas, pelos menos as grandes: ali, pois, há uma igreja no topo e, embaixo, em volta desse outeirinho, aparecem grandes alicerces antigos; agora, aliás, nesse mesmo povoado juntam-se grandes multidões.

\footnotetext{
${ }^{69}$ Homem (homo): pode ter o sentido de homem e mulher ('ser humano', 'pessoa'), mas também o sentido indefinido de 'a gente', que fica melhor aqui neste contexto, tal como on em francês e homem em português arcaico. Sobre o emprego de "homem" com o sentido indefinido, temos vários exemplos fornecidos por J.J. Nunes (1967, p.45), entre os quais este, de um texto do séc. XIV (Batalha do Salado): “(...) Os mouros nõ se lhis oluidaua aquelo porque ali ueerã, ca eles refrescauã cada uez dos mogotes que estauã folgados e feriã os portugueses a destro e seestro, asi que o aficamẽto era tamanho de todas partes que home não poderia mostrar (...)".

${ }^{70}$ Excelentes (optimae satis): o advérbio satis está modificando optimae, mostrando que optimus, neste caso, não desempenha a função de superlativo de bonus. Novamente aparece, nesta função, em aquae optime satis et pure $(15,2)$.
} 
13.4. Ego autem cum uiderem locum tam gratum, requisiui quisnam locus esset ille tam amenus. ${ }^{157}$ Tunc dictum est michi: "Haec est ciuitas regis Melchis et haec, ${ }^{158}$ quae dicta est ante Salem, unde nunc corrupto sermone Sedima appellatur ipse uicus. Nam in isto colliculo, [45] qui est medio uico positus, in summitatem ipsius fabricam quam uides ecclesia est, quae ecclesia nunc appellatur greco ${ }^{159}$ sermone opu Melchis et haec. ${ }^{160}$ Nam hic est locus ubi optulit Melchisedech hostias Deo puras, id est panes et uinum, sicut scriptum est eum fecisse".

157 amenus $A$ edd. amoenus Geyer Pétré ${ }^{158}$ melchis et haec $A$ Gam Melchisedech Geyer edd. ${ }^{159}$ greco A edd. graeco Gam Geyer Pétré ${ }^{160}$ opu melchis et haec $A$ Gam opu Melchisedech Geyer edd. opu corruptum est ex ópos coni. Gam (in nota) ö 
13.4. Eu, entretanto, como visse um lugar tão agradável, perguntei o que era aquele lugar tão ameno. Daí $\mathrm{me}^{71}$ foi dito: "Esta é a cidade do rei Melquisedec ${ }^{\star}$, que antes foi chamada Salém ${ }^{\star}$ de onde agora, por uma alteração da palavra, este povoado se chama Sedima. De fato, neste outeirinho que está situado no meio do povoado, a construção que vês no cimo dele é uma igreja, essa igreja agora se chama, na língua grega, [lacuna] opu Melchisedech. Com efeito, este é o lugar onde Melquisedec ofereceu a Deus hóstias* puras, isto é, pães e vinho, assim como está escrito que o fez" (Gn 14,18).

\footnotetext{
${ }^{71}$ Me (michi): o $h$ tinha uma aspiração fraca em latim desde a época antiga. Provavelmente já na época de Cícero era pronunciado apenas em vocábulos de origem grega, escritos com $\mathrm{ch}$, ph, th, e só por pessoas cultas, influenciadas pela pronúncia grega. Acontecia muitas vezes de pessoas pouco cultas pronunciarem uma aspiração onde não havia, querendo imitar a fala dos patrícios. Catulo (apud TAGLIAVINI, 1962, p.196) dá exemplos em sua Carmen 84, em que um certo Árrio pronunciava um $h$ aspirado até em palavras de origem latina como $c(h)$ ommoda e $(h)$ insidias. Aulo Gélio (Noctes Atticae, XIII, 6, 3) refere-se ao comentário de Públio Nigídio: rusticus fit sermo si adspires perperam: "rústica fica a linguagem, caso aspires incorretamente". Provavelmente, a aspiração do $h$ desapareceu primeiramente entre vogais iguais ou próximas do ponto de vista articulatório (cf. nehemo $<$ [ne homo] $>$ nemo; dehibeo < [de-habeo] $>$ debeo). Quintiliano (Institutio Oratoria, IX, 4, 59) considera a pronúncia deprendere por deprehendere como uma abreviação normal, semelhante a uitasse por uitauisse. Assim, desapareceu bem cedo a aspiração do $h$ na posição inicial da palavra e, do séc. III em diante, são frequentes nas inscrições formas sem $h$ onde deveriam ocorrer e, inversamente, palavras grafadas com $h$ nas quais não deveriam ocorrer. Inúmeros exemplos encontram-se no CIL (Corpus Inscriptionum Latinarum), assim como no texto de Egéria (v. notas 17, 33, 42). Nas línguas românicas, o $h$ só existe na ortografia e se deve à escola. As grafias encontradas em Egéria de michi por mihi e nichil por nihil devem-se à tradição escolástica medieval que reintegra a aspiração do $h$, especialmente o intervocálico. Dessa tentativa de reintrodução de aspiração do $h$, surge a pronúncia de $h$ como $k$ - miki por mihi e nikil por nihil -: daí as grafias michi e nichil, que se devem à ortografia italiana para representar o som de $k$. Essa tradição foi mantida na escola, pelo menos a europeia, até poucas décadas atrás, e pode ser confirmada pela sobrevivência de aniquilar, em português e espanhol, annichilire, em italiano, e anichiler, ao lado de anniller, em francês antigo.
} 
14.1. Statim ergo ut haec audiui, descendimus de animalibus, et ecce occurrere dignatus est sanctus presbyter ipsius loci et clerici; qui nos statim suscipientes duxerunt suso ad ecclesiam. Vbi cum uenissemus, statim iuxta consuetudinem primum facta est oratio, deinde lectus est ipse locus de libro sancti Moysi, dictus est etiam psalmus unus competens loco ipsi, et denuo facta oratione descendimus. 
14.1. Sem demora, pois, assim que ouvi estas coisas, descemos dos animais, e eis que se dignou a correr a nosso encontro o santo presbítero desse lugar, com os clérigos, e eles, acolhendo-nos imediatamente, nos conduziram para cima, ${ }^{72}$ à igreja. E quando aí chegamos, sem demora, conforme o costume, primeiro foi feita uma oração, depois foi lido o próprio passo do livro do santo Moisés, bem como foi dito um salmo que convinha a esse lugar e, feita novamente uma oração, descemos.

72 Para cima (suso): existe de forma não atestada na literatura clássica susum, um advérbio que significa 'para cima, acima', como mostra Ausônio em Jusum uis facere Deum, et te susum "Queres abaixar a Deus e elevar-te a ti". No latim literário, a forma é sursum, de sus + uersum, como atestam os seguintes exemplos: Qui sursum colunt "Os que moram nos lugares altos" (Varrão); Nares sursum sunt "as narinas estão na parte superior < do corpo>" (Cícero). Parece que aqui suso foi "declinado" a partir de susum, mas, de qualquer forma, trata-se de um advérbio, palavra indeclinável. 
14.2. Cum ergo descendissemus, ait nobis ille sanctus presbyter iam senior et de Scripturis bene instructus, id est qui ipsi loco praeerat ${ }^{161}$ ex monacho, cui presbytero et episcopi plurimi, quantum postmodum cognouimus, uitae ipsius testimonium grande ferebant, ${ }^{162}$ nam hoc de ipso dicebant, dignus qui praesit ${ }^{163}$ in hoc loco, ubi sanctus Melchisedech aduenientem sanctum Abraam hostias Deo puras primus optulit: cum ergo descendissemus, ut superius dixi, de ecclesia deorsum, ait nobis ipse sanctus presbyter: "Ecce ista fundamenta in giro colliculo isto, quae uidetis, hae sunt de palatio Melchisedech regis. ${ }^{164}$ Nam inde adhuc sic si quis subito iuxta sibi uult facere domum et fundamenta inde continget, ${ }^{165}$ aliquotiens et de argento et heramento ${ }^{166}$ modica frustella ibi inuenit.

14.3. Nam et $\operatorname{certa}^{167}$ uia quam uidetis transire inter fluuium Iordanem et uicum istum, haec est qua uia regressus est sanctus Abraam de cede ${ }^{168}$ Quodollagomor ${ }^{169}$ regis $^{170}$ gentium, reuertens in Sodomis, qua ei occurrit sanctus Melchisedech, rex Salem".

\footnotetext{
${ }^{161}$ praeerat $A \mathrm{Gam}^{2}$ Geyer Her Pétré Prinz preerat Gam ${ }^{1} \mathrm{FrW}$ Arce Mar Jan Nat MaN

${ }^{162}$ ferebant corr. ex ferebat $A$

${ }^{163}$ praesit $A \mathrm{Gam}^{2}$ Geyer Her Pétré Prinz presit $\mathrm{Gam}^{1} \mathrm{FrW}$ Arce Mar Jan Nat MaN

${ }^{164}$ Melchisedech regis $A$ regis Melchisedech Gam edd.

${ }^{165}$ continget A FrW Prinz Arce Jan Nat MaN contiget Gam Geyer Her Pétré Mar

${ }^{166}$ heramento $A$ edd. aeramento Geyer Pétré

${ }^{167}$ et certa A Gam MaN ecce ista Bern edd.

${ }^{168}$ cede $A$ edd. caede Gam² Geyer Pétré

169 quodollagomor A edd. Codollagomor Geyer Pétré Chodollagomor Gam

${ }^{170}$ et ante regis add. FrW Arce
} 
14.2. Quando, pois, descêramos, nos falou esse santo presbítero, já idoso e bem instruído sobre as Escrituras, isto é, aquele que dirigia esse lugar desde monge, presbítero de cuja vida também vários bispos, como soubemos depois, davam grande testemunho; de fato, diziam do mesmo ser digno que estivesse à testa deste lugar, onde o santo Melquisedec, chegando o santo Abraã $0^{*},{ }^{73}$ ofereceu primeiro a Deus as hóstias puras; quando, pois, descêramos, como disse acima, da igreja para baixo, nos disse o santo presbítero: "Esses alicerces ${ }^{74}$ que vedes ao redor desse outeirinho são os do palácio do rei Melquisedec. Na verdade, até agora ainda, se alguém de improviso quer fazer para si uma casa perto dali, ainda atinge os alicerces de lá, e algumas vezes acha pedacinhos razoáveis de prata e de bronze neste lugar.

14.3. De fato, essa estrada que vedes passar entre o rio Jordão e este povoado é a estrada pela qual regressou o santo Abraão, voltando a Sodoma*, depois da matança de Codorlaomor ${ }^{75}$ (Gn 14,17), rei dos gentios (Gn 14,1), e na qual correu ao seu encontro o honrado Melquisedec, rei de Salém (Gn $14,18)$ ".

${ }^{73}$ Chegando o santo Abraão (aduenientem sanctum Abraam): "acusativo absoluto", construção equivalente ao "ablativo absoluto". V. notas 37, 84.

${ }^{74}$ Esses alicerces (ecce ista fundamenta): em ecce ista tem-se o emprego do demonstrativo iste, ista, istud com o reforço do antigo advérbio (também chamado de partícula epidítica) ecce. Em português e espanhol arcaicos temos aqueste, em catalão aquest, em provençal cest, e em francês antigo (i)cist. Em italiano permanece questo, em engadino quaist, logudorês kuste, romeno acest. Uma outra partícula de reforço é eccu $(m)$, formada do mesmo advérbio ecce com o demonstrativo (h)un(c), acusativo de hic. Ao lado dessas duas formas, algumas línguas românicas (MAURER JR., 1959, p.110) têm a partícula de reforço ${ }^{*} a c c u$, sobre cuja origem há duas hipóteses: ou pelo cruzamento de ecce com atque ou simplesmente de atque. Alguns estudiosos sustentam a provável origem através de atque em ocorrências como esta: Vbi cenamus, inquam? Atque illi abnuunt (Plauto, Captiui, 481). Em português, accu + ille, accu +illa, accu $+i l l u(m)$ originaram aquele, aquela, aquilo, e accu + ipse originou aquesse no português arcaico, e em catalão aqueix. $\mathrm{Na}$ România temos, em linhas gerais, a seguinte distribuição das partículas de reforço: a Ibéria e a Dácia têm ${ }^{\star} a c c u$, e a Gália do Norte conserva ecce. O italiano, o rético e o sardo não apresentam geralmente a vogal inicial, assim torna-se difícil a reconstrução latina, conforme o italiano questo e quello, engadino quaist e quel, sardo kuste, kusse e kudde. Entretanto, como no sardo antigo existia ekuste, é provável que eccu seja a forma primitiva dessas três línguas.

75 Codorlaomor (Quodollagomor): a grafia presente no texto latino segue a

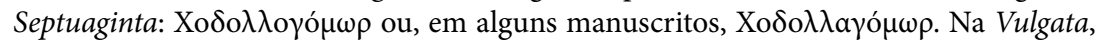
temos Chodorlahomor. Em português, na Bíblia de Jerusalém, é adotada a forma "Quedorlaomer" e, na Bíblia da Editora Vozes, "Codorlaomor". 
15.1. Tunc ergo quia retinebam scriptum esse babtizasse ${ }^{171}$ sanctum Iohannem in Enon iuxta Salim, requisiui de eo, quam longe esset ipse locus. Tunc ait ille sanctus presbyter: "Ecce hic est in ducentis passibus. Nam si uis, ecce modo pedibus duco uos ibi. Nam haec aqua tam grandis et tam pura, quam uidetis in isto uico, de ipso fonte uenit".

15.2. Tunc ergo gratias ei agere coepi et rogare, ut duceret nos ad locum, sicut et factum est. Statim ergo cepimus ${ }^{172}$ ire cum eo pedibus totum per uallem amenissimam, ${ }^{173}$ donec perueniremus usque ad hortum pomarium ualde amenum, ${ }^{174}$ ubi ostendit nobis in medio fontem aquae optime ${ }^{175}$ satis et pure, ${ }^{176}$ quia semel ${ }^{177}$ integrum fluuium dimittebat. Habebat autem ante se ipse fons quasi lacum, ubi parebat fuisse operatum sanctum Iohannem Baptistam.

15.3. Tunc dixit nobis ipse sanctus presbyter: "In hodie hic hortus aliter non appellatur [46] greco ${ }^{178}$ sermone nisi $\operatorname{copos}^{179}$ tu agiu Iohanni, id est quod uos dicitis latine hortus sancti Iohannis". Nam et multi fratres sancti monachi de diuersis locis uenientes tendunt se, ut lauentur in eo loco.

15.4. Denuo ergo et ad ipsum fontem, sicut et in singulis locis, facta est oratio et lecta est ipsa lectio; dictus etiam psalmus competens et singula, quae consuetudinis nobis erant facere, ubicumque ad loca sancta ueniebamus, ita et ibi fecimus.

\footnotetext{
$\overline{{ }^{171} \text { babtizasse } A \text { Gam }^{2} \text { edd }}$. baptizasse Gam ${ }^{1}$ Nat.

${ }^{172}$ cepimus $A$ edd. coepimus Geyer Pétré

${ }^{173}$ amenissimam $A$ edd. amoenissimam Geyer Pétré

${ }^{174}$ amenum $A$ edd. amoenum Geyer Pétré

${ }^{175}$ optime $A$ edd. optimae Gam ${ }^{2}$ Geyer Pétré

${ }^{176}$ pure $A$ edd. purae Gam ${ }^{2}$ Geyer Pétré

177 quia semel $A$ Gam qui a semel Geyer edd.

${ }^{178}$ greco $A$ edd. graeco Gam ${ }^{2}$ Geyer Pétré

${ }^{179}$ copos A Gam Her cepos Geyer edd.
} 
15.1. Então, porque eu lembrava ter sido escrito que São João* batizou em Enon*, próximo a Salim* (Jo 3,23), perguntei-lhe quão longe era esse lugar. Disse então o santo presbítero: "Eis que este fica a duzentos passos; se de fato desejas, vos conduzo agora mesmo a pé nesse lugar. Na verdade, esta água tão abundante e tão pura que vedes neste povoado vem dessa fonte".

15.2. Com isso, portanto, comecei a agradecer a ele e a pedir que nos conduzisse àquele lugar, e assim também foi feito. Sem demora, pois, começamos a ir a pé, com ele, através de todo um vale ameníssimo, até que chegamos a um jardim de árvores frutíferas bastante ameno, onde nos mostrou, no meio, uma fonte de água excelente e pura, que de um jato ${ }^{76}$ formava um perfeito rio. Havia também diante dessa fonte como que um lago, onde parecia ter São João Batista exercido o seu ministério.

15.3. Então nos disse esse santo presbítero: "Hoje em dia este horto não se chama de outro modo, no idioma grego, a não ser cepos tu agiu Iohanni, isto é, o que vós dizeis, em latim, Hortus Sancti Iohannis - Jardim de São João".77 Com efeito, ainda, muitos irmãos, monges santos, vindo de diversos lugares, acampam a fim de se purificarem nesse lugar.

15.4. De novo, pois, ainda perto dessa fonte, assim como também em cada um dos lugares, foi feita uma oração, foi lido o texto apropriado e dito também um salmo apropriado, e cada uma das coisas que era nosso costume fazer toda vez que chegávamos aos lugares santos, assim também aí fizemos.

${ }^{76}$ De um jato (a semel): a semel é composto de preposição + advérbio, e significa, literalmente, 'de uma só vez', que traduzimos "de um jato". A mesma expressão também ocorre em 19,12.

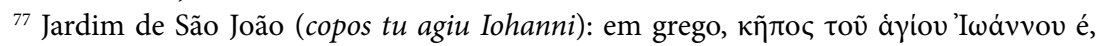
literalmente, "jardim de São João”. 
15.5. Illud etiam presbyter sanctus dixit nobis, eo quod usque in hodierna die semper cata Pascha, quicumque essent baptizandi in ipso uico, id est in ecclesia, quae appellatur opu ${ }^{180}$ Melchisedech, omnes in ipso fonte baptizarentur; sic redirent mature ad candelas cum clericis et monachis dicendo psalmos uel antiphonas et sic a fonte usque ad ecclesiam sancti Melchisedech deducerentur mature omnes, qui fuissent baptizati.

15.6. Nos ergo accipientes de presbytero eulogias, id est de pomario sancti Iohannis Baptistae, similiter et de sanctis monachis, qui ibi monasteria habebant in ipso horto pomario, et gratias semper Deo agentes, profecti sumus iter nostrum, quo ibamus.

16.1. Ac sic ergo euntes aliquandiu per uallem Iordanis super ripam fluminis ipsius, quia ibi nobis iter erat aliquandiu, ad subito uidimus ciuitatem sancti prophetae Heliae, id est Thesbe, unde ille habuit nomen Helias Thesbites. Inibi est ergo usque in hodie spelunca, in qua sedit ipse sanctus, et ibi est memoria sancti Gethae, cuius nomen in libris Iudicum legimus.

${ }^{180}$ opu A edd. opus Geyer Pétré 
15.5. O santo presbítero nos disse também isto ${ }^{78}$ que,${ }^{79}$ até o dia de hoje, sempre em cada Páscoa, todos os que deviam se batizar nesse povoado, isto é, na igreja que se chama Obra de Melquisedec, todos eram batizados nessa fonte; assim voltavam cedo, à luz de velas, com os clérigos e monges, recitando ${ }^{80}$ salmos ou antífonas, e assim eram levados prontamente, desde a fonte até a igreja do santo Melquisedec, todos os que tinham sido batizados.

15.6. Nós, portanto, recebendo eulogias do presbítero, isto é, do pomar de São João Batista, e igualmente dos santos monges que ali nesse jardim de árvores frutíferas tinham seus mosteiros, e dando sempre graças a Deus, partimos pelo nosso caminho que percorríamos.

16.1. E assim, pois, indo durante algum tempo pelo vale do Jordão, sobre a ribanceira do mesmo rio, porque aí era nosso caminho por algum tempo, de súbito vimos a cidade do santo profeta Elias, isto é, Tesbi ${ }^{\star}$, nome a partir do qual ele obteve o nome Elias Tesbita (1Rs 17,1). Ali mesmo está até hoje a gruta na qual permaneceu esse santo, e também aí está a sepultura do santo Jefté*, cujo nome lemos nos livros dos Juízes (Jz 11-12).

\footnotetext{
${ }^{78}$ Isto (illud): illud é o acusativo neutro do pronome demonstrativo ille, illa, illud 'aquele, aquela, aquilo, que aqui funciona como pronome catafórico, anunciando um termo que vem depois, introduzido por eo quod.

${ }^{79}$ Que (quod): este quod (conjunção causal em latim clássico), seguido de verbo no subjuntivo, introduz uma oração subordinada substantiva, em substituição à construção clássica de "acusativo com infinito", na qual o sujeito aparecia em acusativo e o verbo no infinitivo. No texto, há outros exemplos de substituição do "acusativo com infinito", em que quia, outra conjunção causal, introduz uma subordinada substantiva: 12,7 Sed mihi credite, domine uenerabiles, quia columna ipsa iam non paret, locus autem ipse tantum ostenditur (...). Sabe-se que os textos tardios, como este, continuam os procedimentos de coordenação e subordinação, mas simplificam a sintaxe com o uso de pronomes relativos e conjunções. Esse modelo sintático é o que prevaleceu no latim falado e o que se observa nas línguas românicas. Todavia, segundo Maurer Jr. (1959, p.216), todas as línguas provenientes do latim conservam alguma coisa da construção infinitiva. Ele fornece os exemplos a seguir: português vi-o chegar, fi-lo sair; francês il me voit entrer, je l'ai fait entrer; italiano mi vede arrivare, l'abbiamo lasciato partire; romeno sa-i lase pândi si ei "deixe-os espiar também". Além desta ocorrência, aparece também em 8,2: dicent eo quod.

${ }^{80}$ Recitando (dicendo): a forma esperada seria a do particípio presente (dicentes), e não a do gerúndio em ablativo: isso mostra que mais um sincretismo de construções afeta o latim de Egéria. Em 5,10, encontramos o uso correto do particípio presente: reuersi sumus ad iter nostrum, hoc est ubi exeuntes de ualle illa grande reingressi sumus uia, o que mostra a convivência de duas variantes da língua latina - clássica e vulgar - no texto.
} 
16.2. Ac sic ergo et ibi gratias Deo agentes iuxta consuetudinem perexiuimus iter nostrum. Item euntes in eo in $e^{181}$ itinere uidimus uallem de sinistro nobis uenientem amenissima ${ }^{182}$, quae uallis erat ingens, mittens torrentem in Iordanem infinitum. Et ibi in ipsa ualle uidimus monasterium cuiusdam fratris nunc, id est monachi.

16.3. Tunc ego, ${ }^{183}$ ut sum satis curiosa, requirere cepi, ${ }^{184}$ quae esset haec uallis, ubi sanctus monachus nunc monasterium sibi fecisset; non enim putabam hoc sine causa esse. Tunc dixerunt nobis sancti, qui nobiscum iter faciebant, id est loci notores: "Haec est uallis Corra, ubi ${ }^{185}$ sedit sanctus Helias Thesbites temporibus Achab regis, qua famis fuit, et iusso Dei corui escam portabat, ${ }^{186}$ et de eo torrentem ${ }^{187}$ aquam bibebat. Nam hic torrens, quem uides de ipsa ualle percurrentem in Iordanem, hic est Corra".

16.4. Ac sic ergo nichilominus Deo gratias agentes, qui nobis non merentibus, singula, quae desiderabamus, dignabatur ostendere, itaque ergo ire cepimus $^{188}$ iter nostrum sicut singulis diebus. Ac sic ergo facientes iter singulis diebus, ad subito de latere sinistro, unde e contra ${ }^{189}$ partes Fenicis uidebamus, apparuit nobis mons ingens et altus infinitum, qui tendebatur ${ }^{190}$ (...).

[Deest unum folium]

16.5. (...) [47] Qui sanctus monachus, uir ascitis, necesse habuit post tot annos, quibus sedebat in heremum, mouere se et descendere ad ciuitatem Carneas, ut commoneret episcopum uel clericos temporis ipsius, iuxta quod ei fuerat reuelatum, ut foderent in eo loco, qui ei fuerat ostensus, sicut et factum est.

\footnotetext{
${ }^{181}$ in eo bis scriptum A in eo semel scriptum Gam edd. 182 amenissimam $A$ edd. amoenissimam Geyer Pétré ${ }^{183}$ ego corr. ex ergo ego A ergo ego Arce Gam ${ }^{1}$ ${ }^{184}$ cepi $A$ edd. coepi Geyer Her Pétré

${ }^{185}$ Iubi $A$ ubi Gam edd.

${ }^{186}$ corui escam portabat $A$ corui escam portabant Gam MaN coruus ei escam portabat Chol edd. coruii ei escam portabant coni. Her (in nota)

${ }^{187}$ torrentem A edd. torrente Gam Geyer Pétré Arce Jan

${ }^{188}$ cepimus $A$ edd. coepimus Geyer Pétré

${ }^{189}$ e contra uel econtra A econtra Prinz Arce e contra Gam edd.

${ }^{190}$ ui tendebatur $A$ qui tendebatur in longo edd. uerba in longo ad calcem p.46 addita ad fol. seq. pertinent (Arce (in nota)) uerba in longo quibus fol. seq., hodie deperditum, incipiebat, ad calcem pag. 46 addita sunt (FrW (in nota))
} 
16.2. E assim, pois, também ali dando graças a Deus, conforme o costume, saímos para o nosso caminho. Assim, indo nesse caminho, vimos se apresentando à nossa esquerda um vale ameníssimo, e esse vale era enorme, lançando no Jordão uma torrente infinita. E aí, no mesmo vale, vimos o que é atualmente o mosteiro de um certo irmão, isto é, de um monge.

16.3. Então eu, que sou bastante curiosa, comecei a perguntar que vale era esse, onde o santo monge tinha feito agora para si um mosteiro, pois que não pensava isto ser sem motivo. Então nos disseram os monges que faziam o caminho conosco, isto é, os conhecedores do lugar: "Este é o vale de Corra*, onde permaneceu o santo Elias Tesbita nos tempos do rei Acab, em que houve fome, e corvos, por ordem de Deus, lhe traziam alimento, e ele bebia água desta torrente (1Rs 17,3-6). De fato, esta torrente que vês percorrendo desde este vale até o Jordão, este é o Corra".

16.4. E assim, pois, dando não menos graças a Deus, que a nós, não merecedores, dignava-se a mostrar cada uma das coisas que desejávamos, desse mesmo modo começamos a percorrer nosso caminho, como todos os dias. E assim, pois, fazendo o caminho em cada um dos dias, de súbito, do lado esquerdo, onde víamos defronte as regiões da Fenícia*, apareceu para nós um monte enorme e infinitamente ${ }^{81}$ alto que se estendia $<$ em comprimento $>$. (...)

[Falta um fólio]

16.5. (...) E esse santo monge, homem asceta, teve necessidade, depois de tantos anos que morava no deserto, de se mover e descer até a cidade de Cárneas, para que avisasse o bispo e os clérigos desse tempo acerca do que lhe fora revelado, que cavassem naquele lugar que lhe tinha sido mostrado, assim como também foi feito.

\footnotetext{
${ }^{81}$ Infinitamente (infinitum): no texto, o superlativo de adjetivos é formado, muitas vezes, de maneira analítica, própria da língua falada, e não através do sufixo -imus, -a, -um. Assim temos, além desse exemplo, altus infinitum, ualde pulcher, satis admirabile, grate satis, tam grandis, satis curiosa etc. Além desse recurso, é empregado o prefixo per- (cf. permodica) como intensificador, que, de fato, também pertencia ao latim clássico, assim como prae-.
} 
16.6. Qui fodientes in eo loco, qui ostensus fuerat, inuenerunt speluncam, quam sequentes fuerunt forsitan per passus centum, quo ${ }^{191}$ et subito ${ }^{192}$ fudientibus ${ }^{193}$ illis, adparuit lapis: quem lapidem cum perdiscoperuissent ${ }^{194}$ inuenerunt sculptum in coperculo ${ }^{195}$ ipsius Iob. Qui ${ }^{196}$ Iob ad tunc in eo loco facta est ista ecclesia, quam uidetis, ita tamen ut lapis cum corpore non moueretur in alio loco, sed ibi, ubi inuentum fuerat corpus, positum ${ }^{197}$ esset, et ut corpus subter altarium iaceret. Illa autem ecclesia, quam tribunus nescio qui faciebat, sic stat ${ }^{198}$ inperfecta usque in hodie.

16. 7. Ac sic ergo nos alia die mane rogauimus episcopum ut faceret oblationem, sicut et facere ${ }^{199}$ dignatus est, et benedicens nos episcopus profecti sumus. Communicantes ergo et ibi, gratias agentes Deo semper, regressi sumus in Ierusolimam iter facientes per singulas mansiones, per quas ieramus tres annos. ${ }^{200}$

\footnotetext{
${ }^{191}$ quo A edd. cum coni. Her (in nota)

${ }^{192}$ et subito $A$ Gam ad subito Her edd. adsubito Geyer Pétré

${ }^{193}$ fudientibus A Prinz Mar Nat MaN fodientibus Gam edd.

${ }^{194}$ perdiscoperuissent corr. ex perdiscoperuisset $A$

195 coperculo A edd. operculo Her

${ }^{196}$ qui $A$ cui Gam edd.

${ }^{197}$ positum A edd. positus Geyer Her Pétré

${ }^{198}$ stat $A$ edd. fuit Geyer Her Pétré

${ }^{199}$ facere corr. ex faceret $A$

200 tres annos $A$ edd. tres annos om. Mar Jan Nat MaN tres annos ante Geyer (in nota)
} 
16.6. Esses, cavando naquele lugar que tinha sido mostrado, encontraram uma gruta, a qual foram seguindo por cem passos talvez, até que, de repente, aos que cavavam, apareceu uma pedra e, quando descobriram ${ }^{82}$ essa pedra, encontraram esculpido na superfície da mesma $I O B$. Então, em honra de Jó, foi construída esta $^{83}$ igreja que vedes neste lugar, de maneira, contudo, que a pedra com o corpo não fosse removida para outro lugar, mas aí, onde o corpo fora encontrado, fosse colocada (sc. lapidem), e que o corpo repousasse debaixo do altar. Essa igreja, que não sei que tribuno fazia, ainda até hoje se encontra não concluída.

16.7. E assim, pois, no outro dia de manhã, nós pedimos ao bispo que fizesse a oblação, como também se dignou a fazer, e, abençoando-nos o bispo, ${ }^{84}$ partimos. Comungando, pois, também ali, sempre dando graças a Deus, regressamos a Jerusalém, fazendo o caminho por cada uma das pousadas pelas quais fôramos três anos <atrás $>$.

82 Descobriram (perdiscoperuissent): o verbo perdiscoperire é um exemplo de "supercomposição", para usar o termo empregado por Väänänen (1987, p.150). Numa composição como essa, forma-se um verbo com uma segunda prefixação sobre outra já existente: perdiscoperire < discoperire < coperire. A partir de cada uma das prefixações, teríamos esta sequência de significação (da última à primeira): 'descobrir completamente ou acabar de descobrir,' 'descobrir', 'cobrir'. Perdiscoperire parece ser uma criação de Egéria, pois não se encontra em outra obra. Há outros exemplos semelhantes de supercomposição encontrados no texto de Egéria: persubire $(3,4)$ e reingredi $(5,10)$.

${ }^{83}$ Esta (ista): o emprego deste demonstrativo, juntamente com a expressão quam uidetis, mostra claramente que substituiu o clássico haec na função de $1^{\text {a }}$ pessoa do discurso (proximidade da pessoa que fala). V. nota 8.

${ }^{84}$ Abençoando-nos o bispo (benedicens nos episcopus): morfologicamente, a expressão latina é um "nominativo absoluto", construção equivalente ao "ablativo absoluto". Egéria usa com a mesma função de "ablativo absoluto" o que parecem ser os arcaicos "acusativo absoluto" e "nominativo absoluto". V. notas 37, 73. 
17.1. Item in nomine Dei, transacto aliquanto ${ }^{201}$ tempore, cum iam tres anni pleni essent, a quo in Ierusolimam uenisse, ${ }^{202}$ uisis etiam omnibus locis sanctis, ad quos orationis gratiam ${ }^{203}$ me tenderam, et ideo iam reuertendi ad patriam animus esset: uolui, iubente Deo, ut $\mathrm{et}^{204}$ ad Mesopotamiam Syriae accedere ad uisendos sanctos monachos, qui ibi plurimi et tam eximiae uitae esse dicebantur, ut uix referri possit; nec non etiam et gratia orationis ad martyrium sancti Thomae apostoli, ubi corpus illius integrum positum est, id est apud Edessam, quem se illuc missurum, posteaquam in caelis ascendisset, Deus noster Iesus testatus est per epistolam, quam ad Aggarum regem per Ananiam cursorem misit, quoque epistolam ${ }^{205}$ cum grandi reuerentia apud Edessam ciuitatem, ubi est ipsud martyrium, custoditur.

17.2. Nam mihi ${ }^{206}$ credat uolo affectio uestra, quoniam nullus Christianorum est, qui non se tendat illuc gratia orationis, quicumque tamen usque ad loca sancta, id est in Ierusolimis, accesserit; et hic locus de Ierusolima uicesima et quinta mansione ${ }^{207}$ est.

17.3. Et quoniam de Anthiocia ${ }^{208}$ propius est Mesopotamiam, ${ }^{209}$ fuit mihi $^{210}$ iubente Deo oportunum satis ut, quemadmodum reuertebar Constantinopolim, quia per Anthiociam ${ }^{211}$ iter erat, inde ad Mesopotamiam irem, sicut et factum est Deo iubente.

\footnotetext{
${ }^{201}$ aliquanto $A$ edd. aliquando Jan

${ }^{202}$ uenisse $A$ edd. uenissem Gam Geyer Pétré Arce

${ }^{203}$ gratiam $A$ gratia Gam edd.

${ }^{204}$ ut et $A$ edd. et Gam etiam et Geyer Pétré

${ }^{205}$ quoque epistolam $A M a N$ quaeque epistola $\mathrm{Gam}^{2}$ Geyer Pétré que epistola Her FrW

Nat Arce Jan que epistolam Prinz Mar

${ }^{206}$ mihi A edd. michi Nat

${ }^{207}$ quinta ${ }^{\star * * * *}$ mansione $A$

${ }^{208}$ Anthiocia $A$ edd. Antiochia Geyer Pétré

${ }^{209}$ Mesopotamiam A edd. Mesopotamia Gam

${ }^{210}$ mihi $A$ edd. michi Nat

${ }^{211}$ Anthiociam $A$ edd. Antiochiam Geyer Pétré
} 
17.1. Novamente, em nome de Deus, decorrido bastante tempo, quando já fazia três anos inteiros desde que chegara a Jerusalém, vistos também todos os lugares santos a que me dirigira para orar, e sendo já minha intenção voltar à pátria, eu quis ainda, por ordem de Deus, ir também à Mesopotâmia ${ }^{\star}$ da Síria para visitar os santos monges que aí eram ditos ser numerosos e de vida tão exímia, que mal se pode contar, mas ainda também para orar perto do martyrium $^{85}$ do santo apóstolo Tomé ${ }^{\star}$, onde o corpo dele foi sepultado inteiro, isto é, perto de Edessa ${ }^{*}$, que Jesus Cristo nosso Deus, atestou por carta que enviou ao rei Abgar ${ }^{\star}$, através do mensageiro Ananias, que o mandaria para lá após subir aos céus. Carta essa que é guardada com grande respeito perto da cidade de Edessa, onde está o próprio martyrium.

17.2. Efetivamente, quero que me creia, Vossa Afeição, que não há nenhum dentre os cristãos que não almeje ir para lá por motivo de oração, pelo menos todo aquele que tenha se dirigido aos lugares santos, isto é, a Jerusalém; e este lugar fica na vigésima quinta pousada desde Jerusalém.

17.3. E já que de Antioquia* é mais perto para ir à Mesopotâmia, me foi bastante oportuno, por ordem de Deus, conforme eu voltava a Constantinopla*, porque o caminho era por Antioquia, de lá ir à Mesopotâmia, assim como também foi feito, por ordem de Deus.

\footnotetext{
${ }^{85}$ Martyrium: na tradução para o português, mantivemos a palavra latina martyrium, assim como fizeram os outros tradutores, para designar o túmulo de um mártir, quando escrito com letra minúscula e, com letra maiúscula, para designar uma das igrejas de Jerusalém, o Martyrium (ver, no Glossário, martyrium).
} 
18.1. [48] Itaque ergo in nomine Christi Dei nostri profecta sum de Antiochia ad Mesopotamiam habens iter per $^{212}$ mansiones seu ciuitates aliquot prouinciae Sirie ${ }^{213}$ Celen, quae est Anthiociae, ${ }^{214}$ et inde ingressa fines prouinciae Augustofratensis perueni ad ciuitatem Gerapolim, quae est metropolis ipsius prouinciae, id est Augustofratensis. Et quoniam haec ciuitas ualde pulchra et opulenta est atque abundans omnibus, necesse me fuit ibi facere statiuam, quoniam iam inde non longe erant fines Mesopotamiae.

18.2. Itaque ergo proficiscens de Ierapolim in quintodecimo miliario in nomine Dei perueni ad fluuium Eufraten, de quo satis bene scriptum est esse flumen magnum Eufraten et ingens, et quasi terribilis est; ita enim decurrit habens impetum, sicut habet fluuius Rodanus, nisi quod adhuc maior est Eufrates.

18.3. Itaque ergo quoniam necesse erat eum nauibus transire, et nauibus non nisi maioribus, ac sic immorata sum ibi forsitan plus media die; et inde in nomine Dei transito flumine Eufraten ingressa sum fines Mesopotamiae Siriae.

19.1. Ac sic denuo faciens iter per mansiones aliquot perueni ad ciuitatem, cuius nomen in Scripturis positum legimus, id est Batanis, quae ciuitas usque in hodie est. Nam et ecclesia cum episcopo uere sancto et monacho et confessore habet et martyria aliquanta. Ipsa etiam ciuitas habundans multitudine hominum est; nam et miles ibi sedet cum tribuno suo.

19.2. Vnde denuo proficiscens, peruenimus in nomine Christi Dei nostri Edessam. Vbi cum peruenissemus, statim perreximus ad ecclesiam et ad martyrium sancti Thomae. Itaque ergo iuxta consuetudinem factis orationibus et cetera, quae consuetudo erat fieri in locis sanctis, nec non etiam et aliquanta ipsius sancti Thomae ibi legimus.

19.3. Ecclesia autem, ibi que ${ }^{215}$ est, ingens et ualde pulchra et noua dispositione, ut uere digna est esse domus Dei; et quoniam multa erant, quae ibi desiderabam uidere, necesse me fuit ibi statiua triduana facere.

19.4. Ac sic ergo uidi in eadem ciuitatem ${ }^{216}$ martyria plurima nec non et sanctos monachos, commanentes alios per martyria, alios longius de ciuitate in secretioribus locis habentes monasteria.

\footnotetext{
${ }^{212}$ per corr. ex seu $A$

${ }^{213}$ Sirie A edd. Siriae Gam Geyer Pétré

${ }^{214}$ Anthiociae A Antiochiae Geyer Pétré

${ }^{215}$ que $A$ edd. quae Gam Geyer Pétré

${ }^{216}$ ciuitatem A Gam Her Prinz Mar Nat MaN ciuitate Geyer Pétré FrW Arce Jan
} 
18.1. E, portanto, em nome de Cristo nosso Deus, parti de Antioquia em direção à Mesopotâmia, fazendo caminho por acampamentos ou algumas cidades da província* da Celessíria*, que é a província de Antioquia, e daí, após entrar no território da província de Augustofratense ${ }^{\star}$, cheguei à cidade de Hierápolis, ${ }^{\star}$ que é capital dessa província, isto é, a província de Augustofratense. E porque essa cidade é muito bonita e rica, e abundante em tudo, me foi necessário aí fazer uma parada, porque não estavam tão longe daí as fronteiras da Mesopotâmia.

18.2. Assim, pois, partindo de Hierápolis, em nome de Deus, cheguei, na décima quinta milha, ao rio Eufrates ${ }^{\star}$, do qual foi muito bem descrito ser "o grande rio Eufrates" (Gn 15,18). Ele é enorme e quase aterrador; de fato, corre exibindo rapidez, assim como o Ródano* exibe, com a diferença de que o Eufrates é ainda maior.

18.3. E, portanto, porque era necessário atravessá-lo por meio de navios, e navios ainda maiores, e assim fiquei aí talvez mais de meio dia; e daquele lugar, em nome de Deus, atravessando o rio Eufrates, entrei no território da Mesopotâmia da Síria.

19.1. E assim, novamente percorrendo o caminho por algumas pousadas, cheguei à cidade cujo nome, dado nas Escrituras, lemos, isto é, Batânis*, cidade que existe até hoje. De fato, tem não só uma igreja com um bispo verdadeiramente santo, monge e confessor ${ }^{\star}$, mas também alguns martyria. Essa mesma cidade é abundante no número de homens; de fato, também está aí instalado um soldado com o seu tribuno.

19.2. Partindo, pois, outra vez dali, chegamos, em nome de Cristo nosso Deus, a Edessa. Quando aí chegamos, sem demora saímos para a igreja e para o martyrium de São Tomé. E, portanto, conforme o costume, feitas as orações e o restante que era costume ser feito nos lugares santos, lemos também aí algumas coisas do próprio São Tomé.

19.3. Além disso, a igreja que lá está é grande e muito bonita, e com novo arranjo, de modo que é verdadeiramente digna de ser a casa de Deus; e como eram muitas as coisas que eu desejava ver ali, foi necessário eu fazer uma parada de três dias nesse lugar.

19.4. E assim, pois, vi, naquela mesma cidade, numerosos martyria e também santos monges, morando uns por entre os martyria, outros mais longe da cidade, tendo os mosteiros em lugares mais afastados. 
19.5. Et quoniam sanctus episcopus ipsius ciuitatis, uir uere religiosus et $^{217}$ monachus et confessor, suscipiens me libenter ait michi: "Quoniam uideo te, filia, gratia religionis tam magnum laborem tibi imposuisse, ut de extremis porro terris uenires ad haec loca, itaque ergo, [49] si libenter habes, quaecumque loca sunt hic grata ad uidendum Christianis, ostendimus tibi”. Tunc ergo gratias agens Deo primum et sic ipsum ${ }^{218}$ rogaui plurimum, ut dignaretur facere, quod dicebat.

19.6. Itaque ergo duxit me primum ad palatium Aggari regis et ibi ostendit michi archiotepam ipsius ingens, simillimam, ut ipsi dicebant, marmoream, tanti nitoris ac si de margarita esset; in cuius Aggari uultu parebat de contra uere fuisse hunc uirum satis sapientem et honoratum. Tunc ait mihi ${ }^{219}$ sanctus episcopus: "Ecce rex Aggarus, qui antequam uideret Deum, ${ }^{220}$ credidit ei, quia esset uere filius Dei”. Nam erat et iuxta archiotipa similiter de tali marmore facta, quam dixit filii ipsius esse Magni, similiter et ipsa habens aliquid gratiae in uultu.

19.7. Item perintrauimus in interiori parte palatii; et ibi erant fontes piscibus pleni, quale ${ }^{221}$ ego adhuc nunquam uidi, id est tantae magnitudinis et $^{222}$ uel tam perlustres aut tam boni saporis. Nam ipsa ciuitas aliam aquam penitus non habet nunc nisi eam, quae de palatio exit, quae est ac $s^{223}$ fluius ${ }^{224}$ ingens argenteus.

19.8. Et tunc retulit michi de ipsa aqua sic sanctus episcopus dicens: "Quodam tempore, posteaquam scripserat Aggarus rex ad Dominum et Dominus rescripserat Aggaro per Ananiam cursorem, sicut scriptum est in ipsa epistola: transacto ergo aliquanto tempore superueniunt Persi ${ }^{225}$ et girant ciuitatem istam.

\footnotetext{
${ }^{217}$ et corr. ex est $A$

${ }^{218}$ ipsum $A$ edd. ipsi Chol Geyer Her Pétré

${ }^{219}$ mihi $A$ edd. michi Nat

${ }^{220} \operatorname{deum} A \mathrm{Gam}^{2}$ dominum $\mathrm{Gam}^{1}$ edd.

${ }^{221}$ quale $A$ Gam Nat quales Geyer edd.

222 et om. Gam Her Gam

${ }^{223}$ si corr. ex sic $A$

${ }^{224}$ fluius $A$ fluuius Gam edd.

${ }^{225}$ Persi A edd. Perse Her FrW Arce Persae Geyer Pétré
} 
19.5. E porque o santo bispo dessa cidade, homem verdadeiramente religioso, monge e confessor, acolhendo-me com agrado, me disse: "Pois que vejo, filha, que, por causa da religião, tu te impuseste tão grande fadiga, que mais ao longe dos confins da terra ${ }^{86}$ chegaste a este lugar, portanto, [lacuna] se o fazes com prazer, mostramos a ti todos aqueles lugares que aqui são agradáveis de ver para os cristãos”, então, pois, dando graças a Deus em primeiro lugar, e também a ele, pedi muitíssimo para que se dignasse a fazer o que dizia.

19.6. E assim, portanto, conduziu-me primeiramente ao palácio do rei Abgar e ali me mostrou uma grande estátua muito semelhante a ele, como eles mesmos diziam, de mármore, de tanto brilho, como se fosse de pérola; o rosto ${ }^{87}$ de Abgar, de frente, manifestava ter sido este homem verdadeiramente muito sábio e honrado. Então me disse o santo bispo: "Eis o rei Abgar, o qual, antes que visse o Senhor, acreditou nele, porque era realmente filho de Deus". De fato, havia também muito perto uma estátua igualmente feita de tal mármore, que disse ser do filho dele - Magno -, semelhantemente esta também tendo algo de atrativo no rosto.

19.7. Assim, penetramos na parte interior do palácio, e aí havia fontes cheias de peixes de uma qualidade tal que eu até hoje nunca vi, isto é, tão grandes nem tão puras, nem de tão bom sabor. Na verdade, a própria cidade agora não tem absolutamente outra água, a não ser essa que sai do palácio, que é como um imenso rio de prata.

19.8. E então o santo bispo contou-me sobre essa água, dizendo assim: "Algum tempo depois que o rei Abgar escreveu ao Senhor ${ }^{88}$, e o Senhor respondeu a Abgar pelo mensageiro Ananias, assim como está escrito na própria carta, decorrido, pois, bastante tempo, chegam inesperadamente os persas $^{\star}$ e cercam esta cidade.

\footnotetext{
${ }^{86}$ Mais ao longe dos confins da terra (de extremis porro terris): este é o trecho citado pelo monge Valério quando se refere à autora, que, proveniente de um lugar distante, fez uma peregrinação aos Lugares Santos (cf. Introdução, no item "Origem da peregrina"). ${ }^{87}$ Rosto (uultus): literalmente, temos "em cujo rosto de Abgar" (in cuius Aggari uultu), o que não gera uma frase gramaticalmente correta em português, por isso a adaptação.

${ }_{88}$ Ao Senhor (ad Dominum): na passagem posteaquam scripseram Aggarus rex ad Dominum et Dominus rescripserat Aggaro, destacamos, nas expressões em negrito, a convivência lado a lado de duas variantes do latim: $a d+$ acusativo e dativo como complementos de scribere. É interessante notar que aqui $a d$ + acusativo não substituiu o dativo, fenômeno tantas vezes citado como característico do latim vulgar, mas, como se pode observar, no texto de Egéria existem ainda as duas construções, que eram possíveis também no latim clássico.
}

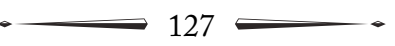


19.9. Sed statim Aggarus epistolam Domini ferens ad portam cum omni exercitu suo publice orauit. Et post dixit: 'Domine Iesu, tu promiseras nobis, ne aliquis hostium ingrederetur ciuitatem istam, et ecce nunc Persae inpugnant nos. Quod cum dixisset tenens manibus leuatis epistolam ipsam apertam rex, ad subito tantae tenebrae factae sunt, foras ciuitatem tamen ante oculos Persarum, cum iam prope plicarent ciuitati, ita ut usque tertium miliarium de ciuitate essent: sed ita mox tenebris turbati sunt, ut uix castra ponerent et pergirarent in miliario tertio totam ciuitatem.

19.10. Ita autem ${ }^{226}$ turbati sunt Persae, ut nunquam uiderent postea, qua parte in ciuitate ${ }^{227}$ ingrederentur, sed custodirent ciuitatem per giro clusam hostibus in miliario tamen tertio, quam tamen custodierunt mensibus aliquod. ${ }^{228}$

19.11. Postmodum autem, cum uiderent se nullo modo posse ingredi in ciuitatem, uoluerunt siti eos occidere, qui in ciuitate erant. Nam monticulum istum, quem uides, filia, super ciuitate hac, in illo tempore ipse huic [50] ciuitati aquam ministrabat. Tunc uidentes hoc Persae auerterunt ipsam aquam a ciuitate et fecerunt ei decursum contra ipso loco, ubi ipsi castra posita habebant.

\footnotetext{
${ }^{226}$ ita autem corr. ex ita tamen autem

${ }^{227}$ ciuitate $A$ edd. ciuitatem $\mathrm{Gam}^{2}$

${ }^{228}$ aliquod corr. ex aquod $A$ edd. aliquot Geyer Pétré
} 
19.9. Mas imediatamente Abgar, trazendo a carta do Senhor à porta da cidade, rezou publicamente, com todo seu exército. E depois disse: 'Senhor Jesus, tu nos prometeras que nenhum inimigo entraria nesta cidade, e eis agora que os persas nos atacam. E depois que o rei disse isso, tendo nas mãos erguidas essa carta aberta, fizeram-se subitamente tão grandes trevas, mas fora da cidade, diante dos olhos dos persas, quando já chegavam perto da cidade, a ponto de estarem a apenas três milhas da cidade. Mas de tal sorte foram logo perturbados pelas trevas, que mal estabeleceram acampamento e circularam a cidade toda a uma distância de três milhas.

19.10. Pois os persas ficaram tão perturbados que não viram, em seguida, por onde entrariam na cidade, mas mantiveram a cidade cercada, porém, a três milhas dos inimigos, que, contudo, a mantiveram cercada por alguns meses.

19.11. Depois, porém, quando viram que de modo nenhum poderiam entrar na cidade, quiseram matar de sede os que estavam na cidade. Pois este montículo que vês, filha, sobre esta cidade, naquele tempo, ele servia a água para essa cidade. Então, vendo isso, os persas desviaram essa água da cidade e fizeramna descer defronte o próprio lugar onde eles haviam estabelecido ${ }^{89}$ acampamento.

\footnotetext{
${ }^{89}$ Haviam estabelecido (posita habebant): os tempos compostos das línguas românicas não existiam no latim clássico. Esse exemplo em Egéria nos mostra terem sido uma criação do latim vulgar. No entanto, o ponto de partida dessa inovação se encontra no latim clássico. Neste, distinguia-se entre um passado (perfeito) simples e um composto: scripsi epistulam era um pretérito denotando uma ação inteiramente passada e habeo scriptam epistulam uma ação realizada (e portanto passada), mas que se prolongava no presente através de suas consequências. A diferença está no que tradicionalmente se distingue entre tempo e aspecto verbal. Muito brevemente podemos dizer que a categoria de tempo diz respeito às relações temporais que são expressas por contrastes gramaticais sistemáticos: passado, presente e futuro. Esses contrastes foram reconhecidos pelos gramáticos tradicionais na análise do grego e do latim. A característica essencial da categoria tempo é que ela relaciona o tempo da ação, do acontecimento ou do estado referidos na frase ao momento do enunciado que é "agora". O tempo gramatical é, pois, uma categoria "dêitica" que faz parte tanto da frase quanto do enunciado. O termo aspecto foi usado primeiro para referir-se à distinção entre o perfeito ou perfectivo e o imperfeito ou imperfectivo no russo e em outras línguas eslavas. Em russo, essa distinção entre o perfectivo e o imperfectivo pode ser ilustrada por duas frases: 1) Ja procital roman; 2) Ja cital roman. Embora as duas frases estejam no passado e possam ser traduzidas por "Li um romance", na primeira, o perfectivo é usado quando se quer dizer que a ação de ler tinha se completado, isto é, que se acabara de ler o livro. $\mathrm{Na}$ segunda, o imperfectivo não diz se a ação de ler se completara ou não; apenas diz que se levou algum tempo lendo um romance. $\mathrm{O}$ aspecto verbal envolve outras noções que não discutiremos aqui: iterativo (ou frequentativo), pontual (ou momentâneo), habitual, incoativo (ou inceptivo) etc. Além disso, deixaremos de lado nessa exposição bastante
} 


\section{Maria Cristina Martins}

19.12. In ea ergo die et in ea hora, qua auerterant Persae aquam, statim hii fontes, quos uides in eo loco, iusso Dei a semel ${ }^{229}$ eruperunt: ex ea die hi fontes usque in hodie permanent hic gratia Dei. Illa autem aqua, quam Persae auerterant, ita siccata est in ea hora, ut nec ipsi haberent uel una die quod biberent, qui obsedebant ${ }^{230}$ ciuitatem, sicut tamen et usque in hodie apparet; nam postea nunquam nec qualiscumque humor ibi apparuit usque in hodie.

19.13. Ac sic iubente Deo, qui hoc promiserat futurum, necesse fuit eos statim reuerti ad sua, id est in Persida. Nam et postmodum quotienscumque uoluerunt uenire et expugnare hanc ciuitatem hostes, haec epistola prolata est et lecta est in porta, et statim nutu Dei expulsi sunt omnes hostes".

19.14. Illud etiam retulit sanctus episcopus: "Eo quod hii fontes ubi erupeierunt, ${ }^{231}$ ante sic fuerit campus intra ciuitatem subiacens palatio Aggari. Quod palatium Aggari quasi in editiori loco positum erat, sicut et nunc paret, ut uides. Nam consuetudo talis erat in illo tempore, ut palatia, quotiensque fabricabantur, semper in editioribus locis fierent.

\footnotetext{
${ }^{229}$ semel $A$ edd. semet Gam

${ }^{230}$ obsedebant $A$ edd. obsidebant Gam

${ }^{231}$ erupeierunt $A$ e rupe ierunt Gam eruperunt Chol edd.
} 
19.12. Naquele dia, pois, e naquela hora em que os persas desviaram a água, imediatamente estas fontes que vês neste lugar, por ordem de Deus, jorraram de um jato; desde aquele dia até hoje estas fontes permanecem aqui pela graça de Deus. Além disso, aquela água que os persas desviaram secou ${ }^{90}$ naquela hora, de modo que nem eles mesmos tiveram, os que sitiavam a cidade, por um só ${ }^{11}$ dia, o que beber, assim como também até hoje se apresenta; de fato, não apareceu jamais até hoje qualquer líquido aí.

19.13. E assim, ordenando Deus, que havia prometido que assim seria, foi-lhes necessário voltar imediatamente à sua pátria, isto é, à Pérsia. Efetivamente, todas as vezes ainda depois que os inimigos quiseram vir e subjugar esta cidade, esta carta foi exibida e lida à porta, e, imediatamente, por um sinal de Deus, todos os inimigos foram expulsos".

19.14. Também isto me contou o santo bispo: "Onde estas fontes brotaram, anteriormente tinha sido uma planície no interior da cidade, que ficava abaixo do palácio de Abgar. E esse palácio de Abgar estava situado como que num lugar mais elevado, como ainda aparece, como vês. De fato, o costume era tal, naquele tempo, que os palácios, todas as vezes que eram construídos, eram feitos nos lugares mais elevados.

simplificada, a intersecção entre tempo e modo e entre tempo e aspecto. Para concluir, o aspecto, diferentemente do tempo, não é uma categoria dêitica. Silvio Elia (1979, p.217237) ilustra essa diferença entre tempo e aspecto no latim com um exemplo de César (De Bello Gallico, I, 15): equitatum (...) quem ex omni prouincia (...) coactum habebat. O sentido deste passado composto não é simplesmente 'reunira' (como seria o de coegerat) mas de 'tinha estado reunido' (um sentido mais de adjetivo do que de verbo). A aproximação de habere + particípio passado, em latim, teria um valor aspectual, indicando não só uma ação completamente realizada e, portanto, passada, mas ainda o fato de que seus efeitos se prolongam no presente. Assim, uma forma verbal como habeo occupatum 'tenho ocupado' é simultaneamente passado (pelo tempo) e durativo (pelo aspecto). A tendência analítica que predominou no latim vulgar levou progressivamente à preferência por habeo scriptum em desfavor do clássico scripsi. Esse processo estendeuse aos demais tempos do perfectum. Daí posita habebant no texto, que constitui o maisque-perfeito românico. Note-se o português que, à maneira latina, continua a dispor de um passado na forma simples: posui 'pus, fixei, estabeleci', posuerant 'puseram' etc. (ver também LYONS, 1979).

${ }^{90}$ Secou (siccata est): o verbo siccare não é depoente em latim clássico, tal como se poderia pensar pelo uso de (aqua) siccata est nesta frase.

${ }^{91}$ Por um só dia (una die): temos aqui o uso clássico de unus 'único', 'um só, que não é o de artigo, mas sim de numeral. V. nota 60. 
19.15. Sed postmodum quam hii fontes in eo loco eruperunt, tunc ipse Aggarus filio suo Magno, id est isti, cuius archiotipa uides iuxta parte ${ }^{232}$ posita, hoc palatium fecit in eo loco, ita tamen, ut hii fontes intra palatium includerentur".

19.16. Postea ergo quam haec omnia retulit sanctus episcopus, ait ad me: "Eamus nunc ad portam, per quam ingressus est Ananias cursor cum illa epistola, quam dixeram". Cum ergo uenissemus ad portam ipsam, stans episcopus fecit orationem et legit nobis ibi ipsas epistolas et denuo benedicens ${ }^{233}$ nos facta est iterato ${ }^{234}$ oratio.

19.17. Illud etiam retulit nobis sanctus ipse dicens: "Eo quod ex ea die, qua Ananias cursor per ipsam portam ingressus est cum epistolam ${ }^{235}$ Domini, usque in praesentem ${ }^{236}$ diem custodiatur, ne quis immundus, ne quis lugubris per ipsam portam transeat, sed nec corpus alicuius mortui eiciatur per ipsam portam".

19.18. Ostendit etiam nobis sanctus episcopus memoriam Aggari uel totius familiae ipsius ualde pulchra, sed facta more antiquo. Duxit etiam nos et ad illum palatium superiorem, quod habuerat primitus rex Aggarus, et si qua praeterea $^{237}$ loca erant, monstrauit nobis.

19.19. Illud ${ }^{238}$ etiam satis $\mathrm{mihi}^{239}$ grato fuit, ut epistolas ipsas siue Aggari ad Dominum siue Domini ad Aggarum, quas nobis ibi legerat sanctus episcopus, acciperem michi ab ipso sancto. Et licet in patria exemplaria ipsarum haberem, tamen gratius mihi ${ }^{240}$ uisum est, ut et ibi eas de [51] ipso acciperem, ne quid forsitan minus ad nos in patria peruenisset; nam uere amplius est, quod hic accepi. Vnde si Deus noster Iesus iusserit et uenero in patria, legi si uos, ${ }^{241}$ dominae animae meae.

\footnotetext{
${ }^{232}$ parte A Gam patre Pom (in nota) edd. pariete coni. Geyer (in nota)

${ }^{233}$ benedicens $A$ edd. bendicens $\mathrm{Her}$

${ }^{234}$ iterato $A$ edd. iterata Gam Geyer Pétré

${ }^{235}$ epistolam $A$ edd. epistola $\mathrm{Gam}^{2}$

${ }^{236}$ praesentem A Gam Geyer Her Pétré Prinz presentem FrW Arce Mar Jan Nat MaN

${ }^{237}$ praeterea $A$ Gam $^{2}$ Geyer Pétré Her Prinz preterea Gam ${ }^{1}$ FrW Arce Mar Jan Nat MaN

238 illud corr. ex illum $A$

${ }^{239}$ mihi $A$ edd. michi Nat

${ }^{240}$ mihi $A$ edd. michi Nat

${ }^{241}$ legi si uos $A$ legetis et uos $\mathrm{Gam}^{2}$ legitis uos Chol edd. legitis et uos Geyer Pétré legetis uos Arce
} 
19.15. Mas, depois que estas fontes irromperam neste lugar, então o próprio Abgar fez este palácio neste lugar para seu filho Magno, isto é, para este cuja estátua vês colocada ao lado da do pai, mas de modo que estas fontes ficassem encerradas dentro do palácio".

19.16. Logo depois que o santo bispo me contou todas essas coisas, me disse: "Vamos agora à porta pela qual entrou o mensageiro Ananias com aquela carta que eu disse". Quando, pois, chegamos àquela porta, o bispo fez, em pé, uma oração e leu para nós ali as próprias cartas e, outra vez nos abençoando, fez-se nova oração.

19.17. Também isto nos contou esse santo bispo, dizendo: "Desde aquele dia em que o correio Ananias entrou por essa porta com a carta do Senhor até o presente dia, está guardada, a fim de que ninguém impuro ou de luto passe por esta porta, e que o corpo de nenhum morto seja retirado por essa porta”.

19.18. Mostrou-nos também o santo bispo o túmulo de Abgar e de toda a família dele, muito bonito, ${ }^{92}$ mas ainda feito à maneira antiga. Conduziu-nos também ainda ao palácio superior que o rei Abgar possuíra primeiro e, se havia mais lugares além desse, mostrou-nos.

19.19. Também foi muito agradável para mim que eu recebesse desse santo tanto as próprias cartas de Abgar ao Senhor como as do Senhor a Abgar, as quais nos lera ali o santo bispo. E ainda que tivesse na $<$ minha $>$ pátria cópia das mesmas, contudo me pareceu mais agradável recebê-las dele, [lacuna] para que nada chegasse a menos até nós, na pátria: na verdade, é bem maior esta que recebi aqui. E se Jesus nosso Deus ordenar e eu voltar desse lugar à pátria, vós também a lereis, ${ }^{93}$ senhoras da minha alma.

\footnotetext{
${ }^{92}$ Bonito (pulchra): o adjetivo pulchra por pulchram refere-se ao substantivo memoriam; por este se encontrar distante, Egéria "esquece" a concordância no acusativo. Mais uma vez, o "erro" mostra a pouca vitalidade das desinências de caso.

${ }^{93}$ Lereis (legi si uos): pelo que está escrito, depreende-se que a autora quis escrever legitis. No entanto, a forma esperada seria a do futuro legetis. A confusão que aparece aqui, entre o presente legitis e o futuro legetis, deve-se a um fenômeno que afetou o latim vulgar: a perda da duração das vogais. As vogais do latim clássico - a, e, i, o, u - possuíam uma característica fonológica capaz de distinguir morfemas gramaticais: a duração ou quantidade. De acordo com a duração, as vogais (tanto as tônicas quanto as átonas) podiam ser longas ou breves. Pela quantidade, ŏs (o breve) era 'osso' e ōs (o longo) era 'boca. Também não se confundiam, por exemplo, rosă em nominativo ( $a$ breve) e rosā no ablativo ( $a$ longo). É certo, no entanto, que essa oposição quantitativa se perdeu no latim vulgar. Meyer-Lübke (apud ELIA, 1979, p.157-8) afirma que a quantidade foi substituída pela qualidade ou timbre durante o séc. I. Ou seja, as vogais longas (com exceção de $a$ ) pronunciavam-se como fechadas e as breves como abertas. A pronúncia das breves como
} 


\section{Maria Cristina Martins}

20.1. Ac sic ergo facto ibi triduano necesse me fuit adhuc in ante accedere usque ad Charris, ${ }^{242}$ quia modo sic dicitur. Nam in Scripturis sanctis dicta est Charra, ${ }^{243}$ ubi moratus est sanctus Abraam, sicut scriptum est in Genesi, dicente Domino ad Abraam: "Exi de terra tua et de domo patris tui et uade in Charram" et reliqua.

20.2. Ergo cum $^{244}$ uenissem, id est in Charra, ibi statim fui ad ecclesiam, quae est intra ciuitate ipsa. Vidi etiam mox episcopum loci ipsius uere sanctum et hominem Dei, et ipsum et monachum et confessorem, qui mox nobis omnia loca ibi ostendere dignatus est, quae desiderabamus.

20.3. Nam duxit nos statim ad ecclesiam, quae est foras ciuitatem in eo loco ubi fuit domus sancti Abrahae, id est in ipsis fundamentis et de ipso lapide, ut tamen dicebat sanctus episcopus. Cum ergo uenissemus in ipsa ecclesia, ${ }^{245}$ facta est oratio et lectus ipse locus de Genesi, dictus etiam unus psalmus, et iterata oratione et sic benedicen $s^{246}$ nos episcopus, egressi sumus foras.

${ }^{242}$ Charris corr. ex Carris $A$ edd.

${ }^{243}$ Charra corr. ex Carra $A$

${ }^{244}$ ergo cum A Gam Arce ibi ergo cum Geyer edd.

${ }^{245}$ in ipsa ${ }^{* * * *}$ ecclesia $A$

${ }^{246}$ benedicens $A$ edd. bendicens $\mathrm{Her}$ 
20.1. E assim, pois, passados aí três dias, foi-me necessário ainda prosseguir até Carres ${ }^{\star}$, que agora assim se diz. De fato, nas Santas Escrituras foi chamada Carra* e ali morou o santo Abraão, assim como está escrito no Gênesis, dizendo Deus a Abraão: "Sai de tua terra e da casa de teu pai e vai para Carra" (Gn 12,1) et cetera.

20.2. Portanto, quando cheguei, isto é, em Carra, aí fui ${ }^{94}$ imediatamente à igreja que fica dentro dessa cidade; vi também, logo depois, o bispo deste lugar, verdadeiramente santo e homem de Deus, ele próprio também monge e confessor, que sem demora dignou-se a nos mostrar ali todos os lugares que desejávamos.

20.3. Com efeito, conduziu-nos imediatamente à igreja que está fora da cidade, àquele lugar onde foi a casa do santo Abraão, isto é, nos mesmos alicerces e da mesma pedra, segundo nos dizia o santo bispo. Quando, pois, chegamos a essa igreja, foi feita uma oração e lido o mesmo passo do Gênesis, dito ainda um salmo e uma nova oração, e assim, nos abençoando o bispo, saímos para fora.

abertas e das longas como fechadas, associada ao fenômeno da perda da quantidade, levou a uma aproximação entre o è de legètis e o $\mathbf{\mathbf { i }}$ de legĭtis, pois esses dois fonemas

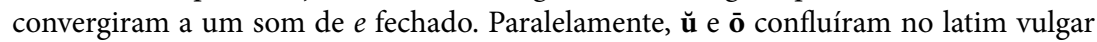
para $o$ fechado. Apenas para citar um exemplo, isso se observa na grafia de con ao invés

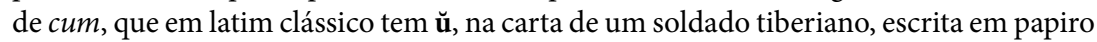
e encontrada em Karanis, datada do séc. II (Corpus Papyrorum Latinarum, 254, apud DÍAZ Y DÍAZ, 1962, p.21-22). Todavia, essa situação de modificação das vogais do latim para as línguas românicas, ainda que seja a mais extensa de todas (pois compreende a Ibero-România - português, espanhol, catalão -, a Galo-România - dialetos réticos -, a Ítalo-România - toda a região, com exceção da Sardenha e do sul e leste da Lucânia -, e a antiga Dalmácia), não ocorreu em toda a România. Segundo alguns estudiosos, entre os quais Lausberg (1981, p.110ss), em toda a România distinguem-se quatro sistemas vocálicos, segundo outros, três. Seja como for, o fenômeno que encontramos nesse exemplo de Egéria faz parte do sistema vocálico mais abrangente, chamado itálico ou do latim vulgar.

${ }^{94}$ Fui (fui): com base no complemento usado com este verbo, ad ecclesiam, parece tratarse do pretérito perfeito do verbo ire e não do verbo esse. Outro exemplo desse emprego encontra-se em 23,1: fui ad episcopum. Tal análise se justifica quando se pensa na conjugação do verbo ire nas línguas ibero-romanas, cujo pretérito perfeito vem do verbo esse e o presente do verbo uadere, permanecendo a conjugação do verbo ire no futuro, gerúndio, imperfeito, particípio passado e imperativo. Em geral, as línguas românicas conservaram muito pouco da conjugação do verbo ire (ver MAURER JR., 1959, p.162 para mais detalhes).

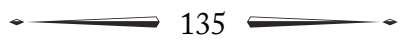


20.4. Item dignatus est nos ducere ad puteum illum, unde portabat aquam sancta Rebecca. Et ait nobis sanctus episcopus: "Ecce puteus, unde potauit $^{247}$ sancta Rebecca camelos pueri sancti Abrahae, id est Eleazari”; et singula ita nobis dignabatur ostendere.

20.5. Nam ecclesia, quam dixi foras ciuitatem, dominae sorores uenerabiles, ubi fuit primitus domus Abrahae, nunc et martyrium ibi positum est, id est sancti cuiusdam monachi nomine Helpidi. Hoc autem nobis satis gratum euenit, ut pridie martyrium ${ }^{248}$ die ibi ueniremus, id est sancti ipsius Helpidii, nono k. Maias, ad quam diem necesse fuit undique et de omnibus Mesopotamiae finibus omnes monachos in Charra descendere, etiam et illos maiores, qui in solitudine sedebant, quos ascites uocant, per diem ipsum, qui ibi satis grandiiter ${ }^{249}$ attenditur, et propter memoriam sancti Abrahae, quia domus ipsius fuit, ubi nunc ecclesia est, in qua positum est corpus ipsius sancti martyris.

20.6. Itaque ergo hoc nobis ultra spem grate satis euenit, ut sanctos et uere homines Dei monachos Mesopotamenos ibi uideremus, etiam et eos, quorum fama uel uita longe audiebatur, quos tamen non estimabam ${ }^{250}$ me penitus posse uidere, non quia inpossibile esset Deo etiam et hoc praestare ${ }^{251}$ michi, qui omnia praestare ${ }^{252}$ dignabatur, sed quia audieram eos, eo quod extra diem Paschae et extra diem hanc non eos descendere de locis suis, quoniam tales sunt, ut et uirtutes faciant multas, et quoniam nesciebam, quo mense [52] esset dies hic martyrii, quem dixi. Itaque Deo iubente sic euenit, ut ad diem, quem nec sperabam, ibi uenirem.

20.7. Fecimus ergo et ibi biduum propter diem martyrii et propter uisionem sanctorum illorum, qui dignati sunt ad salutandum libenti satis animo me suscipere et alloqui, in quo ego non merebar. Nam et ipsi statim post martyrum ${ }^{253}$ diem nec uisi sunt ibi, sed mox de nocte petierunt heremum et unusquisque eorum monasteria sua, qui ${ }^{254}$ ubi habebat.

\footnotetext{
${ }^{247}$ potauit corr. ex portauit $A$

${ }^{248}$ martyrium $A$ edd. martyrii Devos Jan

${ }^{249}$ grandiiter $A$ granditer Gam edd.

250 estimabam $A$ edd. existimabam Gam² aestimabam Geyer Her Pétré

${ }^{251}$ praestare A Gam ${ }^{2}$ Geyer Her Pétré Prinz prestare Gam ${ }^{1}$ FrW Arce Mar Jan Nat MaN

252 praestare A Gam ${ }^{2}$ Geyer Her Pétré Prinz prestare Gam ${ }^{1}$ FrW Arce Mar Jan Nat MaN

${ }^{253}$ martyrum A Gam martyrii Chol edd. martyris Arce martyrium Vään

${ }^{254}$ qui $A$ edd. quae $G^{2} m^{2}$
} 
20.4. Novamente dignou-se a nos conduzir àquele poço de onde a santa Rebeca $^{\star}$ trazia água (Gn 24,15-20). E nos disse o santo bispo: "Eis o poço de onde a santa Rebeca deu de beber aos camelos do escravo do santo Abraão, isto é, de Eleazar". E assim, dignava-se a mostrar-nos cada uma das coisas.

20.5. Na verdade, a igreja que disse estar fora da cidade, senhoras, veneráveis irmãs, onde foi primitivamente a casa de Abraão, aí agora também foi construído um martyrium, isto é, de um certo santo monge de nome

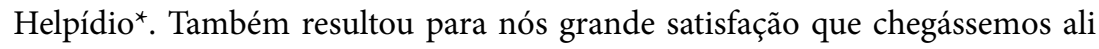
na véspera do dia do martírio, isto é, do mesmo santo Helpídio, nono dia das calendas $^{\star}$ de maio, dia em que foi necessário de todos os lados e de todo o território da Mesopotâmia todos os monges e também aqueles mais velhos, que moravam em solidão, que chamam de ascetas, descer até Carra para esse dia que é grandemente considerado aí, e também pela memória do santo Abraão, porque a casa dele foi onde agora há uma igreja na qual foi sepultado o corpo desse santo mártir.

20.6. E, portanto, isto nos aconteceu com prazer além do esperado, que víssemos aí os monges da Mesopotâmia e verdadeiramente homens de Deus, inclusive aqueles dos quais se ouvia há muito tempo a fama e a vida, aqueles que, ao contrário, eu não pensava de modo algum poder ver, não porque fosse impossível a Deus me oferecer mais isso, pois ele se dignava a dar tudo, mas porque ouvira que eles, exceto neste dia da Páscoa, e salvo neste dia, eles não desciam dos seus locais para lá, visto que são tais que não só praticam muitas virtudes, mas também porque não sabia em qual mês seria esse dia do martírio, que falei. E, por ordem de Deus, assim aconteceu que chegasse aí, perto desse dia que nem esperava.

20.7. Permanecemos, pois, ali por dois dias por causa do dia do martírio e por causa da visita daqueles santos, que se dignaram, com disposição bastante favorável, a me saudar e dirigir a palavra, o que eu não merecia. Na verdade, eles também não foram mais vistos aí imediatamente após o dia do martírio, mas logo depois, de noite, dirigiram-se para o deserto e cada um deles para onde tinha ${ }^{95}$ o seu mosteiro.

\footnotetext{
${ }^{95}$ Dirigiram-se (...) para onde tinha (petierunt... qui ubi habebat): com base no sentido, interpretamos este qui como quisque, quaeque, quidque ou quicque, "cada um", "cada uma". Corrobora essa análise o fato de sabermos que, no latim vulgar, quisque perdeu a enclítica -que. Possivelmente isso se deve ao fato de que no latim clássico quisque declinava-se como quis, ficando a enclítica invariável.
} 
20.8. In ipsa autem ciuitatem ${ }^{255}$ extra paucos clericos et sanctos monachos, si qui tamen in ciuitate commorantur, penitus nullum Christianum inueni, sed totum gentes sunt. Nam sicut nos cum grandi reuerentia attendimus locum illum, ubi primitus domus sancti Abrahae fuit, pro memoria illius, ita et illae gentes forte ad mille passus de ciuitate cum grandi reuerentia adtendunt locum, ubi sunt memoriae Naor et Bathuhelis.

20.9. Et quoniam episcopus illius ciuitatis ualde instructus et ${ }^{256}$ de Scripturis, requisiui ab eo dicens: "Rogo te, domine, ut dicas michi, quod desidero audire". Et ille ait: "Dic, filia, quod uis, et dicam tibi, si scio". Tunc ego dixi: "Sanctum Abraam cum patre Thara et Sarra uxore et Loth fratris filio scio per Scripturas in eo loco uenisse; Naor autem uel Bathuhelem non legi, quando in isto loco transierint, nisi quod hoc solum scio, quia postmodum puer Abraae ut peteret Rebeccam filiam Bathuhelis filii Nahor filio ${ }^{257}$ domini sui Abraae, id est Ysaac, in Charra uenerit".

20.10. Tunc ait mihi ${ }^{258}$ sanctus episcopus: "Vere, filia, scriptum est, sicut dicis, in Genesi sanctum Abraam hic transisse cum suis; Nachor autem cum suis uel Bathuhelem non dicit Scriptura canonis, quo tempore transierint. Sed manifeste postmodum hic transierunt et ipsi; denique et memoriae illorum hic sunt forte ad mille passus de ciuitate. Nam uere Scriptura hoc testatur, quoniam ad accipiendam sanctam Rebeccam huc uenerit puer sancti Abraae et denuo sanctus Iacob hic uenerit, quando accepit filias Laban Syri”.

\footnotetext{
${ }^{255}$ ciuitatem A Her FrW Prinz Mar Nat MaN ciuitate Gam Geyer Pétré Arce Jan

${ }^{256}$ et $A$ est $\mathrm{Gam}^{2}$ edd.

${ }^{257}$ filio corr. ex filio suo $A$

${ }^{258}$ mihi A michi Gam edd.
} 
20.8. Todavia, nessa cidade, exceto os poucos clérigos e santos monges, se é que porventura alguns moram na cidade, não encontrei quase nenhum cristão, mas tudo são gentios. De fato, assim como nós, com grande respeito, dirigimonos àquele lugar onde foi pela primeira vez a casa do santo Abraão, em honra à sua memória, assim também aqueles gentios, com grande respeito, dirigem-se talvez a mil passos da cidade, ao lugar onde estão as sepulturas de Naor e Batuel.

20.9. E já que o bispo daquela cidade é bastante instruído nas Escrituras, pedi a ele, dizendo: "Peço-te, senhor, que me digas o que eu desejo ouvir". E ele disse: "Dize, filha, o que queres e eu te direi, se souber" ${ }^{96}$ Então eu disse: "Sei, pelas Escrituras, que o santo Abraão chegou a este lugar com o seu pai Taré e com a esposa Sara e o filho do irmão Ló (Gn 11,31); porém não li quando passaram por este lugar Naor e Batuel, contudo só sei que, pouco depois, o escravo de Abraão chegou a Carra para buscar Rebeca, filha de Batuel, filho de Naor (Gn 24,15), para o filho de seu senhor Abraão, isto é, Isaac”.

20.10. Nesse momento me disse o santo bispo: "Na verdade, filha, está escrito, assim como dizes, no Gênesis, que o santo Abraão teria passado por aqui com os seus (Gn 11,31); porém a Escritura canônica não diz em que momento passaram Naor e Batuel. Mas, evidentemente, pouco depois passaram aqui também eles, afinal ainda as sepulturas deles aqui estão, talvez a mil passos da cidade. E a Escritura de fato atesta isto, que, para buscar a santa Rebeca, aqui veio o escravo do santo Abraão (Gn 24,1ss), e ainda teria vindo aqui o santo Jacó, quando recebeu as filhas do sírio Labão* (Gn 29,1)”.

\footnotetext{
${ }^{96}$ Se souber (si scio): em latim, o emprego do verbo nas orações condicionais varia de acordo com o grau de possibilidade de acontecer o que é expresso pela oração condicional, isto é, varia de acordo com o fato de exprimir um caso real, um caso potencial ou um caso irreal. No caso real, enuncia-se a condição e a consequência como reais. Emprega-se qualquer tempo do modo indicativo na condicional e na principal, como em si hoc dicis, erras, "se dizes isto, erras". No caso potencial, a condição e a consequência exprimem uma possibilidade. O tempo da condicional e da principal, nesse caso, é o presente do subjuntivo e, mais raramente, o perfeito do subjuntivo - si hoc dicas, erres "se disseres isto, errarás". No caso irreal, a condição é expressa como não sendo real, e por isso a consequência não o é. O tempo empregado na condicional e na principal é o imperfeito do subjuntivo, quando se trata do presente, e o mais-que-perfeito do subjuntivo, quando se trata do passado - si hoc diceres, errares, "se dissesses isto, errarias"; si hoc dixisses, errauisses, "se tivesses dito isto, terias errado". No período Et ille ait: dic filia, quod uis, et dicam tibi, si scio, a oração si scio é uma condicional potencial, em que a condição e a consequência são indicadas como possíveis ou prováveis. Ambas as orações condicional ou prótase e condicionada (principal) ou apódose deveriam estar, à maneira do latim clássico, no presente do subjuntivo. Todavia, Egéria usa na principal o futuro do indicativo (dicam) e o presente do indicativo na subordinada condicional (scio).
} 
20.11. Tunc ego requisiui ubi esset puteus ille, ubi sanctus Iacob potasset pecora, quae pascebat Rachel filia Laban Siri ${ }^{259}$. Et ait mihi ${ }^{260}$ episcopus: "In sexto miliario est hinc locus ipse iuxta uicum, qui fuit tunc uilla Laban Siri, ${ }^{261}$ sed cum uolueris ire, imus tecum et ostendimus tibi, nam et multi monachi ibi sunt ualde sancti et ascites et sancta ecclesia est ibi”.

20.12. Illud etiam requisiui a sancto episcopo, ubinam esset locus ille Chaldeorum, ${ }^{262}$ ubi habitauerant primo Thara cum suis. Tunc [53] ait mihi ${ }^{263}$ ipse sanctus episcopus: "Locus ille, filia, quem requiris, decima mansione est hinc intus in Persida. Nam hinc usque ad Nisibin mansiones sunt quinque, et inde usque ad Hur, ${ }^{264}$ quae fuit ciuitas Chaldeorum, ${ }^{265}$ aliae mansiones sunt quinque; sed modo ibi accessus Romanorum non est, totum enim illud Persae tenent. Haec autem pars ${ }^{266}$ specialiter orientalis ${ }^{267}$ appellatur, quae est in confinium Romanorum et Persarum uel Chaldeorum". 268

20.13. Et cetera plura referre dignatus est, sicut et ceteri sancti episcopi uel sancti monachi facere dignabantur, omnia tamen de Scripturis Dei uel sanctis uiris gesta, id est monachis, siue qui iam recesserant, quae mirabilia fecerint, siue etiam qui adhuc in corpore sunt, quae cotidie faciant, hi tamen qui sunt ascites. Nam nolo estimet ${ }^{269}$ affectio uestra monachorum aliquando aliquando ${ }^{270}$ alias fabulas esse nisi aut de Scripturis Dei aut gesta ${ }^{271}$ monachorum maiorum.

21.1. Post biduo autem, quam ibi feceram, duxit nos episcopus ad puteum illum ubi adaquauerat sanctus Iacob pecora sanctae Rachel, qui puteus sexto miliario est a Charris; in cuius putei honorem fabricata est ibi iuxta sancta ecclesia ingens ualde et pulchra. Ad quem puteum cum uenissemus, facta est ab episcopo oratio, lectus etiam locus ipse de Genesi, dictus etiam unus psalmus competens loco atque iterata oratione benedixit nos episcopus.

\footnotetext{
${ }^{259}$ Siri A edd. Syri Geyer Pétré

${ }^{260}$ mihi A edd. michi Gam Her Prinz Nat

${ }^{261}$ Siri $A$ edd. Syri Geyer Pétré

${ }^{262}$ Chaldeorum $A$ edd. Chaldaeorum Geyer Pétré

${ }^{263}$ mihi $A$ edd. michi Gam Nat

${ }^{264}$ Hur corr. ex $\operatorname{Vr} A$

${ }^{265}$ Chaldeorum $A$ edd. Chaldaeorum Geyer Pétré

${ }^{266}$ pars om. Geyer Pétré

${ }^{267}$ Syria Orientalis coni.Geyer (in nota)

${ }^{268}$ Chaldeorum A edd. Chaldaeorum Geyer Pétré

${ }^{269}$ estimet $A$ edd. aestimet Geyer Pétré

${ }^{270}$ aliquando bis scriptum $A$

${ }^{271}$ gesta $A$ edd. grata Arce
} 
20.11. Então eu perguntei onde seria aquele poço onde o santo Jacó tinha matado a sede dos rebanhos que Raquel ${ }^{*}$, filha do sírio Labão, apascentava. E o bispo me disse: "A seis milhas daqui fica esse lugar, ao lado do povoado que foi naquele tempo propriedade do sírio Labão, mas, como tiveste vontade de ir, vamos contigo e mostramos a ti, pois há muitos monges ali, grandemente santos e ascetas, e ali há ainda uma igreja consagrada".

20.12. Também perguntei para o santo bispo onde era aquele lugar dos caldeus $^{\star}$, onde moraram primeiramente Taré com os seus. Então me disse esse santo bispo: "Esse lugar, filha, que perguntas, fica no décimo acampamento daqui para dentro da Pérsia. De fato, daqui até Nísibis* há cinco pousadas, e daí até Ur*, que foi a cidade dos caldeus (Gn 11,28), há outras cinco pousadas, mas agora não há aí acesso dos romanos; na verdade, os persas ocupam tudo aquilo. Além disso, esta região é chamada, em particular, de oriental, a qual fica na divisa comum dos romanos, persas e caldeus".

20.13. E muito mais se dignou a contar, assim como também os outros santos bispos e monges dignavam-se a fazer; sempre todas as ações tiradas das Escrituras de Deus ou de homens santos, isto é, de monges, ou os que já se foram, que ações admiráveis realizaram, ou ainda os que até agora estão no seu corpo, ${ }^{97}$ que obram diariamente, que são os ascetas. Na verdade, não quero que julgue, Vossa Afeição, ser alguma vez outros os assuntos ${ }^{98}$ dos monges, a não ser ou das Escrituras de Deus ou os atos dos monges mais velhos.

21.1. Mas, depois de dois dias que passei ali, o bispo nos conduziu àquele poço onde o santo Jacó dera de beber aos rebanhos da santa Raquel (Gn 29,2); esse poço fica na sexta milha de Carra e, em honra desse poço, foi construída ali ao lado uma igreja consagrada, ${ }^{99}$ bastante grande e bonita. E, quando chegamos a esse poço, foi feita uma oração pelo bispo, lido também o mesmo passo do Gênesis, dito ainda um salmo apropriado ao lugar e, feita nova oração, abençoou-nos o bispo.

\footnotetext{
${ }^{97}$ No seu corpo (in corpore): a expressão in corpore encontra-se em 2Cor 12,3: siue in corpore, siue extra corpus. O capítulo 23 do relato de Egéria termina com estas palavras: siue in corpore, siue iam extra corpus fuero.

${ }^{98}$ Assuntos (fabulas): fabula é um termo do latim popular, relacionado ao verbo fabulari do latim clássico, que no latim vulgar deixou de ser depoente e se tornou fabulare, com morfologia de voz ativa. Em português, derivam respectivamente de fabula e fabulare o substantivo "fala" e o verbo "falar".

${ }^{99}$ Igreja consagrada (sancta ecclesia): igreja santa ou igreja tornada sagrada, isto é, "consagrada".
} 
21.2. Vidimus etiam locum $^{272}$ iuxta puteum iacente lapipem ${ }^{273}$ illum infinitum nimis, quem mouerat sanctus Iacob a puteo, qui usque hodie ostenditur.

21.3. Ibi autem circa puteo nulli alii commanent ${ }^{274}$ nisi clerici de ipsa ecclesia, quae ibi est, et monachi habentes iuxta monasteria sua, quorum uitam sanctus episcopus nobis retulit, sed uere inauditam. Ac sic ergo facta oratione in aecclesia ${ }^{275}$ accessi cum episcopo ad sanctos monachos per monasteria ipsorum, et Deo gratias agens et ipsis, qui dignati sunt me per monasteria sua, ubicumque ingressa sum, libenti animo suscipere et alloqui illis sermonibus, quos dignum erat de ore illorum procedere. Nam et eulogias dignati sunt dare michi et omnibus, qui mecum erant, sicut est consuetudo monachis dare, his tamen, quos libenti animo suscipiunt in monasteriis suis.

21.4. Et quoniam ipse locus in campo grandi est, de contra ostensus est michi a sancto episcopo uicus ingens satis, forte ad quingentos passos de puteo, per quem uicum iter habuimus. Hic autem uicus, quantum episcopus dicebat, fuit quondam uilla Laban Siri. ${ }^{276}$ qui uicus appellatur Fadana. Nam ostensa est michi in ipso uico memoria Laban Siri, ${ }^{277}$ [54] soceri Iacob, ostensus est etiam michi locus, unde furata est Rachel idola patris sui.

21.5. Ac sic ergo in nomine Dei peruisis omnibus, faciens uale sancto episcopo et sanctis monachis, qui nos usque ad illum locum deducere dignati fuerant, regressi sumus per iter uel mansiones, quas ueneramus de Anthiocia. ${ }^{278}$

22.1. Anthiocia ${ }^{279}$ autem cum fuissem regressa, feci postmodum septimana, quousque ea, quae necessaria erant itineri, pararentur. Et sic proficiscens de Anthiocia ${ }^{280}$ faciens iter per mansiones aliquot perueni ad prouinciam, quae Cilicia appellatur, quae habet ciuitatem metropolim Tharso, ubi quidem Tharso et eundo Ierusolimam iam fueram.

\footnotetext{
${ }^{272}$ locum A Gam Prinz Mar Nat MaN loco Chol Geyer Her Pétré FrW Arce Jan

${ }^{273}$ iacente lapipem $A$ iacentem lapidem Gam Geyer Her Pétré Arce iacente lapidem FrW Prinz Mar Jan Nat MaN

${ }^{274}$ commanent $A$ edd. commanet $\mathrm{Gam}^{2}$

${ }^{275}$ aecclesia $A$ edd. ecclesia Gam Geyer Pétré

${ }^{276}$ Siri A edd. Syri Geyer Pétré

${ }^{277}$ Siri A edd. Syri Geyer Pétré

${ }^{278}$ Anthiocia A edd. Antiochia Geyer Pétré

${ }^{279}$ Anthiocia A edd. Antiochia Geyer Pétré

${ }^{280}$ Anthiocia A edd. Antiochia Geyer Pétré
} 
21.2. Vimos também no lugar próximo ao poço a pedra deitada, demasiadamente grande, que o santo Jacó retirou do poço (Gn 29,10), que até hoje se mostra.

21.3. Porém, ali ao redor do poço ninguém mora, a não ser os clérigos da própria igreja que existe aí e monges que têm seus mosteiros ao lado, de cuja vida o santo bispo nos contou, mas verdadeiramente inaudita. E assim, pois, feita uma oração na igreja, dirigi-me com o bispo até os santos monges pelos seus mosteiros e, dando graças a Deus e a eles, que se dignaram a me receber de bom grado, em qualquer lugar que entrei pelos seus mosteiros, e a falar aqueles assuntos que eram dignos de sair de sua boca. De fato, também se dignaram a me dar eulogias, e a todos que estavam comigo, assim como é costume os monges darem ainda àqueles que de boa vontade acolhem em seus mosteiros.

21.4. E porque esse lugar fica em uma grande planície, foi mostrado a mim, em frente, pelo santo bispo, um povoado muito grande, talvez a quinhentos passos do poço; por essa aldeia fizemos o caminho. Pois este povoado, como dizia o bispo, foi antigamente propriedade do sírio Labão, e esse povoado se chama Fadana*. Com efeito, foi mostrada a mim, nessa aldeia, a sepultura do sírio Labão, sogro de Jacó; me foi mostrado também o lugar onde Raquel roubou os ídolos de seu pai (Gn 31,19).

21.5. E assim, pois, em nome de Deus, contempladas todas as coisas, dizendo adeus ao santo bispo e aos santos monges que tinham se dignado a nos conduzir até aquele lugar, voltamos pela estrada e pelas pousadas pelas quais viéramos de Antioquia.

22.1. Todavia, como eu tinha voltado a Antioquia, passei <ali> uma semana até que fossem preparadas as coisas que eram necessárias para a viagem. E assim, partindo de Antioquia, fazendo o caminho por alguns acampamentos, cheguei à província que se chama Cilícia*, que tem como capital a cidade de Tarso ${ }^{\star}$, Tarso onde na verdade já estivera, indo para Jerusalém. 
22.2. Sed quoniam de Tharso tertia mansione, id est in Hisauria, est martyrium sanctae Teclae, gratum fuit satis, ut etiam illuc accedere ${ }^{281}$, praesertim $^{282}$ cum tam in proximo esset.

23.1. Nam proficiscens de Tharso perueni ad quandam ciuitatem supra mare adhuc Ciliciae, que ${ }^{283}$ appellatur Ponpeiopolim. Et inde, iam ingressa fines Hisauriae, mansi in ciuitate quae appellatur Corico, ac tertia die perueni ad ciuitatem quae appellatur Seleucia Hisauriae. Vbi cum peruenissem, fui ad episcopum uere sanctum ex monacho, uidi etiam ibi ecclesiam ualde pulchram in eadem ciuitate.

23.2. Et quoniam inde ad sanctam Teclam, qui locus est ultra ciuitatem in colle sed plano, habebat de ciuitate forsitam ${ }^{284}$ mille quingentos passus, malui ergo perexire illuc, ut statiua, ${ }^{285}$ quam factura eram, $\mathrm{ibi}^{286}$ facerem. Ibi autem ad sanctam ecclesiam nichil aliud est nisi monasteria sine numero uirorum ac mulierum.

23.3. Nam inueni ibi aliquam amicissimam michi, et cui omnes in oriente testimonium ferebant uitae ipsius, sancta diaconissa nomine Marthana, quam ego aput Ierusolimam noueram, ubi illa gratia orationis ascenderat; haec autem monasteria aput actitum ${ }^{287}$ seu uirginum regebat. Quae me cum uidisset, quod gaudium illius uel meum esse potuerit, nunquid uel scribere possum?

23.4. Sed ut redeam ad rem, monasteria ergo plurima sunt ibi per ipsum collem et in medio murus ingens, qui includet ecclesiam, in qua est martyrium, quod martyrium satis pulchrum est. Propterea autem murus missus est ad custodiendam ecclesiam propter Hisauros, ${ }^{288}$ quia satis mali sunt et frequenter latrunculantur, ne forte conentur aliquid facere circa monasterium, quod est ${ }^{289}$ ibi deputatum.

23.5. Ibi ergo cum uenissem in nomine Dei, facta oratione ad martyrium nec non etiam et lecto omni actus ${ }^{290}$ sanctae Teclae, gratias Christo Deo nostro egi infinitas, qui mihi ${ }^{291}$ dignatus est indignae et non merenti in omnibus desideria complere.

\footnotetext{
${ }^{281}$ accedere $A$ edd. accederem Gam Geyer Pétré

${ }^{282}$ praesertim A Gam ${ }^{2}$ Geyer Her Pétré Prinz presertim Gam ${ }^{1}$ FrW Arce Mar Jan Nat MaN

${ }^{283}$ que $A$ edd. quae Gam Geyer Pétré MaN

${ }^{284}$ forsitam $A$ Gam $^{2} \mathrm{Her}$ forsitan Gam ${ }^{1}$ edd.

${ }^{285}$ statiua $A$ edd. statiuam Gam $^{1}$ Geyer Pétré

${ }^{286}$ ibi corr. ex sibi $A$

${ }^{287}$ aput actitum $A$ aputactitum Gam edd.

${ }^{288}$ hisauros corr. ex hisatiuros coni. Ipse

${ }^{289}$ est ibi A Gam ibi est Geyer edd.

${ }^{290}$ lecto omni actus corr. ex lecta omnia actus A lectus omnis actus Gam Geyer Pétré lecto omni actu Her Mar Jan Nat MaN lectione actus FrW Arce

${ }^{291}$ mihi A edd. michi Nat
} 
22.2. Mas, visto que a três acampamentos de Tarso, isto é, em Isáuria*, fica o martyrium de Santa Tecla ${ }^{\star}$, me aprouve que também me dirigisse para lá, sobretudo porque era tão próximo.

23.1. Partindo, pois, de Tarso, cheguei a uma certa cidade acima do mar, ainda na Cilícia, que se chama Pompeiópolis* ${ }^{\star}$ E daí, entrando já no território de Isáuria, fiquei na cidade que se chama Córico. ${ }^{\star}$ E no terceiro dia cheguei à cidade que se chama Selêucia ${ }^{\star}$ da Isáuria. Assim que cheguei, fui até o bispo, verdadeiramente santo, antigo monge; vi também aí na mesma cidade uma igreja muito bonita.

23.2. E já que daí até Santa Tecla, que é um lugar além da cidade, numa colina, mas na planície, havia da cidade talvez mil e quinhentos passos, preferi, pois, prosseguir até lá para fazer lá a parada que eu ia fazer. Porém, nesse lugar, junto à igreja consagrada, não há nada a não ser um sem-número de mosteiros de homens e mulheres.

23.3. Com efeito, aí encontrei uma grande amiga minha, e de quem todos no Oriente davam testemunho de sua vida, uma santa diaconisa de nome Martana, que eu conhecera perto de Jerusalém, onde ela ${ }^{100}$ subira para orar; ela dirigia conventos de apotactitas ${ }^{\star}$ ou virgens. Acaso posso escrever qual podia ser minha alegria ou dela quando me viu?

23.4. Mas, voltando ao assunto, existem, pois, numerosos mosteiros aí por esta colina e, no meio, um muro enorme que cerca a igreja na qual há um martyrium, martyrium esse que é muito bonito. Por isso, também foi construído um muro para guardar a igreja por causa dos isáurios, que são muito maus e frequentemente salteiam, para que não tentem fazer nada com relação ao mosteiro que aí foi estabelecido.

23.5. E aí, pois, quando cheguei, em nome de Deus, feita uma oração no martyrium e também lidos todos os Atos de Santa Tecla, dei infinitas graças a Cristo nosso Deus, que se dignou a satisfazer a mim, indigna e não merecedora, em todos os desejos.

\footnotetext{
${ }^{100}$ Ela (illa): temos aqui um exemplo do pronome demonstrativo illa sendo usado como pronome pessoal, "ela".
} 
23.6. Ac sic ergo facto ibi biduo, [55] uisis etiam sanctis monachis uel aputactites, ${ }^{292}$ tam uiris quam feminis, qui ibi erant, et facta oratione et communione reuersa sum Tharso ad iter meum, ubi facta statiua, triduana in nomine Dei profecta sum inde iter meum. Ac sic perueniens eadem die ad mansionem, quae appellatur Mansocrenas, qua ${ }^{293}$ est sub monte Tauro, ibi mansi.

23.7. Et inde alia ${ }^{294}$ die subiens montem Taurum et faciens iter iam ${ }^{295}$ notum per singulas prouincias, quas eundo transiueram, id est Cappadociam, Galatiam et Bithiniam, perueni Calcedona, ubi propter famosissimum martyrium sanctae Eufimiae, ab olim michi notum iam, quod ibi est, mansi loco.

23.8. Ac sic ergo alia die transiens mare perueni Constantinopolim, agens Christo Deo nostro gratias, quod michi indignae et non merenti praestare ${ }^{296}$ dignatus est tantam gratiam, id est, ut non solum uoluntatem eundi, sed et facultatem perambulandi, quae desiderabam, dignatus fuerat praestare ${ }^{297}$ et reuertendi denuo Constantinopolim.

23.9. Vbi cum uenissem, per singulas ecclesias uel apostolos nec non et per singula martyria, quae ibi plurima sunt, non cessabam Deo nostro Iesu gratias agere, qui ita super me misericordiam suam praestare ${ }^{298}$ dignatus fuerat.

23.10. De quo loco, domnae, ${ }^{299}$ lumen meum, cum haec ad uestram affectionem darem, iam propositi erat in nomine Christi Dei nostri ad Asiam accedendi, id est Efesum, propter martyrium sancti et beati apostoli Iohannis gratia orationis. Si autem et post hoc in corpo ${ }^{300}$ fuero, si qua praeterea ${ }^{301}$ loca cognoscere potuero, aut ipsa praesens, ${ }^{302}$ si Deus fuerit praestare ${ }^{303}$ dignatus, uestrae affectioni referam aut certe, si aliud animo sederit, scriptis nuntiabo. Vos tantum, dominae, lumen meum, memores mei esse dignamini, siue in corpore siue iam extra corpus fuero.

\footnotetext{
${ }^{292}$ aputactites A Gam Prinz Mar Nat MaN aputactitis Geyer Her Pétré FrW Arce Jan ${ }^{293}$ qua $A$ quae $\mathrm{Gam}^{2}$ edd.

${ }^{294}$ alia corr. ex alie $A$

295 iam om. Gam

${ }^{296}$ praestare A Gam Geyer Her Pétré Prinz prestare FrW Arce Mar Jan Nat MaN

${ }^{297}$ praestare A Gam Geyer Her Pétré Prinz prestare FrW Arce Mar Jan Nat MaN

${ }^{298}$ praestare A Gam Geyer Her Pétré Prinz prestare FrW Arce Mar Jan Nat MaN

${ }^{299}$ domnae A edd. dominae Gam Nat

${ }^{300}$ corpo A Gam FrW Mar Jan MaN corpore Geyer Her Pétré Arce Nat

${ }^{301}$ praeterea $A$ Gam $^{2}$ Geyer Her Pétré Prinz preterea Gam ${ }^{1}$ FrW Arce Mar Jan Nat MaN

302 praesens A Gam Geyer Her Pétré Prinz presens FrW Arce Mar Jan Nat MaN

${ }^{303}$ praestare A Gam Geyer Her Pétré Prinz prestare FrW Arce Mar Jan Nat MaN
} 
23.6. E assim, pois, passados dois dias aí, visitados ainda com os santos monges ou apotactitas, tanto homens quanto mulheres que havia ali, e feita também uma oração e comunhão, voltei ao meu caminho a partir de Tarso, onde, feita uma parada por três dias, em nome de Deus, parti daí para o meu caminho. E assim, chegando no mesmo dia ao acampamento que se chama Mansocrenas*, que fica na base do monte Tauro*, aí fiquei.

23.7. E daí, no outro dia, subindo o monte Tauro e percorrendo o caminho já conhecido, por cada uma das províncias as quais atravessara na ida, isto é, Capadócia*, Galácia* e Bitínia*, cheguei à Calcedônia*, onde, por causa do famosíssimo santuário de Santa Eufêmia*, por mim já conhecido anteriormente e que ali se situa, permaneci no lugar.

23.8. E assim, pois, no outro dia, atravessando o mar, cheguei a Constantinopla, dando graças a Cristo nosso Deus, que a mim, indigna e não merecedora, dignou-se a conceder tão grande graça, isto é, que se dignou a dar não só vontade de ir, mas também a possibilidade de visitar sucessivamente o que desejava e de voltar novamente a Constantinopla.

23.9. E quando aí cheguei, por cada uma das igrejas e <santuários de $>$ apóstolos e por cada um dos martyria, que aí são vários, não cessava de dar graças a Jesus nosso Deus, que assim sobre mim dignara-se a mostrar sua misericórdia.

23.10. E desse lugar, senhoras, minha luz, quando entregasse esta narrativa à Vossa Afeição, já era propósito, em nome de Cristo nosso Deus, dirigir-me à Ásia*, isto é, a Éfeso ${ }^{*}$, para orar no martyrium do santo e bemaventurado apóstolo João. Se, contudo, após isto ainda estiver neste corpo e ainda puder conhecer outros lugares, se Deus se dignar a me oferecer, relatarei certamente à Vossa Afeição de viva voz ou, se me decidir noutro pensamento, anunciarei por escrito. Vós, senhoras, minha luz, dignai-vos tão somente lembrar-vos de mim, quer eu esteja neste corpo, quer já fora do corpo. 


\section{Secunda Pars}

24.1. Vt autem sciret affectio uestra, quae operatio singulis diebus cotidie in locis sanctis habeatur, certas uos facere debui, sciens quia libenter haberetis haec cognoscere. Nam singulis diebus ante pullorum cantum aperiuntur omnia hostia Anastasis et descendent omnes monazontes et parthene ${ }^{304}$, ut hic dicunt, et non solum hii, sed et laici praeter $^{305}$, uiri aut mulieres, qui tamen uolunt maturius uigilare. Et ex ea hora usque in luce ${ }^{306}$ dicuntur ymni et psalmi responduntur, similiter et antiphonae: et cata singulos ymnos fit oratio. Nam presbyteri bini uel terni, similiter et diacones, singulis diebus uices habent simul cum monazontes, qui cata singulos ymnos uel antiphonas orationes dicunt.

\footnotetext{
${ }^{304}$ parthene A edd. parthenae Gam Geyer Pétré Arce ${ }^{305}$ praeter A Geyer Her Pétré Prinz praeterea $\mathrm{Gam}^{2}$ preter FrW Arce Mar Nat Jan MaN ${ }^{306}$ luce A edd. lucem Gam Geyer Pétré
} 


\section{Segunda Parte}

24.1. Para que de fato Vossa Afeição soubesse que ofício ${ }^{101}$ se celebra nos lugares santos em cada dia, julguei dever vos informar, sabendo que teríeis prazer em conhecê-los. De fato, em cada um dos dias, antes do canto dos galos, abrem-se todas as entradas da Anástase ${ }^{\star}$ e descem todos os monazontes ${ }^{\star} \mathrm{e}$ partenas $^{\star}$, como aqui dizem, não só esses, mas também, além deles, leigos ${ }^{\star}$, homens $\mathrm{e}^{102}$ mulheres, que contudo querem fazer vigília mais cedo. E desde essa hora até o amanhecer, entoam-se $\mathrm{e}^{103}$ hinos e respondem-se salmos, semelhantemente também antífonas, e a cada um dos hinos se faz uma oração. De fato, os presbíteros, de dois em dois, ou de três em três, e igualmente os diáconos, têm alternância com os monazontes, que a cada hino ou antífona fazem orações.

\footnotetext{
${ }^{101}$ Ofício (operatio): “ofício", "atividade litúrgica" ou "liturgia” são as palavras empregadas para traduzir operatio, nas diversas edições críticas que apresentam tradução para uma língua moderna. Vale lembrar, no entanto, que "ofício" também é um termo usado para traduzir missa.

${ }^{102} \mathrm{E}$ (aut): este é mais um exemplo de aut que não pode ser traduzido como "ou", mas sim como "e". V. notas 55, 67, 144, 186.

${ }^{103}$ Entoam-se (dicuntur): um dos verbos mais empregados para a descrição da liturgia é dicere. Dicere, como observaram Löfstedt, Väänänen e Bastiaensen, é empregado para qualquer enunciado oral e não está ligado unicamente à oratio. Assim, cada declaração no domínio do culto pode ser expressa através de dicere: 24,6 dicet episcopus stans benedictionem; 24,4 dicuntur etiam psalmi; 24,4 dicuntur ymni uel antiphonae; 25,1 dicuntur predicationes; 35,4 lectiones dicuntur. É impossível saber se, no texto, dicere é usado na declamação dos textos, nos cantos ou em ambos. Löfstedt (2007, p.326-330) fornece exemplos clássicos de Virgílio e Lucrécio, assim como de outros autores pósclássicos, em que dicere é usado como canere e loqui. Conforme o tipo de complemento que acompanha o verbo dicere, adotamos a tradução mais próxima ao seu uso no português: dicet benedictionem, "dá uma bênção", dicet orationem, "faz/diz uma oração", dicet praedicationem/lectionem, "faz uma pregação/leitura", dicunt ymni uel antiphonae, "entoam hinos e antífonas", dicunt psalmi, "cantam/recitam/entoam salmos".
} 
24.2. Iam autem ubi ceperit ${ }^{307}$ lucescere, [56] tunc incipiunt matutinos ymnos dicere. Ecce et superuenit episcopus cum clero et statim ingreditur intro spelunca ${ }^{308}$ et de intro cancellos primum dicet orationem pro omnibus; commemorat etiam ipse ${ }^{309}$ nomina, quorum uult, sic benedicet cathecuminos. Item dicet orationem et benedicet fideles. Et post hoc exeunte episcopo de intro cancellos omnes ad manum ei accedunt, et ille eos uno et uno benedicet exiens iam, ac sic fit missa iam luce. ${ }^{310}$

${ }^{307}$ ceperit $A$ edd. coeperit Geyer Her Pétré

${ }^{308}$ spelunca $A$ edd. speluncam Gam

${ }^{309}$ ipsa coni. Geyer (in nota)

${ }^{310}$ luce $A$ edd. in luce Arce 
24.2. Porém, como já começasse a amanhecer, começam ${ }^{104}$ então a entoar os hinos matutinos. E eis que chega o bispo com o clero e imediatamente entra $^{105}$ na gruta e, de dentro da balaustrada, primeiramente diz uma oração em favor de todos; menciona ele mesmo também os nomes daqueles que deseja lembrar e então benze os catecúmenos* ${ }^{*}$ Igualmente diz ${ }^{106}$ uma oração e benze $^{107}$ os fiéis ${ }^{\star}$. E depois disso, saindo o bispo de dentro da balaustrada, todos se dirigem a ele para beijar-lhe a mão, e ele os benze um a um ao sair, e assim a despedida ${ }^{108}$ acontece quando já está claro.

${ }^{104}$ Começam (incipiunt): o verbo incipiunt, estando na terceira pessoa do plural, retoma presbyteri bini uel terni, similiter et diacones. Nota-se que a tradução de Pierre Maraval como "on commence à dire les hymnes du matin" não é adequada, pois o uso de on dá a entender que Egéria participa da ação, dado que on significa "a gente" e se emprega também como nós.

${ }^{105}$ Entra (ingreditur): o verbo ingredi (inf.) merece um comentário, pois não é nada popular: trata-se de um verbo depoente. Se a voz passiva era rara na língua do povo, imagine-se um verbo depoente, que tem sentido ativo e morfologia passiva. Exemplos como este mostram a concomitância de duas variedades da língua latina no texto, a clássica e a vulgar.

${ }^{106} \mathrm{Diz}$ (dicet): a pronúncia das vogais breves como abertas e das longas como fechadas, associada ao fenômeno da perda da quantidade, levou a uma aproximação entre o /e/ longo e o /i/ breve, pois esses dois fonemas convergiram a um som de /e/ fechado. Por isso, temos aí dicet por dicit. V. notas 198, 201.

${ }^{107}$ Benze (benedicet): benedicet por benedicit, conforme nota acima.

${ }^{108}$ Despedida (missa): a palavra missa só aparece na segunda parte da obra. Väänänen (1987, p.32, 139) afirma que há dois sentidos para a palavra missa: um como "despedida" e outro como "ofício litúrgico", com ou sem eucaristia. Na primeira acepção, um nome de santuário liga-se à missa, seja por genitivo seja por um complemento preposicional: missa + genitivo: 25,10 cum missa ecclesiae facta fuerit; 30,3 post missa Martyrii; et sic missa Anastasi. Infelizmente, o autor não deixa claro qual seria sua interpretação para os exemplos abaixo, que são citados por ele, mas não são comentados: missa + de: 46,1 mox missa facta fuerit de Anastase matutina e missa + sintagma de lugar: 25,6 ut (...) fiat primum missa in ecclesiam maiorem; 43,2 Quemadmodum enim missa facta fuerit ad Martyrium. Em nossa tradução, missa é "despedida" quando se relata uma série de ações realizadas na cerimônia, em cujo desfecho haveria algo semelhante a uma despedida, na qual às vezes o bispo benze os fiéis na saída da igreja, como em 24,2 e 24,9-11. A despedida a que a autora se refere no final da série de atos realizados representa o final ou a "despedida" da missa. Porém, a tradução mais precisa de missa pela própria palavra "missa" está relacionada à indicação no texto latino da "oblação" (oblatio), tal como em 27,8, já que é possível interpretar "oblação" como "eucaristia". Igualmente, quando Egéria refere-se a uma cerimônia que está para acontecer, empregando a palavra missa, trata-se da "missa", porque entendemos que não é plausível se referir ao término do ofício ou da cerimônia, mas sim à própria cerimônia. Há uma indicação sintática, com o uso de ordine suo "conforme o costume", que sugere se tratar da "missa" (usada cinco vezes com a palavra missa, dentre seis ocorrências), tal como em 39,1. Outra construção 
24.3. Item hora sexta denuo descendent omnes similiter ad Anastasim et dicuntur psalmi et antiphonae, donec commonetur episcopus; similiter descendet et $^{311}$ non sedet, sed statim intrat intra cancellos intra Anastasim, id est intra speluncam, ubi et mature, et inde similiter primum facit orationem, sic benedicet fideles, et sic exiens de cancellos ${ }^{312}$ similiter ei ad manum acceditur. Ita ergo et hora nona fit sicuti et ad sexta.

24.4. Hora autem decima, quod appellant hic licinicon, nam nos dicimus lucernare, similiter se omnes ${ }^{313}$ multitudo colliget ad Anastasim, incenduntur omnes candelae et cerei et fit lumen infinitum. Lumen autem de foris non affertur, sed de spelunca interiori eicitur, ubi noctu ac die semper lucerna lucet, id est de intro cancellos. Dicuntur etiam psalmi lucernares, sed et antiphonae diutius. Ecce et commonetur episcopus et descendet et sedet susum, nec non etiam et presbyteri sedent locis suis, dicuntur ymni uel antiphonae.

\footnotetext{
${ }^{311}$ descendet et corr. ex descenderet $A$

${ }^{312}$ de cancellos $A \mathrm{Gam}^{2}$ de intro cancellos Chol edd.

${ }^{313}$ omnes $A$ omnis Gam edd.
} 
24.3. Igualmente, na hora sexta, todos descem de novo à Anástase e são recitados salmos e antífonas até que o bispo seja avisado; semelhantemente desce e não se senta, mas imediatamente entra para dentro da balaustrada na Anástase, isto é, na gruta, onde também entrou cedo, e daí, do mesmo modo, primeiro faz uma oração, então benze os fiéis e, em seguida, saindo de dentro da balaustrada, igualmente dirigem-se a ele para beijar-lhe a mão. Assim, pois, também à nona hora se faz como à sexta $<$ hora $>$.

24.4. Porém, na décima hora, o que aqui chamam licinicon, ${ }^{109}$ com efeito, nós dizemos lucernário, ${ }^{*}$ igualmente toda a multidão se reúne na Anástase, acendem-se todas as velas e círios e se faz uma luz infinita. A luz, contudo, não é trazida de fora, mas é lançada da gruta interior, onde uma lâmpada reluz noite e dia, isto é, de dentro da balaustrada. Recitam-se também salmos lucernários, mas também antífonas por mais tempo. E eis que o bispo é avisado; ele desce e se senta num lugar alto, e também os presbíteros sentam-se em seus lugares, e são entoados hinos ou antífonas.

sintática que sugere a interpretação da palavra latina missa como a "missa" é iuxta consuetudinem "conforme o costume", em 25,10. Em outras ocorrências, a interpretação de missa pela cerimônia que conhecemos como "missa" não é tão clara, tal como em 25,6, em que tanto faz ser "despedida" ou "missa". Vale lembrar que a palavra "missa" para se referir à cerimônia, tal como a conhecemos atualmente, não estava fixada na época, por isso a dificuldade de tradução. Partindo-se da expressão à qual se deve sua origem - Ite, missa est "Ide, <a oração > foi enviada <a Deus>", subentendendo-se aí oratio e Deo -, teríamos a tradução de "despedida" por sua ligação etimológica com o particípio passado (missus, $-a$, $-u m$ ) do verbo mittere "enviar". Talvez seja por isso que "despedida", na maior parte das ocorrências de missa, é a tradução preferida entre todos os editores. Ver Bastiaensen (1962, p.82-88) e Maraval (2002a, p.253) sobre o problema de tradução da palavra missa.V. notas 145, 154.

${ }^{109}$ Licinicon: transcrição aproximada do grego $\lambda u \chi v$ ukóv; trata-se de uma palavra derivada de $\lambda$ úxvoৎ "lâmpada". O licinicon é a hora de um dos ofícios do dia em que se acendem as lâmpadas, entre $15 \mathrm{~h}$ e 17h, conforme a estação. Lucernarium é a forma latina equivalente dessa palavra grega, derivada de lucerna "lâmpada de azeite", em oposição a candela "vela", "candeia", "candelabro", feita de cera. No texto, licinicon é usado uma só vez, enquanto lucernarium aparece 21 vezes (8 vezes na forma de lucernarium e 13 como lucernaris).

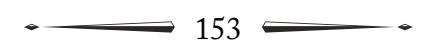




\section{Maria Cristina Martins}

24.5. Et ad ${ }^{314}$ ubi perducti ${ }^{315}$ fuerint iuxta consuetudinem, lebat ${ }^{316}$ se episcopus et stat ante cancellum, id est ante speluncam, et unus ex diaconibus facit commemorationem singulorum, sicut solet esse consuetudo. Et diacono dicente singulorum nomina semper pisinni plurimi stant respondentes semper: "Kyrie eleyson", quod dicimus nos: "Miserere Domine", quorum uoces infinitae sunt.

24.6. Et at ubi diaconus perdixerit omnia, quae dicere habet, dicet orationem primum episcopus et orat pro omnibus; et sic orant omnes, tam fideles quam et cathecumini simul. Item mittet uocem diaconus, ut unusquisque, quomodo stat, cathecuminus inclinet ${ }^{317}$ caput; et sic dicet episcopus stans benedictionem ${ }^{318}$ super cathecuminos. Item fit oratio et denuo mitte ${ }^{319}$ diaconus uocem et commonet, ut unusquisque stans fidelium inclinent capita sua; item benedicet fideles episcopus et sic fit missa Anastasi. Et incipient episcopo ad manum accedere singuli.

\footnotetext{
${ }^{314}$ ad $A$ Her Prinz Arce ad finem coni. Gam at Geyer edd.

${ }_{315}$ perducti $A$ Gam Arce perdicti Geyer edd.

${ }^{316}$ lebat $A$ edd. leuat Geyer Pétré

${ }^{317}$ inclinent corr. ex inclinet $A$

${ }^{318}$ benedictionem $A$ edd. benedictione Arce

${ }^{319}$ mittet $A$ edd. mittit Geyer Pétré
} 
24.5. E quando tenham sido conduzidos até o fim, conforme o costume, o bispo se levanta ${ }^{110} \mathrm{e}$ fica de pé diante da balaustrada, isto é, diante da gruta, e um dos diáconos faz menção de cada um $^{111}$. E sempre com o diácono dizendo os nomes de cada um, sempre respondendo uma grande quantidade de criancinhas em pé: "Kyrie eleyson", o que nós dizemos: "Tende piedade, Senhor", cujas vozes são infinitas.

24.6. E quando o diácono tiver dito tudo o que tem a dizer, primeiro o bispo diz uma oração e ora em favor de todos, e depois todos oram, tanto os fiéis quanto também os catecúmenos simultaneamente. De novo o diácono fala, para que cada catecúmeno, do modo em que está de pé, incline a cabeça; e então o bispo, estando em pé, dá uma bênção sobre os catecúmenos. Igualmente se faz uma oração e de novo o diácono eleva a voz e avisa que cada um dos fiéis que está de pé incline ${ }^{112}$ sua cabeça; de novo o bispo benze os fiéis e depois acontece a despedida da Anástase. E começam $^{113}$ a aproximar-se do bispo para beijar-lhe a mão, um a um.

${ }^{110}$ Levanta-se (lebat se): traduzimos como "levanta-se", interpretando a troca do /b/ pelo $/ \mathrm{v} /$, ou seja, lebat por leuat.

${ }^{111}$ Faz menção de cada um (facit commemorationem singulorum): em 24,2, a autora diz o mesmo de um modo semelhante - (sc. episcopus) commemorat nomina quorum uult, "o bispo lembra os nomes daqueles que quer <lembrar >".

${ }^{112}$ Incline (inclinent): o que ocorre aqui é a concordância ad sensum, pois o sujeito (unusquisque) está no singular, e o verbo (inclinent), no plural. Essa concordância existe no latim clássico, mas é evitada; ao contrário, no latim vulgar, é usada mais frequentemente, no qual domina a preocupação de construir logicamente a sentença. No romance medieval, encontra-se essa concordância, que as línguas românicas literárias modernas evitam. Assim, refletindo uma tradição sintática popular, o romance medieval admite essa concordância anômala, como se pode ver através dos usos do provençal e do italiano medievais: tota la soa gentz monteron, la brigata non seppono (cf. MAURER JR., 1951, p.169; 1959, p.193). Como observa Hofmann (apud MAURER JR., 1959, p.193), essa concordância pertence especialmente à língua pré-literária e popular. Ele dá o exemplo da Vetus Latina, onde se lê populus qui sedebat in tenebris lucem uiderunt magnam (Mt 4,16). De fato, São Jerônimo, ao revisar as traduções da Bíblia, procedimento que culminou na sua própria versão da mesma, chamada Vulgata, substituiu uiderunt por uidit. Diz-se que o público não aceitou logo as modificações de São Jerônimo no texto bíblico e, nesse particular, ele próprio se reprovava por ter um gosto pelas Letras. Inclusive, numa carta endereçada a Eustóquia (Epistula 22, 30, apud MARAVAL, 1998, p.19-21), conta que, em sonho, Deus dirigiu-se a ele, dizendo: "Ciceronianus es, non Christianus".

${ }^{113}$ Começam (incipient): incipient - futuro - está no lugar de incipiunt - presente. Essa é uma das inovações em relação à formação das desinências e dos sufixos verbais no latim vulgar, que ocorre para eliminar as diferenças entre as conjugações. Na $3^{\text {a }}$ pessoa do plural, -ant se mantém na $1^{\text {a }}$ conjugação, mas, nas demais conjugações, o -ent da $2^{\text {a }}$ e o - unt da $3^{\mathrm{a}}$ e da $4^{\mathrm{a}}$ se confundem, prevalencendo nessa disputa -ent. É o que se vê no 
24.7. Et postmodum de Anastasim usque ad Crucem ymnus ducitur ${ }^{320}$ episcopus, simul et omnis populus uadet. Vbi cum peruentum fuerit, primum facit orationem, [57] item benedicet cathecuminos; item fit alia oratio, item benedicit fideles. Et post hoc denuo tam episcopus quam omnis turba uadent ${ }^{321}$ denuo post Crucem et ibi denuo similiter fit sicuti et ante Crucem. Et similiter ad manum episcopus ${ }^{322}$ acceditur sicut ad Anastasim, ita et ante Crucem, ita et post Crucem. Candelae autem uitreae ingentes ubique plurimae pendent et cereofala plurima sunt tam ante Anastasim quam etiam ante Crucem, sed et post Crucem. Finiuntur ergo haec omnia cum crebris $^{323}$. Haec operatio cotidie per dies sex ita habetur ad Crucem et ad Anastasim.

\footnotetext{
${ }^{320}$ ymnus ducitur A ymnus dicitur Gam cum ymnis ducitur Geyer edd.

${ }^{321}$ uadent $A$ edd. uadet Geyer Pétré

${ }^{322}$ episcopus A MaN episcopi Gam episcopo Chol edd.

${ }^{323}$ crebris A FrW Arce Mar Jan MaN tenebris Gam Geyer Her Pétré Nat creperis coni. Her (in nota)
} 
24.7. E logo depois, desde a Anástase até a Cruz, ${ }^{\star}$ o bispo é conduzido com hinos, ${ }^{114} \mathrm{e}$ juntamente com ele vai todo o povo. Assim que ele tiver chegado, primeiro faz uma oração, também benze os catecúmenos; igualmente é feita outra oração, e em seguida benze os fiéis. E depois disso, novamente tanto o bispo quanto toda a multidão vão de novo para trás da Cruz, e aí de novo do mesmo modo se faz assim como diante da Cruz. E semelhantemente vai-se ao bispo $^{115}$ para beijar-lhe a mão, assim como junto à Anástase, e também diante da Cruz e atrás da Cruz. Por outro lado, enormes candeias de vidro pendem por toda parte e há um grande número de candelabros, ${ }^{116}$ tanto diante da Anástase quanto diante da Cruz e atrás da Cruz. Pois todas essas cerimônias terminam quando anoitece ${ }^{117}$. Esses ofícios são celebrados ${ }^{118}$ cotidianamente, durante seis dias, na Cruz e na Anástase. ${ }^{119}$

texto, onde encontramos, além desse exemplo de incipient por incipiunt, descendent por descendunt $(36,2)$ e respondent por respondunt $(24,9)$. Sobre este assunto, ver Maurer Jr. (1959, p.131ss). V. notas 10, 51.

${ }^{114}$ Com hinos (ymnus): para a tradução se tornar coerente, interpretamos cum ymnis em vez de ymnus, com base no que se vê em 32,2 e 46,4, em que a mesma forma verbal ducitur tem como sujeito episcopus, conduzido "com hinos" - cum ymnis.

${ }^{115}$ Ao bispo (episcopus): a tradução "ao bispo" não corresponde ao que se lê - episcopus, no caso nominativo -, pois deveria estar escrito episcopo, no caso dativo, conforme a construção usada em trechos semelhantes com o verbo accedere, tais como em 25,4: episcopo omnes ad manum accedent.

116 Candelabros (cereofala): segundo Ducange (apud GAMURRINI, 1887, p.79), cereofala é o mesmo que candelabros.

${ }^{117}$ Quando anoitece (cum crebris): a palavra crebris não existe. Interpretamos a correção para tenebris, feita por Gamurrini e seguida por Geyer, entre outros. Paleograficamente, é admissível que o escriba tenha escrito involuntariamente o $c r$ - por ter escrito anteriormente sete vezes a palavra crucem.

${ }^{118}$ Esses ofícios são celebrados (haec operatio... habetur): habere operationem significa "celebrar um ofício". Já em Salústio encontramos habere comitia.

${ }^{119} \mathrm{Na}$ Anástase (ad Anastasim): traduzimos "na Anástase” e não "junto à Anástase”, como seria o sentido clássico, porque concordamos com Väänänen (1987, p.39) quando diz que ad está concorrendo com in, para indicar que se entra em um lugar santo ou para indicar onde um ato de culto se desenrola, sobretudo com a palavra Anastasis: 24,9 Intrat intro speluncam ad Anastasim. O mesmo ocorre em 30,3. 


\section{Maria Cristina Martins}

24.8. Septima autem die, id est dominica die, ante pullorum cantum colliget se omnis multitudo, quecumque ${ }^{324}$ esse potest in eo loco, ac si per Pascha, in basilica, quae est loco iuxta Anastasim, foras tamen, ubi luminaria pro $^{325}$ hoc ipsud pendent. Dum enim uerentur, ne ad pullorum cantum non occurrant, antecessus ueniunt et ibi sedent. Et dicuntur ymni nec non et antiphonae, et fiunt orationes cata singulos ymnos uel antiphonas. Nam et presbyteri et diacones semper parati sunt in eo loco ad uigilias propter multitudinem, quae se colliget. Consuetudo enim talis est, ut ante pullorum cantum loca sancta non aperiantur.

24.9. Mox autem primus pullus cantauerit, statim descendet episcopus et intrat intro speluncam ad Anastasim. Aperiuntur hostia omnia et intrat omnis multitudo ad Anastasim, ubi iam luminaria infinita lucent, ${ }^{326}$ et quemadmodum ingressus fuerit populus, dicet psalmum quicumque de presbyteris et respondent omnes; post hoc fit oratio. Item dicit psalmum quicumque de diaconibus, similiter fit oratio, dicitur et tertius psalmus a quocumque clerico, fit et tertio oratio et commemoratio omnium.

\footnotetext{
${ }^{324}$ quecumque $A$ edd. quaecumque Gam Geyer Pétré

${ }^{325}$ pro $A$ edd. per Gam

${ }^{326}$ lucent corr. ex lucet $A$
} 
24.8. Porém, no sétimo dia, isto é, no dia de domingo, antes do canto dos galos, reúne-se toda a multidão que pode haver nesse lugar, e como se $<$ fosse $>$ durante a Páscoa, na basílica que está no lugar junto à Anástase, porém do lado de fora, onde pendem luminárias para isto mesmo. De fato, porque temem que não cheguem até o cantar dos galos, vêm antecipadamente ${ }^{120}$ e aí se sentam. E entoam-se hinos $\mathrm{e}^{121}$ antífonas e fazem-se orações a cada hino ou antífona. Pois também tanto os presbíteros quanto os diáconos estão sempre preparados nesse local para as vigílias por causa da multidão que se reúne. Efetivamente, o costume é tal que antes do canto dos galos não sejam abertos os lugares santos.

24.9. Porém, logo que ${ }^{122}$ tenha cantado o primeiro galo, imediatamente o bispo desce e entra para dentro ${ }^{123}$ na gruta, na Anástase. São abertas todas as portas e toda a multidão entra na Anástase, onde já brilham infinitas luzes e, assim que o povo tiver entrado, um dos presbíteros ${ }^{124}$ recita um salmo e todos respondem; depois disso, se faz uma oração. Igualmente um dos diáconos recita um salmo, semelhantemente se faz uma oração, é recitado também um terceiro salmo por um clérigo, e se faz pela terceira vez uma oração e uma memória de todos.

\footnotetext{
${ }^{120}$ Antecipadamente (antecessus): antecessus foi traduzido como advérbio e não como substantivo. Esse uso adverbial de antecessus no sentido de "primeiramente" observa-se também na obra Mulomedicina Chironis, também do séc. IV: 369 aquam eis bibere dabis, in qua eruum antecessus lotum mansit; 731 ideo autem lino antecessus alligas. Segundo Schmalz (apud LÖFSTEDT, 2007, p.334), o particípio passado antecessus adquiriu gradualmente uma função adverbial, a exemplo do que aconteceu com uersus e prorsus, particípios usados com função adverbial. Outro exemplo de particípio passado com uso adverbial é rectus $(29,6)$.

${ }^{121} \mathrm{E}$ (nec non et): nec e non são termos sinônimos. Este é mais um exemplo da prolixidade do texto, pela justaposição de palavras sinônimas ou quase sinônimas. Neste caso, nenhuma das duas foi traduzida, pois não era possível. V. notas 12, 20.

${ }^{122}$ Logo que (mox): segundo Löfstedt (2007, p.334) e Väänänen (1987, p.121), mox está sendo usado como conjunção e não como advérbio, equivalente à conjunção simulatque "logo que".

${ }^{123}$ Entra para dentro (intrat intro): repare-se novamente o pleonasmo vicioso intrat intro "entra para dentro", assim como a expressão "saímos para fora" em 3,7; 12,4; 20,3.

${ }^{124} \mathrm{Um}$ dos presbíteros (quicumque de presbyteris): o uso da preposição de + ablativo nesta ocorrência substitui o genitivo partitivo do latim clássico. A ocorrência de de com adjetivos, verbos e nomes com o valor de partitivo está bem documentada no latim vulgar. Há que se salientar que no latim clássico empregava-se o ablativo nessa função, mas com a preposição ex: optimus ex illis, unus e nobis (MAURER JR., 1959, p.87). Para mais explicações sobre as inovações sintáticas em relação à preposição de, consultar Väänänen (1987, p.36-38) e Maurer Jr. (loc. cit.). V. nota 131.
} 
24.10. Dictis ergo his tribus psalmis et factis orationibus tribus ecce etiam thiamataria ${ }^{327}$ inferuntur intro spelunca Anastasis, ut tota basilica Anastasis repleatur odoribus. Et tunc ubi ${ }^{328}$ stat episcopus intro cancellos, prendet Euangelium et accedet ad hostium et leget resurrectionem Domnus ${ }^{329}$ episcopus ipse. Quod cum ceperit ${ }^{330}$ legi, tantus rugitus et mugitus fit omnium hominum et tantae lacrimae, ut quamuis durissimus possit moueri in lacrimis, Dominum pro nobis tanta sustinuisse.

24.11. Lecto ergo Euangelio exit episcopus et ducitur cum ymnis ad Crucem et omnis populus cum illo. Ibi denuo dicitur unus psalmus et fit oratio. Item benedicit fideles et fit missa. Et exeunte ${ }^{331}$ episcopo omnes ${ }^{332}$ ad manum accedunt.

24.12. Mox autem recipit se episcopus in domum suam, etiam ${ }^{333}$ ex illa hora reuertuntur omnes monazontes ad Anastasim et psalmi [58] dicuntur et antiphonae usque ad lucem ${ }^{34}$ et cata singulos psalmos uel antiphonas fit oratio: uicibus enim quotidie presbyteri et diacones uigilant ad Anastasim ${ }^{335}$ cum populo. De laicis etiam, uiris aut mulieribus, si qui uolunt, usque ad lucem loco sunt, si qui nolunt, reuertuntur in domos suas et reponent se dormito.

\footnotetext{
${ }^{327}$ thiamataria A edd. thymiataria Geyer Pétré

${ }^{328}$ ubi $A$ edd. ibi Geyer Her Pétré

${ }^{329}$ domnus A Gam domini Bern edd.

${ }^{330}$ ceperit $A$ edd. coeperit Geyer Her Pétré

${ }^{331}$ exeunte $A$ edd. exeunti Geyer Pétré

${ }^{332}$ ei post omnes add. Her (in nota)

${ }^{333}$ etiam uel et iam A etiam Gam et iam Geyer edd.

${ }^{334}$ lucem rest. Gam

${ }^{335}$ Anastasim corr. ex Anasim A
} 
24.10. Recitados, pois, esses três salmos e feitas três orações, eis que também são introduzidos incensários ${ }^{125}$ dentro da gruta da Anástase, de modo que toda a basílica da Anástase se enche de perfumes. E então o bispo, onde está de pé, dentro da balaustrada, toma o Evangelho e dirige-se à entrada e lê ele mesmo o texto da ressurreição do Senhor. Quando isso começa a ser lido, fazem-se tantos gritos e gemidos ${ }^{126}$ de todos os homens, e são tantas lágrimas, que o mais duro < dos homens> poderia ser movido às lágrimas, por tantas coisas ter suportado o Senhor por nós.

24.11. Lido, pois, o Evangelho, o bispo sai e é conduzido com hinos até a Cruz, e todo o povo <vai> com ele. Aí novamente se recita um salmo e se faz uma oração. Igualmente benze os fiéis, e se faz a despedida. E, saindo o bispo, todos se dirigem a ele para beijar-lhe a mão.

24.12. Logo, porém, o bispo recolhe-se para sua casa, e já desde essa hora todos os monazontes voltam à Anástase e entoam-se salmos e antífonas até o amanhecer e, a cada um dos salmos ou antífonas, se faz uma oração: de fato, cotidianamente presbíteros e diáconos alternadamente fazem vigília na Anástase com o povo. Também, a respeito dos leigos, tanto homens quanto mulheres, os que querem ficam no lugar até o amanhecer; os que não querem voltam para suas casas e se restabelecem dormindo. ${ }^{127}$

125 Incensários (thiamataria): thiamataria é uma palavra vulgar derivada de thymiamaterium ou thymiaterium, vocábulos provindos do grego $\theta u \mu\llcorner$ ińpıov, que designa o local em que é queimado o incenso $(\theta v \mu i ́ a \mu \alpha)$.

${ }^{126}$ Gritos e gemidos (rugitus et mugitus): o uso da expressão rugitus et mugitus é um

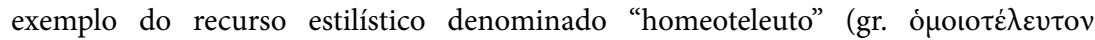
'terminação semelhante'), que consiste na correspondência fonética da última sílaba de uma oração ou verso (p. ex., estudando e trabalhando). Egéria queria enfatizar o sofrimento dos fiéis ao acompanhar a leitura da Paixão de Cristo.

${ }^{127}$ Dormindo (dormito): está escrito dormito em vez de dormitu, supino em ablativo. Todavia, essa circunstância, em latim clássico, seria expressa pelo particípio presente: dormientes. 
25.1. Cum luce autem, quia dominica dies est, et proceditur in ecclesia maiore, quam fecit Constantinus, quae ecclesia ${ }^{336}$ in Golgotha est post Crucem, et fiunt ${ }^{337}$ omnia secundum consuetudinem, que ${ }^{338}$ ubique fit die dominica. Sane quia hic consuetudo sic est, ut de omnibus presbyteris, qui sedent, quanti uolunt, praedicent ${ }^{339}$, et post illos omnes episcopus praedicat, ${ }^{340}$ quae praedicationes $^{341}$ propterea semper dominicis diebus fiunt, ${ }^{342}$ ut semper erudiatur populus in Scripturis et in Dei dilectione: quae praedicationes ${ }^{343}$ dum dicuntur, grandis mora fit, ut fiat missa ecclesiae, et ideo ante quartam horam aut forte quintam missa fit. ${ }^{344}$

\footnotetext{
${ }^{336}$ ecclesia corr. ex eclesia $A$

${ }^{337}$ fiunt $A$ edd. sunt Gam

${ }^{338}$ que $A$ quae Gam qua et Geyer edd.

${ }^{339}$ praedicent $A$ Gam $^{2}$ Her Geyer Pétré Prinz predicent Gam ${ }^{1}$ FrW Arce Mar Jan Nat MaN

${ }^{340}$ praedicat $A \mathrm{Gam}^{2}$ Her Geyer Pétré Prinz predicent Gam ${ }^{1}$ FrW Arce Mar Jan Nat MaN

${ }^{341}$ praedicationes $A$ Gam $^{2}$ Her Geyer Pétré Prinz predicationes Gam ${ }^{1}$ FrW Arce Mar Jan Nat MaN

${ }^{342}$ fiunt $A$ edd. sunt Gam $^{2}$ Geyer Her Pétré

${ }^{343}$ praedicationes A Gam² Her Geyer Pétré Prinz predicationes Gam ${ }^{1}$ FrW Arce Mar Jan Nat MaN

${ }^{344}$ missa fit A Geyer Her FrW Arce missa non fit Gam edd.
} 
25.1. Porém, ao amanhecer, ${ }^{128}$ porque é dia de domingo, vai-se ${ }^{129}$ à igreja maior, a qual fez Constantino*, igreja que está no Gólgota*, atrás da Cruz, e se fazem todas as coisas conforme o costume, que ${ }^{130} \mathrm{em}$ todo lugar se fazem no dia de domingo. Sem dúvida, porque aqui assim é o costume que, de todos os presbíteros presentes, todos os que querem pregam e depois de todos esses o bispo prega. Por essa razão, essas pregações se fazem aos domingos, para que sempre o povo seja instruído nas Escrituras e no amor de Deus; enquanto são ditas essas pregações, faz-se uma grande demora para que se dê a despedida da igreja, e por isso antes da quarta ou talvez antes da quinta hora $<$ não $>$ se faz a despedida.

${ }^{128}$ Ao amanhecer (cum luce): literalmente está escrito cum luce, ou seja, "com luz", "quando está claro".

${ }^{129}$ Vai-se (proceditur): procedo, cessi, cessum, ere em latim clássico significa "avançar", de onde temos, no português, "proceder", "processo" e "procissão". Todas essas palavras carregam o sentido de "avançar". No texto, procedere parece ser usado para indicar uma reunião de pessoas que vai a algum lugar, significado que também se encontra no nosso termo "procissão", como uma "marcha de pessoas para um objetivo religioso em comum". Em Egéria, segundo Blaise (1954, p.666), o verbo possui o sentido de "avançar em procissão" (avancer processionnelment), exatamente a tradução que preferimos, por estar baseada na história da palavra, tanto do latim clássico quanto das línguas românicas. Todavia, alguns editores, tendo por base o trabalho de Bastiaensen (1962, p.26ss), dizem que esse verbo não significa "ir em procissão", mas "o ato de se reunir na Igreja para celebrar um ofício solene da palavra (pregações) e do sacrifício (eucaristia)", cujo significado de "reunirse" toca apenas superficialmente. É interessante que o estudioso George Gingras havia traduzido "they assemble", muito antes do trabalho de Bastiaensen. De fato, a tradução de proceditur tem gerado muita divergência: Hélène Pétré traduz como "on va en procession"; Mariano "vai-se"; Maraval "on se reuni", Janeras "es reuneixem"; Arce "se vai"; Natalucci "se vai"; Novak "dirigem-se"; Gingras "they assemble".

${ }^{130}$ Que (que): interpretamos que aqui deveria ser quae, retomando omnia, erro bastante corrente no texto, mostrando a redução do ditongo para uma simples vogal. Além disso, esse ditongo era escrito de maneira abreviada, com um $e$ marcado com um sinal abaixo, muitas vezes esquecido. De qualquer modo, o verbo deveria estar no plural - fiunt e não fit. A maioria dos editores interpretou o que como qua et, com base na passagem que vem na sequência: 25,2 missa facta fuerit ecclesiae iuxta consuetudinem qua et ubique fit. 
25.2. At ubi autem missa facta fuerit ecclesiae iuxta consuetudinem, qua et ubique fit, tunc de ecclesia monazontes cum ymnis ducunt episcopum usque ad Anastasim. Cum autem coeperit ${ }^{345}$ episcopus uenire cum ymnis, aperiuntur omnia hostia de basilica Anastasis, intrat omnis populus, fidelis tamen, nam cathecumini non.

25.3. Et at ubi intrauerit populus, intrat episcopus et statim ingreditur intra cancellos martyrii ${ }^{346}$ speluncae. ${ }^{347}$ Primum aguntur gratiae Deo, et sic fit orationem ${ }^{348}$ pro omnibus; postmodum mittet uocem diaconus, ut inclinet ${ }^{349}$ capita sua omnes, quomodo stant, et sic benedicet eos episcopus stans intra ${ }^{350}$ cancellos interiores et postmodum egreditur.

\footnotetext{
${ }^{345}$ coeperit $A$ edd. ceperit Gam

${ }^{346}$ intra cancellos martyrii $A$ edd. martyrii om. Geyer Pétré intra cancellos speluncae ubi et mature coni. Her (in nota)

${ }^{347}$ speluncae corr. ex spelunca $A$

${ }^{348}$ fit orationem $A$ edd. fit oratio Gam Geyer Pétré facit orationem coni. Her (in nota)

${ }^{349}$ inclinet $A$ inclinent Gam edd.

${ }^{350}$ intra $A$ edd. intro $\mathrm{Gam}^{2}$
} 
25.2. Mas quando, porém, tiver sido feita a despedida da igreja, conforme o costume pelo qual também se dá por toda parte, então os monazontes conduzem o bispo com hinos desde a igreja até a Anástase. Mas quando o bispo tiver começado a avançar com os hinos, abrem-se todas as portas da basílica ${ }^{131} \mathrm{da}$ Anástase, entra todo o povo, pelo menos os fiéis, ${ }^{132}$ mas $^{133}$ os catecúmenos não.

25.3. E quando tiver entrado o povo, entra o bispo e imediatamente caminha para dentro da balaustrada da gruta do Martyrium. Primeiramente, dão-se graças ${ }^{134}$ a Deus, e assim se faz uma oração ${ }^{135}$ em favor de todos; pouco depois, o diácono fala para que todos inclinem ${ }^{136}$ a cabeça, ${ }^{137}$ do modo em que estão, e assim o bispo os benze, estando em pé dentro das grades interiores, e depois sai.

${ }^{131}$ Da basílica (de basilica): tal como os textos de latim vulgar em geral, a obra oferece um vasto emprego da preposição de, derivado do sentido concreto de separação e de ponto de partida. A preposição de inegavelmente entra em concorrência com o genitivo, que, nesta frase, adquire um valor de genitivo possessivo. Väänänen (1987, p.36-38) distingue sete nuances semânticas do sintagma preposicional constituído pela preposição de, embora nós não consigamos perceber tantas diferenças. V. nota 124 .

${ }^{132}$ Fiéis (fidelis): fidelis está no singular quando deveria estar no plural - fideles.

${ }^{133}$ Mas (nam): este nam, que seria explicativo, aqui tem um valor adversativo (VÄÄNÄNEN, 1987, p.117). Na verdade, parece haver uma nuance adversativa dentro da explicativa.

${ }^{134}$ Dão-se graças (aguntur gratiae): gratias agere é uma expressão que tem sido interpretada com divergência entre os editores. Para alguns, trata-se de uma celebração da eucaristia (CABROL, 1895, apud JANERAS, 1986, p.179), Bastiaensen (1962, p.42ss), porém, interpreta que não se pode considerar como um termo técnico para designar a eucaristia na época de Egéria. No nosso entender, essa consideração se aplica a toda a liturgia, pois os termos não estavam ainda fixados na época de Egéria. Segundo Mariano e Nascimento (1998, p.183), com base no trabalho de Bludau, trata-se de uma simples oração de ação de graças, realizada na Anástase, e da qual os catecúmenos não participavam. No texto, oblatio parece se aproximar bem mais da ideia de eucaristia, pois, como o próprio vocábulo sugere, trata-se de um "sacrifício" ou "oferecimento" celebrado na cerimônia da eucaristia (em grego, "agradecimento"). Wistrand (1955) muda o texto: Primum aguntur gratiae Deo et sic fit <oblatio, item facit $>$ orationem pro omnibus. Essa conjectura, que consideramos plausível, é adotada por Franceschini-Weber e Prinz.

${ }^{135}$ Se faz uma oração (fit orationem): segundo Löfstedt (2007, p.335ss), o acusativo da construção fit orationem se explica por ser um uso popular de um verbo impessoal na voz passiva que conservou um pouco de significado ativo na língua falada. Essa sintaxe é bastante atestada no latim arcaico, como a exemplificada aqui por Plauto (Trinummus, 869: mi aduenienti hac noctu agitandumst uigilias).

${ }^{136}$ Inclinem (inclinet): traduzimos "inclinem" conforme a correção para inclinent, para concordar com o sujeito omnes, mas mantivemos o texto latino conforme o manuscrito. ${ }^{137}$ Cabeça (capita): traduzimos pelo singular (caput) e não consideramos o pronome possessivo sua, por julgá-lo redundante. 
25.4. Egredienti autem episcopo omnes ad manum accedent. Ac sic est, ut prope usque ad quintam aut sextam horam protraitur missa. Item et ad lucernares ${ }^{351}$ similiter fit iuxta consuetudinem cotidianam. Haec ergo consuetudo singulis diebus ita per totum annum custodiatur, ${ }^{352}$ exceptis diebus sollemnibus, ${ }^{353}$ quibus et ipsis quemadmodum fiat infra annotauimus. ${ }^{354}$

25.5. Hoc autem inter omnia satis praecipuum ${ }^{355}$ est, quod faciunt, ut psalmi uel antiphonae apti semper dicantur, tam qui nocte dicuntur, tam qui contra mature, tam etiam qui per diem uel sexta aut nona uel ad lucernare semper ita apti et ita rationabiles, ut ad ipsam rem pertineant, quae agitur.

25.6. Et cum toto anno semper dominica die in ecclesia maiore procedatur, id est quae in Golgotha est, id est post Crucem, quam fecit Constantinus, una tantum die dominica, id est quinquagesimarum per Pentecosten, in Syon proceditur, sicut infra annotatum inuenietis, sic tamen in Syon ut, antequam sit hora tertia, illuc eatur, fiat primum missa in ecclesiam ${ }^{356}$ maiorem (...).

[Deest unum folium]

(...) [59] "Benedictus, qui uenit in nomine Domini" et cetera, quae secuntur. Et quoniam pro $^{357}$ monazontes, qui pedibus uadent, necesse est leuius $^{358}$ iri: ac sic peruenitur in Ierusolima ea hora, qua incipit homo hominem posse cognoscere, id est prope luce, ante tamen quam lux fiat.

\footnotetext{
${ }^{351}$ lucernares A Gam lucernare Geyer edd.

${ }^{352}$ custodiatur A Gam Her MaN custoditur Geyer edd.

${ }^{353}$ sollemnibus A edd. sollennibus Geyer Her Pétré

${ }^{354}$ annotauimus $A$ edd. annotabimus Gam $^{1}$ Geyer Pétré Jan

${ }^{355}$ praecipuum $A \mathrm{Gam}^{2}$ Geyer Her Pétré Prinz precipuum Gam ${ }^{1}$ FrW Arce Mar Jan Nat $\mathrm{MaN}$

${ }^{356}$ ecclesiam A edd. ecclesia Geyer Her Pétré

${ }^{357}$ pro $A$ edd. per Gam

${ }^{358}$ leuius A Gam lenius Geyer edd. lentius coni. Her (in nota)
} 
25.4. Saindo, porém, o bispo, todos se aproximam para beijar-lhe a mão. E assim é que a despedida se prolonga até a quinta ou sexta hora. Igualmente também se faz no lucernário conforme o costume coditiano. Este costume, pois, é guardado todos os dias, assim como durante todo o ano, exceto nos dias solenes, para os quais anotaremos ${ }^{138}$ abaixo o que se faz.

25.5. O que é bastante notável entre todas as coisas é que fazem com que sempre sejam entoados salmos e antífonas apropriados, tanto os que se entoam de noite, quanto os que, pelo contrário, se entoam cedo, e também os que durante o dia, na sexta ou na nona hora, ou no lucernário, são entoados. Assim, sempre apropriados e razoáveis, de modo que sejam pertinentes à própria celebração que se realiza.

25.6. E enquanto durante todo o ano sempre no dia de domingo se vai à igreja maior, isto é, aquela que Constantino fez e que está no Gólgota, atrás da Cruz, somente em um dia de domingo, isto é, um domingo das quinquagésimas, durante o Pentecostes ${ }^{\star}$, se vai a Sião ${ }^{\star}$, conforme encontrareis anotado abaixo; assim, porém, para que se esteja em Sião antes que seja a terceira hora, primeiramente se faz a missa ${ }^{139}$ na igreja maior (...).

[Falta um fólio]

(...) "Bendito aquele que vem em nome do Senhor" (Mt 21,9; Sl 117,26) e as outras coisas que se seguem ${ }^{140}$. E por causa dos monazontes ${ }^{141}$ que vão a pé, é necessário ir-se mais devagar, e assim se chega a Jerusalém naquela hora em que a gente começa a poder reconhecer um ao outro, isto é, quase ao amanhecer, porém antes que se faça luz.

\footnotetext{
${ }^{138}$ Anotaremos (annotauimus): interpretamos que aqui houve uma confusão entre /b/ e $/ \mathrm{v} /$, comum em latim. Isso porque algo que está por ser declarado não pode ser referido como um passado (annotauimus), mas sim como um futuro (annotabimus). Por isso, seguimos a conjectura de Gamurrini (1887), adotada também por Pétré e Janeras.

${ }^{139}$ Missa ( $\left.m i s s a\right)$ : esta é uma das ocorrências em que não está claro em que sentido a palavra missa está sendo usada. A nosso ver, tanto pode ser uma "despedida", de fato, marcando o momento em que as pessoas se despedem para imediatamente irem a Sião, quanto a "missa", cerimônia realizada antes de as pessoas se dirigirem a Sião.

${ }^{140}$ A partir deste trecho $(25,6)$, começa a ser narrada a Epifania. Não sabemos exatamente como começava essa festa, porque justamente aqui falta um fólio no manuscrito. Assim, o que restou da obra não nos revela inteiramente a festa da Epifania e o início do ano litúrgico. ${ }^{141}$ Monazontes (monazontes): Väänänen (1987, p.10) chama a atenção que Egéria substitui monachi por monazontes, na segunda parte da obra, usada como palavra invariável. Na segunda parte da obra, há igualmente uma alternância entre o emprego de septimana e hebdomada (às vezes sem $h$ ), assim como de parthenae, talvez substituindo uirgines. Esse vocabulário é emprestado do grego e provavelmente tem como objetivo mostrar as palavras empregadas na liturgia de Jerusalém às destinatárias do texto de Egéria. Ver, no Glossário, monazonte.
} 
25.7. Vbi cum peruentum fuerit, statim sic in Astase ${ }^{359}$ ingreditur episcopus et omnes cum eo, ubi luminaria iam supra modo lucent. Dicitur ergo ibi unus psalmus, fit oratio, benedicuntur ab episcopo primum cathecumini, item fideles. Recipit se episcopus et uadent se unusquisque ad ospitium ${ }^{360}$ suum ut se resumant. Monazontes autem usque ad lucem ibi sunt et ymnos dicunt.

25.8. At ubi autem resumpserit se populus, hora incipiente secunda colligent se omnes in ecclesia maiore, quae est in Golgotha. Qui autem ornatus sit illa die ecclesiae uel Anastasis aut Crucis aut in Bethleem, superfluum fuit scribi. Vbi extra aurum et gemmas aut sirico nichil aliud uides; nam et si uela uides, auroclaua oleserica ${ }^{361}$ sunt, si cortinas uides, similiter auroclaue oleserica $^{362}$ sunt. Ministerium autem omne gem $^{363}$ aureum gemmatum profertur illa die. Numerus autem uel ponderatio de ceriofalis uel cicindelis aut lucernis uel diuerso ministerio nunquid uel extimari ${ }^{364}$ aut scribi potest?

25.9. Nam quid dicam de ornatu fabricae ipsius, quam Constantinus sub praesentia $^{365}$ matris suae, in quantum uires regni sui habuit, honorauit ${ }^{366}$ auro, musiuo et marmore pretioso, tam ecclesiam maiorem quam Anastasim uel ad Crucem uel cetera loca sancta in Ierusolima?

\footnotetext{
${ }^{359}$ Astase A Anastase Gam edd.

${ }^{360}$ ospitium A edd. hospitium Gam² Geyer Pétré

${ }^{361}$ auroclaua oleserica A edd. auroclaua oloserica Gam Geyer Pétré

${ }^{362}$ auroclaue olesericae $A$ edd. auroclauae olosericae Gam Geyer Pétré auroclaue oleserica Arce

${ }^{363}$ gem $A$ genus Gam edd.

${ }^{364}$ extimari $A$ edd. existimari $G^{2}{ }^{2}$ aestimari Geyer Pétré

${ }^{365}$ praesentia A Gam ${ }^{2}$ Geyer Her Pétré Prinz presentia Gam ${ }^{1}$ FrW Arce Mar Jan Nat MaN

${ }^{366}$ honorauit $A$ edd. hornauit Wöl Geyer Her Pétré
} 
25.7. Assim que se chega, imediatamente o bispo entra na Anástase e todos com ele, onde já brilham luminárias de modo extraordinário. Recitase logo aí um salmo, faz-se uma oração e são benzidos primeiramente, pelo bispo, os catecúmenos e depois os fiéis. $\mathrm{O}$ bispo se retira, e cada um vai ${ }^{142}$ à sua hospedaria para que se restabeleça. Porém, os monazontes permanecem aí até $\mathrm{o}$ amanhecer e entoam hinos.

25.8. Mas quando o povo tenha se restabelecido, começando a segunda hora, todos se reúnem na igreja maior, a qual fica no Gólgota. Como tenha sido a decoração da igreja, naquele dia, ou da Anástase ou da Cruz ou em Belém, é supérfluo ser escrito. Não vês nada além de ouro, gemas e seda; de fato, se vês véus, são todos em seda e bordados de ouro, se vês cortinas, semelhantemente são todas em seda e bordadas de ouro. Quanto aos objetos de culto, todo tipo que é levado em procissão naquele dia é de ouro e cravado de pedras. Ora, o número e o peso de círios, de candelabros e de lucernas ou dos diversos objetos de culto por acaso pode ser estimado? ${ }^{143}$

25.9. Mas o que direi sobre a decoração da própria construção, que Constantino, na presença de sua mãe, enquanto teve as riquezas do seu reino, embelezou com ouro, mosaicos e mármores preciosos, tanto na igreja maior quanto na Anástase, e na Cruz, $\mathrm{e}^{144}$ nos outros locais santos em Jerusalém?

\footnotetext{
${ }^{142}$ Vai (uadent se): no texto, o se reflexivo aparece com verbos intransitivos como uma espécie de expletivo, como em 25,7: uadent se unusquisque in ospitium suo. Isso porque o pronome reflexivo, fazendo recair a ação sobre o sujeito, desenvolve assim uma ideia de interesse, espontaneidade ou intensidade da ação, passando a empregar-se com verbos intransitivos. $\mathrm{O}$ dativo de interesse do latim clássico pode ter contribuído para o aparecimento dessa construção. Em português temos rir-se, sair-se, vir-se, morrerse; romeno a se veni, a se sui "subir", a se ruga "orar"; italiano andar-se, fuggirsi, starsi; francês antigo soi aler; francês moderno s'en aller, se venir, se mourir; espanhol irse, venirse, quedarse.

${ }^{143}$ Ser estimado (extimari): a forma verbal extimari não existe; poderia ser existimari ou aestimari. De fato, existimare deriva-se de ex + aestimare. Interpretamos aestimari. ${ }^{144}$ E na Cruz, e nos outros locais santos (uel ad Crucem uel cetera loca sancta): em concorrência a et... et..., Egéria usa $u e l . . . u e l .$. e seu... seu..., indicando uma adição de termos e não uma alternância. V. notas 55, 67, 102, 186.
} 
25.10. Sed ut redeamus ad rem, fit ergo prima die missa in ecclesia maiore, quae est in Golgotha. Et quoniam dum praedicant, ${ }^{367}$ uel legent singulas lectiones uel dicunt ymnos, omnia tamen apta ipsi diei, et inde postmodum cum missa ecclesiae facta fuerit, hitur cum ymnis ad Anastasim iuxta consuetudinem: ac sic fit missa forsitan sexta hora.

25.11. Ipsa autem die similiter et ad lucernare iuxta consuetudinem cotidianam fit. Alia denuo die similiter in ipsa ecclesia proceditur in Golgotha, hoc idem et tertia die. Per triduo ergo homines ${ }^{368}$ laetitia in ecclesia, quam fecit Constantinus, celebratur usque ad sextam. Quarta die in Eleona, id est in ecclesia quae est in monte Oliueti, pulchra satis, similiter omnia ita ornantur et ita celebrantur ibi, quinta die in Lazariu, quod est ab Ierusolima forsitan ad mille quingentos passus, sexta die in Syon, septima die in Astase, ${ }^{369}$ octaua die ad Crucem. Ac sic ergo per octo dies haec omnes ${ }^{370}$ laetitia et is hornatus $s^{371}$ celebratur in omnibus locis sanctis, quos superius nominaui.

25.12. In Bethleem autem per [60] totos octo dies cotidie is ornatus est et ipsa laetitia celebratur a presbyteris et ab omni clero ipsius loci et a monazontes, qui in ipso loco deputati sunt. Nam et ${ }^{372}$ illa hora, qua omnes nocte in Ierusolima reuertuntur cum episcopo, tunc loci ipsius monachi, quicumque sunt, usque ad lucem in ecclesia in Bethleem peruigilant ymnos seu antiphonas dicentes, quia episcopum necesse est hos dies semper in Ierusolima tenere. Pro sollemnitate autem et laetitia ipsius diei infinite $\mathrm{e}^{373}$ turbae se undique colligent in Ierusolima, non solum monazontes, sed et laici, uiri aut mulieres.

\footnotetext{
${ }^{367}$ praedicant $A$ Gam $^{2}$ Geyer Her Pétré Prinz predicant Gam ${ }^{1}$ FrW Arce MarJan Nat MaN ${ }^{368}$ homines $A$ haec omnis $\mathrm{Gam}^{2}$ edd.

${ }^{369}$ Astase $A$ Anastase Gam edd.

${ }^{370}$ omnes $A$ omnis Gam edd.

${ }^{371}$ is hornatus $A$ edd. his ornatus Arce

${ }^{372}$ et A Gam FrW Prinz Arce Mar MaN ex Chol Geyer Her Pétré Jan Nat

${ }^{373}$ infinite A edd. infinitae Gam Geyer Pétré
} 
25.10. Mas, para que voltemos ao assunto, faz-se, pois, no primeiro dia, a missa ${ }^{145}$ na igreja maior, que fica no Gólgota. E enquanto pregam, leem cada um dos textos e entoam hinos, todas as coisas apropriadas ao próprio dia, e dali, em seguida, depois que se tenha feito a despedida da igreja, vai-se com hinos à Anástase, conforme o costume. E assim, talvez por volta da sexta hora, se faz a despedida.

25.11. No mesmo dia, faz-se semelhantemente também no lucernário conforme o costume cotidiano. Novamente, no outro dia, se vai igualmente à mesma igreja no Gólgota, e isso também se faz no terceiro dia. Durante três dias, pois, toda essa festa ${ }^{146}$ é celebrada até a sexta $<$ hora $>$ na igreja que fez Constantino. No quarto dia, no Eleona*, isto é, na igreja muito bela que fica no Monte das Oliveiras*, aí tudo é igualmente decorado e celebrado do mesmo modo; no quinto dia, tudo acontece no Lazário*, que está talvez a mil e quinhentos passos de Jerusalém, no sexto dia, em Sião, no sétimo dia, na Anástase, e no oitavo dia, na Cruz. E assim, pois, durante oito dias, toda essa festa e essa decoração ocorre em todos os lugares santos os quais nomeei mais acima.

25.12. Além disso, em Belém, durante todos os oito dias, diariamente há essa decoração e é celebrada essa mesma festa, pelos presbíteros e por todo o clero do próprio lugar, e pelos monazontes que foram atribuídos a esse lugar. De fato, a partir daquela hora na qual todos voltam de noite a Jerusalém com o bispo, então os bispos do próprio lugar, quem quer que sejam, fazem vigília até o amanhecer na igreja, em Belém, entoando hinos e antífonas, porque é necessário que o bispo permaneça todos esses dias sempre em Jerusalém. Por causa da solenidade e da festa desse mesmo dia, multidões infinitas, vindas de todos os lados, se reúnem em Jerusalém, não apenas monazontes, mas também leigos, homens e mulheres.

\footnotetext{
${ }^{145}$ Missa (missa): nesta ocorrência, o vocábulo missa é traduzido de diferentes maneiras entre os editores: alguns o traduzem como "despedida"; outros como "ofício", outros, ainda, como "missa", um ofício eucarístico. Arce e Pétré traduzem-no como "missa". Natalucci, Mariano, Janeras e Maraval adotam o termo genérico "ofício". Janeras e Maraval explicitam que o fato de terem traduzido missa por "ofício" não exclui o ritual eucarístico da cerimônia, o que significaria para nós uma "missa". Esse uso contrasta com outro, que se pode ver neste exemplo: 24,11 Item benedicit (sc. episcopus) fideles et fit missa, "Igualmente benze (sc. o bispo) os fiéis e se faz a despedida". Em situações como essa, Egéria parece referir-se a uma despedida, pois, depois da bênção final, todos vão embora, ou seja, realiza-se a despedida. V. notas 108, 154.

${ }^{146}$ Festa (laetitia): trata-se de uma alegria (laetitia) especial, que se refere às festas cristãs, conforme Blaise (1954, p.484). Por isso, traduzimos por "festa".
} 
26. Sane quadragesimae de Epiphania ualde cum summo honore hic celebrantur. Nam eadem die processio est in Astase, ${ }^{374}$ et omnes procedunt et ordines $^{375}$ aguntur omnia cum summa laetitia ac si per Pascha. Predicant ${ }^{376}$ etiam omnes presbyteri et sic episcopus, semper de eo loco tractantis ${ }^{377}$ Euangelii ubi quadragesima die tulerunt Dominum in templo Ioseph et Maria et uiderunt eum Symeon uel Anna prophetissa filia Fanuhel, ${ }^{378}$ et de uerbis eorum, quae dixerunt uiso Domino, uel de oblatione ipsa, qua ${ }^{379}$ optulerunt ${ }^{380}$ parentes. Et postmodum celebratis omnibus per ordinem, quae consuetudines ${ }^{381}$ sunt, aguntur sacramenta et sic fit missa.

27.1. Item dies paschales cum uenerint, celebrantur sic. Nam sicut apud nos quadragesimae ante Pascha adtenduntur, ita hic octo septimanas ${ }^{382}$ attenduntur ${ }^{383}$ ante Pascha. Propterea autem octo septimane ${ }^{384}$ attenduntur, quia dominicis diebus et sabbato non ieiunantur, excepta una die sabbati, qua uigiliae paschales sunt et necesse est ieiunari; extra ipsum ergo diem penitus nunquam hic toto anno sabbato ieiunatur. Ac sic ergo de octo septimanis deductis octo diebus dominicis et septem sabbatis, quia necesse est una sabbati ieiunari, ut superius dixi, remanent dies quadraginta et unum ${ }^{385}$ qui ieiunantur, quod hic appellant eortae, id est quadragesimas.

\footnotetext{
${ }^{374}$ Astase A Anastase Gam edd.

${ }^{375}$ ordines $A$ ordine Gam ordine suo Geyer edd.

${ }^{376}$ predicant $A$ edd. praedicant $\mathrm{Gam}^{2}$ Geyer Pétré Prinz

377 tractantis $A$ tractantes Gam edd.

${ }^{378}$ Fanuhel $A$ edd. Samhuel Gam

${ }^{379}$ qua $A$ edd. quam Gam Geyer Her Pétré

${ }^{380}$ optulerunt $A$ edd. obtulerunt Gam

${ }^{381}$ consuetudines $A$ consuetudinis $\mathrm{Gam}^{2}$ edd.

${ }^{382}$ septimanas A edd. septimanae Gam Geyer Pétré FrW

${ }^{383}$ attenduntur $A$ edd. adtenduntur $\mathrm{Gam}^{2}$

${ }^{384}$ septimane A Her FrW Prinz Nat septimanae Gam edd.

${ }^{385}$ unum $A$ edd. unus Gam Geyer Pétré
} 
26. Sem dúvida, o quadragésimo dia a partir da Epifania é celebrado aqui com grande solenidade. De fato, no mesmo dia há uma procissão na Anástase e todos vão, e todas as coisas são feitas segundo o costume, ${ }^{147}$ com grande alegria, como durante a Páscoa. Pregam também todos os presbíteros, assim como os bispos, sempre tratando daquele passo do Evangelho em que, ao quadragésimo dia, José e Maria levaram o Senhor ao Templo, e Simeão e a profetisa Ana, filha de Fanuel, o viram, e das palavras que disseram quando viram o Senhor, e daquela oblação com a qual se apresentaram os pais (Lc 2,22-36). E depois, com tudo celebrado segundo o costume e de acordo com a ordem habitual, realizam-se os ritos sagrados < da Santa Missa $>,{ }^{148}$ e assim se faz a despedida.

27.1. Igualmente, quando chegam os dias pascais, se celebram assim. Pois, assim como são observados entre nós os quarenta dias antes da Páscoa, aqui se observam oito semanas antes da Páscoa. Por esta razão, são observadas oito semanas: porque nos dias de domingo e de sábado não se jejua, exceto em um só dia de sábado, no qual há as vigílias pascais e é necessário jejuar-se; ${ }^{149}$ exceto esse dia, em todo o ano, aqui, absolutamente nunca se jejua ao sábado. Assim, pois, de oito semanas, deduzidos oito domingos e sete sábados, porque é necessário jejuar um sábado, como disse acima, restam quarenta e um dias em que se jejua, que aqui chamam Eortae, ${ }^{150}$ isto é, a Quaresma*.

\footnotetext{
${ }^{147}$ Segundo o costume (ordines): seguindo a conjectura de Geyer, adotada por todos os editores, interpretamos aqui ordine suo. Todavia, mantemos o texto latino conforme o manuscrito. V. nota 22.

${ }^{148}$ Ritos sagrados <da Santa Missa> (sacramenta): nesta ocorrência, segundo Blaise (1954, p.731), sacramenta refere-se à Santa Missa, através da expressão agere sacramenta. Mariano traduz o termo por "mistérios", Gingras por "Eucharist", Maraval e Pétré por "mystères", Arce por "oblación”, Natalucci por "il sacramento dell' Eucarestia”, Janeras por "misteris".

${ }^{149}$ É necessário jejuar-se (necesse est ieiunari): o verbo ieiunare não pertence à língua clássica. Ieiunare (< ieiunium 'jejum'), é um neologismo cristão, que aparece em alguns autores cristãos além de Egéria, como em Tertuliano (ca. 155/160 - ca. 220), Santo Agostinho (354-430) e São Jerônimo (ca. 345/347 - ca. 419/420). Na língua clássica, observa-se o uso da expressão em locuções verbais com a palavra ieiunium, como nos atestam os seguintes exemplos: Tito Lívio, Ab Vrbe Condita, 36, 37: ieiunium Cereri instituere; Horácio, Satyrae, 2, 3, 291: ieiunia indicere.

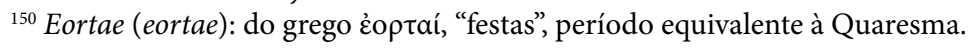




\section{Maria Cristina Martins}

27.2. Singuli autem dies singularum ebdomadarum aguntur sic, id est ut die dominica de pullo primo legat episcopus intra Anastase locum resurrectionis Domini de Euangelio, sicut et toto anno dominicis diebus fiet ${ }^{386}$ similiter usque ad lucem aguntur ${ }^{387}$ ad Anastasem et ad Crucem, quae et toto anno dominicis diebus fiunt.

27.3. Postmodum mane sicut et semper dominica die proceditur, et aguntur quae dominicis diebus consuetudo est agi, in ecclesia maiore, quae appellatur Martyrio, quae est in Golgotha post Crucem. Et similiter missa de ecclesia facta ad Anastase ${ }^{388}$ itur cum ymnis, sicut semper dominicis diebus fit. Haec ergo dum aguntur, facit se hora quinta; lucernare hoc idem ${ }^{389}$ hora sua fit sicut semper ad Anastasem et ad Crucem, sicut et singulis locis sanctis fit: dominica enim die nona fit. ${ }^{390}$

27.4. [61] Item secunda feria similiter de pullo primo ad Anastasem itur sicut et toto anno, et aguntur usque ad mane, que ${ }^{391}$ semper. Denuo ad tertia itur ad Anastasim et aguntur quae ${ }^{392}$ toto anno ad sextam solent agi, quoniam in diebus quadragesimarum et hoc additur, ut et ad tertiam eatur. Item ad sextam et nonam et lucernare ita aguntur, sicut consuetudo est per totum annum agi semper in ipsis locis sanctis.

\footnotetext{
${ }^{386}$ fiet $A$ Gam Arce fit et Bern edd.

${ }^{387}$ aguntur $A$ edd. agantur Gam

${ }^{388}$ Anastase $A$ edd. Anastasi $\mathrm{Gam}^{2}$

${ }^{389}$ hoc idem A edd. totidem coni. Geyer (in nota)

${ }^{390}$ nona fit $A$ Gam Geyer Her FrW Arce Mar nona non fit Duch Pétré Prinz Jan Nat MaN non fit coni. FrW (in nota)

${ }^{391}$ que A Her Prinz quae Gam edd.

${ }^{392}$ quae A Gam Geyer Her Pétré Prinz que FrW Arce Mar Jan Nat MaN
} 
27.2. Em cada dia de cada uma das semanas, as coisas são feitas assim, isto é, de modo que, no dia de domingo, ao primeiro cantar do galo, o bispo leia, dentro da Anástase, o passo do Evangelho sobre a ressurreição do Senhor; assim como é feito também, em todo o ano, nos dias de domingo, semelhantemente, até o amanhecer, se celebram todas as cerimônias na Anástase e na Cruz as quais se realizam também em todo o ano nos dias de domingo.

27.3. Depois, de manhã, assim como também sempre no dia de domingo, vai-se à igreja maior, que se chama Martyrium, que se localiza no Gólgota, atrás da Cruz, e se faz tudo o que é costume ser feito nos dias de domingo. Igualmente feita a despedida da igreja, vai-se à Anástase com hinos, assim como se faz sempre nos dias de domingo. Enquanto são realizadas essas cerimônias, já se faz ${ }^{151}$ a quinta hora; o lucernário se faz à mesma hora, como sempre na Anástase e na Cruz, assim como também se faz em cada um dos lugares santos: no dia de domingo, na verdade, se faz na nona hora.

27.4. Igualmente na segunda-feira vai-se à Anástase ao primeiro cantar do galo, assim como também em todo o ano, e se fazem todas as coisas que sempre são feitas até de manhã. De novo, à terceira hora vai-se à Anástase e é feito tudo o que costuma ser feito todo o ano à sexta hora, porque também esse ofício é acrescido nos dias da Quaresma, de modo que se vá também à terceira hora. Fazem-se, igualmente, assim, à sexta e à nona hora, como é costume ser feito durante todo o ano sempre nos mesmos lugares santos.

${ }^{151}$ Se faz (facit se): no texto, observa-se o uso de se facere no sentido médio-passivo em algumas expressões temporais, como aqui nesta passagem, e também em 29,3; 31,1; 37,$4 ; 37,7$. Esse emprego de se facere = fieri pertencia sem dúvida à língua falada e se manteve em todas as línguas românicas. Porém, em outros autores, ao contrário de Egéria, não aparece frequentemente (LÖFSTEDT, 2007, p.190). 
27.5. Similiter et tertia feria similiter omnia aguntur sicut et secunda feria. Quarta feria autem similiter itur de noctu ${ }^{393}$ ad Anastase et aguntur ea, quae semper, usque ad mane; similiter et ad tertiam et ad sexta; ${ }^{394}$ ad nonam autem, quia consuetudo est semper, id est toto anno, quarta feria et sexta feria ad nona ${ }^{395}$ in Syon procedi, quoniam in istis locis, excepto si martiriorum ${ }^{396}$ dies euenerit, semper quarta et sexta feria etiam et a cathecuminis ieiunari: ${ }^{397}$ et ideo ad nonam in Syon proceditur. Nam si fortuito in quadragesimis martyrorum ${ }^{398}$ dies euenerit quarta feria aut sexta feria, atque ${ }^{399}$ ad nona in Syon proceditur.

27. 6. Diebus uero quadragesimarum, ${ }^{400}$ ut superius dixi, quarta feria ad nona in Sion ${ }^{401}$ proceditur iuxta consuetudinem totius anni et omnia aguntur, quae consuetudo est ad nonam agi, praeter ${ }^{402}$ oblatio. $^{403} \mathrm{Nam}$ ut semper populus discat legem, et episcopus et presbyter praedicant ${ }^{404}$ assidue. Cum autem facta fuerit missa, inde cum ymnis populus deducet episcopum usque ad Anastasem; inde sic uenitur, ut cum intratur in Astase, ${ }^{405}$ iam et tota lucernari; sic $^{406}$ dicuntur ymni et antiphonae, fiunt orationes et fit missa lucernaris in Astase $^{407}$ et ad Crucem.

\footnotetext{
${ }^{393}$ de noctu corr. ex denuo tu $A$

${ }^{394}$ sexta $A$ edd. sextam Gam ${ }^{1}$ Geyer Pétré

${ }^{395}$ nona $A$ edd. nonam Geyer Pétré

${ }^{396}$ martiriorum A Gam ${ }^{2}$ martyriorum Gam ${ }^{2}$ Nat martyrorum Geyer Pétré martirorum Her FrW Arce Mar Jan MaN

${ }^{397}$ ieiunari $A \mathrm{Gam}^{2}$ ieiunatur $\mathrm{Gam}^{1}$ edd. ieiunatu $\mathrm{Her}$

${ }^{398}$ martyrorum $A$ edd. martyriorum Nat

${ }^{399}$ atque $A$ edd. neque $\mathrm{Gam}^{1}$ Geyer Pétré aeque $\mathrm{Fr} W$ ad quem penitus nemo ieiunat nec add. ante atque Her (in nota)

${ }^{400}$ quadragesimarum corr. ex quadragesimerum $A$

${ }^{401}$ Sion A edd. Syon Gam Geyer Pétré

${ }^{402}$ praeter A Gam Geyer Her Pétré Prinz preter FrW Arce Mar Jan Nat MaN

${ }^{403}$ oblatio A edd. oblationem coni. Geyer (in nota)

${ }^{404}$ praedicant $A$ Gam $^{2}$ Geyer Pétré Her Prinz predicant FrW Arce Jan MaN Mar Nat

${ }^{405}$ Astase A Anastase Gam edd.

${ }^{406}$ tota lucernari sic $A$ tota lucernaris fit $\mathrm{Gam}^{2}$ hora lucernari sit Geyer edd.

${ }^{407}$ Astase A Anastase Gam edd.
} 
27.5. De modo semelhante, também à terça-feira todas as coisas são feitas igualmente como à segunda-feira. Porém, na quarta-feira vai-se igualmente de noite à Anástase, e se fazem aquelas coisas que sempre são feitas até o amanhecer; igualmente também à terceira e à sexta; à nona, porém, porque é costume sempre, isto é, todo o ano, ir-se a Sião à nona hora, porque nesses lugares, exceto se ocorrer um dia de mártires, ${ }^{152}$ quarta e sexta-feira sempre se jejua, também os catecúmenos, e de novo se vai para Sião à nona hora. Se, por acaso, ocorrer na Quaresma um dia de mártires na quarta ou na sexta-feira, também se vai a Sião à nona hora.

27.6. Na verdade, nos dias da Quaresma, como disse acima, vai-se a Sião na quarta-feira à nona hora, conforme o costume de todo o ano, e fazemse todas as coisas que é costume serem feitas à nona hora, exceto a oblação. Pois, para que o povo aprenda a Lei, não só o bispo, como o presbítero, pregam assiduamente. Quando, porém, tenha sido feita a despedida, o povo acompanha o bispo até a Anástase com hinos; quando se chega aí e se entra na Anástase, já éa hora do lucernário, entoam-se hinos e antífonas, fazem-se orações, e se faz a despedida do lucernário na Anástase e na Cruz.

${ }^{152}$ Mártires (martiriorum): interpretamos aqui a conjectura de Geyer - martyrorum (grafado no manuscrito com $i$ ) -, ou seja, martirorum em vez de martiriorum, que nos acarretaria uma tradução como "dia de martírios", o que não faz sentido no texto. 
27.7. Missa autem lucernari ${ }^{408}$ in isdem diebus, id est quadragesimarum, serius fit semper quam per toto anno. Quinta feria autem similiter omnia aguntur sicut secunda feria et tertia feria. Sexta feria autem similiter omnia aguntur sicut quarta feria, et similiter ad nonam in Syon itur et similiter inde cum ymnis usque ad Anastase adducetur episcopus. Sed sexta feria uigiliae in Astase $^{409}$ celebrantur ab ea hora, qua de Sion uentum fuerit cum ymnis, usque in mane, id est de hora lucernarii, ${ }^{410}$ quemadmodum intratum fuerit in alia die mane, id est sabbato. Fit autem oblatio in Astase ${ }^{411}$ maturius, ita ut fiat missa ante solem.

27.8. Tota autem nocte uicibus dicuntur psalmi responsorii, uicibus antiphonae, uicibus lectiones diuersae, quae omnia usque in mane protrahuntur. Missa autem, quae fit sabbato ad Anastase, ante solem fit, hoc est oblatio, ut ea hora, qua incipit sol procedere, ad missam ${ }^{412}$ in Astase ${ }^{413}$ facta sit. Sic ergo singulae septimanae celebrantur quadragesimarum.

\footnotetext{
${ }^{408}$ lucernari A edd. lucernaris Gam lucernarii Geyer Pétré

${ }^{409}$ Astase A Anastase Gam edd.

${ }^{410}$ lucernarii A edd. lucernari $\mathrm{Gam}^{1} \mathrm{Her}$

${ }^{411}$ Astase A Anastase Gam edd.

${ }^{412}$ ad missam $A$ et missa Geyer edd. iam missa Gam

${ }^{413}$ Astase A Anastase Gam edd.
} 
27.7. Mas a despedida do lucernário nesses dias da Quaresma é feita sempre mais tarde do que durante todo o ano. No entanto, na quinta-feira, ${ }^{153}$ todas as coisas são feitas de modo semelhante, assim como na segunda e terçafeira. Porém, na sexta-feira tudo é feito igualmente como na quarta-feira e, da mesma forma, se vai a Sião à nona hora. Semelhantemente, o bispo é conduzido daí até a Anástase com hinos. Mas sexta-feira as vigílias são celebradas na Anástase desde a hora em que se tenha chegado de Sião com hinos até de manhã, isto é, desde a hora do lucernário até que se entre no outro dia de manhã, isto é, sábado. Faz-se, porém, uma oblação mais cedo na Anástase, para que assim a despedida se faça antes do sol.

27.8. Durante toda a noite, alternadamente, dizem-se salmos responsórios, antífonas e leituras diversas, e todas essas coisas se estendem até de manhã. A missa, ${ }^{154}$ porém, que se faz no sábado, na Anástase, se faz antes do sol, isto é, a oblação, de modo que naquela hora em que o sol começa a nascer seja feita a despedida na Anástase. Assim, pois, celebra-se cada uma das semanas da Quaresma.

\footnotetext{
${ }^{153}$ Quinta-feira (quinta feria): a palavra "feira", de "segunda-feira" etc., é este feria do latim (note-se que "feriado" retoma feria). O processo que modificou feria em "feira" recebe o nome de "metátese", que é a transposição de um fonema, podendo ocorrer na mesma sílaba ou entre sílabas (ver o capítulo "Metaplasmos" em COUTINHO, 1973). Dentre tantos outros exemplos, vejam-se semper, que em português deu "sempre", e inter, que deu "entre" (inter > intre > entre). A única língua românica que tem os dias da semana provenientes desse uso eclesiástico é o português: esse é um forte argumento em favor da tese da nacionalidade lusitana de Egéria. Sobre a origem dos dias da semana em português, ver ELIA, 1979 e SALUM, 1968.

${ }^{154}$ Missa (missa): esta é uma das ocorrências em que a missa está sendo identificada com a oblação, ou seja, a eucaristia. Por isso, encontramos as traduções "missa", "ofício", "cerimônia" entre os diversos editores. V. notas 108, 145.
} 
27.9. Quod autem dixi, maturius fit missa sabbato, [62] id est ante solem, propterea fit, ut citius absoluant hi, quos dicunt hic domadarios. ${ }^{414} \mathrm{Nam}$ talis consuetudo est hic ieiuniorum in quadragesimis, ut hi, quos appellant ebdomadarios, id est qui faciunt septimanas, dominica die, quia hora quinta fit missa, ut manducent. Et quemadmodum prandiderint dominica die, iam non manducant nisi sabbato mane, mox communicauerint in Astase. ${ }^{415}$ Propter ipsos ergo, ut citius absoluant, ante sole fit missa in Astase ${ }^{416}$ sabbato. Quod autem dixi, propter illos fit missa mane, non quod illi soli communicent, sed omnes communicant, qui uolunt eadem die in Astase ${ }^{417}$ communicare.

28.1. Ieiuniorum enim consuetudo hic talis est in quadragesimis, ut alii, quemadmodum ${ }^{418}$ manducauerint dominica die post missa, id est hora quinta aut sexta, iam non manducent per tota septimana nisi sabbato ueniente post missa Anastasis, hi qui faciunt ebdomadas.

28.2. Sabbato autem quod manducauerint mane, iam nec sera manducant, sed ad aliam diem, id est dominica, prandent post missa ecclesiae, hora quinta uel plus et postea iam non manducent, ${ }^{419}$ nisi sabbato ueniente, sicut superius dixi.

${ }^{414}$ domadarios A Gam ebdomadarios Geyer edd.

${ }^{415}$ Astase A Anastase Gam edd.

${ }^{416}$ Astase A Anastase Gam edd.

${ }^{417}$ Astase A Anastase Gam edd.

${ }^{418}$ alii quemadmodum corr. ex ali quemadmodum $A$

${ }^{419}$ manducent $A$ Gam manducant Geyer edd. 
27.9. Ora, como eu disse, no sábado a missa é feita mais cedo, isto é, antes do sol, para que se liberem mais cedo aqueles que chamam aqui hebdomadários*. De fato, tal é o costume dos jejuns aqui na Quaresma, de modo que esses que se chamam hebdomadários, isto é, que fazem semanas $<$ de jejum>, comam no dia de domingo, porque se faz a despedida na quinta hora. Uma vez que ${ }^{155}$ terão comido ${ }^{156}$ no domingo, já não comem mais a não ser no sábado de manhã, logo após terem comungado na Anástase. Por causa desses, pois, para que se liberem mais cedo, a missa se faz no sábado, antes do sol, na Anástase. Como disse, por causa deles se faz a missa de manhã, não porque apenas eles comunguem, mas todos os que querem comungar comungam naquele dia na Anástase.

28.1. Na verdade, o costume dos jejuns na Quaresma aqui é tal que os outros, após terem comido no dia de domingo, depois da missa, isto é, na quinta ou sexta ${ }^{157}$ hora, não comem durante toda a semana, a não ser no sábado seguinte, após a despedida da Anástase. São esses que fazem as semanas $<$ de jejum $>$. $^{158}$

28.2. Porém, no sábado, porque se terá comido de manhã, já não comem de tarde, mas no outro dia, isto é, no domingo, almoçam depois da despedida da igreja, na hora quinta ou mais tarde, e depois já não comem, senão no sábado seguinte, como disse acima.

\footnotetext{
${ }^{155}$ Uma vez que (quemadmodum): em latim clássico, quemadmodum é um advérbio de modo ou conjunção que introduz uma oração adverbial de modo. Nesta ocorrência, observa-se que essa conjunção introduz uma oração temporal.

${ }^{156}$ Terão comido (prandiderint): prandiderint está sendo usado no lugar de pranderint. Dioméde (apud VÄÄNÄNEN, 1987, p.59) diz que essa é uma forma refeita a partir do modelo dos compostos de dare. De fato, em latim clássico, alguns verbos formavam o pretérito perfeito com redobro: curro, cucurri; do, dedi, entre outros. Em italiano permanece o verbo pranzare, que significa "jantar", pranzo "janta" ou o substantivo "jantar". Em português, temos as palavras eruditas "prândio", substantivo, e "prandial", adjetivo, contrariamente ao italiano, em que essas palavras são da linguagem corrente.

${ }^{157}$ Sexta: gostaríamos de registrar que o numeral ordinal sexta, assim como quarta, em 29,1, está escrito em número romano, mas com um caractere manuscrito que não tem correspondência em nenhuma fonte moderna, por isso não podemos mostrá-lo.

${ }^{158}$ Semanas <de jejum> (ebdomadas): para designar o período de sete dias, Egéria usa mais frequentemente septimana (29 ocorrências) do que $<h>$ ebdomada, que parece ter um emprego particular para significar a semana de jejum; daí $<h>$ ebdomadarius ser aquele que faz jejum de uma semana.
} 
28.3. Consuetudo enim hic talis est, ut omnes, qui sunt, ut hic dicunt, aputactite, ${ }^{420}$ uiri uel feminae, non solum diebus quadragesimarum, sed et toto anno, qua manducant, semel in die manducant. Si qui autem sunt de ipsis aputactites, ${ }^{421}$ qui non possunt facere integras septimanas ieiuniorum, sicut superius diximus, in totis quadragesimis in medio quinta feria cenant. Qui autem nec hoc potest, biduanas facit per totas quadragesimas; qui autem nec ipsud, de sera ad seram ${ }^{422}$ manducant.

28.4. Nemo autem exigit, quantum debeat facere, sed unusquisque ut potest id facit; nec ille laudatur, qui satis fecerit, nec ille uituperatur, qui minus. Talis est enim hic consuetudo. Esca autem eorum quadragesimarum diebus haec est, ut nec panem, quid liberari ${ }^{423}$ non potest, nec oleum gustent, nec aliquid, quod de arboribus est, sed tantum aqua et sorbitione modica de farina. Quadragesimarum ${ }^{424}$ sic fit, ut diximus.

29.1. Et completo earum septimanarum uigiliae ${ }^{425}$ in Astase $e^{426}$ sunt de hora lucernarii sexta feria, qua de Syon uenitur cum psalmis, usque in mane sabbato, qua oblatio fit in Astase. ${ }^{427}$ Item secunda septimana et tertia et quarta et quinta et sexta similiter fiunt, ut prima de quadragesimis.

\footnotetext{
${ }^{420}$ aputactite $A$ edd. aputactitae Gam $^{2}$ Geyer Pétré

${ }^{421}$ aputactites A Gam Prinz Mar Jan Nat MaN aputactitis Geyer Pétré Her FrW Arce

${ }^{422}$ seram $\mathrm{A}$ edd. sera $\mathrm{Her}$

${ }^{423}$ quid liberari A quod librari Gam Geyer qui delibari coni. Her (in nota) Pétré Prinz Arce Nat Jan quidem libari Mar MaN quid libari Web FrW quod liberari Her

${ }^{424}$ ieiunium ante quadragesimarum add. Gam ergo ieiunium post quadragesimarum add. Her lacuna ante quadragesimarum Pétré Geyer ieiunium post quadragesimarum add. Arce

${ }^{425}$ ieiunio ante uigiliae add. Arce lacuna ante uigiliae Geyer Pétré ieiunio ... prima septimana ante uigiliae add. Her

${ }^{426}$ Astase A Anastase Gam edd.

${ }^{427}$ Astase A Anastase Gam edd.
} 
28.3. De fato, o costume aqui é tal que todos os que são apotactitas, como chamam aqui, homens ou mulheres, não somente nos dias da Quaresma, mas também durante todo o ano, quando comem, comem uma vez por dia. Se há, porém, entre esses apotactitas, os que não podem fazer semanas inteiras de jejum, como dissemos acima, em toda a Quaresma jantam no meio $<$ da semana $>$, na quinta-feira. Aquele que não pode nem isso, faz dois dias de jejum durante toda a Quaresma; os que nem isso podem, comem a cada anoitecer.

28.4. Mas ninguém exige o quanto se deva fazer $<$ de jejum $>$, mas cada um faz o que pode, nem é louvado aquele que tiver feito bastante, nem é repreendido aquele que faz menos. Efetivamente, tal é o costume aqui. A comida desses dias da Quaresma é esta, que nem pão se pode provar ${ }^{159}$, nem saborear óleo, nem algo que venha de árvores, mas apenas água e um pouco de caldo de farinha. Assim se faz a Quaresma, como dissemos.

29.1. E completadas essas semanas, ${ }^{160}$ há vigílias na Anástase a partir da hora do lucernário, na sexta-feira, quando ${ }^{161}$ de Sião se vem com salmos, até sábado de manhã, quando é feita a oblação na Anástase. Igualmente na segunda semana, bem como na terceira, na quarta, ${ }^{162}$ na quinta e na sexta, fazem-se as mesmas coisas à semelhança da primeira semana da Quaresma.

\footnotetext{
${ }^{159}$ Provar (liberari): aceitamos a conjectura libari proposta por Franceschini-Weber, já que liberari não faz sentido na frase. Mesmo assim, mantivemos o texto latino com a palavra original, prática que seguimos sempre.

${ }^{160}$ E completadas essas semanas (et completo earum septimanarum): seguimos a interpretação de Väänänen (1987, p.89), para quem o ablativo completo representa o equivalente a um ablativo absoluto. Nesta ocorrência, do ponto de vista do latim clássico, deveríamos ter completis eis septimanis. Por isso, Väänänen afirma que este é um caso de não concordância entre o sujeito e o complemento do ablativo absoluto. Interpretando à maneira de Väänänen, não é preciso que se acrescente a palavra ieiunio, tal como propôs Arce.

${ }^{161}$ Quando (qua): este qua é chamado de “qua temporal” por Väänänen (1987, p.80), em concorrência com quando e cum. Seu uso também aparece em 5,4 his diebus, qua fecerunt uitulum; 19,12 in ea hora, qua auerterant; 3,2 in ea die qua mons fumigabat; 5,7 incensa est quedam pars castrorum, tunc qua orante sancto Moyse, cessauit ignis. V. nota 18.

${ }^{162}$ Quarta: v. nota 157.
} 
29.2. Septima autem septimana cum uenerit, id est quando iam due $e^{428}$ superant cum ipsa, ut Pascha sit, singulis diebus omnia quidem sic aguntur sicut et ceteris septimanis, quae transierunt; tantummodo quod uigiliae, quae $\mathrm{e}^{429}$ in iliis $\operatorname{sex}^{430}$ septimanis in Astase ${ }^{431}$ factae sunt, septima autem septimana, id est sexta feria, in Syon [63] fiunt uigiliae iuxta consuetudinem ea quae ${ }^{432}$ in Astase $^{433}$ factae sunt per sex septimanas. Dicuntur autem toti singulis ${ }^{434}$ apti psalmi semper uel antiphonae tam loco quam diei.

29.3. At ubi autem ceperit ${ }^{435}$ se mane facere sabbato illucescente, offeret episcopus et facit oblationem mane sabbato. Iam ut fiat missa, mittit uocem archidiaconus et dicit: "Omnes hodie hora septima in Lazario parati simus". Ac sic ergo cum ceperit ${ }^{436}$ se hora septima facere, omnes ad Lazarium ueniunt. Lazarium autem, id est Bethania, est forsitan secundo miliario a ciuitate.

29.4. Euntibus autem de Ierusolima in Lazarium forsitan ad quingentos passus de eodem loco ecclesia est in strata in eo loco, in quo occurrit Domino Maria soror Lazari. Ibi ergo cum uenerit episcopus, occurrent illi ${ }^{437}$ omnes monachi, et populus ibi ingreditur, dicitur unus ymnus et una antiphona et legitur ipse locus de Euangelio ubi occurrit soror Lazari Domino. Et sic facta oratione et benedictis omnibus, inde iam usque ad Lazarium cum ymnis itur.

\footnotetext{
${ }^{428}$ due $A$ edd. duae Gam $^{2}$ Geyer Pétré

${ }^{429}$ quae om. Geyer Pétré

${ }^{430}$ sex om. Gam

${ }^{431}$ Astase A Anastase Gam edd.

${ }^{432}$ ea quae $A$ eae quae Gam eam qua Chol Geyer Her Pétré FrW Arce Jan ea, qua Prinz Mar Nat MaN

${ }^{433}$ Astase A Anastase Gam edd.

${ }^{434}$ toti singulis A Gam totis uigiliis Geyer edd. horis singulis FrW Arce

${ }^{435}$ ceperit $A$ edd. coeperit Geyer Pétré

${ }^{436}$ ceperit $A$ edd. coeperit Geyer Pétré

${ }^{437}$ illi $A$ edd. ibi Gam
} 
29.2. Porém, quando chega a sétima semana, isto é, quando faltam apenas duas semanas, junto com ela, para que seja a Páscoa, em cada um dos dias, as coisas são feitas precisamente do mesmo modo como também nas demais semanas que passaram; somente que as vigílias que foram feitas naquelas seis semanas na Anástase, na sétima semana, porém, isto é, na sexta-feira, são feitas vigílias em Sião, conforme aquele costume pelo qual ${ }^{163}$ foram feitas na Anástase durante seis semanas. Aliás, em todas as vigílias são sempre entoados salmos e antífonas apropriados tanto ao lugar quanto ao dia.

29.3. Quando, porém, tenha começado a se fazer ${ }^{164}$ manhã, ao raiar do sábado, o bispo oferece <um sacrifício> e faz uma oblação na manhã de sábado. Já para que se faça a despedida, o arquidiácono* eleva a voz e diz: "Hoje todos, na hora sétima, estejamos preparados no Lazário”. E assim, pois, quando começa a se fazer a hora sétima, todos chegam ao Lazário. O Lazário, isto é, Betânia, ${ }^{*}$ está talvez a duas milhas ${ }^{165}$ da cidade.

29.4. Indo, pois, de Jerusalém para o Lazário, talvez a quinhentos passos do próprio lugar, há uma igreja na estrada, ${ }^{166}$ no lugar em que Maria, irmã de Lázaro, foi ao encontro do Senhor. Ali, pois, depois de ter chegado o bispo, todos os monges dirigem-se a ele, e o povo entra aí, entoam-se um hino e uma antífona e lê-se aquele mesmo passo do Evangelho onde a irmã de Lázaro vai ao encontro do Senhor (Jo 11,29). E assim é feita uma oração e, todos tendo sido abençoados, daí se vai ao Lazário com hinos.

\footnotetext{
${ }^{163}$ Pelo qual (ea quae): adotamos a conjectura proposta por Cholodniak (1899), seguida por vários editores, a qual substitui ea por eam, para concordar com consuetudinem, e quae por qua.

${ }^{164}$ Se fazer (se facere): este sentido de se facere determina um ponto no tempo. Além desta ocorrência, encontra-se em 27,3: haec ergo dum aguntur, facit se hora quinta, "se faz a hora quinta". Segundo Väänänen (1987, p.67), essa expressão não é atestada em outros textos com vulgarismos, no entanto, pertence às línguas românicas: em português, já se faz tarde; em francês, il se fait tard; em italiano, si fa tardi; em espanhol, se hace tarde. ${ }^{165}$ Milhas (miliario): deveria estar escrito com dois $l l$ : milliarium "distância de mil passos", equivalente a mille/millia.

${ }^{166}$ Estrada (strata): esta é a única ocorrência de strata no texto. Egéria prefere o uso da palavra uia. Resta saber se havia diferença entre uia e strata, tal como a etimologia do termo strata sugere: "caminho calçado".
} 
29.5. In Lazario autem cum uentum fuerit, ita se omnis multitudo colligit, ut non solum ipse locus, sed et campi omnes in giro pleni sint hominibus. Dicuntur ymni etiam et antiphonae apti ipsi diei et loco; similiter et lectiones apte $^{438}$ diei, quaecumque leguntur. Iam autem, ut fiat missa, denuntiatur Pascha, id est subit presbyter in altiori loco et leget illum locum, qui scriptus est in Euangelio: "Cum uenisset Iesus in Bethania ante sex dies Paschae" et cetera. Lecto ergo $\mathrm{eo}^{439}$ loco et annuntiata Pascha, fit missa.

29.6. Propterea autem ea die hoc agitur, quoniam, sicut in Euangelio scriptum est, ante sex dies Paschae factum hoc fuisset in Bethania; de sabbato enim usque in quinta feria, qua post cena noctu comprehenditur Dominus, sex dies sunt. Reuertuntur ergo $^{440}$ omnes ad ciuitatem rectus ad Anastase et fit lucernare iuxta consuetudinem.

30.1. Alia ergo die, id est dominica, quae ${ }^{441}$ intratur in septimana paschale, quam hic appellant septimana maior, celebratis de pullorum cantatis, ${ }^{442}$ quae consuetudinis sunt in Anastase uel ad Crucem usque ad mane agitur: ${ }^{433}$ die ergo dominica mane proceditur iuxta consuetudinem in ecclesia maiore, quae appellatur Martyrium. Propterea autem Martyrium appellatur, quia in Golgotha est, id est post Crucem, ubi Dominus passus est, et ideo Martyrio.

30.2. Cum ergo celebrata fuerint omnia iuxta consuetudinem in ecclesia maiore, et antequam fiat missa, mittet uocem archidiaconus et dicit primum: "Iuxta ${ }^{444}$ septimana omne ${ }^{445}$ id est die ${ }^{446}$ crastino, hora nona omnes ad Martyrium conueniamus, id est in ecclesia maiore". Item mittet uocem alteram et dicet: "Hodie omnes hora septima in eo leona ${ }^{447}$ parati simus".

\footnotetext{
${ }^{438}$ apte $A$ edd. aptae Gam Geyer Pétré

${ }^{439}$ ergo eo corr. ex ergo $A$

${ }^{440}$ ergo add. supra lineam $A$

${ }^{441}$ quae $A$ MaN qua Gam edd.

${ }^{442}$ cantatis $A$ cantu eis Gam cantu his Chol edd.

${ }^{443}$ agitur $A$ Gam agi Geyer edd.

${ }^{444}$ iuxta $A$ Gam ista Geyer edd.

${ }^{445}$ omne A edd. omni Geyer Pétré

${ }^{446}$ die A Gam de ante die add. Chol edd.

${ }^{447}$ in eo leona $A$ in Eleona $\mathrm{Gam}^{2}$ edd.
} 
29.5. Quando, porém, depois de se ter chegado ao Lazário, toda a multidão se reúne, de modo que não só o próprio lugar, mas também todos os campos ao redor estão cheios de pessoas. Também são entoados hinos e antífonas apropriados ao próprio dia e local; as leituras apropriadas ao dia, sejam quais forem, são lidas. Prontamente, porém, para que se faça a despedida, é anunciada a Páscoa, isto é, o presbítero sobe a um local mais alto e lê aquele passo que está escrito no Evangelho: "Como tivesse chegado Jesus a Betânia seis dias antes da Páscoa" (Jo 12,1) e o resto. Lido, pois, esse passo e anunciada a Páscoa, é feita a despedida.

29.6. A razão pela qual nesse dia se faz isso é porque, conforme está escrito no Evangelho, seis dias antes da Páscoa isso foi feito em Betânia; de fato, desde sábado até quinta-feira, em que após a Ceia, à noite, o Senhor é preso, são seis dias. Voltam, pois, à cidade, diretamente ${ }^{167}$ para a Anástase, e se faz o lucernário conforme o costume.

30.1. No outro dia, pois, isto é, no domingo em que se entra na semana pascal, que aqui chamam de semana maior, celebradas aquelas coisas as quais são de costume serem feitas na Anástase e na Cruz desde o canto dos galos até de manhã, no dia de domingo, pois, de manhã, vai-se, conforme o costume, à igreja maior, que se chama Martyrium. A razão por que é chamada Martyrium é porque está no Gólgota, isto é, atrás da Cruz, onde o Senhor sofreu e, por isso, Martyrium.

30.2. Quando, pois, tudo foi celebrado conforme o costume na igreja maior, e antes que fosse feita a despedida, o arquidiácono eleva a voz e diz primeiramente: “Toda esta semana, a partir do dia de amanhã, todos nos encontremos à nona hora no Martyrium, isto é, na igreja maior". Do mesmo modo, eleva a voz outra vez e diz: "Hoje todos estejamos preparados, na hora sétima, no Eleona”.

\footnotetext{
${ }^{167}$ Diretamente (rectus): o adjetivo rectus não concorda com nenhuma palavra. Nesta ocorrência, o vocábulo está sendo usado como advérbio.
} 
30.3. Facta ergo missa in ecclesia maiore, id est ad Martyrium, deducitur episcopus cum ymnis ad Anastase, et ibi completis quae [64] consuetudo est diebus dominicis fieri in Anastase post missa Martyrii, et iam ${ }^{48}$ unusquisque hiens ad domum suam festinat manducare, ut hora inquoante ${ }^{449}$ septima omnes in ecclesia parati sint, quae est in Eleona, id est in monte Oliueti, $\mathrm{ibi}^{450}$ est spelunca illa, in qua docebat Dominus.

31.1. Hora ergo septima omnis populus ascendet in monte Oliueti, id est in Eleona, in ecclesia; sedet ${ }^{451}$ episcopus, dicuntur ymni et antiphonae apte ${ }^{452}$ diei ipsi uel loco, lectiones etiam similiter. Et cum ceperit ${ }^{453}$ se facere hora nona, subitur cum ymnis in Inbomon, id est in eo loco, de quo ascendit Dominus in caelis, et ibi seditur; nam omnis populus semper praesente ${ }^{454}$ episcopo iubetur sedere, tantum quod diacones soli stant semper. Dicuntur et ibi ymni uel antiphonae aptae loco aut diei: similiter et lectiones interpositae et orationes.

31.2. Et iam ${ }^{455}$ cum coeperit ${ }^{456}$ esse hora undecima, legitur ille locus de Euangelio, ubi infantes cum ramis uel palmis occurrerunt Domino dicentes: "Benedictus, qui uenit in nomine Domini". Et statim leuat se episcopus et omnis populus, porro inde de summo monte Oliueti totum pedibus itur. Nam totus populus ante ipsum ${ }^{457}$ cum ymnis uel antiphonis respondentes semper: "Benedictus, qui uenit in nomine Domini".

31.3. Et quotquot sunt infantes in hisdem locis, usque etiam quae ${ }^{458}$ pedibus ambulare non possunt, quia teneri sunt, in collo illos parentes sui tenent, omnes ramos tenentes alii palmarum, alii oliuarum; et sic deducetur episcopus in eo typo, quo tunc Dominus deductus est.

\footnotetext{
${ }_{448}^{48}$ etiam uel et iam $A$ etiam Gam et iam Geyer edd.

${ }^{449}$ inquoante $A$ edd. inchoante Geyer Pétré

${ }^{450}$ ibi A Gam Arce Nat MaN ubi Geyer edd.

${ }^{451}$ sedet uel sed et $A$ sedet Gam edd. sed et Geyer Her Pétré

${ }^{452}$ apte $A$ edd. aptae $\mathrm{Gam}^{2}$ Geyer Pétré

${ }^{453}$ ceperit $A$ edd. coeperit Geyer Pétré

${ }^{454}$ praesente $A \mathrm{Gam}^{2}$ Geyer Her Pétré Prinz presente Gam ${ }^{1}$ FrW Arce Mar Jan Nat MaN

${ }^{455}$ etiam uel et iam $A$ etiam Gam et iam Geyer edd.

${ }^{456}$ coeperit $A$ edd. ceperit Gam

${ }^{457}$ ante ipsum $A$ edd. ante ipsum uadit coni. Geyer (in nota)

${ }^{458}$ quae $A$ qui Gam edd.
} 
30.3. É feita, pois, a despedida na igreja maior, isto é, no Martyrium, o bispo é conduzido com hinos à Anástase, e aí terminadas as coisas que costumeiramente são feitas nos dias de domingo, na Anástase, depois da despedida do Martyrium, e logo, cada um indo para a sua casa se apressa para comer, para que no começo da sétima hora todos estejam preparados na igreja que fica no Eleona, isto é, no Monte das Oliveiras; aí está aquela gruta na qual o Senhor ensinava.

31.1. Na hora sétima, todo o povo sobe ao Monte das Oliveiras, isto é, ao Eleona, à igreja; o bispo se senta, entoam-se hinos e antífonas apropriados ao dia e local, igualmente também <fazem-se> leituras. E quando começa a se fazer a hora nona, sobe-se com hinos ao Imbomon*, isto é, àquele lugar do qual subiu o Senhor aos céus e aí tomou assento; pois, sempre que o bispo está presente, todo o povo é ordenado a sentar, e apenas os diáconos ficam sempre em pé. São também entoados aí hinos e antífonas apropriados ao lugar e ao dia; igualmente também $<$ fazem-se $>$ leituras intercaladas e orações.

31.2. E quando já começa a décima primeira hora, é lido aquele passo do Evangelho onde as crianças com ramos e palmas correram ao encontro do Senhor, dizendo: "Bendito aquele que vem em nome do Senhor" (Mt 21,8-9; Sl 117,26). E imediatamente levantam-se o bispo e todo o povo; avançando a partir daí, do cume do Monte das Oliveiras, se vai totalmente a pé. Pois todo o povo < vai > à frente do bispo, com hinos e antífonas, respondendo sempre: "Bendito aquele que vem em nome do Senhor".

31.3. E todos aqueles que são crianças nesses lugares, até mesmo as que não podem caminhar a pé, porque são jovens, os seus ${ }^{168}$ pais as têm no colo, todas tendo ramos, umas de palmeiras e outras de oliveiras; e assim o bispo é conduzido do mesmo modo pelo qual então o Senhor foi conduzido (Mt 21,8).

\footnotetext{
${ }^{168}$ Seus (sui): conforme a gramática do latim clássico, esperar-se-ia eorum, referindo-se a infantes: "os pais delas" (sc. "das crianças"). O mesmo uso ocorre em 49,2: cum illis ueniunt multi clerici sui.
} 
31.4. Et de summo monte usque ad ciuitatem et inde ad Anastase per totam ciuitatem totum pedibus omnes, sed et si quae matrone ${ }^{459}$ sunt aut si qui domini, sic deducunt episcopum respondentes et sic lente et lente, ne lassetur populus, porro iam sera peruenitur ad Anastase. Vbi cum uentum fuerit, quamlibet sero sit, tamen fit lucernare, fit denuo oratio ad Crucem et dimittitur populus.

32.1. Item alia die, id est secunda feria, aguntur quae consuetudinis sunt de pullo primo agi usque ad mane ad Anastase, similiter et ad tertia et ad sexta aguntur ea, quae totis quadragesimis. Ad nona autem omnes in ecclesia maiore, id est ad Martyrium, colligent se et ibi usque ad horam primam noctis semper ymni et antiphonae dicuntur; lectiones etiam aptae diei et loco leguntur; interpositae semper orationes.

32.2. Lucernarum ${ }^{460}$ etiam agitur ibi, cum ceperit ${ }^{461}$ hora esse; sic est ergo, ut nocte etiam ${ }^{462}$ fiat missa ad Martyrium. Vbi cum factum ${ }^{463}$ fuerit missa, inde cum ymnis ad Anastase ducitur episcopus. In quo autem ingressus fuerit in Anastase, dicitur unus ymnus, fit oratio, benedicuntur cathecumini, item fideles, et fit missa.

33.1. Item tertia feria similiter omnia [65] fiunt sicut secunda feria. Illud solum additur tertia feria, quod nocte sera, posteaquam missa facta fuerit ad Martyrium et itum fuerit ad Anastase et denuo in Anastase missa facta fuerit, omnes illa hora noctu uadent in ecclesia, quae est in monte Eleona.

\footnotetext{
${ }^{459}$ matrone A edd. matronae Gam Geyer Pétré

${ }^{460}$ lucernarum A Gam lucernarium Pom edd.

${ }^{461}$ ceperit $A$ edd. coeperit Geyer Pétré

${ }^{462}$ etiam A edd. iam Wistr Mar Nat MaN

${ }^{463}$ factum A edd. facta Geyer Her Pétré
} 
31.4. E desde o cume do monte até a cidade e daí à Anástase, através de toda a cidade, todos $<$ fazem o trajeto $>$ todo a pé, mas também senhoras distintas ou senhores, se houver, assim acompanham o bispo, respondendo, e assim muito lentamente, ${ }^{169}$ para que o povo não se canse; na verdade, já se chega tarde à Anástase. Logo que se chega, ainda que seja tarde, se faz, contudo, o lucernário, e se faz novamente uma oração na Cruz e o povo se despede.

32.1. Igualmente, no outro dia, isto é, na segunda-feira, fazem-se todas as coisas que são de costume serem feitas desde o primeiro cantar do galo até de manhã, na Anástase. Na terceira e na sexta hora, fazem-se todas as coisas semelhantemente como em toda a Quaresma. Na nona hora, porém, todos se reúnem na igreja maior, isto é, no Martyrium, e aí até a primeira hora da noite são entoados sem interrupção hinos e antífonas; também são feitas leituras apropriadas ao dia e lugar; sempre são interpostas orações.

32.2. Também se faz aí o lucernário quando começa a ser a hora, de modo que a despedida se faz de noite no Martyrium. Assim que se faz a despedida, o bispo é conduzido dali com hinos até a Anástase. Porém, tendo ele entrado na Anástase, entoa-se um hino, faz-se uma oração, benzem-se os catecúmenos, do mesmo modo os fiéis, e se faz a despedida.

33.1. Novamente, na terça-feira, todas as coisas são feitas assim como na segunda-feira. Somente o que se acrescenta na terça-feira é que, tarde da noite, depois de feita a despedida no Martyrium e de se ter ido à Anástase e novamente na Anástase se ter feito a despedida, todos vão nessa hora da noite à igreja que está no monte Eleona.

\footnotetext{
${ }^{169}$ Muito lentamente (lente et lente): a repetição do advérbio lente em lente et lente é um recurso para produzir o superlativo do advérbio, por isso traduzimos como "muito lentamente". A mesma construção ocorre em 3,1; 36,2; 43,6; 43,7.
} 


\section{Maria Cristina Martins}

33. 2. In qua ecclesia cum uentum fuerit, intrat episcopus intra spelunca, in qua spelunca solebat Dominus docere discipulos, et accipit codicem Euangelii, et stans ipse episcopus leget uerba Domini, quae scripta sunt in Euangelio in cata Matheo, id est ubi dicit: ${ }^{464}$ "Videte, ne quis uos seducat". Et omnem ipsam allocutionem perleget episcopus. At autem ${ }^{465}$ ubi illa perlegerit, fit oratio, benedicuntur cathecumini, item et fideles, fit missa et reuertuntur a monte unusquisque ad domum suam satis sera iam nocte.

34. Item quarta feria aguntur omnia per tota die a pullo primo sicut secunda feria et tertia feria, sed posteaquam missa facta fuerit nocte ad Martyrium et deductus fuerit episcopus cum ymnis ad Anastase, statim intrat episcopus in spelunca, quae est in Anastase, et stat intra cancellos; presbyter autem ante cancellum stat et accipit Euangelium et legit illum locum, ubi Iudas Scariothes hiuit ad Iudeos, definiuit ${ }^{466}$ quid ei darent, ut traderet Dominum. Qui locus at ubi lectus fuerit, tantus rugitus et mugitus est totius populi, ut nullus sit, qui moueri non possit in lacrimis in ea hora. Postmodum fit oratio, benedicuntur cathecumini, postmodum fideles et fit missa.

\footnotetext{
${ }^{464}$ dicit corr. ex dicitur A dicitur Gam

${ }^{465}$ autem ubi $A$ Gam ubi autem Geyer edd.

${ }^{466}$ definiuit $A$ edd. et ante definiuit add. Geyer Pétré
} 
33.2. Quando se chega a essa igreja, o bispo entra dentro da gruta na qual o Senhor costumava ensinar os discípulos e toma o livro do Evangelho e, estando de pé, o próprio bispo lê as palavras do Senhor que estão escritas no Evangelho segundo ${ }^{170}$ Mateus, isto é, onde diz: "Vigiai para que ninguém vos seduza" (Mt 24,4). E o bispo lê inteiramente toda essa alocução. Mas, tendo terminado de lê-la, se faz uma oração, benzem-se os catecúmenos, assim como os fiéis, e se faz a despedida, e cada um volta do monte para sua casa bastante tarde, já de noite.

34. Igualmente na quarta-feira, todas as coisas são feitas, durante todo o dia, ${ }^{171}$ desde o primeiro canto do galo, assim como na segunda-feira e terçafeira, mas depois de ter sido feita a despedida de noite no Martyrium e de ter sido conduzido com hinos o bispo à Anástase, imediatamente entra o bispo na gruta que fica na Anástase e fica em pé dentro da balaustrada; e, por outro lado, um presbítero fica em pé diante da balaustrada, toma o Evangelho e lê aquele passo onde Judas Iscariotes foi até os judeus e definiu o que dariam a ele para que entregasse o Senhor (Mt 26,14). Mas quando esse passo foi lido, houve tantos gritos e gemidos que não havia ninguém que não pudesse ficar comovido até as lágrimas naquela hora. Depois se faz uma oração, benzem-se os catecúmenos, depois os fiéis, e é feita a despedida.

\footnotetext{
${ }^{170}$ Segundo Mateus (cata Matheo): nesta ocorrência, cata não possui o valor de pronome indefinido ou distributivo, como em cata singulos ymnos (v. nota 44). Aqui cata está sendo empregado com o sentido de "segundo" ou "conforme", uma vez que no texto jamais aparece iuxta ou secundum Iohannem, por exemplo. Em 37,7, lê-se cata Iohannem, o que mostra a influência da língua grega na liturgia. Vale lembrar que a língua grega era de fato a mais usada no Império Romano do Oriente, além de ser a língua da pregação em geral. Na frase em questão - quae scripta sunt in Euangelio in cata Matheo -, percebe-se que cata Matheo está representando o caso ablativo. No texto, cata rege tanto o acusativo quanto o ablativo, dependendo do que está sendo dito. Obviamente, Egéria ouvia esses usos na pregação. Na Vulgata, São Jerônimo emprega Euangelium secundum Mattheum etc.

${ }^{171} \mathrm{Dia}$ (die): repare-se aqui o acusativo sem o - $m$ final: per tota die em vez de per totam diem. Do ponto de vista do latim clássico, dies “dia”, em seu sentido geral ou comum, a exemplo de como está sendo usado aqui, é um vocábulo do gênero masculino, portanto o correto seria per totum diem (dies indicando um prazo determinado é feminino).
} 
35.1. Item quinta feria aguntur ea de pullo primo quae consuetudinis est usque ad mane ad Anastase; similiter ad tertia et ad sexta. Octaua autem hora iuxta consuetudinem ad Martyrium colliget se omnis populus, propterea autem temporius quam ceteris diebus, quia citius missa fieri necesse est. Itaque ergo collecto omni populo aguntur, quae agenda sunt; fit ipsa die oblatio ad Martyrium et facitur missa hora forsitan decima ibidem. Antea ${ }^{467}$ autem quam fiat missa, mittet uocem archidiaconus et dicet: "Hora prima noctis omnes in ecclesia, quae est in Eleona, conueniamus, quoniam maximus labor nobis instat hodie nocte ista".

35. 2. Facta ergo missa Martyrii uenit ${ }^{468}$ post Crucem, dicitur ibi unus ymnus tantum, fit oratio et offeret episcopus ibi oblationem et communicant omnes. Excepta enim ipsa die una, per totum annum nunquam offeritur post Crucem nisi ipsa die tantum. Facta ergo et ibi missa, itur ad Anastase, fit oratio, benedicuntur iuxta consuetudinem cathecumini et sic fideles et fit missa. Et sic unusquisque festinat reuerti in domum suam, ut manducet, quia statim ut manducauerint, omnes uadent in Eleona in ecclesia ea, in qua est spelunca, in qua ipsa die Dominus cum apostolis fuit.

35.3. Et ibi usque ad hora noctis forsitan quinta semper aut ymni aut antiphonae apte ${ }^{469}$ diei et loco, similiter et lectiones dicuntur; interpositae orationes fiunt; loca etiam ea de Euangelio leguntur, in quibus Dominus allocutus est discipulos eadem die sedens in eadem spelunca, quae in ipsa ecclesia est.

35.4. Et inde iam hora noctis forsitan sexta itur susu in Imbomon cum ymnis in eo loco unde ascendit Dominus in caelis. [66] Et ibi denuo similiter lectiones et ymni et antiphonae aptae diei dicuntur; orationes etiam ipsae quecumque ${ }^{470}$ fiunt, quas dicet episcopus, semper et diei et loco aptas dicet.

\footnotetext{
${ }^{467}$ antea $A$ edd. ante Löfst FrW Mar Nat Jan

${ }^{468}$ uenit $A$ Gam uenitur Pom edd.

${ }^{469}$ apte $A$ edd. aptae Gam Geyer Pétré

${ }^{470}$ quecumque $A$ edd. quaecumque Gam Geyer Pétré
} 
35.1. Do mesmo modo, na quinta-feira, desde o primeiro cantar do galo, são feitas essas coisas as quais são de costume <serem feitas> até de manhã na Anástase, semelhantemente na terceira e na sexta hora. Porém, na hora oitava, conforme o costume, todo o povo se reúne no Martyrium, porém um pouco mais cedo, porque é necessário que a despedida seja feita mais depressa. E assim, pois, com todo o povo reunido, são feitas aquelas coisas que devem ser feitas; no mesmo dia, se faz uma oblação no Martyrium e é feita a despedida no mesmo lugar, talvez na hora décima. Porém, antes que seja feita a despedida, o arquidiácono eleva a voz e diz: "Na primeira hora da noite, encontremo-nos todos na igreja que fica no Eleona, porque hoje de noite nos espera uma grande fadiga".

35.2. Feita, pois, a despedida do Martyrium, vai-se para detrás da Cruz, se entoa aí apenas um hino, se faz uma oração, e o bispo oferece aí a oblação, e todos comungam. De fato, com exceção desse único dia, durante todo o ano nunca se oferece <a oblação $>$ atrás da Cruz, a não ser somente nesse próprio dia. Feita, pois, também aí a despedida, vai-se até a Anástase, se faz uma oração, benzem-se os catecúmenos, conforme o costume, e assim os fiéis, e é feita a despedida. E assim, cada um se apressa para voltar à sua casa para comer, porque, logo que tiverem comido, todos vão ao Eleona, àquela igreja na qual fica a gruta em que, nesse mesmo dia, o Senhor esteve com os apóstolos.

35.3. E nesse lugar, até talvez a quinta hora da noite, sempre são entoados hinos e antífonas apropriados ao dia e ao lugar e igualmente <são feitas> leituras; fazem-se orações intercaladas; também são lidos aqueles passos do Evangelho nos quais o Senhor falou aos discípulos, nesse mesmo dia, sentado nessa mesma gruta, que fica na própria igreja.

35.4. E daí, talvez já na sexta hora da noite, se vai para cima, para o Imbomon, com hinos, àquele local de onde o Senhor ascendeu aos céus. E aí, de novo, igualmente $<$ são feitas $>$ leituras e entoados hinos e antífonas apropriados ao dia; também são feitas as mesmas orações, sejam quais forem, as que diga o bispo, sempre também apropriadas ao dia e ao lugar. 
36.1. Ac sic ergo cum ceperit ${ }^{471}$ esse pullorum cantus, descenditur de Imbomon cum ymnis et accedit ${ }^{472}$ eodem $^{473}$ loco ubi orauit Dominus, sicut scriptum est in Euangelio: "Et accessit quantum iactum ${ }^{474}$ lapidis et orauit" et cetera. In eo enim loco ecclesia est elegans. Ingreditur ibi episcopus et omnis populus, dicitur ibi oratio apta loco et diei, dicitur etiam unus ymnus aptus et legitur ipse locus de Euangelio, ubi dixit discipulis suis: "Vigilate, ne intretis in temptationem". Et omnis ipse locus perlegitur ibi et fit denuo oratio.

36.2. Et iam ${ }^{475}$ inde cum ymnis usque ad minimus ${ }^{476}$ infans in Gessamani pedibus cum episcopo descendent, ubi prae $\mathrm{e}^{477} \mathrm{tam}^{478}$ magna turba multitudinis et fatigati de uigiliis et ieiuniis cotidianis lassi, quia tam magnum montem necesse habent descendere, lente et lente cum ymnis uenitur in Gessamani. Candelae autem ecclesiasticae super ducente ${ }^{479}$ paratae sunt propter lumen omni populo.

36.3. Cum ergo peruentum fuerit in Gessamani, fit primum oratio apta, sic dicitur ymnus; item legitur ille locus de Euangelio ubi comprehensus est Dominus. Qui locus ad quod lectus fuerit, tantus rugitus et mugitus totius populi est cum fletu, ut forsitan porro ad ciuitatem gemitus populi omnis auditus sit. Et iam ${ }^{480}$ ex illa hora hitur ad ciuitatem pedibus cum ymnis, peruenitur ad portam ea hora qua incipit quasi homo hominem cognoscere; inde totum per mediam ciuitatem omnes usque ad unum, maiores atque minores, diuites, pauperes, toti ibi parati, specialiter illa die nullus recedit a uigiliis usque in mane. Sic deducitur episcopus a Gessemani usque ad portam ${ }^{481}$ et inde per totam ciuitate ${ }^{482}$ usque ad Crucem.

36.4. Ante Crucem autem at ubi uentum fuerit, iam lux quasi clara incipit esse. Ibi denuo legitur ille locus de Euangelio ubi adducitur Dominus ad Pilatum, et omnia, quaecumque scripta sunt Pilatum ad Dominum dixisse aut ad Iudeos, totum legitur.

\footnotetext{
${ }^{471}$ ceperit $A$ edd. coeperit Geyer Pétré

${ }^{472}$ accedit $A$ Gam acceditur Chol edd.

${ }^{473}$ eodem corr. ex eadem $A$

${ }^{474}$ iactum $A$ edd. iactus $G^{2}{ }^{2}$ Geyer Her Pétré

${ }^{475}$ etiam uel et iam A etiam Gam et iam Geyer edd.

${ }^{476}$ minimus $A$ edd. minimum Gam

${ }^{477}$ prae $A \mathrm{Gam}^{2}$ Geyer Pétré Her Prinz pre Gam ${ }^{1}$ FrW Arce Mar Jan Nat MaN

478 tam $A$ edd. iam Prinz

${ }^{479}$ ducente $A$ edd. ducentae Gam Geyer Her Pétré

${ }^{480}$ etiam uel et iam $A$ etiam Gam et iam Geyer $e d d$.

${ }^{481}$ ad portam corr. ex ad crucem portam $A$

${ }^{482}$ ciuitate $A$ edd. ciuitatem Gam Geyer Pétré Arce
} 
36.1. E assim, pois, quando começa o canto dos galos, desce-se do Imbomon com hinos e se chega ao mesmo lugar onde orou o Senhor, assim como está escrito no Evangelho: "E avançou o tanto de um arremesso de pedra e orou" (Lc 22,41) et cetera. De fato, naquele local há uma bela igreja. O bispo entra aí e também todo o povo; faz-se aí uma oração apropriada ao lugar e ao dia, é entoado também um hino apropriado e é lido esse mesmo passo do Evangelho onde o Senhor disse: "Vigiai para que não entreis em tentação" (Mt 26,41; Mc 14,38). E todo esse passo é lido inteiramente aí, e se faz de novo uma oração.

36.2. E logo, daí, com hinos, descem com o bispo a pé, até mesmo a menor criança, a Getsêmani*. Por causa de tão grande quantidade de pessoas fatigadas pelas vigílias e cansadas pelos jejuns cotidianos, e porque eles têm necessidade de descer um monte tão grande, se chega aí ${ }^{172}$ com hinos muito lentamente a Getsêmani. As velas da igreja, acima de duzentas, são preparadas para dar luz a todo o povo.

36.3. Quando, pois, se tiver chegado a Getsêmani, se faz primeiramente uma oração apropriada, então ${ }^{173}$ se entoa um hino; igualmente se lê aquele passo do Evangelho onde foi preso o Senhor (Mt 26,47-56). E no momento em que foi lido esse passo, houve tantos gritos e gemidos de todo o povo em lágrimas, que o pranto de todo o povo talvez tenha sido ouvido ao longe, até a cidade. E já desde aquela hora se vai até a cidade a pé com hinos; chega-se à porta $<$ da cidade $>$ naquela hora em que um homem quase começa a reconhecer o outro; daí, <fazem> todo <o caminho> pelo meio da cidade, todos, sem exceção, os mais velhos e os mais moços, ricos, pobres, todos aí preparados, ninguém volta das vigílias nesse dia até de manhã. Assim, o bispo é conduzido de Getsêmani até a porta, e daí, por toda a cidade, até a Cruz.

36.4. Mas quando se chega diante da Cruz já começa a ser quase dia claro. Aí de novo é lido aquele passo do Evangelho onde o Senhor é conduzido até Pilatos, e tudo o que está escrito ter dito Pilatos ao Senhor e aos judeus (Mt 27,2; Mc 15,1).

\footnotetext{
${ }^{172}$ Aí (ubi): este ubi parece estar sendo empregado no lugar de eo "aí", "lá".

${ }^{173}$ Então (sic): como observado por Väänänen (1987, p.115), o advérbio sic toma, muitas vezes, uma nuance temporal, como nesta ocorrência. Sic se repete ao longo da segunda parte da obra com o valor temporal, como na expressão benedicuntur cathecumini et sic fideles $(43,9)$ e benedicuntur iuxta consuetudinem cathecumini et sic fideles et fit missa $(25,2)$.
} 


\section{Maria Cristina Martins}

36.5. Postmodum autem alloquitur episcopus populum confortans eos, quoniam et tota nocte laborauerint et adhuc laboraturi sint ipsa die, ut non lassentur, sed habeant spem in Deo, qui eis pro eo labore maiorem mercedem redditurus sit. Et sic confortantes ${ }^{483}$ eos, ut potest ipse, alloquens dicit eis: "Ite interim nunc unusquisque ad domumcellas uestras, sedete uobis et modico, ${ }^{484}$ et ad horam prope secundam diei omnes parati estote hic, ut de ea hora usque ad sextam ${ }^{45}$ sanctum lignum crucis possitis uidere ad salutem sibi unusquisque nostrum credens profuturum. De hora enim sexta denuo necesse habemus hic omnes conuenire in isto loco, id est ante Crucem, ut lectionibus et orationibus usque ad noctem operam demus".

37.1. Post hoc ergo missa [67] facta de Cruce, id est antequam sol procedat, statim unusquisque animosi uadent in Syon orare ad columnam illam, ad quem ${ }^{486}$ flagellatus est Dominus. Inde reuersi sedent modice in domibus suis et statim toti parati sunt. Et sic ponitur cathedra episcopo in Golgotha post Crucem, quae ${ }^{487}$ stat nunc; residet episcopus in cathedra; ponitur ante eum mensa sublinteata; stant in giro mensa ${ }^{488}$ diacones et affertur loculus argenteus deauratus, in quo est lignum sanctum crucis, aperitur et profertur, ponitur in mensa tam lignum crucis quam titulus.

\footnotetext{
${ }^{483}$ confortantes $A$ confortans Gam edd.

${ }^{484}$ et modico <resumite uos > coni. Geyer (in nota) ad modico coni. Her (in nota)

${ }^{485}$ sextam $A$ edd. sexta Gam Geyer Her Pétré

${ }^{486}$ quem A edd. quam Gam Geyer Pétré Arce

${ }^{487}$ quae $A$ edd. qua Bast Mar

${ }^{488}$ mensa $A$ edd. mensae Gam
} 
36.5. Logo, porém, o bispo fala ao povo, confortando-o, por terem sofrido toda a noite e porque ainda haveriam de sofrer naquele dia, para que não se deixassem abater, mas que tivessem esperança em Deus, o qual haveria de retribuir-lhes uma recompensa maior por esse esforço. E assim, confortandoos como ele próprio pode, falando lhes diz: "Ide, por enquanto, agora, cada um para a vossa casinha, repousai um pouco e, perto da segunda hora do dia, estai todos prontos aqui, de modo que, a partir dessa hora até a sexta, possais ver o santo lenho da cruz, cada um de nós crendo que isso há de ser útil para a salvação de si. De fato, desde a hora sexta, novamente temos necessidade de todos nos encontrarmos aqui neste local, isto é, diante da Cruz, para que nos dediquemos às leituras e às orações até a noite".

37.1. Depois disso, pois, feita a despedida da Cruz, isto é, antes de o sol nascer, imediatamente todos, estando animados, vão a Sião orar junto àquela coluna na qual o Senhor foi flagelado. Tendo voltado daí, repousam um pouco em suas casas e logo todos estão preparados. E assim, põe-se uma cadeira para o bispo no Gólgota, atrás da Cruz, que agora está fixada; o bispo senta-se na cadeira; é posta diante dele uma mesa coberta ${ }^{174}$ com pano de linho; os diáconos ficam em pé em volta da mesa, e é trazido um relicário de prata dourado, no qual está o santo lenho da cruz; < o relicário > é aberto e exposto, <e > põe-se na mesa tanto o lenho da cruz quanto a inscrição. ${ }^{175}$

\footnotetext{
${ }^{174}$ Coberta (sublinteata) : linteatus, - $a$, -um é um adjetivo derivado de linteum "linho", daí "coberto de linho". Sublinteata refere-se à mesa que está "sob uma toalha de linho". Há que chamar atenção que o foco recai na mesa, a qual está embaixo de uma toalha de linho. Não encontramos esse adjetivo nos dicionários de latim clássico consultados. É provável que se trate de um neologismo de Egéria, pois em 37,4 temos subdiuanus, formado a partir da expressão sub diuo (do subst. Subdiuum, "ao ar livre"), com o acréscimo do sufixo -anus, bastante popular. Em outros autores tardios, encontra-se a forma subdiualis.

${ }^{175}$ Inscrição (titulus): a palavra titulus em latim clássico significa "inscrição", "título de um livro", "rótulo de garrafa de vinho", "escrito ou plaquinha pendurada no pescoço de um escravo", "epitáfio de um túmulo", "título de honra de nobreza". Na primeira parte da obra, essa palavra aparece em 12,6, onde tem o sentido de "pedra monumental", "obelisco", "estátua" (v. nota 66). Aqui, porém, a significação recai mais sobre a inscrição que puseram sobre a cabeça de Jesus do que sobre o material onde a mesma foi grafada. O uso de titulus por Egéria é uma referência à passagem de Mateus 27,37: Et inposuerunt super caput eius causam ipsius scriptam hic est Iesus rex Iudaeorum (Vulgata).
} 
37.2. Cum ergo positum fuerit in mensa, episcopus sedens de manibus suis summitates de ligno santo premet, diacones autem, qui in giro stant, custodent. ${ }^{499}$ Hoc autem propterea sic custoditur, quia consuetudo est ut unus et unus omnis populus ueniens, tam fideles quam cathecumini, acclinant ${ }^{490}$ se ad mensam, osculentur sanctum lignum et pertranseant. Et quoniam nescio quando dicitur quidam fixisse morsum et furasset ${ }^{491}$ sancto ligno, ideo nunc a diaconibus, qui in giro stant, sic custoditur, ne qui ueniens audeat denuo sic facere.

37.3. Ac sic ergo omnis populus transit unus et unus toti acclinantes se, primum de fronte, sic de oculis tangentes crucem et titulum, et sic osculantes crucem pertranseunt ${ }^{492}$, manum autem nemo mittit ad tangendum. At ubi autem osculati fuerint crucem, pertransierint ${ }^{493}$, stat diaconus, tenet anulum Salomonis et cornu illud, de quo reges unguebantur. Osculantur et cornu, attendunt ${ }^{494}$ et anulum ${ }^{495}$ [lacuna] minus secunda [lacuna] usque ad horam sextam omnis populus transit, per unum ostium intrans, per alterum per alterum ${ }^{496}$ perexiens, quoniam hoc in eo loco fit, in quo pridie, id est quinta feria, oblatio facta est.

\footnotetext{
${ }^{489}$ custodent corr. ex custodeant $A$

${ }^{490}$ acclinant $A$ Gam acclinantes Geyer edd.

${ }^{491}$ furasset $A$ Gam furasse de Pom edd.

${ }^{492}$ pertranseunt corr. ex pertranseant $A$

${ }^{493}$ pertransierint $A$ edd. et ante pertransierint add. Chol Geyer Pétré

${ }^{494}$ attendunt corr. ex attendent $A$ attendent Gam

${ }^{495}$ post anulum lacunam circa 12 litteras, post secunda lacunam ca. 7 litt. exhibet $A$ feria post secunda deleta est $A$ anulum de hora plus minus secunda ac sic ergo usque rest. FrW Arce

${ }^{496}$ per alterum bis scriptum A Gam per alterum semel scriptum Geyer edd.
} 
37.2. Depois de ter sido colocado na mesa, o bispo, sentado, aperta com as suas mãos ${ }^{176}$ as extremidades do santo lenho; ${ }^{177}$ por sua vez, os diáconos que estão de pé ao redor o vigiam. De fato, este é assim vigiado porque é costume que, vindo um a um, todo o povo, tanto os fiéis quanto os catecúmenos, inclinem-se ${ }^{178}$ à mesa, beijem o santo lenho e sigam adiante. E porque se diz alguém ter cravado, não sei quando, uma mordida, e ter roubado < um pedaço $>$ do santo lenho, por isso agora ele é guardado pelos diáconos, os quais ficam em pé à volta, para que ninguém, ao chegar $<$ perto $>$, ouse novamente proceder assim.

37.3. E assim, pois, todo o povo passa, um por um, todos se inclinando, primeiro tocando com a testa e depois com os olhos, a cruz e a inscrição, e assim beijando a cruz, passam adiante, porém ninguém põe a mão para tocá-la. Mas, quando tiverem beijado a cruz e tiverem passado adiante, um diácono fica em pé, segura o anel de Salomão e aquela âmbula ${ }^{179}$ a partir da qual os reis eram ungidos. Não só beijam a âmbula, mas também veneram o anel [lacuna] menos na segunda [lacuna] até a sexta hora todo o povo passa, entrando por uma porta e saindo por outra, porque isso é feito naquele local, no qual na véspera, isto é, na quinta-feira, foi feita uma oblação.

\footnotetext{
${ }^{176}$ Com as suas mãos (de manibus suis): de manibus suis é um ablativo de meio, também chamado de ablativo de instrumento, o qual em latim clássico era construído sem preposição. Esse exemplo mostra, mais uma vez, a extensão de uso das preposições no latim popular. Além dessa ocorrência, temos outros dois ablativos de valor instrumental em 37,3: de fronte, sic de oculis.

${ }^{177}$ Do santo lenho (de ligno sancto): de ligno sancto é um partitivo formado com de + ablativo em concorrência com o genitivo, embora falte o termo que denota a parte que foi destacada do todo.

${ }^{178}$ Inclinem-se (acclinant se): traduzimos o presente do indicativo como presente do subjuntivo, para que haja correlação sintática com o presente do subjuntivo osculentur. Assim, interpretamos que aqui deveria estar escrito acclinent. Todos os outros editores, exceto Gamurrini, optaram pela conjectura de Geyer, que é a correção para o particípio presente acclinantes, em correlação sintática com ueniens.

${ }^{179}$ Âmbula (cornu): cornus, -us ou cornu, - $u$ ou cornu, -us é um substantivo neutro que significa "corno" ou "chifre" e, por extensão, pode representar tudo o que é análogo a um corno, ou pela forma ou pela substância. Neste caso, foi traduzido por "âmbula", que é o recipiente utilizado na liturgia para guardar os santos óleos. "Âmbula", por sua vez, vem de ampulla, que deu também "ampula" e "ampola", em português, e ampulle, em francês, por exemplo.
} 
37.4. At ubi autem sexta hora se fecerit, sic itur ante Crucem, siue pluuia siue estus ${ }^{497}$ sit, quia ipse locus subdiuanus est, id est quasi atrium ualde grandem ${ }^{498}$ et pulchrum satis, quod est inter Cruce et Anastase. Ibi ergo omnis populus se colliget, ita ut nec aperiri possit.

37.5. Episcopo autem cathedra ponitur ante Cruce, et de sexta usque ad nona aliud nichil fit nisi leguntur lectiones sic: id est ita legitur primum de psalmis, ubicumque de passione dixit; legitur et de apostolo ${ }^{499}$ siue de epistolis apostolorum uel de actionibus, ubicumque de passione Domini dixerunt: nec non et de Euangeliis leguntur loca, ubi patitur; item legitur de prophetis, ubi passurum Dominum dixerunt; item legitur de Euangeliis, ubi passionem $^{500}$ dicit.

37.6. Ac sic ab hora sexta usque ad horam nonam semper sic leguntur lectiones aut dicuntur ymni, ut ostendatur omni populo quia, quicquid dixerunt prophetae futurum de passione Domini, ostendatur tam per Euangelia quam etiam per apostolorum scripturas factum esse. Et sic per illas tres horas docetur populus omnis nichil factum esse, quod non prius dictum sit, et nichil dictum esset $^{501}$, quod non totum completum sit. [68] Semper autem interponuntur orationes, quae orationes et ipsae apte $\mathrm{e}^{502}$ diei sunt.

\footnotetext{
${ }^{497}$ estus $A$ edd. aestus Geyer Pétré

${ }^{498}$ grandem $A$ edd. grande Gam $^{1}$ Geyer Pétré

${ }^{499}$ apostolo $A$ edd. apostolis Geyer Pétré

${ }^{500}$ passionem $A$ edd. de passione Geyer Pétré

${ }^{501}$ esset $A$ esse $\mathrm{Gam}^{2}$ edd.

${ }^{502}$ apte $A$ edd. aptae Gam Geyer Pétré
} 
37.4. Mas, quando tiver chegado a hora sexta, assim se vai diante da Cruz, quer faça chuva, quer calor ardente, porque o próprio lugar é ao ar livre, isto é, como que um átrio muito grande e bastante belo, que está entre a Cruz e a Anástase. Aí, pois, todo o povo se reúne de tal maneira que não se pode abrir $<$ caminho $>{ }^{180}$

37.5. Põe-se uma cadeira para o bispo diante da Cruz, e da sexta até a nona hora não se faz nenhuma outra coisa a não ser as leituras que se fazem assim: lê-se, primeiramente, a partir dos salmos, onde quer que se tenha falado sobre a Paixão; lê-se também a partir do Apóstolo ou das Epístolas dos apóstolos ou dos Atos dos Apóstolos, em todo lugar que tenham falado da Paixão do Senhor: e também são lidos aqueles passos dos Evangelhos onde sofreu $<0$ Senhor $>$; igualmente se leem $<$ os trechos $>$ dos profetas onde disseram que o Senhor sofreria a Paixão; igualmente se leem $<$ os trechos $>$ dos Evangelhos onde se relata a Paixão.

37.6. E assim, desde a hora sexta até a hora nona, sempre deste modo fazem-se leituras e entoam-se hinos, para que se mostre a todo o povo que os profetas disseram tudo o que haveria de suceder a respeito da Paixão do Senhor, e para que se mostre tanto pelos Evangelhos, como também pelas escrituras dos apóstolos, isso ter sido realizado. $\mathrm{E}$ assim, durante aquelas três horas, todo o povo é instruído de que nada foi feito que não tenha sido dito antes, e de que nada foi dito que não tenha sido inteiramente cumprido. Sempre se interpõem orações; essas orações são também elas mesmas apropriadas ao dia.

\footnotetext{
${ }^{180}$ Aí, pois, todo o povo se reúne, de tal maneira que não se pode abrir <caminho> (Ibi ergo omnis populus se colliget, ita ut nec aperiri possit): ita ut nec aperire possit é uma oração em que não há sujeito sintático. Alguns editores interpretam o sujeito omitido como se referindo às portas, como Maraval, Mariano e Pétré, cujas traduções são: "Tout le peuple y afflue de telle manière qu'on ne peut plus en ouvrir les portes" (Maraval), “(...) qu’on ne peut même plus ouvrir les portes” (Pétré) e “(...) de tal maneira que não se podem abrir as portas” (Mariano). Por outro lado, Arce e Janeras traduzem como "de modo que ni pasar se puede" e "de tal manera que hom no pot obrir-se pas", interpretando a omissão do sujeito como indeterminação do mesmo. Natalucci traduz como "cosicché non è più praticabile". Interpretamos que há a ausência da palavra iter na frase, pois aperire iter "abrir caminho" é uma expressão clássica (cf. Salústio, De coniuratione Catilinae, 58, 7; Tito Lívio, Ab Vrbe Condita, 7, 33, 11).
} 
37.7. Ad singulas autem lectiones et orationes tantus affectus et gemitus totius populi est, ut mirum sit; nam nullus est neque maior neque minor, qui non ${ }^{503}$ illa die illis tribus horis tantum ploret, quantum nec extimari ${ }^{504}$ potest, Dominum pro nobis ea passum fuisse. Post hoc cum coeperit ${ }^{505}$ se iam hora nona facere, legitur iam ille locus de Euangelio cata Iohannem, ubi reddidit spiritum; quo lecto iam fit oratio et missa.

37.8. At ubi autem missa facta fuerit de ante Cruce, statim omnes ${ }^{506}$ in ecclesia maiore ad Martyrium aguntur ${ }^{507}$ ea, quae per ipsa septimana de hora nona, qua ad Martyrium conuenitur, consueuerunt agi usque ad sero per ipsa septimana. Missa autem facta de Martyrium uenitur ad Anastase. Et ibi cum uentum fuerit, legitur ille locus de Euangelio ubi petit corpus Domini Ioseph a Pilato, ponet ${ }^{508}$ illud in sepulcro nouo. Hoc autem lecto fit oratio, benedicuntur cathecumini, sic fit missa. ${ }^{509}$

37.9. Ipsa autem die non mittitur uox ut peruigiletur ad Anastase, quoniam scit populum fatigatum esse; sed consuetudo est ut peruigiletur ibi. Ac sic qui uult de populo, immo qui possunt, uigilant; qui autem non possunt, non uigilant ibi usque in mane, clerici autem uigilant $\mathrm{ibi}^{5}{ }^{510}$ id est qui aut ${ }^{511}$ fortiores sunt aut iuueniores; et tota nocte dicuntur ibi ymni et antiphonae usque ad mane. Maxima autem turba peruigilant alii de sera, alii de media nocte, qui ut possunt.

\footnotetext{
${ }^{503}$ non $A$ edd. in Gam

${ }^{504}$ extimari $A$ edd. existimari Gam aestimari Geyer Pétré

${ }^{505}$ coeperit $A$ edd. ceperit Gam

${ }^{506}$ omnes A edd. omnia Gam

${ }^{507}$ aguntur A Gam ... aguntur Geyer Pétré procedunt et aguntur coni. Geyer (in nota) Her

Prinz conueniunt et aguntur FrW Arce Mar Jan Nat MaN

${ }^{508}$ ponet $A$ edd. et ante ponet add. Gam Geyer Pétré

${ }^{509}$ sic fit missa A Gam Geyer Her Pétré FrW Arce sic < fideles ac sic> fit missa Chol Prinz

Mar Jan Nat sic <fideles ac> fit missa Wistr MaN

${ }^{510}$ ibi om. Nat MaN

${ }^{511}$ qui aut uel quia ut $A$ quia ut Gam qui aut Geyer edd.
} 
37.7. Porém, a cada uma das leituras e orações, há tanto sentimento e gemido de todo o povo, que é admirável; não há ninguém, grande ou pequeno, que não chore, naquele dia, naquelas três horas, tanto quanto o que se possa estimar ter o Senhor sofrido por nós. ${ }^{181}$ Depois disto, como já começasse a se fazer a hora nona, lê-se logo aquele passo do Evangelho segundo João onde <o Senhor > entregou o espírito (Jo 19,30); lido isso, logo é feita uma oração e a despedida.

37.8. E, logo que a despedida tiver sido feita diante da Cruz, imediatamente todos se encontram na igreja maior, no Martyrium, e é feito aquilo que, durante essa semana, desde a nona hora, quando todos se encontram no Martyrium, costumava ser feito até tarde durante essa semana. Feita a despedida do Martyrium, vai-se à Anástase. E, quando se tiver chegado aí, lê-se aquele passo do Evangelho onde José $^{182}$ pede o corpo do Senhor a Pilatos e o põe num sepulcro novo. Lido esse passo, faz-se uma oração, benzem-se os catecúmenos; em seguida, se faz a despedida.

37.9. Nesse mesmo dia, porém, não se anuncia que se vele na Anástase, porque se sabe que o povo está fatigado, mas é costume que se vele aí. E assim, aquele que dentre o povo deseja, ou melhor, aqueles que podem, velam; os que, entretanto, não podem, não velam aí até de manhã; os clérigos, por outro lado, velam aí, isto é, aqueles que são mais fortes ou mais jovens; e durante toda a noite são entoados hinos e antífonas até de manhã. Uma multidão numerosíssima vela: uns desde a tarde e outros desde a meia-noite, cada $\mathrm{um}^{183}$ como pode.

\footnotetext{
${ }^{181}$ Por nós (pro nobis): a preposição per do latim passou para o português, mas, contraída com os artigos, resultou em pelo e pela. Pro, por influência de per, passou a por, que, contraído com o artigo, no português arcaico gerou pôlo e pola. Porém, no português moderno, a contração de por com o artigo definido origina, igualmente, pelo e pela, o que faz com que não fique clara a sua origem etimológica - per "através de"; pro "a favor de", "em lugar de". Väänänen (1987, p.43) observa que Egéria emprega pro em substituição a $o b$ ou propter para indicar causa ou motivo, como nesta ocorrência, e em 25,6: pro monazontes, qui pedibus uadent, necesse est lenius iri, "por causa dos monazontes, que vão a pé, é necessário ir-se mais lentamente" (temos o mesmo sentido em 5,10 e 25,12). Väänänen aponta ainda outros sentidos de pro: em 3,6 statim sancti monachi pro diligentia sua arbusculas ponunt, onde teria o sentido de "segundo", "conforme", "na medida de", e em 20,8 (...) attendimus locum illum, ubi primitus domus sancti Abrahae fuit, pro memoria illius, em que adquire um sentido final, como também em 24,8.

${ }^{182}$ José (Ioseph): conforme Jo 19,38-42, José de Arimateia pede o corpo de Jesus a Pilatos para sepultá-lo.

${ }^{183}$ Cada um (qui): o qui desta frase foi interpretado como unusquisque, a partir dos seguintes testemunhos: 25,7 petierunt (...) unusquisque eorum monasteria sua, qui ubi habebat; 43,4 unusquisque quomodo potest, "cada um do modo que pode"; 44,1 omnes ieiunant (...), qui pro ut potest; 44,3 aputactitae omnes uadent, de plebe autem qui quomodo possunt uadent (VÄÄNÄNEN, 1987, p.54).
} 
38.1. Sabbato autem alia die iuxta consuetudinem fit ad tertia, item fit ad sexta; ad nonam autem iam non fit sabbato, sed parantur uigiliae paschales in ecclesia maiore, id est in ${ }^{512}$ Martyrium. Vigiliae autem paschales sic fiunt, quemadmodum ad nos; hoc solum hic amplius fit, quod infantes, cum baptidiati fuerint et uestiti, quemadmodum exient ${ }^{513}$ de fonte, simul cum episcopo primum ad Anastase ducuntur.

38.2. Intrat episcopus intro cancellos Anastasis, dicitur unus ymnus, et sic facit orationem episcopus pro eis, et sic uenit ad ecclesiam maiorem cum eis, ubi iuxta consuetudinem omnis populus uigilat. Aguntur ibi quae consuetudinis est etiam et aput nos, et facta oblatione fit missa. Et post facta missa uigiliarum in ecclesia maiore, statim cum ymnis uenitur ad Anastase et ibi denuo legitur ille locus Euangelii resurrectionis, fit oratio et denuo ibi offeret episcopus; sed totum ad momentum fit propter populum, ne diutius tardetur, et sic iam dimittetur populus. Ea autem hora fit missa uigiliarum ipsa die, qua hora et aput nos. ${ }^{514}$

39.1. Sero ${ }^{515}$ autem illi dies paschales sic attenduntur, quemadmodum et ad nos, et ordine suo fiunt missae per octo dies paschales, sicut et ubique fit per Pascha usque ad octauas. Hic autem ipse ornatus est et ipsa compositio et per octo dies Paschae, quae et per Epiphania, tam in ecclesia maiore quam ad Anastase aut ad Crucem uel [69] in Eleona, sed et in Bethleem nec non etiam in Lazariu uel ubique, quia dies paschales sunt.

\footnotetext{
${ }^{512}$ in $A$ edd. ad Arce

${ }^{513}$ exient corr. ex exent $A$ exierint Geyer Her Pétré

${ }^{514}$ aput nos $A$ edd. aput nos sero $M a N$

${ }^{515}$ sero A Gam Geyer Her Pétré FrW Arce octo Wistr Prinz Mar MaN uerum Devos Jan Nat
} 
38.1. No outro dia, no sábado, porém, <tudo > é feito segundo o costume na terceira hora, bem como na sexta hora; por outro lado, no sábado, já não se faz na nona hora, mas se preparam as vigílias pascais na igreja maior, isto é, no Martyrium. As vigílias pascais são feitas assim como entre nós, apenas isto que aqui se faz a mais, que os neófitos, ${ }^{\star} 184$ logo que tiverem sido batizados e vestidos, quando saem da fonte, em primeiro lugar são conduzidos juntamente com o bispo até a Anástase.

38.2. Entra o bispo para dentro da balaustrada da Anástase, é cantado um hino e assim o bispo faz uma oração em favor desses <neófitos> e assim chega à igreja maior com eles, onde, conforme o costume, todo o povo vela. Faz-se aí o que é de costume também entre nós e, feita a oblação, se faz a despedida. E depois de feita a despedida das vigílias na igreja maior, imediatamente se chega à Anástase com hinos e aí de novo se lê aquele passo do Evangelho sobre a Ressurreição (Mt 28,5-7; Jo 20,1-10; Mc 16,5-7; Lc 24,3-8), faz-se uma oração e novamente aí o bispo oferece <a oblação>; mas tudo se faz prontamente por causa do povo, para que não se demore por mais tempo, para que assim o povo seja dispensado. Nessa hora, pois, é feita a despedida das vigílias nesse dia, na mesma hora que entre nós.

39.1. Na verdade, entretanto, esses dias pascais são celebrados assim como entre nós e, conforme o costume, realizam-se as missas durante os oito dias pascais, assim como também em todo lugar é feito durante a Páscoa até as

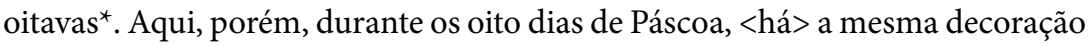
e a mesma organização ${ }^{185}$ que $<$ há $>$ também durante a Epifania, tanto na igreja maior, como na Anástase, e na Cruz e no Eleona, ${ }^{186}$ mas também em Belém e no Lazário e em todo lugar, porque são dias pascais.

\footnotetext{
${ }^{184}$ Neófitos (infantes): aqui, assim como em 39,3, infantes tem o sentido de "neófitos", ou seja, são os "recém-batizados" ou as "crianças da fé", independentemente da idade. Porém, em algumas passagens, a palavra infans (pl. infantes) é usada em seu sentido primitivo, ou seja, "criança" em geral. Etimologicamente, infans significa "aquele que não fala”. Ver, no Glossário, neófito.

185 Organização (compositio): de acordo com Blaise (1954, p.184), a palavra compositio, nesta ocorrência, toma o sentido de "organização <de uma festa>". Outros editores, porém, traduziram-na, conforme o idioma, como ornamentação, arreglo, ordonnance, preparazione. ${ }^{186}$ E na Cruz e no Eleona (aut ad Crucem uel in Eleona): segundo Väänänen, aut e uel não são conjunções de valor disjuntivo nesta ocorrência, mas de valor copulativo. V. notas 55, 67, 102, 144.
} 
39.2. Proceditur autem ipsa die dominica prima in ecclesia maiore, id est ad Martyrium, et secunda feria et tertia feria, ubi ita tamen, ut semper missa facta de Martyrio ad Anastase ueniatur cum ymnis. Quarta feria autem in Eleona proceditur, quinta feria ad Anastase, sexta feria in Syon, sabbato ante Cruce, dominica autem die, id est octauis, denuo in ecclesia maiore, id est ad Martyrium.

39.3. Ipsis autem octo diebus paschalibus cotidie post prandium episcopus cum omni clero et omnibus infantibus, id est qui baptidiati fuerint, et omnibus, qui aputactitae sunt, uiri ac feminae, nec non etiam et de plebe quanti uolunt, in Eleona ascendent. Dicuntur ymni, fiunt orationes tam in ecclesia, quae in Eleona est, in qua est spelunca, in qua docebat Iesus discipulos, tam etiam in Imbomon, id est in eo loco, de quo Dominus ascendit in caelis.

39.4. Et posteaquam dicti fuerint psalmi et oratio facta fuerit, inde usque ad Anastase cum ymnis descenditur hora lucernae: hoc per totos octo dies fit. Sane dominica die per Pascha post missa lucernarii, id est de Anastase, omnis populus episcopum cum ymnis in Syon ducet.

39.5. Vbi cum uentum fuerit, dicuntur ymni apti diei et loco, fit oratio et legitur ille locus de Euangelio ubi eadem die Dominus in eodem loco, ubi ipsa ecclesia nunc in Syon est, clausis ostiis ingressus est discipulis, id est quando tunc unus ex discipulis ubi ${ }^{516}$ non erat, id est Thomas, qua reuersus est et dicentibus ei aliis apostolis quia Dominum uidissent, ille dixit: "Non credo, nisi uidero". Hoc lecto fit denuo oratio, benedicuntur cathecumini, item fideles, et reuertuntur unusquisque ad domum suam sera, hora forsitan noctis secunda.

${ }^{516}$ ubi $A$ ibi Gam edd. 
39.2. Vai-se nesse primeiro dia de domingo à igreja maior, isto é, ao Martyrium, e também na segunda-feira e terça-feira, mas ${ }^{187}$ de modo que sempre, feita a despedida do Martyrium, se chegue à Anástase com hinos. Porém, na quarta-feira vai-se ao Eleona, na quinta-feira à Anástase, na sextafeira a Sião, no sábado diante da Cruz, mas no dia de domingo, isto é, nas oitavas, de novo <se vai >à igreja maior, isto é, ao Martyrium.

39.3. Nesses oito dias pascais, cotidianamente, depois do almoço, o bispo com todo o clero e todos os neófitos, isto é, os que tenham sido batizados, e com todos os que são apotactitas, homens e mulheres, e também tantos quantos do povo queiram, sobem ao Eleona. Entoam-se hinos, fazem-se orações, tanto na igreja que fica no Eleona, na qual está a gruta onde Jesus ensinava os discípulos, como também em Imbomon, isto é, naquele local de onde o Senhor subiu aos céus.

39.4. E depois que tenham sidos recitados os salmos e tenha sido feita a oração, daí até a Anástase desce-se com hinos na hora do lucernário: isto se faz durante todos os oito dias. De fato, no dia de domingo, durante a Páscoa, depois da despedida do lucernário, todo o povo conduz o bispo com hinos a Sião.

39.5. Assim que se tiver chegado, entoam-se hinos apropriados ao dia e ao lugar, faz-se uma oração e se lê aquele passo do Evangelho onde o Senhor, naquele mesmo lugar onde fica essa igreja agora em Sião, estando os discípulos a portas fechadas, entrou, isto é, quando então um dos discípulos que não estava aí, isto é, Tomé, quando ${ }^{188}$ voltou e, ao dizerem os outros apóstolos a ele que tinham visto o Senhor, ele disse: "Não creio, a não ser que tenha visto" (Jo 20,19-25). Lido isso, faz-se novamente uma oração, benzem-se os catecúmenos, igualmente os fiéis, e cada um volta a sua casa tarde, talvez na segunda hora da noite.

\footnotetext{
${ }^{187}$ Mas (ubi ita tamen): a locução ubi ita tamen é uma justaposição de conjunções, e a tradução literal e em conjunto de todas elas é impossível. Todos os editores-filólogos que apresentaram uma tradução para sua respectiva língua moderna escolheram apenas uma conjunção para traduzir, que foi sempre a que dá a ideia adversativa: tamen. Assim nós também procedemos.

${ }^{188}$ Quando (qua): Egéria usa diversas vezes um qua com sentido adverbial temporal no lugar de cum ou quando, tanto nesta ocorrência como em 5,4 his diebus qua fecerunt uitulum e em 28,3 toto anno qua manducant (VÄÄNÄNEN, 1987, p.80, 120). V. notas 18,161 .
} 


\section{Maria Cristina Martins}

40.1. Item octauis Paschae, id est die dominica, statim post sexta omnis populus cum episcopo ad Eleona ascendit; primum in ecclesia, quae ibi est, aliquandiu sedetur; dicuntur ymni, dicuntur antiphonae aptae diei et loco, fiunt orationes similiter aptae diei et loco. Denuo inde cum ymnis itur in Imbomon susu, similiter et ibi ea aguntur, quae et illic. Et cum ceperit ${ }^{517}$ hora esse, iam omnis populus et omnes aputactite ${ }^{518}$ deducunt episcopum cum ymnis usque ad Anastase. Ea autem hora peruenitur ad Anastase, qua lucernarium fieri solet.

40.2. Fit ergo lucernarium tam ad Anastase quam ad Crucem, et inde omnis populus usque ad unum cum ymnis ducunt episcopum usque ad Syon. Vbi cum uentum fuerit, similiter dicuntur ymni apti loco et diei, legitur denuo et ille locus de Euangelio, ubi octauis Paschae ingressus est Dominus ubi erant discipuli, et arguet Thomam quare incredulus fuisset. Et tunc omnis ipsa lectio perlegitur; postmodum fit oratio; benedictis cathecuminis ${ }^{519}$ quam fidelibus iuxta consuetudinem reuertuntur unusquisque ad domum suam similiter ut die dominica Paschae, hora noctis secunda.

41. A Pascha autem usque ad quinquagesima, id est Pentecosten, hic penitus nemo ieiunat, nec ipsi aputactitae qui sunt. Nam semper ipsos dies sicut toto anno ita ad Anastase de pullo primo usque ad mane consuetudinaria aguntur, [70] similiter et ad sexta et ad lucernare. Dominicis autem diebus semper in Martyrio, id est in ecclesia maiore, proceditur iuxta consuetudinem et inde itur ad Anastase cum ymnis. Quarta feria autem et sexta feria, quoniam ipsis diebus penitus nemo ieiunat, in Syon proceditur, sed mane; fit missa ordine suo.

\footnotetext{
${ }^{517}$ ceperit $A$ edd. coeperit Geyer Pétré

${ }^{518}$ aputactite corr. ex actite $A$ aputactitae Gam Geyer Pétré

${ }^{519}$ cathecuminis $A$ edd. tam ante cathecuminis add. Gam Geyer Pétré Arce
} 
40.1. Igualmente nas oitavas de Páscoa, isto é, no dia de domingo, imediatamente após a sexta hora, todo o povo sobe ao Eleona com o bispo; primeiro se fica por algum tempo na igreja que fica aí, entoam-se hinos, cantamse antífonas apropriadas ao dia e ao lugar, fazem-se orações semelhantemente apropriadas ao dia e ao lugar. Novamente daí se vai com hinos para cima, a Imbomon, semelhantemente fazem-se todas as coisas que também $<$ foram feitas> lá. E quando tenha começado a ser a hora, já todo o povo e todos os apotactitas conduzem o bispo com hinos até a Anástase. Chega-se à Anástase, porém, naquela hora em que costuma ser feito o lucernário.

40.2. Faz-se, pois, o lucernário tanto na Anástase quanto na Cruz, e daí todo o povo, sem exceção, conduz, com hinos, o bispo até Sião. Logo que se chega, entoam-se, semelhantemente, hinos apropriados ao lugar e ao dia, lê-se, novamente, também aquele passo do Evangelho onde, nas oitavas de Páscoa, entrou o Senhor onde estavam os discípulos e repreendeu Tomé porque tinha sido incrédulo (Jo 20,26-29). E então todo esse passo é lido inteiramente; depois se faz uma oração; benzidos os catecúmenos assim como os fiéis, conforme o costume, cada um volta para sua casa semelhantemente como no domingo de Páscoa, na segunda hora da noite.

41. E desde a Páscoa até a quinquagésima, isto é, Pentescostes, absolutamente ninguém jejua, nem os que são apotactitas. Pois sempre nesses dias, assim como em todo o ano, na Anástase, desde o primeiro canto do galo até de manhã, fazem-se as coisas que são de costume semelhantemente também na sexta hora e no lucernário. Porém, nos dias de domingo, sempre se vai ao Martyrium, isto é, à igreja maior, conforme o costume, e daí se vai à Anástase com hinos. Porém, na quarta-feira e na sexta-feira, porque nesses dias absolutamente ninguém jejua, vai-se a Sião, mas de manhã; se faz a missa conforme o costume. 
42. Die eadem ${ }^{520}$ quadragesimarum post Pascha, id est quinta feria, pridie omnes post sexta, id est quarta feria, in Bethleem uadunt propter uigilias celebrandas. Fiunt autem uigiliae in ecclesia in Bethleem, in qua ecclesia spelunca est ubi natus est Dominus. Alia die autem, id est quinta feria quadragesimarum, celebratur missa ordine suo, ita ut et presbyteri et episcopus praedicent ${ }^{521}$ dicentes apte diei et loco; et postmodum sera reuertuntur unusquisque in Ierusolima.

43.1. Quinquagesimarum autem die, id est dominica, qua die maximus labor est populo, aguntur omnia sic de pullo quidem primo iuxta consuetudinem: uigilatur ${ }^{522}$ in Anastase, ut legat episcopus locum illum Euangelii, qui semper dominica die legitur, id est resurrectionem Domini; et postmodum sic ea aguntur in Anastase, quae consuetudinaria sunt, sicut toto anno.

43.2. Cum autem mane factum fuerit, procedit omnis populus in ecclesia maiore, id est ad Martyrium, aguntur etiam omnia, quae consuetudinaria sunt agi; praedicant ${ }^{523}$ presbyteri, postmodum episcopus, aguntur omnia legitima, id est offertur iuxta consuetudinem, qua dominica die consueuit fieri; sed eadem adceleratus ${ }^{524}$ missa in Martyrium, ut ante hora tertia fiat. Quemadmodum enim missa facta fuerit ad Martyrium, omnis populus usque ad unum cum ymnis ducent episcopum in Syon, sed hora ${ }^{525}$ tertia plena in Syon sint.

\footnotetext{
${ }^{520}$ eadem A Gam MaN autem Geyer edd.

${ }^{521}$ praedicent $A \mathrm{Gam}^{2}$ Geyer Her Pétré Prinz predicent Gam ${ }^{1}$ FrW Arce Mar JaN Nat MaN

${ }^{522}$ uigilatur corr. ex uigiliarum $A$

${ }^{523}$ praedicant $A \mathrm{Gam}^{2}$ Geyer Her Pétré Prinz predicant Gam ${ }^{1}$ FrW Arce Mar JaN Nat MaN

${ }^{524}$ adceleratus $A$ adceleratur Gam edd.

${ }^{525}$ ut ante hora add. Chol edd.
} 
42. No próprio dia das quadragésimas, ${ }^{189}$ depois da Páscoa, isto é, na quinta-feira, um dia antes, na quarta, depois da sexta hora, todos vão a Belém para celebrar as vigílias. Fazem-se as vigílias na igreja, em Belém, igreja na qual está a gruta onde nasceu o Senhor. E no outro dia, isto é, na quinta-feira das quadragésimas, celebra-se a missa conforme o costume, assim como também os presbíteros e o bispo pregam, dizendo o que é próprio ao dia e ao lugar; e logo depois, à tarde, todos voltam para Jerusalém.

43.1. E no dia das quinquagésimas ${ }^{190}$, isto é, no domingo, dia no qual o povo tem um grande trabalho, de fato, faz-se tudo assim como no primeiro cantar do galo, conforme o costume: faz-se vigília na Anástase, para que o bispo leia aquele passo do Evangelho que sempre é lido no dia de domingo, isto é, a ressurreição do Senhor; e depois se fazem, assim, aquelas cerimônias na Anástase as quais são de costume, assim como em todo o ano.

43.2. Como, porém, tenha amanhecido, todo o povo vai à igreja maior, isto é, ao Martyrium, e são feitas também todas as coisas que são de costume serem feitas; pregam os presbíteros, depois o bispo, faz-se tudo conforme as normas, isto é, se faz a oblação conforme o costume em que, no dia de domingo, é hábito ${ }^{191}$ ser feita; mas, nesse < dia>, ${ }^{192}$ a despedida é adiantada no Martyrium, para que se faça antes da terceira hora. De fato, como tenha sido feita a despedida no Martyrium, todo o povo, sem exceção, conduz o bispo a Sião de modo que estejam às três horas em ponto em Sião.

\footnotetext{
189 Quadragésimas (quadragesimae): quadragesimae traduz-se literalmente por "as quadragésimas". Na verdade, porque é especificado que esses dias são "depois da Páscoa” (post Pascha), pode-se traduzir por "quarenta dias depois da Páscoa”. Anteriormente, no texto, o termo quadragesimae se refere ao período de quarenta dias antes da Páscoa, isto é, à Quaresma.

${ }^{190}$ No dia das quinquagésimas (quinquagesimarum autem die): as "quinquagésimas" ou "o dia das quinquagésimas" corresponde ao dia de Pentecostes (gr. $\pi \varepsilon v \tau \eta \kappa o \sigma \tau \eta \dot{~}<\dot{\eta} \mu \varepsilon \dot{\rho} \rho$ 'quinquagésimo < dia>’), o $50^{\circ}$ dia após a Páscoa, em que se celebra a descida do Espírito Santo sobre os apóstolos.

${ }^{191}$ É hábito (consueuit): literalmente, temos o pretérito perfeito de consuesco, ou seja, consueuit "costumou", o que não faz sentido na frase. Por isso, traduzimos o verbo por uma expressão equivalente no presente.

${ }^{192}$ Nesse < dia> (eadem): seguimos a conjectura de Väänänen (1987, p.50), que interpreta o pronome eadem desta frase como substituto de ea e, ainda, subentende a palavra die. Forma-se, assim, um sintagma em ablativo significando "nesse dia".
} 
43.3. Vbi cum ${ }^{526}$ uentum fuerit, legitur ille locus de actus apostolorum ubi descendit spiritus, ut omnes linguae ${ }^{527}$ intellegerent quae dicebantur; postmodum fit ordine suo missa. Nam presbyteri de hoc ipsud, quod lectum est, quia ipse est locus in Syon, alia modo ecclesia est, ubi quondam post passionem Domini collecta erat multitudo cum apostolis, qua hoc factum est, ut superius diximus, legi ${ }^{528}$ ibi de actibus apostolorum. Postmodum fit ordine suo missa, offertur et ibi, et iam ${ }^{529}$ ut dimittatur populus, mittit uocem archidiaconus et dicet: "Hodie statim post sexta omnes in Eleona parati simus Inbomon ${ }^{530}$ ".

43.4. Reuertitur ergo omnis populus unusquisque in domum suam resumere se, et statim post prandium ascenditur mons Oliueti, id est in Eleona, unusquisque quomodo potest, ita ut nullus Christianus ${ }^{531}$ remaneat in ciuitate, qui non ${ }^{532}$ omnes uadent.

43.5. Quemadmodum ergo subito ${ }^{533}$ fuerit in monte Oliueti, id est in Eleona, primum itur in Imbomon, id est in eo loco unde ascendit Dominus in caelis, et ibi sedet episcopus et presbyteri, sed et ${ }^{534}$ omnis populus, leguntur ibi lectiones, dicuntur interposite ${ }^{535} \mathrm{ymni}$, dicuntur et antiphonae aptae diei ipsi et loco; orationes etiam, quae interponuntur, [71] semper tales pronuntiationes habent, ut et diei et loco conueniunt. Legitur etiam et ille locus de Euangelio ubi dicit de ascensu Domini; legitur et denuo de actus apostolorum, ubi dicit de ascensu Domini in celis ${ }^{536}$ post resurrectionem.

\footnotetext{
${ }^{526}$ cum om. Arce

${ }^{527}$ linguae audirentur et omnes (Bonnet in ed. Geyer) Pétré

${ }^{528}$ legi $A$ legunt Gam edd.

${ }^{529}$ etiam uel et iam $A$ etiam Gam et iam Geyer edd.

${ }^{530}$ Inbomon A Gam in Inbomon Chol edd.

${ }^{531}$ christianus A edd. christianorum Geyer Her Pétré

${ }^{532}$ qui non $A$ edd. quoniam $\mathrm{Gam}^{2}$

${ }^{533}$ subito A Gam subitum Gam ${ }^{2}$ (in nota) edd.

${ }^{534}$ sedet $u e l$ sed et $A$ sed et Pom edd. sedet Gam Geyer Her Pétré

${ }^{535}$ interposite $A$ edd. interpositi Geyer Her Pétré

${ }^{536}$ celis $A$ edd. caelis $\mathrm{Gam}^{2}$ Geyer Pétré
} 
43.3. Logo que se chega, lê-se aquele passo dos $\operatorname{Atos}^{193}$ dos Apóstolos onde desceu o Espírito, para que <os falantes de> todas as línguas ${ }^{194}$ entendessem aquilo que era dito (At 2,1-12); depois se faz a missa conforme o costume. De fato, os presbíteros, a partir disso que foi lido, leem aí os Atos dos Apóstolos, porque esse é o lugar em Sião em que agora há outra igreja, onde outrora, depois da Paixão do Senhor, a multidão tinha se reunido com os apóstolos, na qual ocorreu isso, como dissemos acima. Pouco depois, se faz a missa conforme o costume, faz-se a oblação e aí, para que já se dispense o povo, o arquidiácono eleva a voz e diz: "Hoje, imediatamente após a sexta hora, estejamos todos prontos no Eleona, em Imbomon".

43.4. Assim, todo o povo volta, cada um para a sua casa, para se recuperar e, imediatamente depois do almoço, sobe-se ao Monte das Oliveiras, isto é, ao Eleona, cada um como pode, de modo que nenhum cristão permanece na cidade, visto que todos vão.

43.5. Logo que se estiver no Monte das Oliveiras, isto é, no Eleona, primeiro se vai a Imbomon, isto é, àquele lugar de onde o Senhor subiu aos céus, e aí se sentam o bispo e os presbíteros, e também todo o povo, leemse aí textos, entoam-se hinos intercaladamente, cantam-se também antífonas apropriadas a esse dia e local; também as orações que são intercaladas têm um conteúdo tal que convém tanto ao dia quanto ao local. Igualmente, lê-se aquele passo do Evangelho onde diz sobre a Ascensão do Senhor (Lc 24,50-51; Mc 16,19); lê-se também novamente a partir dos Atos dos Apóstolos onde diz sobre a Ascensão do Senhor aos céus depois da Ressurreição (At 1,9-11).

\footnotetext{
${ }^{193}$ Atos (Actus): observa-se que a palavra actus não foi declinada no ablativo, como se esperaria. Este é um exemplo de não flexão de caso, pois a palavra aparentemente está no nominativo. Interpretamos que o erro se deve ao fato de ocorrer abundantemente o sintagma Actus Apostolorum.

${ }^{194}<$ Os falantes de> todas as línguas (omnes linguae): interpretamos que em vez de ter ocorrido um equívoco no uso de um caso, uma vez que poderíamos pensar que a autora escreveu linguae (nominativo) por linguas (acusativo), o que resultaria na tradução "entendessem todas as línguas", na verdade ocorreu uma metonímia, onde se utilizou a "língua", pelo "falante da língua". Por isso, acrescentamos "os falantes de".
} 
43.6. Cum autem hoc factum fuerit, benedicuntur cathecumini, sic fideles, et hora iam nona descenditur inde et cum ymnis itur ad illam ecclesiam, qua ${ }^{537}$ et ipsa in Eleona est, id est in qua spelunca ${ }^{538}$ sedens docebat Dominus apostolos. Ibi autem cum uentum fuerit, iam est hora plus decima; fit ibi lucernare, fit oratio, benedicuntur cathecumini et sic fideles. Et iam ${ }^{539}$ inde descenditur cum ymnis, omnis populus usque ad unum toti cum episcopo ymnos dicentes uel antiphonas aptas diei ipsi; sic uenitur lente et lente usque ad Martyrium.

43.7. Cum autem peruenitur ad portam ciuitatis, iam nox est et occurrent candele ${ }^{540}$ ecclesiasticae uel ducente ${ }^{541}$ propter populo. De porta autem, quoniam satis est usque ad ecclesia maiore, id est ad Martirium, ${ }^{542}$ porro hora noctis forsitan secunda peruenitur, quia lente et lente itur totum pro populo, ne fatigentur pedibus. Et apertis baluis ${ }^{543}$ maioribus, quae sunt de quintana parte, omnis populus intrat in Martyrium cum ymnis et episcopo. Ingressi autem in ecclesia, dicuntur ymni, fit oratio, benedicuntur cathecumini $\mathrm{et}^{544}$ sic fideles; et inde denuo cum ymnis itur ad Anastase.

43.8. Similiter ad Anastase cum uentum fuerit, dicuntur ymni seu antiphone, ${ }^{545}$ fit oratio, benedicuntur cathecumini, sic fideles; similiter fiet ${ }^{546}$ ad Crucem. Et denuo inde omnis populus Christianus usque ad unum cum ymnis ducunt episcopum usque ad Syon.

\footnotetext{
${ }^{537}$ qua $A$ quae $\mathrm{Gam}^{2}$ edd.

${ }^{538}$ post spelunca <est, in qua $>$ add. Geyer (in nota)

${ }_{539}$ etiam uel et iam $A$ etiam Gam et iam Geyer edd.

${ }^{540}$ candele $A$ edd. candelae Gam Geyer Pétré

${ }^{541}$ ducente $A$ edd. ducentae Gam Geyer Her Pétré

${ }^{542}$ Martirium A Her FrW Prinz Jan MaN Mar Martyrium Gam Geyer Pétré Arce Nat

${ }^{543}$ baluis $A$ edd. ualuis Geyer Pétré

${ }^{544}$ et om. Gam

${ }^{545}$ antiphone $A$ edd. antiphonae Gam Geyer Pétré

${ }^{546}$ fiet $A$ Gam Arce fit et Chol edd.
} 
43.6. Quando, pois, isso tiver sido feito, benzem-se os catecúmenos, bem como os fiéis, e já na hora nona desce-se daí e se vai com hinos àquela igreja que está ela mesma também no Eleona, isto é, à gruta na qual, sentado, o Senhor ensinava os apóstolos. Aí, porém, quando se tiver chegado, já é mais que a décima hora; aí se faz o lucernário, faz-se uma oração, benzem-se os catecúmenos, bem como os fiéis. E já desce daí todo o povo com hinos, todos, sem exceção, com o bispo, entoando hinos e cantando antífonas apropriadas a esse dia; assim se vai lentamente até o Martyrium.

43.7. Quando, porém, se chega à porta da cidade, já é noite e vêm ao encontro tochas da igreja, talvez duzentas, por causa do povo. Todavia, desde a porta até a igreja maior, isto é, ao Martyrium, é bastante <longo o caminho>, chega-se talvez depois da segunda hora da noite, porque se vai lentamente todo $<$ o caminho>, por causa do povo, para que não se canse <andando> a pé. E, tendo sido abertas as portas maiores, as quais dão para o mercado, ${ }^{195}$ todo o povo entra com o bispo no Martyrium, com hinos. Tendo, pois, entrado na igreja, entoam-se hinos, faz-se uma oração, benzem-se os catecúmenos, bem como os fiéis, e daí, novamente, se vai com hinos à Anástase.

43.8. Semelhantemente, quando se tiver chegado à Anástase, entoam-se hinos e antífonas, faz-se uma oração, benzem-se os catecúmenos, bem como os fiéis, e o mesmo se faz na Cruz. E de novo daí todo o povo cristão, sem exceção, conduz o bispo com hinos até Sião.

\footnotetext{
${ }^{195}$ Que dão para o mercado (quae sunt de quintana parte): quintana, em latim clássico, é um pequeno mercado no acampamento. Quintana pars, segundo Janeras (1986, p.210), é o mesmo que o cardo maximus de Jerusalém, que, por sua vez, Eusébio de Cesareia chama de "ágora" (equivalente ao Forum romano).
} 
43.9. Vbi cum uentum fuerit, leguntur lectiones aptae, dicuntur psalmi uel antiphone, ${ }^{547}$ fit oratio, benedicuntur cathecumini et sic fideles, et fit missa. Missa autem facta accedunt omnes ad manum episcopi et sic reuertuntur unusquisque ad domum suam hora noctis forsitan media. Ac sic ergo maximus labor in ea die suffertur, quoniam de pullo primo uigilatum est ad Anastase et inde per tota die nunquam cessatum est; et sic omnia, quae celebrantur protrahuntur ut nocte media post missa, quae facta fuerit in Sion, ${ }^{548}$ omnes ad domos suas reuertantur.

44.1. Iam autem de alia die quinquagesimarum omnes ieiunant iuxta consuetudinem sicut toto anno, qui prout potest, excepta die sabbati et dominica, qua nunquam ${ }^{549}$ ieiunatur in hisdem locis. Etiam postmodum ceteris diebus ita singula aguntur ut toto anno, id est ${ }^{550}$ semper, de pullo primo ad Anastase uigiletur. ${ }^{551}$

44.2. Nam si dominica dies est, primum leget de pullo primo episcopus Euangelium iuxta consuetudinem intro Anastase locum resurrectionis Domini, qui semper dominica die legitur, et postmodum ymni seu antiphone ${ }^{52}$ usque ad lucem dicuntur in Anastase. Si autem dominica dies non est, tantum quod ymni uel antiphone ${ }^{553}$ similiter de pullo primo usque ad lucem dicuntur in Anastase.

\footnotetext{
${ }^{547}$ antiphone A edd. antiphonae Gam Geyer Pétré

${ }^{548}$ Sion $A$ edd. Syon Gam

${ }^{549}$ nunquam $A$ edd. numquam Gam ${ }^{1}$ Geyer Pétré

${ }^{550}$ id est $A$ edd. id est ut Geyer Her Pétré

${ }^{551}$ uigiletur $A$ edd. uigilatur Arce

${ }^{552}$ antiphone $A$ edd. antiphonae Gam Geyer Pétré

${ }^{553}$ antiphone $A$ edd. antiphonae Gam Geyer Pétré
} 
43.9. Logo que se chega, leem-se os passos apropriados, recitam-se salmos e antífonas, faz-se uma oração, benzem-se os catecúmenos e, desse modo, os fiéis, e se faz a despedida. Feita, pois, a despedida, todos se dirigem ao bispo para beijar-lhe a mão, e assim cada um volta à sua casa talvez na hora da meia-noite. E assim, pois, sofre-se um máximo esforço nesse dia, porque se fez vigília desde o primeiro cantar do galo na Anástase e daí, durante todo o dia, nunca se cessou, e assim todas as coisas que são celebradas são prolongadas para que à meia-noite, depois da despedida a qual é feita em Sião, todos voltem para as suas casas.

44.1. Porém, já desde o dia seguinte das quinquagésimas, todos jejuam conforme o costume, assim como em todo o ano, cada um ${ }^{196}$ como pode, exceto no dia de sábado e de domingo, em que nunca se jejua nesses lugares. ${ }^{197} \mathrm{E}$ ainda depois, nos restantes dias, faz-se cada coisa como em todo o ano, isto é, sempre se faz vigília desde o primeiro cantar do galo na Anástase.

44.2. Com efeito, se é dia de domingo, em primeiro lugar, o bispo lê, ${ }^{198}$ desde o primeiro cantar do galo, conforme o costume, dentro da Anástase, o Evangelho, o passo da ressurreição do Senhor que sempre é lido no dia de domingo, e depois são entoados hinos e antífonas até o amanhecer na Anástase. Mas se não é dia de domingo, apenas entoam-se hinos e antífonas semelhantemente desde o primeiro cantar do galo até o amanhecer na Anástase.

\footnotetext{
${ }^{196}$ Cada um (qui): este qui está no lugar de quisque. Além desta ocorrência, encontra-se também em 20,7 qui ubi habebat, e em 44,3 de plebe autem qui quomodo possunt uadent. ${ }^{197}$ Nesses lugares (hisdem locis): aparentemente, nesta frase, hisdem locis significa "nestes mesmos lugares". Digno de nota é que a autora cria um pronome de reforço tendo por base hic, haec, hoc, quando, de fato, o pronome de reforço clássico é idem, eadem, idem. Todavia, convém dizer que Väänänen (1987, p.50) e Löfstedt (2007, p.68) afirmam que Egéria usava idem no lugar de is e de hic, ou seja, idem e a inovação da autora hicdem estão no lugar de um simples demonstrativo.

${ }^{198}$ Lê (leget): este é mais um exemplo da confusão que envolvia a flexão dos verbos de $3^{\text {a e }} 2^{\text {a }}$ conjugação - leget por legit -, ocasionada pelo /i/ e o /e/ longo confluírem para o som de /e/ fechado. V. notas 106, 201.
} 


\section{Maria Cristina Martins}

44.3. Aputactitae omnes uadent, de plebe autem qui quomodo possunt uadent, clerici autem [72] cotidie uicibus uadent clerici autem de pullo primo ${ }^{554}$; episcopus autem albescente uadet semper, ut missa fiat matutina, cum omnibus clericis, excepta dominica die, quia ${ }^{555}$ necesse est illum de pullo primo ire, ut Euangelium legat in Anastase. Denuo ad horam sextam aguntur quae consuetudinaria sunt, in Anastase, similiter et ad nona, similiter et ad lucernare iuxta consuetudinem, quam ${ }^{556}$ consueuit toto anno fieri. Quarta autem et sexta feria semper nona in Syon fit iuxta consuetudinem.

45.1. Et illud etiam scribere debui, quemadmodum docentur hi qui baptidiantur per Pascha. Nam qui dat nomen suum, ante diem quadragesimarum dat, et omnium nomina annotat presbyter, hoc est ante illas septimanas octo ${ }^{557}$, quibus dixi hic attendi quadragesima ${ }^{558}$

45.2. Cum autem annotauerit omnium nomina presbyter, postmodum alia die de quadragesimis, id est qua inchoantur octo ebdomadadae, ${ }^{559}$ ponitur episcopo cathedra media ecclesia maiore, id est ad Martyrium, sedent hinc et inde presbyteri in cathedris et stant clerici omnes. Et sic adducuntur unus et unus conpetens; si uiri sunt, cum patribus suis ueniunt, si autem feminae, cum matribus suis.

\footnotetext{
${ }^{554}$ uadent clerici autem de pullo primo A Gam Geyer Pétré uadent de pullo primo Her edd.

${ }^{555}$ quia $\mathrm{A} \mathrm{Gam}^{2}$ Geyer Pétré FrW Prinz Arce qua Chol Mar Jan Nat MaN

${ }^{556}$ quam $A$ edd. qua Chol Geyer Pétré

${ }^{557}$ septimanas octo A octo septimanas $\mathrm{Gam}^{2}$ edd.

${ }^{558}$ quadragesima $A$ Gam MaN quadragesimas Geyer edd.

${ }^{559}$ ebdomadadae $A$ ebdomadae Gam edd.
} 
44.3. Todos os apotactitas vão, mas do povo cada um vai como pode; os clérigos, porém, vão cotidianamente em alternância, desde o primeiro cantar do galo, mas o bispo vai sempre ao alvorecer, para que se faça a missa matutina, com todos os clérigos, exceto no dia de domingo, porque é necessário que ele vá, desde o primeiro cantar do galo, para que leia o Evangelho na Anástase. De novo, são feitas aquelas coisas que são costumeiras, na Anástase, semelhantemente também à nona <hora $>$, semelhantemente também no lucernário, conforme o costume, ${ }^{199} \mathrm{em}$ todo o ano. Porém, na quarta e na sexta-feira, sempre na nona hora, se faz <tudo> em Sião, conforme o costume.

45.1. E também isto julguei dever escrever, como são instruídos aqueles que são batizados durante a Páscoa. Pois aquele que dá o seu nome dá antes do dia da Quaresma, e o presbítero anota os nomes de todos, isto é, antes daquelas oito semanas as quais disse aqui serem consideradas a Quaresma.

45.2. Quando, porém, tiver anotado os nomes de todos, o presbítero, depois do dia seguinte da Quaresma, isto é, em que se iniciam as oito semanas, põe-se para o bispo a cadeira no meio da igreja maior, isto é, o Martyrium, os presbíteros sentam de um lado e de outro nas cadeiras, e todos os clérigos ficam de pé. E assim são chamados a vir os competentes ${ }^{\star}$ ao batismo, um a um; se são homens, vão com seus padrinhos, mas se são mulheres, com suas madrinhas. ${ }^{200}$

${ }^{199}$ Conforme o costume (iuxta consuetudinem): deixamos de traduzir quam consueuit fieri, em iuxta consuetudinem quam consueuit fieri, pois geraria uma repetição: “(...) conforme o costume que costumou ser feito".

${ }^{200}$ Com seus padrinhos (...) com suas madrinhas (cum patribus suis... cum matribus suis): a maior parte das edições críticas com as quais trabalhamos traduzem "com seus padrinhos e madrinhas" e não "com seus pais e mães", que seria a tradução literal da expressão. Blaise (1954), em seu dicionário de latim cristão, sustenta esta acepção. Apenas Arce traduz patribus e matribus como padres e madres, "pais" e "mães". Bastiaensen (1962, p.17ss) chama a atenção para o fato de que muitos candidatos ao batismo deveriam ser adultos, como se pode ver pela enquete que lhes foi feita a respeito de sua conduta de vida. Assim, segundo Bastiaensen, seguramente as pessoas que acompanhavam os que seriam batizados eram seus padrinhos e madrinhas, tal como se verifica hoje em dia, e não os pais e as mães dos mesmos. 
45.3. Et sic singulariter interrogat episcopus uicinos eius, qui intrauit, dicens: "Si bonae uitae est hic, si parentibus deferet, si ebriacus non est aut uanus?" Et singula uitia, quae sunt tamen grauiora in homine, requiret.

45.4. $\mathrm{Vt}^{560}$ si probauerit sine reprehensione esse de his omnibus, quibus requisiuit praesentibus ${ }^{561}$ testibus, annotat ipse manu sua nomen illius. Si autem in aliquo accusatur, iubet illum foras exire dicens: "Emendet se et, cum emendauerit se, $\operatorname{tun}^{562}$ accedet ad lauacrum.". ${ }^{563}$ Sic de uiris, sic de mulieribus requirens dicit. Si quis autem peregrinus est, nisi testimonia habuerit, qui eum nouerint, non tam facile accedet ad baptismum.

46.1. Hoc autem, dominae sorores, ne extimaretis ${ }^{564}$ sine ratione fieri, scribere debui. Consuetuetudo ${ }^{565}$ est enim hic talis, ut qui accedunt ad baptismum per ipsos dies quadraginta, quibus ieiunatur, primum mature a clericis exorcizentur, mox missa facta fuerit de Anastase matutina. Et statim ponitur cathedra episcopo ad Martyrium in ecclesia maiore, et sedent omnes in giro prope episcopo, qui baptidiandi sunt, tam uiri quam mulieres, stant ${ }^{566}$ loco etiam patres uel matres, nec non etiam qui uolunt audire de plebe omnes intrant et sedent, sed fideles.

\footnotetext{
${ }^{560}$ ut A Gam at Wöl Geyer Pétré et Her edd.

${ }^{561}$ praesentibus A Gam Geyer Her Pétré Prinz presentibus FrW Arce Mar Jan Nar MaN

562 tun $A$ tunc Gam edd.

${ }^{563}$ lauacrum corr. ex lauacra $A$

${ }^{564}$ extimaretis $A$ edd. existimaretis Gam aestimaretis Geyer Pétré

${ }^{565}$ consuetuetudo A consuetudo Gam edd.

${ }^{566}$ stant loco etiam A Gam² Her etiam loco stant Pom Pétré stant etiam loco FrW edd.
} 
45.3. E assim o bispo interroga individualmente os vizinhos daquele que entrou, dizendo: "É este de vida honesta, honra ${ }^{201}$ os pais, não é ébrio ou frívolo?". ${ }^{202}$ $\mathrm{E}$ interroga ${ }^{203}$ acerca de cada um dos vícios, pelo menos os mais graves no homem.

45.4. E, se for provado ser sem repreensão a respeito de todas essas coisas que perguntou às testemunhas presentes, anota com sua própria mão o nome daquele. Mas se < o candidato > é acusado em relação a alguma coisa, ordena que ele saia para fora, ${ }^{204}$ dizendo: "Que se corrija e, quando tiver se corrigido, que se dirija ao banho <batismal>”. Assim diz, perguntando não só em relação aos homens, mas também às mulheres. Se alguém, porém, é peregrino, a não ser que tenha testemunhas ${ }^{205}$ que o conheçam, não acede tão facilmente ao batismo.

46.1. Isto, porém, senhoras irmãs, para que não penseis ser feito sem razão, julguei dever escrever. De fato, aqui o costume é tal que os que se dirigem ao batismo, durante esses quarenta dias em que se jejua, primeiramente sejam exorcizados cedo pelos clérigos, logo que tenha sido feita a despedida matutina da Anástase. E imediatamente põe-se uma cadeira para o bispo no Martyrium, na igreja maior, e sentam-se todos em volta, perto do bispo, os que estão para serem batizados, tanto os homens quanto as mulheres; também no lugar há os padrinhos e madrinhas, e também todos do povo que querem ouvir entram e sentam, pelo menos ${ }^{206}$ os fiéis.

${ }^{201}$ Honra (deferet): deferet deveria estar escrito à maneira clássica defert, $3^{\text {a }}$ pessoa do presente do indicativo de defero. Tal como está escrito, parece ser a $3^{\text {a }}$ pessoa do futuro imperfeito do indicativo. Na verdade, a autora está usando o futuro pelo presente, tal como mostramos anteriormente quando ela usou leget (fut.) por legit (pres.), conforme as notas 106, 198. De fato, ela teria em mente deferit, seguindo o modelo dos verbos de terceira conjugação, ao invés de defert. Isso também evidencia o fenômeno de congruência do /i/ breve e do /e/ longo a um som de /e/ fechado. V. notas nº 106, 198.

${ }^{202}$ É este de vida honesta, honra os pais, não é ébrio ou frívolo? (si bonae uitae est hic, si parentibus deferet, si ebriacus non est aut uanus?): trata-se, em latim, de uma oração interrogativa direta, introduzida por $s i$. Essa é uma característica das traduções da Bíblia, desenvolvida sob a influência grega. Não é possível manter, em português, a tradução do $s i$, pois normalmente essa conjunção introduz uma oração interrogativa indireta.

${ }^{203}$ Interroga (requiret): interpretamos que este requiret está no lugar de requirit, conforme a nota 201.

${ }^{204}$ Ordena que ele saia para fora (iubet illum foras exire): trata-se de um pleonasmo vicioso - "sair para fora".

${ }^{205}$ Testemunhas (testimonia): além de usar equivocadamente qui (nominativo masculino) para retomar testimonia, que é uma palavra neutra, Egéria usa a palavra que significa a coisa, testimonia "testemunhos", pelo agente, testes "testemunhas". Este é mais um caso de metonímia, conforme a nota 194.

${ }^{206}$ Pelo menos (sed): segundo Väänänen (1987, p.118), este sed serve para exprimir uma precisão, como se fosse um "isto é", "ou seja" ou "pelo menos". 
46.2. Cathecuminus autem ibi non intrat tunc qua episcopus docet illos legem, id est sic: ${ }^{567}$ inchoans a Genese per illos dies quadraginta percurret omnes Scripturas, primum exponens carnaliter et sic illud soluens ${ }^{568}$ spiritualiter. ${ }^{569}$ Nec non etiam et de resurrectione, similiter et de fide omnia docentur per illos dies; hoc autem cathecisis appellatur.

46.3. Et iam ${ }^{570}$ quando completae fuerint septimanae ${ }^{571}$ quinque, a quo docentur, tunc accipient simbolum; cuius simboli rationem similiter sicut omnium Scripturarum ratione ${ }^{572}$ exponet eis singulorum sermonum, primum [73] carnaliter et sic spiritualiter, ${ }^{573}$ ita et simbolum exponet. Ac sic est, ut in hisdem locis omnes fideles sequantur Scripturas, quando leguntur in ecclesia, quia omnes docentur per illos dies quadraginta, id est ab hora prima usque ad horam tertiam, quoniam per tres horas fit cathecisin. ${ }^{574}$

\footnotetext{
${ }^{567}$ id est sic $A$ edd. sic: id est Geyer Pétré

${ }^{568}$ soluens corr. ex soluet $A$

${ }^{569}$ spiritualiter $A$ edd. spiritaliter Bast Mar Nat MaN

${ }^{570}$ etiam uel et iam $A$ etiam Gam et iam Geyer edd.

${ }^{571}$ septimanae $A$ edd. septimanas Arce

${ }^{572}$ ratione $A$ edd. rationem Geyer Her Pétré

${ }^{573}$ spiritualiter $A$ edd. spiritaliter Bast Mar Nat MaN

${ }^{574}$ cathecisin A edd. cathecisis Gam $^{2}$
} 
46.2. O catecúmeno, porém, não entra aí naquele momento em que o bispo ensina a Lei, isto é, assim, começando pelo Gênesis, durante aqueles quarenta dias percorre todas as Escrituras, primeiramente expondo-as literalmente, depois explicando-as espiritualmente. E também é ensinado tudo sobre a Ressurreição e igualmente sobre a fé, durante aqueles dias: e isto se chama catequese. ${ }^{207}$

46.3. E quando já tiverem sido cumpridas cinco semanas desde que são ensinadas <as Escrituras>, então recebem o Símbolo ${ }^{*},{ }^{208}$ do qual lhes expõe o conteúdo, ${ }^{209}$ igualmente como expôs o conteúdo de todas as Escrituras, cada uma das passagens, primeiro literalmente, depois espiritualmente. E assim é que nestes lugares todos os fiéis seguem as Escrituras, quando são lidas na igreja, porque todos são ensinados naqueles quarenta dias, isto é, desde a primeira hora até a terceira hora, visto que por três horas é realizada a catequese.

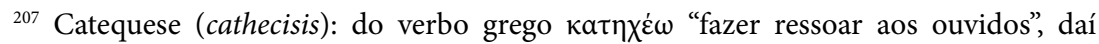

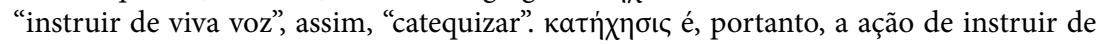
viva voz, particularmente a ação de dar uma instrução religiosa, ou seja, de catequizar. ${ }^{208}$ Símbolo (Simbolum): Simbolum encontra-se seis vezes no texto, sempre com $i$, quando deveria ser com $y$.

${ }^{209}$ Conteúdo (rationem): segundo Bastiaensen (1962, p.108-110), a palavra ratio, que é empregada apenas na parte da obra que fala sobre a catequese, adquire dois sentidos ligeiramente divergentes. O primeiro é aqui neste trecho $(46,3)$, em que ratio é a explicação ou o conteúdo do Símbolo. Em 46,6, ratio é igualmente o conteúdo da Escritura e do Símbolo: Per istas septem septimanas legem omnem edocti estis Scripturarum nec non etiam de fide audistis; audistis etiam et de resurrectionem carnis, sed et Simboli omnem rationem ut potuistis tamen adhuc cathecumini audire. Em 46,3 e 46,6, ratio trata daquilo que o bispo explica, ou seja, o conteúdo da Escritura e do Símbolo. Com um sentido ligeiramente diferente, ratio aparece em 46,1 e 46,6. Em 46,1, ratio é usada no contexto de admissão dos candidatos ao batismo: Hoc autem, dominae sorores, ne extimaretis sine ratione fieri, scribere debui. Consuetudo est enim hic talis (...). Em seguida, Egéria relata de que forma os candidatos ao batismo escutam a catequese, durante os quarenta dias da Quaresma, após terem passado pelo exorcismo, que é mencionado apenas de passagem, enquanto que a catequese é descrita em todos seus passos: a explicação das Escrituras, da Ressurreição, da fé e, por fim, após as cinco semanas de instrução, a do Símbolo. A suposição de que aqui ratio se refere a essa instrução catequética parece ser confirmada pela segunda passagem $(46,6)$, onde, novamente, o bispo se dirige aos candidatos: Et ne extimetis aliquid sine ratione fieri, cum in nomine Dei baptidiati fueritis, per octo dies paschales post missa facta de ecclesia in Anastase audietis. Ou seja, aqui ratio parece significar a "explicação do conteúdo", a "explicação daquilo que se faz", enquanto que, em 46,3, diz respeito ao "conteúdo" ou "matéria" do que foi ensinado na catequese. Ver, no Glossário, Símbolo. 
46.4. Deus autem scit, dominae sorores, quoniam maiores uoces sunt fidelium, qui ad audiendum intrant in cathecisen, ad ea quae dicuntur uel exponuntur per episcopum, quam quando sedet et praedicat ${ }^{575}$ in ecclesia ad singula, quae taliter exponuntur. Missa autem facta cathecisis hora iam tertia statim inde cum ymnis ducitur episcopus ad Anastase et fit missa ad tertia; ac sic tribus horis docentur ad $d_{i}{ }^{576}$ per septimanas septem. Octaua enim septimana quadragesimarum, id est quae appellatur septimana maior, uacat ${ }^{577}$ eos doceri, ut impleantur ea, quae superius sunt. ${ }^{578}$

46.5. Cum autem iam transierint septem septimanae, superat ${ }^{579}$ illa una septimana paschalis, quam hic appellant septimana maior, iam tunc uenit episcopus mane in ecclesia maiore ad Martyrium. Retro in absida post altarium ponitur cathedra episcopo, et ibi unus et unus uadet, uiri ${ }^{580}$ cum patre suo aut mulier cum matre sua, et reddet simbolum episcopo.

\footnotetext{
${ }^{575}$ praedicat $A$ Gam $^{2}$ Geyer Her Pétré Prinz predicat Gam ${ }^{1}$ FrW Arce Mar Jan Nat MaN ${ }^{576}$ ad die $A$ edd. ad diem Gam

577 in loco aqua aspersa euanuit litteras inter maior et uacat $A$ maior iam uacat Gam maior iam non uacat Geyer edd.

${ }^{578}$ sunt $A$ Gam dicta ante sunt add. Geyer edd.

${ }^{579}$ superat $A$ edd. et ante superat add. Geyer Pétré

${ }^{580}$ uiri $A$ edd. uir Geyer Pétré
} 
46.4. E Deus sabe, senhoras irmãs, que as vozes dos fiéis que entram na catequese para ouvir aquelas coisas que são ditas ou expostas pelo bispo são maiores do que quando ele se senta e prega na igreja cada uma das coisas que do mesmo modo são expostas. Feita a despedida da catequese, já na terceira hora, imediatamente se conduz o bispo até a Anástase e se faz a missa à terceira hora; e assim instruem-se $<$ os fiéis $>$ durante três horas ${ }^{210}$ por dia, por sete semanas. De fato, na oitava semana da Quaresma, isto é, a que se chama semana maior, já não há mais tempo de eles serem ensinados, para que sejam cumpridas aquelas coisas que mais acima foram ditas. ${ }^{211}$

46.5. Quando já tiverem transcorridas sete semanas, resta ${ }^{212}$ aquela única semana pascal que aqui chamam semana maior, então já chega o bispo de manhã no Martyrium. No fundo da abside, atrás do altar, põe-se uma cadeira para o bispo e aí vão um a um, o homem com seu padrinho e a mulher com a sua madrinha, e entregam o Símbolo para o bispo.

${ }^{210}$ Durante três horas (tribus horis): tribus horis, evidentemente, é um ablativo plural. Este caso é usado no latim clássico para expressar os complementos de tempo que respondem à pergunta "quando?", ou seja, quando a resposta é um tempo preciso em que uma ação se realiza. Trata-se de um ablativo-locativo. Por outro lado, quando a pergunta é "por quanto tempo?", emprega-se o acusativo, usado absolutamente, ou preposicionado, normalmente com a preposição per. Parece que aqui a autora deveria ter usado o acusativo preposicionado, pois a ação demonstra um tempo transcorrido.

${ }^{211}$ (...) isto é, a que se chama semana maior, já não há mais tempo de eles serem ensinados, para que sejam cumpridas aquelas coisas que mais acima foram ditas (...id est quae appellatur septimana maior, uacat eos doceri, ut impleantur ea, quae superius sunt): este período oferece dificuldade de tradução. O manuscrito apresenta um borrão antes da palavra uacat e, nesse lugar, certamente havia uma palavra que possibilitaria interpretar corretamente a frase. Os editores-filólogos propuseram duas interpolações: iam foi proposto por Gamurrini e iam non por Geyer. Dois são os motivos para que tenham sido sugeridas as palavras iam non e non. Um deles é o tamanho do borrão, que sugere uma palavra pequena no espaço; o outro é a interpretação da frase, cujo sentido parece ser completado por um non. Nesse mesmo período, Geyer propôs a interpolação da forma nominal dicta, antes de sunt, para dar sentido à frase. Todos os editores assumiram a conjectura de Geyer, inclusive nós.

${ }^{212}$ Resta (superat): segundo Väänänen (1987, p.155), superare está sendo usado no lugar de superesse. Em espanhol, português e catalão, sobrevive o verbo superare como "sobrar". Além disso, nessas línguas ainda se manteve a significação clássica de "superar", "vencer". No italiano, só se tem a forma erudita, e no francês não há sobrevivência desse verbo. 
46.6. Reddit ${ }^{581}$ autem simbolo episcopo, alloquitur omnes episcopus et dicet: "Per istas septem septimanas legem omnem edocti estis Scripturarum nec non etiam de fide audistis; audistis etiam et de resurrectione carnis, sed et singuli ${ }^{52}$ omnem rationem, ut potuistis tamen adhuc cathecumini audire: uerbum $^{583}$ autem, quae sunt misterii ${ }^{584}$ altioris, id est ipsius baptismi, qui ${ }^{585}$ adhuc cathecumini ${ }^{586}$, audire non potestis. Et ne extimeti ${ }^{587}$ aliquid sine ratione fieri, cum in nomine Dei baptidiati fueritis, per octo dies paschales post missa facta de ecclesia in Anastase audietis: qui ${ }^{58}$ adhuc cathecumini estis, misteria Dei secretiora dici uobis non possunt".

47.1. Post autem uenerint dies Paschae, per illos octo dies, id est a Pascha usque ad octauas, quemadmodum missa facta fuerit de aecclesia ${ }^{589}$, et itur cum ymnis ad Anastase, mox fit oratio, benedicuntur fideles, et stat episcopus imcumbens $s^{590}$ in cancello interiore, qui est in spelunca Anastasis, et exponet omnia, quae aguntur in baptismo.

47.2. Illa enim hora cathecuminus nullus accedet ad Anastase; tantum neofiti et fideles, qui uolunt audire misteria, in Anastase intrant. Clauduntur autem ostia, ne qui cathecuminus se dirigat. Disputante autem episcopo singula et narrante, tante ${ }^{591}$ uoces sunt collaudantium, ut porro foras ecclesia audiantur uoces eorum. Vere enim ita misteria omnia absoluent, ${ }^{592}$ ut nullus non possit commoueri ad ea quae audit sic exponi.

\footnotetext{
${ }^{581}$ reddit $A$ reddito Gam edd.

${ }^{582}$ singuli A Gam simboli Geyer edd.

${ }^{583}$ uerbum $A$ uerba Gam² Geyer Her Pétré Arce uerum Chol FrW Mar Jan Nat MaN

${ }^{584}$ misterii $A$ edd. mysterii Gam

${ }^{585}$ qui $A$ Gam $^{2}$ Jan Nat MaN quia Gam ${ }^{1}$ edd.

${ }^{586}$ estis post cathecumini add. Geyer Her Pétré

${ }^{587}$ extimetis $A$ edd. aestimetis Geyer Pétré

${ }^{588}$ qui $A \mathrm{Gam}^{2} \mathrm{Jan}$ Nat quia $\mathrm{Gam}^{1}$ edd.

${ }^{589}$ aecclesia A FrW Arce Mar Jan Nat MaN ecclesia Gam Geyer Her Pétré Prinz

${ }^{590}$ imcumbens $A$ MaN incumbens Gam edd.

${ }^{591}$ tante $A$ edd. tantae Geyer Pétré

${ }^{592}$ absoluent $A$ MaN absoluet Geyer edd.
} 
46.6. Entregue, pois, o Símbolo para o bispo, o bispo se dirige a todos e diz: "Durante essas sete semanas fostes instruídos em toda a Lei das Escrituras e ouvistes sobre a fé; ouvistes também sobre a ressurreição da carne e ainda sobre toda explicação do Símbolo, para que pudesses, pelo menos, ouvir ainda sendo catecúmenos: na verdade, porém, aquelas coisas que são de um mistério mais profundo, isto é, do próprio batismo, porque até agora não pudestes ouvir como catecúmenos. E para que não julgueis algo ser feito sem explicação, quando tiverdes sido batizados em nome de Deus, durante os oito dias pascais, após a despedida da igreja na Anástase ouvireis: visto que até agora sois catecúmenos, os mistérios mais secretos de Deus não podem ser ditos a vós”.

47.1. E, depois que tiverem chegado os dias da Páscoa, durante aqueles oito dias, isto é, desde a Páscoa até as oitavas, quando a despedida da igreja tiver sido feita, vai-se também com hinos à Anástase, logo se faz uma oração, benzem-se os fiéis, e o bispo fica de pé, encostado no interior da balaustrada que fica na gruta da Anástase, e expõe todas as coisas que são feitas no batismo.

47.2. De fato, naquela hora nenhum catecúmeno se aproxima da Anástase; tanto os neófitos quanto os fiéis que querem ouvir os mistérios entram na Anástase. Fecham-se, porém, todas as portas da Anástase para que aquele que é catecúmeno não se dirija <para lá>. Discorrendo e narrando o bispo cada uma das coisas, são tantas as vozes dos que dão louvores, que < as suas vozes> são ouvidas para além da igreja. De fato, assim ele desvela todos os mistérios, de modo que ninguém possa deixar de ser comovido por essas coisas $^{213}$ as quais ouve assim serem expostas.

\footnotetext{
${ }^{213}$ Por essas coisas ( $a d$ ea): o complemento de um verbo na voz passiva é formado pelo ablativo regido pela preposição $a b$, se o agente da passiva for animado, e sem preposição se for inanimado. Neste caso, temos ad ea como complemento de um verbo na voz passiva, quando deveríamos ter $a b$ eis ou ab iis. Rigorosamente, esse agente da passiva, por ser inanimado, não é usado com preposição. Seria, assim, eis ou iis, referindo-se a misteria omnia.
} 
47.3. Et quoniam in ea prouncia ${ }^{593}$ pars populi et greci ${ }^{594}$ et siriste nouit, pars etiam alia per se grece ${ }^{595}$, aliqua etiam pars tantum siriste, itaque quoniam episcopus, licet siriste nouerit, tamen semper grece ${ }^{596}$ loquitur et nunquam siriste: itaque ergo stat ${ }^{597}$ semper presbyter, qui episcopo grece $\mathrm{e}^{598}$ dicente, siriste interpretatur, ut omnes audiant [74] ut omnes audiant, ${ }^{599}$ quae exponuntur.

47.4. Lectiones etiam, quecumque ${ }^{600}$ in ecclesia leguntur, quia necesse est grece $^{601}$ legi, semper stat, qui siriste interpretatur propter populum, ut semper discant. Sane quicumque hic latini sunt, id est qui nec siriste nec grece $^{602}$ nouerunt, ne contristentur, et ipsis exponitur eis, ${ }^{603}$ quia sunt alii fratres et sorores grecolatini, ${ }^{604}$ qui latine exponunt eis.

47.5. Illud autem hic ante omnia ualde gratum fit et ualde admirabile, ${ }^{605}$ ut semper tam ymni quam antiphonae et lectiones nec non etiam et orationes, quas dicet episcopus, tales pronuntiationes habeant, ut et diei, qui celebratur, et loco, in quo agitur, aptae et conuenientes $\operatorname{sint}^{606}$ semper.

48.1. Item dies enceniarum appellantur quando sancta ecclesia, quae in Golgotha est, quam Martyrium uocant, consecrata est Deo; sed et sancta ecclesia quae est ad Anastase, id est in eo loco ubi Dominus resurrexit post passionem, ea die et ipsa consecrata est Deo. Harum ergo ecclesiarum sanctarum encenia cum summo honore celebrantur, quoniam crux Domini inuenta est ipsa die.

\footnotetext{
${ }^{593}$ prouncia $A$ prouincia Gam edd.

${ }^{594}$ greci $A$ grece $G{ }^{1}{ }^{1}$ edd. graece Geyer Pétré

${ }^{595}$ grece $A$ edd. graece Gam $^{2}$ Geyer Pétré

${ }^{596}$ grece $A$ edd. graece $\mathrm{Gam}^{2}$ Geyer Pétré

${ }^{597}$ stat corr. ex statim $A$

${ }^{598}$ grece $A$ edd. graece Gam $^{2}$ Geyer Pétré

${ }^{599}$ omnes audiant bis scr. A ut omnes audiant semel scr. Gam edd.

${ }^{600}$ quecumque $A$ quaecumque Gam Geyer Pétré

${ }^{601}$ grece $A$ edd. graece Gam Geyer Pétré

${ }^{602}$ grece $A$ edd. graece Gam Geyer Pétré

${ }^{603}$ exponitur eis $A$ edd. exponit episcopus Gam

${ }^{604}$ grecolatini $A$ edd. graeci latini $G a^{2}$ graecolatini Geyer Pétré

${ }^{605}$ admirabile $A$ edd. memorabile Gam

${ }^{606}$ uocabulum paene euanuit: sint uel sunt $A$ sunt Gam sint Geyer edd.
} 
47.3. E porque nessa província uma parte do povo não só conhece ${ }^{214}$ o grego, mas também o siríaco ${ }^{\star}$, uma parte só $^{215}$ o grego, e outra parte ainda só o siríaco, assim, por isso, embora o bispo conheça o siríaco, todavia sempre fala em grego e nunca em siríaco: por isso, então, sempre há um presbítero em pé que, quando o bispo fala em grego, traduz para o siríaco, para que todos ouçam o que é exposto.

47.4. Além disso, quaisquer textos que são lidos na igreja, porque é necessário serem lidos em grego, sempre fica de pé quem (sc. presbyter) traduz em siríaco, por causa do povo, para que compreenda sempre. Na verdade, todos aqueles que aqui são latinos, isto é, que não conhecem nem o siríaco nem o grego, para que não se entristeçam, são expostas as mesmas coisas também a eles, porque há outros irmãos e irmãs grecolatinos que explicam a eles em latim.

47.5. E acontece aqui, antes de tudo, algo muito agradável e admirável: que sempre tanto os hinos quanto as antífonas, e não só as leituras mas também as orações que o bispo diz, possuam exposições tais que sejam sempre apropriadas e convenientes ao dia que se celebra e ao lugar em que se fazem.

48.1. Além disso, chamam-se os dias das Encênias* quando a santa igreja que fica no Gólgota, que chamam de Martyrium, foi consagrada a Deus, mas também a santa igreja que fica na Anástase, isto é, naquele local onde o Senhor ressuscitou após a Paixão, naquele dia também essa foi consagrada a Deus. As Encênias destas santas igrejas são celebradas com a mais elevada honra, porque a cruz do Senhor foi encontrada nesse mesmo dia.

${ }^{214}$ Conhece (nouit): Egéria forma o presente do verbo noscere com a raiz do pretérito perfeito, por isso, nouit em lugar de noscit.

${ }^{215}$ Só o grego (per se grece): per se, em latim clássico, traduzir-se-ia por "por si”. Aqui nesta passagem, segundo Väänänen (1987, p.42), adquire o sentido de "somente" ou "só". 
48.2. Et ideo propter hoc ita ordinatum est, ut quando primum sanctae ecclesiae suprascriptae consecrabantur, ea dies esset qua crux Domini fuerat inuenta, ut simul omni laetitia eadem die celebrarentur. Et hoc per Scripturas sanctas inuenitur, quod ea dies sit enceniarum, qua et sanctus Salomon consummata domo Dei, quam edificauerat, ${ }^{607}$ steterit ante altarium Dei et orauerit, sicut scriptum est in libris Paralipomenon.

49.1. Hi ergo dies enceniarum cum uenerint, octo diebus attenduntur. Nam ante plurimos dies incipiunt se undique colligere $\mathrm{ubi}^{608}$ non solum monachorum uel actito ${ }^{609}$ de diuersis prouinciis, id est tam de Mesopotamia uel Syria uel de Egypto aut Thebaida, ubi plurimi monazontes sunt, sed et de diuersis omnibus locis uel prouinciis; nullus est enim, qui non se eadem die in Ierusolima tendat ad tantam laetitiam et tam honorabiles dies; seculares ${ }^{610}$ autem tam uiri quam feminae fideli animo propter diem sanctum similiter sed et ${ }^{611}$ omnibus prouinciis isdem diebus Ierusolima colligunt. ${ }^{612}$

49.2. Episcopi autem, quando parui fuerint, hisdem diebus Ierusolima plus quadraginta aut quinquaginta sunt; et cum illis ueniunt multi clerici sui. Et quid plura? Putat se maximum peccatum incurrisse, qui in hisdem diebus tante sollennitati ${ }^{613}$ inter non fuerit, si tamen nulla necessitas contraria fuerit, que ${ }^{614}$ hominem a bono praeposito ${ }^{615}$ retinet.

49.3. His ergo diebus enceniarum ipse ornatus omnium ecclesiarum est, qui et per Pascha uel per ${ }^{616}$ Epiphania, et ita per singulos dies diuersis locis sanctis proceditur ut per Pascha uel Epiphania. Nam prima et secunda die in ecclesia maiore, quae appellatur Martyrium, proceditur. Item tertia die in Eleona, id est in ecclesia, quae est in ipso monte, a quo ascendit Dominus in caelis post passionem, intra qua ecclesia est spelunca illa, in qua docebat Dominus apostolos in monte Oliueti. Quarta autem die (...). ${ }^{617}$

\footnotetext{
${ }^{607}$ edificauerat $A$ edd. aedificauerat $G^{2}{ }^{2}$ Geyer Pétré

${ }^{608}$ ubi A Gam turbae Chol edd.

${ }^{609}$ actito $A \mathrm{Gam}^{2}$ aputactitum Geyer edd.

${ }^{610}$ seculares A edd. saeculares Gam² Geyer Pétré

${ }^{611}$ sed et $A$ sed et de Gam se de Geyer edd.

${ }^{612}$ colligunt $A$ edd. se colligunt Gam

${ }^{613}$ tante sollennitati $A$ edd. tantae sollemnitati Gam tantae sollennitati Geyer Pétré

${ }^{614}$ que $A$ edd. quae Gam Geyer Pétré

${ }^{615}$ praeposito A proposito Gam edd.

${ }^{616}$ per om. Geyer Pétré

${ }_{617}$ "Quarta autem die" encontra-se na extremidade direita inferior da p.74, a última do manuscrito. Essas palavras servem como um anúncio ou indicação do que virá na página seguinte. Todo o resto, infelizmente, foi perdido.
} 
48.2. E por causa disso, porque isto assim foi disposto, de modo que quando primeiramente as santas igrejas supracitadas eram consagradas, fosse no dia em que a cruz tinha sido encontrada, para que com toda a alegria fossem celebradas simultaneamente, no mesmo dia. E isto se descobre por meio das Escrituras Santas, que aquele dia é das Encênias, no qual o santo Salomão, concluída a casa de Deus a qual edificara, teria ficado em pé diante do altar de Deus e orado, assim como foi escrito nos livros dos Paralipômenos* $(2 \mathrm{Cr} 7,8)$.

49.1. Portanto, quando tiverem chegado esses dias das Encênias, são observados oito dias. Com efeito, vários dias antes começam a se reunir de todos os lados não só multidões de monges e apotactitas de diversas províncias, isto é, não só da Mesopotâmia, Síria, Egito e Tebaida, onde há uma grande quantidade de monazontes, mas também de todos os lugares e províncias diversas: de fato, não há ninguém, nesse mesmo dia, que não se dirija a Jerusalém, junto a tanta festa e tantos dias solenes; e também leigos, tanto homens quanto mulheres de espírito fiel, de todas as províncias, por causa do dia santo, igualmente se reúnem naqueles dias em Jerusalém.

49.2. E em relação aos bispos, naqueles dias em Jerusalém, quando poucos, são mais de quarenta ou cinquenta, e com eles chegam muitos de seus clérigos. ${ }^{216}$ E o que mais? Aquele que não tenha estado presente ${ }^{217}$ naqueles dias de tanta solenidade pensa ter incorrido em máximo pecado, exceto se tiver ocorrido alguma necessidade contrária a qual impeça o homem de um bom propósito.

49.3. Ora, nesses dias das Encênias, a decoração de todas as igrejas é a mesma que durante a Páscoa e a Epifania, e assim durante cada um dos dias

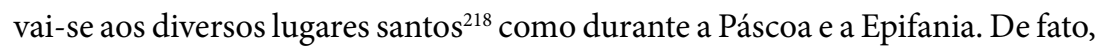
no primeiro e no segundo dia, vai-se à igreja maior, que se chama Martyrium. Igualmente, no terceiro dia, vai-se ao Eleona, isto é, à igreja que fica no mesmo monte a partir do qual subiu o Senhor aos Céus, depois da Paixão, igreja dentro da qual há uma gruta, em que o Senhor ensinava os apóstolos, no Monte das Oliveiras. No quarto dia (...).

\footnotetext{
${ }^{216}$ Muitos de seus clérigos (multi clerici sui): este é mais um emprego equivocado de sui por eorum, conforme foi visto na nota 168.

${ }^{217}$ Não tenha estado presente (inter non fuerit): para uma explicação do que ocorre aqui, ou seja, uma tmese, ver nota 52.

${ }^{218}$ Aos diversos lugares santos (diuersis locis sanctis): repare-se aqui a construção em ablativo - diuersis locis sanctis - como complemento de um verbo de movimento, ao invés do acusativo.
} 


\section{Glossário}

Aarão (Aaron, -onis ou indecl.): Sept. 'Aapúv. Irmão e porta-voz de Moisés perante os israelitas e o Faraó, foi também o primeiro sumo sacerdote dos hebreus (Ex 4,27-30; $5,1-5 ; 29,1-30)$. Permitiu que os hebreus acampados ao pé do monte Sinai adorassem o bezerro de ouro, após Moisés ter subido para receber de Deus as tábuas da Lei (Ex 4,14; $28,1 ; 32,1)$.

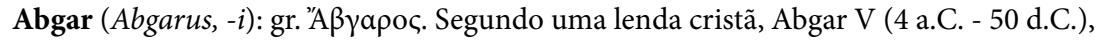
rei de Edessa, estando acometido de uma doença incurável e tendo ouvido falar dos poderes milagrosos de Cristo, escreveu-lhe uma carta rogando a cura de sua doença e proteção da cidade contra os inimigos. Jesus ter-lhe-ia respondido por escrito, abençoando-o e dizendo que não poderia ir até ele, mas prometendo que, após Sua Ascensão, enviaria um de seus discípulos para curá-lo e proteger a cidade. Por inspiração divina, o apóstolo Tomé encarregou Tadeu (São Tadeu de Edessa) dessa missão. A carta de Cristo supostamente curou Abgar de sua enfermidade, converteu-o ao cristianismo e o ajudou a resistir à invasão persa. A primeira fonte dessa lenda, que surgiu no séc. III, é a História eclesiástica (I, 13, 1-5) de Eusébio de Cesareia, que afirma ter lido as cartas originais nos arquivos públicos de Edessa e tê-las traduzido do siríaco para o grego. A tradução latina da obra de Eusébio, por Tirânio Rufino de Aquileia, em 403, tornou a lenda conhecida no Ocidente. Atualmente, tais cartas são consideradas apócrifas; além disso, é opinião difundida entre os Padres da Igreja que Jesus não deixou nenhum testemunho redigido de sua própria mão (cf. Agostinho, Contra Faustum manichaeum, 28, 4; Jerônimo, Commentaria in Ezechielem, 44, 29). Segundo Mariano e Nascimento (1998, p.141), apenas duas fontes merecem ser consultadas em relação a essa lenda: o testemunho de Eusébio e a Doctrina Addai (Addai é o verdadeiro nome do apóstolo de Edessa, personalidade histórica que exerceu sua ação na província romana de Osroena na segunda metade do séc. II - Eusébio teria substituído o verdadeiro nome por "Tadeu", a fim de atribuir um caráter apostólico à lenda). Para mais informações sobre a lenda, consultar: SKEMER, Don. Binding Words: textual amulets in the middle ages. Penn State University Press, 2006. O livro, citado na edição de O. Prinz, faz referência a essa passagem do texto de Egéria. V. Edessa.

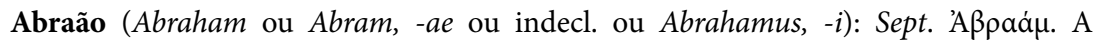
tradição situa Abraão (Gn 12-25) no início do segundo milênio a.C. Originário de um clã politeísta estabelecido em Ur, na Caldeia, aos 75 anos de idade recebe de Deus a ordem de deixar sua pátria e partir para um país desconhecido. Após uma estadia no Egito (v. Carres), Abraão estabelece-se em Canaã com a esposa Sara e o sobrinho Ló: assim, Canaã torna-se a Terra Prometida, a terra que Deus promete a Abraão e seus 


\section{Maria Cristina Martins}

descendentes. Sara, que é estéril, mas deseja dar um filho a seu marido, oferece sua serva egípcia Agar para que gere o primeiro filho a Abraão; Agar então dá à luz Ismael, considerado pelos muçulmanos o ancestral dos povos árabes. Aparecendo novamente a Abraão, Deus ordena que ele e todos os homens de sua casa sejam circuncidados e que toda criança do sexo masculino receba esse sinal da Aliança ao oitavo dia de vida. Nessa ocasião, Deus muda os nomes de Abraão e de Sara, os quais até então se chamavam Abrão e Sarai, e promete um filho a ela, pondo fim à sua esterilidade. Assim, Isaac e Jacó, filho e neto de Abraão, dão continuidade à Aliança. Abraão é o ancestral comum de três religiões monoteístas: judaísmo, cristianismo e islamismo.

Alexandria (Alexandrea ou Alexandria, -ae): gr. 'A $\lambda \varepsilon \xi \dot{\alpha} v \delta \rho \varepsilon ı$. Na antiguidade helênica, havia várias cidades com esse nome, mas o texto se refere à Alexandria que foi capital do Egito, desde sua fundação por Alexandre o Grande, em 332 a.C., até a conquista do país pelos muçulmanos, em 642 d.C. Situada na borda oeste do delta do Nilo, tornouse um importante centro da cultura helenística. Era muito conhecida por seu Farol, uma das Sete Maravilhas do Mundo Antigo, e sua Biblioteca, a maior do mundo antigo. Atualmente é o principal porto e um importante centro industrial do Egito, sua segunda maior cidade e segunda maior região metropolitana, apenas menor que a Grande Cairo, da qual distam aproximadamente $183 \mathrm{~km}$.

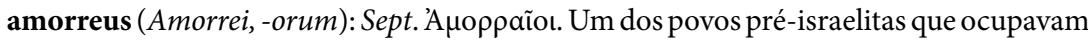
Canaã e contra os quais os hebreus guerrearam antes de entrar na Terra Prometida, após o Êxodo do Egito (Nm 21,25). Seus principais reis foram Og, do reino de Basan, e Seon, cuja capital era Hesebon. Ao serem derrotados por Moisés, os territórios de ambos os reis tornaram-se herança das tribos de Ruben, Gad e da metade da tribo de Manassés. Mais tarde, cinco reis amorreus haveriam de lutar contra Josué pelas terras a oeste do Jordão (Js 10). V. Fogor, Hesebon e Safdra.

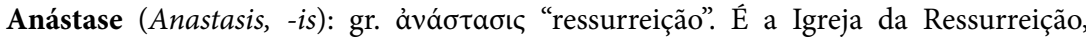
caracterizada por uma majestosa cúpula que cobria o sepulcro de Cristo, em Jerusalém. Ali era realizado diariamente o ofício divino. Juntamente com a Cruz, uma pequena capela atrás da Cruz e o Martyrium, a Anástase formava a Basílica do Santo Sepulcro, um complexo construído em 335 por Constantino e sua mãe (Santa Helena), que é o mais conhecido e venerado dos Lugares Santos cristãos. Hoje, nada resta dessas suntuosas construções de Constantino, destruídas em 1009 por ordem do sultão Hakim. A Basílica do Santo Sepulcro atual data de 1149, e sua construção e sobrevivência só foram possíveis graças a um acordo do Império Bizantino com os muçulmanos e à conquista de Jerusalém pelos cruzados. V. Martyrium e Cruz.

ancião (senior, -oris, comparativo de superioridade de senex, senis "velho", pl. seniores "os mais velhos"). No período tribal de Israel, a autoridade era exercida pelos chefes das tribos, em geral os mais velhos, aos quais cabia a chefia em tempos de guerra e o poder judicial em tempos de paz. No Novo Testamento, os anciãos eram os membros do senado judeu (Mt 16,21; At 4,5). Também denominados "presbíteros" nas primeiras comunidades cristãs, eram os chefes que administravam as Igrejas locais (At 15,6;22). 
O termo também pode se referir aos mais velhos dentre os leigos de uma comunidade cristã, que formavam uma espécie de conselho.

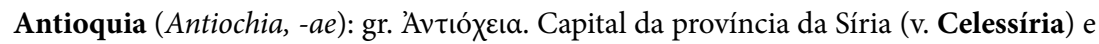
rico centro comercial e da cultura helênica. Em Antioquia, havia uma avançada civilização grega mesclada com vários elementos orientais, especialmente com superstições da astrologia caldeia, as quais, segundo São João Crisóstomo (ca. 347-407), infelizmente eram praticadas até por cristãos de sua época. $\mathrm{O}$ gosto por divertimentos frívolos também tornou-se uma paixão, como as corridas no hipódromo, onde as rivalidades e fortes emoções do povo muitas vezes acabavam em derramamento de sangue (SMITH, 1854, s.v. "Antiocheia"). Nesse importante foco da cristandade primitiva, foi fundada a primeira comunidade cristã mista, composta de judeus e de pagãos convertidos, da qual partiram Paulo e Barnabé para suas viagens missionárias. Os convertidos de Antioquia foram os primeiros a serem denominados "cristãos" (At 11,26). Corresponde à atual Antakya, uma moderna cidade da Síria a cerca de $95 \mathrm{~km}$ a oeste de Alepo.

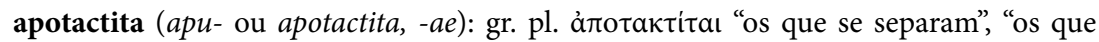
renunciam". Tipo de asceta, homem ou mulher, praticante de jejuns e assíduo aos ofícios religiosos. São os monazontes e as partenas.

Arábia (Arabia, -ae): gr. Apaßía. Nos cap. 7-9 do texto, o nome significa o vigésimo dos 44 nomos ou distritos administrativos em que o Egito estava dividido desde a época ptolomaica até a bizantina, cujo território fazia parte da terra de Gessen bíblica, no Delta oriental, bem como a metrópole desse nomo. Pode-se identificar a cidade de Arábia com a atual Faqus, pois ela era chamada nas épocas romana e bizantina de Phacusa (cf. A.H.M. JONES, Cities of Eastern Roman Empire. Oxford, 1971, p.337, apud NATALUCCI, 1991, p.254). A partir do cap. 10, o nome refere-se à província romana da Arábia, a leste do Jordão, situada na região da Moab bíblica, cujas principais cidades eram Bostra (capital), localizada no sul da atual Síria, e Petra, no sudoeste da atual Jordânia.

Arabot: Sept. 'A $\alpha \beta \omega \theta$ “campinas", "planícies”; Vulg. Arabot. Na Septuaginta, a expressão "Arabot Moab", que corresponde ao latim "campestria Moab", significa "campinas de Moab". Todavia, em 10,1, Egéria equivoca-se ao citar uma passagem bíblica e chama de "Arabot", ao invés de "Abarim" (Dt 32,49), a cadeia montanhosa cujo monte mais alto e setentrional é o Nebo. Em 10,4, a autora recorda outra passagem bíblica (Dt 34,8) contendo o nome "Arabot", mas dessa vez não erra. V. Moab e Nebo.

arquidiácono (archidiaconus, -i): diácono principal de uma Igreja local ou diocese (unidade territorial da Igreja administrada por um bispo). V. clérigo e diácono.

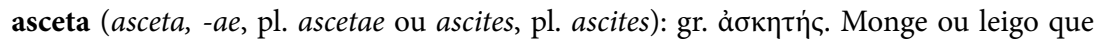
vivia na solidão e praticava o celibato e um alto grau de abstinência e penitência; eremita; anacoreta. No texto, os ascetas (ou monges ascetas) também são chamados de apotactitas, monazontes e partenas.

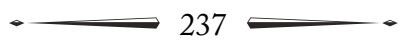


Ásia (Asia, -ae): gr. 'Ađía. Província romana situada no extremo oeste na atual Turquia. Sua capital era Éfeso.

Augustofratense (Augustofratensis, -is): v. Celessíria.

Ausítis: Hebr. e Vulg. Hus; Sept. Avoíııৎ (Jó 1,1). Terra natal de Jó. Uma antiga tradição localiza Ausítis na região de Hauran, no distrito de Naiwa, na atual Síria, situada quase na mesma latitude do extremo norte do mar da Galileia. Essa localização é possível, mas faltam provas. A terra de Hus é também mencionada em Jr 25,20 e Lm 4,21.

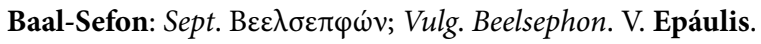

Basan: Sept. Baбáv; Vulg. Basan. V. Safdra.

Batânis (Batnae, -arum ou Batne, -es): gr. Bátval. Cidade da província romana de Osroena (ou Mesopotâmia da Síria), de grande importância militar. Os cristãos sírios chamavam essa cidade de Batna Sarugi ou Batna in Sarugo (ASSEMANN, Bibliotheca Orientalis, v.I, p.285, apud SMITH, 1854, s.v. "Batnae"). De acordo com Amiano Marcelino (Rerum gestarum, XIV, 3, 3; 23, 2, ibid.), Batânis havia sido construída pelos macedônios, a uma pequena distância do Eufrates. Muitos comerciantes ricos viviam ali, e durante o mês de setembro havia uma grande feira, frequentada por mercadores da Índia e da China. Atualmente, chama-se Suruç e encontra-se no território da Turquia.

Belém (Bethleem, Bethlehem ou Bethlem, indecl.): Sept. Baı $\theta \lambda \varepsilon \varepsilon \dot{\mu} \mu$. Cidade da Judeia, a 8 $\mathrm{km}$ ao sul de Jerusalém, antigamente também chamada Efrata (Gn 48,7; Mq 5,1), e seus habitantes, efrateus (Rt 1,2; 1Sm 17,12). Ambos os nomes - Bethlehem "casa de pão" e Ephrathah ou Ephrath "frutífero" - devem-se provavelmente à fecundidade de seu solo, e esta ainda é uma das partes mais férteis e cultivadas da Palestina. Desde a época de Davi, Belém foi celebrada como seu local de nascimento, sendo denominada "a cidade de Davi” (Lc 2,4; 11; Jo 7,42), e posteriormente tornou-se ainda mais célebre como o lugar em que se profetizava que o Messias haveria de nascer. Pelo menos após o séc. II, a lembrança do nascimento de Cristo é associada a uma gruta, sobre a qual Santa Helena, mãe de Constantino, construiu a Basílica da Natividade, que existe até hoje, ao mesmo tempo em que construía a Basílica do Santo Sepulcro, em 325 (Eusébio, Vida de Constantino, III, 41; 43, apud SMITH, 1854, s.v. "Bethlehem"). No século seguinte, a cidade tornou-se o refúgio escolhido pelos mais eruditos Padres Latinos e o cenário de seus importantes trabalhos em favor da literatura sacra, entre os quais a tradução latina da Bíblia feita por São Jerônimo - a Vulgata.

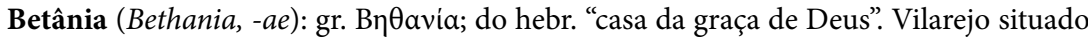
sobre o flanco oriental do Monte das Oliveiras, a $5 \mathrm{~km}$ de Jerusalém, hoje El-Azarieyh (literalmente, "aldeia de Lázaro"), em Israel. Aí Jesus tinha alguns amigos: Lázaro e suas irmãs Marta e Maria, além de Simão, o leproso - foi na casa deste que uma mulher se aproximou de Jesus com um perfume caríssimo e o derramou sobre sua cabeça, causando indignação nos discípulos, que condenaram o desperdício (Mc 14,3). Foi em Betânia que Jesus ressuscitou Lázaro, que estava no túmulo já há quatro dias (Jo 11). 
bispo (episcopus, -i): gr. દ̇ंíбколос. Etimologicamente, significa "supervisor"; assim, o bispo é o supervisor ou chefe de uma comunidade cristã, hierarquicamente acima dos presbíteros e diáconos. Os bispos são considerados os sucessores dos doze apóstolos, aos quais Jesus Cristo confiou a tríplice missão do magistério, da jurisdição e da ordenação de novos clérigos. O episcopado é o último e supremo grau do sacramento da Ordem - sacramento graças ao qual a missão confiada por Cristo aos seus apóstolos continua a ser exercida na Igreja, até o final dos tempos (CCIC, $\left.n^{\circ} 322\right)$. V. clérigo.

Bitínia (Bithynia, -ae): gr. BıӨvvía. Província romana situada no noroeste da península da Anatólia (que é ocupada em grande parte pela atual Turquia), junto ao mar de Mármara, ao estreito de Bósforo e ao Mar Negro. Segundo relatos de alguns geógrafos e historiadores antigos como Estrabão, Heródoto, Tucídides e Xenofonte, os bitínios seriam um povo de origem trácia (SMITH, 1854, s.v. "Bithynia").

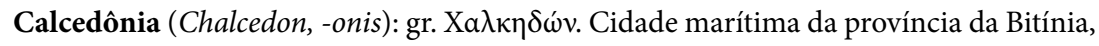
no litoral oriental do Bósforo, oposta a Constantinopla (antiga Bizâncio). Foi sede do quarto Concílio Ecumênico da Igreja Católica (451), no qual foi rejeitada a doutrina do monofisismo e apresentada a Definição de Calcedônia, que descreve a completa humanidade e a completa divindade de Jesus Cristo, a Segunda Pessoa da Trindade. Em Calcedônia se encontra o túmulo de Santa Eufêmia, visitado por Egéria $(23,7)$. Hoje corresponde a Kadikoi, o distrito mais populoso da cidade de Istambul (Turquia), localizado na parte asiática da cidade.

caldeus (Chaldaei, -orum): gr. Xa $\lambda \delta$ 反ĩot. Antigo povo da Babilônia, estabelecido na confluência do Eufrates e do Tigre e célebre pelos conhecimentos em astronomia.

calendas (kalendae ou calendae, -arum): É o primeiro dia do mês, no calendário romano. Em cada mês, havia três dias principais: calendae "calendas" = dia 1; nonae "nonas" = dia 5; idus "idos" = dia 13 ou 15 (conforme o mês). Para designar um dia qualquer, vê-se quanto falta para as próximas calendas, nonas ou idos. Assim, nono kalendas maias = faltam 9 dias para o $1^{\circ}$ de maio $=23$ de abril (cap. 20,5).

caminho (iter, itineris): Significa tanto um caminho concreto (uma estrada), como aqui $(2,3)$, quanto um caminho espiritual. No latim cristão, o termo também aparece no sentido metafórico da vida e da conduta do homem. Indica também o modo de agir de Deus para com os homens - "os caminhos de Deus" - e as normas que Ele traçou para o modo de agir do ser humano, isto é, os Mandamentos. No Novo Testamento, a doutrina de Deus é denominada "caminho" (At 16,17).

Canaã (Chanaan e Chanan, indecl.): Sept. Xaváav; do hebr. "país da púrpura”. Esse território se estendia do sul da Fenícia ao deserto de Neguebe, correspondendo aproximadamente à Palestina romana. Seus antigos habitantes estavam agrupados em sete clãs principais: cananeus, amorreus, gergeseus, heteus, heveus, jebuseus e ferezeus (Dt 7,1; Js 3,10). A Canaã, à qual Abraão se dirige (Gn 11,31), onde estabelece sua família e onde vivem Isaac e Jacó, é a Terra Prometida, que teve que ser reconhecida e 


\section{Maria Cristina Martins}

conquistada através das armas. Essa é a consequência da maldição de Noé, que submete Canaã, filho de Cam, a Sem, ancestral de Israel (Gn 9,24-26). Apesar das maldições lançadas pelos israelitas contra os cananeus e suas cidades, eles sobrevivem, mas os casamentos mistos são numerosos, assim como as práticas idólatras (Jz 3,5-6; Esd 9,12), apesar das advertências (Ex 34,15-16; Dt 7,4-6). A Terra Prometida é idealizada pela tradição como uma terra boa e desejável pela fertilidade e recursos naturais, "terra que emana leite e mel" (Ex 3,8). Após o exílio babilônico, torna-se o objeto central da esperança de Israel (Sl 133), e o tema do retorno (Ez 20,41-42) estará presente no pensamento e na oração do povo judeu até a época moderna.

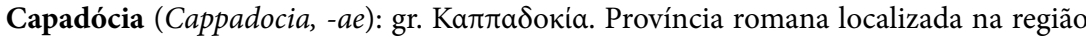
central da atual Turquia. Os capadócios eram chamados de "sírios" pelos gregos (Heródoto, História, I, 72, apud SMITH, 1854, s.v. “Cappadocia”), tendo sido dominados primeiramente pelos medos e depois pelos persas, antes de seu território cair nas mãos dos macedônios e, finalmente, dos romanos.

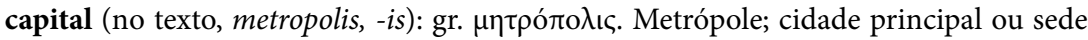
de região ou província.

Cárneas (Carneas): cidade da província da Arábia, a leste do mar da Galileia, onde a partir do séc. IV venera-se o túmulo de Jó, sobre o qual é construído um santuário. Não pode corresponder, como diz Egéria, à Denaba bíblica, pois esta era uma cidade do reino de Edom, no sul da Palestina. Segundo Natalucci (1991, p.265), o engano pode ter ocorrido devido à fusão de duas diferentes tradições: por um lado, uma tradição mais antiga dizia que Jó vivera "na terra de Ausítis, nos confins da Idumeia e da Arábia", e que "o nome de sua cidade era Denaba" (Sept. Jó 42,17d); por outro, uma segunda tradição teve início em Cárneas, após a descoberta relatada por Egéria em 16,6. Segundo Gamurrini (1887, p.57), Cárneas corresponde à bíblica Astarot ou Astarot-Carnaim (Dt 1,4; Gn 14,5; Js 9,10) e atual Tell Ashtarah, no sul da Síria.

Carra (Vulg. Charra): gr. Xáppav, transcrição do hebraico Haran. Segundo o testemunho de Egéria, o nome dessa cidade bíblica, quando de sua visita, é Carres (cf. 20,1). Do terceiro milênio a.C. até os tempos medievais, a cidade é mencionada como um importante centro de comércio no norte da Mesopotâmia, situada na estrada que ia do Mediterrâneo até o coração da Assíria (nordeste do atual Iraque, na margem leste do Tigre). No séc. IV, foi uma importante cidade fortificada da província de Osroena, constantemente disputada entre os romanos e os persas sassânidas, até que, em 639, foi capturada pelos árabes. Situada na região denominada Padã-Aram, é uma das cidades em que Taré se estabelece com o filho Abraão e demais familiares, vindos de Ur, antes de prosseguirem em viagem a Canaã (Gn 11,31). O poço onde um servo de Abraão encontrou Rebeca, que se tornaria esposa de Isaac (Gn 24), pode ser visto ainda hoje. Corresponde ao atual vilarejo de Harran, no sudeste da Turquia, a $38 \mathrm{~km}$ a sudeste de Urfa (antiga Edessa), próximo à fronteira com a Síria.

Carres (lat. Charrae; no texto, Charris): v. Carra. 


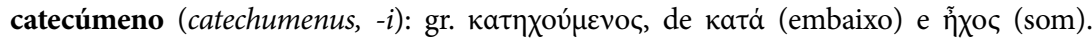
Indica a pessoa instruída oralmente. Na Igreja antiga, era o nome aplicado àquele que ainda não havia sido iniciado nos sagrados mistérios, mas estava assistindo a um curso de preparação para esse propósito, ou seja, estava participando da catequese. Como a aceitação do cristianismo envolvia a crença numa doutrina e a observância da Lei Divina - "Ide, pois, fazei discípulos meus todos os povos, batizando-os em nome do Pai, do Filho e do Espírito Santo, ensinando-os a observar tudo quanto vos mandei" (Mt 28,19-20) -, é claro que alguma espécie de instrução preliminar deve ter sido dada aos convertidos desde o início da Igreja. O termo ocorre em Gl 6,6: "O catecúmeno [gr. ho katechoúmenos; lat. is qui catechizatur] reparta todos os seus bens com quem o catequiza [gr. tò katechoûnti; lat. ei qui catechizat]". Outras passagens em que o verbo "catequizar" ocorre são Cor 14,19; Lc 1,4 ; At 18,24. No texto, portanto, o catecúmeno é aquele que ainda não foi batizado, em oposição ao "fiel".

Celessíria (Coelesyria, -ae, simpl. Coele, -es ou Syria Coele): no final do séc. II, a província da Síria (gr. Lvpia), que tinha Antioquia como capital e correspondia aos atuais sul da Turquia e norte da Síria, foi dividida em Syria Magna e Syria Coele (gr. Koí $\lambda \eta$ "oca”, "vazia"), cujo nome, segundo Estrabão (Geografia, XVI, 2, 21, apud SMITH, 1854, s.v. "Syria"), descreve bem o vale entre as cordilheiras do Líbano e do Antilíbano. Por volta de 341, da Celessíria se separou a província Augusta Euphratensis (também chamada Augustophratensis, numa provável forma coloquial, ou simplesmente Euphratensis), que abrangia Comagena, um antigo e importante distrito da Síria, na porção de terra que costeava o Eufrates a oeste, cuja capital primeiramente foi Samósata e depois, sob Constantino, passou a ser Hierápolis.

cidade (ciuitas, -atis): o termo ciuitas não significa necessariamente a cidade encarada do ponto de vista urbanístico, equivalente a urbs, mas pode também significar a "sociedade de homens", a "comunidade": em Santo Agostinho, p. ex., a ciuitas Dei "cidade de Deus" é uma espécie de recorte da humanidade.

Cilícia (Cilicia, -ae): gr. Kı入ıкía. Província romana cuja capital era Tarso. Situada na Anatólia, no sul da atual Turquia, em seu território encontra-se a grande cordilheira do Tauro, que se estende paralelamente à costa do Mediterrâneo. V. Tarso.

clérigo (clericus, - $i$, pl. clerici): no texto, "clérigos" designa os membros da Igreja que receberam uma ordenação, por oposição a "leigos", "fiéis" ou "povo". Com a mesma acepção, mas num número bem menor de vezes, Egéria usa também a palavra "clero" (clerus, - $i$

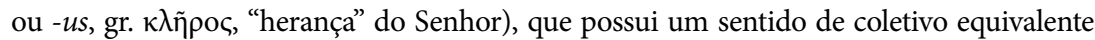
ao plural "clérigos". Egéria menciona as seguintes categorias da hierarquia eclesiástica: 1) clérigos: bispo, presbítero, arquidiácono e diácono; 2) pessoas que podiam ser tanto leigos de vida consagrada como membros do clero: irmãos, irmãs, hebdomadários e ascetas (entre os ascetas, incluíam-se os apotactitas, monges, monazontes e partenas); 3) leigos.

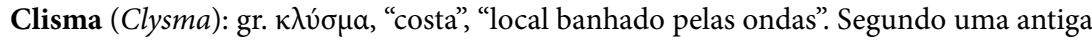
tradição, testemunhada por escrito, pela primeira vez, por Eusébio de Cesareia no 


\section{Maria Cristina Martins}

Onomastikon e contestada por estudiosos modernos (v. Vermelho), Clisma foi o local onde os hebreus, perseguidos pelos egípcios, atravessaram a seco o Mar Vermelho (Ex 14). O local fora uma fortaleza ptolomaica, que havia sucedido um mais antigo posto faraônico. Na época de Egéria, era um importante porto de comércio com as Índias e cidades do Mar Vermelho e da Arábia. Suas ruínas situam-se em Qom Qoulzoum, a $500 \mathrm{~m}$ ao norte da atual Suez (Egito).

competente (con- ou competens, -tis): termo que aparece uma única vez no texto $(45,2)$, é o nome dado por Egéria ao catecúmeno que, no início da Quaresma, inscreve-se para ser batizado na Páscoa. Embora a palavra fosse um termo técnico usado por outros autores e em outras regiões para designar o candidato ao batismo (em Roma, porém, o termo usado era electi), poder-se-ia também pensar que está sendo usada em seu sentido primitivo: "aquele que pede" para ser admitido ao batismo, sendo que tal pedido podia ou não ser aceito pelo bispo, conforme é relatado em 45,3-4.

confessor (confessor, -is): a palavra latina confessor é derivada de confiteri "confessar", “professar", mas não é encontrada em autores do período clássico, tendo sido usada pela primeira vez pelos cristãos. É um título de honra com um sentido bem específico, usado para designar aqueles bravos cristãos que, numa época de perseguição, professaram publicamente sua fé e foram punidos com prisão, tortura, exílio ou trabalho nas minas, permanecendo fiéis à fé em Cristo até o fim da vida, ou ainda aos que lutaram pela ortodoxia católica, isto é, contra as heresias e sectarismos (Blaise, 1954, p.195). O título, portanto, distingue-os dos mártires, que foram assim chamados porque perderam a vida por causa da fé. Assim como seu equivalente grego homologetés, confessor foi muitas vezes aplicado às vítimas da perseguição de Valente, imperador entre 364 e 378 (Maraval, 2002a, p.29-30). No texto, o título de confessor é aplicado aos bispos de Batânis (19,1), Edessa $(19,5)$ e Carres $(20,2)$, cidades da região da Mesopotâmia.

Constantino (Constantinus, -i): imperador romano entre 306 e 337. Construiu uma nova residência imperial em Bizâncio, que viria a se chamar Constantinopla em sua honra. É considerado o primeiro imperador romano a professar o cristianismo, após sua vitória na batalha da ponte Mílvia, perto de Roma, em 312, que mais tarde ele atribuiu ao Deus cristão. Segundo a tradição, antes da batalha, Constantino teve uma visão que lhe assegurou a vitória por ter lutado sob o símbolo de Cristo: in hoc signo uinces - "neste símbolo, vencerás". Então mandou que pintassem o símbolo - o monograma de Cristo (o "chi-rô", isto é, as duas primeiras letras gregas do nome de Cristo superpostas) - nos escudos dos soldados e conseguiu uma vitória esmagadora. Este relato teve origem na fusão de fatos narrados por Eusébio de Cesareia, em sua biografia do imperador, e não é considerado um fato histórico. É certo, porém, que Constantino legalizou e apoiou o cristianismo, através do Édito de Milão, em 313. Sua mãe, Santa Helena, provavelmente nascida cristã, demonstrou muita piedade no fim da vida, quando realizou uma peregrinação à Terra Santa, localizou em Jerusalém aquela que foi tida como a Verdadeira Cruz de Cristo e dirigiu a construção de várias igrejas, tais como a Anástase, o Martyrium e as igrejas de Eleona e de Belém. 
Constantinopla (Constantinopolis, -is): colônia fundada por gregos oriundos da cidade

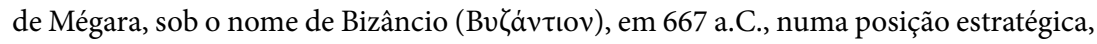
junto ao estreito de Bósforo e o mar de Mármara, em território europeu. Às vezes como uma ponte, às vezes como uma barreira, por mais de 2500 anos a cidade esteve no centro de conflitos religiosos, culturais e militares, tendo sido uma das mais cobiçadas cidades do mundo. Em 330, foi reinaugurada por Constantino e tornou-se a capital do Império Romano do Oriente (ou Império Bizantino), por mais de mil anos. Em 1453, foi tomada pelos turcos e passou a ser a capital do Império Otomano até 1923, quando se tornou capital da República Turca. Posteriormente, passou a se chamar Istambul (corruptela

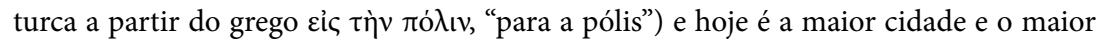
porto marítimo da Turquia.

Córico (Corycus, -i): gr. Kúpvкоc. Cidade portuária que, não longe da fronteira com a Isáuria, encontrava-se não nessa província, como diz Egéria, mas na Cilícia (Maraval, 2002a, p.227). Atualmente se chama, em turco, Kizkalesi (Turquia), onde ainda se encontram restos notáveis do que foi uma ilustre cidade cristã.

Corra: Sept. Xoppa日; Vulg. Charith. Torrente (atual rio Yabis, afluente da margem esquerda do Jordão), onde Elias habitou, por ordem do Senhor (1Rs 17,3).

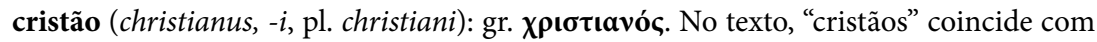
"povo". É um termo aplicado a todos que possuem a fé cristã, opondo-se, portanto, a “pagãos” (gentes) (cf. 20,8).

Cruz (crux, crucis): no texto, o termo designa a cruz colocada na colina do Gólgota ou Calvário (Caluaria, "crânio" é o nome latino correspondente ao aramaico Golgotha; nesse local, ocorriam as execuções na época de Jesus Cristo), entre a Anástase e o Martyrium. Diante da Cruz, havia um átrio, que Egéria chama de Ante Crucem ou Ad Crucem; detrás da Cruz, havia uma pequena capela, chamada por ela de Post Crucem, utilizada para certos atos litúrgicos e cerimônias, p. ex., a adoração da Verdadeira Cruz e de outras relíquias conservadas no Martyrium (37,1-3).

Denaba: Sept. $\Delta \varepsilon v v a \beta a ;$ Vulg. Denaba. V. Cárneas.

diácono (diaconus, -i): gr. $\Delta$ tákovoc, "servidor", “ajudante". No Novo Testamento, a palavra tem muitas vezes uma acepção genérica, designando todos aqueles que trabalham no santo ministério, inclusive os bispos e presbíteros. $\mathrm{O}$ apóstolo Paulo aplica o termo a Cristo ( $\mathrm{Rm} \mathrm{15,8),} \mathrm{a} \mathrm{si} \mathrm{mesmo} \mathrm{e} \mathrm{a} \mathrm{outros} \mathrm{pregadores} \mathrm{(1Cor} \mathrm{3,5;} \mathrm{Ef} \mathrm{3,7).} \mathrm{Em}$ seu sentido estrito, porém, aplica-se aos clérigos do terceiro grau da hierarquia, que possuem o primeiro grau do sacramento da Ordem, tendo sido ordenados não para o sacerdócio, mas para assistir os bispos e padres nas funções sagradas, encarregando-se, por exemplo, da distribuição de esmolas, da administração temporal, da proclamação da Palavra e da liturgia. É nesse sentido que Egéria emprega o termo. V. clérigo.

Edessa (Edessa, -ae): gr.”E $\delta \varepsilon \sigma \sigma \alpha$. Situada na extremidade norte da Mesopotâmia, foi a capital da província romana de Osroena e metrópole cultural do Oriente Médio entre os 


\section{Maria Cristina Martins}

sécs. IV e VIII, tornando-se o centro irradiador da cultura e do cristianismo ortodoxo oriental, através do idioma siríaco. Foi marcada por uma forte implantação monástica e por escolas de teologia que recebiam alunos oriundos de várias partes do mundo. Em Edessa viveu, durante dez anos, Santo Efrém da Síria (306-373), que para aí se deslocara após a invasão de sua cidade natal, Nísibis, pelos persas, em 363. A visita a Edessa, como a própria Egéria diz $(17,2)$, era uma peregrinação que todos desejavam fazer naquela época, pois a cidade era um dos mais antigos centros do cristianismo oriental. Edessa corresponde à atual cidade de Urfa, na Turquia, próxima à fronteira com a Síria.

Edom: Sept.'E $\delta \omega ́ \mu ;$ Vulg. Edom. Reino fundado pelos descendentes de Esaú (também chamado Edom), localizado entre o Mar Morto e o golfo de Ácaba, no atual território de Israel. Sob a liderança de Moisés, os hebreus pretendiam atravessar Edom para ir a Canaã, mas o rei de Edom negou-lhes passagem, obrigando-os a contornar suas terras

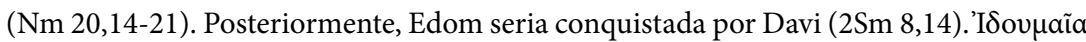
e Idumaea são as formas clássicas do nome semítico "Edom".

Éfeso (Ephesus, -i): gr. "E $\varphi \varepsilon \sigma o c$. Cidade da Lídia, uma das doze cidades jônicas (Heródoto, História, I, 142, apud Smith, 1854, s.v. "Ephesus"). Capital da província romana da Ásia na época de Egéria, foi uma importante cidade greco-romana no litoral oeste da Ásia Menor, célebre pelo Templo de Ártemis (Diana), uma das Sete Maravilhas do Mundo Antigo, e pelas práticas de feitiçaria. Foi um importante centro para o cristianismo primitivo: o apóstolo Paulo aí estabeleceu uma igreja e permaneceu por três anos, usando a cidade como base. Em At 19,23-41, é narrada uma discussão entre Paulo e artesãos cuja sobrevivência dependia do templo de Ártemis. Paulo escreveu a Primeira Carta aos Coríntios a partir de Éfeso, e depois enviou a carta aos Efésios à comunidade cristã que ali fundara. De acordo com a tradição, a cidade foi o lar de São João Apóstolo nos últimos anos de sua vida - aí se encontra seu túmulo, que é venerado desde o fim do séc. II. As ruínas de Éfeso podem ser vistas perto do povoado de Selçuk, no oeste da Turquia.

Egito (Aegyptus, -i): gr. Aľ $v \pi \tau \tau$ ç. Localizado na região do nordeste da África e do curso inferior do Nilo, torna-se um império a partir do terceiro milênio a.C. Entra na história bíblica na época patriarcal, como terra de refúgio para Abraão (Gn 12,10; 13,1). Jacó envia seus filhos ao Egito, para livrá-los da fome, e aí eles reencontram o irmão José, anteriormente vendido por eles, que então havia se tornado ministro e conselheiro do Faraó. Em seguida, Jacó também se estabelece no Egito, e seus descendentes se multiplicam (Ex 1,6-7), mas o país acaba tornando-se uma terra de opressão para eles sob os faraós hicsos (Ex 1,8-14). Finalmente, Moisés é escolhido por Deus para conduzir a saída dos hebreus do Egito - o Êxodo (Ex 3,10-12).

Eleona: basílica situada numa parte elevada do Monte das Oliveiras, também chamado monte Eleona (do gr. 'E $\lambda a \iota \omega ́ v$, "olival", acrescido de uma terminação aramaica). Encontrava-se nesse local a gruta onde Jesus teria ensinado os apóstolos (Mc 13,3; At 1,6-12) e, segundo a tradição, teria passado as noites da segunda, terça e quarta-feira anteriores à Paixão. 
Élia (Aelia, -ae): após a segunda guerra judaico-romana, ou Revolta de Bar Kokhba (132135), a antiga cidade de Jerusalém foi reconstruída pelo imperador Adriano (Publius Aelius Hadrianus), que lhe deu seu próprio nome: Colonia Aelia Capitolina, chamada correntemente apenas de Aelia (é Capitolina em memória de Júpiter Capitolino, em cuja honra foi construído um templo pagão no local do antigo templo judeu). Assim, Élia é o nome oficial da cidade de Jerusalém quando da visita de Egéria, uma cidade completamente nova, diferente da Jerusalém de Herodes ou da do Novo Testamento.

Elias (Elias ou Helias, -ae): gr.'H入iac; hebr. “meu deus é Iavé”. Um dos profetas de Israel, chamado "tesbita", por ter nascido em Tesbi, Elias é considerado o pai dos profetas, isto é, daqueles que, a partir da oração, nutrem-se de força e luz para exortar o povo à fé e à conversão do coração (CCIC, $\mathrm{n}^{\circ}$ 539). É também um dos personagens mais populares da Bíblia: em 1Rs 17 e 2Rs 2, há diversos relatos de caráter lendário sobre sua pessoa e seus milagres. Viveu no reino do Norte, na época de Acab (séc. IX a.C.); morou na torrente do Corra, onde corvos milagrosamente proveram sua alimentação; desafiou o rei Acab, ao pregar a adoração de Iavé e rejeitar o culto ao deus fenício Baal. Em 2Rs 2,11, é narrada sua misteriosa ascensão ao céu, numa carruagem de fogo. Seu retorno foi previsto pelos profetas para os tempos messiânicos, isto é, ele voltaria para anunciar a vinda do Messias. No Novo Testamento, Elias aparece ao lado de Moisés durante a Transfiguração de Cristo (Mt 17).

Encênias (Encaenia, -orum, neutro pl.): gr.'Eүкaívıa. Termo que designa, na Septuaginta e no Novo Testamento, a festa de consagração ou dedicação do templo (cf. 2Cr 6,12; $1 \mathrm{Mac}$ 4,59; Jo 10,22). Egéria refere-se à festa das Encênias da Anástase e do Martyrium, igrejas que foram consagradas em 335, em cuja solenidade o historiador Eusébio de Cesareia pronunciou a oração panegírica. Segundo Egéria, nessas mesmas Encênias comemoravase também a descoberta da Verdadeira Cruz do Senhor. A data exata da festa oscila entre 13 (cf. Eusébio, Vida de Constantino, IV, 40-46, apud Mariano e Nascimento, 1998, p.251) ou 15 de setembro (cf. Teodósio, De situ terrae sanctae, 31, ibid.).

Enon: gr. Aivwóv; Vulg. Aennon. Em hebraico, "abundância de água”; um dos locais de atividade de João Batista, com a fonte e o tanque onde ele exercia seu ministério (Jo 3,23). Provavelmente localizava-se no vale do Jordão, nos confins do território samaritano e na estrada frequentada pelos galileus, numa região com fontes abundantes. Esse local hoje se chama Ain ed Deir (cf. D. Buzy, Saint Jean-Baptiste. Études historiques et critiques. Paris, 1922, p.221-228, apud Maraval, 2002a, p.188) e se situa a cerca de $3 \mathrm{~km}$ a oeste da corrente do rio e $10 \mathrm{~km}$ ao sul da atual Beisan, cidade situada no norte de Israel e conhecida como Scythopolis durante o período helenístico (Heinlein, 1907, apud The Catholic Encyclopedia, s.v. "Aenon”).

Epáulis: o nome Epauleum usado por Egéria origina-se do termo grego ह̌ $\pi a v \lambda ı$, "acampamento", "bivaque", "local para passar a noite", da Septuaginta, que, por sua vez, traduz o hebraico Phiahiroth (a Vulgata mantém este nome). Era um local próximo a uma das estações onde os hebreus acamparam durante a fuga do Egito, assim como Magdol e Baal-Sefon. As três localidades, segundo Ex 14,1-2, deviam se situar próximo ao lugar de 
passagem do Mar Vermelho; nos tempos faraônicos, possuíam templos de divindades orientais, como Hator, Baal-Sefon etc. e, na época romana, foram transformadas em guarnições militares (Abel, Géographie de la Palestine. Paris, 1938, p.208ss, apud Arce, 1980, p.89).

Epifania (epiphania, -ae): gr. દ̇đıpavía, “aparição”. Epifania é a aparição ou manifestação de Jesus Cristo aos pagãos em diversos momentos: em seu nascimento, em seu batismo e nas bodas de Caná. Também é a festa que a Igreja contrapõe às festas pagãs do solstício de inverno celebradas em Roma, em 25 de dezembro, e no Egito, em 6 de janeiro. $\mathrm{Na}$ época de Egéria, a Igreja de Jerusalém também celebrava a festa da Epifania e o nascimento de Jesus em 6 de janeiro, incluindo a adoração dos magos. Em Jerusalém, o Natal passa a ser celebrado em 25 de dezembro somente a partir do final do séc. IV (Maraval, 2002a, p.250). A Epifania marca o início do ano litúrgico nas Igrejas cristãs.

Etam (Vulg. Aetham; no texto, Oton): Sept. 'OӨó $\mu$. Uma das etapas dos hebreus em direção ao Mar Vermelho (Ex 13,20; Nm 33,6). Corresponde a Serapeum, ao norte dos Lagos Amargos (lagos salgados conectados ao canal de Suez) (Pétré, 1948, p.38-39).

Eufêmia (Euphemia, -ae): gr. Eủ visitado por Egéria, na Calcedônia, local em que viveu a santa, martirizada em 303-304. Foi em seu magnífico santuário, localizado no alto do monte Haider Pasha, que ocorreu o Concílio de Calcedônia, em 451. O santuário foi destruído pelo sultão otomano Solimão (séc. XVI), para construir sua mesquita em Constantinopla. Santa Eufêmia é considerada uma grande santa e mártir pela Igreja Ortodoxa, e a maior parte de suas relíquias encontra-se atualmente na Igreja de São Jorge, em Istambul (Turquia).

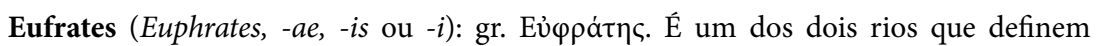
"Mesopotâmia”, ou seja, "terra entre rios". Com 2780 km, é o mais longo e um dos mais importantes rios da Ásia ocidental; nasce no leste da Turquia, corre através da Síria e do Iraque, une-se ao Tigre e desemboca no Golfo Pérsico.

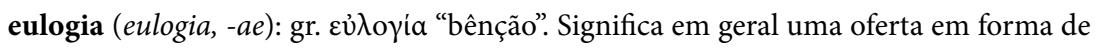
presente, sinal de caridade e comunhão, mas que a princípio consistia em alimentos, tais como pães, biscoitos, frutas etc. O termo também pode significar parte da hóstia (corpo ou sangue de Cristo) ou ainda pão bento, distribuído ao povo em sinal de comunhão ou caridade, ou dado aos amigos em sinal de afeição.

Fadana (Fadana): cidade localizada na região de Padã-Aram (hebr.) ou da Mesopotâmia da Síria (Sept. e Vulg.) no Antigo Testamento (Gn 25,20; 28,2), próxima a Carra. É a terra do sírio Labão, sogro de Jacó. Suas atuais ruínas provavelmente situam-se em Telfidan (ou Tell Fadan), no sudeste da Turquia.

Faran (Pharan, indecl.): Sept. Фapáv. A palavra pode referir-se à cidade de Faran ou ao deserto em que ela está situada, entre o Sinai e a Palestina. É a cidade bíblica de Rafidim, onde teria ocorrido o milagre da água brotando da pedra e o combate entre os hebreus e os amalecitas (Ex 17-18). Corresponde à atual Feiran (Egito), que é um oásis e 
o centro mais importante da península do Sinai. Feiran tem sido chamada de "Pérola do Sinai”, por sua incomparável beleza, por sua grandiosa vista e pelas ruínas de mosteiros e igrejas que remontam até o séc. IV.

Fenícia (Phoenicia, -ae): gr. Фoเvíkn. Província romana localizada na região do atual Líbano, cujas cidades principais eram Tiro, Sidon, Biblos e Berito (moderna Beirute). Seus habitantes, os fenícios, foram notáveis mercadores, navegadores e colonizadores do Mediterrâneo durante o primeiro milênio a.C., tendo fundado, entre outras, a cidade de Cartago. O alfabeto usado pelos fenícios causou um grande impacto na história da escrita, pois deu origem a outros importantes sistemas de escrita, como o alfabeto aramaico (do qual provêm principalmente os alfabetos hebraico, árabe e siríaco) e o grego (que deu origem aos alfabetos latino e cirílico, entre outros).

fiel (fidelis, -e, pl. fideles): no latim eclesiástico, é aquele que tem fé, o crente, o cristão, o seguidor de Cristo. Na segunda parte do texto, refere-se especificamente ao cristão batizado há mais de um ano, em clara oposição ao catecúmeno, o pretendente ao batismo. Segundo Bastiaensen (1962, p.9ss), não se pode afirmar que a equivalência "fiel" = "batizado" existia desde as origens do cristianismo, mas essa tradição já se encontra em Tertuliano (início do séc. III) e torna-se comum no séc. IV.

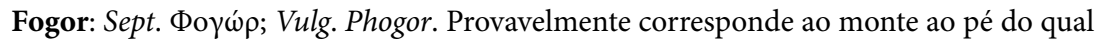
se situava a cidade de Betfogor (Nm 23,28). Fazia parte do território dos amorreus. V. Hesebon.

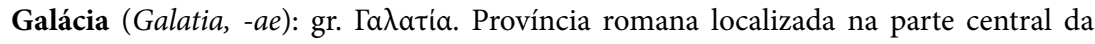
Anatólia, cuja capital era Ancira (atual Ancara, capital da Turquia). O nome da região se deve às tribos celtas - Galatae ou Gallograeci - que aí se estabeleceram, vindos do oeste, no início do séc. III a.C. (SMITH, 1854, s.v. “Galatia”). Na Galácia, o apóstolo Paulo fundou igrejas, às quais posteriormente escreveu a Epístola aos Gálatas. Sua primeira visita à província é mencionada em At 16,6, e a segunda, em At 18,23.

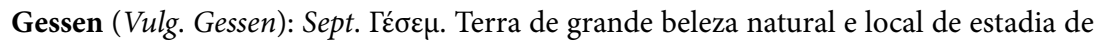
José e seus irmãos (Gn 45,10), no norte do Egito, situada entre o deserto e o braço mais oriental do Nilo.

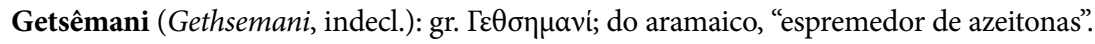
Jardim cercado situado um pouco para fora de Jerusalém, ao pé do Monte das Oliveiras, onde Jesus costumava rezar. Nesse local ocorreram importantes fatos da Paixão de Cristo: a prece, durante Sua agonia, e a prisão, após a traição de Judas (Mt 26,36).

Gólgota (Golgotha, indecl.): gr. Гo $\lambda$ $ү \theta \tilde{a}$. V. Cruz.

hebdomadário (hebdomadarius, -i): termo derivado de hebdomada (cf. 27,2; 28,1; $45,2)$, empréstimo latino popular e tardio sobre o acusativo grego de $\dot{\varepsilon} \delta$ o $\mu a \dot{\varsigma}$, "sete dias", "semana". No texto, denota especificamente o cristão que jejuava durante uma semana inteira, o apotactita, homem ou mulher, cujo jejum era rigorosíssimo, como se lê em $28,3-4$. 


\section{Maria Cristina Martins}

Helpídio (Helpidius, -i): o Santo Helpídio mencionado por Egéria não consta em nenhum martirológio. Bludau (apud Gingras, 1970, p.208) acredita que ele tenha sido um santo local de Carres que provavelmente morreu durante a perseguição de cristãos promovida pelo rei persa Sapor II, entre 310 e 380. No texto, o "dia do martírio" corresponde à festa em comemoração a esse santo, no dia 23 de abril (cap. 20,5).

\section{Hero: v. Herópolis.}

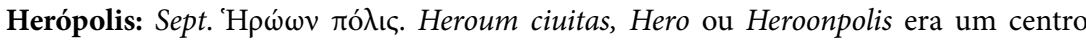
portuário e militar localizado junto ao delta do Nilo. É o local onde José recebeu Jacó em sua chegada de Canaã (Gn 46,28-29). Provavelmente situa-se no atual sítio arqueológico de Tell el-Mashuta (Egito), que abrange também Pitom.

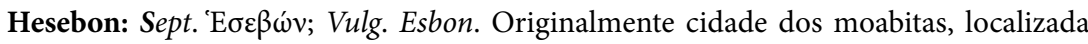
a nordeste do Mar Morto, foi capturada por Seon, tornando-se a capital do reino dos amorreus, mas após a invasão israelita passou ao controle das tribos de Ruben e Gad (Nm 32,37; Js 21,39). Mais tarde chamada Esbus, quando do domínio romano, corresponde à atual Hesban (Irã). Segundo Egéria $(12,8)$, a cidade se chama Exebon quando de sua visita, mas essa grafia não é encontrada em nenhum outro lugar.

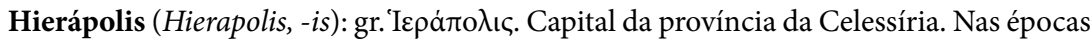
helenística e romana, foi um importante centro comercial e entroncamento rodoviário no caminho de Antioquia a Nísibis. Como a cidade era um importante centro religioso e aí se encontrava o mais famoso templo de Atagartis, deusa síria da natureza, os gregos deram-lhe o nome de "Cidade Sagrada". Segundo Cumont (Études syriennes, 27, n 3, apud Janeras, 1986, p.156), apesar do cristianismo, Atagartis foi considerada a deusa da cidade até o ano 500; por outro lado, a cidade foi o berço de escritores cristãos notáveis, como Filoxeno de Hierápolis (ca. 440-523), um dos maiores prosadores siríacos. Hoje encontra-se parcialmente ocupada pela cidade de Membij, no norte da Síria, a cerca de $80 \mathrm{~km}$ a nordeste de Alepo.

hora (hora, -ae): no costume romano, o dia se dividia em 12 horas iguais, sendo que a sexta hora coincidia sempre com o meio-dia. A primeira hora do dia era a hora prima, e assim por diante para as horas diurnas. A noite estava dividida em quatro vigílias (uigiliae), dentro do intervalo entre o pôr e o nascer do sol; a terceira vigília começava sempre à meia-noite, e a quarta correspondia ao período entre as 3 horas da madrugada e o nascer do sol. No entanto, para se referir às horas da noite, Egéria segue a mesma lógica das horas diurnas: como o período da noite tem início com o pôrdo-sol, aproximadamente às 6 horas da tarde (18h), hora prima noctis, "primeira hora da noite" corresponde a $19 \mathrm{~h}$; do mesmo modo, hora sexta noctis, "sexta hora da noite" corresponde à meia-noite.

Horeb (Vulg. Horeb; no texto, Choreb): Sept. X $\omega p \eta ́ \beta$. Para Egéria e a antiga tradição cristã, é um monte que faz parte do maciço montanhoso em que também se encontra o monte Sinai, mas distinto do ponto em que houve a manifestação de Deus a Moisés, isto é, um pouco mais abaixo do topo do Sinai. No Horeb, recorda-se o profeta Elias (1Rs 19,8). 
hóstia (hostia, -ae): no latim clássico, é a vítima expiatória oferecida aos deuses; no latim eclesiástico, a palavra refere-se à vítima eucarística, ou seja, ao pão consagrado durante a missa e distribuído aos fiéis, que é de fato o corpo de Jesus Cristo, ofertado para a salvação de todos os homens. A palavra pode significar também a oferenda do próprio corpo - é o que faz um mártir, ao dar sua vida pela fé - ou uma oferenda espiritual.

\section{Idumeia (Idumaea, -ae): v. Edom.}

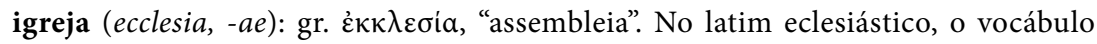
pode assumir diversos significados: assembleia do povo, congregação, comunidade de fiéis, lugar de reunião de fiéis, lugar sagrado para celebrar os ofícios divinos, templo, sinagoga. Em Mt 16,18, Jesus diz ao discípulo Simão Pedro: "és Pedro, e sobre esta pedra edificarei minha Igreja”. O Compêndio do Catecismo da Igreja Católica define "Igreja" como "o povo que Deus convoca e reúne de todos os recantos da terra, para constituir a assembleia dos que, pela fé e pelo Batismo, se tornam filhos de Deus, membros de Cristo e templo do Espírito Santo" ( $\left.n^{\circ} 147\right)$. Com inicial maiúscula, "Igreja" também pode designar um conjunto de fiéis católicos de um Estado, cidade ou região, ou equivaler a "diocese" ou "Igreja local" ou "Igreja particular", ou seja, uma unidade administrada por um bispo. Em suas

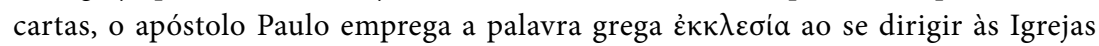
ou comunidades locais e, segundo sua formulação, a Igreja se reconhece como um corpo cuja cabeça é Cristo $(\mathrm{Col} 1,18)$. Sem inicial maiúscula, designa o edifício onde se reúnem os cristãos - é nessa acepção que Egéria usa o termo.

Imbomon: gr. દ̉v ßouvẹ̃, "na colina”. Cimo do Monte das Oliveiras, de onde ocorreu a Ascensão de Cristo (Mc 16,19; Lc 24,50; At 1,12). É apenas no fim do séc. IV, provavelmente entre 392 e 395 (após, portanto, a visita de Egéria), que é construída aí uma igreja, denominada Santa Ascensão.

irmã (soror, -oris, pl. sorores): "freira", "mulher consagrada a Deus", "membro de uma congregação religiosa feminina”, ou simplesmente "irmã na fé, ainda que leiga. No texto, Egéria chama de irmãs aquelas a quem escreve, ou seja, as companheiras de vida religiosa em sua pátria.

irmão (frater, -tris, pl. fratres): na Igreja primitiva, os cristãos se chamavam entre si de irmãos e irmãs, no sentido de "irmãos e irmãs na fé" ou "irmãos e irmãs em Cristo". Egéria emprega a palavra não apenas nessa acepção (cf. 47,4), mas também no sentido de "monge" (cf. 10,3; 15,3; 16,2).

Isáuria (Isauria, -ae): gr.'Iбavpía. Província romana situada no complexo montanhoso do Tauro, num terreno acidentado e selvagem, cujos povoados eram temidos pelos peregrinos, em virtude da frequente ação de saqueadores e ladrões. São João Crisóstomo (ca. 347-407) descreve suas dificuldades durante uma viagem pela província: “(...) sem médico, sem banho, sem o necessário, sem o mínimo repouso, acometido de todos os lados pelo medo dos isáurios (...)"; e a presença constante de soldados na região: “(...) fomos libertados do medo dos isáurios, pois aqui há muitos soldados, muito bem 
armados contra eles" (Epistulae ad Olympiadem, VI, \$1a-b, apud Mariano e Nascimento, 1998, p.167). A Isáuria localizava-se no sul da atual Turquia, junto ao Mediterrâneo.

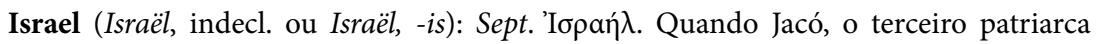
bíblico, combateu contra o anjo, recebeu o nome de Israel, ao qual a etimologia popular dá o significado de "aquele que lutou contra Deus" (Gn 32,28). Assim, Israel passa a ser o nome do país fundado por Jacó e seus descendentes, os ancestrais das doze tribos de Israel. Com a morte do rei Salomão, o reino se separa em dois: o reino de Israel, ao norte, e o reino de Judá, ao sul. O nome de Israel designa então uma parte da população (1Rs 12,19). Após a conquista do reino do Norte pelos assírios em 721 a.C., o termo passa a designar a comunidade político-religiosa dos judeus. Israel tem também o sentido espiritual de povo de Deus fiel à Aliança de Abraão e Moisés, e o termo foi utilizado inclusive pelos cristãos nesse sentido. A partir de 1948, o termo designa também o moderno Estado de Israel, após a divisão - posta em prática pelas Nações Unidas - do território da Palestina em setores judeus e árabes palestinos.

Jacó (Jacob ou Iacob, indecl.): Sept.'Iakẃß. Também chamado Israel, Jacó foi o terceiro patriarca dos hebreus, neto de Abraão, filho de Isaac e de Rebeca e irmão gêmeo de Esaú. Teve doze filhos, os ancestrais epônimos das doze tribos de Israel. v. Israel.

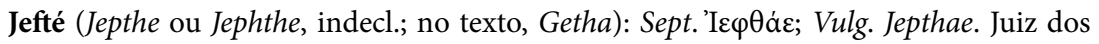
hebreus (Jz 12,7), que fez voto de oferecer a Deus o primeiro ser que saísse ao seu encontro quando voltasse da guerra, sorte que caiu sobre sua filha única.

Jericó (Jericho ou Hiericho, indecl.): Sept.'Iepıðẃ. Cidade da antiga Palestina situada no vale do rio Jordão, na Cisjordânia (atualmente, parte do território de Israel). No Antigo Testamento, é citada como a primeira cidade a ser tomada na Terra Prometida, após o retorno dos hebreus da escravidão do Egito, liderados por Josué (Js 6). É considerada a cidade mais antiga ainda existente, com mais de 10 mil anos.

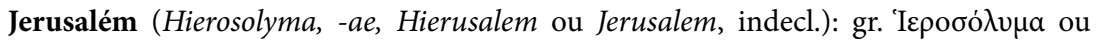

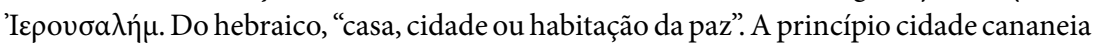
do povo jebuseu, no séc. X a.C. é conquistada por Davi $(2 \mathrm{Sm} 5,6)$, que a escolhe como capital das doze tribos de Israel. Com a presença da Arca da Aliança e a construção do Templo de Salomão, torna-se o foco religioso dos hebreus, onde se celebra a grandeza de Deus e da casa de Davi. Após o cisma entre os reinos do Sul e do Norte, Jerusalém passa a ser capital do pequeno reino de Judá. Destruída pelos babilônios em 587 a.C. (2Rs 25), é reconstruída após o exílio dos hebreus (Esd 3-6). É sitiada e novamente destruída pelo imperador romano Tito, em 70 d.C. Em 135, Adriano destrói o que resta da cidade, a reconstrói e moderniza, e assim Jerusalém passa de mãos em mãos através dos séculos. A cidade torna-se um símbolo religioso da salvação universal (Mt 20,17; Lc 13,33; 18,31), da comunidade fundada por Cristo $(\mathrm{Gl} 4,26)$ e da glória definitiva do Reino de Deus (Ap 21, 2-22), tendo uma grande importância como Cidade Santa para judeus, cristãos e muçulmanos. Além de maior cidade, Jerusalém é também a capital proclamada do Estado de Israel, embora a condição de capital não tenha o reconhecimento unânime da 
comunidade internacional. No início do séc. XX, a cidade tornou-se o foco da disputa entre as aspirações nacionalistas dos sionistas e dos árabes palestinos - um conflito que, muitas vezes, tem gerado violência até hoje.

Jó (Job, indecl.): Sept.'Túß. Personagem de um dos livros mais antigos da Bíblia (ainda que não pertença ao gênero histórico, pois Jó não teria existido), célebre por sua resignação ao sofrimento. Piedoso e justo, Jó vivia na abundância e na felicidade. Deus, porém, permite a Satanás pôr à prova a fidelidade de Jó, que perde todos os filhos e toda a riqueza, além de ter o corpo todo coberto de úlceras. Jó suporta os tormentos sem perder a fé, clamando por sua inocência. Finalmente, Deus reverte sua situação, dandolhe em dobro tudo o que antes possuía, tanto filhos quanto bens materiais.

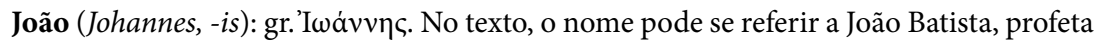
e parente de Jesus (15,1-6), ou ao apóstolo e evangelista João, um dos doze discípulos de Jesus $(23,10)$. João Batista era filho de Zacarias e Isabel, um casal idoso e estéril (Lc 1,7). Seu nascimento, anunciado pelo anjo Gabriel, precedeu de pouco tempo o de Jesus, cuja mãe, Maria, era parente de Isabel. Profeta, ele pregava no deserto da Judeia a conversão dos corações e anunciava a proximidade do Reino de Deus. Batizou muitos judeus e gentios no rio Jordão, inclusive Jesus, que foi até ele para receber o batismo antes de começar sua vida pública. Preso por Herodes Antipas, a quem tinha criticado pelo segundo casamento, foi decapitado por ordem da rainha Herodíades. É chamado também de Precursor: aquele que vem antes de outro para anunciá-lo (Lc 1,57-80). O apóstolo João é também chamado de "o discípulo bem-amado" de Jesus. Filho de Zebedeu e irmão de Tiago, é o autor do quarto Evangelho, além de três epístolas, sendo também atribuída a ele a autoria do Apocalipse de João de Patmos. Foi testemunha da Transfiguração de Jesus, que, antes de morrer, confiou-lhe Sua mãe (Jo 19,25-27). Após viajar muito e dirigir dioceses na Ásia, estabeleceu-se em Éfeso.

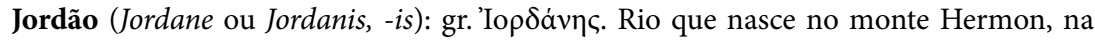
fronteira sírio-libanesa, e corre para o sul, em terras do norte de Israel, em direção ao mar da Galileia; a partir daí, o rio serve de fronteira natural entre Israel e Jordânia, antes de desaguar no Mar Morto, a 400 m abaixo do nível no mar (sendo o rio com menor elevação no mundo), percorrendo, ao todo, $360 \mathrm{~km}$. Os hebreus o atravessaram a seco para alcançar a Terra Prometida (Js 3,17), e em suas águas, Jesus Cristo foi batizado por São João Batista (Mt 3,13; Mc 1,9; Lc 3,21). O rio é reverenciado por cristãos, judeus e muçulmanos.

Josué (Josue, indecl.): Hebr. Yehoshua ou Yeshua, "Iavé salva"; gr. 'Inooṽc; lat. Iesus ou Jesus. Também chamado Oseias, foi ajudante e sucessor de Moisés após sua morte. Liderou o povo de Israel na travessia do Jordão (Js 3,5) e nas guerras de conquista de Canaã, relatadas ao longo do livro de Josué, de sua autoria. Ali se conta, p. ex., de que modo ele parou o movimento do sol e da lua para ter tempo de vencer os inimigos de Israel (Js 10,12-13). O livro de Josué é também denominado "livro de Josué, filho de Nave" (liber Iesu Naue), citado por Egéria em 10,3. Esse título provém da Septuaginta:

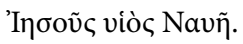

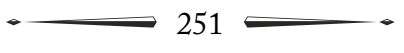




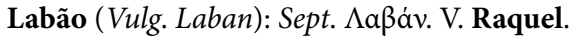

Lazário (Lazarium, -i): igreja situada no vilarejo de Betânia. O Lazário foi construído após 330, no local onde é lembrada a ressurreição de Lázaro (Jo 11), e ali era celebrado especialmente o ofício solene do sábado anterior ao Domingo de Ramos, o Sábado de Lázaro (cf. cap. 29).

leigo (laicus, $-i$, pl. laici): no latim cristão, designa aquele que não pertence ao clero, sendo, portanto, oposto a "clérigo". Na mesma acepção, Egéria emprega seculares, "seculares" (49,1). V. clérigo.

Lívias (Liuias, -adis): nome dado à cidade de Bet-Aram (cf. Js 13,27) por Herodes Antipas, em honra da segunda esposa de Augusto, nos primeiros anos da era cristã. Antipas a fortificou e transformou num importante centro viário, conhecido também por seus produtos agrícolas e águas termais. Situava-se além do Jordão, defronte a Jericó, correspondendo à atual Tell er-Rameh (Jordânia).

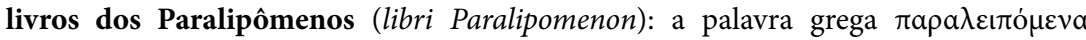
significa literalmente "o que foi deixado de lado". O título "livros dos Paralipômenos", ou seja, "livros das coisas omitidas", passou da Septuaginta às bíblias latinas antigas e à Vulgata. Na bíblia protestante, na hebraica impressa e em muitas bíblias católicas, estes dois livros são intitulados "livros das Crônicas". Constituem uma obra histórica do Antigo Testamento, contendo uma sinopse da história sagrada, desde Adão até o fim do cativeiro dos hebreus na Babilônia. Segundo São Jerônimo, os Paralipômenos seriam uma espécie de "epítome do Antigo Testamento".

livros dos Reinos (libri Regnorum): tradução literal do título $\beta i \beta \lambda_{\iota} \alpha \beta a \sigma \iota \lambda \varepsilon i \omega v$ da Septuaginta, usada pelas versões latinas antigas. Na Vulgata, São Jerônimo retoma a designação hebraica para os livros dos Reinos: libri Regum, "livros dos Reis".

Ló (Lot ou Loth, indecl.): Sept. $\Lambda \omega ́ \tau$. V. Sodoma.

lucernário (lucernare, -is e lucernarium, -i): hora em que se acendem as lâmpadas, começo da noite. No texto, refere-se ao ofício vespertino ou Vésperas.

Magdol: Sept. Má $\delta \omega \lambda o v ;$ Vulg. Magdolum. V. Epáulis.

majestade (maiestas ou majestas, -atis): "majestade", "grandeza", “divindade" (em oposição a "humanidade"). Egéria cita o passo bíblico a partir de uma versão latina anterior à Vulgata; de fato, a Vulgata traduz o termo $\delta$ ó $\zeta \alpha$, da Septuaginta, como gloria.

Mansocrenas: etapa ou estação visitada também pelo Peregrino de Bordéus - "mansio Mansucrinae, milia XII" (Itinerarium Burdigalense, 579, 2-3) -, citada como a etapa que se seguia a Tarso, a 12 milhas dessa cidade. Situava-se no caminho entre Tarso e Constantinopla, na província da Cilícia, ao sopé do monte Tauro. Corresponde à atual Mopsukrene (Turquia).

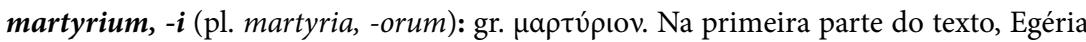
usa o termo normalmente na acepção de "túmulo de mártir", "santuário dedicado a 
um mártir ou que contém suas relíquias". Nessa acepção, martyrium é o termo mais empregado no Oriente, enquanto que, no Ocidente, emprega-se memoria, conforme testemunho da própria Egéria em 1,1. Na segunda parte, Martyrium refere-se a uma das igrejas do complexo da Basílica do Santo Sepulcro, em Jerusalém, construída sobre a gruta onde foi encontrada a Verdadeira Cruz, junto à Anástase e à Cruz, e assim denominada por ser um testemunho da Paixão - do martírio - de Cristo. O Martyrium ou Ecclesia Maior, "Igreja Maior", como Egéria o chama, continha o relicário da Verdadeira Cruz e outras relíquias da Paixão. Era a igreja paroquial de Jerusalém, onde se celebravam os principais ofícios do domingo e dos dias de festa. V. Anástase.

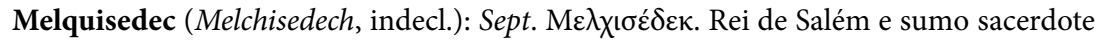
do Altíssimo (Gn 14,18-20); oferecendo a Deus pão e vinho, pronunciou uma bênção sobre o patriarca Abraão, que lhe ofertou os dízimos do povo. No Novo Testamento, Melquisedec é apresentado como um tipo (figura ou modelo) de Cristo, por causa de sua dignidade, tanto como sacerdote quanto como rei, pelo significado de seu nome, "rei de justiça", pela cidade que ele governou, "rei de Salém, isto é, rei de paz" (Hb 7,2), e também porque "sem pai, sem mãe, sem genealogia, seus dias não têm começo, sua vida não tem fim, assemelhando-se assim ao Filho de Deus, permanece sacerdote para sempre" (Hb 7,3).

memória (memoria, -ae): "memória", "lembrança", mas também "túmulo de um mártir", "santuário contendo as relíquias de um mártir", "santuário ou sepulcro em geral", "monumento erigido para celebrar um feito ou pessoa memorável"; nas acepções de "sepulcro" ou "santuário", memoria é mais usado no Ocidente, enquanto que martyrium, também usado por Egéria, é mais empregado no Oriente. Em 1,1, tem-se a expressão memoriae concupiscentiae, "memórias da concupiscência", que é a tradução literal de

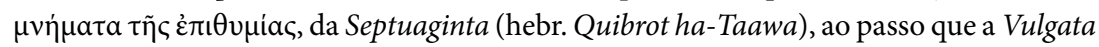
apresenta sepulchra concupiscentiae (isso seria uma evidência de que a versão da Bíblia usada por Egéria não teria sido a Vulgata, mas sim uma versão latina anterior, baseada na Septuaginta). Essa expressão encontra-se em Nm 11,34: no deserto, os hebreus queixaram-se com Moisés por estarem morrendo à míngua, alimentando-se somente de maná (semente parecida com a do coentro, que o povo moía para fazer broas), mas desejando comer carne. Moisés orou ao Senhor pedindo auxílio e recebeu a ordem de reunir setenta anciãos dentre o povo. O Senhor derramou sobre os anciãos o espírito de Moisés, para que pudessem ajudá-lo a levar a carga do povo. Em seguida, para satisfazer a ânsia carnívora do povo judeu, Deus fez soprar um vento que trouxe um bando de codornizes e as fez pousar sobre o acampamento. Os judeus comeram tanta carne, que Deus, irado, lançou sobre eles uma grande epidemia. Assim, o nome do lugar passou a se chamar "Cemitério da Gula", pois ali foi sepultado o povo glutão, ou seja, o povo que teve a "cobiça dos alimentos" (concupiscentia escarum) (cf. 5,7).

Mesopotâmia (Mesopotamia, -ae): gr. $\mu \varepsilon \sigma o \pi о \tau \alpha \mu i$. Como um termo genérico, o nome pode se referir à região geográfica no sudoeste da Ásia onde se desenvolveu a civilização mais antiga do mundo. O nome vem de uma palavra grega que significa "entre rios", 


\section{Maria Cristina Martins}

referindo-se à terra entre os rios Eufrates e Tigre. No entanto, a região pode ser definida mais amplamente incluindo a área em que hoje se situam o leste da Síria, o sudeste da Turquia e a maior parte do Iraque. A região foi o centro de uma cultura cuja influência estendeu-se por todo o Oriente Médio, alcançando até o vale do Indo, o Egito e o Mediterrâneo. Todavia, o termo pode também se referir a uma província romana; nesse caso, há a Mesopotâmia da Síria (Mesopotamia Syriae) ou Osroena, a oeste, cuja capital era Edessa, e a Mesopotâmia propriamente dita, a leste. Essas províncias situavam-se no sudeste da Turquia e norte da Síria atuais.

milha (mille, indecl., pl. millia ou milia, -ium): medida romana de comprimento equivalente a mil passos, ou cerca de $1,5 \mathrm{~km}$.

Moab: Sept. Mwáß; Vulg. Moab. Platô ao longo da margem oriental do Jordão e a leste do Mar Morto, onde os hebreus acamparam e receberam ensinamentos de Moisés, antes de saírem em expedições de conquista ( $\mathrm{Nm} 22,1 ; 31,12 ; 36,13)$. Na época de Egéria, fazia parte da província romana da Arábia. Situa-se no território da atual Jordânia. V. Arabot.

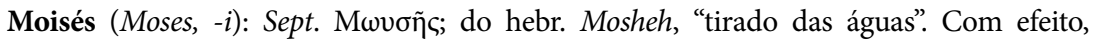
sendo uma criança hebreia nascida quando seu povo era oprimido no Egito, Moisés foi “tirado das águas" do Nilo pela filha do Faraó e recebeu uma educação egípcia (Ex 2,5). Enviado por Deus para libertar seu povo, lidera-o na travessia do Mar Vermelho: todos os israelitas atravessam-no a seco, mas os carros egípcios que os perseguem são engolidos pelo mar (Ex 14,27). Moisés conduz o povo através do deserto até o monte Sinai, onde é concluída a Aliança com Deus e lhe são entregues as tábuas da Lei (Ex 24,12), ou seja, os Dez Mandamentos. Descendo do monte, Moisés encontra o povo adorando o bezerro de ouro e, irritado, destrói o ídolo e quebra as tábuas; Deus, porém, renova a Aliança e lhe dá novas tábuas (Ex 34). Depois disso, Moisés funda a comunidade religiosa conhecida como "Israel" e, como intérprete da Aliança, organiza as tradições civis e religiosas da comunidade. Ele e seu povo andam pelo deserto e finalmente chegam às planícies de Moab, a leste da Terra Prometida, a qual Moisés avista de cima do monte Nebo, antes de morrer (Dt 34,1-5). Na tradição judaica, é reverenciado como o maior profeta e mestre, o personagem mais importante da história da salvação, uma figura do Messias (Dt 18,15-18). Sua influência continua a ser sentida na vida religiosa e nas questões morais e costumes da civilização ocidental - é aqui que reside sua imperecível significância. Atribui-se-lhe a Lei de Moisés (Pentateuco ou Torá, ou seja, os primeiros cinco livros do Antigo Testamento: Gênesis, Êxodo, Levítico, Números e Deuteronômio), um cântico (Dt 32,1-43), uma bênção (Dt 33,1-29) e um salmo (Sl 90). No Novo Testamento, é visto como mensageiro de Deus e mediador da Lei que recebeu no Sinai, embora Jesus lhe seja superior como chefe, redentor, legislador e profeta (Mt 17,3; Jo 1,45; At 7,35; Hb 3,2).

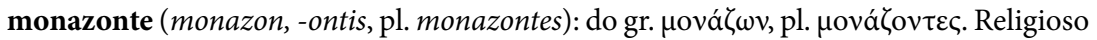
eremita ou solitário, que podia ou não pertencer ao clero. Vivia só, mas sua cabana podia ser vizinha a outras. No Oriente, talvez a palavra evocasse a ideia de celibato, tendo assim o mesmo sentido de "asceta". Empregada na mesma acepção de "monazonte", temos também "partena", exceto pelo fato de que "monazonte" pode se referir aos dois 
sexos, enquanto que "partena" é usada somente em relação ao sexo feminino. Os dois termos juntos, "monazontes e partenas", aparecem também em Cirilo de Jerusalém, bispo de Igreja de Jerusalém entre 350 e 386 (Catequeses, IV, 24 i XVI, 22). Bastiaensen (1962, p.20) observa que, no relato de Egéria, parece não haver diferença semântica entre monazontes e monachi, "monges", embora o primeiro termo se empregue apenas na segunda parte da obra. Segundo ele, usam-se ambas as palavras não só para designar aqueles que vivem na solidão, mas também aqueles que abraçaram uma vida em comum. Como aponta Mariano e Nascimento (1998, p.23), os monges que viviam nos lugares santos tinham várias funções, p. ex., realizar a liturgia dos santuários (cf. 24,1; 12) e acolher e guiar os peregrinos (cf. 1,$2 ; 3,1 ; 5,1 ; 12,3$ ).

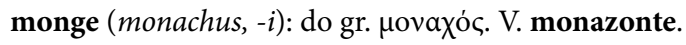

Morto (mar)(Mortuum, -i; mare, -is): lago ou mar interno situado entre os territórios de Israel, a oeste, e da Jordânia, a leste, cujo nome provém da taxa de salinidade (25\%, ao invés da habitual taxa de 3,5\%), que impede quase que toda forma de vida, à exceção de algumas bactérias e algas. Situa-se na depressão de Arabá, a cerca de $400 \mathrm{~m}$ abaixo do nível do mar, no ponto mais baixo da Terra; com $80 \mathrm{~km}$ de comprimento e $18 \mathrm{~km}$ de largura máxima, recebe, em sua extremidade norte, as águas do rio Jordão. O Mar Morto figura em relatos bíblicos que datam do tempo de Abraão e da destruição de Sodoma e Gomorra, que se situavam ao longo do lago. A desolação do deserto ao redor do Mar Morto serviu de refúgio a Davi, rei de Israel, e depois a Herodes o Grande, rei da Judeia, que, na época do sítio de Jerusalém pelos partos, em 40 a.C., isolou-se numa fortaleza em Massada, no litoral sudoeste do lago. Massada também foi o cenário do sítio de dois anos que culminou no suicídio em massa de seus defensores judeus zelotes e na ocupação da fortaleza pelos romanos, em 73 d.C. A cerca de $1,5 \mathrm{~km}$ a noroeste do Mar Morto, numa região denominada Qumran, abrigava-se em cavernas uma seita judaica - muito provavelmente, uma comunidade de essênios, os quais existiram entre os séc. II a.C. e I d.C. -, que deixou os manuscritos bíblicos conhecidos como os "manuscritos do Mar Morto”. Desde a época da descoberta desses manuscritos, em 1947, a região é um importante sítio arqueológico.

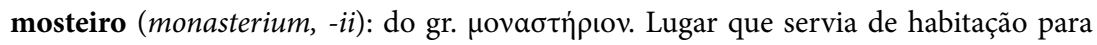
um monge, geralmente na vizinhança de uma igreja ou santuário; no plural monasteria, trata-se de um agrupamento dessas habitações. No capítulo 7,2, porém, o termo monasteria está sendo usado no sentido de "posto militar" (cf. Blaise, 1954, p.538): pode-se pensar que se tratava de um posto estabelecido num local onde viviam monges, ou que o copista errou, ou ainda que esta era uma variante popular do sentido do termo, baseada na ideia de solidão e afastamento ou na semelhança exterior do posto com um edifício monástico (Maraval, 2002a, p.154). Para mais detalhes sobre monasterium, consultar: Bosch, J.v.d. Capa, Basilica, Monasterium et le culte de Saint Martin de Tours: étude lexicologique et sémasiologique. Nijmegen: Dekker and van de Vegt, 1959.

Nebo: Vulg. e Hebr. Nebo; Egéria escreve Nabau, conforme a Septuaginta (Naßaú). monte mais alto da cadeia do Abarim, situado na província da Arábia (Transjordânia), 
na altura da foz do Jordão, de onde se avistam o Mar Morto e o oásis de Jericó. É de seu cume que Moisés contempla a Terra Prometida (Dt 32,49), na qual não poderá entrar, pois havia duvidado da palavra de Deus, e é aí que ele morre (Dt 34,5). O monte Nebo corresponde ao atual Ras Siyagha, no território da Jordânia. V. Arabot.

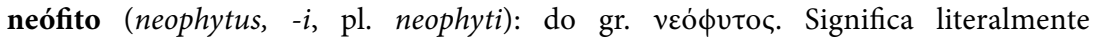
"recentemente plantado", "nova planta", sendo usado também nesse sentido em latim: neophytam oliuam (...) id est nuper plantatam (Santo Hilário, ca. 315-367). No cristianismo, desde Tertuliano (ca. 155/160 - ca. 220), passou a significar "o novo convertido". Assim, no texto, seguindo essa acepção, os novos batizados se chamam "neófitos". Porém, em 38,1 e 39,3 a palavra infantes (infans, -tis) é empregada com o sentido de "neófitos", designando os novos batizados, independentemente de idade. Nas demais ocorrências, infantes mantém seu sentido habitual, isto é, "criança" (cf. 31,2-3 e 36,2). Santo Agostinho, que recorria ao vocábulo nos sermões da semana da Páscoa, explica seu sentido: "qui paulo ante uocabantur competentes, modo uocantur infantes (...) infantes dicuntur, quia modo nati sunt Christo": "os que pouco antes eram chamados competentes agora se chamam neófitos (...) chamam-se neófitos porque neste instante nasceram para Cristo" (Sermões, 228, I).

Nilo (Nilus, -i): gr. Neĩ $\lambda$ oc. Rio mais extenso do mundo, com $6650 \mathrm{~km}$, situado no nordeste do continente africano. A porção norte do Nilo corre quase que inteiramente através do deserto, do Sudão para o Egito, país cuja civilização dependeu do rio desde épocas muito remotas. De fato, quase todos os sítios históricos e culturais do Egito antigo encontram-se ao longo das margens do Nilo. O rio termina num largo delta, que deságua no Mediterrâneo.

Nísibis (Nisibis, -is): gr. Nıбıßíc. Foi um importante centro romano e cristão, onde, por volta do ano 300, foi fundada uma importante escola de teologia e filosofia. A escola permaneceu em Nísibis até 363, quando a cidade foi capturada pelos persas, segundo o relato de Joviano (Amiano Marcelino, Rerum gestarum, XXV, 9, apud Maraval, 2002a, p.28), migrando para a cidade vizinha de Edessa. Ali permaneceu até 489, quando foi fechada pelo imperador Zenão, e retornou a Nísibis. Em 366, por meio de um tratado, Joviano cedeu Nísibis aos persas, que a ocuparam até 629, quando foi retomada pelos romanos, sob o imperador Heráclio. Portanto, na época de Egéria, Nísibis estava situada além do limite oriental do Império Romano, e isso impossibilitava a peregrina de ir até Ur, pois era preciso passar por Nísibis para chegar à cidade caldeia $(20,12)$. Visto que foi em 363 que os persas tomaram Nísibis, depreende-se daí que a viagem de Egéria só pode ter ocorrido após essa data. Em 1515, o sultão Selim I capturou-a, transformando-a em cidade do Império Otomano. Nísibis corresponde à atual Nusaybin (sudeste da Turquia, próximo à fronteira com a Síria).

oblação (oblatio, -onis): ação de oferecer ou dar voluntariamente; oferenda ou presente; sacrifício; pode ser também o "sacrifício eucarístico" - a "hóstia" - e a "missa", tal como a concebemos hoje, pois a missa é a oferenda de pão e vinho, os elementos do sacrifício eucarístico oferecidos pelos fiéis. No Antigo Testamento, a oblação era o sacrifício 
incruento à base de produtos vegetais cultivados pelo homem, destinada à manutenção dos sacerdotes (Lv 2,1-14).

oitava (octaua, -ae, pl. octauae, subentendendo-se dies, "dia"): esse termo litúrgico possui dois sentidos: 1) o oitavo dia após uma festa, contando-se como primeiro dia o próprio dia da festa, de modo que a oitava caia no mesmo dia da semana da festa original; 2) todo o período de oito dias, durante o qual a festa do primeiro dia continua a ser observada. No texto, embora esteja sempre no plural, o termo é empregado na primeira acepção, referindo-se especificamente ao domingo seguinte ao domingo de Páscoa, ou seja, à "oitava de Páscoa" (39,1-2; 40,1-2; 47,1). Quando se refere ao período de oito dias de uma festa, Egéria escreve "oito dias": p. ex., "oito dias pascais" é o período que vai do domingo de Páscoa até o domingo seguinte (cf. 39,1,3; 46,6; 47,1).

\section{Oliveiras (Oliuetum, $-i)$ : v. Eleona.}

oração (oratio, -onis): no latim clássico, significa "linguagem", "discurso", "palavra"; no latim eclesiástico, adquire também o sentido de "oração", "pedido", "súplica”, "prece de intercessão".

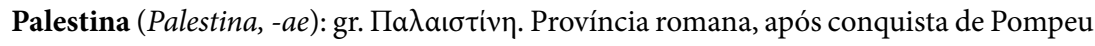
em 63 a.C.; faixa de terras entre os desertos da Síria e da Arábia e o mar Mediterrâneo, compreendendo, de oeste a leste, um litoral plano, uma montanha central, o vale do Jordão e a montanha transjordaniana. A população, agrupada em cidades independentes até o fim do segundo milênio a.C., foi presa fácil de invasores e só foi unificada pela monarquia, de Saul a Salomão, diante da ameaça dos filisteus, os habitantes do litoral. Os filisteus, "povo do mar", de origem cretense (não-semita), que ocupavam a região desde o séc. XII a.C. e durante a época dos reis de Israel (Ex 13,17), deram seu nome a essa região costeira - designação que a princípio referia-se apenas a uma estreita faixa litorânea ao sul do monte Carmelo e, em seguida, passou a abranger a região continental adjacente, como Canaã e, sob o Império Romano, toda a região entre o mar e o Jordão, sob a forma latinizada de "Palestina".

partena (parthena, -ae): do gr. Па $\rho \theta \dot{v} v o \varsigma$, "virgem”. V. monazonte.

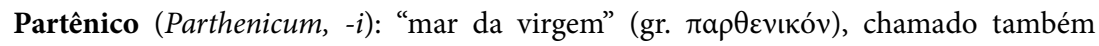
Isiacum, é a parte oriental do Mediterrâneo, entre o Egito e o Chipre. Outros autores contemporâneos de Egéria testemunham essa denominação, p. ex., Amiano Marcelino (Rerum gestarum, XIV, 8, 10) e Gregório de Nazianzo (Orationes, XVIII).

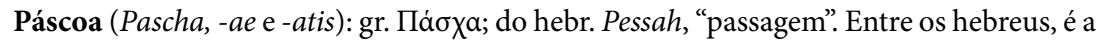
fusão de duas festas outrora independentes: a festa das primícias do rebanho (Ex 13,11) e a festa dos ázimos (Ex 12,1-27), posteriormente acrescidas de significado histórico - a "passagem" do anjo exterminador (décima praga do Egito, que vitimou os primogênitos dos egípcios, mas poupou os dos hebreus, passando por cima de suas casas, que estavam marcadas com sangue de cordeiro) e a saída do Egito, portanto, a salvação do povo de Israel. Na Páscoa judaica, um cordeiro pascal era imolado no Templo, prática que 


\section{Maria Cristina Martins}

acabou sendo abolida. Para os cristãos, a celebração da Páscoa - o ápice do ano litúrgico - compreende a lembrança dos últimos momentos de Jesus: na Quinta-feira Santa, a Ceia (última refeição de Jesus com seus discípulos) e a instituição da Eucaristia; na Sexta-Feira Santa, a crucificação, morte e sepultamento de Jesus; e da noite do Sábado Santo ao Domingo de Páscoa, a Ressurreição. Para os cristãos, Jesus é o cordeiro pascal, imolado para a salvação de todos os homens.

passo (passus, -us): medida romana de comprimento equivalente a 5 pés; o pé (pes, pedis) corresponde a $29 \mathrm{~cm}$, portanto o passo equivale a cerca de $1,5 \mathrm{~m}$. Mil passos, por sua vez, correspondem a uma milha (aproximadamente $1,5 \mathrm{~km}$ ).

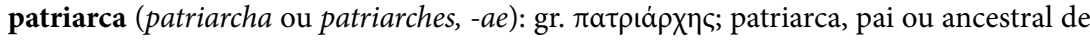
uma raça. Para os judeus, os patriarcas eram Abraão, Isaac e Jacó.

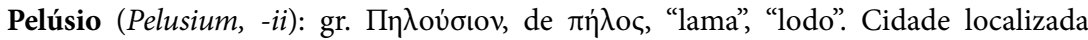
na parte leste do delta do Nilo (junto ao Ostium Pelusiacum, ao qual deu seu nome), estendendo-se entre a costa do Mediterrâneo e os pântanos do delta. Foi um importante centro comercial e militar romano, além de um dos principais portos do Egito antigo e cidade conhecida pela produção de linho. Nela e em seus arredores havia muitos mosteiros famosos no séc. IV. Pelúsio conservou sua importância durante todo o período da civilização romana e bizantina, iniciando sua decadência com a conquista árabe no séc. VII. Em Ez 30,15, é denominada “Sin, a fortaleza do Egito". Uma colina coberta com ruínas dos períodos romano e bizantino, chamada Tell Farameh, a cerca de $50 \mathrm{~km}$ a sudeste da atual Port Said e do Canal de Suez, marca o local onde Pelúsio se situava. Aí também há as ruínas de um forte chamado Tineh.

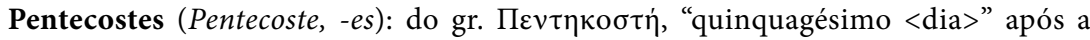
Páscoa. No texto, é o mesmo que quinquagesimarum dies, "dia das quinquagésimas". No Antigo Testamento, em sua origem, o Pentecostes era a festa da colheita, dia de alegria e de ação de graças: ofereciam-se a Deus as primícias, ou seja, os primeiros produtos do que a terra tinha produzido. Era, portanto, uma festa da agricultura. Acrescentou-se depois a comemoração da Aliança concluída no monte Sinai, entre Deus e seu povo, e da entrega das tábuas da Lei (Ex 19,1-16; 31,18). No dia do Pentecostes judaico que se seguiu à morte, ressurreição e ascensão de Jesus, os onze apóstolos e a mãe de Jesus estavam reunidos no Cenáculo, quando um barulho como um golpe de vento encheu a casa; línguas de fogo apareceram sobre cada um deles e todos se encheram do Espírito Santo e começaram a falar em diferentes línguas (At 2,1-13). Os apóstolos viram aí a realização da profecia de Joel (Jl 3,1-5) sobre a vinda do Espírito de Deus sobre todo ser vivo e o sinal da restauração da unidade perdida após Babel. É com o derramamento do Espírito no dia de Pentecostes, cinquenta dias após a ressurreição de Cristo, que a Santíssima Trindade é plenamente revelada aos homens (CCIC, $\mathrm{n}^{\circ}$ 144). Para os cristãos, a manifestação da graça divina através do Pentecostes representa o nascimento da Igreja, com seu caráter sobrenatural e sua vocação universal. 
persas (persae, -arum): gr. Пદ́рбаı. O Império Persa teve início em 558 a.C., na planície iraniana, com a ascensão ao trono de Ciro o Grande, da dinastia aquemênida. Ao conquistar os reinos da Lídia e da Babilônia, os persas tornam-se o poder dominante da região, e Ciro, célebre por sua sabedoria e benevolência, autoriza os judeus a voltarem à Palestina, pondo fim ao período do cativeiro babilônico. No séc. II, Ardashir I funda a dinastia dos sassânidas e institui o zoroastrismo como religião oficial; é sucedido por seu filho Sapor I, que reina entre 240 e 273 e perde duas guerras para o Império Romano; o sucessor Narsés I renova a guerra contra os romanos, mas também é vencido. Em 350, Sapor II declara guerra novamente e marcha sobre a Síria, mas a campanha é malsucedida e termina em trégua. Em 363, o imperador Juliano o Apóstata decide invadir os domínios persas, mas é derrotado. Seu sucessor Joviano faz um acordo com Sapor II: os persas deveriam prover guias e alimentação para a retirada, enquanto que os romanos prometeriam ceder Nísibis e desistir do protetorado sobre a Armênia e a Ibéria (região do Cáucaso), que assim acabam se tornando províncias persas.

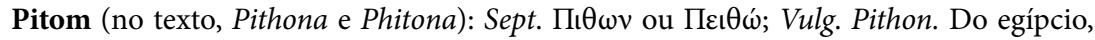
"morada de Atum (ou seja, o deus-sol, ou Ra)". Assim como Ramsés, é uma cidadeceleiro construída pelos hebreus, por ordem do Faraó (Ex 1,11). Provavelmente situavase no atual sítio arqueológico de Tell el-Mashuta (Egito), que abrange também Herópolis.

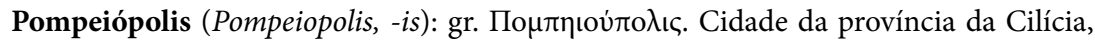
correspondente à atual Mezitli (Turquia).

povo (populus, -i): significa o povo cristão em seu conjunto, a Igreja. No texto, porém, o termo refere-se especificamente ao conjunto dos fiéis, ou seja, a comunidade cristã de Jerusalém que participa dos ofícios litúrgicos, não se aplicando, portanto, aos clérigos. Em 3,7, no entanto, a palavra designa o povo judeu. Com o mesmo sentido de populus, mas bem menos frequentemente, Egéria usa também plebs $(39,3 ; 44,3 ; 46,1)$.

presbítero (presbyter, -eri): palavra emprestada do grego, é o mesmo que "ancião", chefe de uma comunidade cristã. $\pi \rho \varepsilon \sigma \beta \dot{\tau} \tau \varepsilon \rho \rho$ é a forma substantivada do comparativo de superioridade do adjetivo $\pi \rho \varepsilon \dot{\sigma} \beta v \varsigma$, "velho", diferindo de $\gamma \dot{\varepsilon} \rho \omega \nu$ "homem velho", por denotar sabedoria e importância e, assim, respeitabilidade. Daí o uso dessa palavra como "chefe" e "embaixador", que já existia em grego e passou a denominar também o líder religioso de certas comunidades judias, assim como no latim cristão, em que o presbyter é o encarregado de uma Igreja e, ao mesmo tempo, "o mais antigo" - "o ancião" - entre os cristãos (At 2,30). O presbítero, ou padre, possui o segundo grau do sacramento da Ordem - encontrando-se, na hierarquia da Igreja Católica, entre o diácono e o bispo -, e exerce as funções de pregar a Palavra, administrar os sacramentos e orientar os fiéis de uma comunidade. V. clérigo.

província (prouincia, -ae): "província", "país", "região". O termo remete à organização administrativa da antiga Roma (tanto na República quanto no Império), referindose à unidade básica territorial e administrativa das posses territoriais fora da península itálica. 


\section{Maria Cristina Martins}

Quaresma (quadragesima, -ae): em 27,1, Egéria relata a Quaresma de Jerusalém como o período de oito semanas antes da Páscoa caracterizado por jejum e ofícios especiais, também denominado eortae, "festas" (do gr. Éoptai), dada sua atmosfera de júbilo espiritual (o termo grego não é incomum para designar a Quaresma; p. ex., as cartas quaresmais de Atanásio de Alexandria, bispo dessa cidade entre 328 e 373, são intituladas,

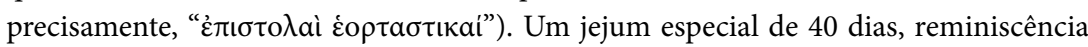
hebraica (cf. Ex 34,28; Dt 9,9-18), mas também memória do jejum de Cristo no deserto (cf. Mt 4,2; Mc 1,13), preparava os fiéis e catecúmenos para a Páscoa. Por causa desses 40 dias de jejum, a Quaresma durava oito semanas, já que deviam ser descontados os sábados e domingos, em que não se jejuava (exceto o Sábado Santo, a vigília da Páscoa). Era durante a Quaresma que se ministrava a catequese aos pretendentes ao batismo, isto é, aos catecúmenos.

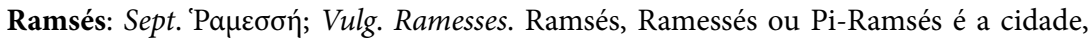
localizada na terra de Gessen, de onde os hebreus partiram do Egito (Ex 12,37; Nm 33,3). Foi fundada ou restaurada por Ramsés II (ca. 1290-1224 a.C.), o maior dos faraós, cuja múmia atualmente se encontra no Museu do Cairo. Assim como Pitom, Ramsés é uma cidade-celeiro construída pelos hebreus, por ordem do Faraó (Ex 1,11). Corresponde provavelmente às atuais ruínas de Qantir.

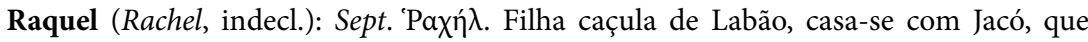
trabalhou quatorze anos para ter sua mão (Gn 29,6-31). É a mãe de José e de Benjamim, em cujo parto morre (Gn 35,16-20).

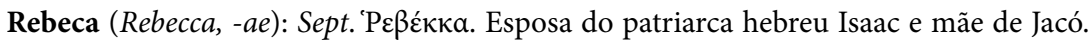
Um empregado de Abraão é enviado à Mesopotâmia para buscar uma esposa para o filho de seu senhor. Ele encontra Rebeca junto a um poço e nela reconhece aquela que Deus destinou a Isaac (Gn 24). Rebeca é filha de Batuel e neta de Naor, irmão de Abraão. Assim como Sara, esposa de Abraão, Rebeca é estéril; então Isaac ora a Deus e Rebeca tem dois filhos gêmeos, Esaú e Jacó. V. Carres.

Ródano (Rhodanus, -i): em francês, Rhône. Rio que nasce nos Alpes suíços e termina o curso na França, desaguando no Mediterrâneo após percorrer $812 \mathrm{~km}$. É o rio francês mais caudaloso e o mais importante rio europeu a desaguar no Mediterrâneo. A alusão de Egéria ao Ródano, numa comparação com o Eufrates $(18,2)$, é considerada pelos estudiosos uma evidência de que a peregrina seria originária da Gália.

Safdra: cidade que pareceria corresponder à bíblica Edrai (atual Der’a, na Síria), capital da terra de Basan, do rei amorreu Og, derrotado por Moisés (Nm 21,33). No entanto, Egéria não poderia ter visto essa longínqua cidade a partir do monte Nebo, como afirma em 12,8. Logo, ou lhe foi mostrada apenas a direção em que a cidade se situava, ou lhe mostraram outra cidade, e não Edrai (ou Der'a). Segundo R. Hill (Aetheria and the site of biblical Edrei, Vetus Testamentum, 16, 1966, p.412-419, apud Maraval, 2002a, p.179), é possível que os guias tenham-lhe mostrado Elealeh, situada uma milha a nordeste de Hesban (v. Hesebon). A aproximação errônea das cidades de 
Hesebon e Safdra (ou Edrai) pode ter tido origem na Bíblia, onde muitas vezes elas ou seus reis, Seon e Og, são mencionados conjuntamente (Nm 21,21-35; Dt 1,4; 3,1-6; Js 12,2-3; Sl 134,11; 135,19-20).

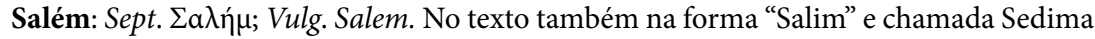
à época de Egéria. Como aponta Gingras (1970, p.197), Egéria não identifica Salém com a Jerusalém histórica, como fazem Flávio Josefo, Jerônimo e comentadores modernos, mas com um local no vale da porção superior do Jordão, próximo a Enon, o lugar associado ao ministério de São João Batista. V. Melquisedec.

Salim: v. Salém.

santo (sanctus, - $i$, pl. sancti): no latim eclesiástico, pode significar "sagrado", "consagrado a Deus", "aquele que leva uma vida santa", "o servidor de Deus", "o justo". O termo foi aplicado em primeiro lugar ao povo de Israel $(\operatorname{Ex} 19,6)$ e, em particular, à comunidade dos tempos messiânicos (Dn 7,18). Na Igreja primitiva, o termo refere-se aos cristãos ou fiéis em geral, porque pelo batismo foram consagrados a Cristo (Rm 1,7; 1Cor 1,2)

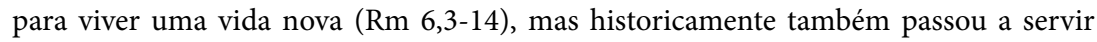
como epíteto a um grupo especial de cristãos, a saber, homens e mulheres canonizados pela Igreja e venerados como santos. No texto, a palavra é usada neste último sentido (p. ex., Santa Tecla; São João), mas também como epíteto de figuras do Antigo Testamento (p. ex., santo Abraão; santa Rebeca), bem como de bispos, presbíteros, monges etc. (p. ex., "santos monges"), acepção em que é empregada também a expressão homo Dei, "homem de Deus" (cf. 2,3; 20,6). A autora emprega a palavra também em expressões como "santa igreja", "santas Escrituras" e "Lugares Santos". Esta última expressão surgiu com Eusébio (Vida de Constantino, V, 3, 52) e passou a ser usada correntemente desde o fim do séc. IV, inclusive por São Jerônimo. Como aponta Natalucci (1991, p.235), o uso frequente do termo "santo" é indicativo da atitude de maravilhamento e veneração do peregrino.

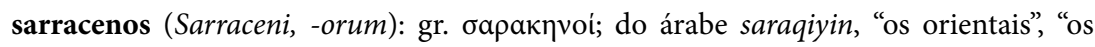
povos do leste”. A princípio, são os habitantes do deserto de Et Tih, no norte da península do Sinai; a partir do séc. III, o termo designa todos os povos nômades das províncias da Arabia Felix e da Arabia Petrea, sendo que várias tribos eram foederati, "aliados" dos romanos. Pelo menos a partir do séc. VI, o termo designa todos os povos de língua árabe (Moritz, s.v. "Saraka" 2, Pauly-Wissowa-Kroll, Realencyclopädie der classischen Altertumswissenschaft, 2te Reihe, 1, 2388-2390, apud Maraval, 2002a, p.137).

\section{Sedima: v. Salém.}

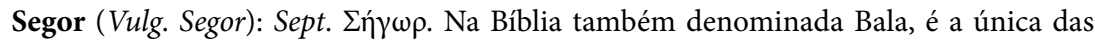
cinco cidades citadas em Gn 14,2 (as outras são Sodoma, Gomorra, Adama e Seboim), que fazem parte das "terras dos sodomitas" referidas no texto, que sobrevive até a época de Egéria. Segundo Maraval (2002a, p.176), atualmente costuma-se situar essas terras ao sul do Mar Morto, tradição que se encontra também em São Jerônimo (Epistula $108,11)$, mas existe outra tradição que a situa ao seu norte. Com efeito, Egéria parece 


\section{Maria Cristina Martins}

ter testemunhado esta última tradição, pois a partir do monte Nebo não seria possível avistar tais terras caso elas se localizassem ao sul do Mar Morto.

Selêucia (Seleucia ou Seleuceia, -ae): gr. $\Sigma \varepsilon \lambda \varepsilon v ́ \kappa \varepsilon ı$. No Império Romano, havia várias cidades com esse nome, mas Egéria refere-se à que estava situada na Isáuria, construída por Seleuco I, rei da Síria, por volta de 300 a.C., e considerada um importante centro da província. Nos arredores da cidade, num lugar atualmente denominado Ayatecla, na localidade de Meriamlik, encontra-se o principal santuário, a Santa Tecla, uma grandiosa basílica do séc. V. Ali viveu em solidão o Padre Capadócio e Doutor da Igreja Gregório de Nazianzo (Carmen de uita sua, p.545-551, ed. C. Jungck, 1974, p.88), entre 375 e 379, poucos anos antes da visita de Egéria. Selêucia da Isáuria corresponde à atual Silifke (Turquia).

setenta (septuaginta, indecl.): no cap. 5,7, há uma referência aos setenta anciãos que Deus designou para que dividissem com Moisés a carga de liderar o povo de Israel, que, por sua vez, relacionam-se à história da Septuaginta, tradução do Antigo Testamento para o grego koiné. Segundo a tradição, o faraó egípcio Ptolomeu II solicitou ao seu bibliotecário, Demétrio, a tradução da Bíblia do hebraico para o grego, para incluí-la na biblioteca de Alexandria, que deveria conter uma cópia de cada livro do mundo. A tradução teria ocorrido em etapas, entre os sécs. III e I a.C. Existem duas versões para o fato: uma diz que a tradução teria sido feita por 72 estudiosos, seis para cada uma das doze tribos de Israel, e que essa tradução teria durado 72 dias. Noutra versão, setenta homens a teriam realizado e, dessa forma, traça-se um paralelo com os setenta líderes que estiveram com Moisés para, primeiramente, receber as tábuas da Lei no monte Sinai (Ex 24) e, depois, ajudá-lo no fardo de conduzir o povo descontente (Nm 11), ou com os setenta discípulos enviados por Jesus (Lc 10; Mt 10). Seja como for, a tradução da Bíblia conhecida como Septuaginta (lit. "setenta”) tornou-se a versão grega padrão das Escrituras, tendo sido usada pelos primeiros cristãos, inclusive para fazer citações do Antigo Testamento, e adquiriu grande prestígio entre os cristãos, que logo a consideraram a versão cristã da Bíblia. No séc. II, porém, os judeus adotaram três novas traduções para o grego: as dos estudiosos judeus Áquila, Símaco e Teodocião (diz-se que a tradução mais elegante e mais agradável é a de Símaco). A versão oficial judaica da Bíblia foi estabelecida após a conclusão da Septuaginta, o que resultou em algumas diferenças entre elas: a principal divergência é o fato de a Septuaginta conter livros que não fazem parte da bíblia hebraica padrão, que permanece a mesma desde o séc. II. Para mais informações sobre a Septuaginta, consultar Miller et al., 2006.

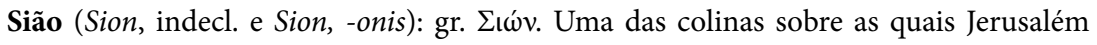
foi construída. A palavra "Sião" perdeu seu sentido geográfico e passou a servir para designar Jerusalém, tendo sido empregada sobretudo pelos profetas (Is 2,3-4; Am 1,2) e nos Salmos (Sl 76,3). Sião ou "a filha de Sião" torna-se a personificação do povo eleito (Is 62). No texto, Sião é o santuário do Cenáculo, no Monte das Oliveiras, a duzentos passos do Gólgota, construído no lugar em que se encontrava a casa onde Cristo celebrou a Última Ceia, instituindo, assim, a Eucaristia. Esse também foi o local onde Jesus teria 
aparecido aos discípulos após a Ressurreição (Jo 20,19 e 26), onde eles se refugiaram após a Ascensão (At 1,13) e onde desceu o Espírito Santo sobre eles, no dia de Pentecostes (At 2,1). Segundo Arce (1980, p.103ss), uma tradição antiga e ininterrupta assegura a autenticidade do local do Cenáculo, que foi a primeira igreja do mundo cristão, chamada com razão de mater omnium ecclesiarum, "a mãe de todas as igrejas". Depois da Basílica do Santo Sepulcro, Sião é o mais importante local de peregrinação em Jerusalém.

sicômoro (sycomorus, -i): gr. бvкó árvore sagrada da deusa egípcia Hator, também usada para fabricar sarcófagos de múmias. Os cristãos continuaram a venerar a árvore, atribuindo sua plantação aos patriarcas. Na Bíblia, há diversas referências ao sicômoro e seus frutos (cf. 1Rs 10,27; Lc 19,4; Is 9,9), que, segundo a tradição, possuem propriedades terapêuticas, já relatadas por Plínio o Velho, em sua Naturalis historia, XXIII, 70.

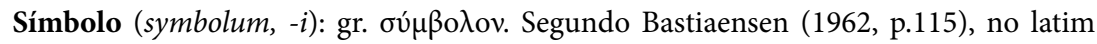
cristão a palavra é encontrada pela primeira vez em Cipriano (?-258), na Epistula 69,7, onde se trata do enunciado da fé cristã, dividida em diversos pontos que deveriam ser afirmados pelo candidato no momento do batismo, sobretudo a respeito dos dogmas da Igreja: "Nam cum dicunt: 'credis in remissionem peccatorum et uitam aeternam per Sanctam Ecclesiam?', mentiuntur interrogatione quando non habent ecclesiam”. Nesse sentido, accipere symbolum e reddere symbolum são os termos técnicos para descrever o recebimento do Credo pelos competentes e sua posterior recitação em resposta ao bispo (o ensino do Símbolo ao candidato chamava-se traditio symboli, e sua récita ao bispo chamava-se reditio symboli). O Símbolo deveria ser conhecido de cor, não podendo ser escrito e assim correr o risco de cair nas mãos de um pagão. Segundo o CCIC, os Símbolos da fé "são fórmulas articuladas, chamadas também de 'profissões de fé" ou 'Credo', com que a Igreja, desde suas origens, expressou de modo sintético e transmitiu a própria fé com uma linguagem normativa e comum a todos os fiéis". Os mais antigos Símbolos da fé são os batismais - uma vez que o batismo é feito "em nome do Pai, do Filho e do Espírito Santo", as verdades de fé neles professadas são articuladas em referência às três pessoas da Santíssima Trindade -, e os mais importantes são o Símbolo dos Apóstolos, que é o antigo Símbolo batismal da Igreja de Roma, e o Símbolo nicenoconstantinopolitano, fruto dos Concílios de Niceia (325) e de Constantinopla (381), até hoje comum às grandes Igrejas do Ocidente e do Oriente (CCIC, $\left.\mathrm{n}^{\text {os }} 33-35\right)$.

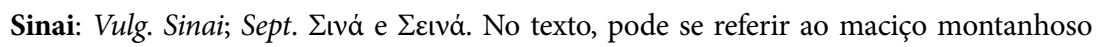
como um todo $(1,1)$ ou a um pico do maciço, o monte Sinai "propriamente dito" $(2,7)$, em cujo cimo, segundo a tradição das religiões abraâmicas, Deus entregou a Moisés as tábuas da Lei (Ex 19; Dt 5). É atualmente identificado com o monte Djebel Musa, "monte de Moisés", situado na península do Sinai, uma região desértica e montanhosa, entre os golfos de Suez e Ácaba, que une a África e a Ásia e faz parte do território do Egito. O Sinai foi o refúgio de muitos anacoretas cristãos durante as perseguições à Igreja no séc. III. Em 557, Justiniano mandou construir, no sopé norte do monte, um mosteiro fortificado para servir de asilo a monges assediados pelos sarracenos. No séc. IX, esse mosteiro passou a 


\section{Maria Cristina Martins}

ser chamado de Santa Catarina, tornando-se muito famoso. Sua biblioteca contém cerca de 500 volumes de valiosos manuscritos em grego, árabe, siríaco, etíope etc. Foi aí que, em 1844, Constantin von Tischendorf encontrou um antiquíssimo manuscrito grego (a partir de então conhecido como Codex Sinaiticus) contendo a maior parte da Septuaginta, todo o Novo Testamento, a Epístola de Barnabé e a primeira parte do Pastor de Hermas (Reagan, 1912, apud The Catholic Encyclopedia, s.v. "Sinai”).

siríaco (Syriacus, - $a$, - um, adj.; syriace, adv. "em siríaco", "na língua síria"): adjetivo derivado do gr. ¿vpía, "Síria". O siríaco é um dialeto do aramaico médio, pertencendo ao ramo ocidental da família linguística semita. Escrito no alfabeto siríaco, derivado do alfabeto aramaico, historicamente, o idioma foi falado em grande parte do Crescente Fértil, região compreendendo os atuais países de Israel, Cisjordânia e Líbano, bem como partes da Síria, Iraque, Egito, sudeste da Turquia e sudoeste do Irã. Surgido por volta do séc. I, o siríaco clássico tornou-se um dos principais idiomas literários em todo o Oriente Médio, entre os séculos IV e VIII, e foi a língua clássica de Edessa, conservada num grande corpus de literatura siríaca. Tornou-se o principal veículo da cultura e do cristianismo ortodoxo oriental, alcançando a costa do Malabar (sudoeste da Índia) e a China oriental. Foi um importante polo de comunicação e disseminação cultural entre os árabes e, em menor escala, entre os persas. Primordialmente um meio de expressão cristão, o siríaco teve uma influência literária e cultural fundamental no desenvolvimento do árabe, que o substituiu na região no fim do séc. VIII. O siríaco continua a ser a língua litúrgica do cristianismo siríaco. Para mais informações, consultar: Beyer, K. The aramaic language: its distribution and subdivisions. Göttingen: Vandenhoeck und Ruprecht, 1986.

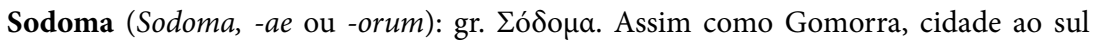
do Mar Morto, foi célebre pelos pecados de seus habitantes: desprezo pelas regras da hospitalidade (Gn 19,8), homossexualidade (Gn 19,4-11) e orgulho (Eclo 16,8). Para castigar Sodoma e Gomorra, Deus as destrói, fazendo chover enxofre e fogo (Gn 19,25; Dt 29,22). Apenas o justo Ló é poupado, enquanto que sua mulher, tendo olhado para trás, é transformada numa coluna de sal (Gn 19,1-29). Sodoma e Gomorra faziam parte de um conjunto de cinco cidades aliadas, das quais outras duas também recebem o castigo divino na mesma ocasião; a única cidade sobrevivente é Segor. O destino de Sodoma e Gomorra é um exemplo do que haveria de vir para os ímpios $(2 \mathrm{Pd} 2,6)$ e um ensinamento sobre o fim dos tempos (Lc 17,28-32). V. Segor.

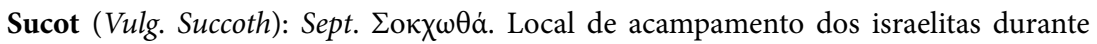
o Êxodo, entre Ramsés e Etam, onde lhes foi dada a Lei da Páscoa (Ex 12,43). Provavelmente localizava-se numa colina à margem oeste do Lago Timsah, a $20 \mathrm{~km}$ da atual Tell el-Mashuta, no Egito (Arce, 1980, p.89).

tabernáculo (tabernaculum, -i): "tenda", "cabana"; no Antigo Testamento, refere-se à tenda portátil de culto e ao pátio que a cercava, construída por Moisés no deserto; posteriormente, seus objetos, como a Arca da Aliança, foram transferidos para o templo de Salomão, em Jerusalém. Pode significar também o local usado para guardar objetos sagrados, tais como relíquias, ou, nos templos católicos, o sacrário (armário ou caixa 
que contém as hóstias da Eucaristia). O termo é empregado ainda com a acepção de "habitação ou morada eterna de Deus".

Táfnis (Vulg. Taphnis): Sept. Tápvạ (Jr 2,16; Ez 30,18). Cidade situada na terra de Gessen, às margens do Nilo, próximo a Pelúsio, tendo sido uma antiga capital do Faraó. É a atual Tell Defenne (Egito).

Tarso (Tarsus, -i): gr. Tapoóc. Principal cidade da Cilícia (tornada capital da província, em 67 a.C., por Pompeu), situada no centro-sul da atual Turquia, a cerca de $20 \mathrm{~km}$ da costa do Mediterrâneo, e um dos lugares mais importantes em toda a Ásia Menor. Sua fundação é atribuída ao rei assírio Sardanapalo, e o próprio nome da cidade parece indicar sua origem semita, embora os gregos reclamem para si a honra de terem colonizado o local desde muito cedo. A primeira menção histórica de Tarso ocorre na Anábase de Xenofonte, que a descreve como uma grande e próspera cidade, situada numa extensa e fértil planície no sopé do monte Tauro (Anábase, I, 2, 23ss, apud Smith, 1854, s.v. "Tarsus"). Além de ser um importante centro comercial, Tarso foi ao mesmo tempo um importante centro de erudição e filosofia, e Estrabão (Geografia, XIV, 5, ibid.) fornece uma longa lista de homens eminentes na literatura e na filosofia que adicionam brilho à cidade - mas nenhum deles é mais ilustre que o apóstolo Paulo (At 9,11;21,39; 22,3), que pertencia a uma das muitas famílias judias estabelecidas em Tarso. Foi aí também que Paulo buscou refúgio após a conversão (At 9,30), e a ele se reuniu Barnabé (At 11,25). É provável que aí tenha se estabelecido uma comunidade cristã nessa época, embora o primeiro bispo, Heleno, seja apenas do séc. III (Vailhé, 1912, apud The Catholic Encyclopedia, s.v. “Tarsus”).

Tauro (Taurus, -i): gr. Taṽ poç. V. Isáuria.

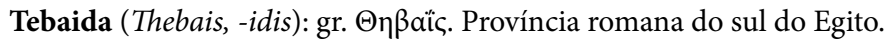

Tebas (Thebae, -arum): gr. $\Theta \tilde{\eta} \beta a ı$ (com a conquista do Egito por Alexandre o Grande, no séc. IV a.C., a cidade, chamada Diospolis pelos gregos, passou a se chamar Tebas, em referência à Tebas original, na Grécia). Foi uma das mais antigas cidades do Egito: sua fundação, assim como a de Mênfis, é atribuída ao rei Menés, ou seja, remonta ao período mítico da história egípcia. Tebas teve seu auge entre os séc. XVI e XIII a.C., quando foi capital do Império do Egito; bem mais tarde, também foi capital da província romana da Tebaida. Encontra-se próxima à atual Luxor e é famosa por sua necrópole. Ao falar sobre "uma grande pedra de Tebas", Egéria provavelmente está se referindo a uma pedra extraída das minas tebanas de pórfiro (uma espécie de granito vermelho), ou a uma pedra feita à semelhança das que ela mesma pode ter visto em Tebas e, possivelmente, ter descrito na parte perdida de seu relato de viagem (Gamurrini, 1887, p.49). Como aponta Mariano e Nascimento (1998, p.109), considerando-se a atitude da religião hebraica, explicitamente contrária à arte figurativa, apenas a fantasia dos guias de Egéria poderia identificar a pedra com uma estátua de Moisés e Aarão. Provavelmente as duas estátuas eram as de um rei ao lado de seu deus, um tipo de representação comum no Egito antigo. 


\section{Maria Cristina Martins}

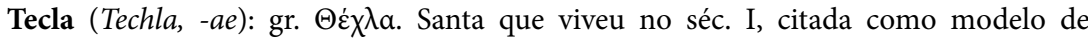
virgindade e ascetismo para as mulheres. Tornou-se muito conhecida a partir do séc. II, através dos apócrifos Atos de Paulo e Tecla, segundo os quais Paulo a converteu durante sua missão em Icônio, cidade natal da santa (At 14,1). Santa Tecla estabeleceuse em Selêucia, onde por muitos anos pregou a palavra de Deus, curou enfermos e converteu pagãos ao cristianismo. Recebeu da Igreja os títulos de "igual aos apóstolos" e "protomártir entre as mulheres” (por ter sido a primeira mártir mulher).

Tesbi (Thesbe): Local de nascimento do profeta Elias (1Rs 17,1), possivelmente situado na parte sul do vale do atual rio Yabis, um dos afluentes da margem esquerda do Jordão. Provavelmente corresponde às ruínas de El-Istib, na Jordânia.

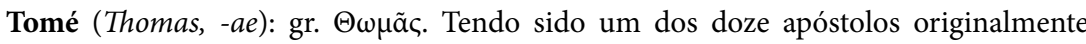
escolhidos por Jesus (Mt 10,3), duvidou da Ressurreição e exigiu provas (Jo 20,2429). A ele são atribuídos os Atos de Tomé, um evangelho apócrifo que, segundo K. Smelik (Aliquanta ipsius sancti Thomae, Vigiliae Christianae, 28. La Haye, 1974, p.290294, apud Maraval, 2002a, p.203), é o texto de Tomé que Egéria afirma ter lido. Essa obra, escrita por volta de 225, relata como Tomé evangelizou os indianos e contém intermináveis discursos atribuídos ao apóstolo. O original foi escrito em siríaco, mas logo foi traduzido para o grego e o latim. Em relação à versão latina, o primeiro testemunho documentado de sua existência é o de Egéria. Baseando-se em J. Quasten (Patrologia. 3 v. Westminster, Md.-Utrecht, Antuerpia, v. I, 1950) e em F.L. Cross (The Oxford Dictionary of the Christian Church. Oxford, 1961, p.1351), Gingras diz que os Atos de Tomé teriam sido escritos por um membro da seita gnóstica do filósofo siríaco Bardaisan (ca. 154-222), de Edessa. Tomé também possui um papel na lenda do rei Abgar por ter enviado Addai para curar o rei e evangelizar Edessa.

Ur ( $V r$, indecl.): cidade da Caldeia, no sul da Mesopotâmia, à margem direita do Eufrates, e cidade natal de Taré, pai de Abraão (Gn 11,28). Suas ruínas situam-se junto à moderna Tell el-Muqayyar, no sul do Iraque. V. caldeus.

Vermelho (mar) (Rubrum, -i; mare, -is): estreita faixa de água que separa a África e a Ásia. É dividido pela península do Sinai em dois golfos: o de Suez (antigo Heroopoliticus sinus) no oeste, com aproximadamente $210 \mathrm{~km}$ de comprimento e 30 $\mathrm{km}$ de largura média, e o de Ácaba (antigo Aelaniticus sinus) no leste, mais estreito e com apenas $145 \mathrm{~km}$ de comprimento. O Mar Vermelho não recebe as águas de nenhum rio importante, mas sempre foi muito utilizado para a navegação comercial, que aumentou muito desde a abertura do Canal de Suez (em 1869), que passou a conectar Port Said, porto egípcio no mar Mediterrâneo, a Suez, na extremidade norte do golfo de Suez. Suas águas desembocam no golfo de Áden, no mar Arábico, que, por sua vez, conecta-se ao Oceano Índico. A tradição identifica o Mar Vermelho como o "mar de juncos", o local da travessia do mar a seco $($ Ex 14,15) durante o Êxodo dos hebreus, mas atualmente tende-se a situar essa travessia mais ao norte, nos Lagos Amargos, lagos salgados conectados ao canal de Suez (Fouilloux, 2010, p.339). 


\section{Índices}

\section{Índice de palavras que compõem o Glossário}

Aarão: 75, 79, 93, 235

Abgar: 34, 123, 127-133, 235

Abraão: 113, 135-139, 235

Alexandria: 17, 27, 73, 97, 236

amorreus: 105, 236

Anástase (igreja): 17, 35-43, 149-161, 165, 169-195, 203-213, 217-231, 236

ancião: 75,236

Antioquia: 18, 28, 123, 125, 143, 237

apotactita: 145, 147, 183, 209, 211, 221, 233, 237

Arábia: 17, 34, 87-99, 107, 237

Arabot: 97, 99, 237

arquidiácono: 185, 187, 195, 215, 237

asceta: 36, 69, 101, 119, 137, 141, 237

Ásia: 147, 238

Augustofratense: 125, 238

Ausítis: 107, 238

Baal-Sefon: 89, 238

Basan: 105, 238

Batânis: 28, 125, 238

Belém: 17, 18, 28, 35, 39, 42, 169, 171, 207, 213, 238

Betânia: 35, 40, 185, 187, 238

bispo: $17,18,24,25,27,28,30,36,38,40,42,93,95,105,113,119,121,125,127,131$ $145,151-179,185,189-203,207-233,239$

Bitínia: 147, 239

Calcedônia: 22, 147, 239

caldeus: 141,239

calendas: 137, 239 


\section{Maria Cristina Martins}

caminho: 32, 65, 81, 87, 89, 95, 97, 107, 117-125, 143, 147, 197, 203, 217, 239

Canaã: 97, 239

Capadócia: 147, 240

capital: 95, 125, 143, 240

Cárneas: 107, 119, 240

Carra: 28, 135-141, 240

Carres: $34,135,240$

catecúmeno: 37-39, 41, 42, 151, 155, 157, 165, 169, 177, 191-195, 201, 205, 209, 211, 217 , $219,225,229,241$

Celessíria: 125,241

cidade: $16-18,28,30,34,40,41,79,87-91,95,99,105,109,117,119,123-131,135-145$, $185,187,191,197,215,217,241$

Cilícia: $143,145,241$

clérigo: 17, 38, 39, 89, 101, 111, 117, 119, 139, 143, 159, 205, 221, 223, 233, 241

Clisma: 87, 89, 241

competente: $41,221,242$

confessor: $28,125,127,135,242$

Constantino: 12, 18, 19, 33, 163, 167-171, 242

Constantinopla: 22, 23, 25, 123, 147, 243

Córico: 145, 243

Corra (torrente): 119, 243

cristão: 16, 18-20, 26, 27, 36, 67, 103, 105, 123, 127, 139, 173, 215, 217, 221, 243

Cruz: 35, 38, 40-43, 157, 161, 163, 167-171, 175, 177, 187, 191, 195-207, 211, 217, 231, 233, 243

Denaba: 107, 243

diácono: 38, 97, 149, 155, 159, 161, 165, 189, 199, 201, 243

Edessa: 25, 28, 123, 125, 243

Edom: 105, 244

Éfeso: 147, 244

Egito: 18, 19, 22, 34, 73, 81, 87, 91, 95, 97, 233, 244

Eleona (igreja): 34, 35, 40-42, 171, 187-191, 195, 207-211, 215, 217, 233, 244

Élia: 97, 245

Elias: 22, 73, 117, 119, 245

Encênias: 43, 231, 233, 245

Enon: 115, 245 
Epáulis: 89, 245

Epifania: 22, 36, 39, 95, 167, 173, 207, 233, 246

Etam: 91, 246

Eufêmia: 34, 147, 246

Eufrates (rio): 25, 125, 246

eulogia: 71, 101, 117, 143, 246

Fadana: 143, 246

Faran: 32, 65, 83, 85, 246

Fenícia: 119, 247

fiel: $17,18,21,36,38,41,151-157,161,165,169,171,191-195,201,209,211,217,219$, 223-229, 247

Fogor: 105, 247

Galácia: 147, 247

Gessen: 22, 87, 91, 95, 97, 247

Getsêmani (jardim): 18, 41, 197, 247

Gólgota (colina): 17, 35, 163, 167-171, 175, 187, 199, 231, 247

hebdomadário: 181, 247

Helpídio: 34, 137, 248

Hero: 91, 248

Herópolis: 34, 91, 248

Hesebon: 105, 248

Hierápolis: 125, 248

hora: $36-41,43,69,75,77,149,153,161,163,167-171,175-229,248$

Horeb (monte): 73, 248

hóstia: 109, 113, 249

Idumeia: 22, 107, 249

igreja (templo) 11, 18, 21, 22, 33-36, 38-42, 67-77, 91, 95, 101-113, 117, 121, 125, 135, $137,141-147,151,163-171,175,181,185-197,205-217,221-233,249$; Igreja (instituição) $12,17,21,23,25,33,37,40-43,79,249$

Imbomon (igreja): 34, 35, 40-42, 189, 195, 197, 209, 211, 215, 249

irmã: 27, 73, 137, 223, 227, 231, 249

irmão: 67, 97, 115, 119, 231, 249

Isáuria: 145, 249

Israel: 34, 63, 75-83, 87-101, 105, 250

Jacó: 91, 139-143, 250 


\section{Maria Cristina Martins}

Jefté: 22, 117, 250

Jericó: 18, 97, 99, 103, 107, 250

Jerusalém: 15-18, 21, 22, 26-28, 34-41, 97, 107, 121, 123, 143, 145, 167-171, 185, 213, 233, 250

Jó: 22, 32, 107, 121, 251

João: apóstolo 41, 42, 147, 205, 251; Batista 22, 115, 117, 251

Jordão (rio): 17, 18, 97, 99, 103, 107, 113, 117, 119, 251

Josué: 79, 97, 99, 251

Labão: 139-143, 252

Lazário (igreja): 35, 171, 185, 187, 207, 252

leigo: $27,37,149,161,171,233,252$

Lívias: 99-103, 252

livros dos Paralipômenos: 233, 252

livros dos Reinos: 73, 252

Ló: 105, 139, 252

lucernário: 36-38, 42, 153, 167, 171, 175-179, 183, 187, 191, 209, 211, 217, 221, 252

Magdol: 89, 252

majestade: 65-69, 252

Mansocrenas: 17, 147, 252

martyrium: martyrium ("túmulo") 123, 125, 137, 145, 147, 252; Martyrium (igreja de Jerusalém) 17, 35, 36, 38-43, 123, 151, 165, 175, 187-198, 205-213, 217, 221, 223, 227, $231,233,252$

Melquisedec: 22, 109, 113, 117, 253

memória: 59, 81, 137, 139, 253

Mesopotâmia: 22, 28, 123, 125, 137, 233, 253

milha: $61,75,85,91,101,105,125,129,141,185,254$

Moab: 97, 99, 254

Moisés: 22, 34, 63, 69, 71, 75-81, 87, 93-105, 111, 254

monazonte: $37,149,161,165-171,205,233,254$

monge: $17,19,20,26,27,30,33,67-77,81,89-97,101,103,107,113-119,123-127,135$ $147,185,233,255$

Morto (mar): 46, 103, 105, 255

mosteiro: 11, 18, 26-28, 30, 31, 67-71, 75, 81, 83, 89, 91, 95, 101, 117, 119, 125, 137, 143, 145,255

Nebo (monte): 22, 97, 101, 103, 255 
neófito: 207, 209, 229, 256

Nilo (rio): 91, 95, 256

Nísibis: 28, 141, 256

oblação: 71-77, 81, 121, 151, 173, 177, 179, 183, 185, 195, 201, 207, 213, 215, 256

oitava: $36,42,207-211,229,257$

Oliveiras (monte): 17, 18, 35, 36, 40, 42, 171, 189, 215, 233, 257

oração: 19, 32, 38, 61, 65, 73-77, 99-103, 107, 111, 115, 123, 133, 135, 141-161, 165, 169 , $185,191-197,205-211,217,219,229,257$

Palestina: 16, 18-20, 31, 73, 97, 103, 257

partena: 37, 149, 257

Partênico (mar): 73, 257

Páscoa: 22, 28, 29, 36, 39, 41, 42, 81, 91, 117, 137, 159, 173, 185, 207-213, 221, 229, 233 , 257

passo: $53,71,77,93,99,113,117,119,135,147,258$

patriarca: 93, 258

Pelúsio: 95, 97, 258

Pentecostes: 22, 35, 36, 42, 167, 213, 258

persas: $28,127-131,141,259$

Pitom: 34, 91, 259

Pompeiópolis: 145, 259

povo: cristão $36,38,40,41,157-165,177,185,189,191,195-217,221,223,231,259$; judeu 71, 259

presbítero: 38, 46, 67-71, 75, 77, 97, 101, 111-117, 149, 153, 159-163, 171, 173, 177, 187, $193,213,215,221,231,259$

província: 12, 17, 125, 143, 147, 231, 233, 259

Quaresma: 22, 36, 37, 39-41, 173-183, 191, 213, 221, 225, 227, 260

Ramsés: 87, 91, 93, 97, 260

Raquel: 141, 143, 260

Rebeca: 137, 139, 260

Ródano (rio): 25, 26, 125, 260

Safdra: 105,260

Salém: 109, 113, 261

Salim: 115, 261

santo: expressão "Lugares Santos" 11, 15-24, 27, 31, 33, 43, 65, 75, 83, 103, 107, 115, $123-127,149,159,171,175,233,261$; santo lenho da cruz 35, 41, 199, 201, 261; santa diaconisa Martana 26, 30, 145, 261 
Maria Cristina Martins

sarracenos: 73, 91, 261

Sedima: 107, 109, 261

Segor: 103, 105, 261

Selêucia: 22, 26, 145, 262

setenta (anciãos): 34, 35, 39-43, 167, 171, 177, 179, 183, 185, 199, 209-221, 262

Sião (igreja): 34, 35, 39-43, 167, 171, 177, 179, 183, 185, 199, 209-221, 262

sicômoro: 93, 263

Símbolo: 41, 225, 229, 263

Sinai (monte): 22, 28, 32, 34, 59, 67-71, 81, 87, 97, 263

siríaco: 17, 231, 264

Sodoma: 113, 264

Sucot: 91, 264

tabernáculo: 81, 264

Táfnis: 95, 97, 265

Tarso: 22, 143-147, 265

Tauro (monte): 147, 265

Tebaida: 95, 97, 233, 265

Tebas: 93, 265

Tecla: 30, 34, 145, 266

Tesbi: 117, 266

Tomé: 34, 42, 123, 125, 209, 211, 266

Ur: 141, 266

Vermelho (mar): 34, 73, 87, 89, 266

\section{Índice de palavras referidas nas notas filológicas}

Abençoando-nos o bispo (benedicens nos episcopus), 121

Acampamento (castra), 80

Acampamos (fecimus mansionem), 77

Acerca da qual (unde), 91

Afastemos (camsemus), 101

Aí (ubi), 197

Aí... não se pode abrir <caminho> (ibi... nec aperiri possit), 203

Âmbula (cornu), 201

Anotaremos (annotauimus), 167 
Antecipadamente (antecessus), 159

Ao amanhecer (cum luce), 163

Ao bispo (episcopus), 157

Aos diversos lugares santos (diuersis locis sanctis), 233

Ao Senhor (ad Dominum), 127

Ao todo (totum), 61

Areal (arenosae), 85

Assuntos (fabulas), 141

Atos (Actus), 215

Através do vale (per ualle illa), 61

Benze (benedicet), 151

Bonito (pulchra), 133

Cabeça (capita), 165

Cada um (qui), 205

Cada um (qui), 219

Candelabros (cereofala), 157

Catequese (cathecisis), 225

Chegando o santo Abraão (aduenientem sanctum Abraam), 113

Coberta (sublinteata), 199

Codorlaomor (Quodollagomor), 113

Colônia (possessionem), 97

Comandantes (praepositis), 89

Com as suas mãos (de manibus suis), 201

Com bondade (humane), 67

Começam (incipiunt), 151

Começam (incipient), 155

Com hinos (ymnus), 157

Com... com suas madrinhas (cum... cum matribus suis), 221

Conforme o costume (ordine suo), 71

Conforme o costume (iuxta consuetudinem), 221

Conhece (nouit), 231

Construções (fabricas), 91

Conteúdo (rationem), 225

Cume (summitate), 69 
Maria Cristina Martins

Da basílica (de basilica), 165

Dão-se graças (aguntur gratiae), 165

Decidimos (optati sumus), 101

De entre (de inter), 87

De frente (de contra), 67

Descobriram (perdiscoperuissent), 121

Deserto (heremi), 87

Despedida (missa), 87

De um jato (a semel), 115

Dia (die), 193

Diáconos (diaconibus), 97

Diretamente (rectus), 187

Dirigiram-se... para onde tinha (petierunt... qui ubi habebat), 137

Diz (dicet), 151

Dizem (dicent), 93

Dizendo (dicentes), 61

Dormindo (dormito), 161

Do santo lenho (de ligno sancto), 201

Durante três horas (tribus horis), 227

$\mathrm{E}$ (hac), 69

$\mathrm{E}($ aut $), 149$

$\mathrm{E}$ (nec non et), 159

E completadas essas semanas (et completo earum septimanarum), 183

É este de vida honesta... ou frívolo? (si bonae uitae est hic... aut uanus?), 223

É hábito (consueuit), 213

Ela (illa), 145

Em que (qua), 69

E na Cruz e no Eleona (aut ad Crucem uel in Eleona), 207

E na Cruz, e nos outros locais santos (uel ad Crucem... loca sancta), 169

É necessário jejuar-se (necesse est ieiunari), 173

Enorme (ingens), 59

Então (itaque ergo), 65

Então (sic), 197

Entoam-se (dicuntur), 149 
Entra (ingreditur), 151

Entra para dentro (intrat intro), 159

Eortae, 173

Esse (ipse), 63

Esses alicerces (ecce ista fundamenta), 113

Esses ofícios são celebrados (haec operatio... habetur), 157

Esta (ista), 121

Estela (titulus), 105

Estrada (ager), 95

Estrada (strata), 185

É útil a eles (prode illis est), 93

Excelentes (optimae satis), 107

Faran (Faram), 85

Faz menção de cada um (facit commemorationem singulorum), 155

Festa (laetitia), 171

Fiéis (fidelis), 165

Fui (fui), 135

Gessen (Gesse), 87

Gritos e gemidos (rugitus et mugitus), 161

Habitações (abitationes), 79

Havia (habebat), 61

Haviam estabelecido (posita habebant), 129

Homem (homo), 107

Honra (deferet), 223

Igreja consagrada (sancta ecclesia), 141

Incensários (thiamataria), 161

Incline (inclinent), 155

Inclinem (inclinet), 165

Inclinem-se (acclinant se), 201

Infinitamente (infinitum), 97, 197

Inscrição (titulus), 199

Interroga (requiret), 223

Isto (illud), 117

Isto é,... mais acima foram ditas (id est... superius sunt), 227 
Jardim de São João (copos tu agiu Iohanni), 115

José (Ioseph), 205

Lavouras (orationes), 71

Lê (leget), 219

Lereis (legi si uos), 133

Levanta-se (lebat se), 155

Licinicon, 153

Lido, pois, todo o passo correspondente (lecto ergo ipso loco omnia), 71

Logo que (mox), 159

Lugar (locum), 77

Mais ao longe dos confins da terra (de extremis porro terris), 127

Mártires (martiriorum), 177

Martyrium (martyrium), 123

Mas (nam), 165

Mas (ubi ita tamen), 209

Me (michi), 109

Milhas (miliario), 185

Missa (missa), 167

Missa (missa), 171

Missa (missa), 179

Monazontes (monazontes), 167

Mostravam (ostendebant), 65

Muito lentamente (lente et lente), 191

Muitos de seus clérigos (multi clerici sui), 233

Na Anástase (ad Anastasim), 157

Não tenha estado presente (inter non fuerit), 233

Nele (in se), 97

Neófitos (infantes), 207

Nesse $<$ dia $>$ (eadem), 213

Nesses lugares (hisdem locis), 219

No dia das quinquagésimas (quinquagesimarum autem die), 213

No dia seguinte (alia die), 77

No monte (in montem), 81

No qual (qui), 59 
No seu corpo (in corpore), 141

Oblação (oblationem), 73

O famoso bezerro (uitulus ille), 79

Ofício (operatio), 149

Ordena que ele saia para fora (iubet illum foras exire), 223

Organização (compositio), 207

$<$ Os falantes de> todas as línguas (omnes linguae), 215

Para cima (suso), 111

Pelo menos (tamen), 83

Pelo menos (sed), 223

Pelo qual (ea quae), 185

Por essas coisas (ad ea), 229

Por nós (pro nobis), 205

Porta (hostium), 103

Por um só dia (una die), 131

Posto militar (monasteria), 89

Povoado (come), 91

Próprio (ipsa), 103

Provar (liberari), 183

Quadragésimas (quadragesimae), 213

Quando (quod), 63

Quando (qua), 63

Quando (qua), 73

Quando (qua), 183

Quando (quando), 93

Quando anoitece (cum crebris), 157

Quando então (tunc qua), 81

Quarta, 183

Que (eo quod), 93

Que (qua), 65

Que (quod), 117

Que (que), 163

Que dão para o mercado (quae sunt de quintana parte), 217

Que fazes tu aqui, Elias? (quid tu hic Helias?), 73 
Maria Cristina Martins

Quinta-feira (quinta feria), 179

Recitando (dicendo), 117

Responde (praesidet), 89

Resta (superat), 227

Ritos sagrados < da Santa Missa $>$ (sacramenta), 173

Rosto (uultus), 127

Saímos para fora (egressi sumus foras), 103

Secou (siccata est), 131

Se faz (facit se), 75

Se fazer (se facere), 185

Se faz uma oração (fit orationem), 165

Segundo Mateus (cata Matheo), 193

Segundo o costume (ordines), 173

Semanas < de jejum $>$ (ebdomadas), 181

Ser estimado (extimari), 169

Se souber (si scio), 139

Seus (sui), 189

Sexta, 181

Símbolo (Simbolum), 225

Só o grego (per se grece), 231

Tão... como..., (aut... tam...), 95

Terão comido (prandiderint), 181

Testemunhas (testimonia), 223

Tínhamos que atravessar (trauersare habebamus), 63

Um (unus), 99

Uma vez que (quemadmodum), 181

Um dos presbíteros (quicumque de presbyteris), 159

Vai (uadent se), 169

Vai-se (proceditur), 163

Vergônteas (uirgultas), 75

Vistos todos os lugares santos (uisa loca sancta omnia), 83

Vossa Afeição (affectio uestra), 81 


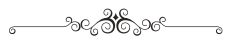

Manuscrito do séc. XI

Codex Aretinus (405)

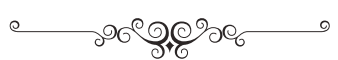




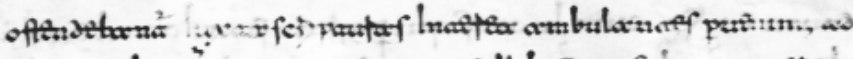

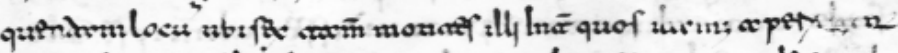

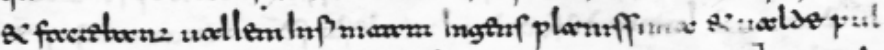

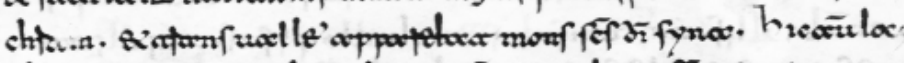

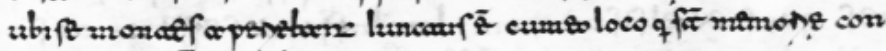

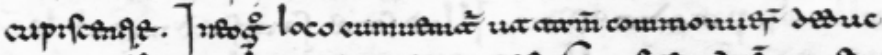

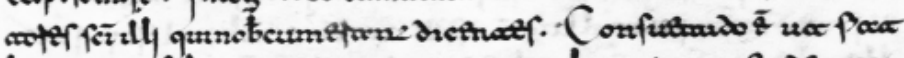

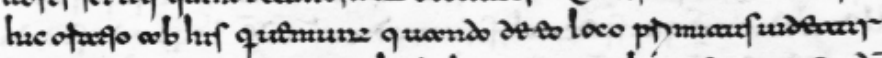

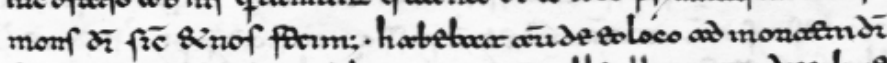

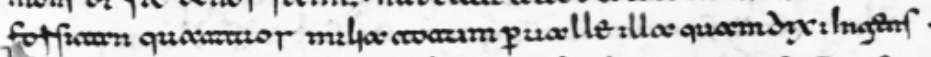

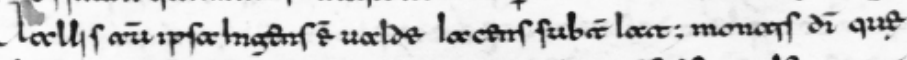

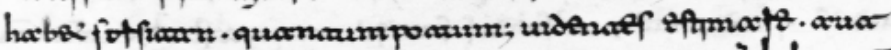

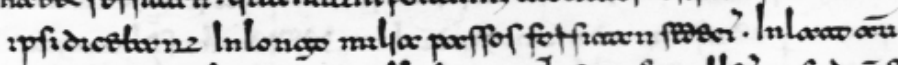

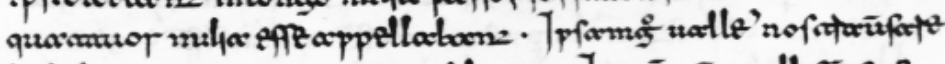

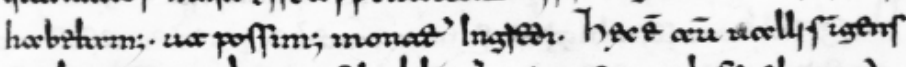

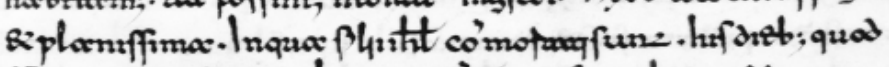

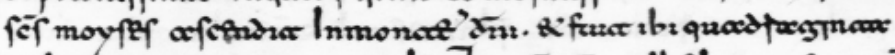

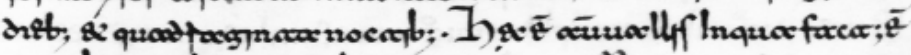

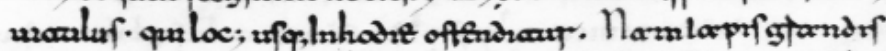

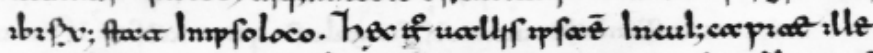

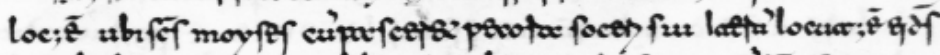

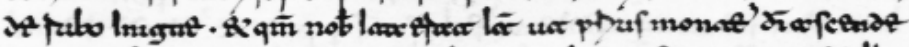

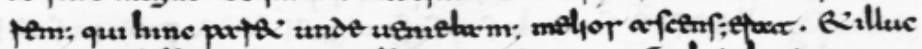

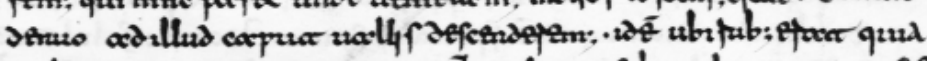

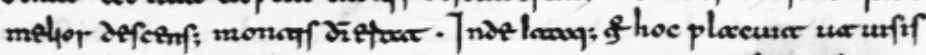

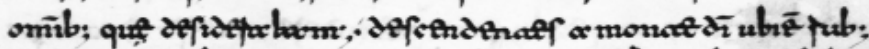

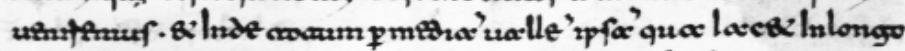

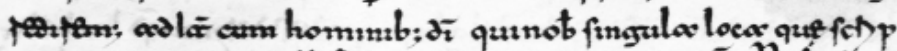

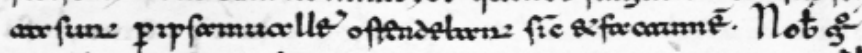

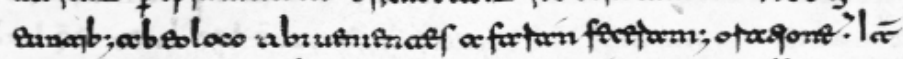

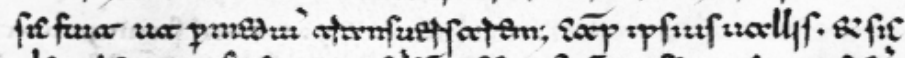

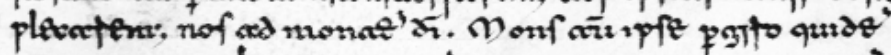

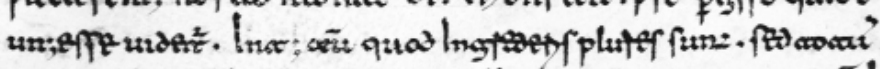

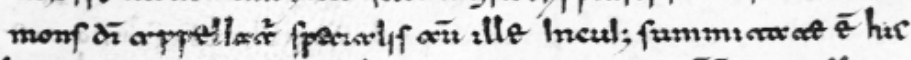

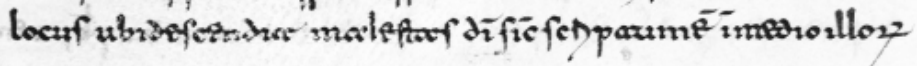




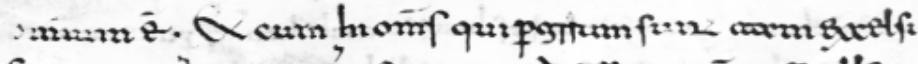

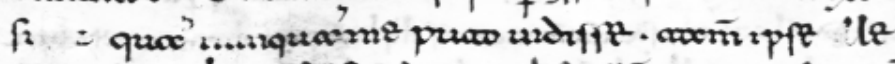

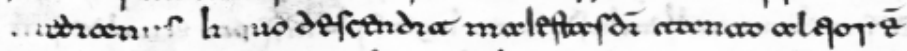

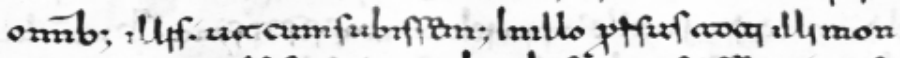

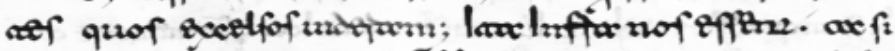

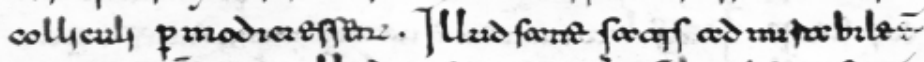

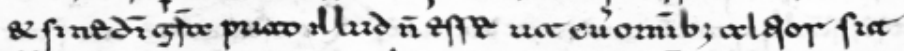

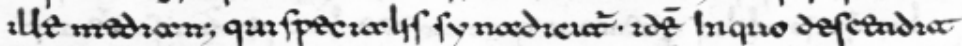

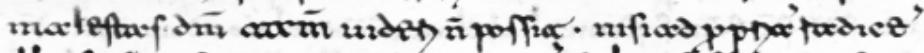

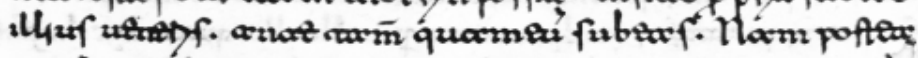

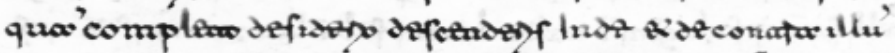

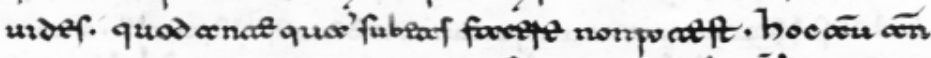

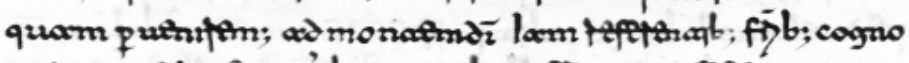

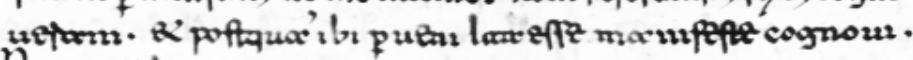

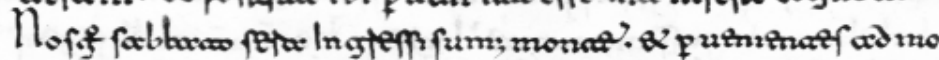

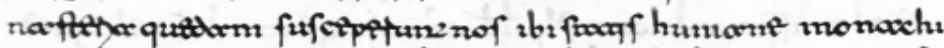

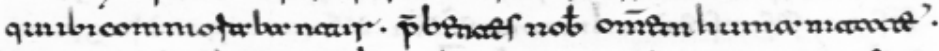

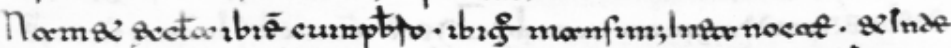

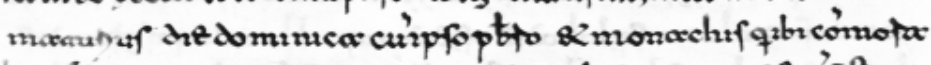

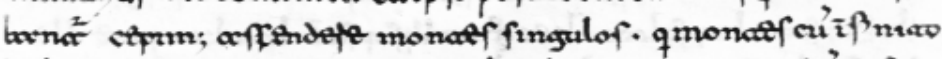

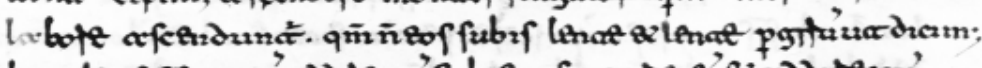

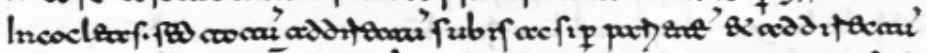

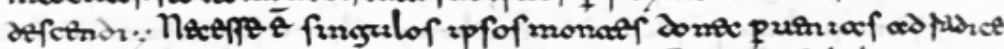

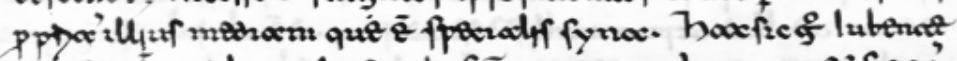

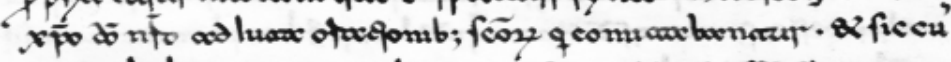

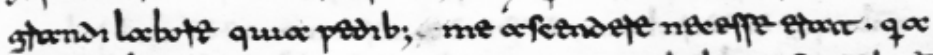

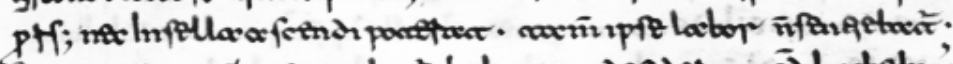

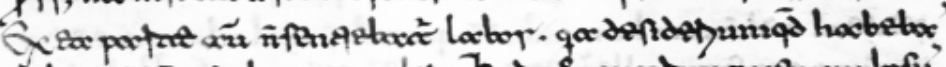

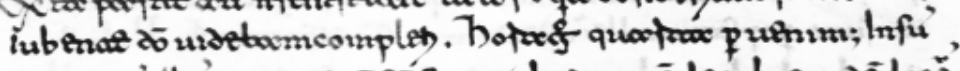

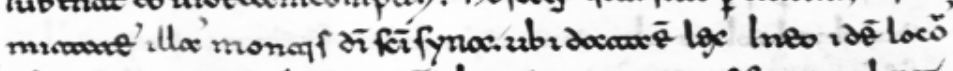

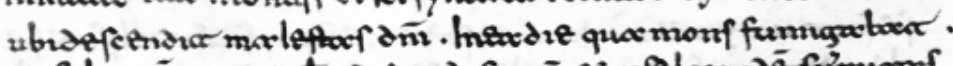

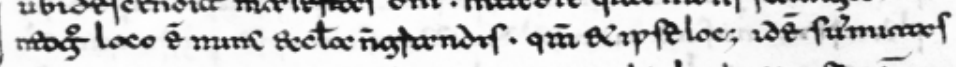

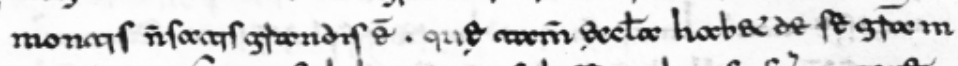

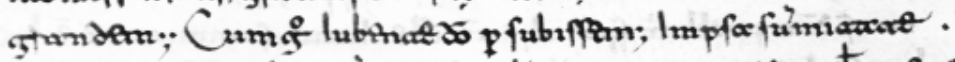

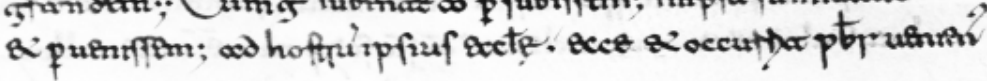




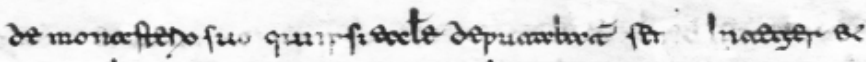

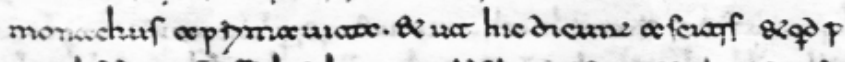

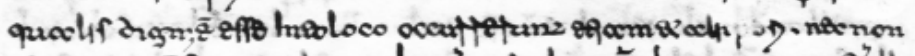

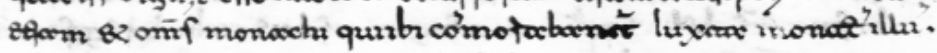

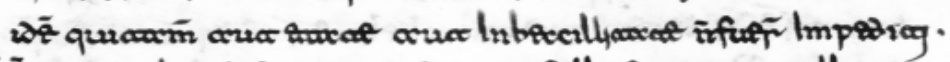

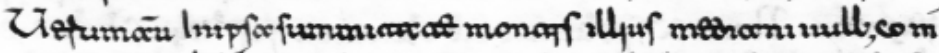

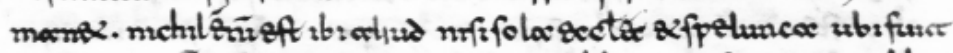

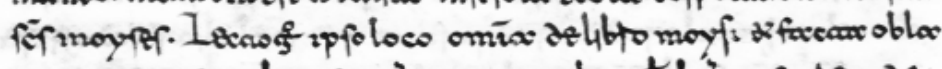

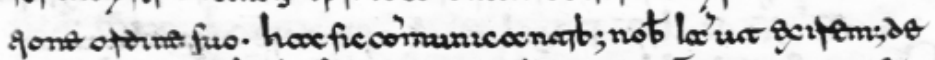

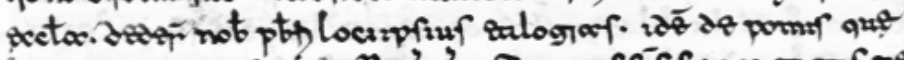

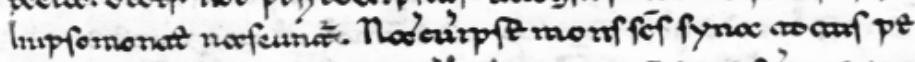

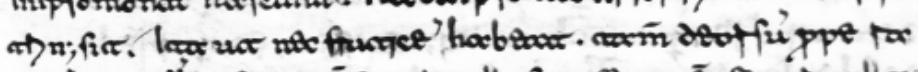

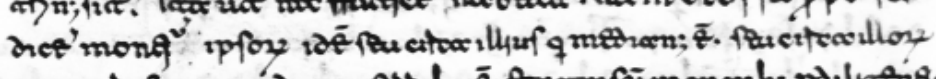

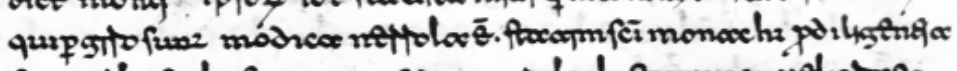

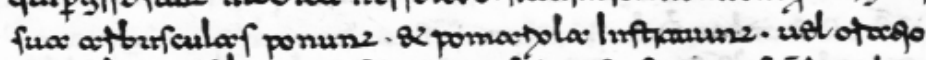

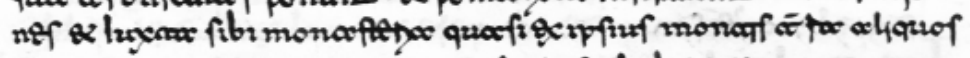

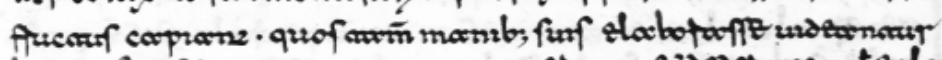

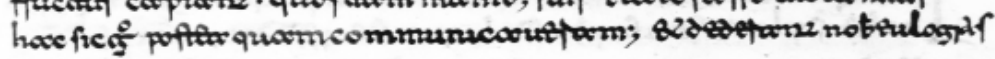

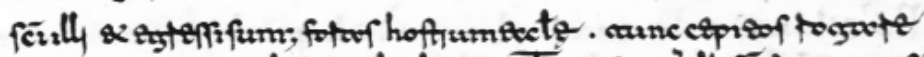

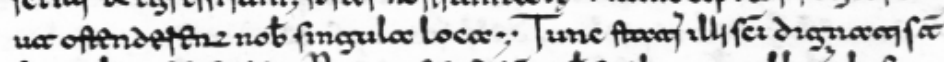

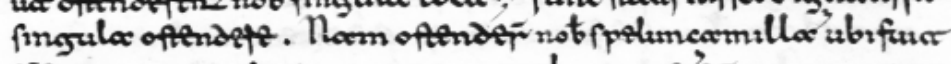

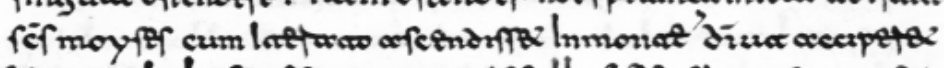

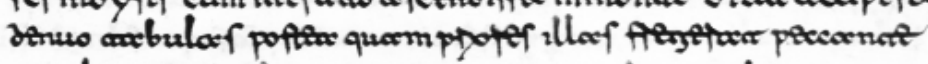

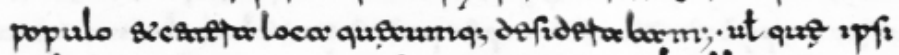

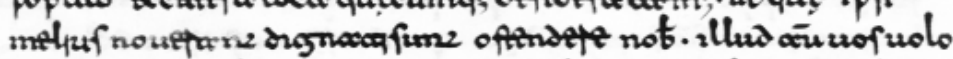

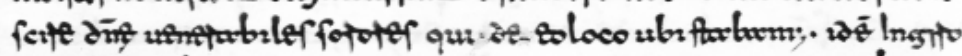

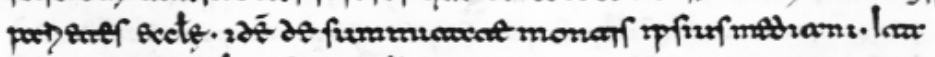
Inf

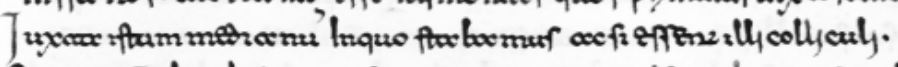

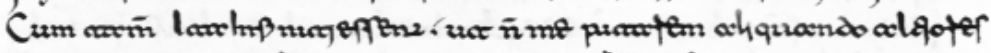

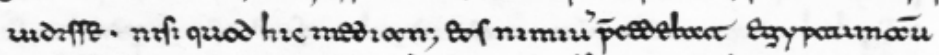

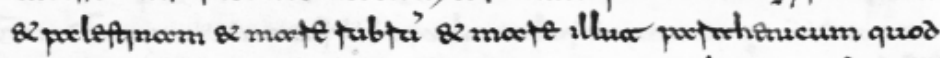

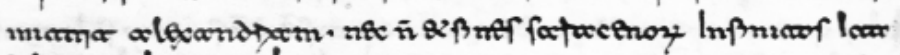

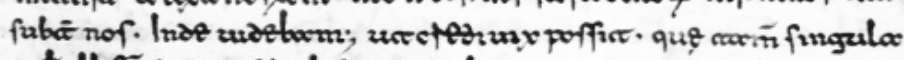

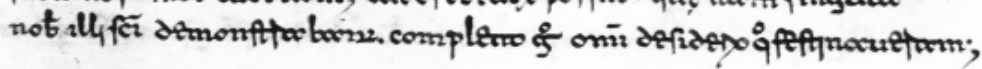




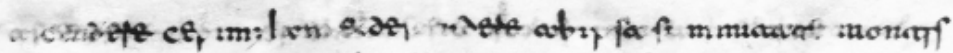

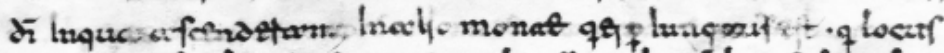

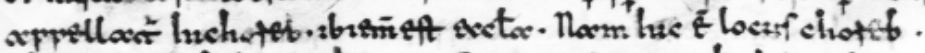

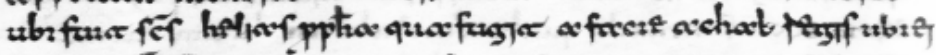

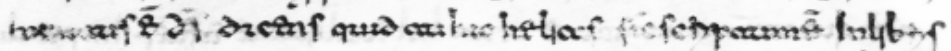

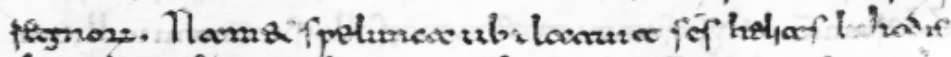

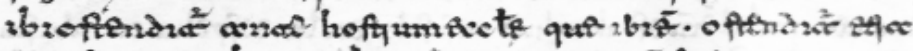

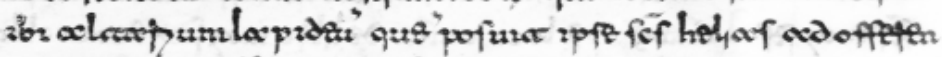

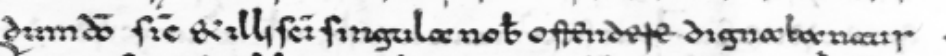

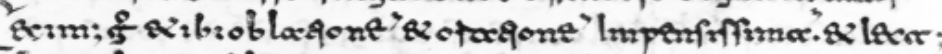

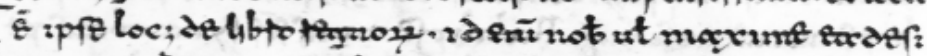

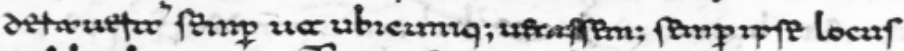

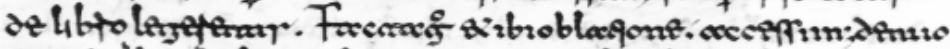

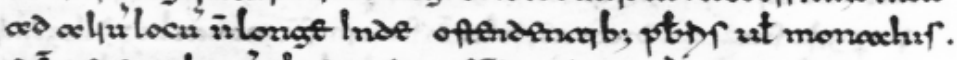

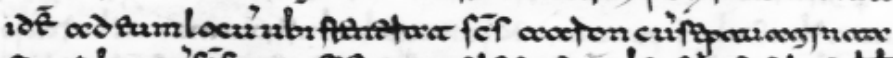

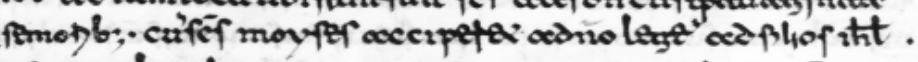

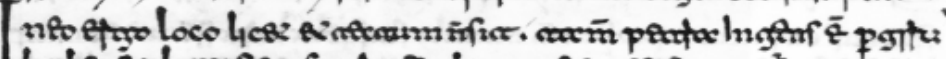

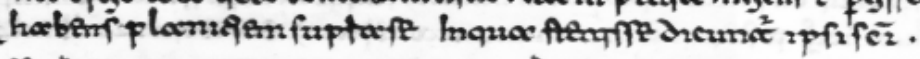

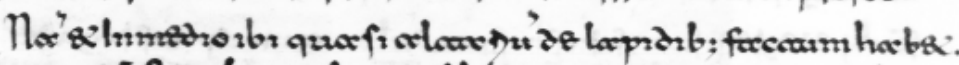

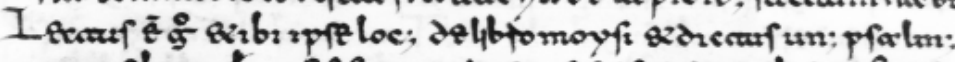

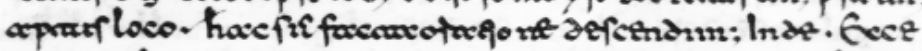

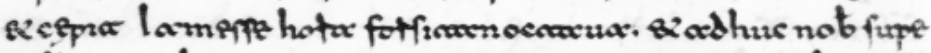

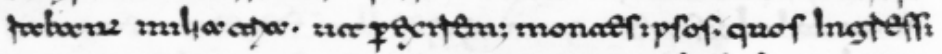

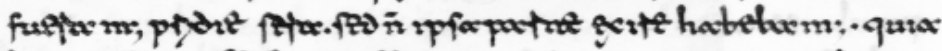

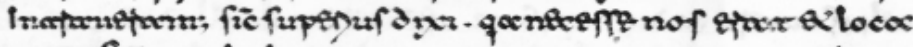

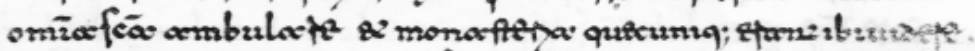

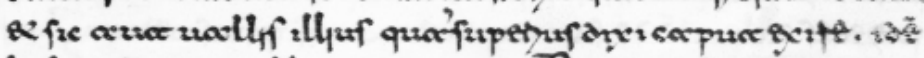

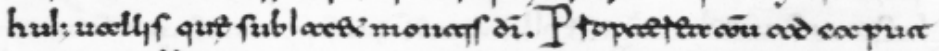

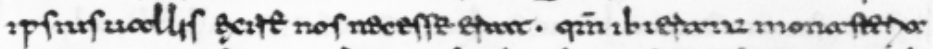

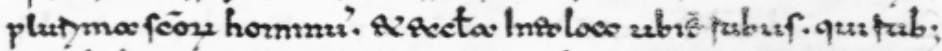

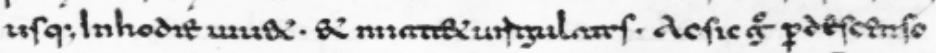

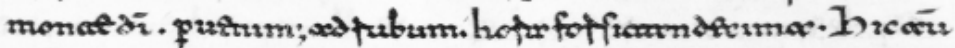

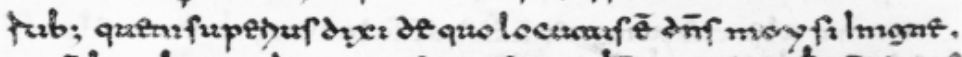

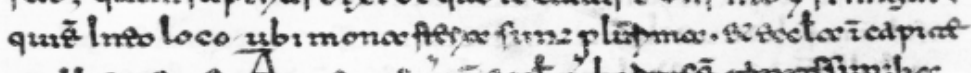

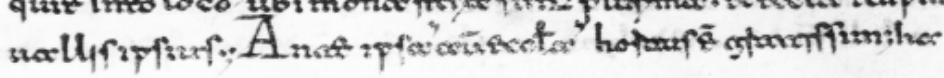




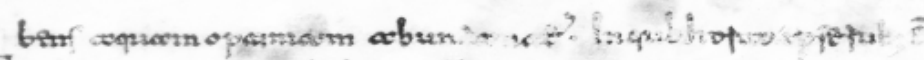

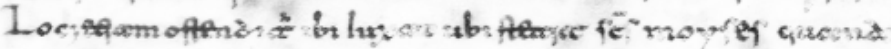

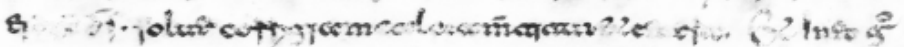

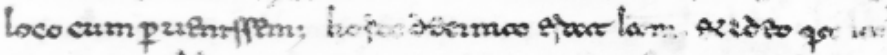

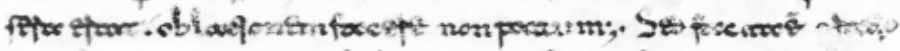

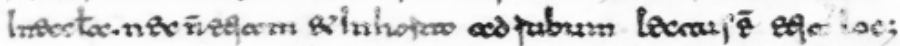

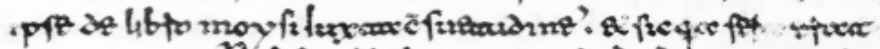

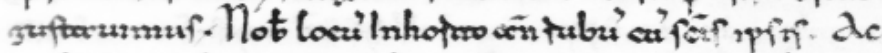
fie

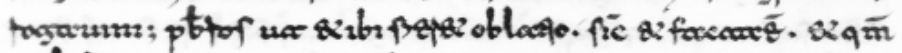

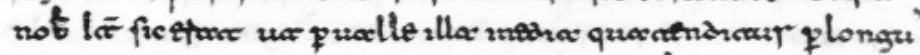

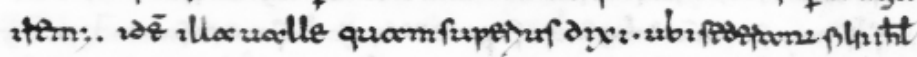

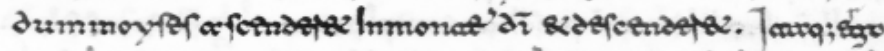

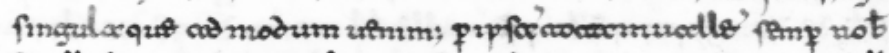

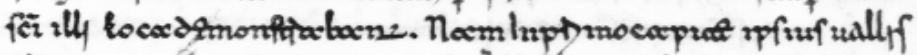

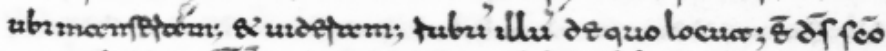

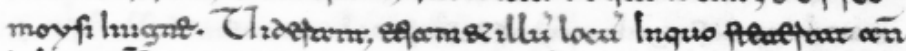

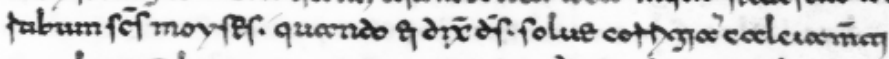

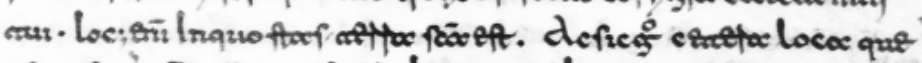
ca madu' petur furm, aetabo pup not cepê oftendeye. $n_{\infty}$

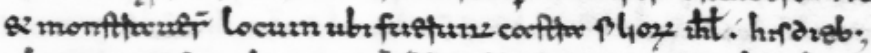

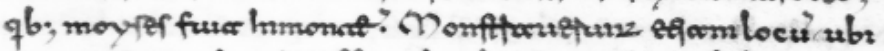

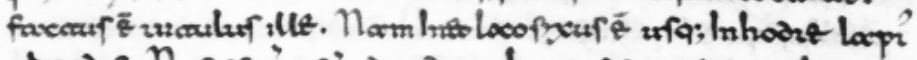

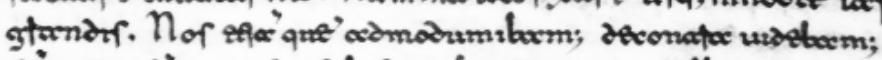

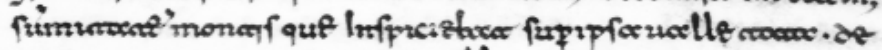

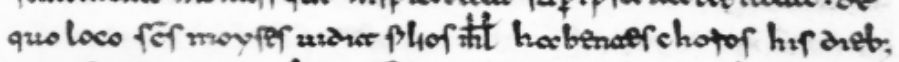

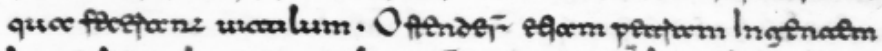

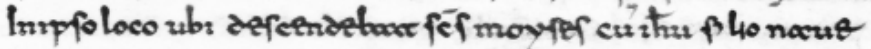

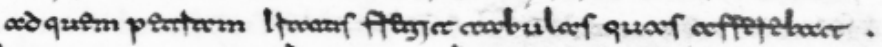

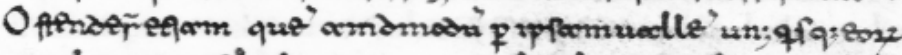

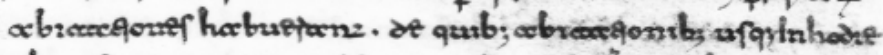

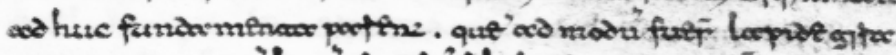

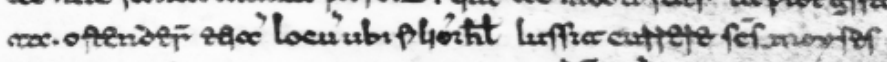

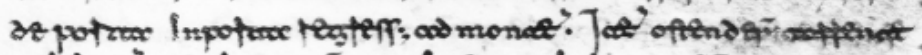

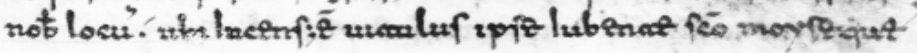




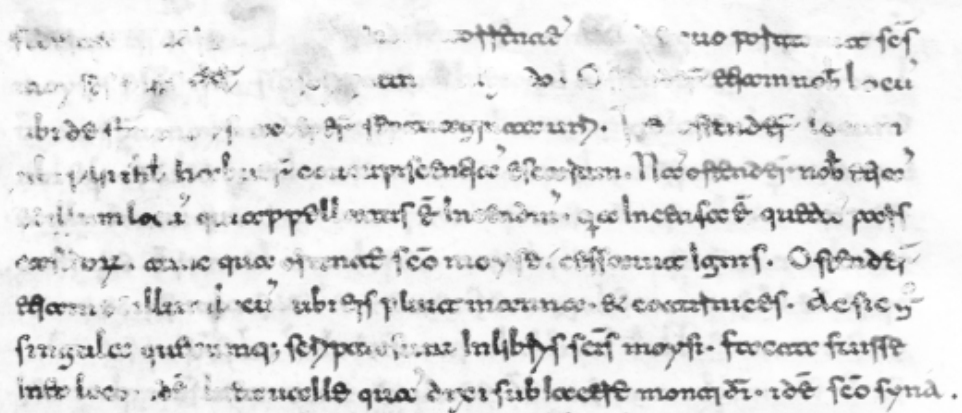

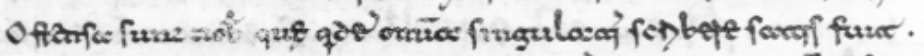

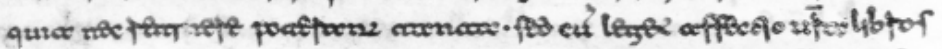

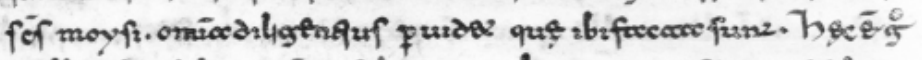

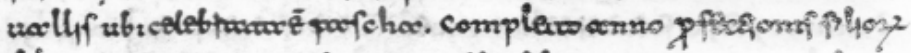

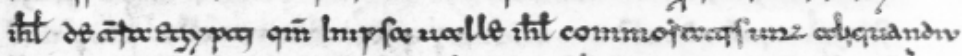

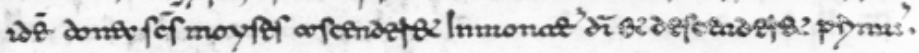

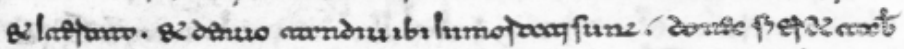

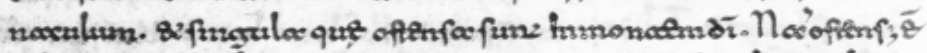

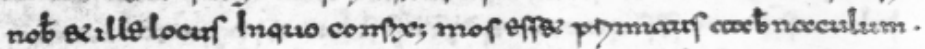

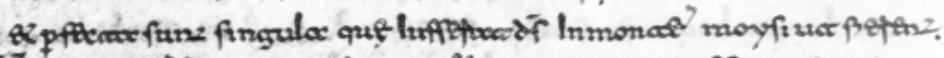

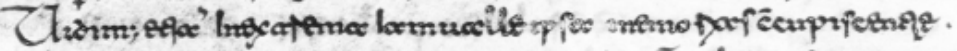

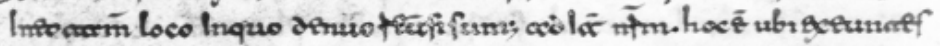

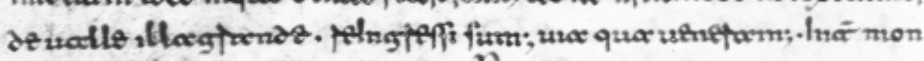

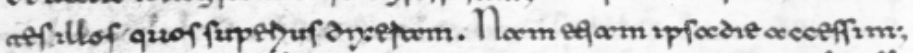

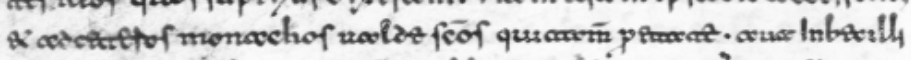

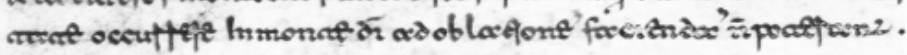

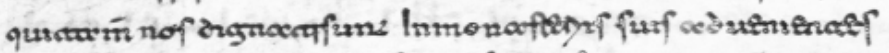

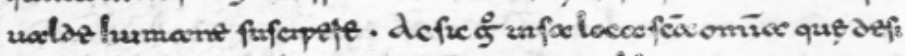

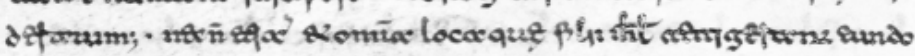

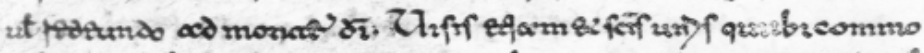

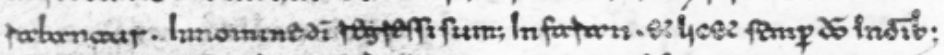

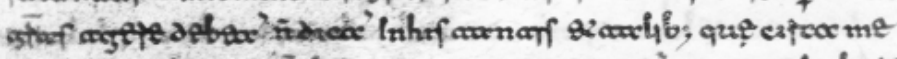

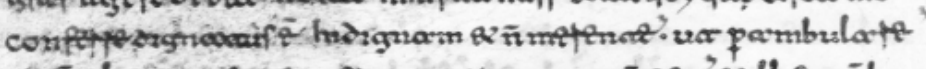

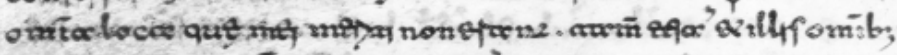

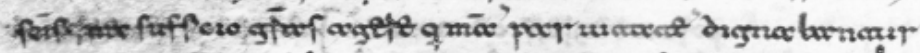

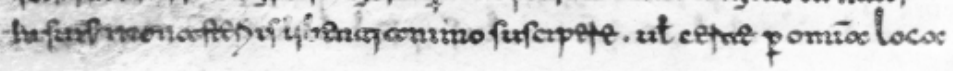




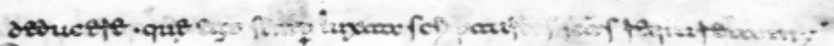

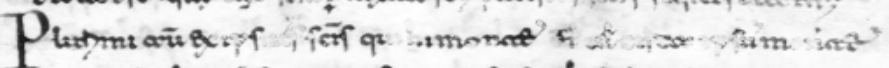

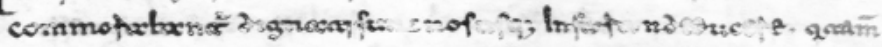

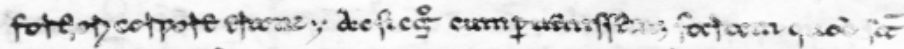

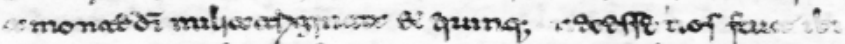

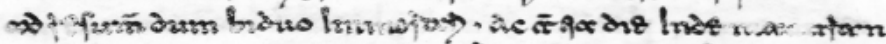

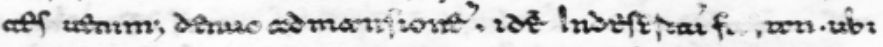

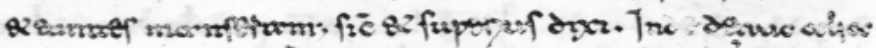

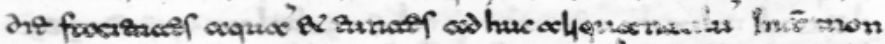

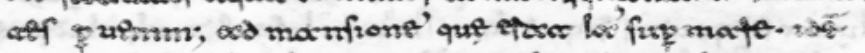

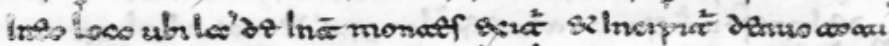

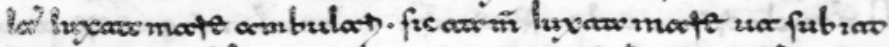

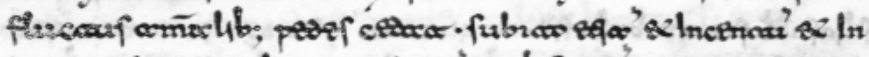

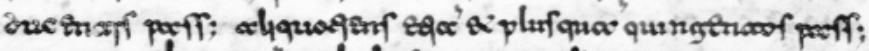

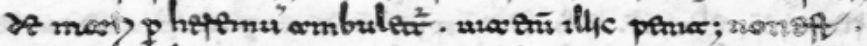

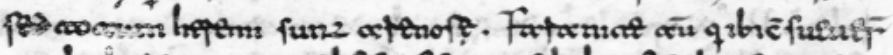

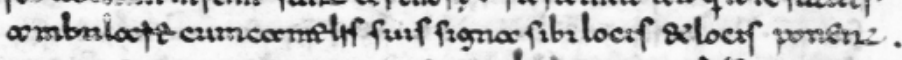

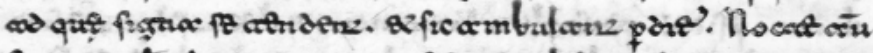

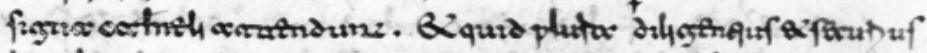

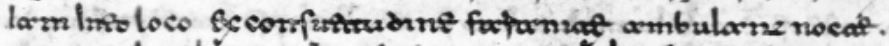

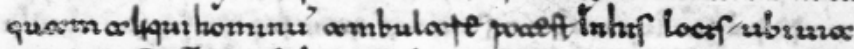

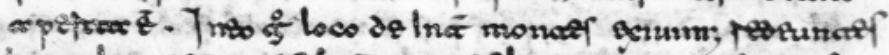

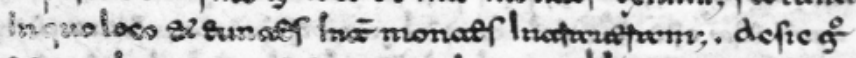

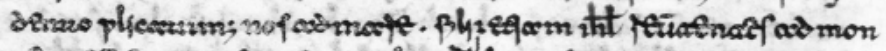

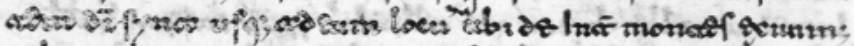

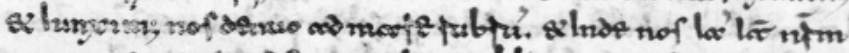

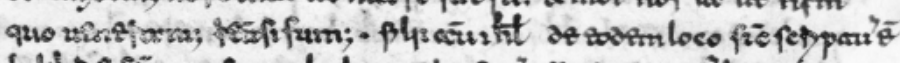

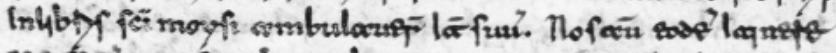

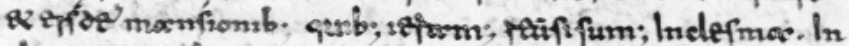

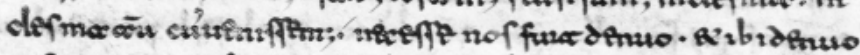

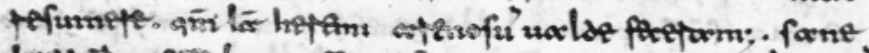

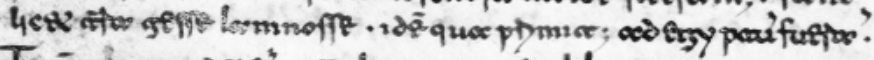

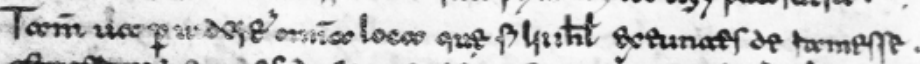

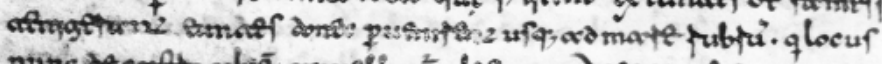

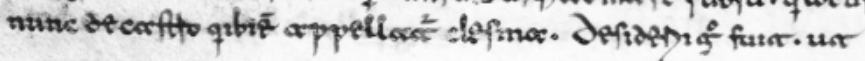

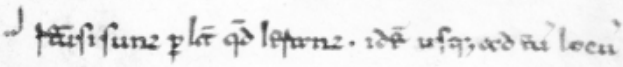




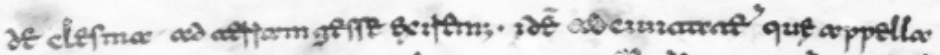

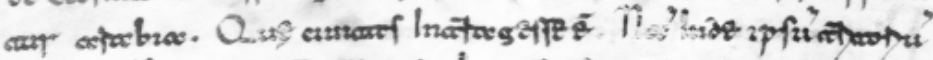

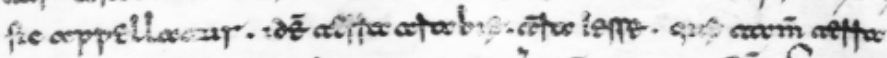

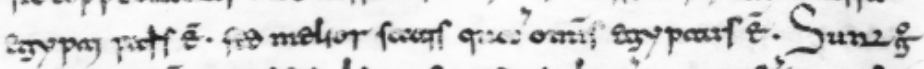

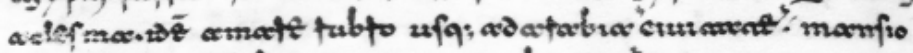

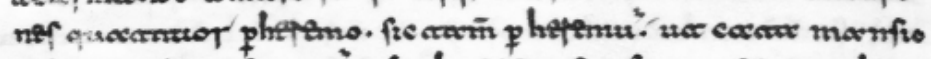

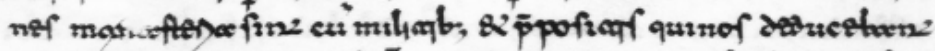

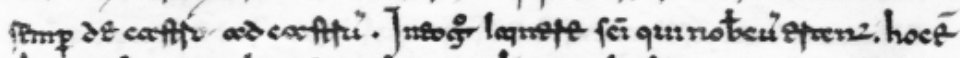

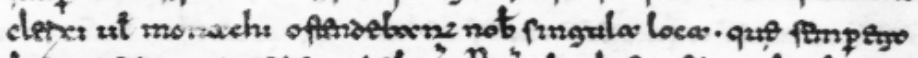

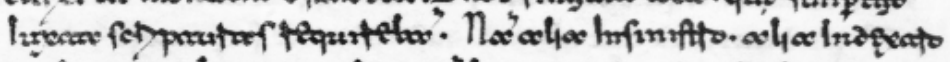

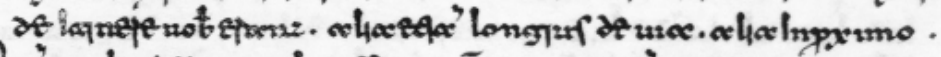

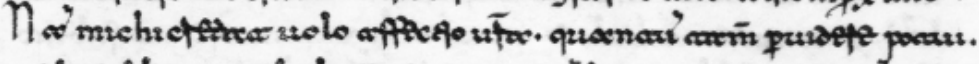

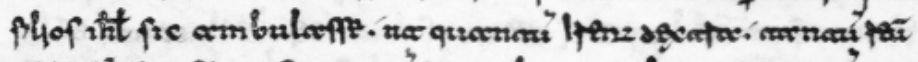

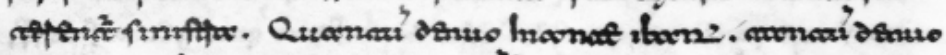

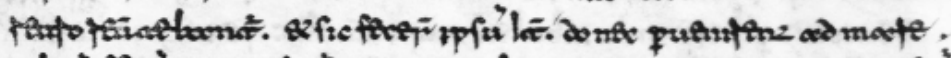

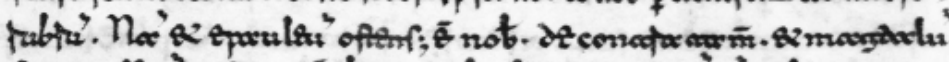

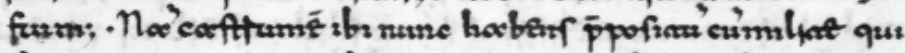

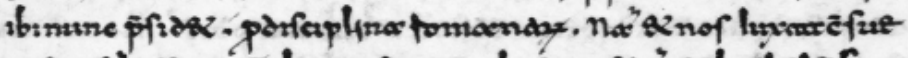

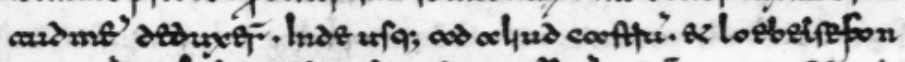

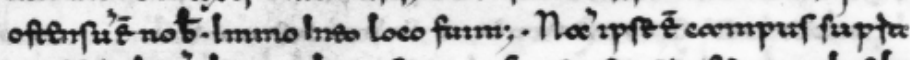

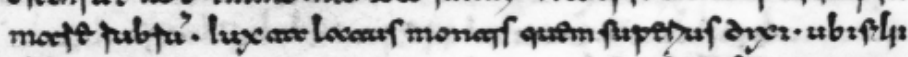

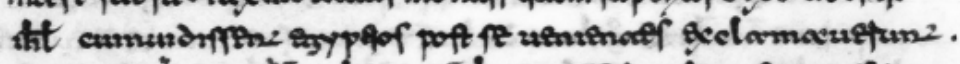

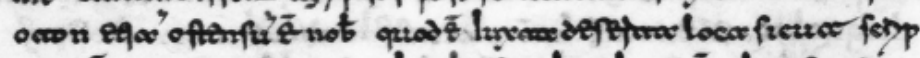

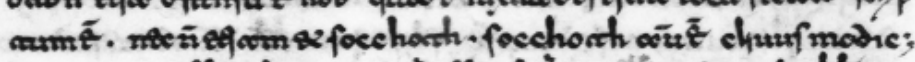

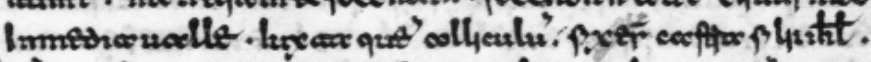

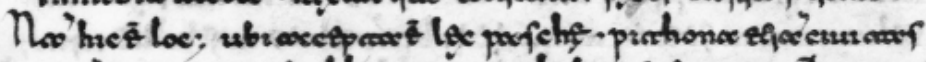

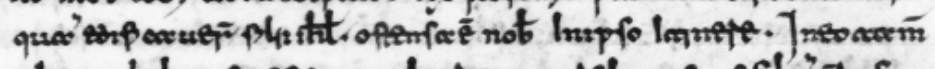

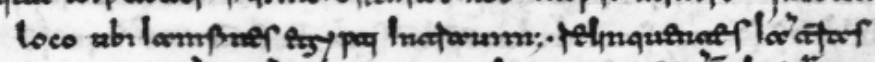

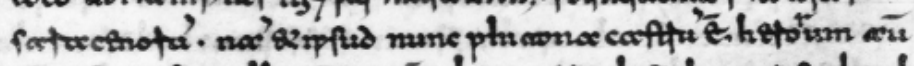

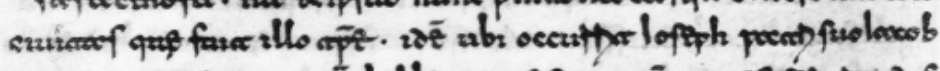

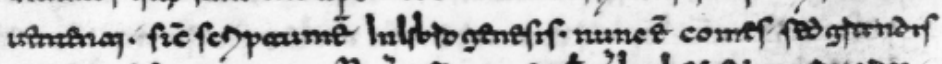

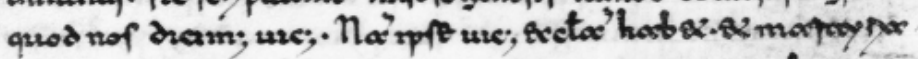

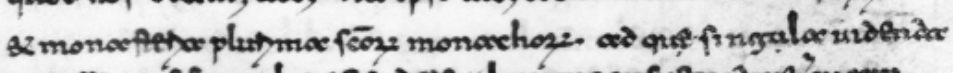

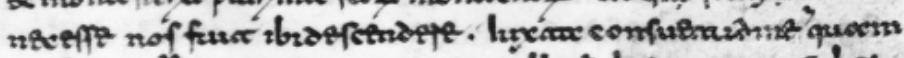

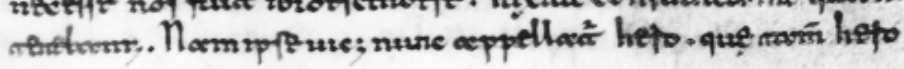




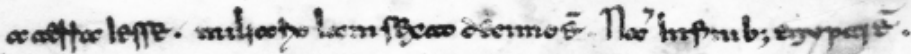

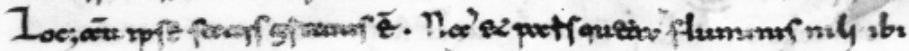

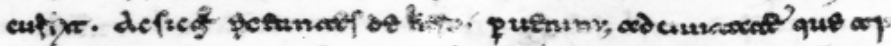

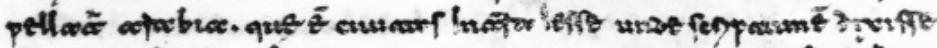

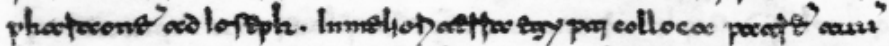

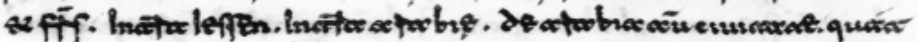

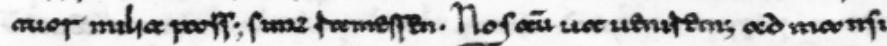

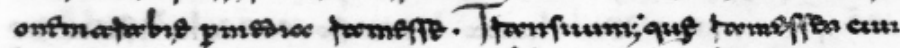

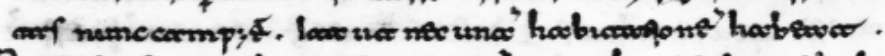

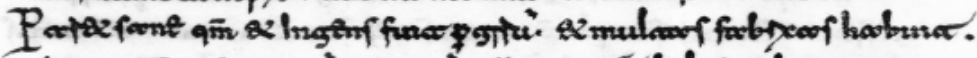

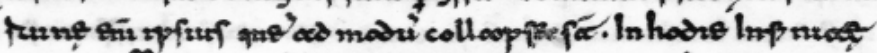

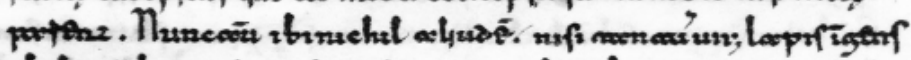

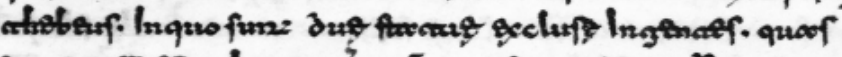

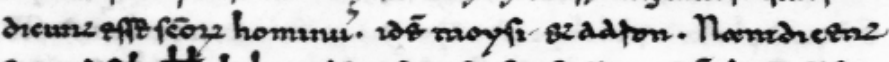

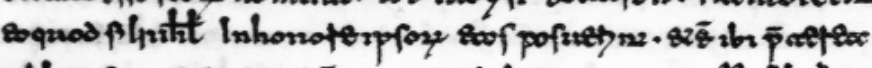

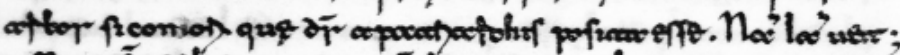
भा

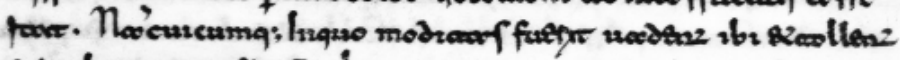

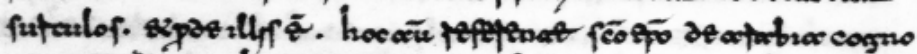

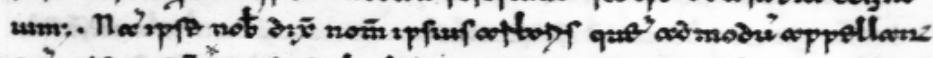

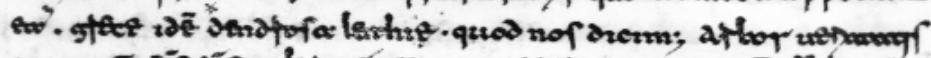

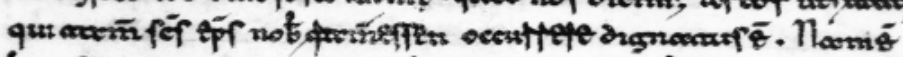

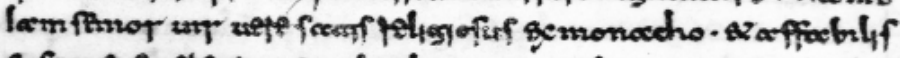

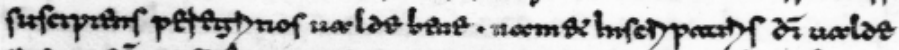

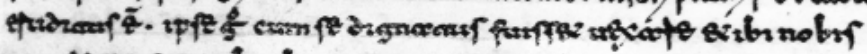

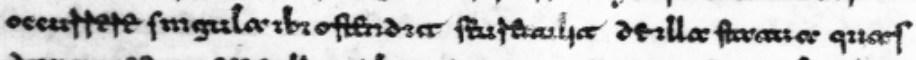

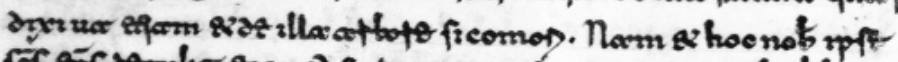

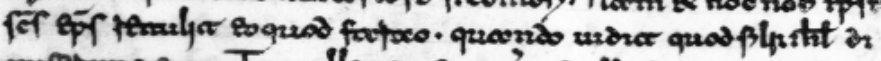

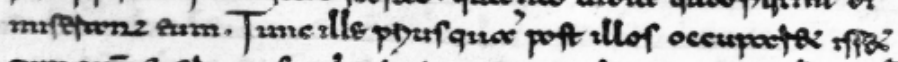

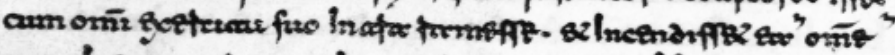

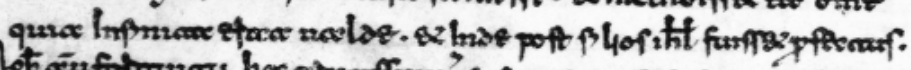

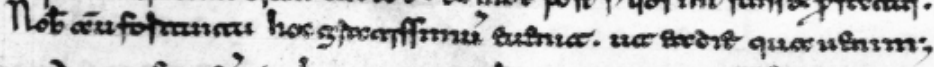

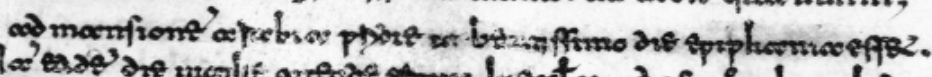

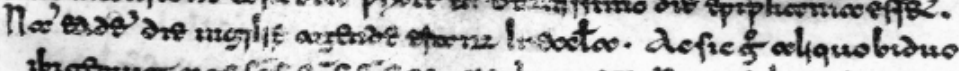

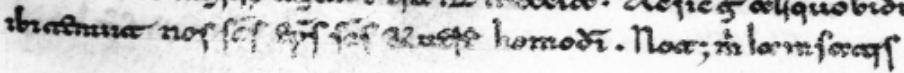




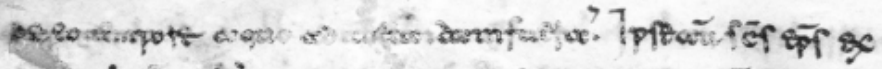

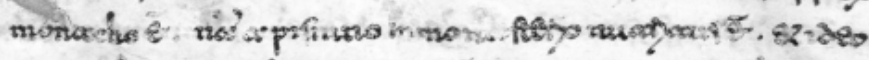

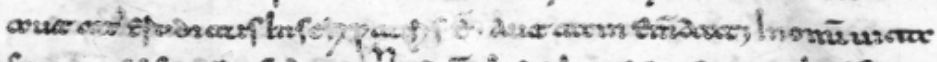

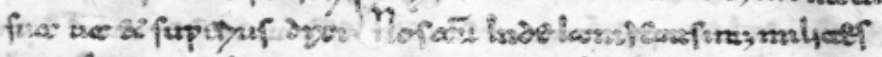

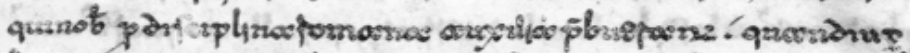

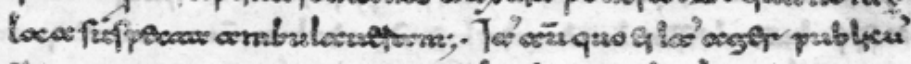

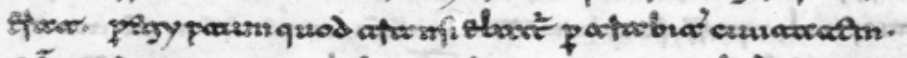

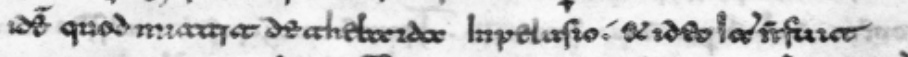

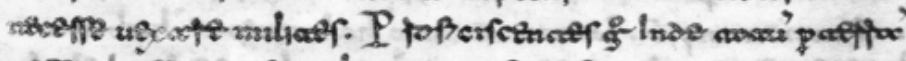

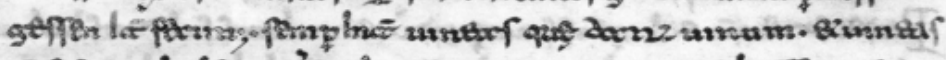

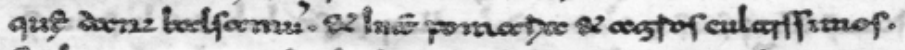

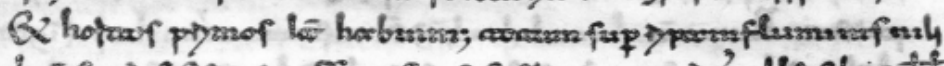

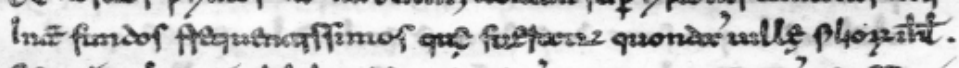

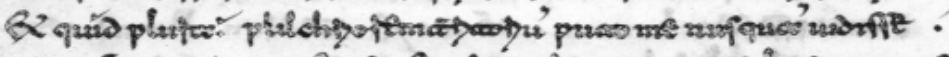

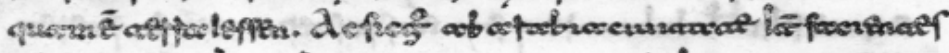

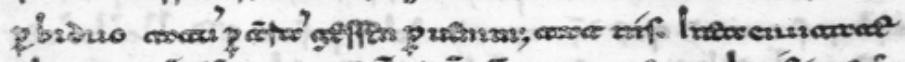

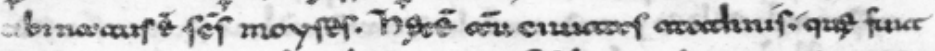

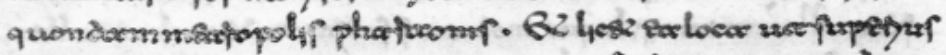

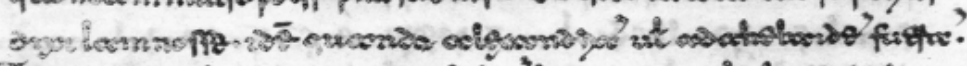

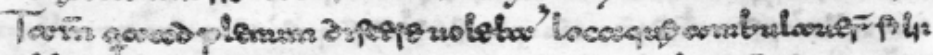

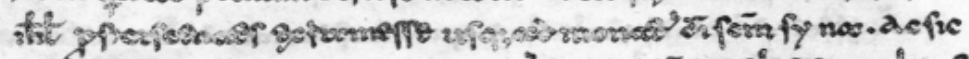

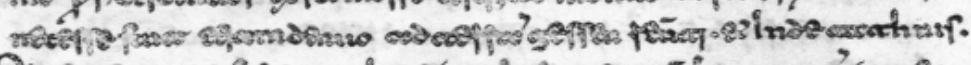

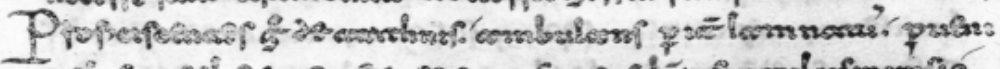

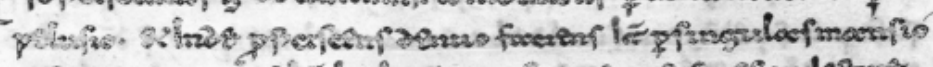

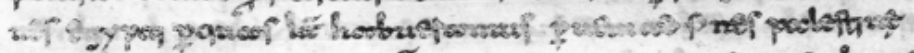

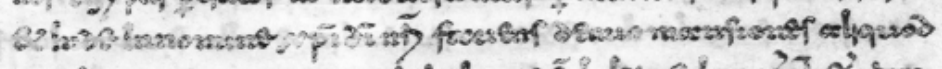

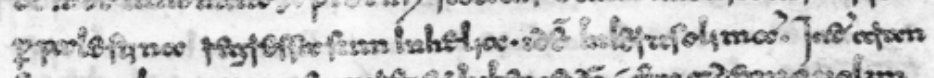

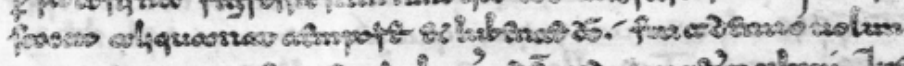

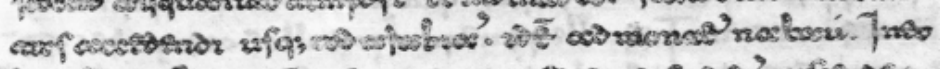

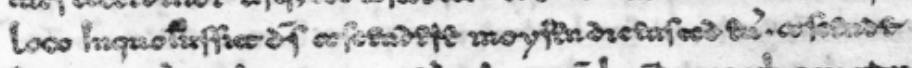

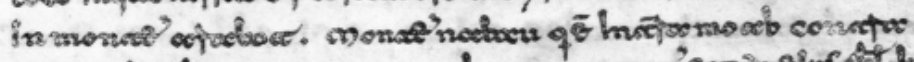

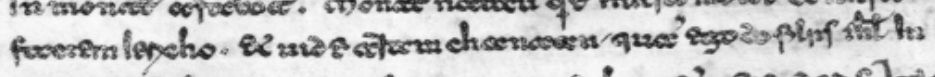

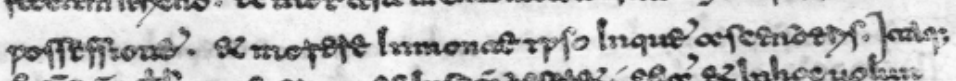

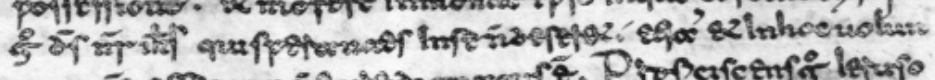
cose rin of 


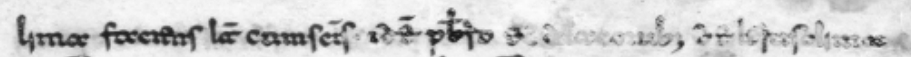

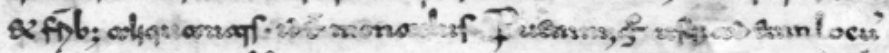

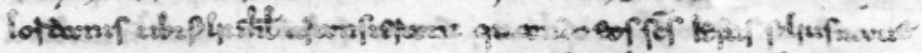

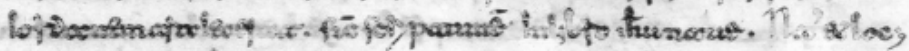

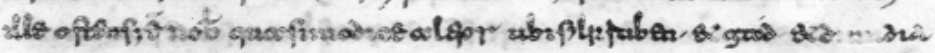

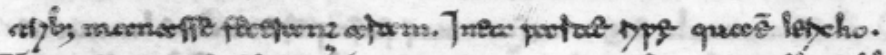

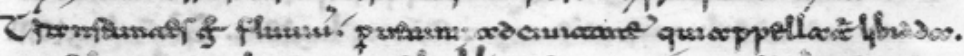

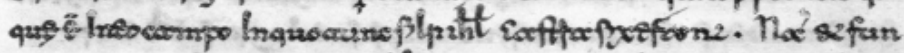

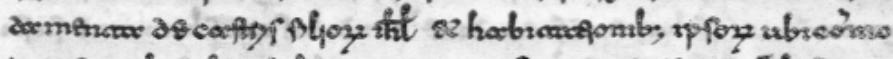

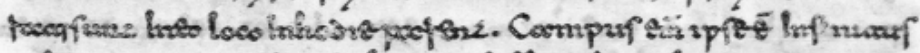

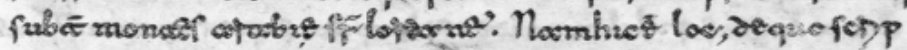

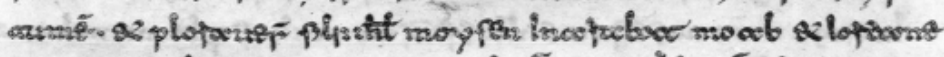

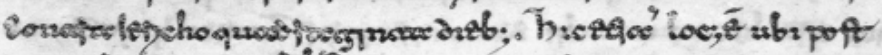

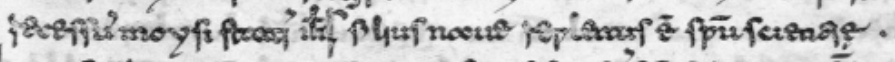
nom

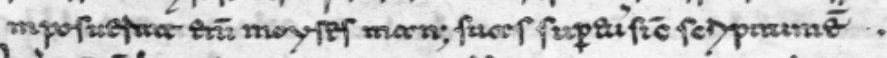

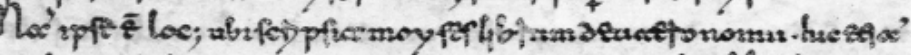

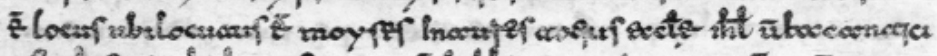

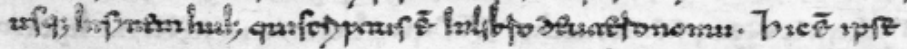

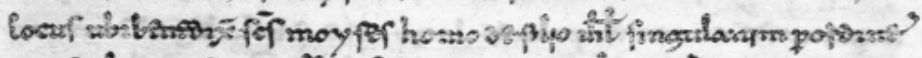

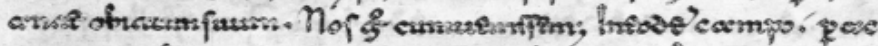

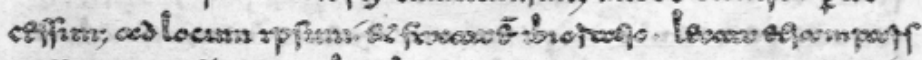

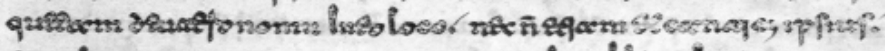

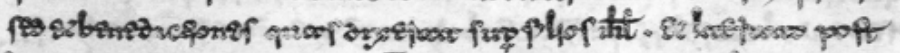

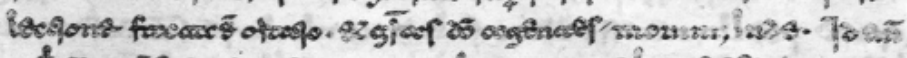
nof ค เ

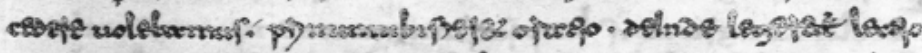

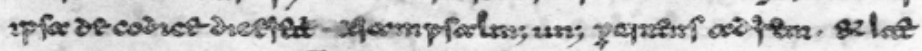

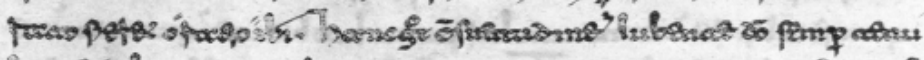

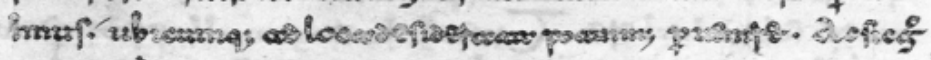

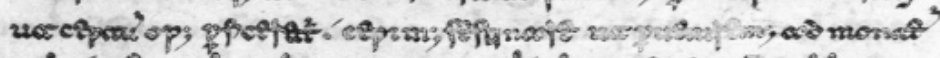

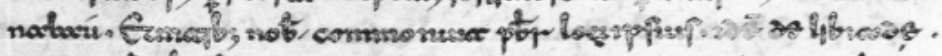

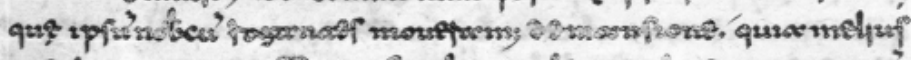

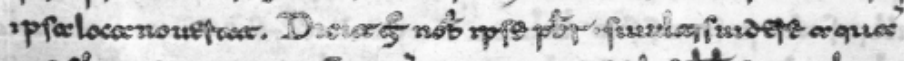

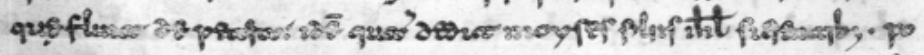

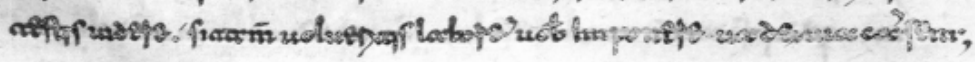




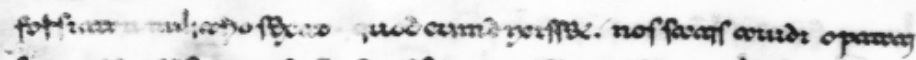

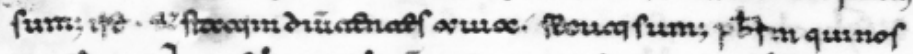

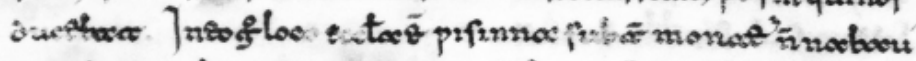

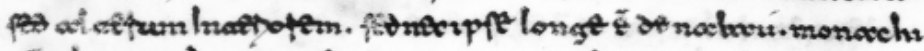

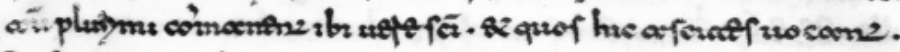

T) sis fir monochs argnouxfire nof fuferpete uadas husuane.

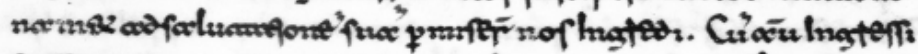

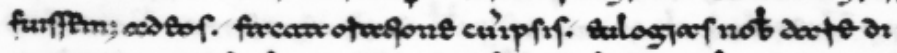

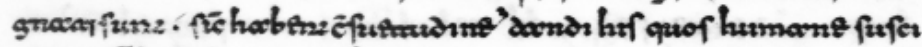

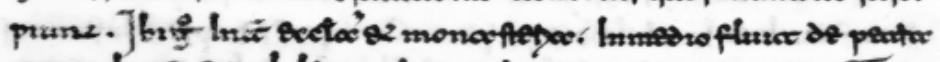

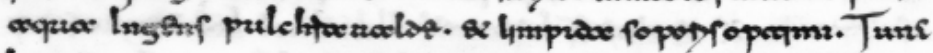

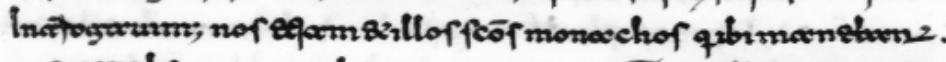

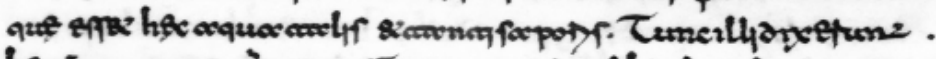

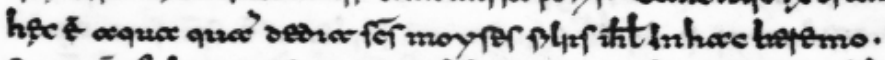

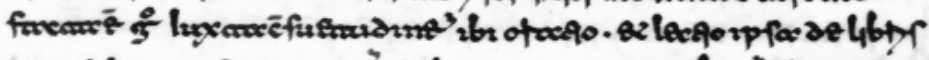

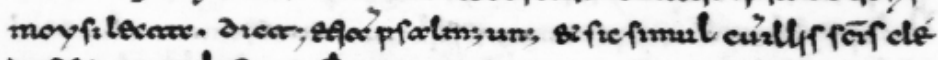

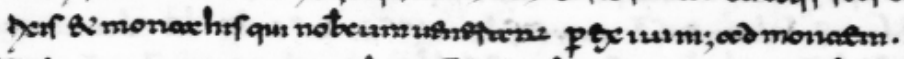
(i)

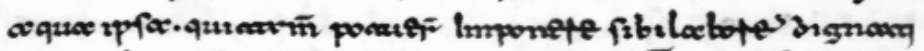

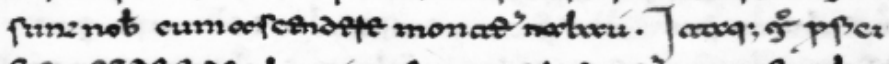

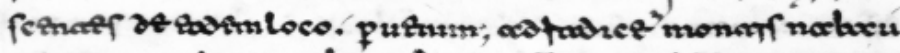

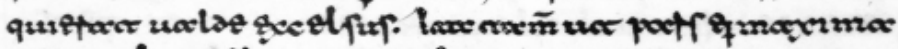

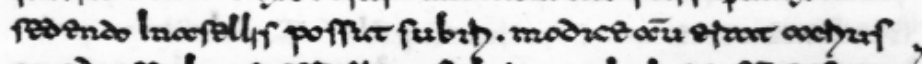

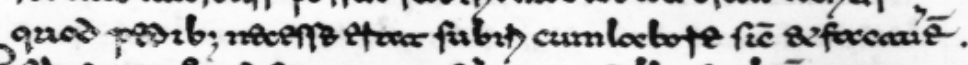

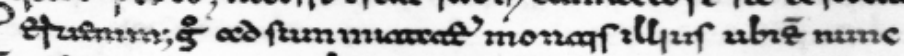

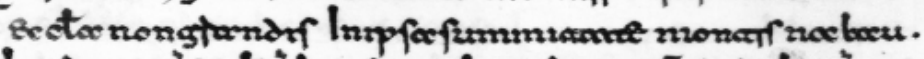

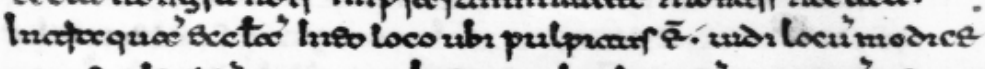

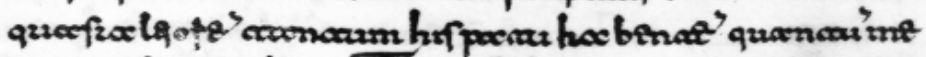

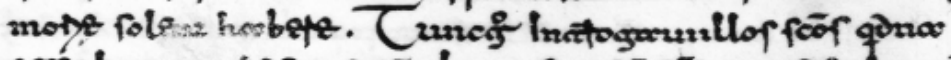

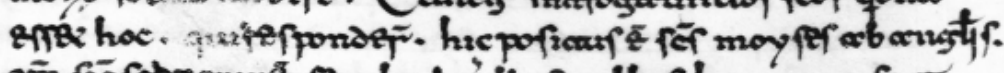

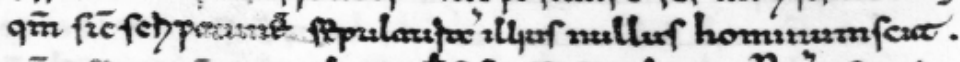
q

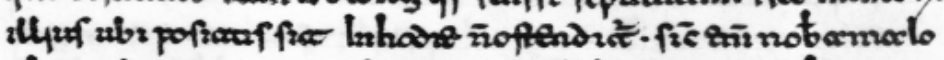

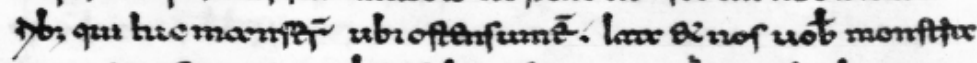

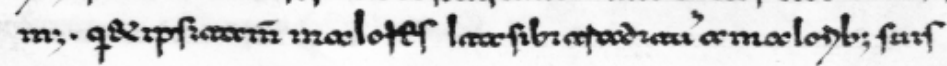


EFt an els

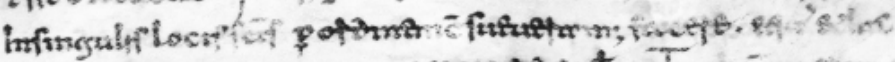

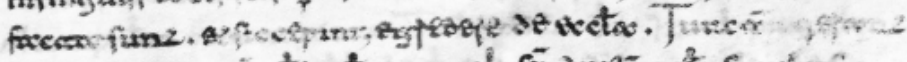

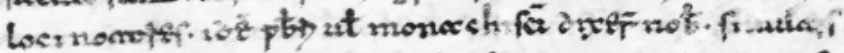
us

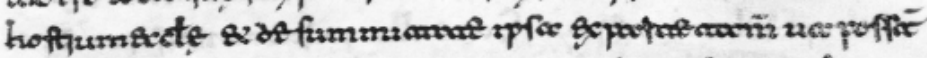

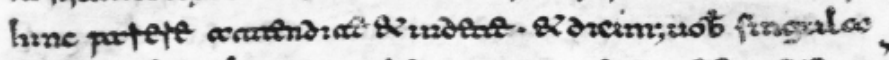

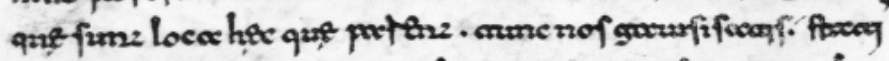

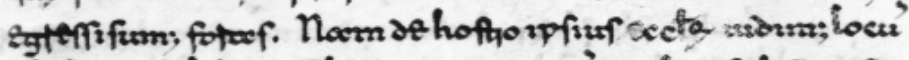

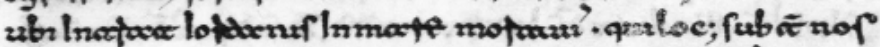

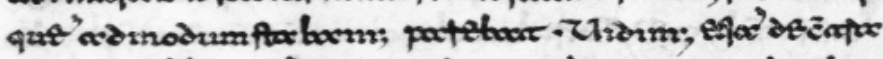

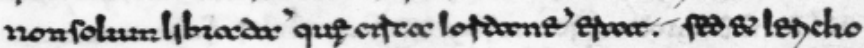

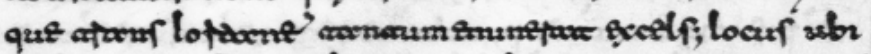

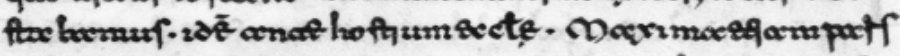

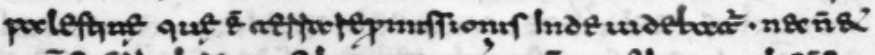

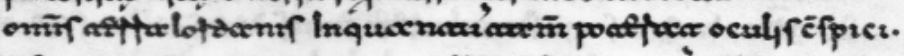

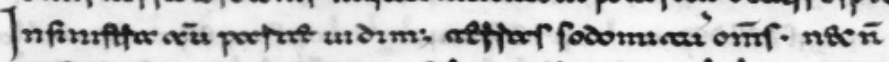

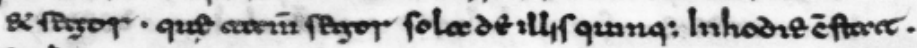

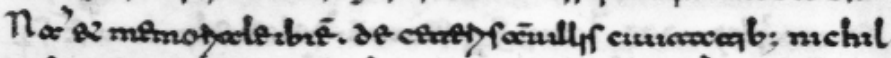

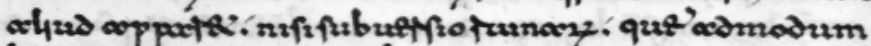

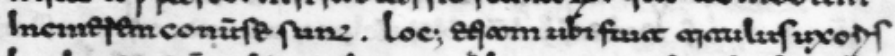

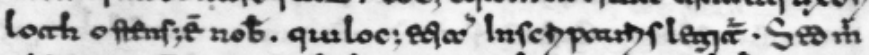

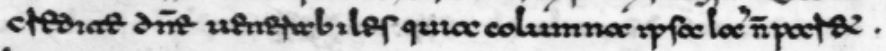

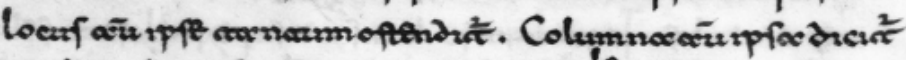

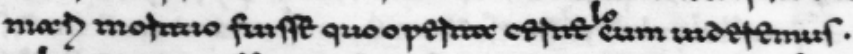

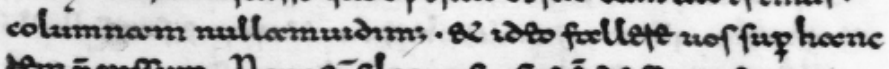

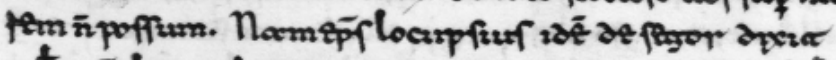

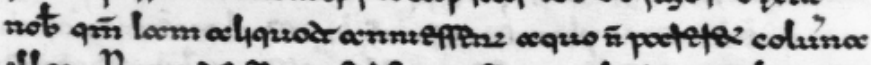

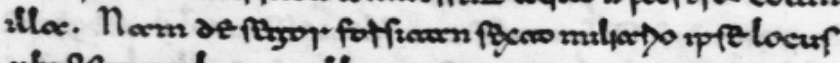

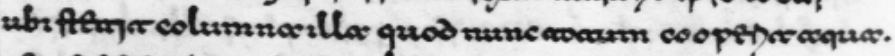

J

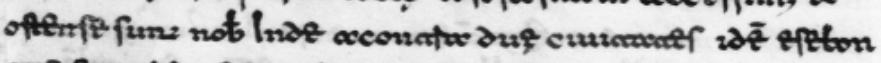

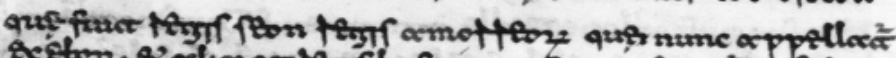

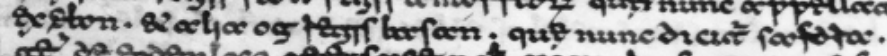

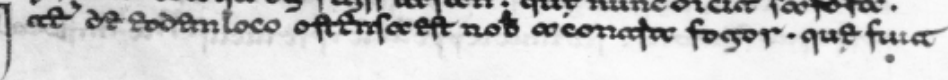




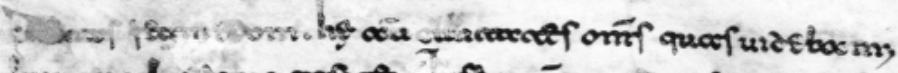

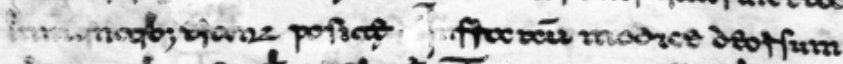
p.

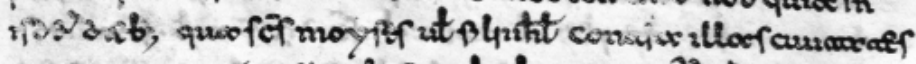

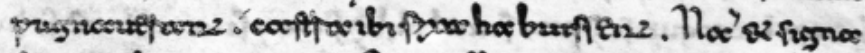

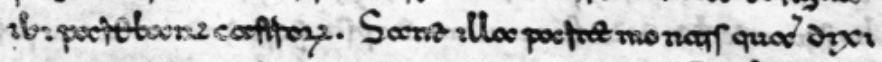

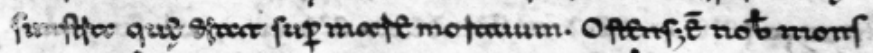

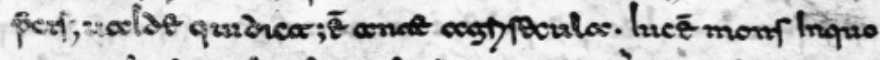

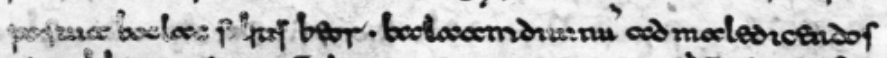

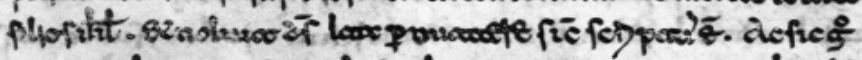

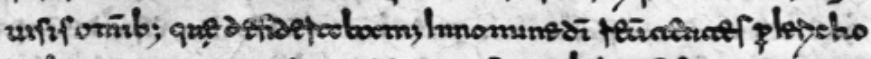

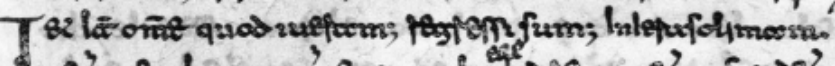

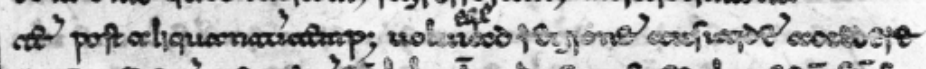

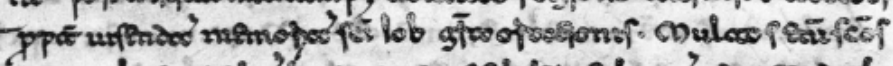

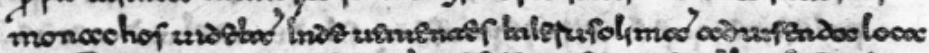

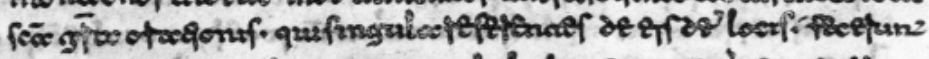

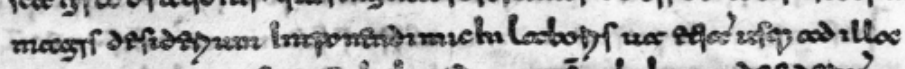

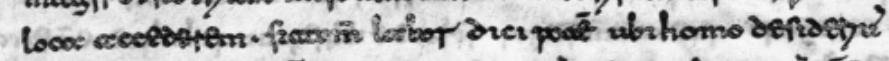

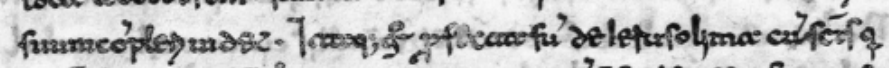

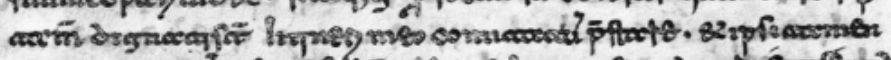

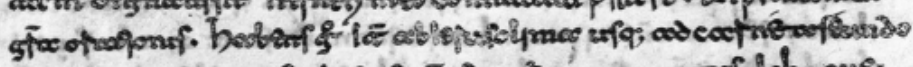

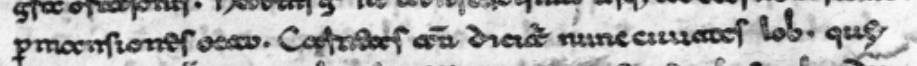

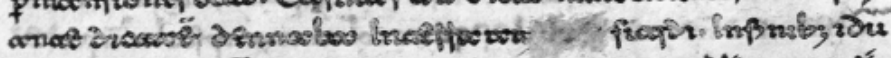

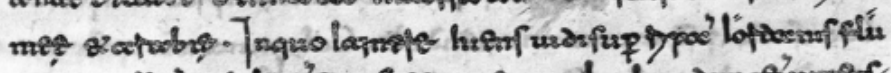

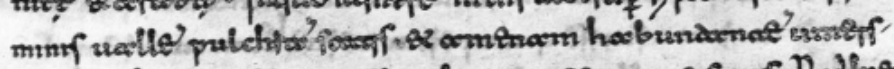

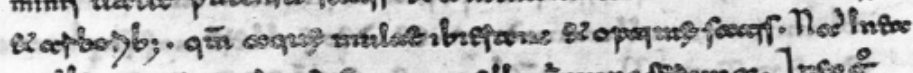

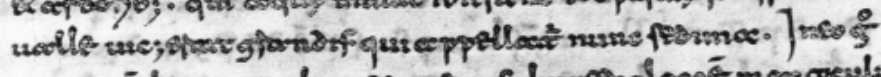
usco quเ

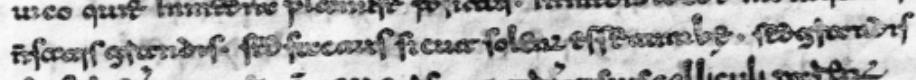

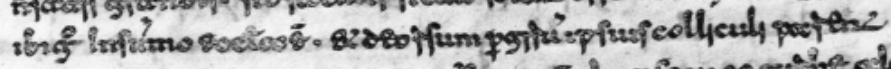

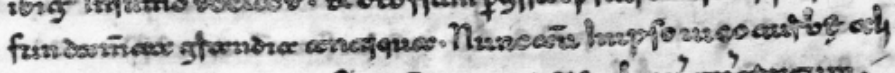

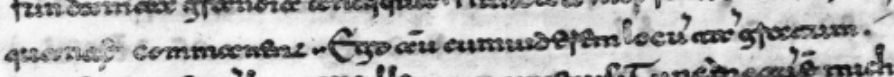

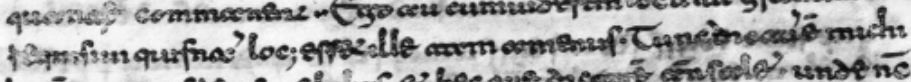

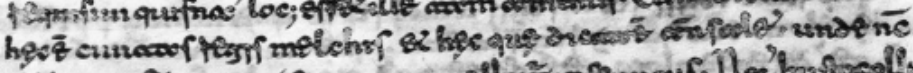

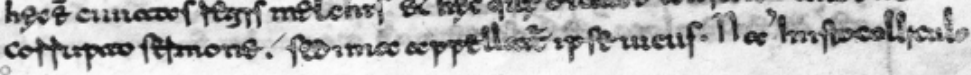




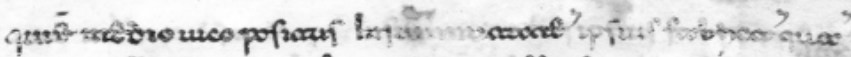

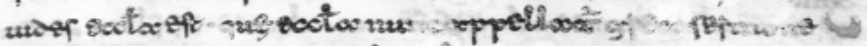

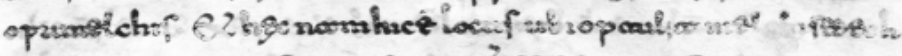

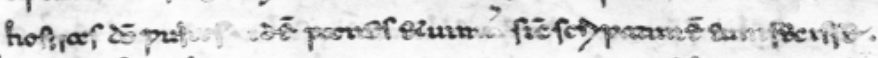

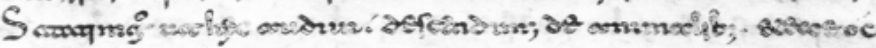

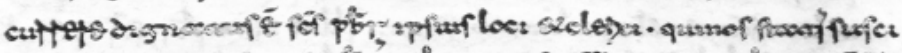

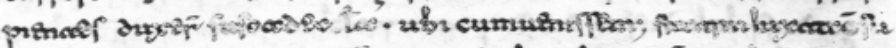

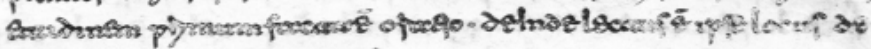

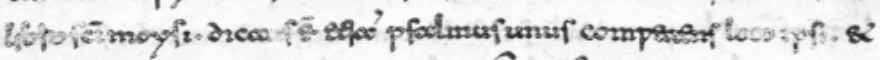

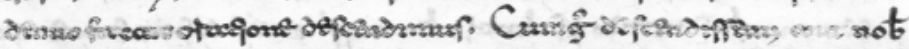

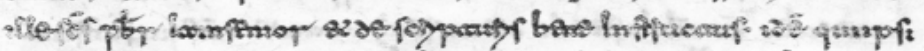

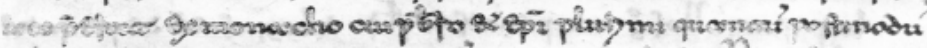

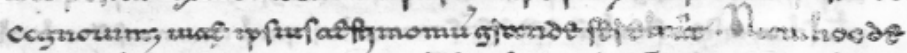

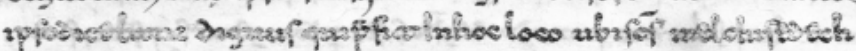

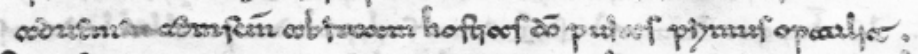

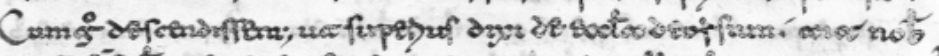

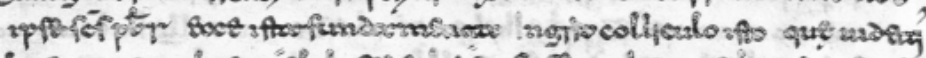

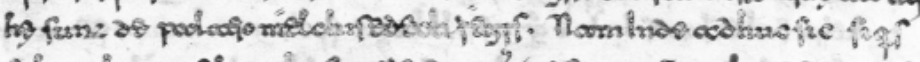

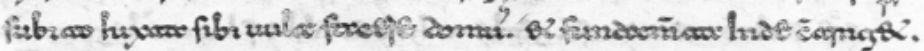

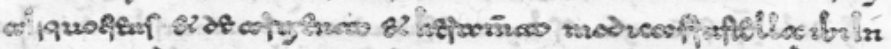

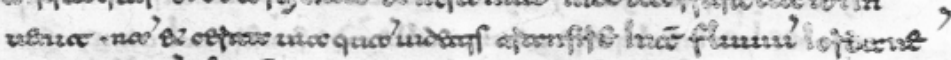

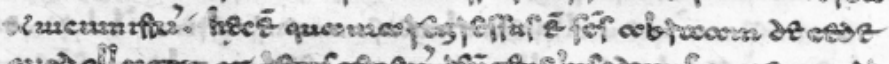

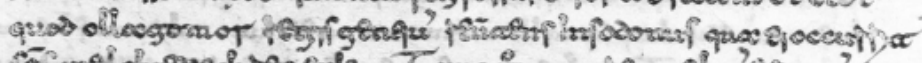

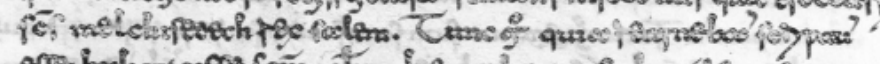

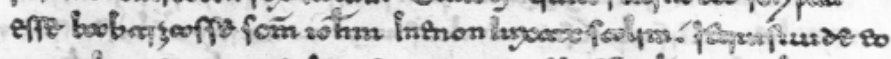

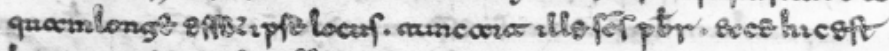

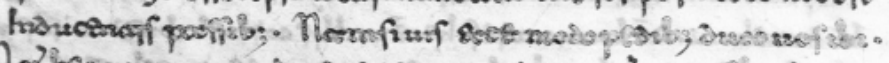

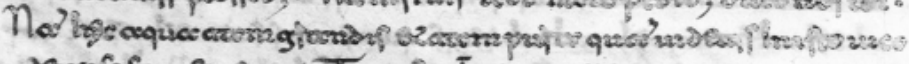

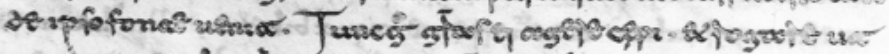

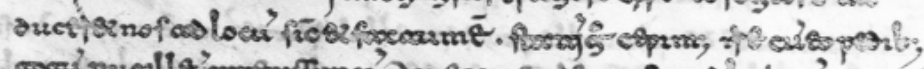

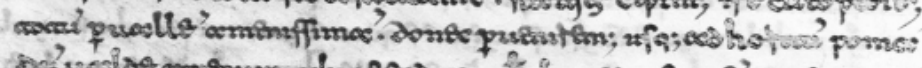

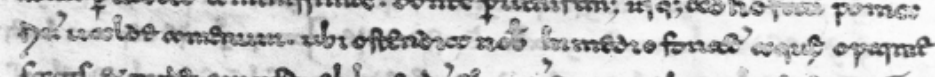

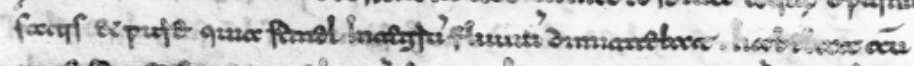

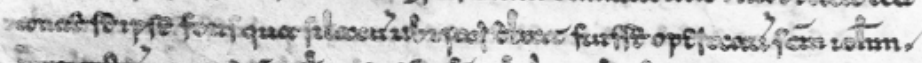
bu piवfor. 


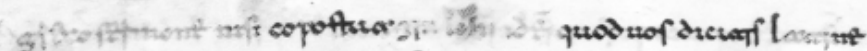

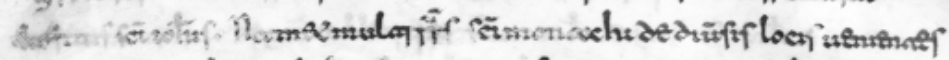

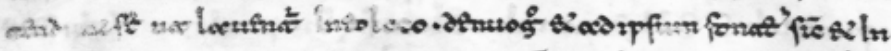

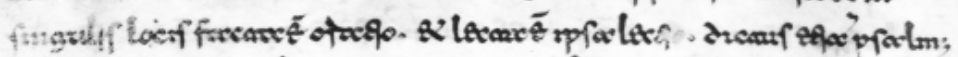

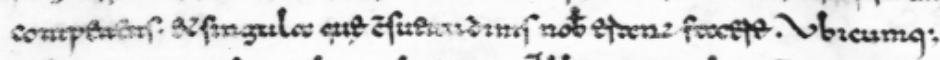

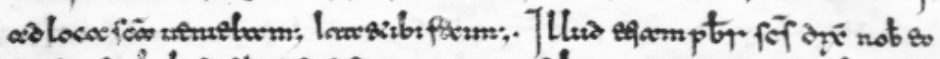

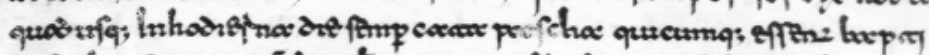

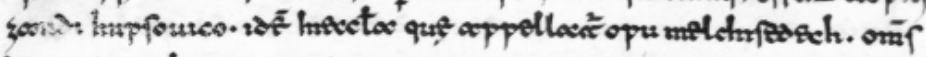

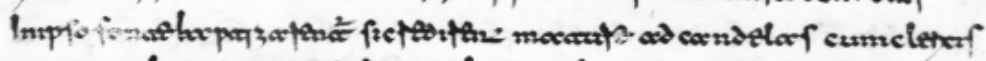

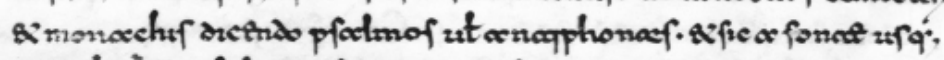

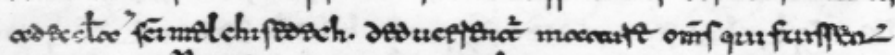

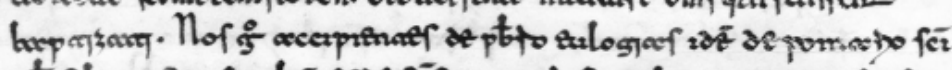

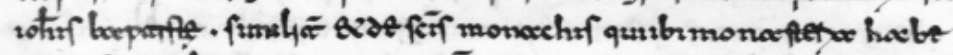

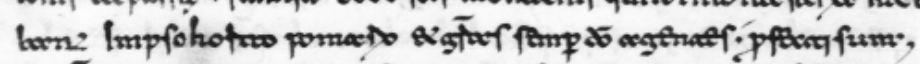

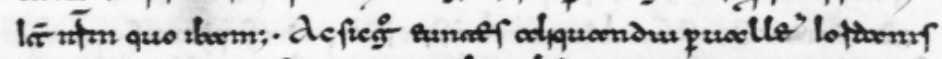

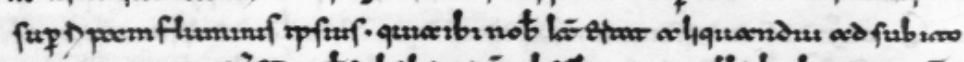

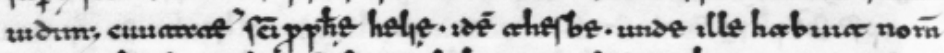

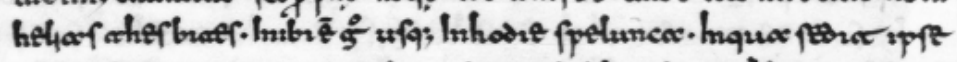

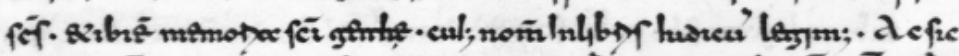

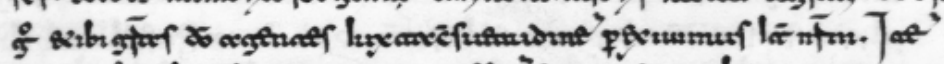

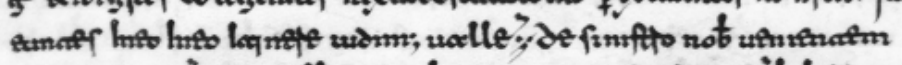

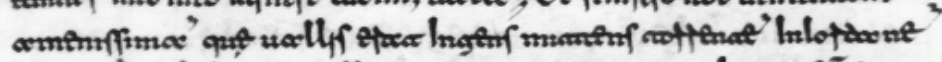

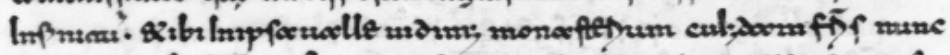

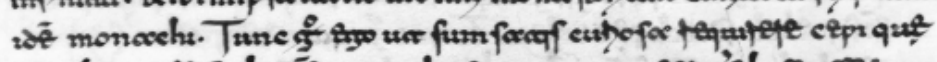

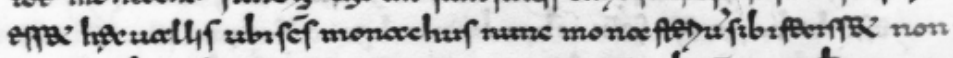

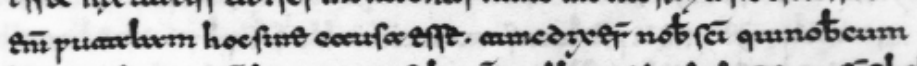

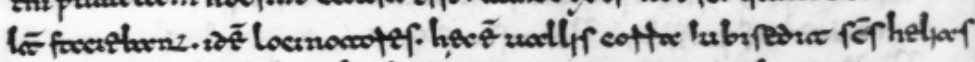

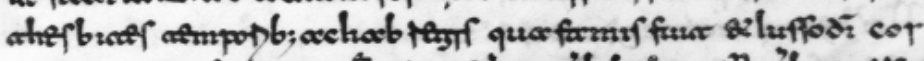

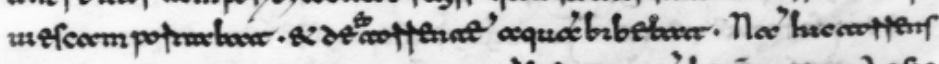

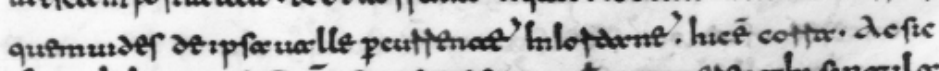

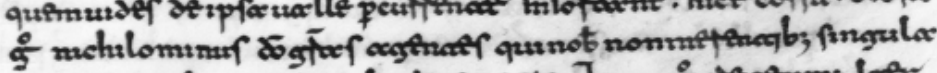

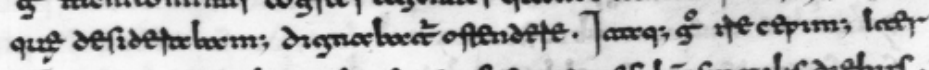

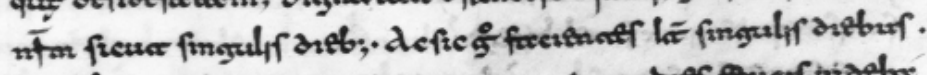

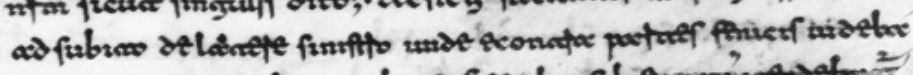

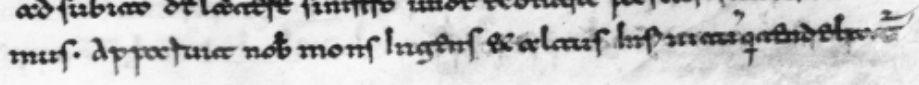




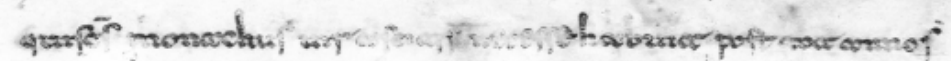

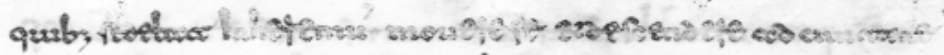

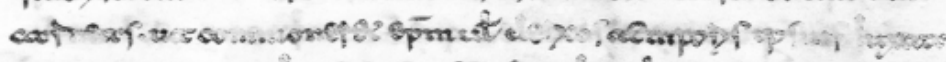

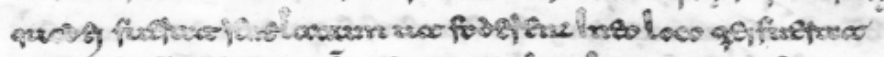

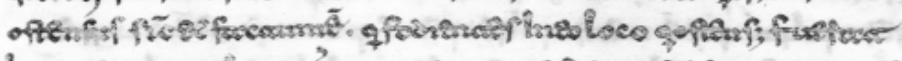

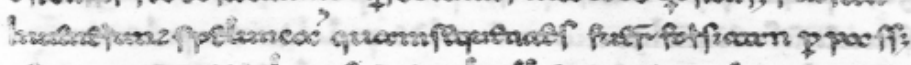

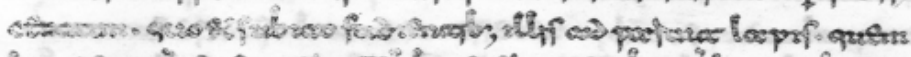

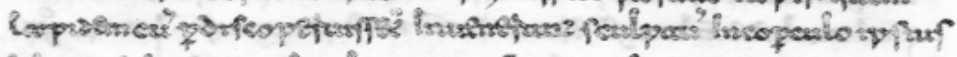

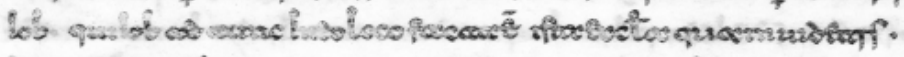

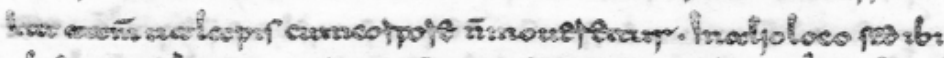

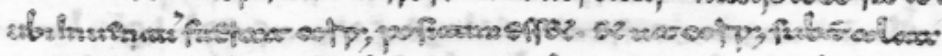

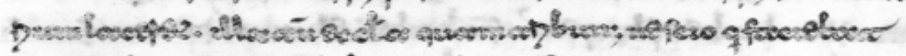

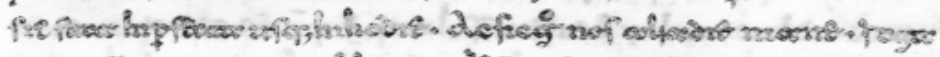

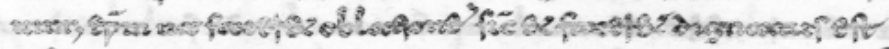
Q3bsh

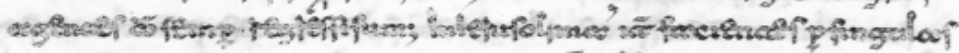

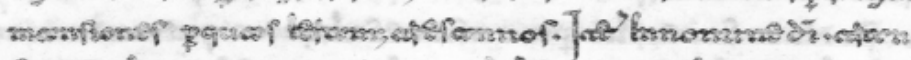

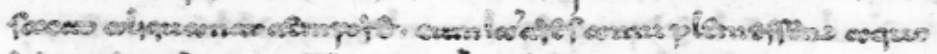

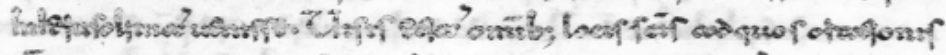

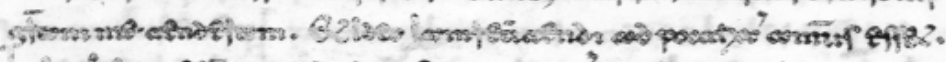

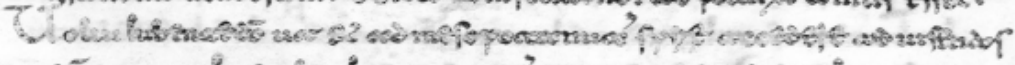

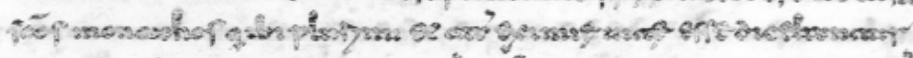

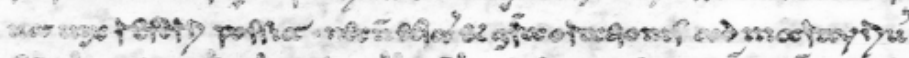

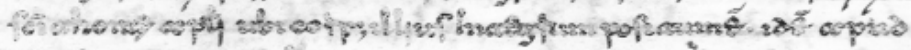

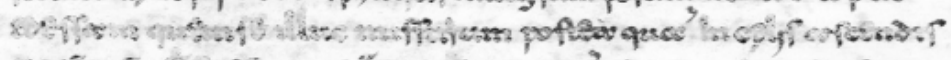

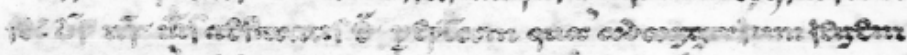

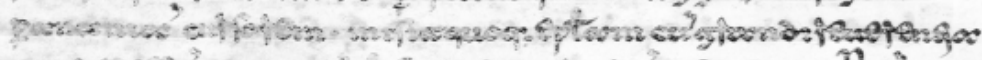

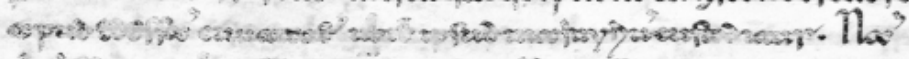

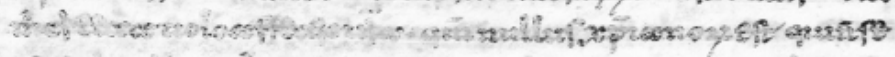

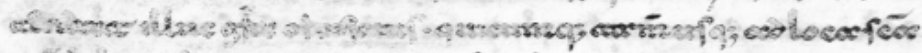

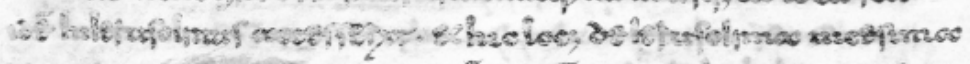

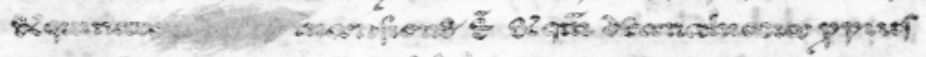

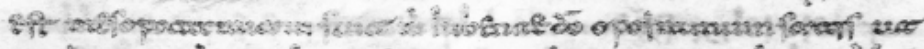

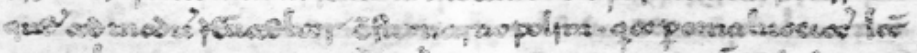

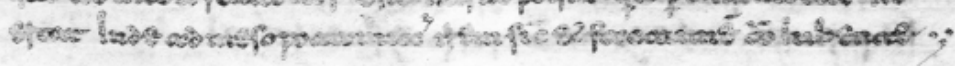




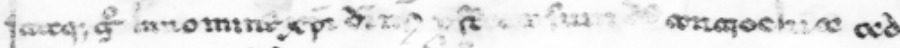

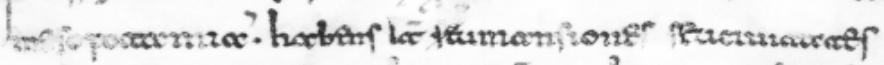

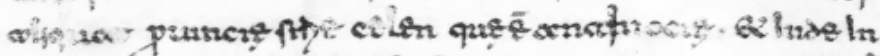

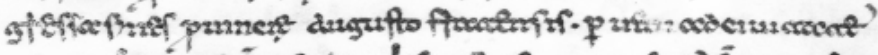

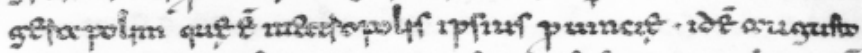

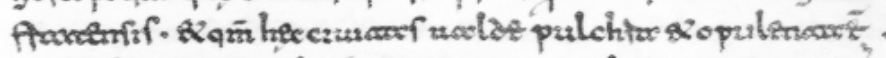

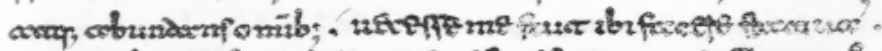

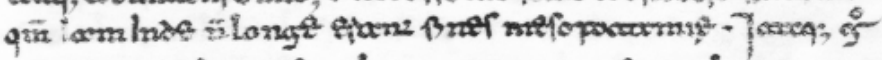

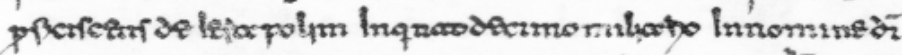

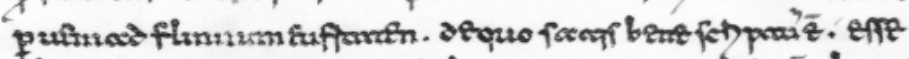

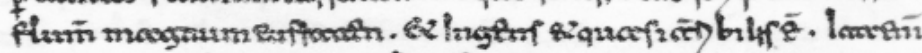

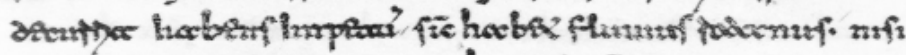

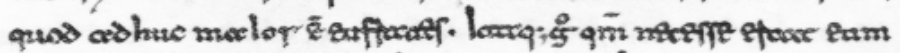

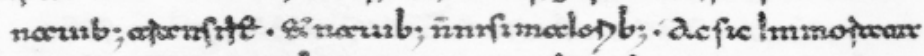

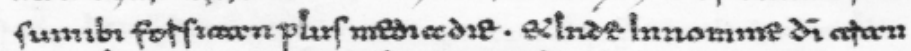
f 200 f flum:

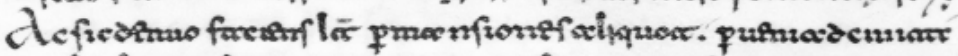

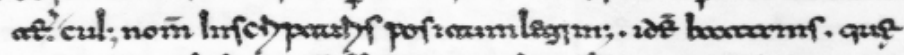

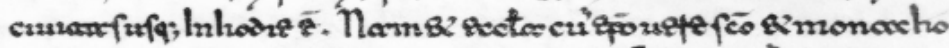

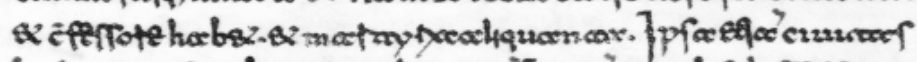

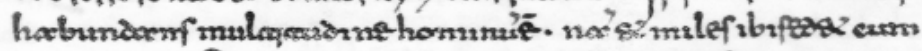

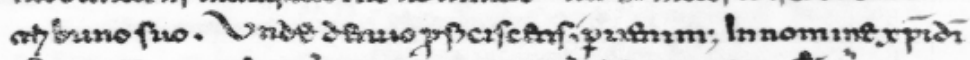

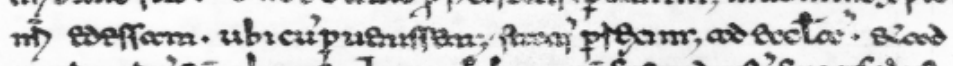

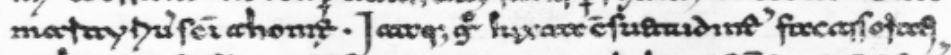

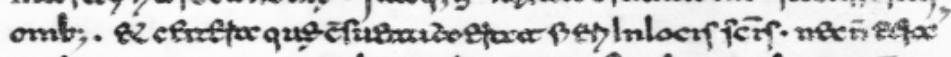

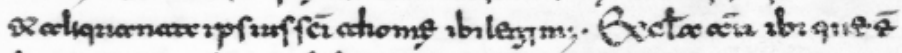

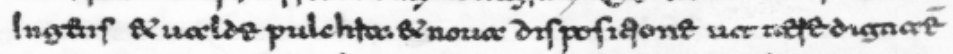

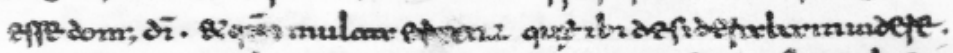

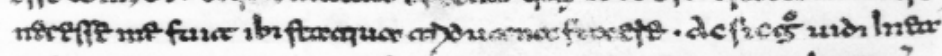

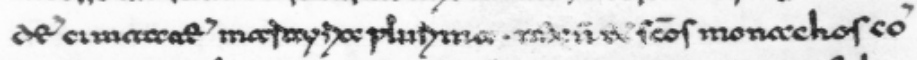

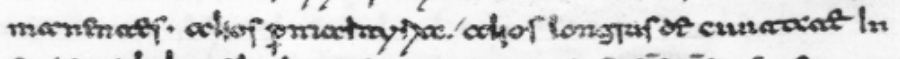

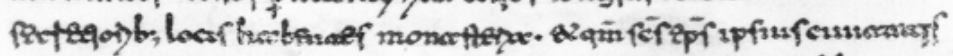

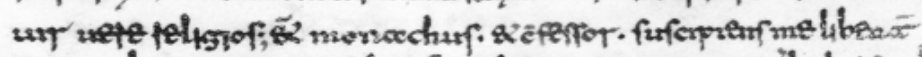

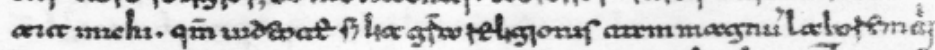

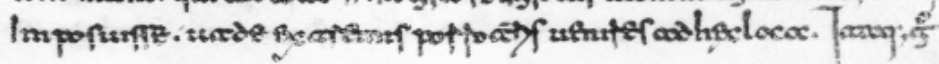




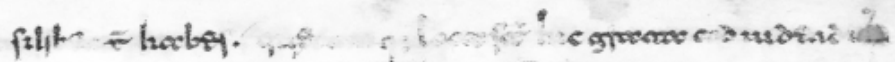

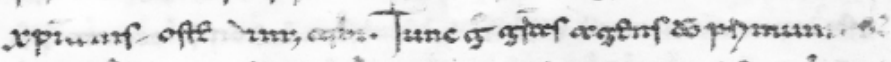

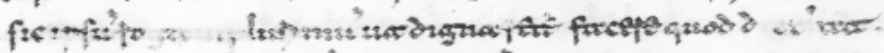

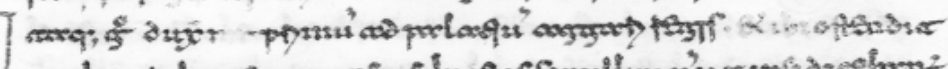
machs atchoodtparm ip ma)

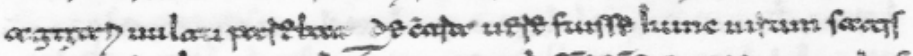

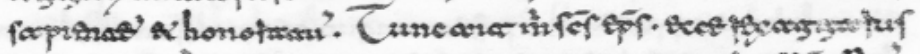

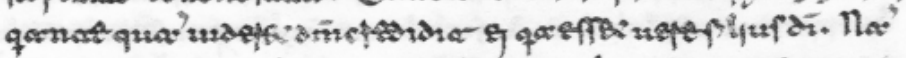

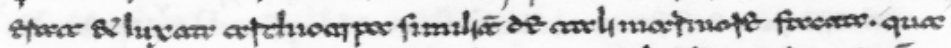

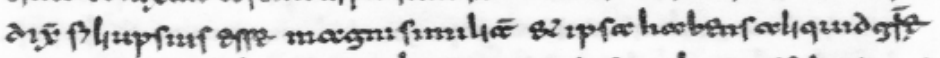

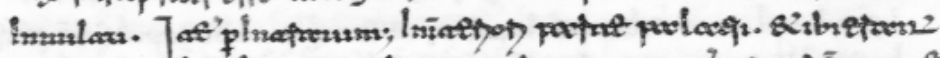

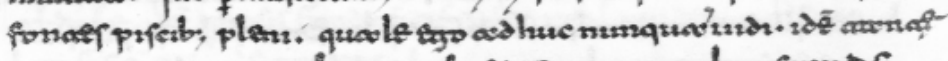

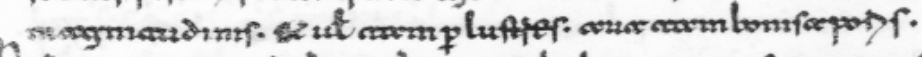

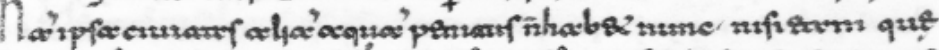

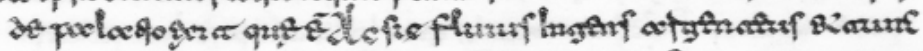

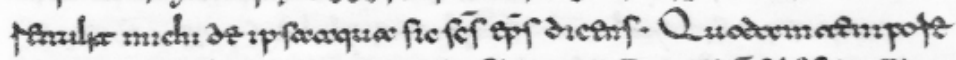

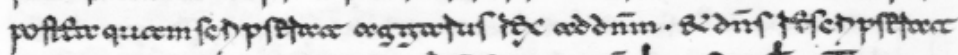

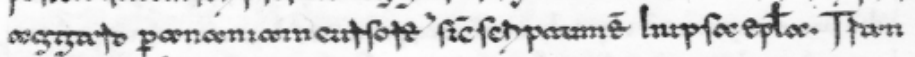

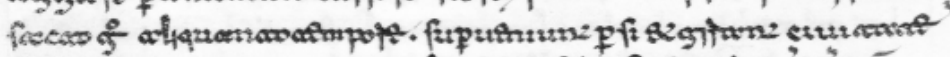
Tी

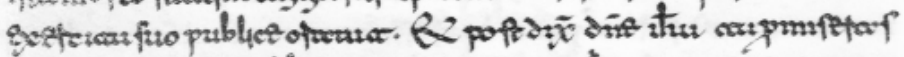

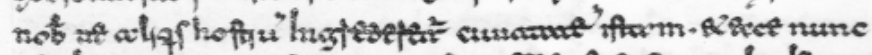

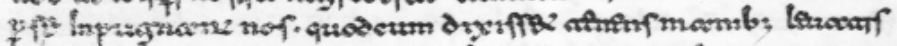
Pिi.

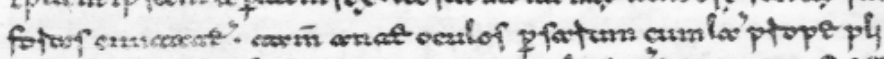

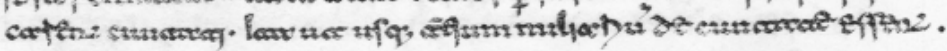

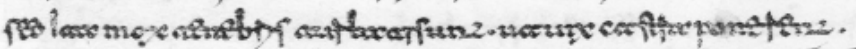

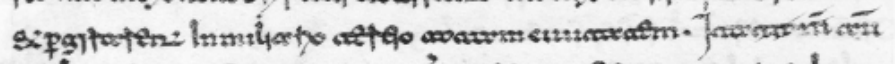

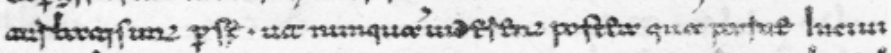

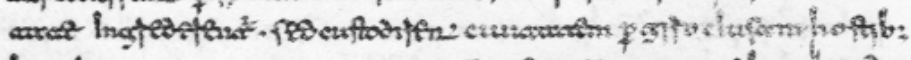

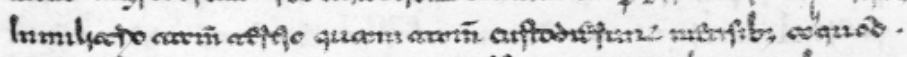

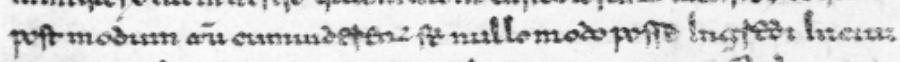

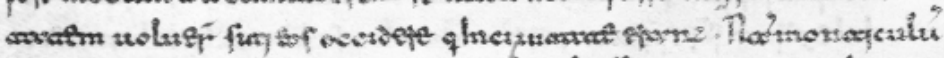

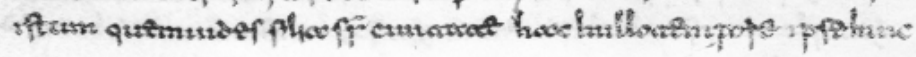


As

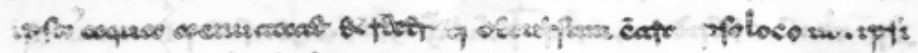

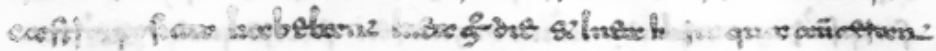

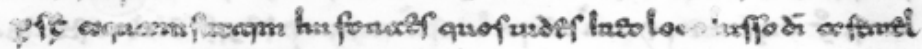

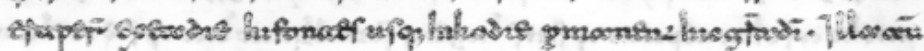

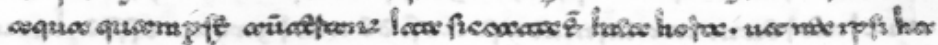

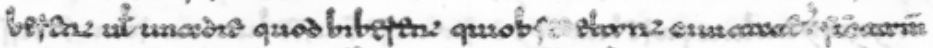

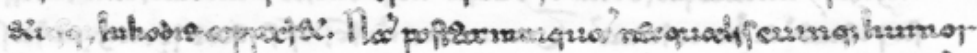

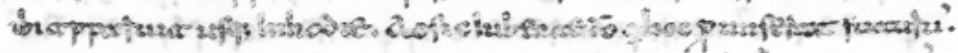

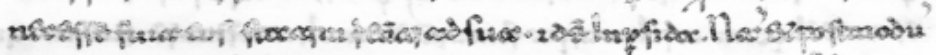

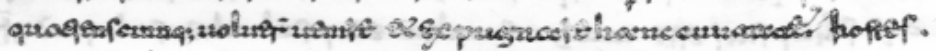

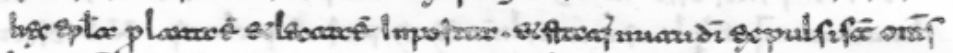

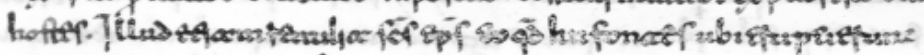

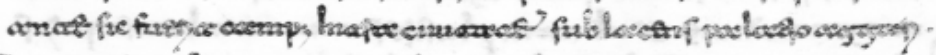

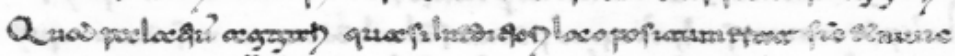

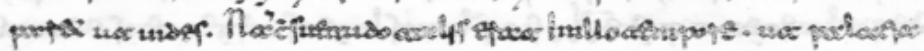

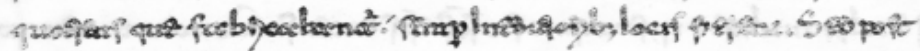

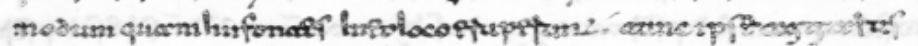

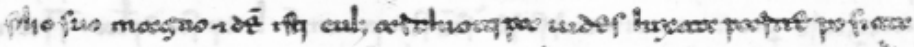

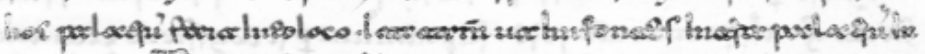

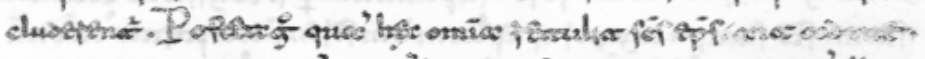

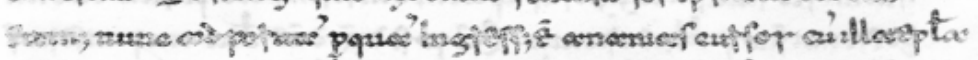

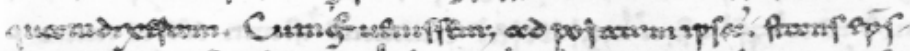

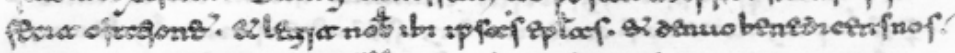

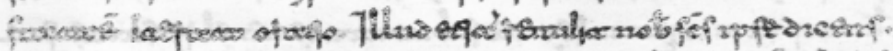

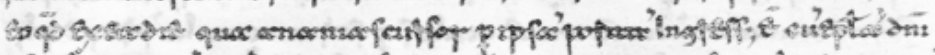

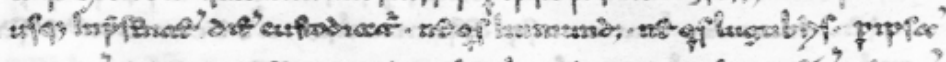

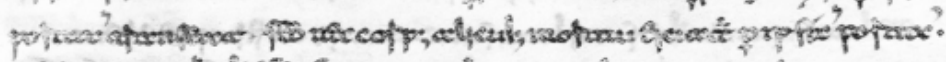

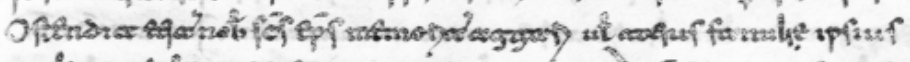

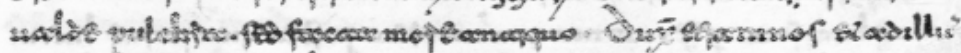

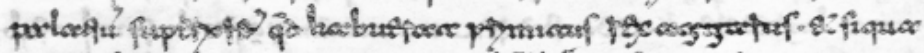

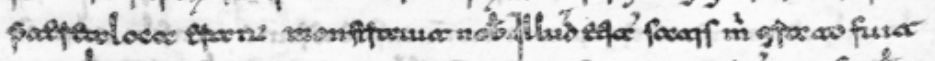

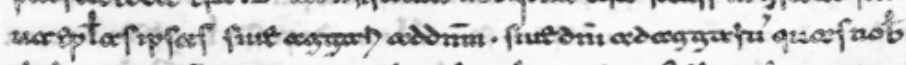

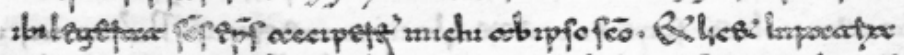

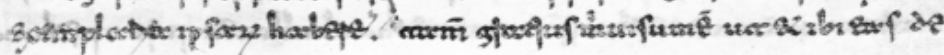




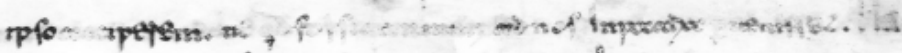

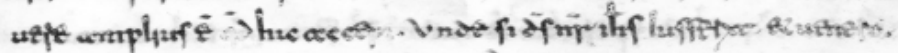

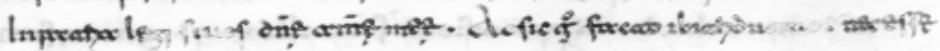

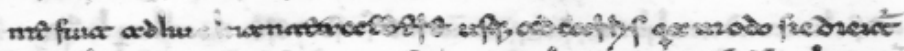

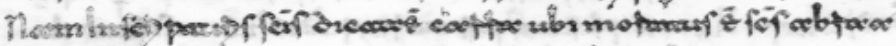

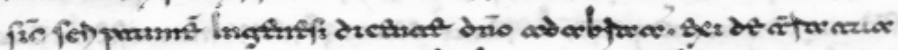

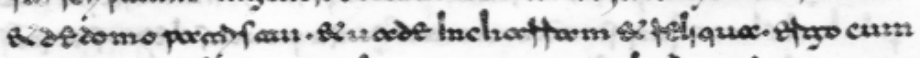

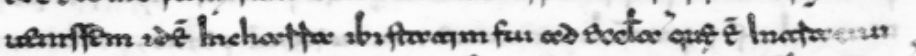

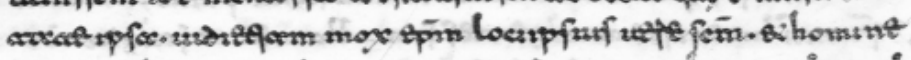

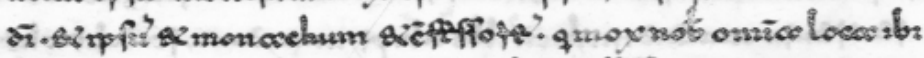

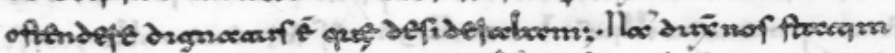

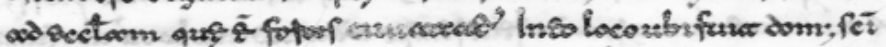

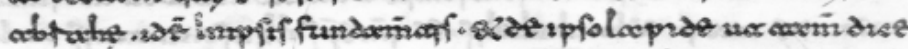

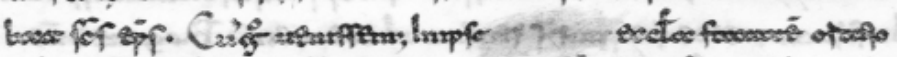

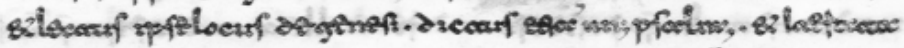

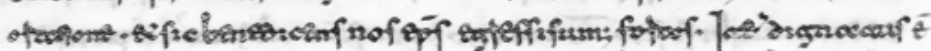

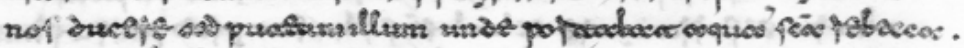

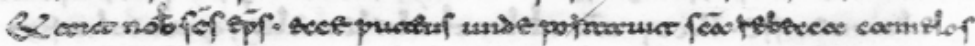

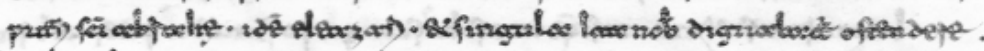

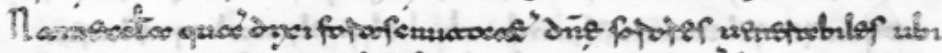

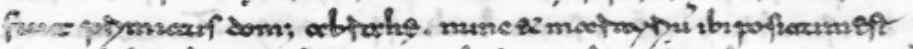

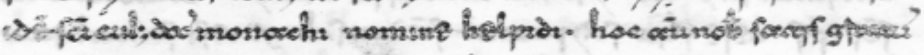

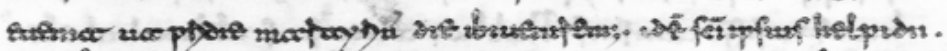

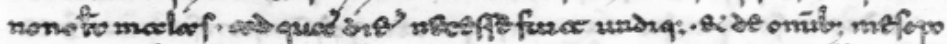

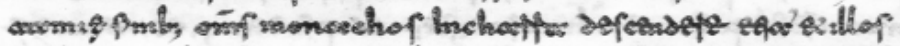

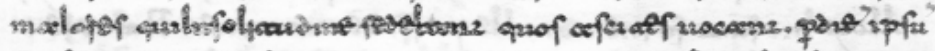

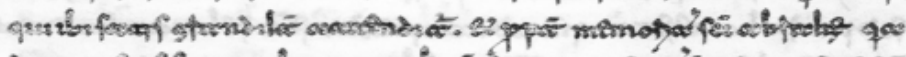
bom: rp

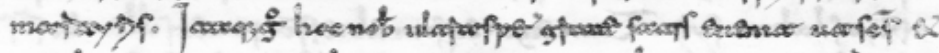

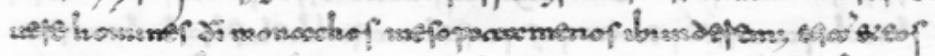

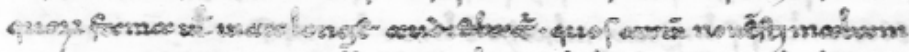

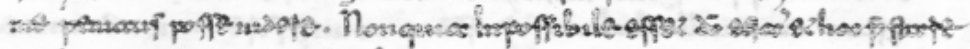

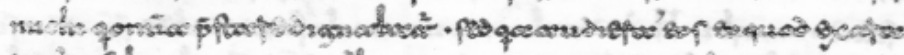

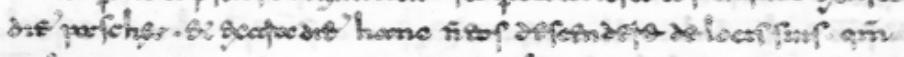

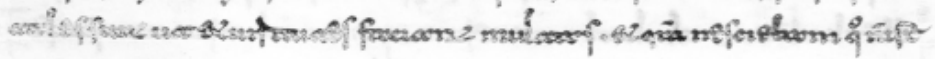




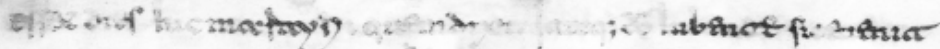

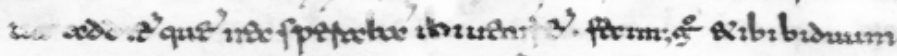

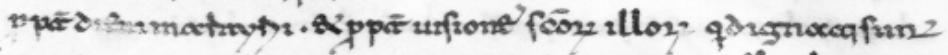

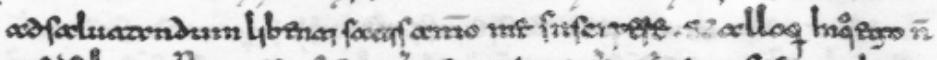

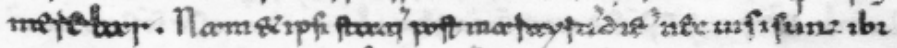

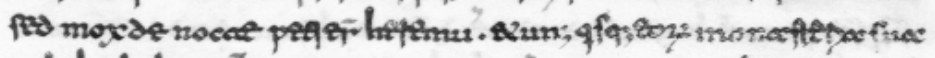

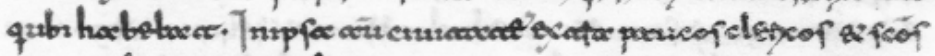

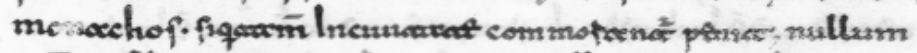

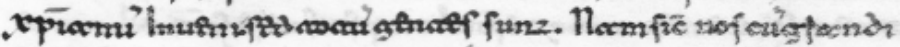

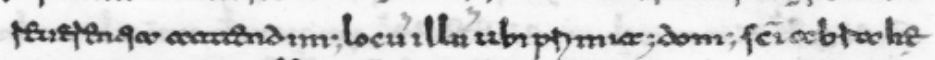

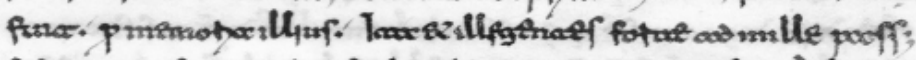

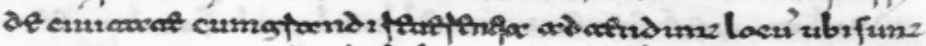

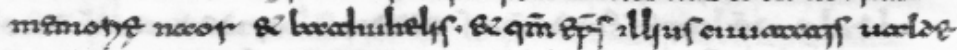

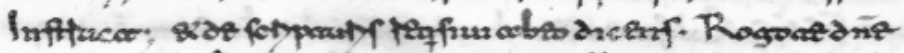

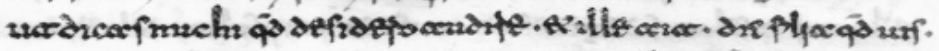

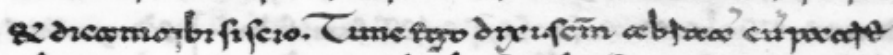

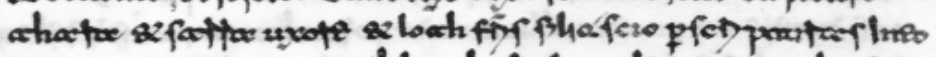

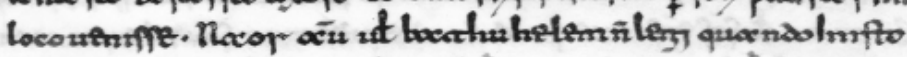

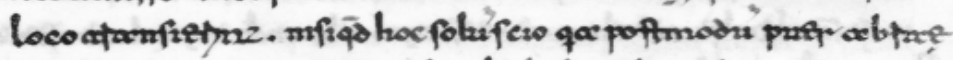

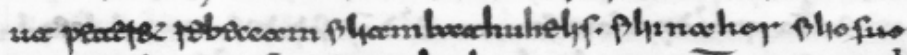

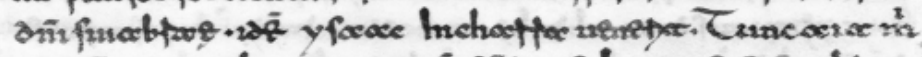

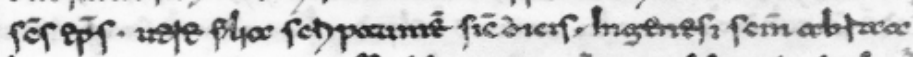

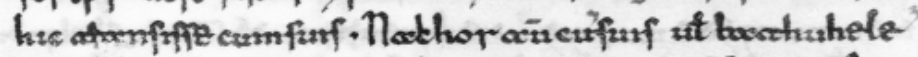

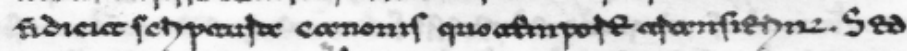

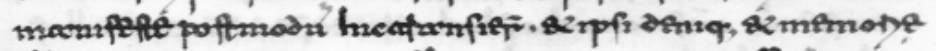

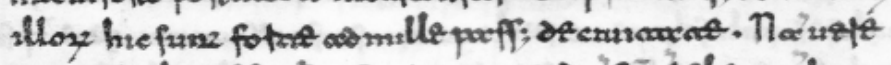

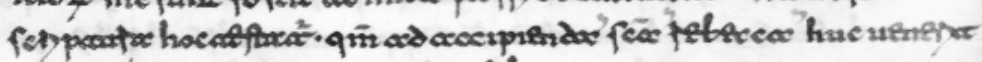

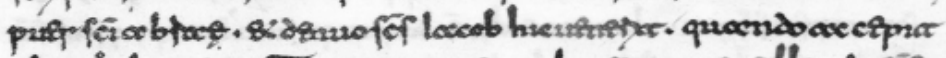
plyor lotom fy

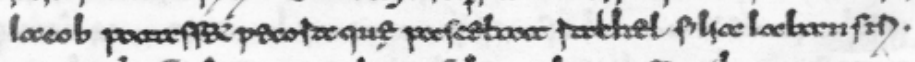

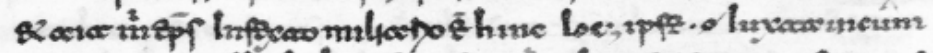

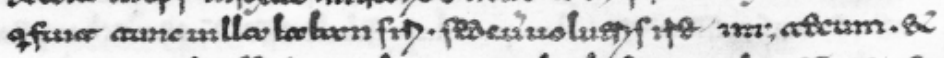

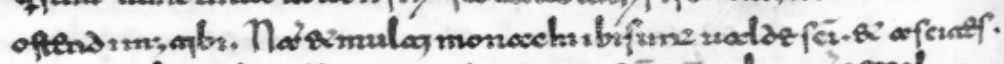

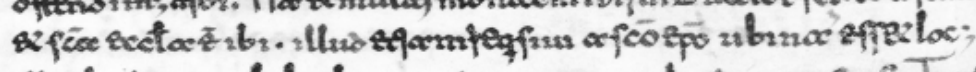

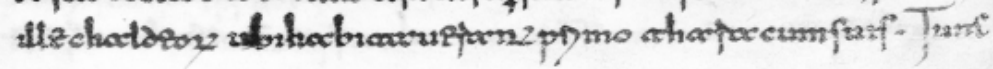




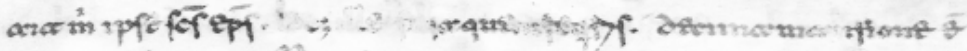

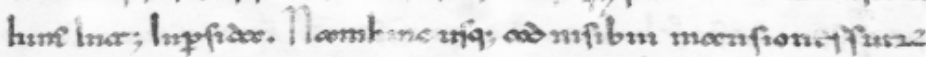

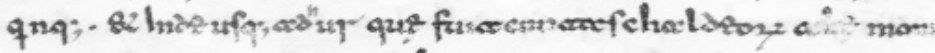

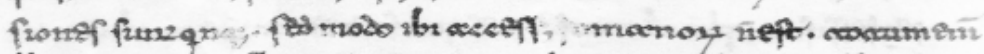

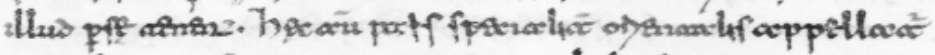
quक्ष

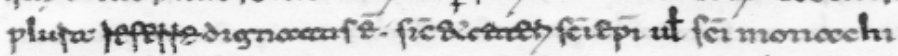

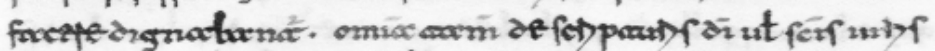

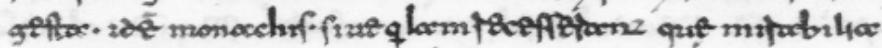

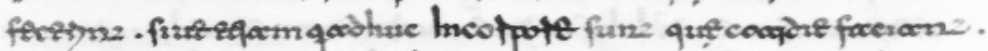

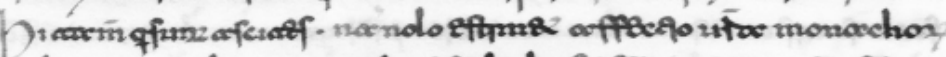

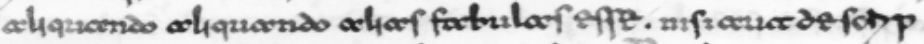

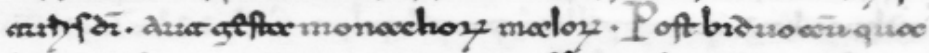

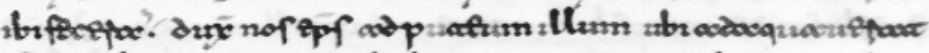

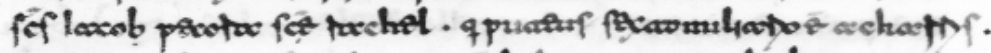

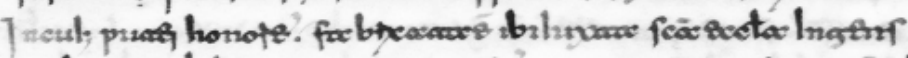

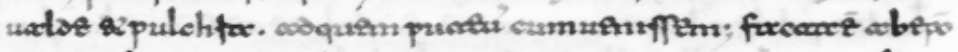

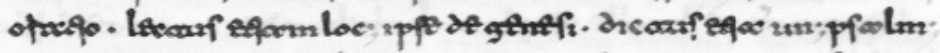

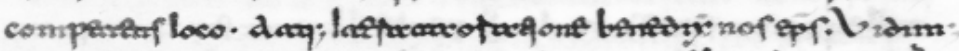

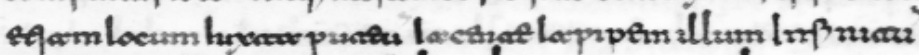

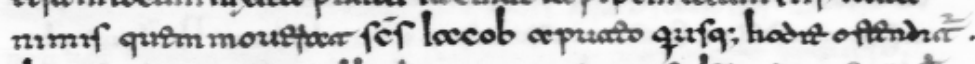

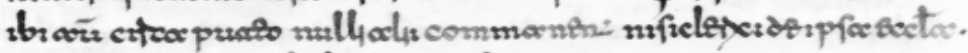

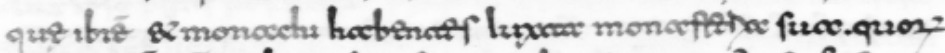

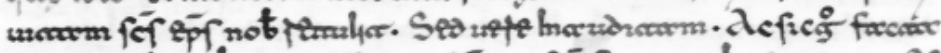

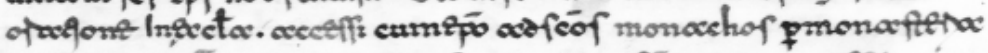

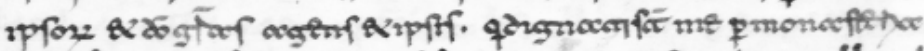

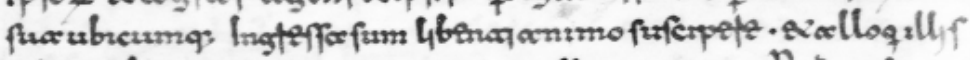

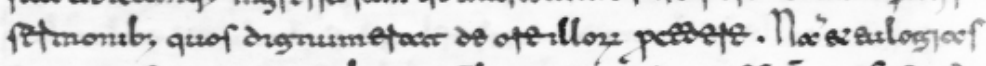

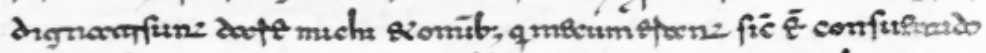

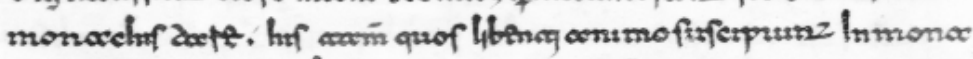

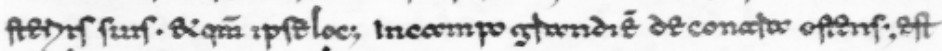

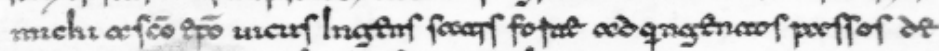

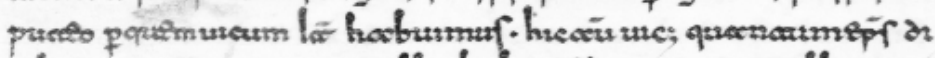

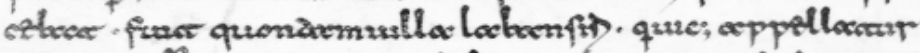

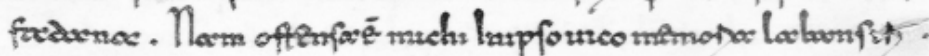




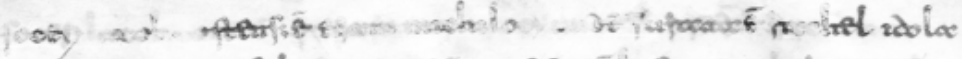

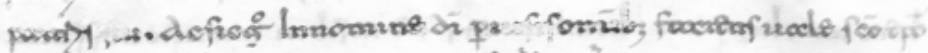

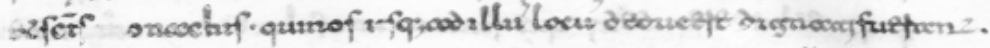

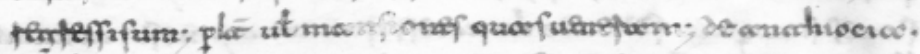

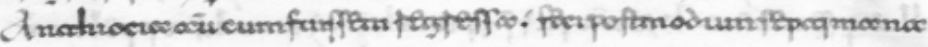

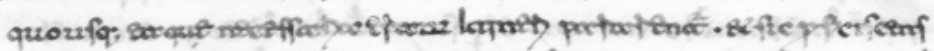

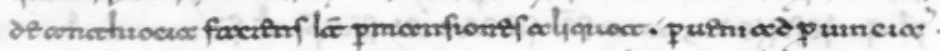

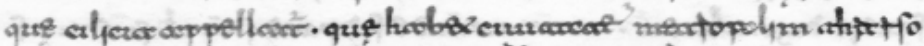

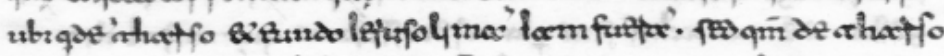

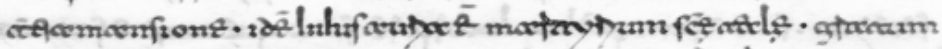

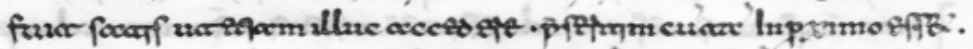

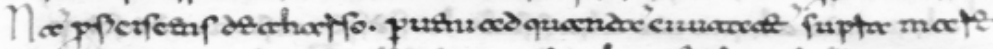

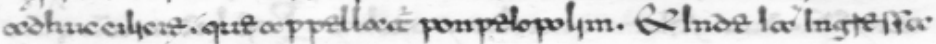

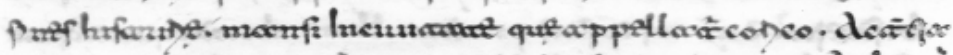

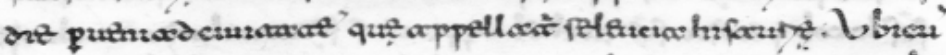
pritriffe? funcom

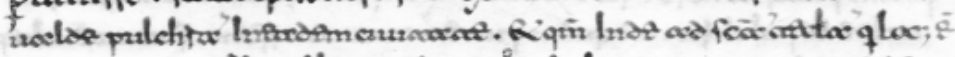

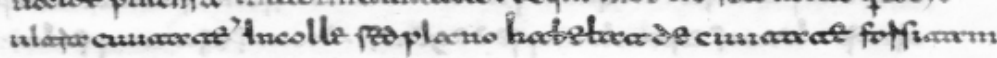

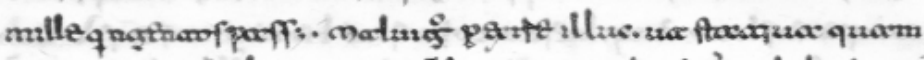

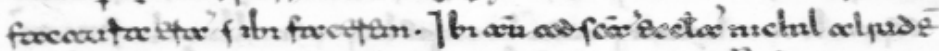

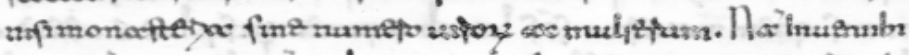

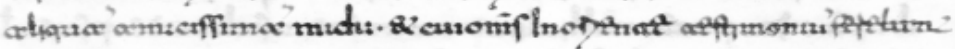

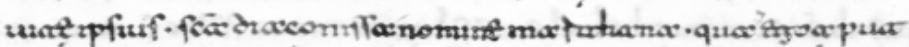

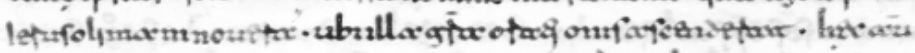

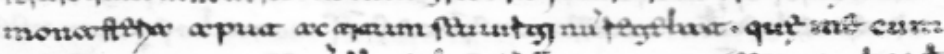
zodp

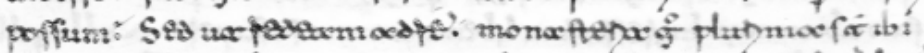

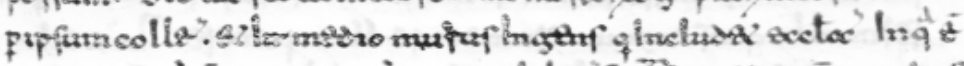

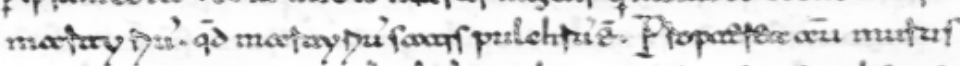

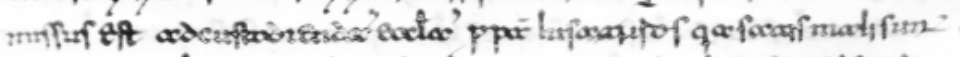

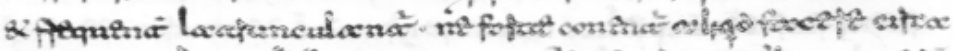

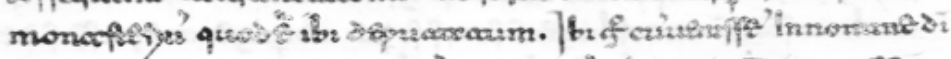
fecese of

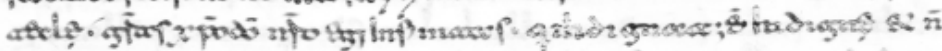

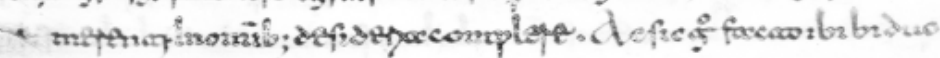




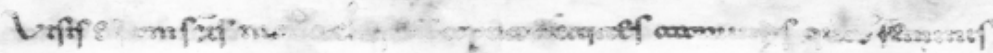

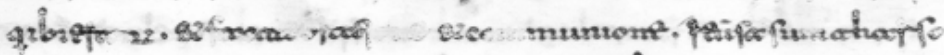

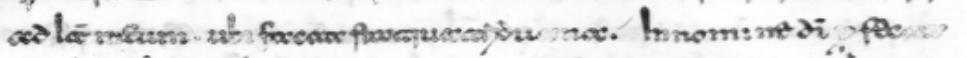

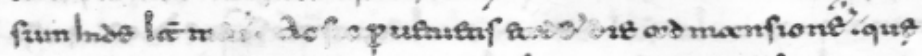

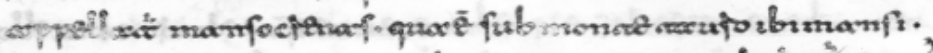

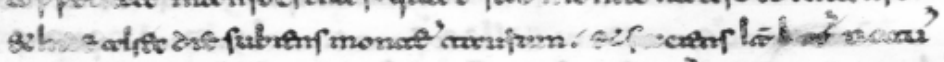

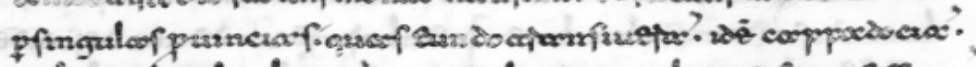

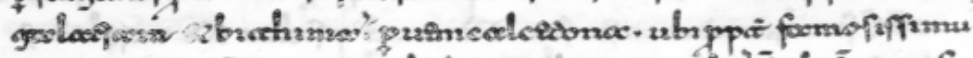

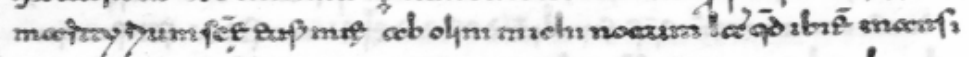

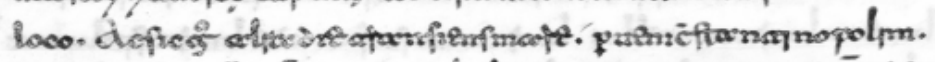

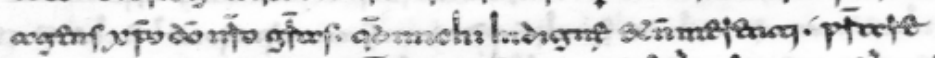

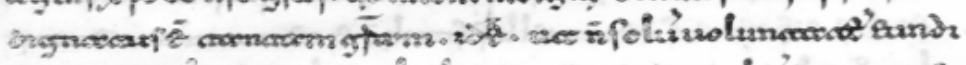

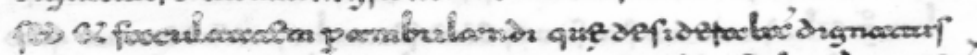

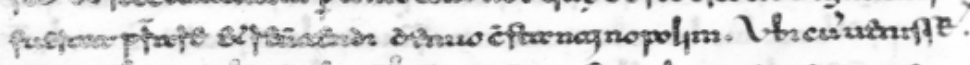

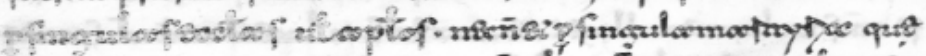

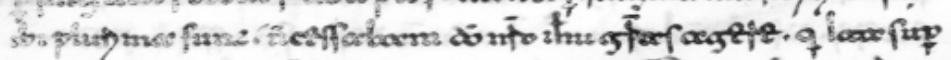

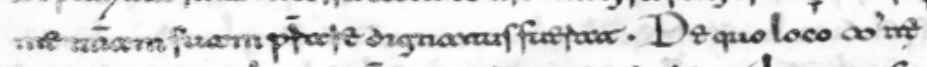

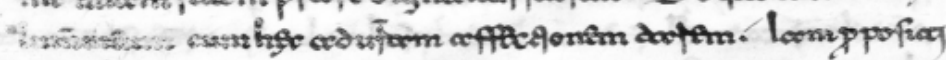

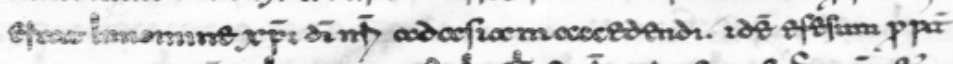

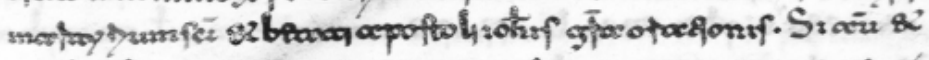

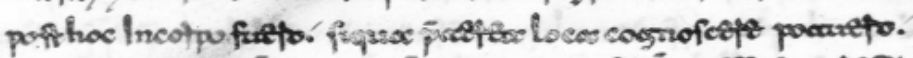

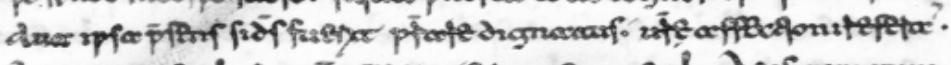

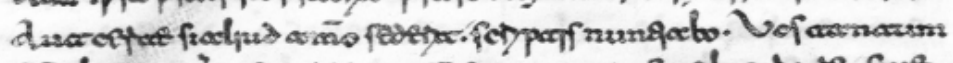

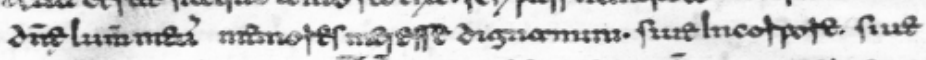

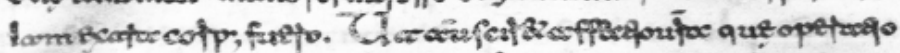

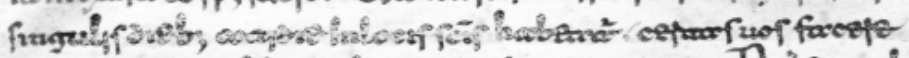

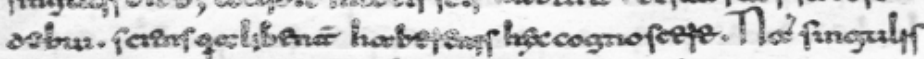

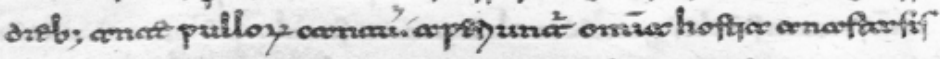

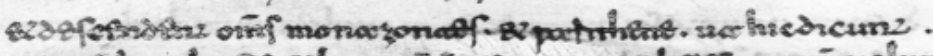

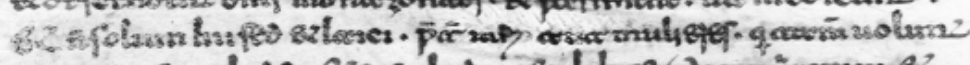

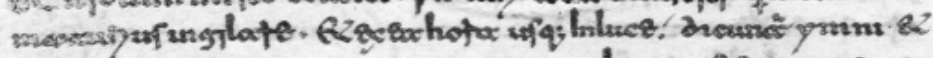

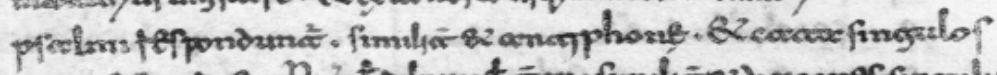

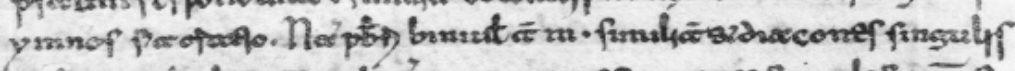

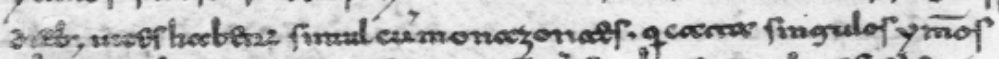

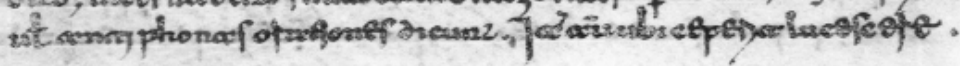




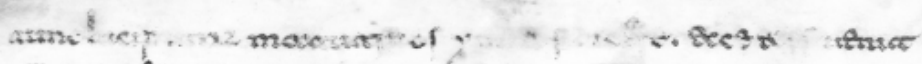

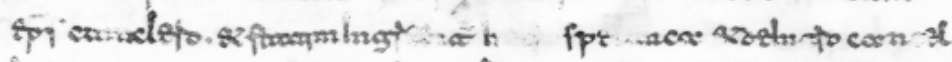

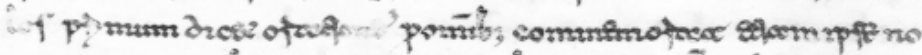

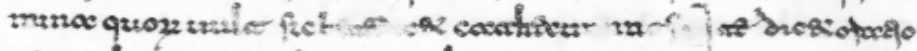

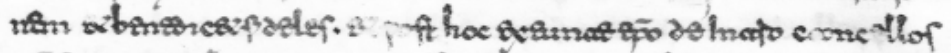

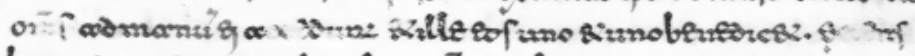

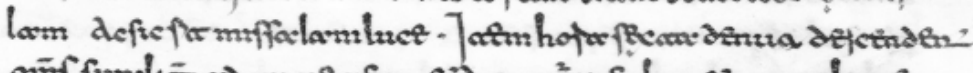

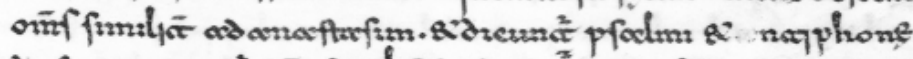

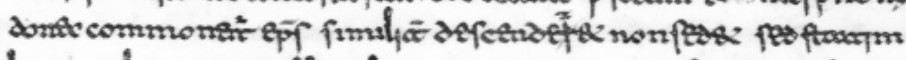

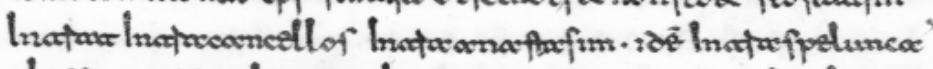

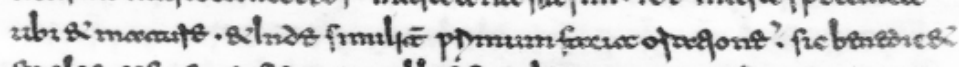

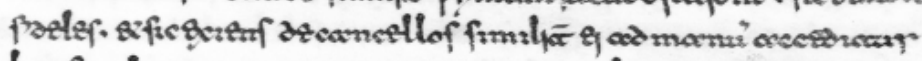

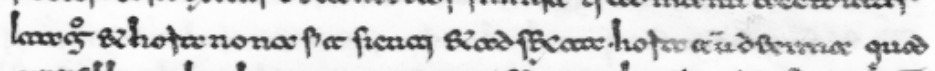

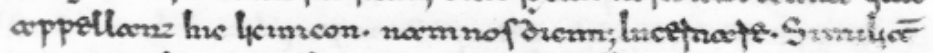

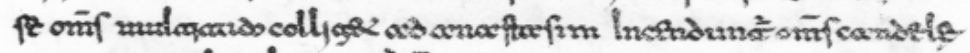

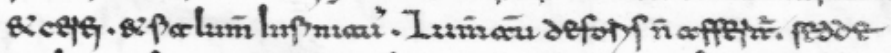

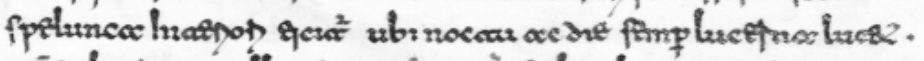

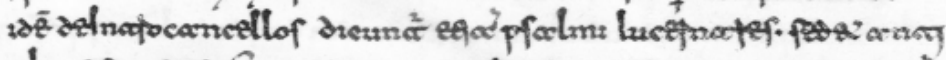

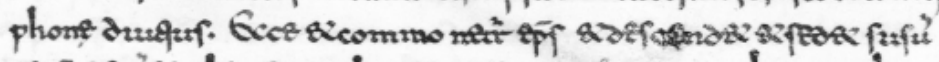

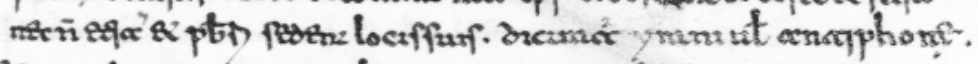

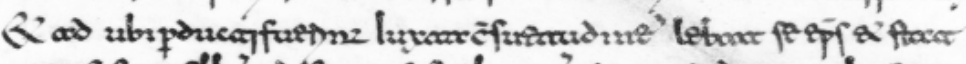

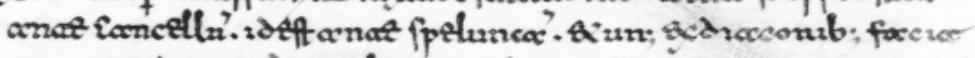

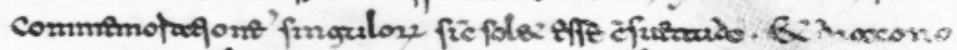

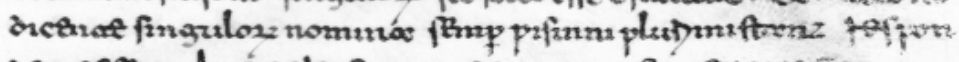

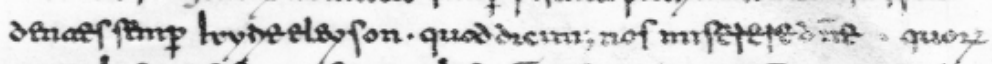

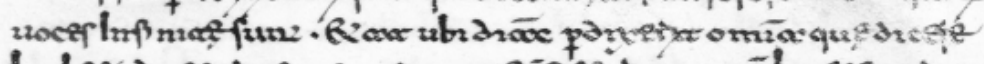

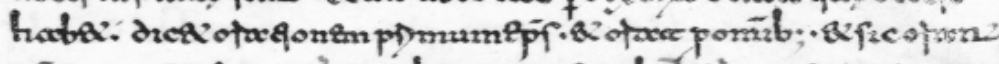
oxin

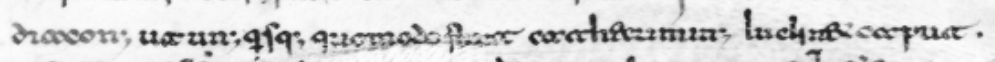

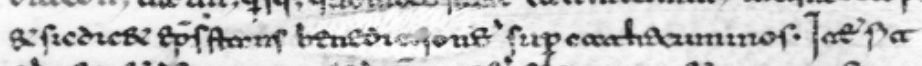

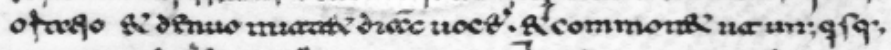

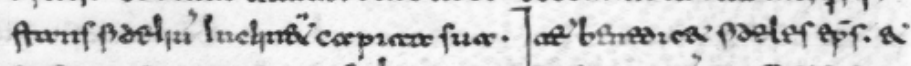

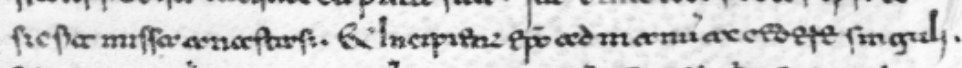

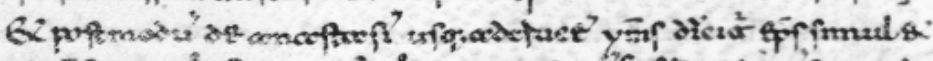

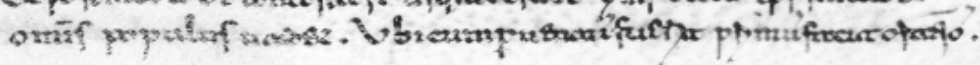
- 
d

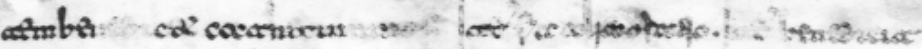

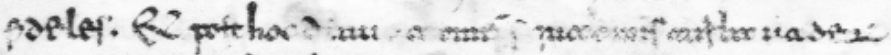

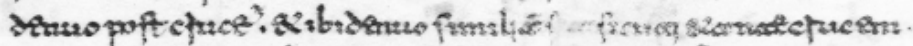
Q 1 irmli

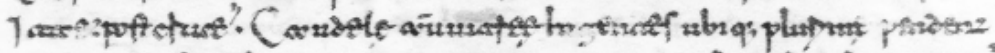

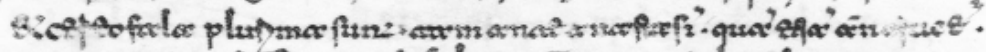

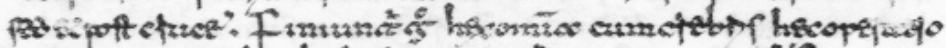

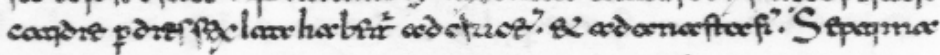

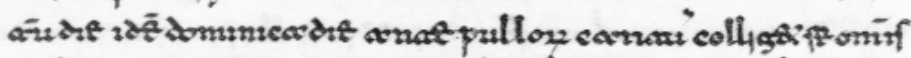

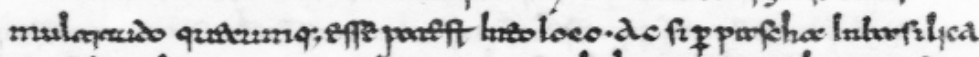

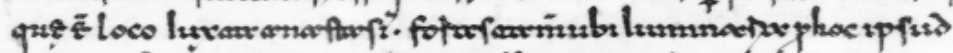

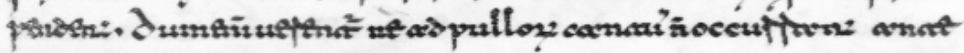

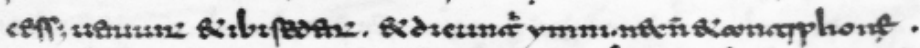

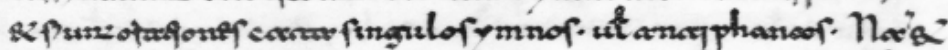

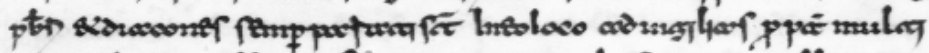

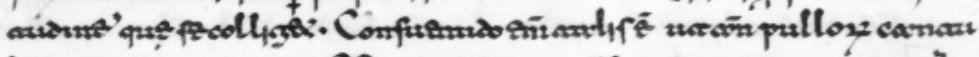

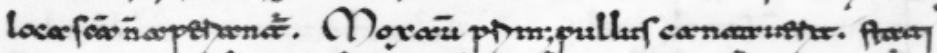

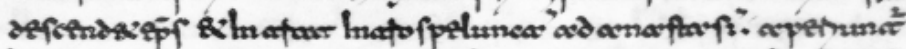

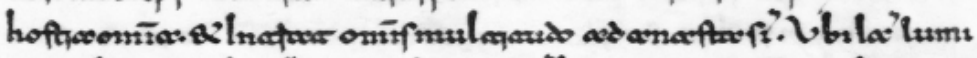

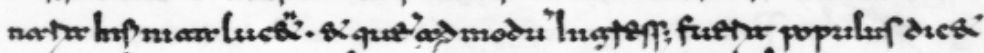

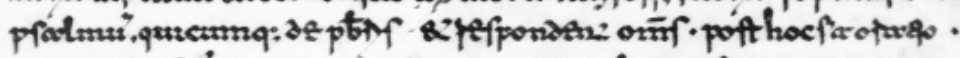

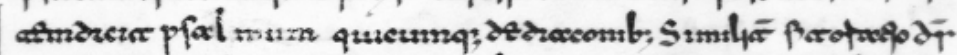
Q

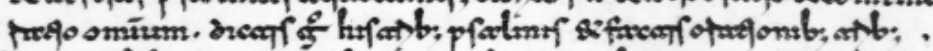

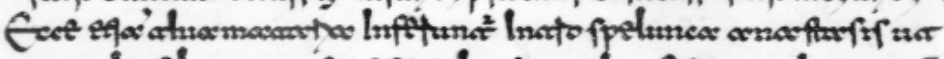

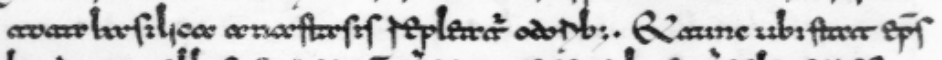

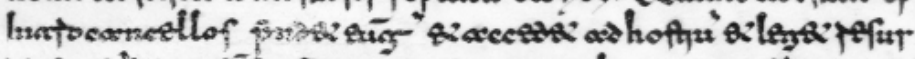

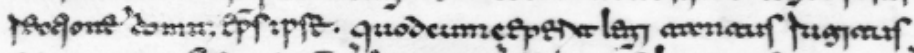

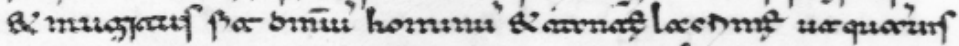

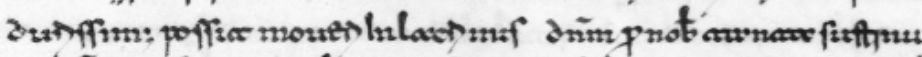

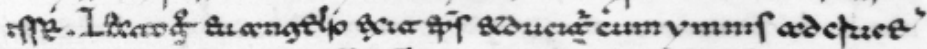

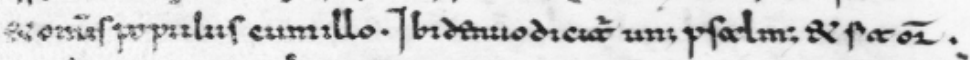

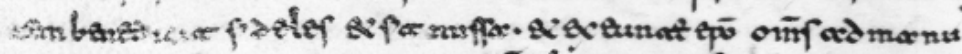

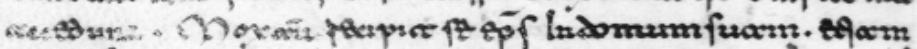

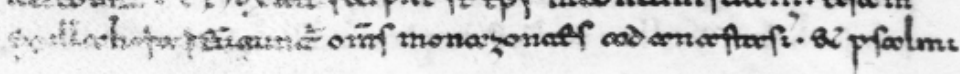




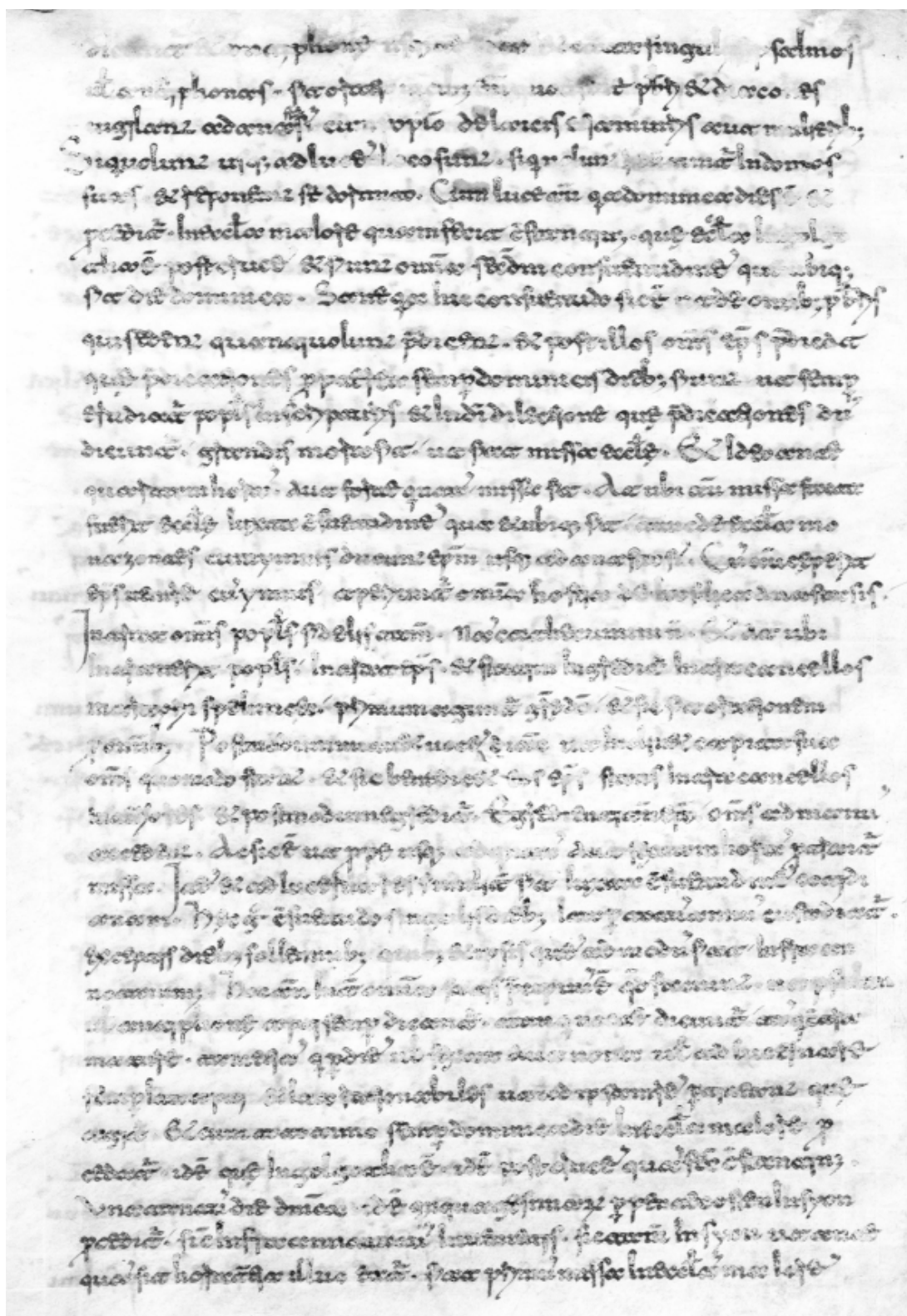




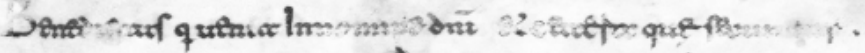
Q2nin ymonazon of of

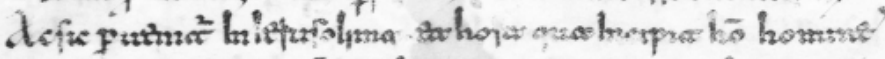

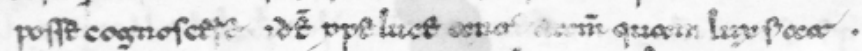

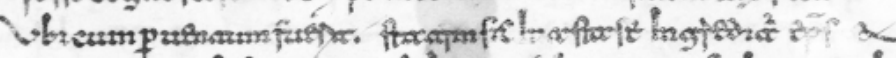

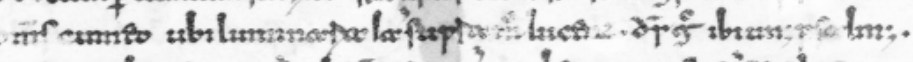

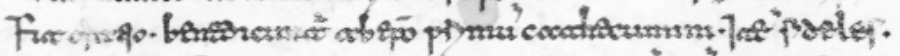
pसrprafof

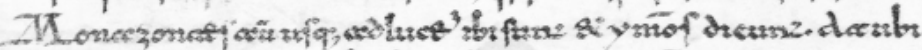

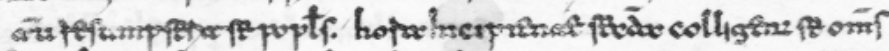

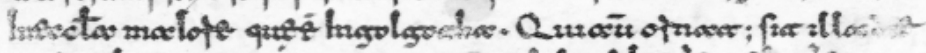

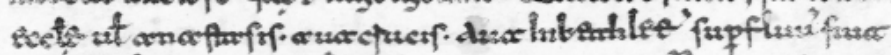

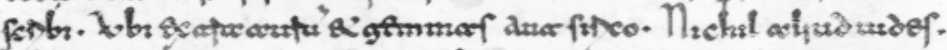

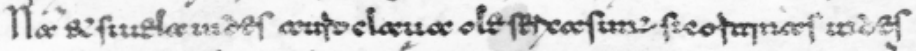

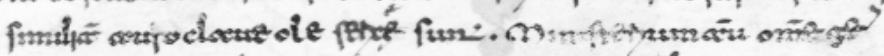

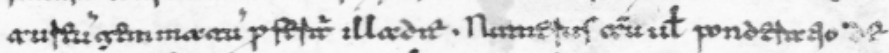

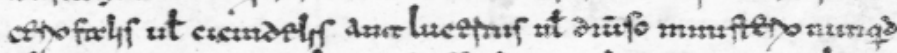

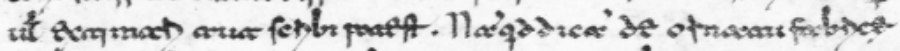

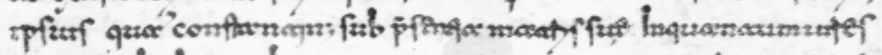

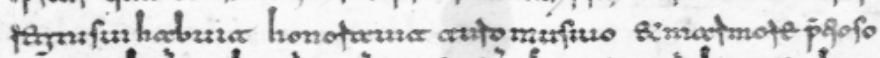

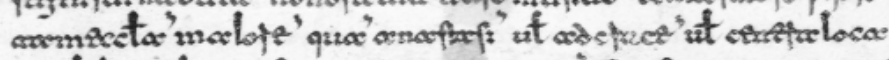
fex Inlefufol

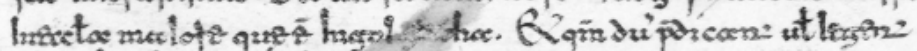

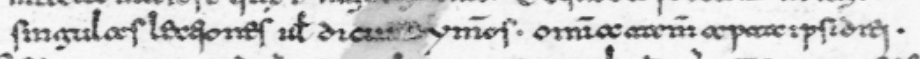

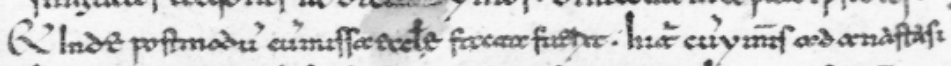

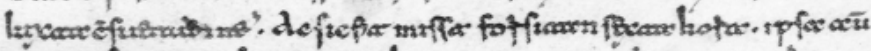

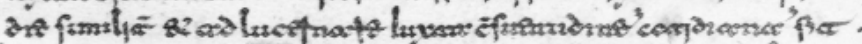

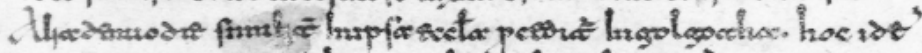

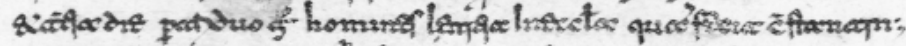

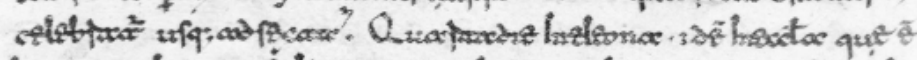

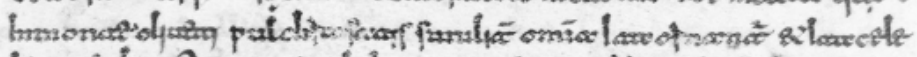

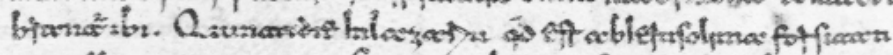

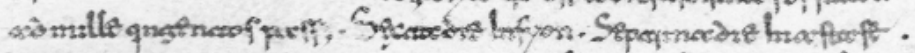

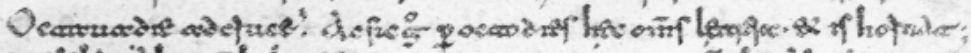

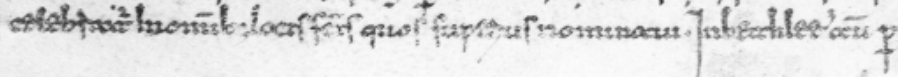




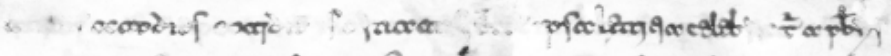

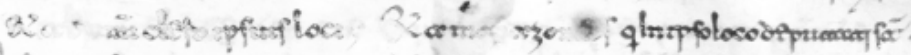

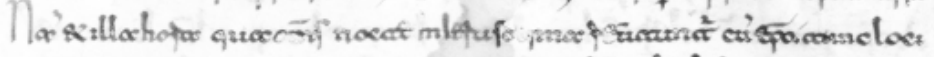

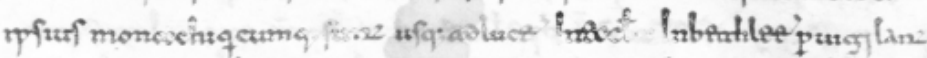

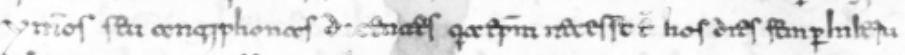

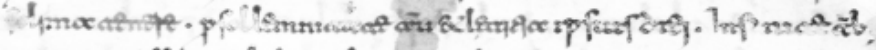

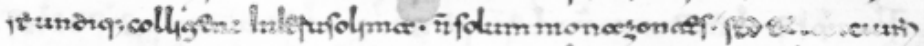

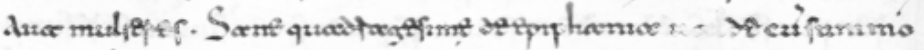

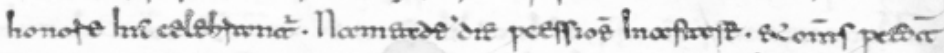

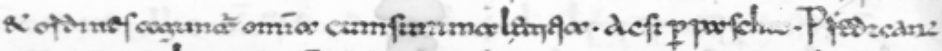

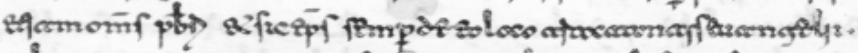

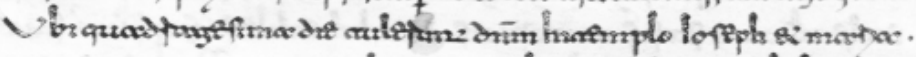

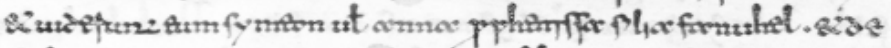

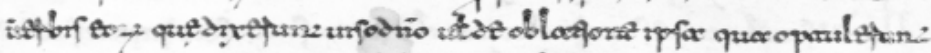

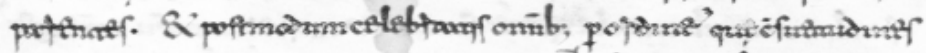

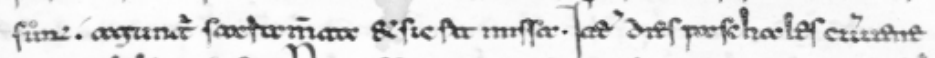

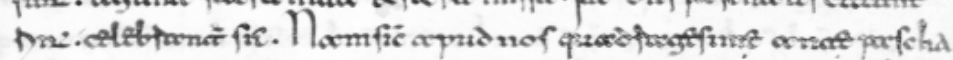

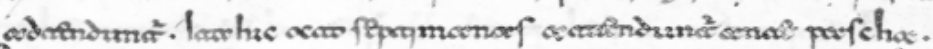

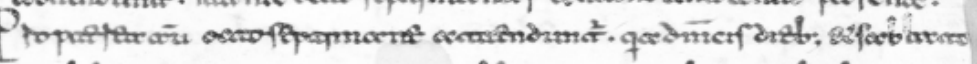

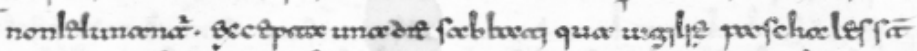

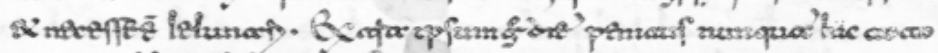

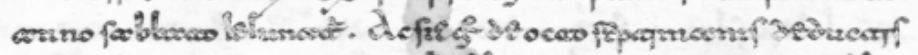

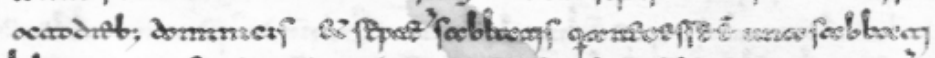

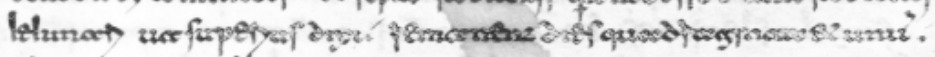

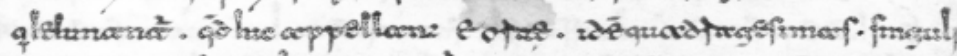

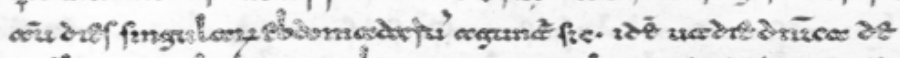

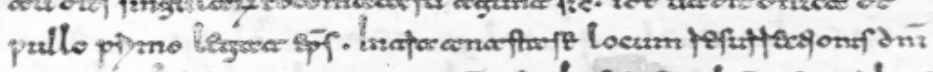
के sur

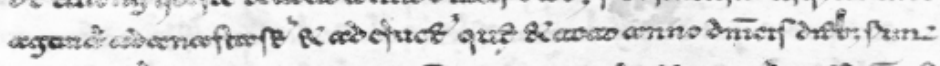

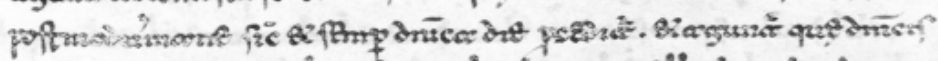

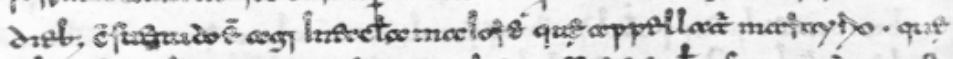

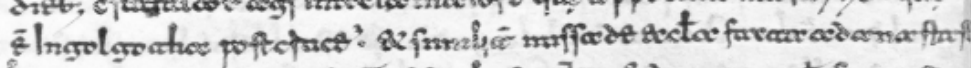

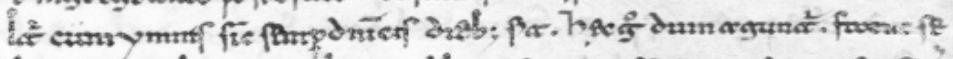

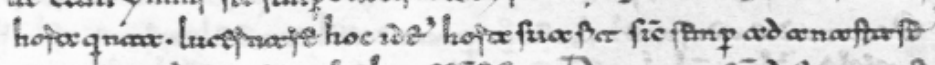

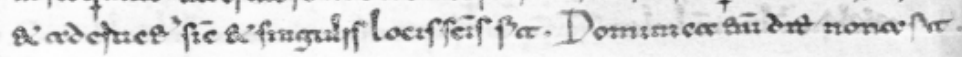




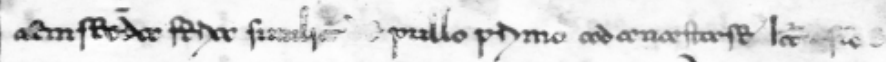

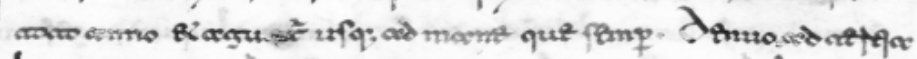

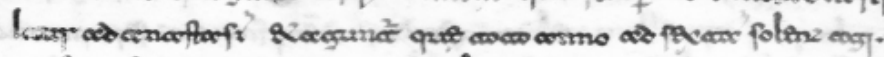

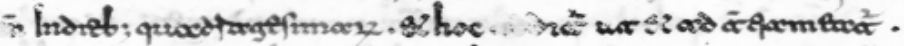

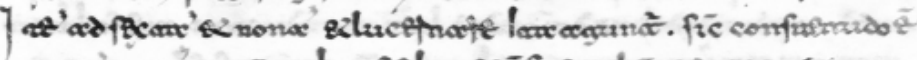

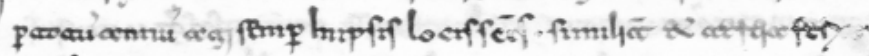

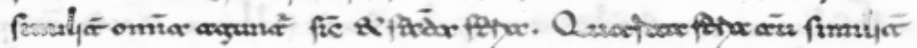

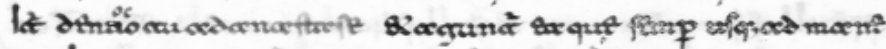
frmlर

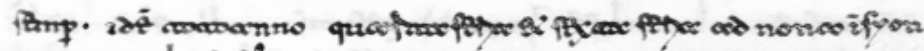

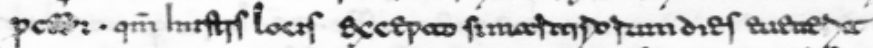

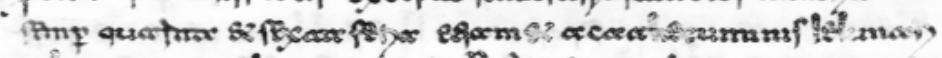

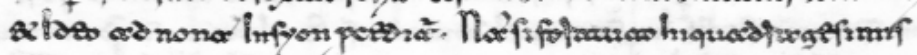

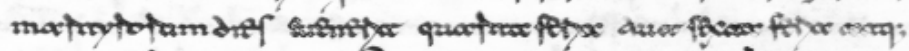

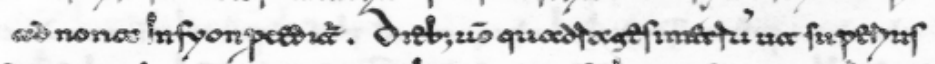

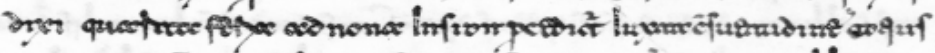

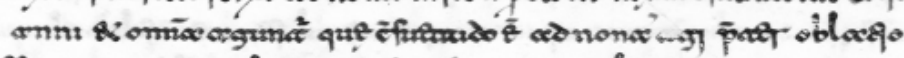

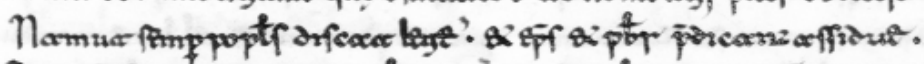

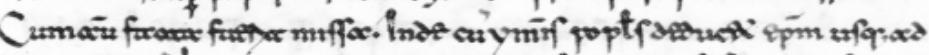

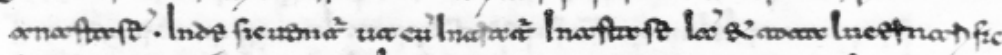

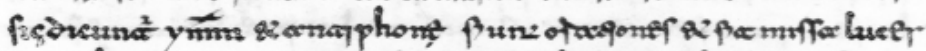

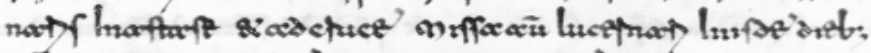

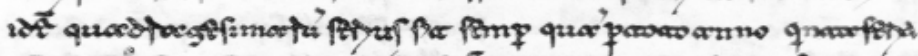

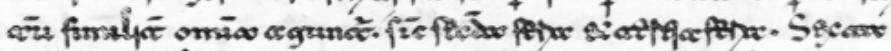

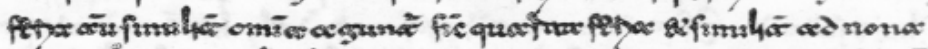

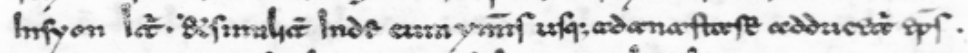

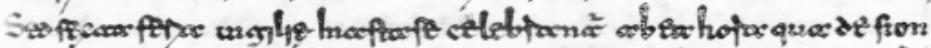

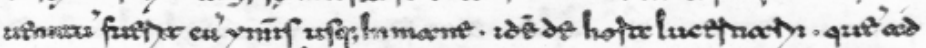

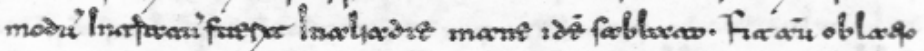

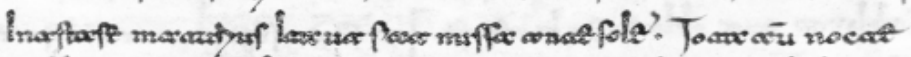

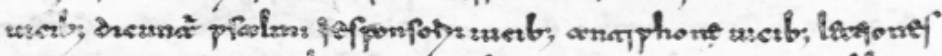

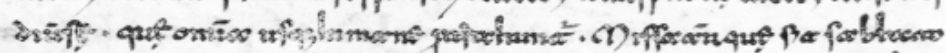

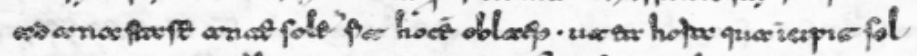

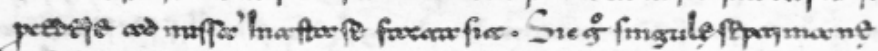

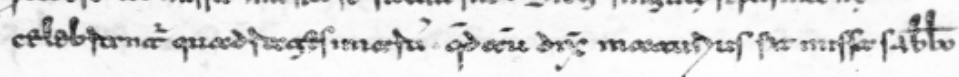




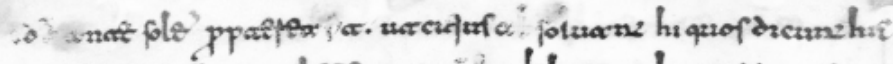

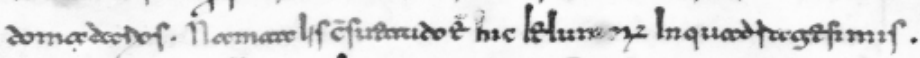

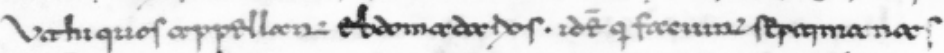

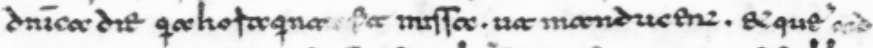

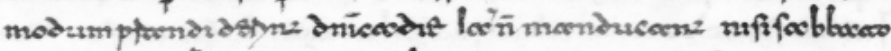

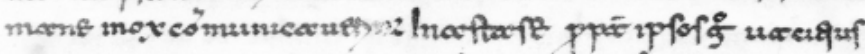

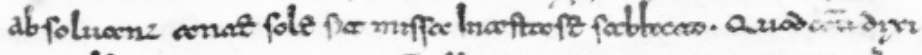

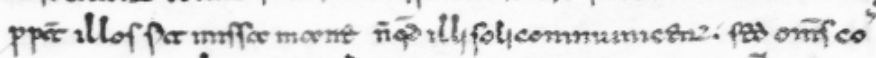

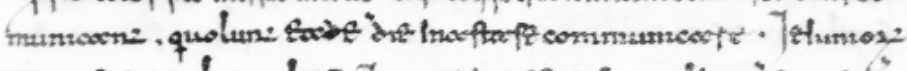

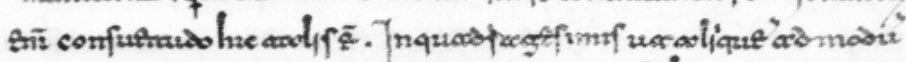

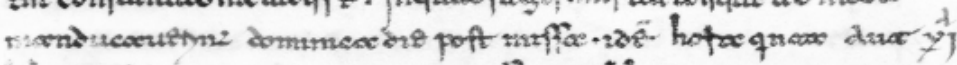

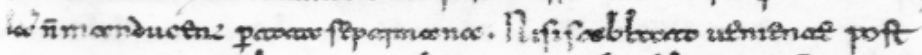

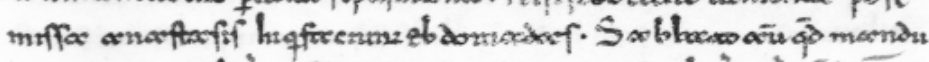

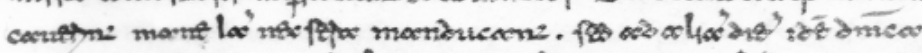

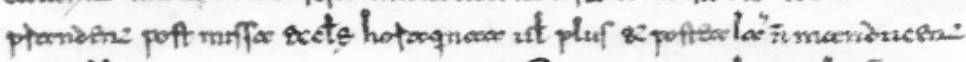

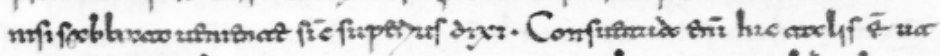

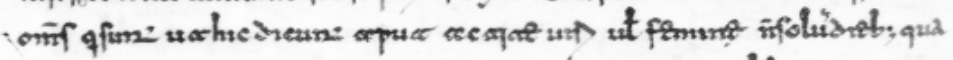

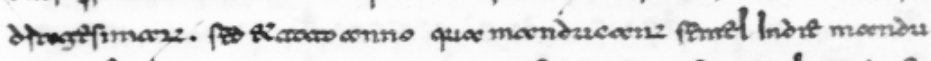

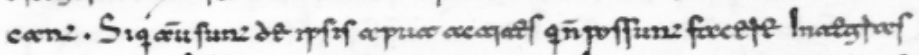

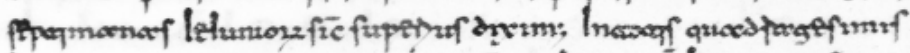

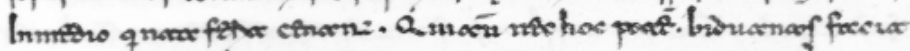

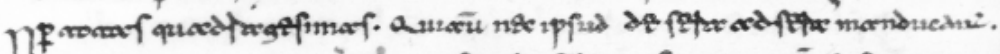

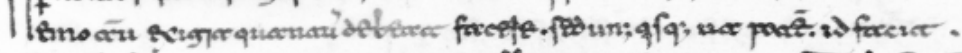

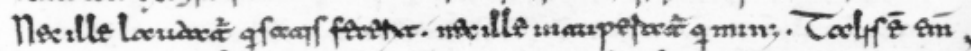

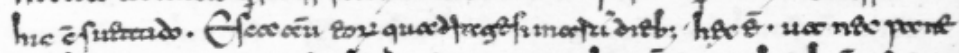

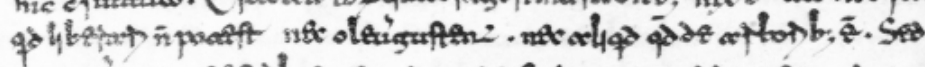

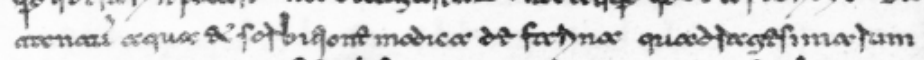

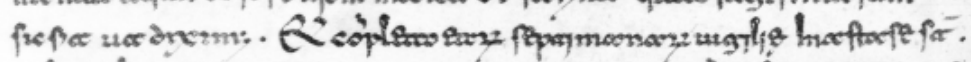

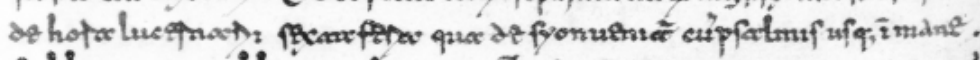

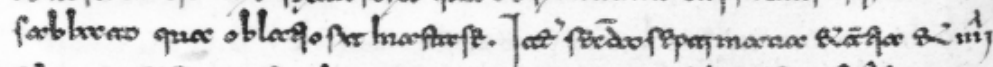

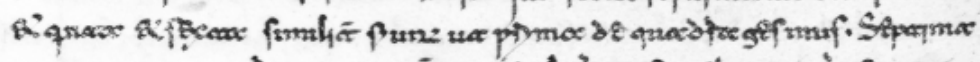

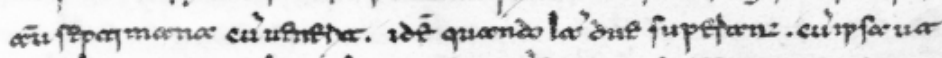

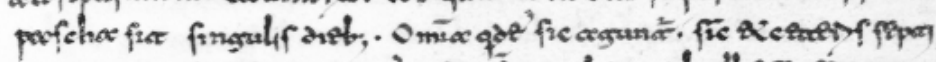
man of $q u$ of or

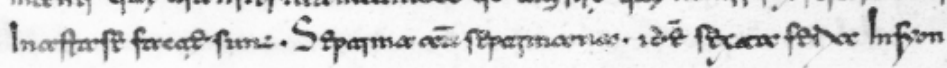




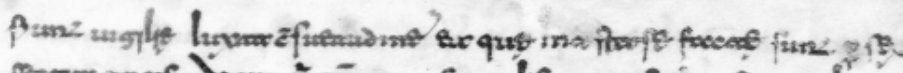

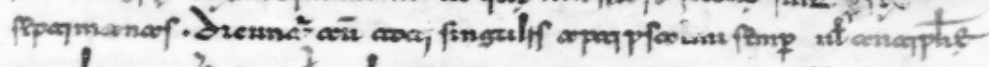

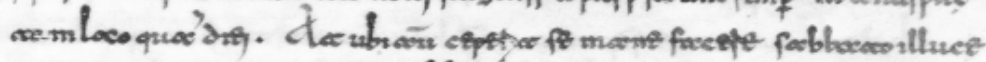

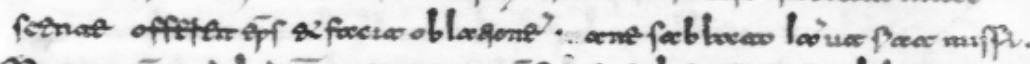

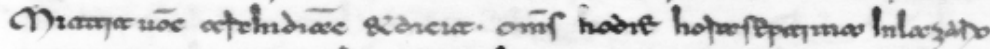

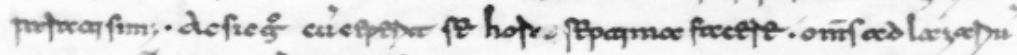

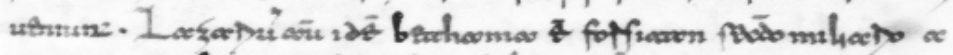

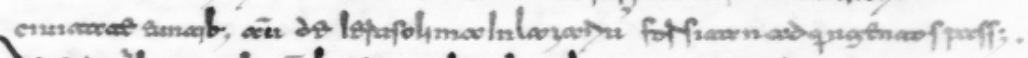

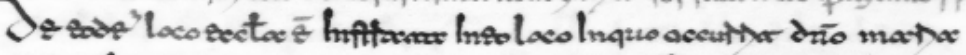

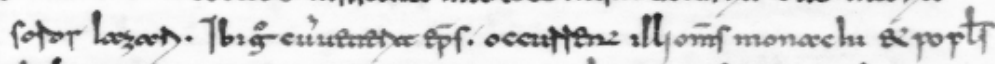

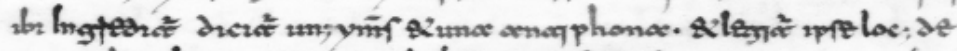

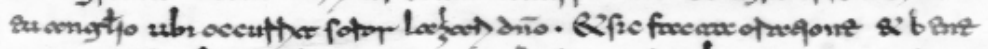

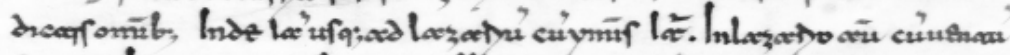

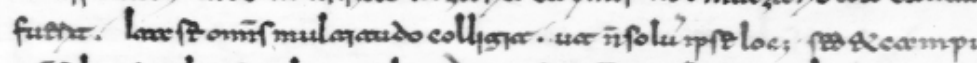

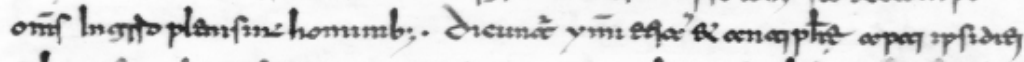

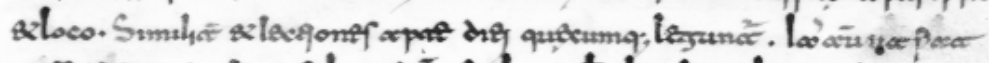

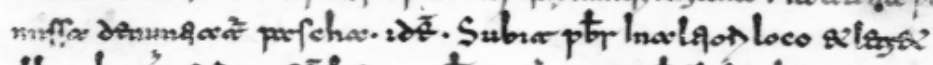

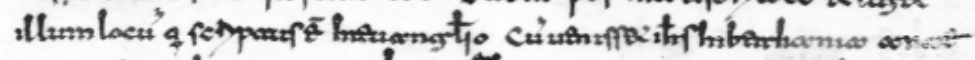

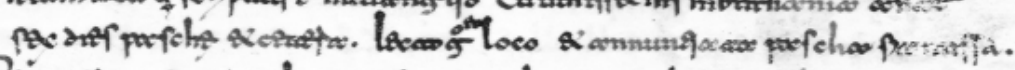

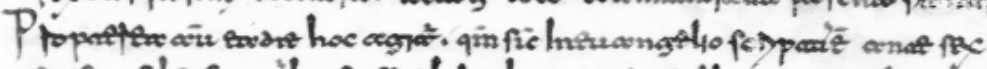

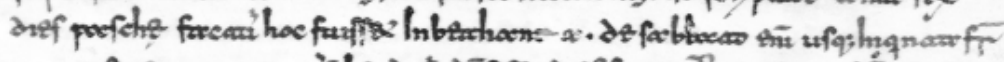

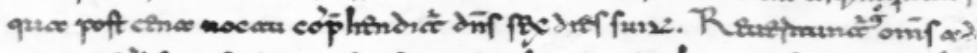

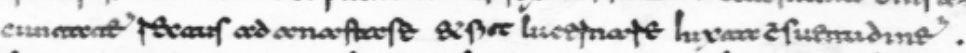

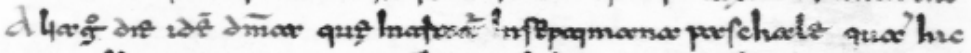

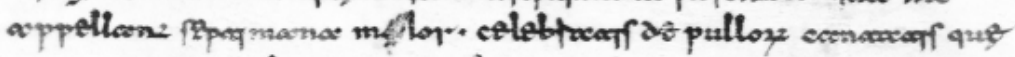

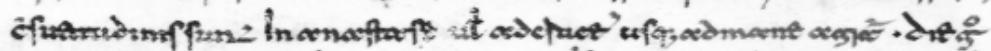

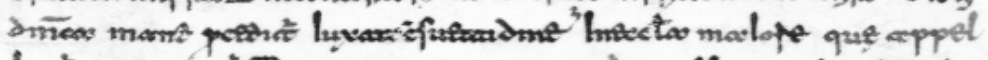

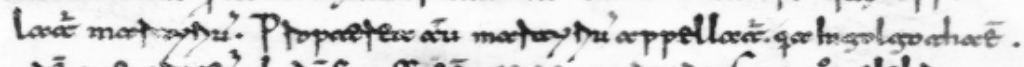

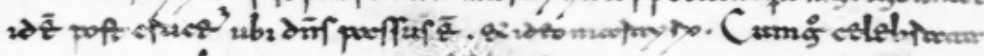

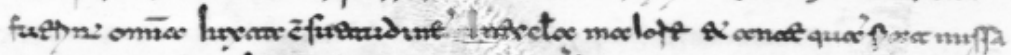

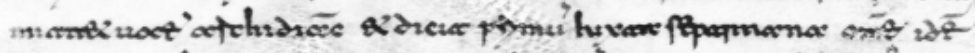

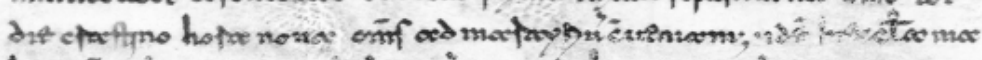

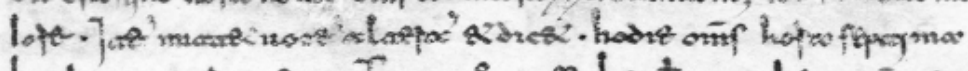

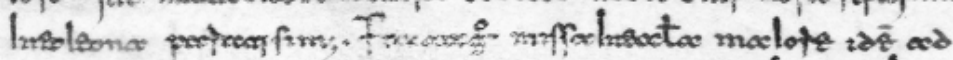

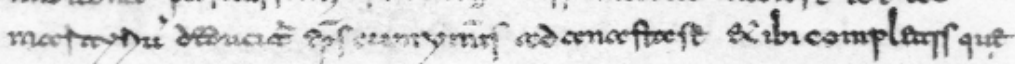




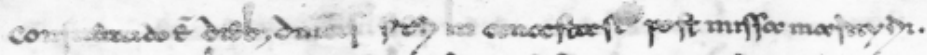

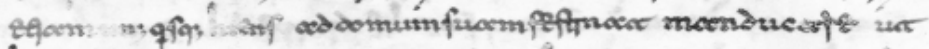

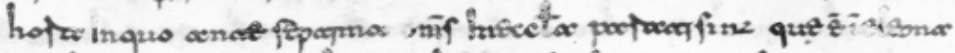

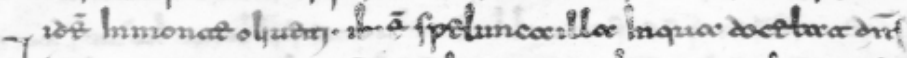

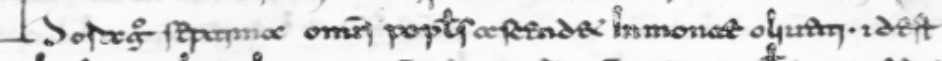

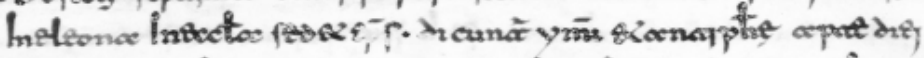

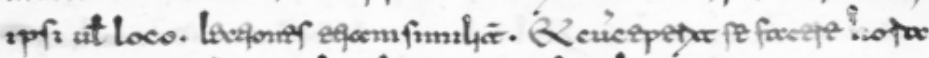

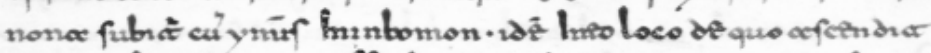

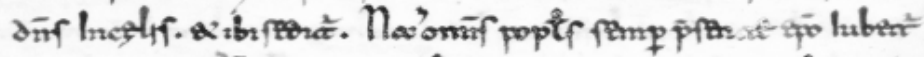

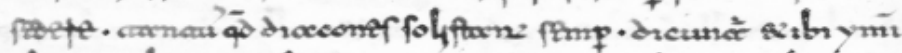

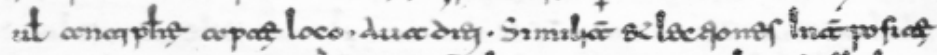

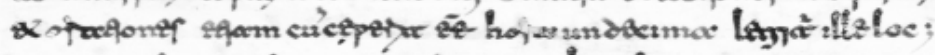

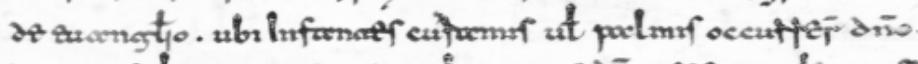

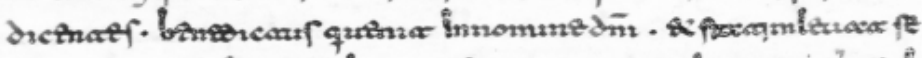

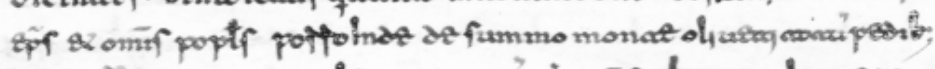

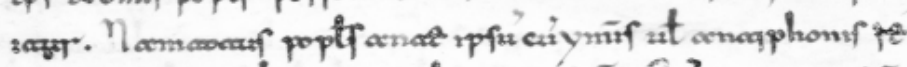

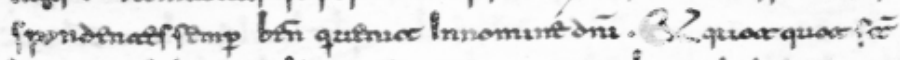

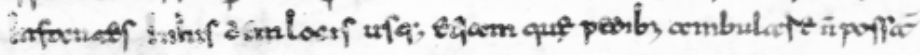

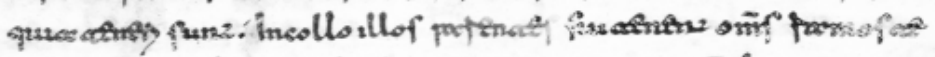

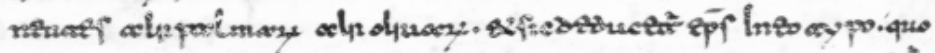

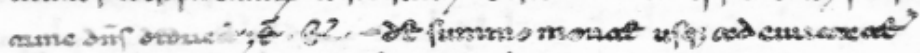

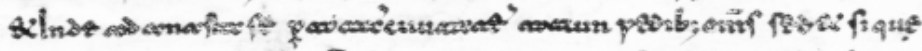

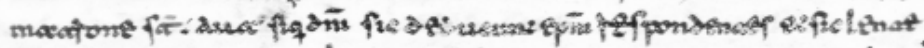

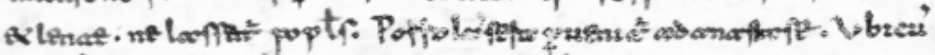

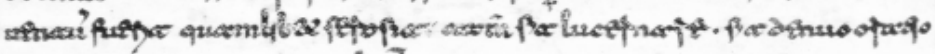

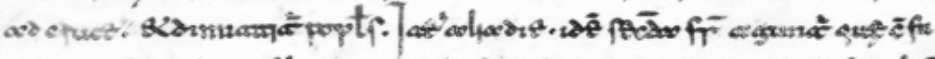

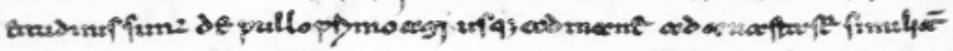

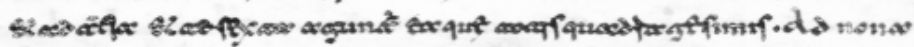

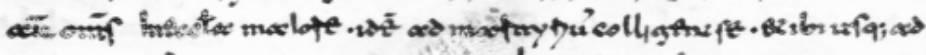

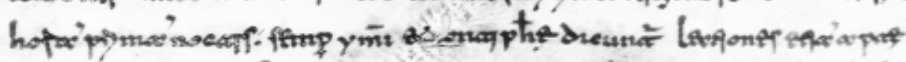

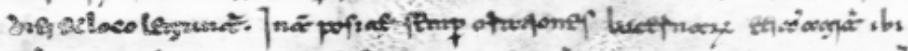

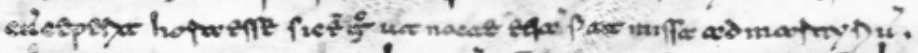

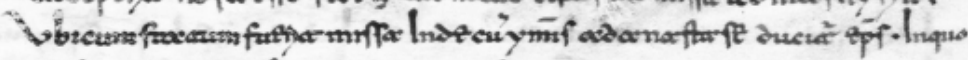

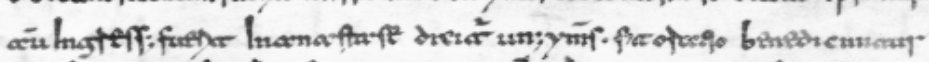

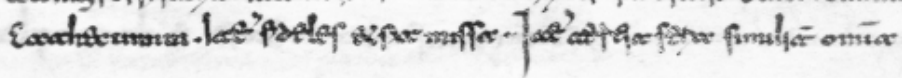




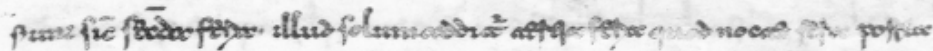

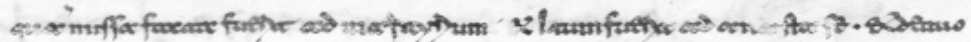

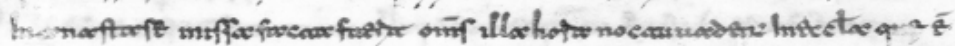

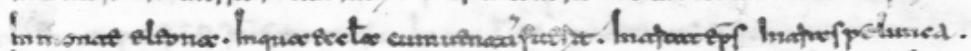

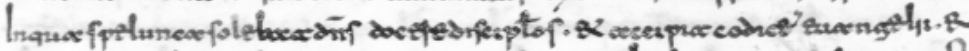

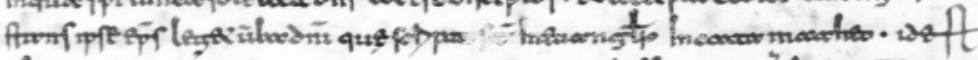

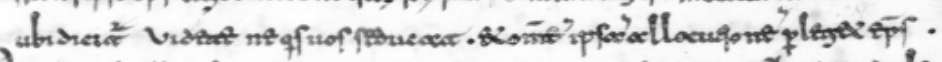

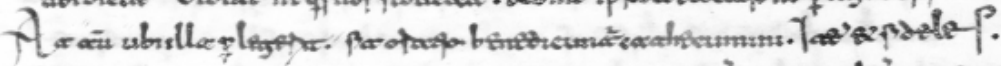

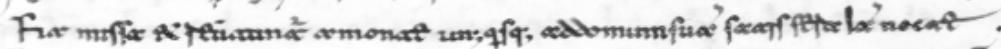

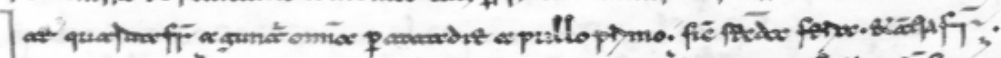

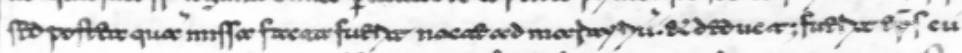

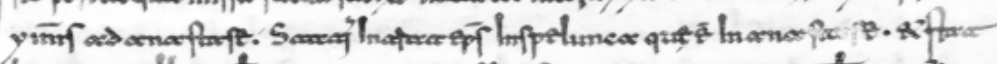

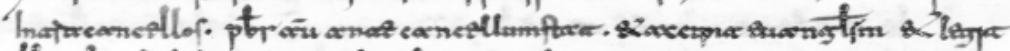

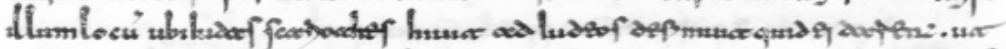

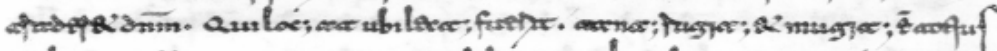

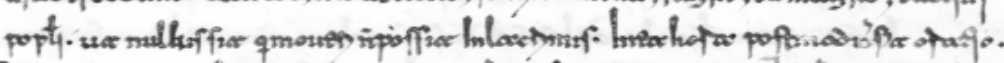

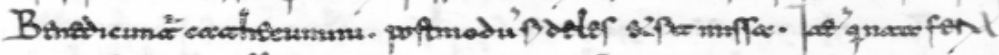

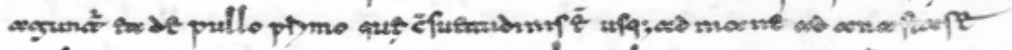

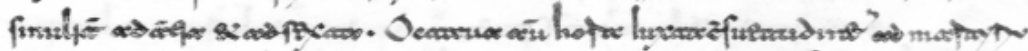

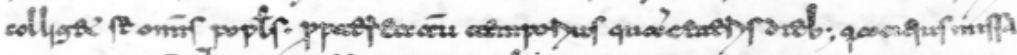

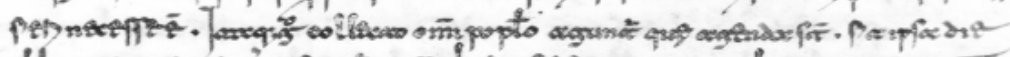

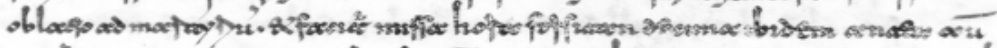

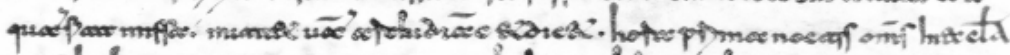

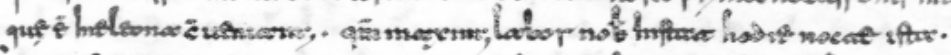

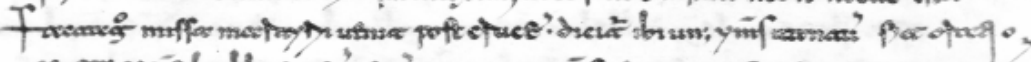

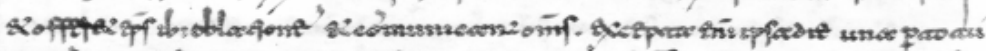

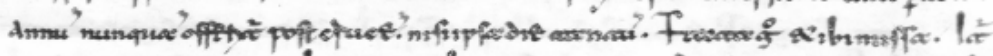

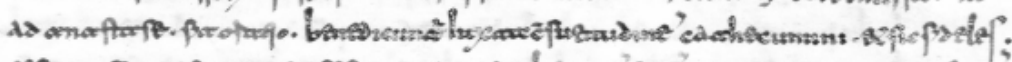

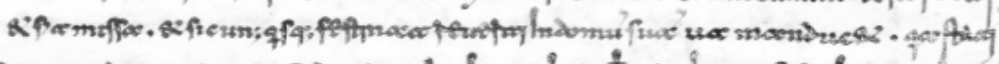

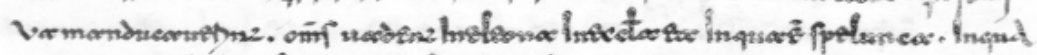

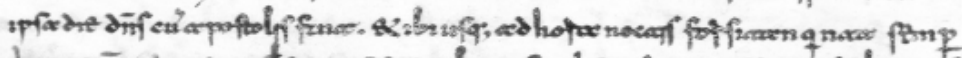

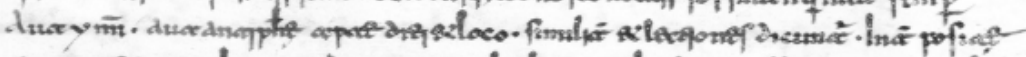

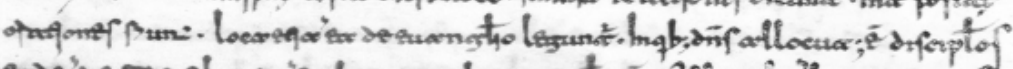

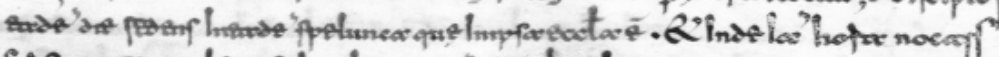

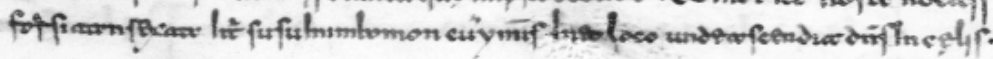




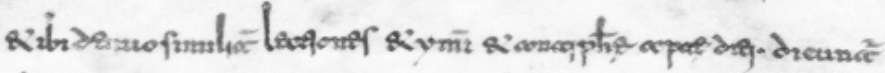

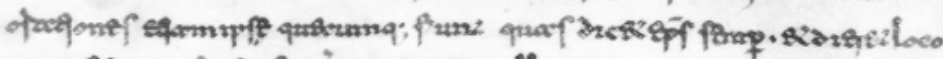

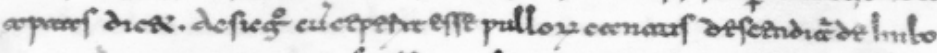

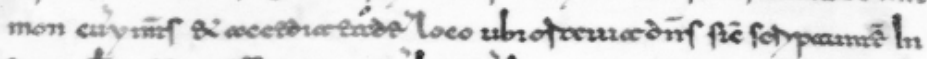

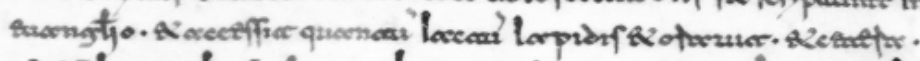

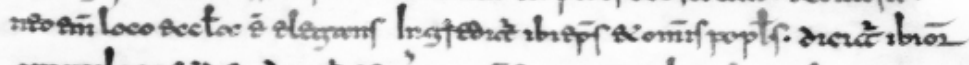

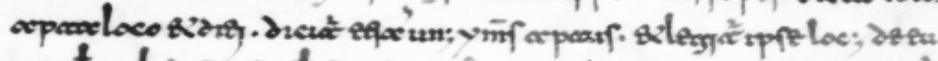

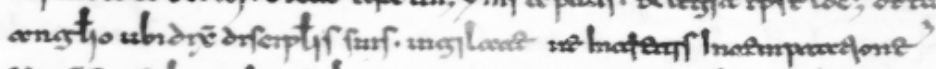

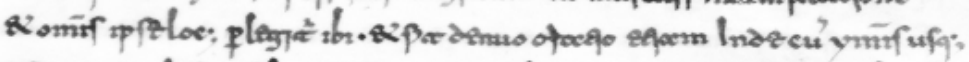

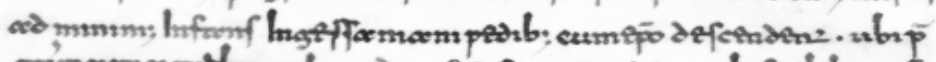

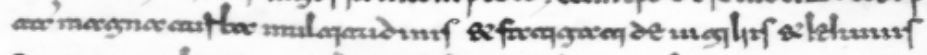

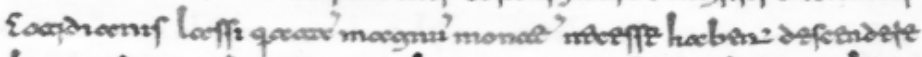

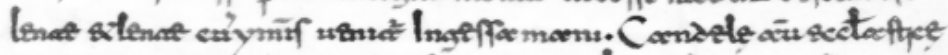

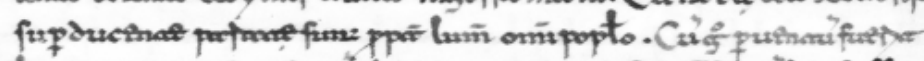

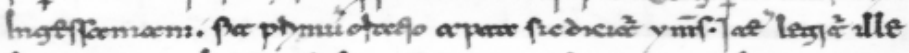

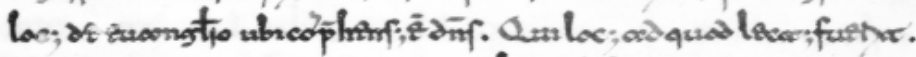

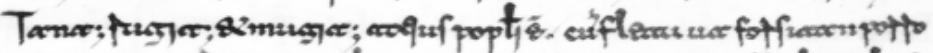

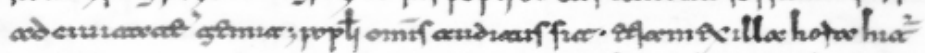

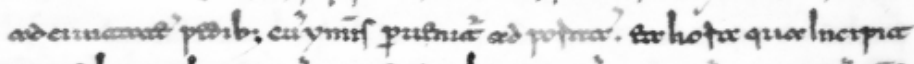

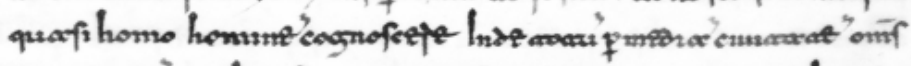

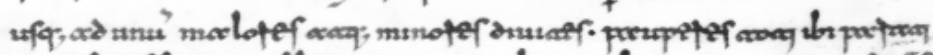

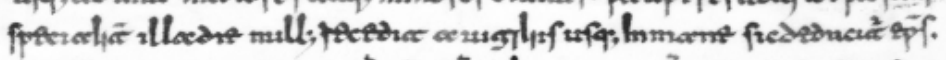

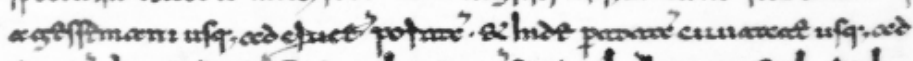

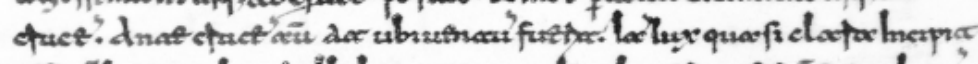

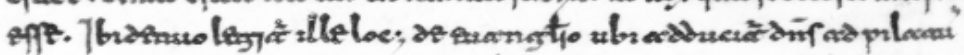

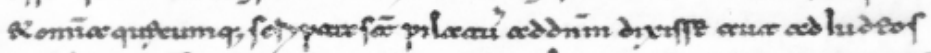

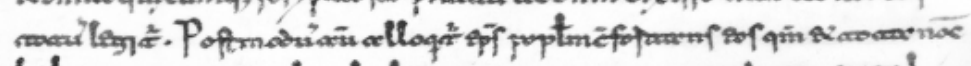

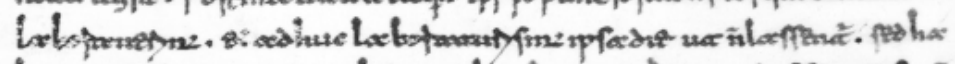

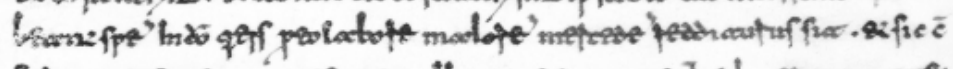

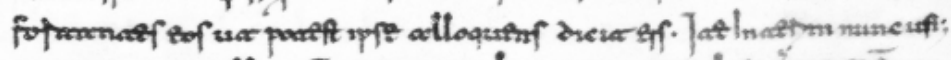

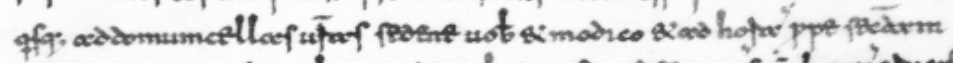

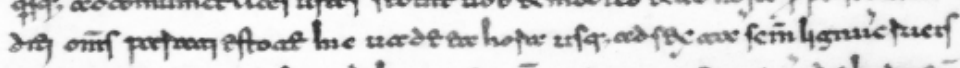

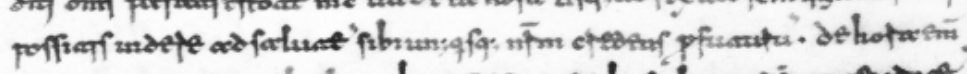

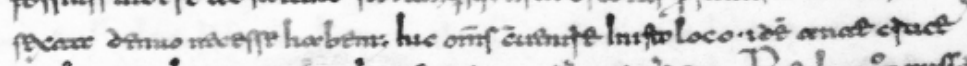

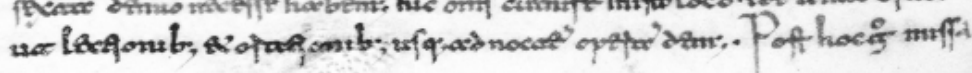




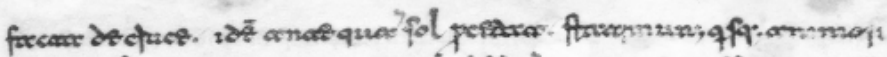

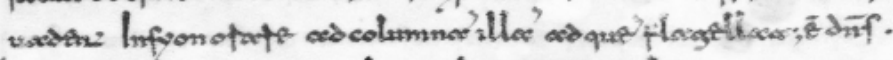

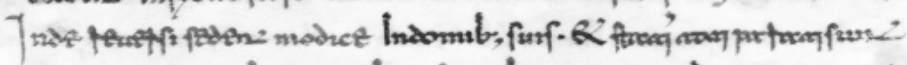

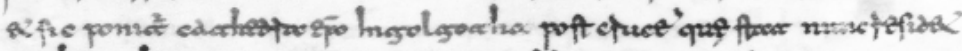

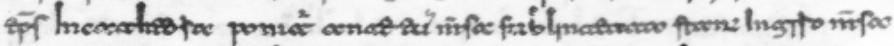

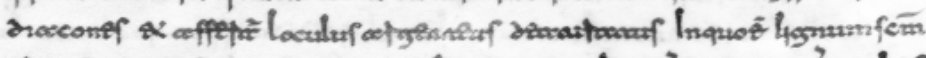

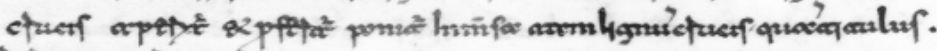

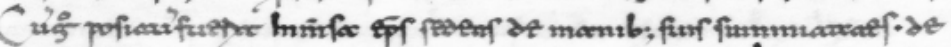

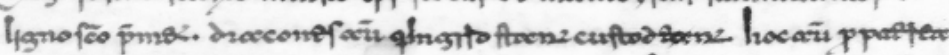

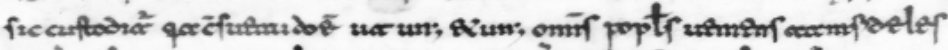

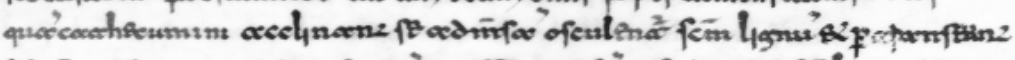

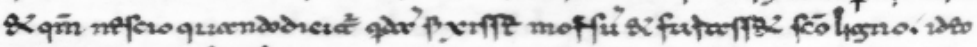

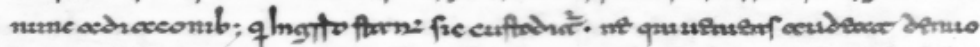

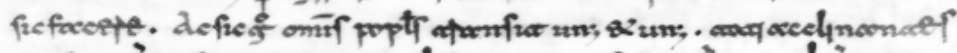

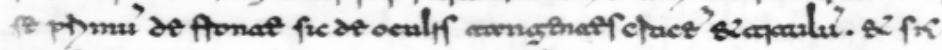

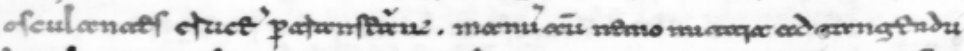

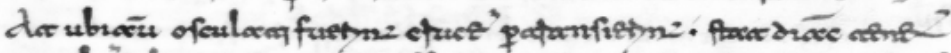

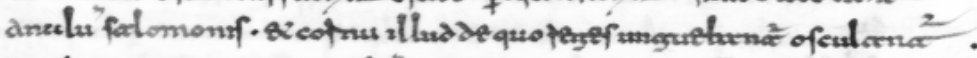

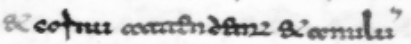

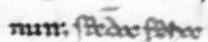

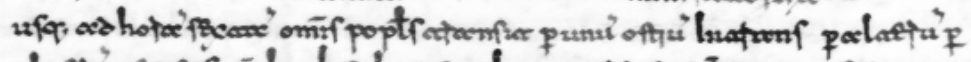

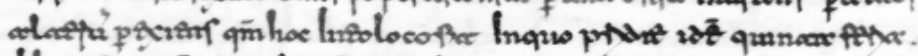

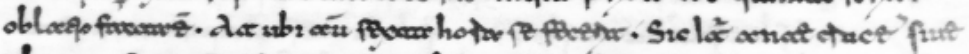

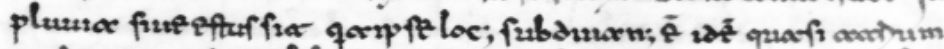

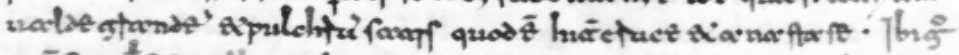

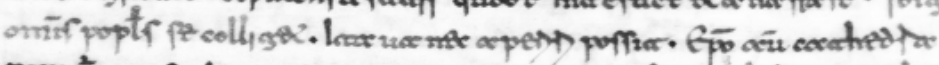

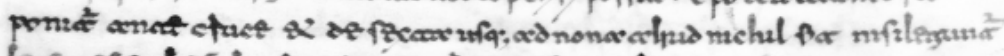

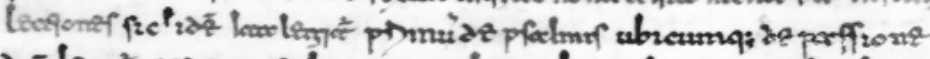

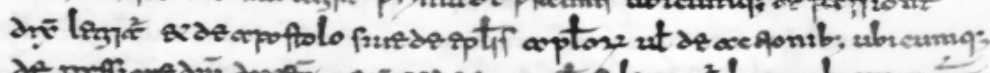

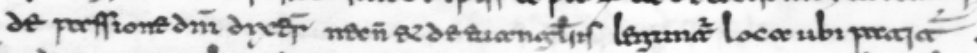

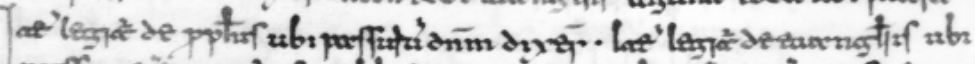

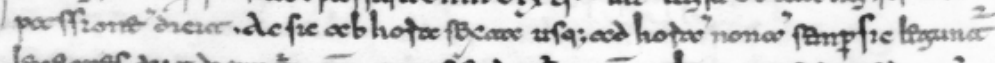

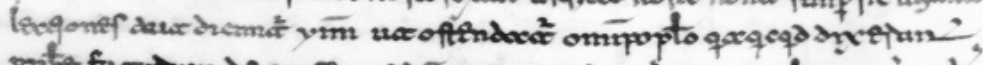

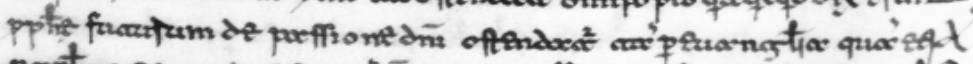

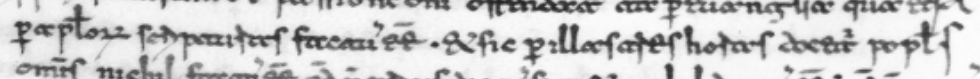

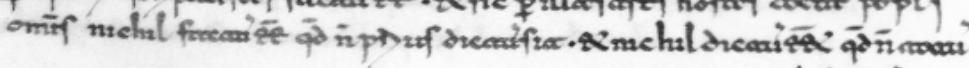

$$
\text { copltirifín. }
$$




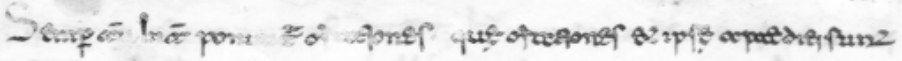

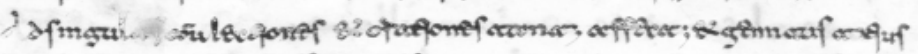

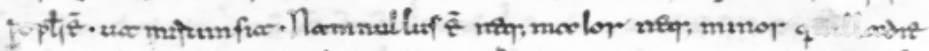

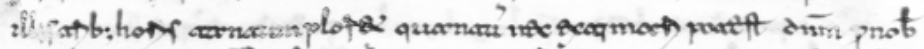

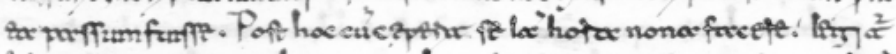

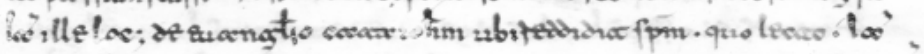

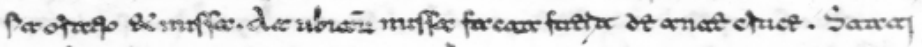

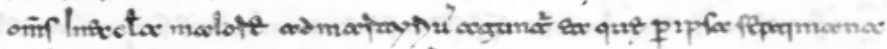

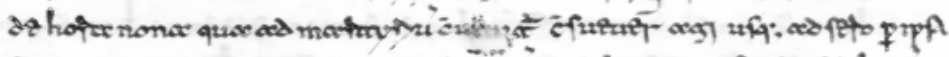

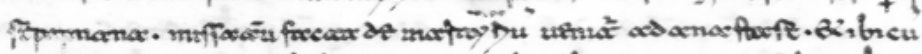

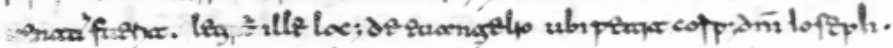

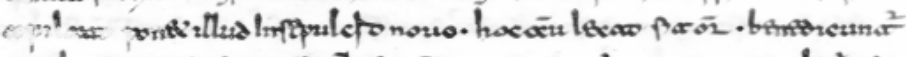

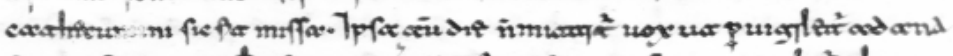

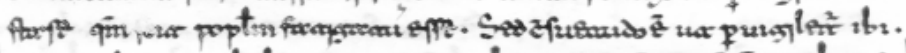

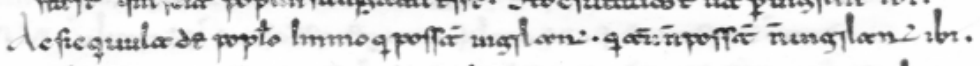

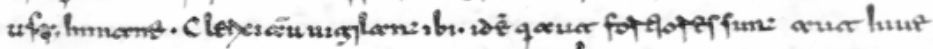

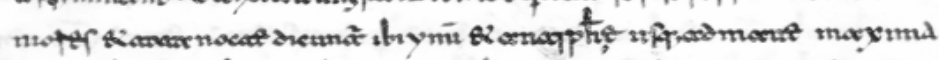

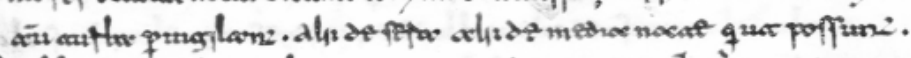

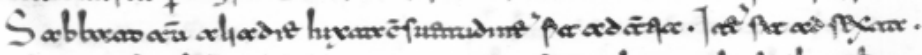

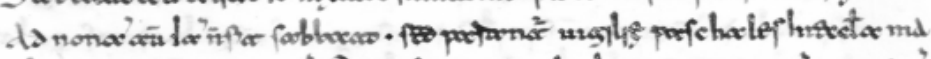

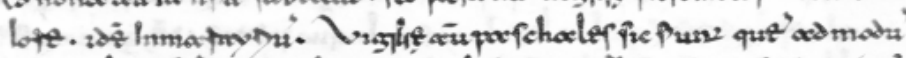

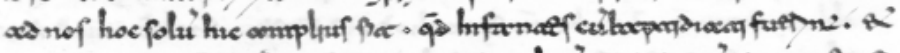

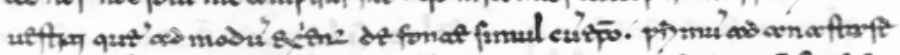

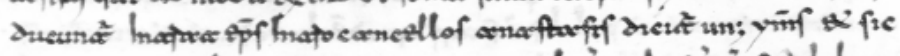

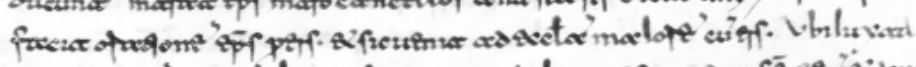

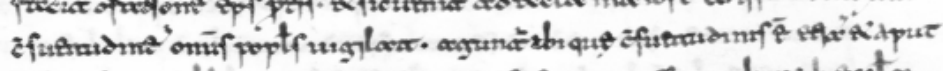

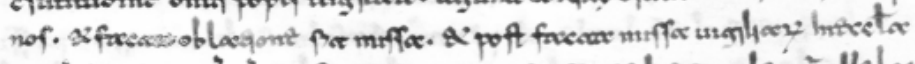

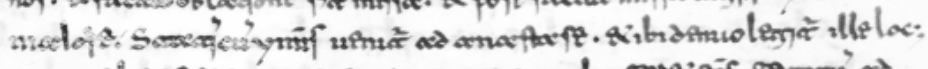

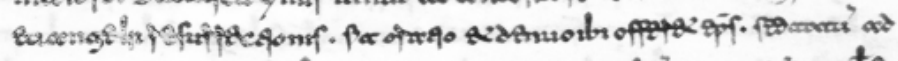

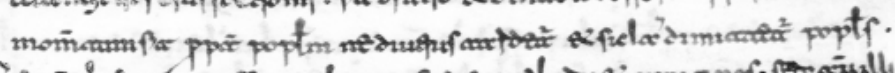

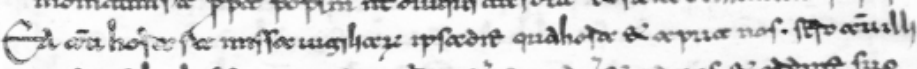

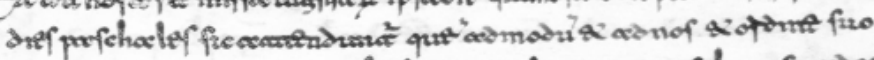

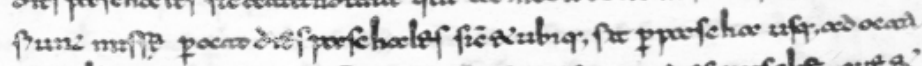

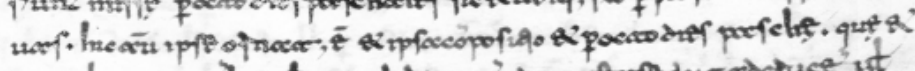

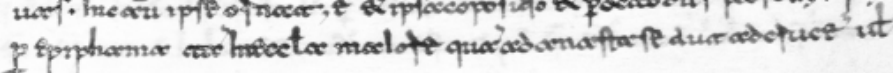
. 


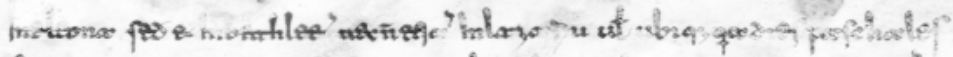

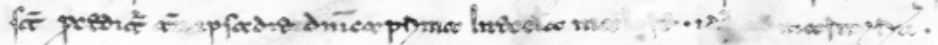

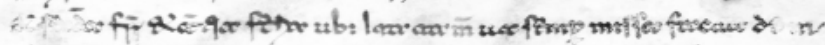

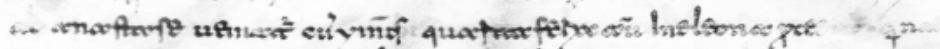

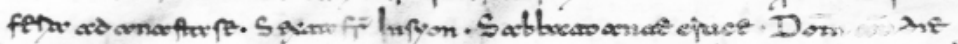

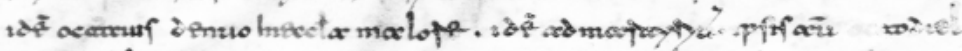

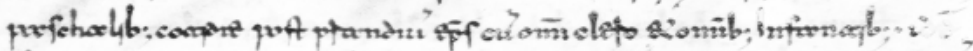

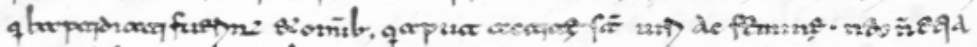

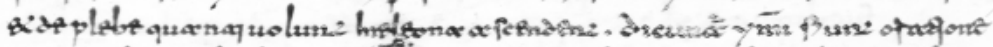

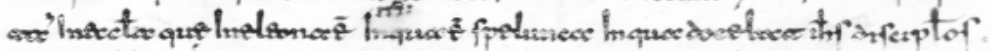

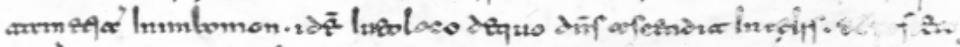

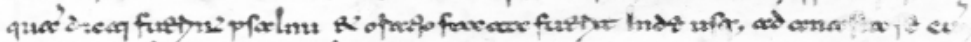

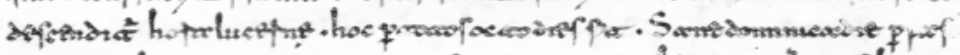

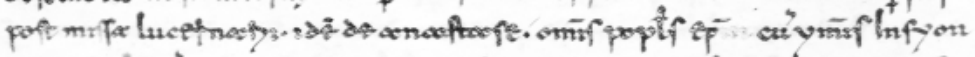

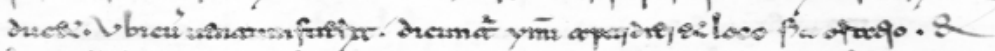

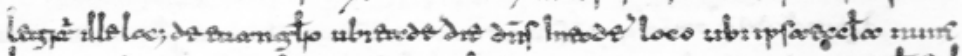

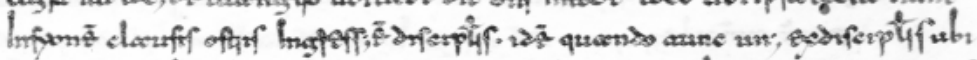
in

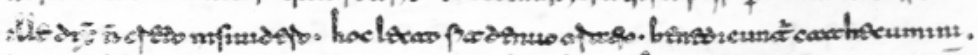

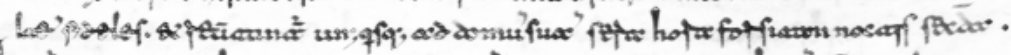

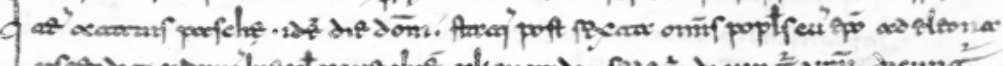

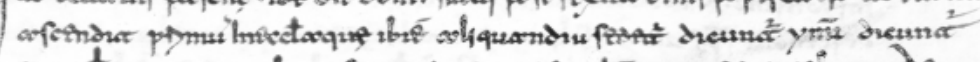

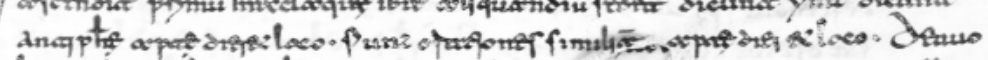
m2a cu'y

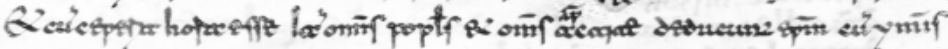

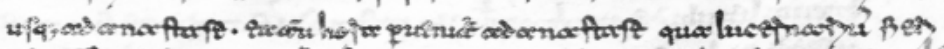

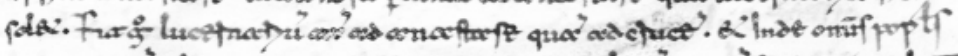

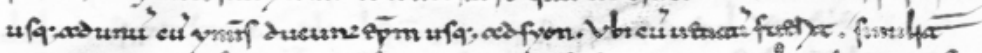

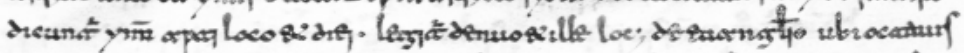

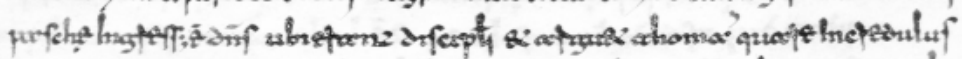

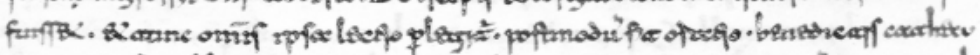

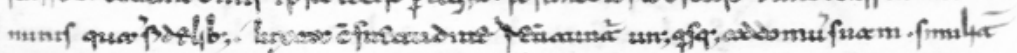

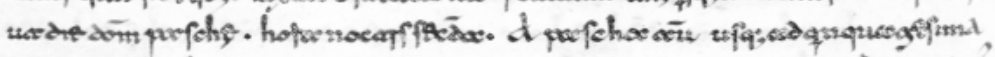

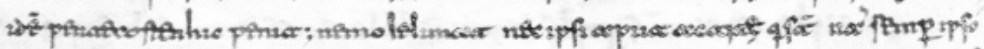

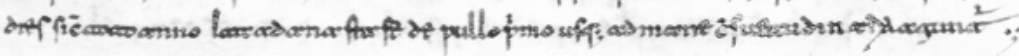




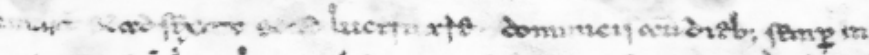

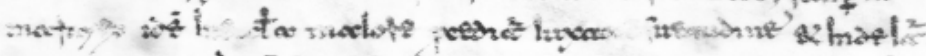

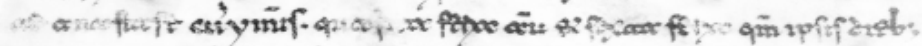

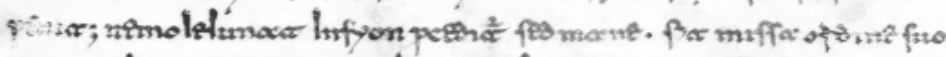

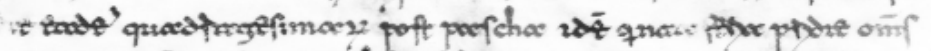
pet fि

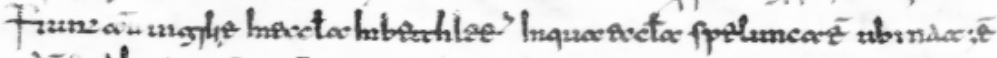

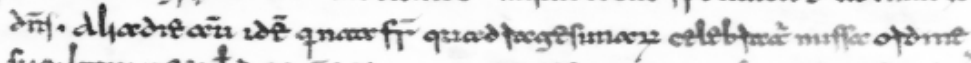

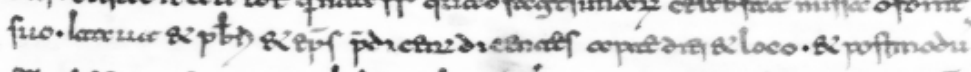

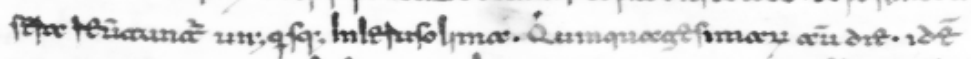

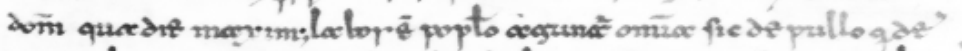
Tho heve हैं

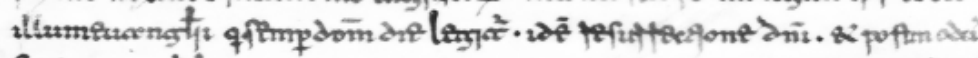

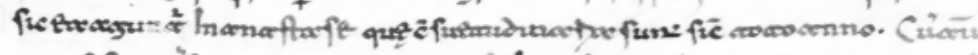

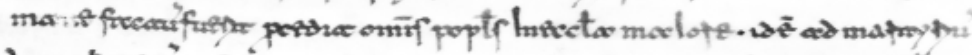

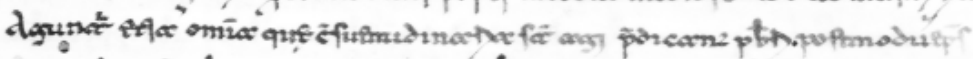

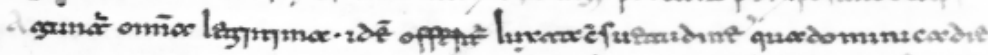

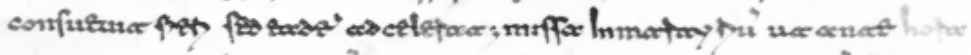

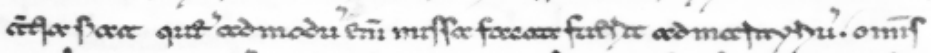

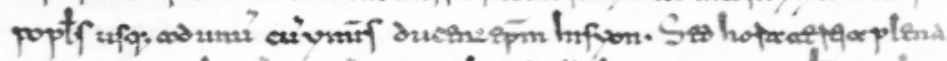

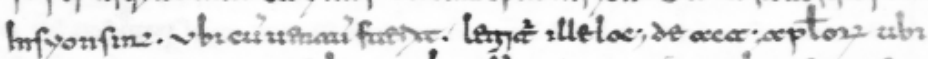

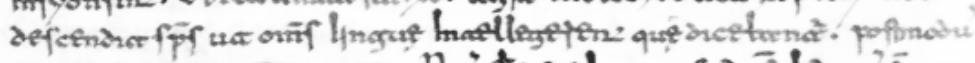

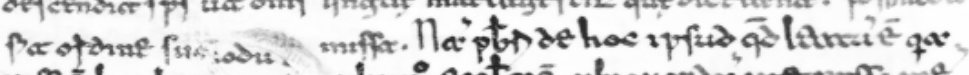

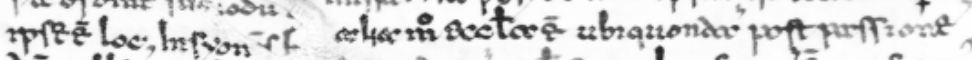

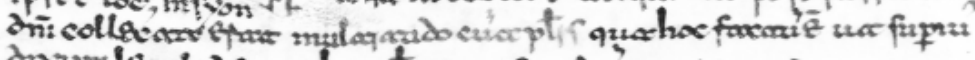

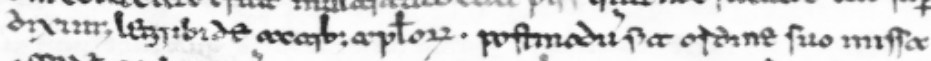

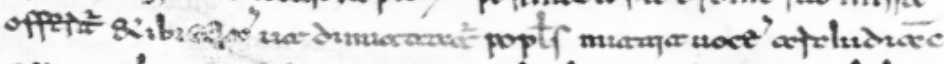

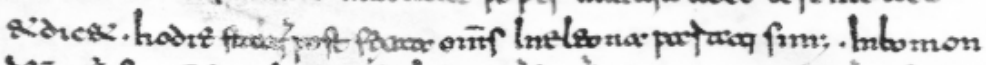

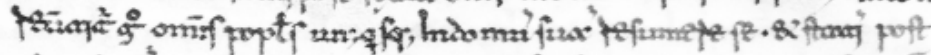

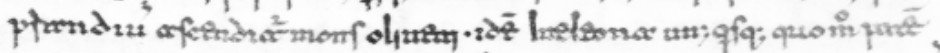

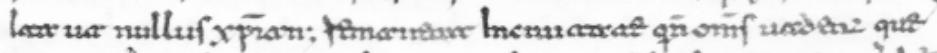

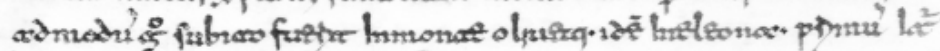

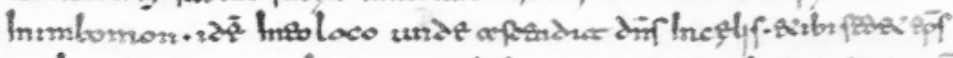

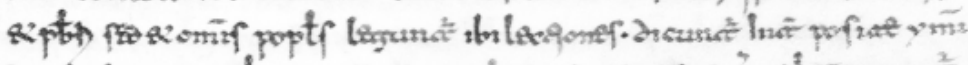

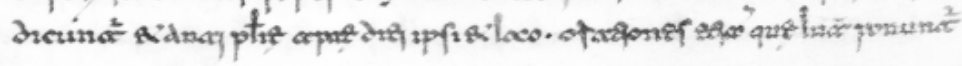




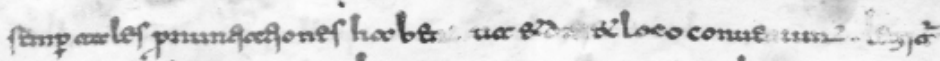

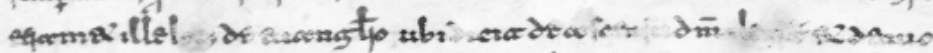

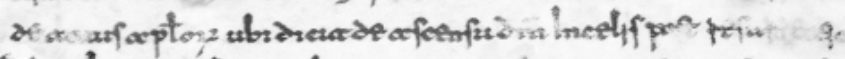

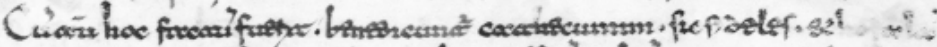

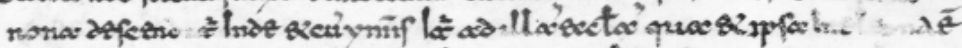

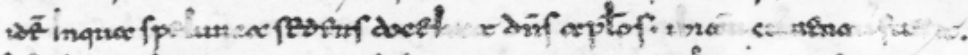

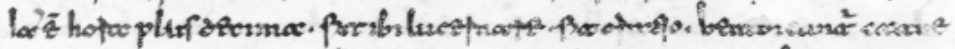

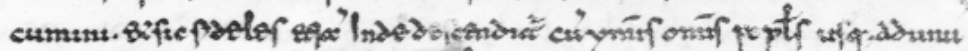

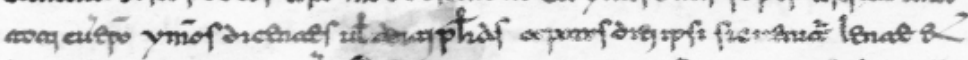
Cone uf

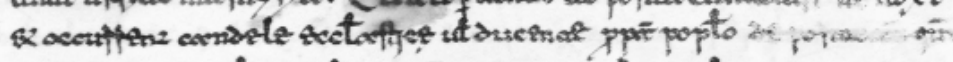

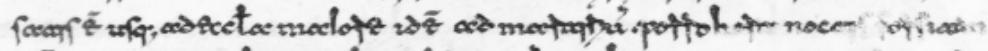

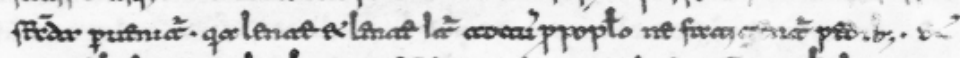

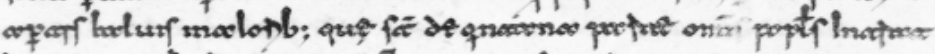

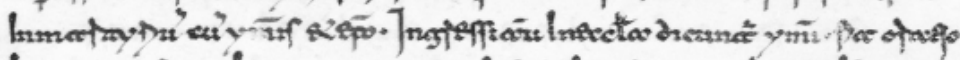

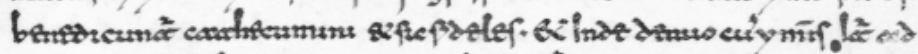
anafue

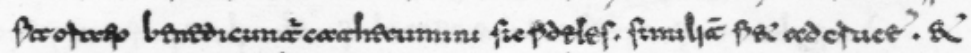

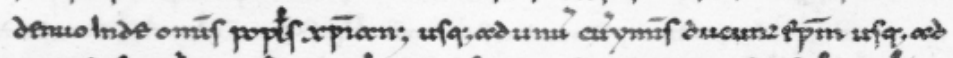

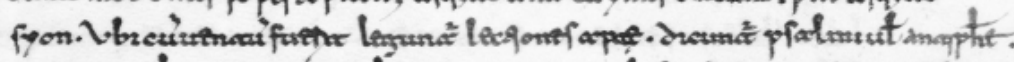

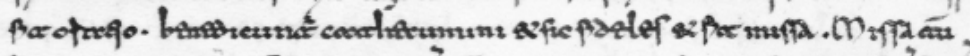

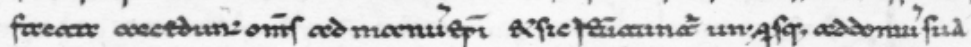

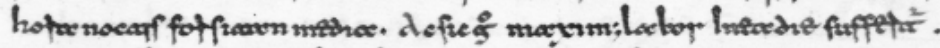

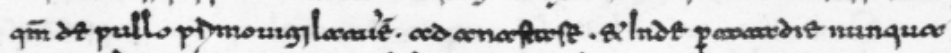

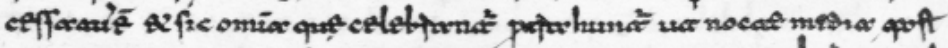

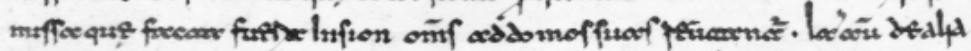

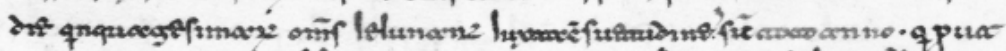

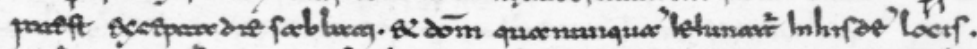

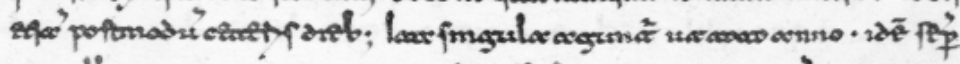

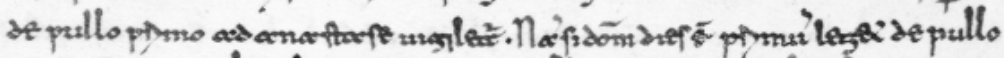

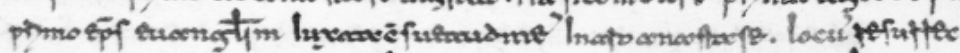

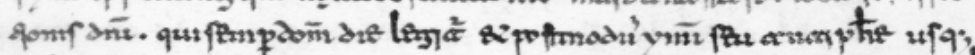

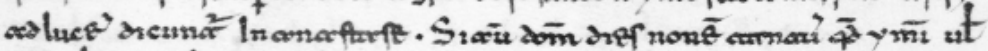

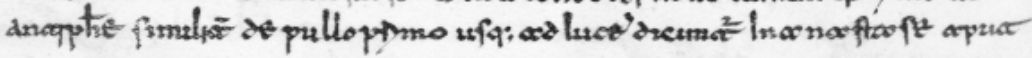

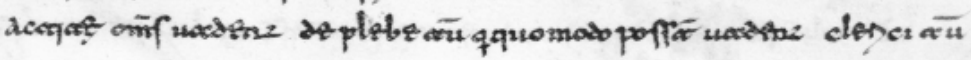




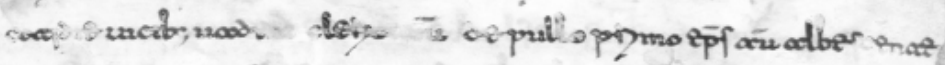

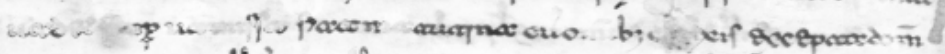

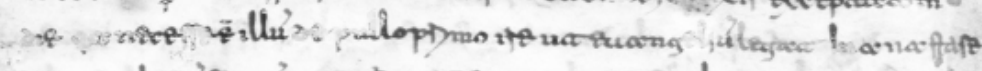

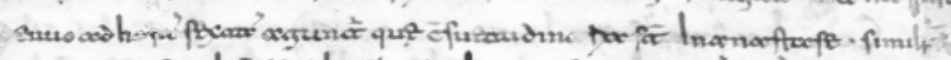

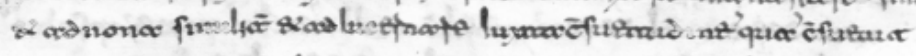

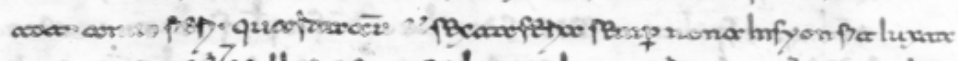

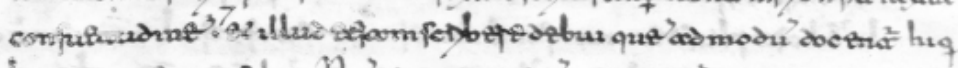

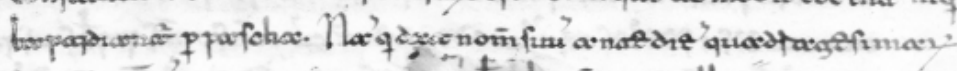

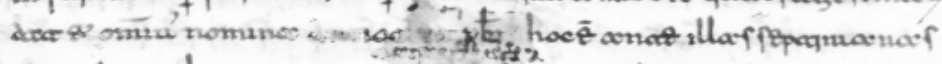

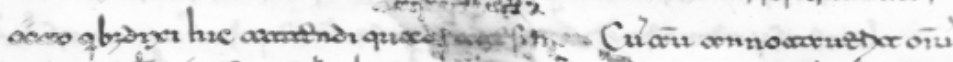

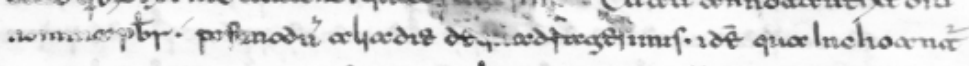

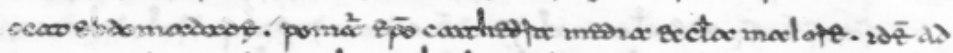

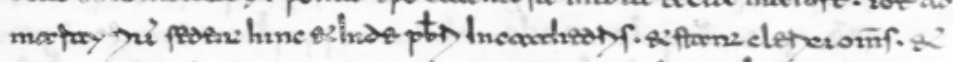

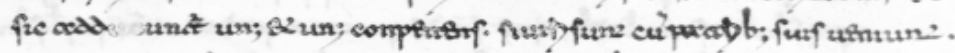

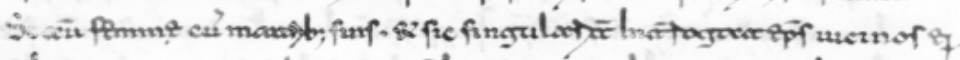

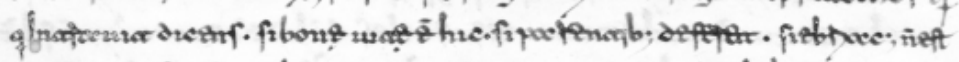

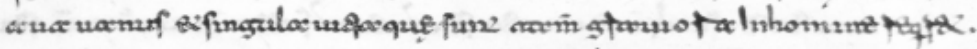

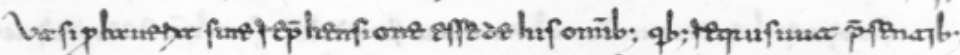

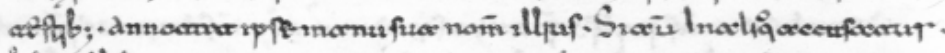

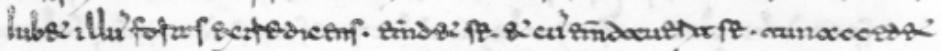

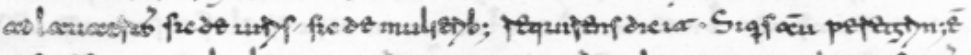

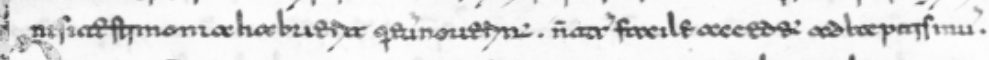

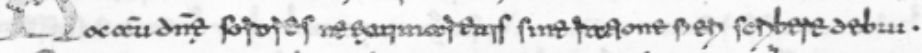

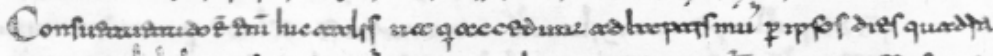

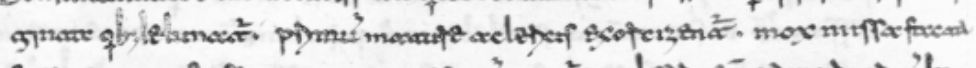

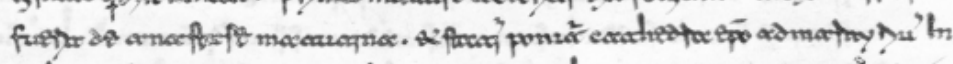

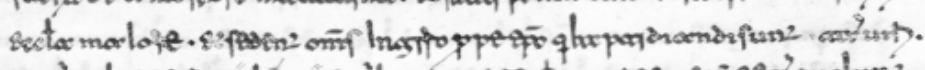

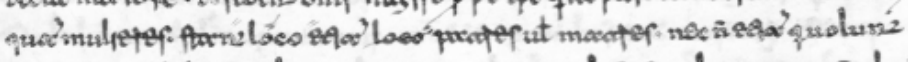

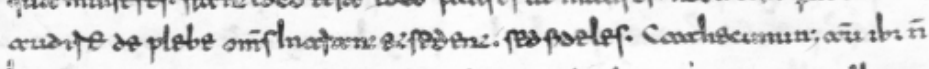

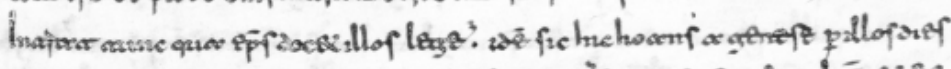

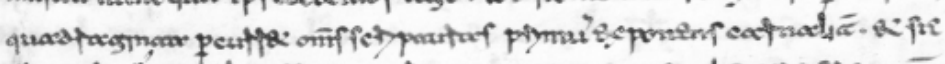

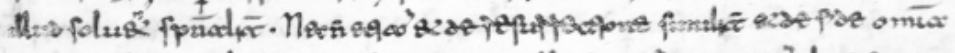

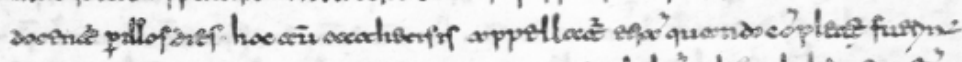

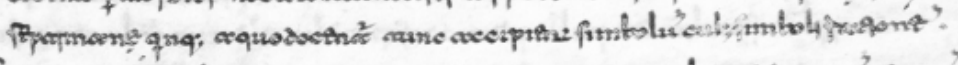
Simal 


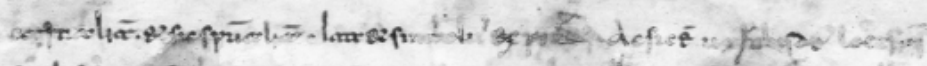

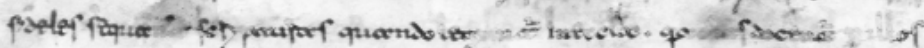

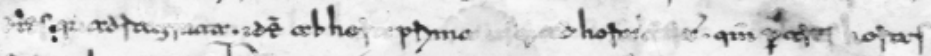

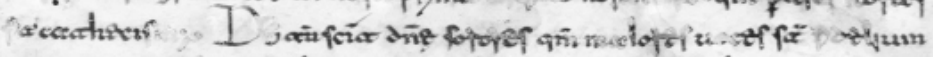

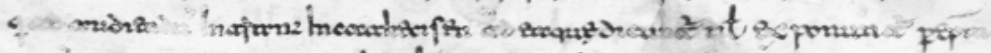

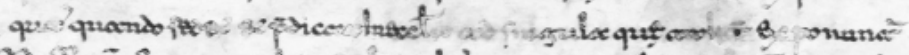

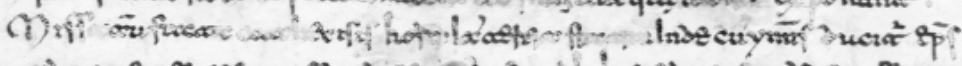

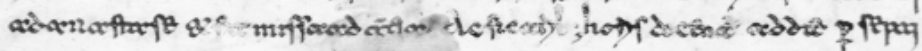

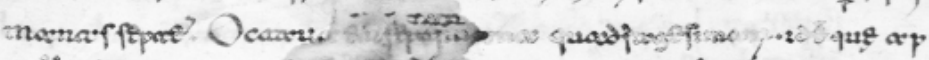

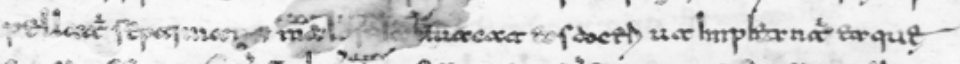

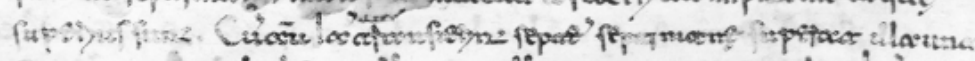

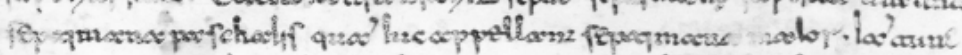

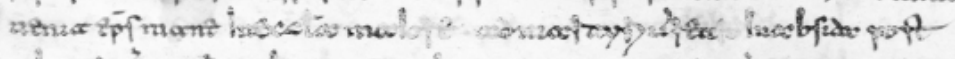

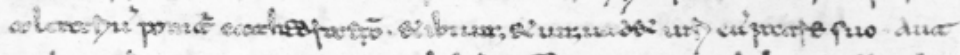

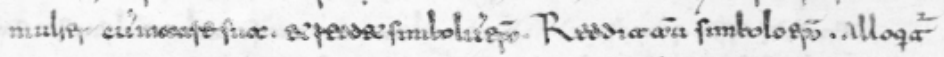

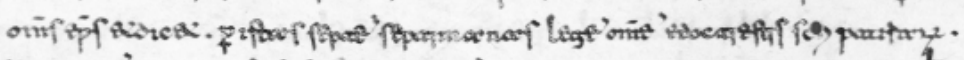
nave equ

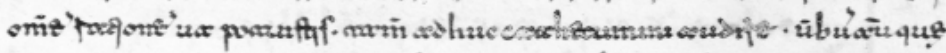

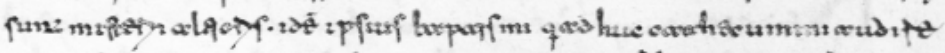

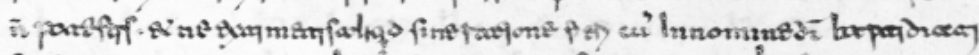

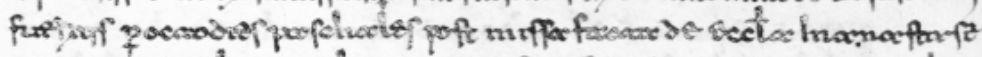

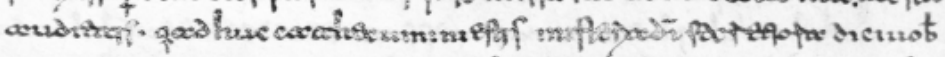

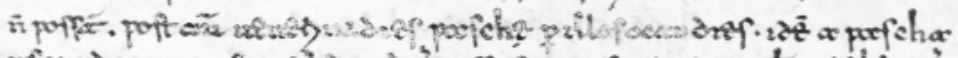

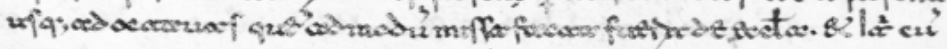

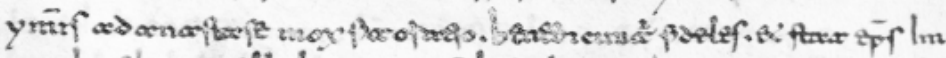

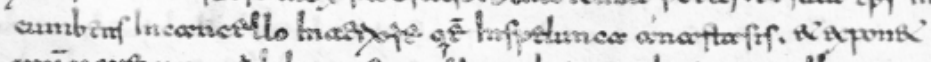

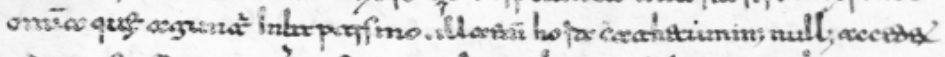

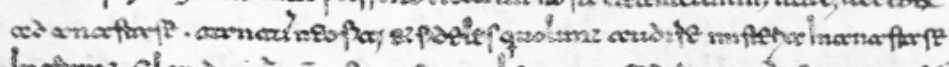

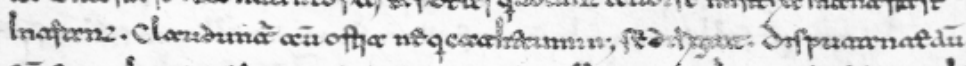

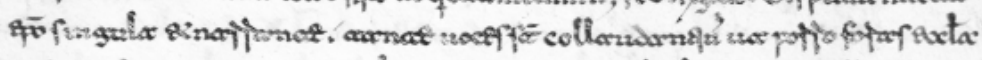

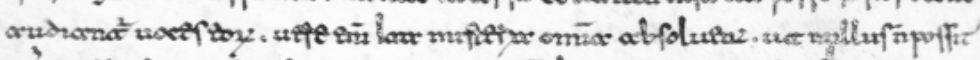

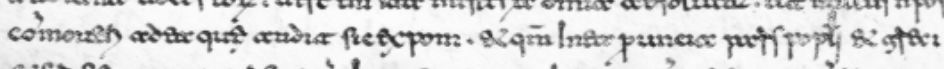

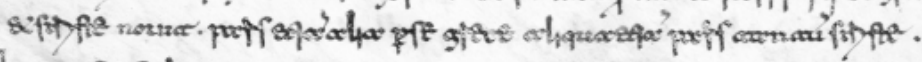

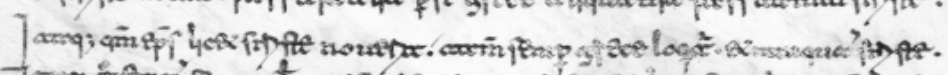

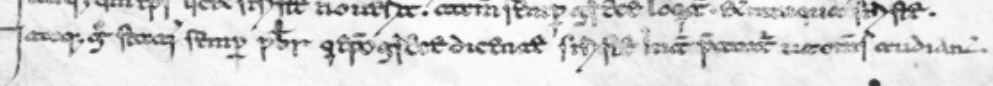




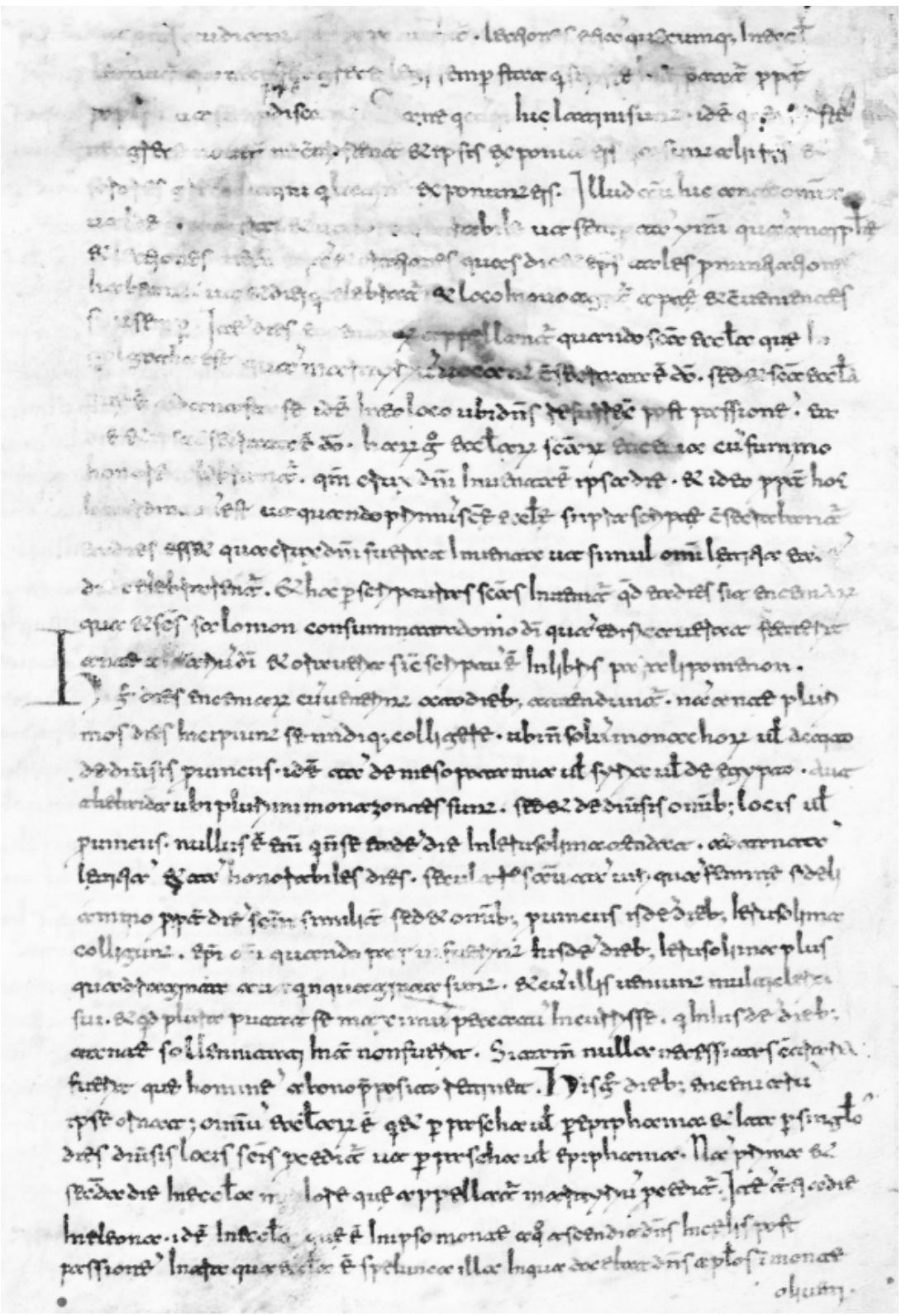


Sobre o livro

$\begin{array}{cl}\text { Formato } & 16 \mathrm{~cm} \mathrm{x} 23 \mathrm{~cm} \\ \text { Tipologia } & \text { Minion Pro } \\ & \text { Balmoral D } \\ \text { Papel } & \text { Sulfite } 75 \mathrm{~g}\end{array}$

